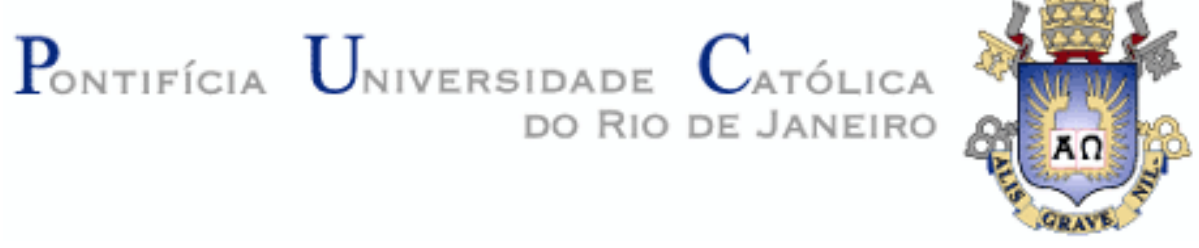

Silvana Castro Nicolli

\title{
Arquiteturas do desaparecimento
}

\author{
Tese de Doutorado
}

Tese apresentada como requisito parcial para obtenção do grau de Doutor pelo Programa de Pós-Graduação em História Social da Cultura, do Departamento de História da PUC-Rio.

Orientador: Prof. Antonio Edmilson Martins Rodrigues 


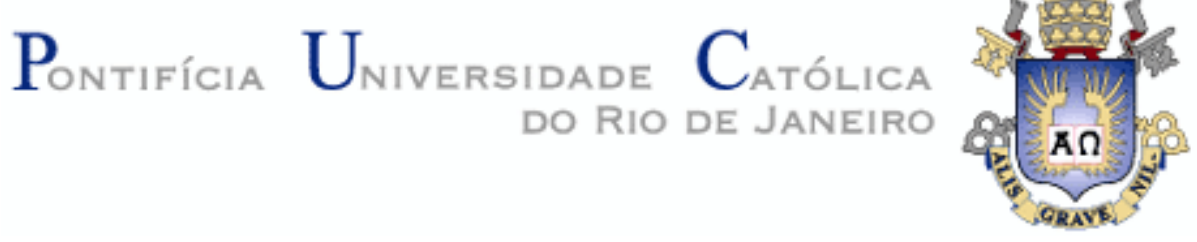

Silvana Castro Nicolli

\section{Arquiteturas do desaparecimento}

Tese apresentada como requisito parcial para obtenção do grau de Doutor pelo Programa de Pós-Graduação em História Social da Cultura do Departamento de História do Centro de Ciências Sociais da PUC-Rio. Aprovada pela Comissão Examinadora abaixo.

Prof. Antonio Edmilson Martins Rodrigues
Orientador
Departamento de História - PUC-Rio

Prof. João Masao Kamita Departamento de História - PUC-Rio

Prof. Luiz de França Costa Lima Filho Departamento de História - PUC-Rio

Prof. - Verônica Miranda Damasceno Escola de Belas Artes - UFRJ

Prof. Carlos Eduardo Forte Feferman Faculdade de Arquitetura e Urbanismo-UFRJ

Rio de Janeiro, 03 de maio de 2019. 
Todos os direitos reservados. É proibida a reprodução total ou parcial do trabalho sem autorização da universidade, da autora e do orientador.

\section{Silvana Castro Nicolli}

Graduou-se em Arquitetura e Urbanismo na Universidade Federal do Rio de Janeiro em 1994. Especializou-se em Filosofia Contemporânea na PUCRio em 2000. Obteve o grau de Mestre em História também pela PUC-Rio em 2014.

Ficha Catalográfica

Nicolli, Silvana Castro

Arquiteturas do desaparecimento / Silvana Castro Nicolli ; orientador: Antonio Edmilson Martins Rodrigues. - 2019.

377 f. : il. color. ; $30 \mathrm{~cm}$

Tese (doutorado)-Pontifícia Universidade Católica do Rio de Janeiro, Departamento de História, 2019.

Inclui bibliografia

1. História - Teses. 2. História Social da Cultura - Teses. 3. Transparência abjeta. 4. Estética do desaparecimento. 5. Corpo digital. 6. Participação. 7. Toyo Ito. I. Rodrigues, Antonio Edmilson Martins. II. Pontifícia Universidade Católica do Rio de Janeiro. Departamento de História. III. Título.

CDD: 900 
Para Armando Barros de Castro, que partilhou da centelha expressionista. 


\section{Agradecimentos}

Agradeço ao professor Luiz Costa Lima e aos meus colegas de curso, Ana Carolina, Edson Lima, Lucas Peleias Gahiosk, Maycon Da Silva Tannis, Matheus Drummond e Patrícia Bastos, pelas trocas, apoio e presença que fizeram valer a persistência.

Ao meu orientador, Antonio Edmilson Martins Rodrigues.

Ao CNPQ e à PUC-Rio, pelos auxílios concedidos.

Aos funcionários do Departamento de História, pela atenção e solicitude. À Edna, pela dedicação sempre carinhosa.

Aos meus pais, Julieta e Domingos, pela formação.

À amiga Betina von Staa, pela abordagem sempre realista e pelo prumo.

Ao Paulo, pelo apoio, estímulo e compreensão.

Aos meus filhos, Mônica e Marcelo, pela torcida mais amada e doce desse mundo.

O presente trabalho foi realizado com apoio da Coordenação de Aperfeiçoamento de Pessoal de Nível Superior - Brasil (CAPES) - Código de Financiamento 001. 


\section{Resumo}

Nicolli, Silvana Castro. Rodrigues, Antonio Edmilson Martins. Arquiteturas do Desaparecimento. Rio de Janeiro, 2019. 377 p. Tese de Doutorado - Departamento de História, Pontifícia Universidade Católica do Rio de Janeiro.

Este trabalho examina o fenômeno de retomada da estética da transparência na arquitetura a partir dos anos 1990, depois de anos de latência desde a substituição da linguagem moderna, abstrata e etérea, das primeiras vanguardas por outra que expressasse aspectos regionais e fenomenológicos. Tal retomada estaria associada ao desenvolvimento das novas tecnologias digitais e à realidade estruturada segundo a dinâmica do capitalismo pós-industrial. Estas configurariam uma estrutura urbana desmaterializada, instável e independente da construção física. Tais mudanças teriam tornado obsoletos os paradigmas da solidez, funcionalidade e beleza, herdados da tradição clássica. A tendência ao desaparecimento das qualidades substanciais da arquitetura e a consequente perda dos referenciais fenomenológicos nos recolocou a questão do habitar. A estética da transparência estaria inicialmente associada à concepção iluminista, que pressupunha a clareza dos objetos e a emancipação do sujeito, mas se desdobrará no sentido da ambiguidade em função da ruptura com o conceito de espaço euclidiano, ocorrida em torno de 1910. Tal ruptura teria sido promovida tanto pelas descobertas científicas que unificavam as dimensões de tempo e espaço, quanto pela disseminação de imagens aéreas cinematográficas. As imagens retratavam o espaço topológico e apresentavam a realidade sob a ordem da fragmentação e da perda de perspectiva. A concepção de espaço topológico foi também associada aos sentimentos de angústia e desenraizamento, experimentados pelo homem moderno. A expressão dessa patologia nas artes de vanguarda será criticada por fomentar a desarticulação do engajamento político através de um método que promoveria a perda de visão da totalidade do real. Tal método teria sido desenvolvido por Wilhelm Worringer a partir da noção de Vontade de Arte, expressa no impulso para abstração, este relativo ao conceito do espaço topológico. Este trabalho verificou que tal mudança na concepção de espaço levará à reformulação do conceito de transparência de literal para fenomênica, caracterizada nas artes pela representação de múltiplos pontos de 
vista, da interpenetração espacial e da perda de profundidade. A transparência fenomênica será associada contemporaneamente ao espaço paranoico, que viria sendo desenvolvido com a contribuição da tecnologia digital em termos espaciais e da mutação dos corpos segundo sua conexão com a realidade virtual. A tecnologia cibernética determinaria um novo tipo de expressão da alienação e o desdobramento da noção de transparência, que qualificamos como abjeta. A transparência foi associada pelos primeiros modernos à expressão de japonidade na arquitetura, cuja essência o desenvolvimento da história tratou de contrariar ao evidenciar seu modo interativo. Verificamos neste trabalho algumas das contribuições japonesas em função de suas qualidades locais. Tomamos o edifício para a Midiateca Sendai (2001) de Toyo Ito como objeto de estudo. A Midiateca levaria ao extremo a noção de transparência ao estendê-la das fachadas às estruturas vazadas, pensadas como expressão do espaço puro na linguagem abstrata moderna. Seu programa seria multifuncional e aberto a mudanças, considerando a participação da comunidade e dos demais membros institucionais desde o processo de projeto. Esta obra responderia tanto à questão da autonomia artística quanto à da perda de função social, associadas ao esteticismo das vanguardas modernas.

\section{Palavras-chave}

Modernidade fraca; abstração e empatia; Unheimlich; transparência abjeta; estética do desaparecimento; corpo digital; participação; Toyo Ito. 


\section{Abstract}

Nicolli, Silvana Castro. Rodrigues, Antonio Edmilson Martins. Architectures of Disappearance. Rio de Janeiro, 2019. 377 p. Tese de Doutorado - Departamento de História, Pontifícia Universidade Católica do Rio de Janeiro.

This dissertation examines the phenomenon of the revival of the aesthetics of transparency in architecture since the 1990s, when the expression of regional and phenomenological aspects has been replaced by a modern, abstract and ethereal language. This revival has been associated with the development of new digital technologies and with post-industrial capitalism, producing dematerialized and unstable urban structures which are independent of their physical construction. Such changes would have rendered the classical tradition paradigms of solidity, functionality and beauty obsolete. The tendency towards the disappearance of the substantial qualities of architecture and the consequent loss of phenomenological references has brought us back to the question of dwelling. The aesthetics of transparency has been associated with the Enlightenment and it presupposes clarity of objects and emancipation of the subject. However, around 1910 , it produced a sense of ambiguity due to the rupture with the concept of Euclidean space. Such a rupture may have been promoted both by the scientific discoveries that unified the dimensions of time and space, and by the dissemination of cinematographic aerial images. These images portrayed the topological space and presented a fragmented reality without perspective. The conception of topological space has also been associated with the feelings of anguish and uprooting of the modern human being. The expression of this pathology in the avant-garde arts has been criticized for fomenting the disarticulation of the political engagement through a method that would promote the loss of a complete vision of reality. Wilhelm Worringer has allegedly developed the method from the notion of the Will to Art expressed as an urge to abstraction, which is related to the concept of topological space. The present study verified that such a change in the conception of space leads to a literal and phenomenal reformulation of the concept of transparency, which is characterized in the arts by the representation of multiple points of view, spatial interpenetration and loss of depth. Phenomenal transparency is nowadays associated with a 
paranoid space, which is developed with the contribution of digital technology in spatial terms and the transformation of bodies according to their connection with virtual reality. Cybernetic technology may be determining a new kind of expression of alienation of the notion of transparency, which we consider to be abject. The early moderns have associated transparency with the expression of Japan-ness, which has been described as essentially interactive. Here we verify some of the Japanese contributions due to their local qualities. Our object of study is the Sendai Mediatheque (2001), by Toyo Ito. This building takes the notion of transparency to the extreme by extending it from the facades to the hollow structures, which is considered an expression of pure space in modern abstract language. Its program is multifunctional and open to change, and the community and other institutional members are involved with the project. Ito's work brings into question the artistic autonomy as well as the loss of social function, which is associated with the aestheticism of modern avant-gardes.

\section{Keywords}

Weak modernity; abstraction and empathy; Unheimlich; abject transparency; aesthetics of disappearance; digital body; participation; Toyo Ito. 


\section{Zusammenfassung}

Nicolli, Silvana Castro. Rodrigues, Antonio Edmilson Martins. Architekturen des Verschwindens. Rio de Janeiro, 2019. 377 p. Tese de Doutorado - Departamento de História, Pontifícia Universidade Católica do Rio de Janeiro.

Die vorliegende Doktorarbeit untersucht das Phänomen der Wiederaufnahme der Ästhetik der Transparenz in der Architektur ab den 1990er Jahren, nach einer Latenzzeit während eine moderne, abstrakte und äthetische Spracheder ersten Avantgarde durch eine andere Sprache ersetzt wurde, die regionale und phänomenologische Aspekte zum Ausdruck brachte. Diese Wiederaufnahme soll mit der Entwicklung neuer digitaler Technologien und dem Nachindustriellen Kapitalismus verbunden sein. Daraus folgt eine entmaterialisierte, instabileStadtstruktur, die unabhängig vom physischen Gebäude ist. Solche Änderungen hätten die Paradigmen der klassischen Tradition mit Solidität, Funktionalität und Schönheit, obsolet gemacht. Die Tendenz der wesentlichen Qualitäten der Architektur zum Verschwinden und der damit einhergehende Verlust der phänomenologischen Bezüge hat uns zur Wohnungsfrage zurückgeführt. Die Ästhetik der Transparenz wurde zunächst mit der Aufklärung verbunden, die die Klarheit der Objekte und die Emanzipation des Subjekts voraussetzte. Um 1910, wird es wird aber zweideutig aufgrund des Bruches mit dem Begriff des euklidischen Raums. Dieser Bruch wurde sowohl durch die wissenschaftliche Entdeckungen der Vereinheitlichung der Dimensionen von Zeit und Raum gefördert, , als auch durch die Verbreitung kinematografischer Luftbilder. Diese Bilder porträtierten den topologischen Raum und präsentierten eine fragmentierte Realität mit Perspektivverlust. Die Konzeption des topologischen Raums war auch mit den Gefühlen der Angst und Entwurzelung des modernen Menschen verbunden. Der Ausdruck dieser Pathologie bei der künstlerischen Avantgarde wird zur Förderung des Abbaus des politischen Engagements durch ein Verfahren kritisiert werden, die den Verlust des Sehvermögens der Gesamtheit der Wirklichkeit fördern würden. Diese Methode soll von Wilhelm Worringer aus dem Begriff der Kunstwollen entwickelt worden sein. Sie ist durch den Abstraktionsdrang ausgedrückt, und ist auf den Begriff des topologischen Raumsbezogen. Diese Studie ergab, dass eine solche 
Änderung in der Gestaltung des Raumes auf die Neuformulierung des Konzepts der Transparenz von wörtliches zu phänomenale führen wird, was in der Kunst durch mehrere Gesichtspunkte, räumlichen Dringen und Verlust der Tiefe gekennzeichnet ist. Phänomenale Transparenz wird gleichzeitig mit paranoidem Raum assoziiert, der mit dem Beitrag der digitalen Technologie in räumlicher Hinsicht und der Mutation von Körpern entsprechend ihrer Verbindung mit virtueller Realität entwickelt wird. Die kybernetische Technologie würde einen neuen Ausdruck der Entfremdung und die Entfaltung des Begriffs der Transparenz bestimmen, was wir als abjekt bezeichnen. Transparenz wurde in der Modernität mit Japan-heit verbunden. Ihr interaktiven Modus wurde in der Geschichte demonstriert. Wir überprüfen in dieser Arbeit einige der japanischen Beiträge mit ihren lokalen Qualitäten. Unser Untersuchungsobjekt ist das Gebäude für die Mediathek in Sendai (2001), von Toyo Ito. Die Mediathek nimmt den Begriff der Transparenz zum Extrem, da ihre Fassaden sich an den hohlen Strukturen erweitert. Diese Strukturen sind ein Ausdruck des reinen Raumes in der modernen abstrakten Sprache. Die Mediathek ist multifunktional und veränderungsfähig, und die Gemeinschaft ist am Projekt beteiligt. Das Werk von Toyo Ito stellt in Frage die künstlerische Autonomie als Verlust der sozialen Funktion entsprechen, die mit dem Ästhetizismus der modernen Avantgarde verbunden ist.

\section{Schlüsselwörter}

Schwache Moderne; Abstraktion und Empathie; Unheimlich; abjekte Transparenz; Ästhetik des Verschwindens; digitaler Körper; Teilnahme; Toyo Ito. 


\section{Sumário}

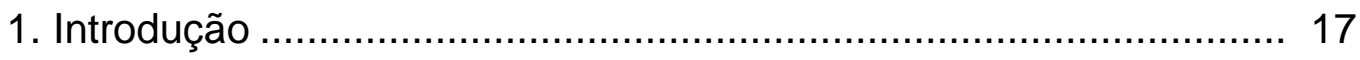

2. Arquiteturas do desaparecimento............................................... 22

2.1. A Metrópole Abstrata........................................................... 22

2.2. Mercado e autonomia artística .............................................. 27

2.3. Estética do desaparecimento ............................................... 40

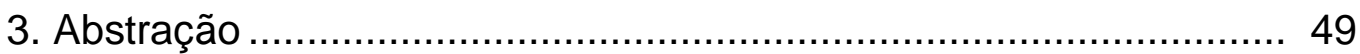

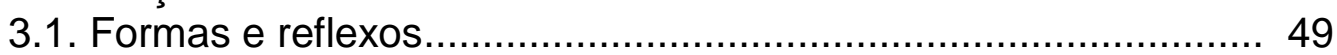

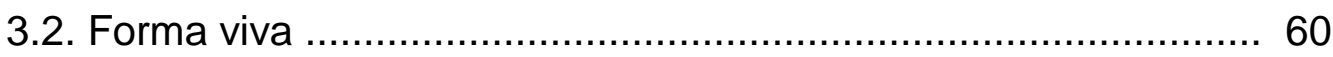

3.3. Vontade e Representação..................................................... 83

3.3.1. Nietzsche e a superação da abstração da vontade na valorização da vida ....................................................... 83

3.3.2. A importância da Estética de Schopenhauer: a matéria como representação da vontade ........................................ 87

3.3.3. Abstração e Empatia .........................................................128

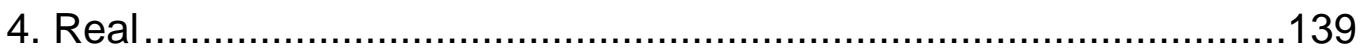

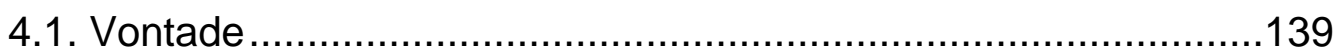

4.2. A linha abstrata gótica..........................................................160

4.3. A Alegoria como abstração …………………………….......169

4.4. Do Expressionismo à realidade virtual .....................................178

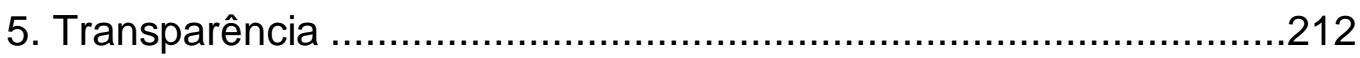

5.1. O mito da Sociedade transparente ........................................212

5.2. Transparência abjeta.............................................................222

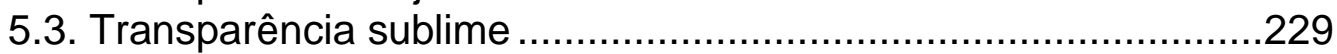

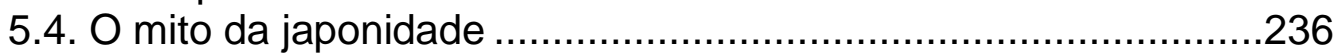

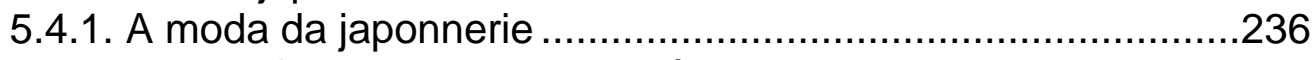

5.4.2. Escuridão e vazio como princípios da vida ..........................249

5.4.3. Japonnerie, japônica e japonidade.......................................256

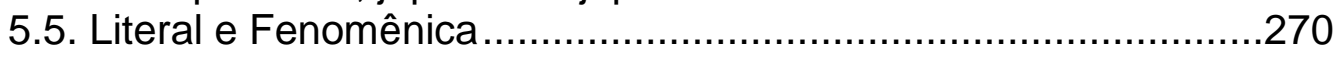

6. Obra analisada com estudo de campo .......................................283

6.1 A Japonização do mundo da arquitetura .....................................283

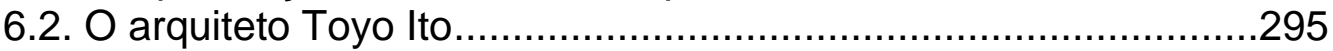

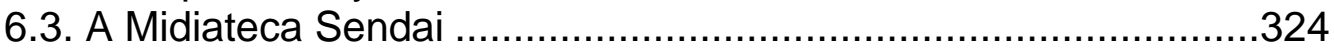

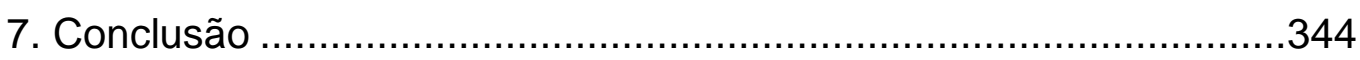

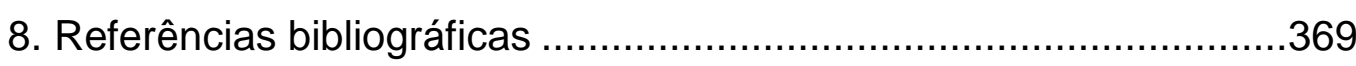




\section{Lista de figuras}

Figura 1: Obras de Hokusai (detalhes): "Il vento"(1830-32)

"Cose che scorrono veloci"(1833)..........................................243

Figura 2: Obras de Hokusai (detalhes): "Il vento"(1830-32)

"Cose che scorrono veloci"(1833). 243

Figura 3: Vista Frontal Santuário Principal de Ise, século VII, Foto de Yasuhiro Ishimoto .243

Figura 4: Palácio Katsura, Quioto. Fotografia de Yasuhiro Ishimoto ........244

Figura 5: Planta de situação, Palácio Katsura, meados século XVII ........244

Figura 6: "Barroco Japonês" do século XVII. Tosho-gu Shrine, Nikko .....245

Figura 7: Memorial da Paz em Hiroshima, Kenzo Tange (1949-1955).....245

Figura 8: Projetos dos edifícios para os clubes noturnos Ichi-Ban-Kan e Ni-Ban-Kan, Minoru Takeyama, 1969 e 1970..246

Figura 9: Projetos dos edifícios para os clubes noturnos Ichi-Ban-Kan e Ni-Ban-Kan, Minoru Takeyama, 1969 e 1970..246

Figura 10: Arata Isozaki: Aquarela da Praça do Tsukuba Centre em ruínas, Ibaragi no Japão (1979-83) .247

Figura 11: Paul Cézanne: O Monte Sainte-Victoire (1904-6) ...................247

Figura 12: Walter Gropius: Bauhaus, Dessau, 1926 .............................248

Figura 13: Projeto de Le Corbusier para Villa Stein de Monzie 1926-29..248

Figura 14: Projeto de Le Corbusier para Villa Stein de Monzie 1926-29..249

Figura 15: Kiyonori Kitutake, Croqui Cidade Marinha, 1959 ....................306

Figura 16: Kiyonori Kitutake, Croqui Cidade Marinha, 1959 ....................307

Figura 17: Projeto de Kazuo Shinohara, Casa em Seijo, 1973 .................307

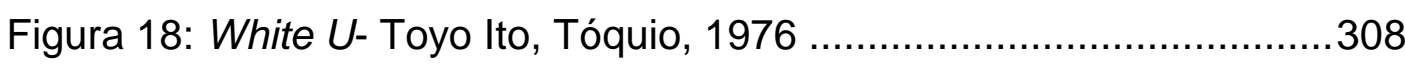

Figura 19: White U- Toyo Ito, Tóquio, 1976 ..........................................309

Figura 20: White U- Toyo Ito, Tóquio, 1976 ..........................................309

Figura 21: Projeto do OMA para a Trés Grande Bibliotèque 1989 ............310 
Figura 22: Projeto do OMA para a Trés Grande Bibliotèque 1989...........310

Figura 23: Projeto do OMA para a Trés Grande Bibliotèque 1989 ...........310

Figura 24: Projeto do OMA para o Zentrum für Kunst und Medientechnologie 1989-92

Figura 25: Projeto do OMA para o Zentrum für Kunst und Medientechnologie 1989-92

Figura 26: Planta de situação, maquete e croquis conceituais Midiateca Senda 2000, Toyo Ito

Figura 27: Maquete da competição, Midiateca Sendai 2000, Toyo Ito.....313

Figura 28: Planta-baixa andares. Midiateca Sendai- Toyo Ito, 2000 ........313

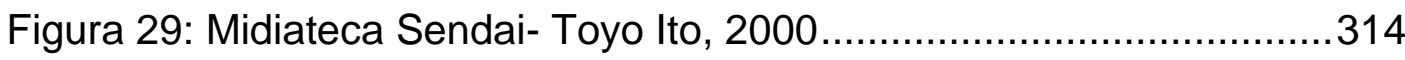

Figura 30: Fachada Principal, Midiateca Sendai- Toyo Ito, 2000 .............314

Figura 31: Visadas em perspectiva da Midiateca Sendai ........................315

Figura 32: Visadas em perspectiva da Midiateca Sendai ........................315

Figura 33: Fachadas Midiateca Sendai ........................................316

Figura 34: Fachadas Midiateca Sendai .........................................316

Figura 35: Fachada Midiateca Sendai ...........................................316

Figura 36: Fachada principal da Midiateca Sendai à esquerda e fachada lateral com tela metálica

Figura 37: Fachada principal da Midiateca Sendai à esquerda e fachada lateral com tela metálica

Figura 38: Fachada de fundos da Midiateca Sendai ...........................317

Figura 39: Fachada de fundos da Midiateca Sendai ............................317

Figura 40: Vista interior estrutura vazada. Midiateca

Sendai- Toyo Ito, 2000

Figura 41: Corte acima e Visada do pavimento da biblioteca,

Midiateca Sendai- Toyo Ito, 2000

Figura 42: Corte acima e Visada do pavimento da biblioteca,

Midiateca Sendai- Toyo Ito, 2000 
Figura 43: Pavimento da Biblioteca. Mezanino com área de estudos Midiateca Sendai

Figura 44: Detalhe do acréscimo da cortina na parte inferior da mesa de estudos. Mezanino no pavimento da Biblioteca da Midiateca Sendai

Figura 45: Midiateca Sendai 321

Figura 46: Midiateca Sendai 321

Figura 47: Exposições escolares na Midiateca Sendai em 2017 321

Figura 48: Exposições escolares na Midiateca Sendai em 2017 321

Figura 49: Exposição na Midiateca com as fotos de danos causados pelo Terremoto de 2011 na Midiateca e na Cidade

Figuras 50: Exposição na Midiateca com as fotos de danos causados pelo Terremoto de 2011 na Midiateca e na Cidade 322

Figura 51: Projeto Tubos, instalação na escadaria interior aos tubos da Midiateca, desenvolvida pela equipe de curadoria 323

Figura 52: Ritual de elevação da Onbashira em Nagano 324 
Lucrécio quer escrever o poema da matéria, mas nos adverte, desde logo, que a verdadeira realidade dessa matéria se compõe de corpúsculos invisíveis. É o poeta da concreção física, entendida em sua substância permanente e imutável, mas a primeira coisa que nos diz é que o vácuo é tão concreto quanto os corpos sólidos. A principal preocupação de Lucrécio, pode-se dizer, é evitar que o peso da matéria nos esmague. No momento de estabelecer as rigorosas leis mecânicas que determinam todos os acontecimentos, ele sente a necessidade de permitir que os átomos se desviem imprevisivelmente da linha reta, de modo a garantir tanto a liberdade da matéria quando a dos seres humanos.

Seis propostas para o próximo milênio: lições americanas, Italo Calvino. 


\section{1. \\ Introdução}

Os limites das cidades contemporâneas dificilmente correspondem a fronteiras físicas nitidamente demarcadas. Tal fenômeno pode ser considerado como efeito da existência de redes de tecnologia, serviços e informações que atravessam tanto o espaço arquitetônico quanto o urbano e que denominamos como correspondente à Modernidade Fraca, tomando de empréstimo a terminologia utilizada pelo arquiteto Andrea Branzi para descrever essa realidade de limites turvos e estrutura instável. Nesse trabalho, verificaremos o impacto causado pela revolução tecnológica desencadeada pelas inovações eletrônicas tanto sobre a arquitetura quanto sobre os corpos e as relações sociais. Entre outras transformações, as novas tecnologias possibilitaram o estabelecimento de relações sociais e econômicas flexíveis, reforçando a tendência instável das configurações espaciais.

Das transformações que podemos perceber sobre a forma arquitetônica contemporânea, podemos ressaltar a tendência a ser tratada como um objeto leve, transparente, pouco estável, um sólido desmaterializado. Tais qualidades associadas à abstração e universalidade da linguagem, herdadas da primeira modernidade, teriam permanecido em latência, ressurgindo a partir dos anos 1990 nos Grandes Projetos da Era Miterrand. A tendência à abstração contraria os fundamentos tradicionais da arquitetura, que se baseiam na ideia do habitar associada ao abrigo protegido, interiorizado, sólido, opaco, tátil etc. Este trabalho se pergunta, a partir da obra da Midiateca Sendai (1995-2000) do arquiteto Toyo Ito, se essa aparente desmaterialização da arquitetura seria efeito de leis onipresentes do mercado, se ela estaria oferecendo a mais nova embalagem da arquitetura, ou se poderíamos considerá-la uma expressão autônoma da arquitetura, poética do habitar nesse novo real, onde nossos corpos se estenderiam através de fluxos eletrônicos invisíveis.

Não só poeticamente, mas também, funcionalmente, os espaços estariam sendo ocupados de modo desmaterializado. A presença dos produtos industriais mecânicos e eletrônicos teria permitido refuncionalizar antigas e modernas construções numa rapidez antes inimaginável. A tecnologia informacional, gerada 
pelo uso de tecnologias eletrônicas, promoveria uma mutação silenciosa na lógica de funcionamento do mundo contemporâneo. A arquitetura precisou rever seus limites disciplinares históricos. Ela não se fundamentaria mais como a "arte da construção”, já que a função de seus espaços poderia ser determinada pela presença dos equipamentos eletrônicos e independeria da forma física da arquitetura. Também a unidade de concepção entre a arquitetura, o urbanismo e os produtos industriais se comprovaria como inviável, dada a possibilidade de subversão promovida pelos produtos eletrônicos. Os fundamentos epistemológicos tradicionais da arquitetura, Forma, Função e Técnica (Solidez), estariam caducos frente ao processo de desmaterialização da arquitetura.

Se, para os expressionistas, a transparência simbolizava a continuidade do espaço social partilhado, hoje ela é interpretada como mais um espectro do exibicionismo, típico da sociedade do consumo e de sua exacerbação na sociedade do espetáculo. $\mathrm{O}$ desaparecimento da solidez e da opacidade arquitetônica seriam o resultado de uma estratégia ilusionista de manipulação de sua forma, expressão do virtuosismo técnico dos arquitetos e resultado do alto investimento financeiro para produzir mais uma forma-mercadoria. O significado da transparência teria se mostrado ambivalente. A dimensão sombria de tal arquitetura teria sido revelada como a outra face da razão e da clareza iluministas através da arquitetura panóptica e da estética do sublime. A estética do sublime espelharia o sentimento de desenraizamento do sujeito moderno, vivido como a experiência psicológica do estranhamente familiar. Tal estranhamento espelharia também a morte do sujeito como preâmbulo da condição do sujeito-ciborgue contemporâneo e sua alienação. Assim, colocamos em questão neste trabalho a persistência do referencial antropomórfico, herdado da tradição clássica, como medida da alienação do sujeito.

A expressão de transparência, que marcou a arquitetura da primeira modernidade, estaria relacionada à incorporação de uma nova concepção de espaço. Os anos em torno de 1910 teriam correspondido ao desenvolvimento do espaço topológico incorporado a partir de descobertas científicas, que associavam tempo e espaço, e da experiência da visão em movimento, proporcionada pelos meios mecânicos. $\mathrm{O}$ espaço se apresentaria como fragmentado, remetendo à perda 
de perspectiva que teria dominado a concepção do espaço euclidiano desde o Renascimento. A referência à fragmentação da realidade servirá também para expressar a condição patológica do sujeito metropolitano e se manifestará na arte pela tendência à abstração. Tal tendência será associada ao conceito do impulso para a abstração, desenvolvido por Wilhelm Worringer, e associado às artes primitiva e gótica. O impulso para a abstração seria associado ao medo do espaço e seria criticado pelo filósofo György Lukács por fomentar a ideologia de fuga e de intermediação que teriam promovido a desarticulação revolucionária e facilitado o estabelecimento do Fascismo. Tal crítica é recuperada hoje e associada à abstração da realidade proporcionada pelos meios digitais. Geoffrey Waite e Anthony Vidler associam a abstração à perda das referencial do corpo orgânico, da imagem do homem e da mobilização social. Retomaremos o debate sobre o impulso para a abstração, iniciado nos anos 1930, para avaliar o impacto que a abstração pode ter tido sobre o aparato sensório corporal e sobre a função social da arte.

A vontade de expressar a nova concepção de espaço levará ao desenvolvimento de uma técnica, iniciada pela pintura cubista e traduzida na noção de transparência. Tal técnica implicava em romper com a visada naturalística, associada à perspectiva; à percepção da totalidade e da profundidade espacial. Na arquitetura, ela teria implicado no desenvolvimento de um dispositivo que implicava na percepção do espaço segundo as qualidades topológicas da visão aproximada e fragmentada, que representaria a visão em movimento e a apreensão de múltiplos pontos de vista simultâneos determinando a interpenetração e ambiguidade espacial. Os arquitetos Colin Rowe e Robert Slutzky distinguem tal noção de transparência ambígua e fenomênica no contraste com a literal, que desenvolveremos neste trabalho a fim de recolocar a questão da alienação associada à transparência da Midiateca Sendai.

A arquitetura japonesa teria sido descrita e incorporada à arquitetura mundial sob o signo da japonidade como transparente, leve e funcional. A construção da japonidade teria dependido da relação dos arquitetos japoneses com o olhar estrangeiro e teria sido contrariada diversas vezes em função da mudança do contexto político e mesmo da relação com esse olhar, que hoje não seria 
determinado pelo exotismo inicial. Examinamos a discussão sobre a japonidade a fim de nos aproximarmos da arquitetura através da linguagem e dos conceitos utilizados pelos arquitetos japoneses. Retomamos os ensaios e textos teóricos do arquiteto Toyo Ito, assim como de seus críticos, e aqueles do arquiteto Arata Isozaki por sua qualidade de historiador. A pesquisa contou ainda com uma pesquisa de campo, correspondendo à visita da obra durante vários dias em que foram feitos levantamentos fotográficos. Tentou-se através desse método promover uma abertura para a obra e cuidar para que ela sobrevivesse ao olhar de pesquisador.

A tese se estruturou em função do problema colocado pelo significado ambíguo da transparência e da necessidade de compreendê-lo para situar a obra de Toyo Ito. Assim, temos uma história do conceito associado à arquitetura ocidental, que foi projetado sobre a japonesa, e outra desenvolvida pelos arquitetos japoneses. A análise da Midiateca derivou dessas duas abordagens e o capítulo final (6) corresponde à síntese desses dois momentos.

O capítulo inicial (2), Arquiteturas do desparecimento, apresenta a problemática da arquitetura na Era Digital, sua relação com a cidade, o mercado, com a política e com as artes; colocando a questão da possibilidade do habitar.

O capítulo seguinte (3), Abstração, representa um retorno à Querela dos Universais estendida na tentativa de solução do dualismo entre concreto e abstrato e entre corpo e espírito através do conceito de Vontade como coisa em si, definido por Schopenhauer. Assim preparando o instrumental para verificar nos capítulos seguintes se a abstração artística corresponderia à alienação do corpo ou do sujeito.

No capítulo (4), Real, partimos para o debate sobre o Expressionismo, através do qual questões importantes para o desenvolvimento do conceito de transparência são apresentadas: o conceito do impulso para a abstração, a fragmentação e abstração da realidade nas obras vanguardistas, a alegoria, o fragmento crítico, a crise do conceito de espaço euclidiano, a noção de participação associada ao desejo e não à necessidade, a perda da função social da arte e a tendência ao esteticismo patológico. 
No capítulo (5), Transparência, recolocamos o problema da fragmentação da realidade, associado às novas mídias de comunicação, e da crise dos conceitos de progresso, da metafísica da verdade e do sujeito transcendente. Apresentamos o conceito da transparência abjeta como um desdobramento da transparência sublime e fenomênica na arquitetura contemporânea. Discutimos o mito da japonidade e apresentamos os conceitos da transparência fenomênica e literal.

E finalmente, no capítulo (6), fazemos um esforço de interpretação da Midiateca Sendai. 


\section{2.}

\section{Arquiteturas do Desaparecimento}

\section{1.}

\section{A Metrópole abstrata}

O fenômeno da globalização, seja ele entendido pelo recorte da integração econômica ou da cultural nos permite pensar que estamos ocupando um espaço contínuo, constituído por redes de tecnologia, serviços e informações que se sobrepõem às fronteiras nacionais demarcadas. Tal conjuntura nos leva a pensar a arquitetura contemporânea em termos de um único fenômeno universal, cujo ciclo se inicia no século XVIII com a Revolução Industrial e seu impacto sobre a produção arquitetônica. $\mathrm{O}$ desenvolvimento da arquitetura moderna pode ser entendido como uma resposta a questões da técnica, da linguagem e do programa social trazidos pelo processo de industrialização. Assim, ao escolher tratar de arquitetos japoneses contemporâneos, tentarei inicialmente evocar o que suas obras nos trazem em termos de continuidade com o movimento moderno como fenômeno mundial que se desenvolve até o período contemporâneo, que denominarei de Modernidade $\mathrm{Fraca}^{l}$, e que fora organizado em torno da temática da revolução tecnológica, da configuração espacial decorrente das novas relações de trabalho e do desenvolvimento de um instrumental de linguagem abstrata e universal. Desse modo, pretendo distinguir duas dimensões em minha análise sobre o tema da desaparição da arquitetura: aquela que se constitui como fenômeno da realidade contemporânea diante do uso das novas tecnologias digitais, daquela que surge evocando significados histórico-culturais locais e de fertilização por outras culturas, que aparecerão diante da análise aproximada das obras.

Se o paradigma da arquitetura moderna era primordialmente mecânico, hoje tornou-se sobretudo, eletrônico e não se esgota num sistema fechado, sólido e material. A realidade contemporânea pode ser descrita também como Modernidade Líquida ${ }^{2}$, fluida, constituída por fluxos, que atravessam corpos

\footnotetext{
${ }^{1}$ Conforme descrita pelo arquiteto de teórico Andrea Branzi. Weak and Diffuse Modernity: The World of Projects at the beginning of the 21st Century. NY: Rizzoly, 2006.

${ }^{2}$ BAUMAN, Zygmunt. Modernidade Líquida. SP: Zahar, 2001.
} 
interligados e não necessariamente homogêneos, tais como os corpos humanos e os dos computadores, controles remotos, carros, aviões etc.

A Modernidade Líquida é marcada pela transitoriedade e precariedade das relações tanto no âmbito individual quanto social e econômico. Os mercados livres e flexíveis são parte desse sistema que alimenta e é alimentado pelo desejo de consumo e pela necessária e crescente obsolescência dos produtos. Tal sistema impede planejamentos a longo prazo e implica uma reestruturação da disciplina arquitetônica, entendida, desde o Renascimento, como aquela que anteciparia, através do desenho e seus desígnios, a realidade construída. A produção, de um modo geral, ocorre de maneira difusa na contemporaneidade. Diferente da estrutura da sociedade industrial, ela independe das grandes organizações que se concentravam em determinado limite geográfico. A necessidade de flexibilização da economia promoveu um desmantelamento dessas estruturas. As atuais estruturas são provisórias e dispersas e se interconectam virtualmente, compostas por agentes terceirizados e microempreendedores que precisam ser constantemente reinventados. A grande massa de trabalhadores dispensados das grandes fábricas e escritórios tendem a se recolocar no mercado atual informalmente. A tecnologia de rede possibilita a entrada desses trabalhadores de forma independente, pela oferta de produtos e serviços $e$-comercializados e, às vezes, de microinvenções. Eles seguem um modelo de autonomia antes comum somente entre os artistas, que deviam se auto empreender. Desse modo, se relacionam com grandes empresas, que se renovam através de uma estrutura descentralizada. No mundo da modernidade neoliberal, há pouca ou nenhuma estrutura econômica e social garantida pelo Estado. O Estado tende a uma posição secundária, garantindo as liberdades individuais apenas pela observação da livre concorrência no mercado. Tal modernidade difusa choca todas as expectativas de ordem sonhada pelos progressistas dos séculos XVIII e XIX, que imaginavam que as revoluções desencadeariam a propagação de um modelo distinto e racional, ancorado nos valores Iluministas. 
Para o arquiteto e teórico, Andrea Branzi ${ }^{3}$, teríamos, do período da Revolução Francesa até a Queda do Muro de Berlim, vivido o que ele chama de Modernidade Forte, caracterizada pela internalização humana da experiência de movimento da máquina. A tecnologia mecânica pressupôs "a forte fricção dos corpos e a tensão das engrenagens" e representou para os modernos, ao ser internalizada, o modo de mudar a história e transformar o mundo. Para Branzi, a força revolucionária desses homens se pautava na crença inabalável de que estavam desvelando a Verdade encoberta por um sistema hipócrita que deveria ser destruído, à direita ou à esquerda. Vivemos hoje num mundo sem certezas políticas e morais, mas dispomos da energia fraca e difusa que age sem estrondos e que "cria forças similares àquelas criadas pelas estrelas, a lua, e os planetas, capazes de se mover a cada noite e todos os oceanos sem produzir um único som." ${ }^{\prime 4}$

A denominada Modernidade Fraca não deve ser vista apenas negativamente. Para Branzi, não dispomos de soluções totalizantes e gigantescas como a modernidade anterior, mas apenas daquelas fracas e abertas. Estas soluções requerem muita energia criativa porque não se elevam sobre sedimentos cognitivos anteriores, podem ser exemplos tanto da riqueza do improviso quanto da precariedade do sistema. O conhecimento não se desenvolve por meio de sínteses modernistas e sim como matéria dúctil e transformável. A tecnologia informacional, gerada pelo uso de tecnologias eletrônicas "volteicas", se aproxima da fisiologia do cérebro humano e promove uma mutação silenciosa na lógica de funcionamento do mundo contemporâneo imerso em redes. Ela estabelece um tipo de lógica fraca que modifica a configuração da arquitetura, que se determina agora como não-composicional e anti-tipológica. A arquitetura contemporânea se caracteriza como uma "enzima capaz de transformar um vasto terreno de acordo com os critérios de reversibilidade e navegabilidade, completamente novos a respeito dos limites tipológicos, físicos e reforçados da modernidade clássica. ",

\footnotetext{
${ }^{3}$ Membro de 1966-74 do grupo italiano de arquitetura radical, Archizoom

4 "A Strong Century" em BRANZI, Andrea. Weak and Diffuse Modernity: The World of Projects at the beginning of the 21st Century. NY: Rizzoly, 2006.

${ }^{5}$ Idem, ibidem.
} 
Seria, pois, um equívoco tomar a arquitetura contemporânea a partir de paradigmas da modernidade clássica, tais como o primado do ato de edificação, "da construção de espaços visíveis", e quando procura se atribuir a função de depositário de códigos figurativos e simbólicos. A metrópole contemporânea não seria observável nem a partir do paradigma tectônico, nem do formal ${ }^{6}$ e sim a partir de questões fisiológicas internas do organismo urbano, que escapam ao que se entendia como questões espaço-funcionais. $\mathrm{O}$ mundo da arquitetura se encontraria, portanto, cada vez mais desligado do mundo dos objetos e da cidade. As tentativas dos primeiros modernos de unificar arquitetura, urbanismo e objeto afinal não resistiram: essas três entidades se tornaram autônomas. Os objetos e os instrumentos eletrônicos alteraram por completo o funcionamento das cidades; evidentemente, os princípios clássicos que regiam a arquitetura têm que ser repensados. Inexiste a relação entre forma e função: “o computador não tem uma função, mas funções tão numerosas quanto as necessidades do operador. Nós saímos da era do funcionalismo para a era dos funcionoides, instrumentos que não possuem um função única, mas tantas funções quanto as necessidades do operador. ",

Branzi propõe uma arquitetura Não-Figurativa e não compositiva. Ela seria enzimática, capaz de modificar o território urbano sem se restringir aos limites edificados e aos códigos figurativos. Corresponderia a um sistema aberto e ambiental, que penetraria transversalmente o território, que não se identifica mais com limites físicos. O programa seria determinado sem ideologias ou metafísicas, e sim pelo resultado de uma "energia genética difusa". Tal arquitetura iria além de si própria com a contribuição da realidade imaterial das redes de computadores "que criaram de fato uma metrópole dinâmica, invisível e abstrata, que está progressivamente substituindo (ou movendo para o fundo) a metrópole fisica e figurativa. ",

A determinação dos espaços contemporâneos pelos objetos industriais subverte tanto a tradicional disputa pela hierarquia existente entre a arquitetura e o urbanismo sobre si e sobre os objetos quanto a unidade desses elementos

\footnotetext{
${ }^{6}$ Trataremos os dois paradigmas no item seguinte: Firmitas, Utilitas, Venustas.

7 "For a Non-Figurative Architecture". Idem, ibidem.

${ }^{8}$ Idem, Ibidem.
} 
pressuposta pelos arquitetos modernos ${ }^{9}$. Tal unidade de concepção, que englobava o design de produtos, a arquitetura e o urbanismo, chegou ao fim, numa inevitável crise disciplinar. Cada um desses elementos segue agora sua própria lógica e são os produtos industriais que assumem, muitas vezes, um papel preponderante. Caducaram os fundamentos epistemológicos da arquitetura, que se pautavam nos princípios da Forma, Função e Técnica (Solidez). O design contemporâneo não se desenvolve como algo subordinado à construção, tanto em termos de sua organização na cadeia produtiva que coloca os designers como autônomos, quanto pelo próprio modo de conceber por meio da tecnologia digital que permite, por exemplo, a inversão da ordem de projetação pela ferramenta do zoom, que possibilita a antecipação do detalhamento em relação às disposições gerais. Tal "estado esquizofrênico do mundo do design" requalificaria a arquitetura como algo diferente da "arte da construção", podendo ser entendida como "processo de pensamento cognitivo mutante" que se refere "às energias fracas e difusas de transformação do relevo e do espaço". A relação entre o mundo virtual e a sólida realidade construída se altera, dado que o espaço urbano cada vez mais é tomado pelos sistemas virtuais de informações, serviços e redes relacionais de forma independente da arquitetura enquanto sólido construído. Arquitetura seria agora um diafragma transponível que separa os serviços urbanos de rede e virtuais e os espaços internos dos sistemas operativos, dos utensílios ambientais adaptáveis às mutações contínuas das funções sociais e produtivas. A arquitetura tende a desempenhar um papel perimetral, operando como interface de dois processos formativos da dinâmica urbana: um filtro a ser pensado como líquido e como realidade transponível e reversível. Ela não determinaria soluções definitivas e teria, sim, um papel ativo aberto para disposições futuras. Para tanto, ela se via obrigada a ultrapassar seus limites disciplinares históricos.

\footnotetext{
${ }^{9}$ Unidade prevista método da Bauhaus e defendida por Le Corbusier. Para Giulio Argan, o que determinava tal unidade no sistema era a Função Social. O Racionalismo na arquitetura de Walter Gropius se justificava pela função social-urbana. ARGAN, Giulio C. Projeto e Destino. São Paulo: Editora Ática, 2004.
} 


\section{2.}

\section{Mercado e autonomia artística}

\section{Disciplina, autonomia na arquitetura e mercadoria}

O mais antigo tratado de arquitetura a que tivemos acesso é o vitruviano. Foi dedicado ao imperador Otávio Cesar Augusto, para que o orientasse na execução de obras à altura de sua grandeza, mas destinava-se também aos eruditos e às pessoas comuns que desejassem se precaver frente a profissionais despreparados ou mal-intencionados. Segundo Vitrúvio, seu tratado explicava todos os preceitos da arquitetura, cuja disciplina consistia da obra de edifícios públicos e privados, bem como da gnomônica e da mecânica. Dentre as obras públicas, estariam as fortificações, as obras de utilidade pública e as religiosas. Soldado do exército romano, ele teria se ocupado da construção de pontes, testemunhado a construção de aquedutos e a escolha de lugares apropriados para futuras cidades imperiais. Efetivamente, seu tratado incluía todos os temas depois tratados pelos arquitetos modernos e mais as obras de engenharia. Excetuando as orientações astrológicas, seu tratado até o início do movimento moderno era considerado, guardadas as devidas proporções, relativamente atual. A tríade vitruviana, Firmitas, Utilitas e Venustas, constituía a base fundamental da arquitetura. A Solidez estaria relacionada aos princípios técnicos empregados para manter o equilíbrio estático ou elástico do edifício, a funcionalidade diria respeito à boa distribuição da planta-baixa e a beleza para muitos arquitetos modernos manteria aquela qualidade agradável da Eurritmia, obtida através do respeito à lógica das comensurabilidades: "Pois nenhum templo poderá ter esse sistema sem conveniente equilíbrio e proporção e se não tiver uma rigorosa disposição como os membros de um homem bem configurado. " ${ }^{10} \mathrm{O}$ pé deste homem bem configurado corresponderia à sexta parte de sua altura. $\mathrm{O}$ número seis era considerado um número perfeito para alguns matemáticos gregos. Para Platão, contudo, seria o número 10, que por perfeição da natureza também corresponderia à altura da cabeça em relação ao corpo do tal homem bem configurado. Já os romanos concluíram que se 10 e 6 constituíam módulos perfeitos, perfeitíssimo seria o número 16 e o módulo do pé, que tem 16 dedos. Esta noção arbitrária ou abstrata da escala humana somente seria questionada no

${ }^{10}$ Vitruvius, Pollio. Tratado de Arquitetura/Vitrúvio. Tradução M. Justino Manoel. SP: Martins, 2007. 
século XIX, quando Choisy recomenda tomar como parâmetro o uso e certa consciência de ergonomia ${ }^{11}$. No entanto, as relações de proporções, retiradas da tradição clássica, tais como a proporção áurea e os traçados reguladores nas fachadas continuarão a ser usadas pelos arquitetos modernos, como Le Corbusier, ainda que afirmasse, contraditoriamente, que "a planta é geradora". Do mesmo modo, a noção de Firmitas, ou o princípio técnico, é repetida como se estivéssemos tratando do mesmo grau de consciência tectônica do mundo greco-romano, quando a maior parte das soluções estruturais eram determinadas no canteiro de obras e as prescrições de Vitrúvio eram relativas mais à racionalização do canteiro e à disponibilização de materiais necessários a obras. Alguma noção da resistência dos materiais estava presente, assim como noções empíricas do comportamento estrutural de determinados materiais, nada comparável, entretanto, à autonomização do projeto estrutural feita parcialmente a partir do Renascimento e, mais integralmente, a partir do cálculo estrutural já no século XVIII, graças ao cálculo diferencial. É justamente nessa época, a partir do período da Revolução Industrial, que as bases naturalistas do tratado vitruviano e seus descendentes começam a ser desveladas. Tanto o cálculo, como o aparecimento dos materiais industrializados, modificam o modo de construir e projetar. Mesmo a racionalidade objetiva da beleza não passa incólume ao século das Luzes, sendo antagonizada àquela do saber construtivo. A arquitetura passa a oscilar entre os campos da Engenharia e das Belas-Artes. O foco do debate arquitetônico se desvia gradativamente das qualidades e regras formais para interpretações que contextualizavam o uso racional das formas históricas e técnicas construtivas, considerando sua interação com determinantes da natureza. Alguns arquitetos no século XIX reivindicarão o campo da verdade da racionalidade construtiva, tais como Viollet-Le-Duc (1814-1879) e August Choisy (1841-1909), reconhecendo-a nas soluções de canteiro góticas e abrindo campo para reintegração com a engenharia. Viollet-Le-Duc identificava nas obras góticas a existência de um esqueleto estrutural-formal que se estenderia coerentemente aos detalhes, que caracterizava o estilo e que corresponderia diretamente à dinâmica das forças em ação na edificação. Esse enfoque construtivo ainda teve desdobramentos mais radicais como a redefinição da

${ }^{11}$ BANHAM, Reyner. Teoria e projeto na primeira era da máquina. São Paulo: Perspectiva, 2003. 
própria noção da arquitetura, conforme apresentada por Gottfried Semper (18031879), a partir de elementos construtivos (aterramento, lareira, cobertura e vedação) e mesmo a partir de uma noção de demarcação territorial, que ultrapassava a noção de abrigo contra as intempéries e da necessidade de socialização, presentes em Vitruvio. Para Semper, o modo de construir dos povos expressava também seu sentido existencial. A fachada, enquanto pele e símbolo aparente forneceria o significado do edifício e não sua disposição interna, demanda do cliente, ou suas colunas. O passado têxtil da habitação humana seria a base para essa redefinição que tomava a fachada como meio expressivo subjetivo e coletivo, através da reinterpretação dos tipos retirados do passado.

É claro que os estilos históricos, qualificados por seus ornamentos, dominavam o cenário arquitetônico da época. Mas começava-se gradativamente a colocar em questão a arbitrariedade desses estilos frente à complexidade dos novos programas apresentados pela sociedade industrializada e a necessidade de resolvê-los a partir da planta-baixa ${ }^{12}$. Nessa época, não somente as coletâneas com tipos de ornamentos estão à disposição dos arquitetos, como também dicionários tipológicos relativos às plantas baixas de arquiteturas históricas abstraídas, que poderiam ser adaptadas para novas funções. O termo "Forma"13 substituirá a noção de beleza da tríade vitruviana, associada até então às referências de tipo, caráter e estilo. Técnica, Função e Forma tomarão a pauta moderna, ainda ancorada na relação com a estabilidade do abrigo, a funcionalidade do espaço e a beleza, estética, ou plástica de suas formas.

Até a Revolução industrial, podemos inferir que a discussão sobre a Forma, ou beleza ${ }^{14}$, segue preponderante. Quando a industrialização da

\footnotetext{
${ }^{12}$ Durand, Jean-Nicolas-Louis. Recueil et parallèle des edifices de tout genre ancien et modernes. 1800. Durand (1760-1835)

13 "Choisy: racionalismo e técnica" em BANHAM, Reyner. Teoria e projeto na primeira era da máquina. São Paulo: Perspectiva, 2003.

${ }^{14}$ 1.PLATÃO, Hípias Maior. Lisboa: edições 70, 1989. O Belo em si platônico existiria apenas no Mundo das Formas ou Ideias. As dimensões manifestas do Belo seriam parciais, mas poderiam promover a ascese, se: correspondessem ao ideal de racionalidade presente nas leis de comensurabilidade, se fossem agradáveis aos sentidos (mais puros: ouvido e visão) e se promovessem o bem, se fossem úteis. Pode-se inferir, nesse caso, que o Belo é uma Forma (Ser, essência e universal) passível apenas de intuição, não reprodutível. Nesse sentido, contradiz a noção de Belo moderna, influenciada pela teoria aristotélica que distingue Forma e matéria, como constituintes da Substância como um todo que define a essência das coisas. Um universal não
} 
construção e a disseminação das técnicas de concreto armado e aço se mostraram um fato consumado e, aparentemente, irrevogável no início do século XX, o paradigma da Função se torna preponderante e a ênfase é dada ao espaço. Para aqueles modernos que não se filiam à vertente estritamente produtivista, como os arquitetos ligados ao grupo $\mathrm{ABC}$, a discussão é centrada numa concepção plástica do espaço, conforme definida pelos neoplasticistas:

A nova arquitetura é elementar, quer dizer, ela se desenvolve, a partir de elementos do edifício no sentido amplo. Esses elementos - tais como função, massa, superfície, tempo, espaço, luz, cor, material etc. - são plásticos. (...)

A nova arquitetura não tem forma, e ainda assim é claramente definida, quer dizer, não é sujeita a qualquer tipo formal estético fixo. (...)

O espaço funcional é estritamente dividido em superfícies retangulares não tendo individualidade por si. Apesar de cada uma ser fixada na base das outras, elas devem ser vistas como extensíveis infinitamente, pois formam um sistema coordenado no qual todos os pontos correspondem ao mesmo número de pontos no universo. Daí segue que as superfícies têm uma conexão com o espaço infinito. ${ }^{15}$

Essa noção do espaço universal então almejada estava ancorada num desejo de democratização da arquitetura, conforme vinha sendo sonhada pelos expressionistas da Catedral de Vidro:

Vivemos na maior parte dentro de espaços fechados. Estes formam o ambiente do qual nossa cultura cresce. Nossa cultura é em certo sentido um produto da nossa arquitetura. Se quisermos elevar nossa cultura para um nível superior, nós somos forçados para o bem ou para o mal a transformar nossa arquitetura. E isso só será possível se nós removermos a qualidade fechada dos espaços dentro dos quais nós vivemos. Isso só será possível através da introdução da arquitetura de vidro que permite a luz do sol e a luz da lua e das estrelas nos nossos aposentos não meramente através de poucas janelas, mas simultaneamente através do maior número possível de paredes que são feitas inteiramente de vidro - vidro colorido.

seria uma substância, não seria uma coisa. "A substância de cada coisa é aquela qual peculiar a ela, que não pertence a nada mais, mas o universal é comum, já que é chamado universal o que é tal o que pertence a mais de uma coisa. " Para Aristóteles as Formas seriam substanciais, os universais não; a Forma dá unidade à matéria; Forma é substância. Matéria é potencialmente uma forma. Contrariando Platão, as Formas se atualizariam (realizariam) no Mundo Fenomenológico, com exceção de Deus, que é puro pensamento. ARISTÓTELES em RUSSEL, B. History of Western Philosophy. NY: Routledge, 2002. P.176.

2. Até a revolução industrial, a criação artística é praticamente sinonímia da criação de BelasFormas (Gestalt, shape). Já no período moderno, Max Bill sugere que a beleza participa da elaboração da "Boa Forma", segundo a equação: "Forma, Função, Beleza=Gestalt", (1958). BILL, Max. Architecture Words. Form, Function, Beauty = Gestalt. London: AA Publications, 2010.

${ }^{15}$ VAN DOESBURG, Theo. “Towards a Plastic architecture”. (1924) Tradução livre. 
O novo ambiente que deveremos criar através dele deverá trazer consigo uma nova cultura. ${ }^{16}$

A transparência, a interpenetração de espaço interiores e exteriores eram sinais de uma arquitetura a ser compartilhada. Mesmo a economia e racionalização da construção que dominaram os discursos das variadas vertentes modernas do período visavam tal democratização. Se, por um lado, os processos de produção industrial e de metropolização levavam à alienação do homem, por outro, a utilização da tecnologia industrial poderia salvá-lo, acreditavam os arquitetos progressistas. É claro que muito do caráter experimental dessas primeiras modernidades se perdeu, principalmente no que tange às pesquisas mais voltadas para questões tectônicas, conforme se via nas obras Construtivistas. Tendeu-se à padronização e simplificação construtivas a fim de efetivamente atender à demanda da massa, tal como se via defendida pelo arquiteto Hannes Meyer, substituto de Walter Gropius na direção da Bauhaus:

\footnotetext{
“a edificação é um processo biológico. edificação não é um processo estético.

no seu design a nova habitação se torna não somente uma "máquina de morar", mas também um aparato biológico servindo às necessidades do corpo e da mente.

a nova era provê os novos materiais do edifício para o novo modo de construir casas:(...)

nós organizamos esses materiais para a edificação num todo construtivo baseado em princípios econômicos. Logo a forma individual, o corpo da estrutura, a cor do material e a textura da superfície desenvolvem-se por elas mesmas e são determinadas pela vida. (comodidade e prestígio não são motivos temáticos para a construção habitacional) ( a primeira depende do coração humano e não das paredes do espaço) (o segundo manifesta ele mesmo no modo do anfitrião e não por seu tapete persa!)

a arquitetura como "um ato emocional do artista" não tem justificativa.

a arquitetura como "uma continuação das tradições da edificação" significa ser levada pela história da arquitetura.

essa interpretação funcional, biológica, da arquitetura como dando forma às funções da vida, logicamente leva à pura construção: o mundo das formas construtivas não conhece países nativos. É a expressão de uma atitude internacional na arquitetura. Internacionalidade é um privilégio do período.

pura construção é a base e a característica do novo mundo das formas.
}
1. vida sexual
5. higiene pessoal
9. cozinhar

${ }^{16}$ SCHEERBART, PAUL. “Glass architecture”. (1914). CONRADS, ULRICH. Programs and manifestoes on $\mathbf{2 0}^{\text {th }}$-century architecture. Tradução livre. 

2. hábitos de dormir
6. proteção climática
10. aquecimento
3. animais de estimação
7. higiene na casa
11. exposição ao sol
4. jardinagem
8. manutenção do carro
12. serviço $(\ldots)^{\prime \prime}{ }^{17}$

O Funcionalismo arquitetônico será enormemente criticado a partir dos anos 1950, exatamente após sua aplicação em larga escala após a Segunda Guerra. No interior dos próprios Congressos Internacionais de Arquitetura Moderna (CIAM), onde inicialmente dominaram os preceitos racionalistas e funcionalistas, é que se levanta a crítica sobre o mecanicismo resultante das soluções modernas. O grupo dissidente TEAM X (1953-1981) se forma em torno dessa crítica, entre os membros do grupo está o casal Smithsons ${ }^{18}$, que aponta a baixa qualidade de vida desenvolvida em muitos dos conjuntos habitacionais modernistas então construídos, defendendo o tratamento da arquitetura e do urbanismo como um sistema unitário configurado em função das características particulares dos lugares, das associações humanas, das necessidades de mobilidade e de interação com a natureza. $\mathrm{O}$ resultado dessas considerações os leva a dar ênfase aos espaços intermediários como pontos estratégicos de atuação, definidos por eles como "espaços vazios carregados" (Charged Voids).

Robert Venturi e Denise Scott Brown também criticarão a ênfase dos modernos sobre as qualidades abstratas do espaço. Eles também vêm o espaço construído existente como base para o desenvolvimento do projeto, considerando, como os Smithsons, as contribuições iconográficas da cultura pop.

\footnotetext{
${ }^{17}$ MEYER, HANNES. Building. (1928). CONRADS, ULRICH. Programs and manifestoes on $2^{\text {th }}$-century architecture. Tradução livre.

${ }^{18} \mathrm{O}$ casal pertencia ao grupo dissidente Team $\mathrm{X}$, que se formou a partir de um movimento de crítica dos preceitos abstratos do urbanismo defendido nos CIAMs por uma geração de modernos anteriores. Eles defendiam uma abordagem urbanística que considerasse os laços comunitários, contrariando o planejamento urbano para sociedade de massas de influência marxista. Eles também criticam o academicismo formalista dos primeiros modernos, ainda que seguissem a tendência corbusiana do concreto aparente. Utilizavam elementos da linguagem moderna despidos do detalhamento, deixando instalações estruturas evidenciadas, o que definia a estética do feio do chamado Novo Brutalismo. Eles estavam preocupados em desenvolver uma imagem que comunicasse e nesse sentido têm pontos em comum com o chamado Populismo de Venturi (ainda que sua estética não fosse popular), noutro sentido, inspiravam-se na Art Brut de Jean Dubuffet, Jackson Pollock, Alberto Burri. Diferente do Brutalismo de Le Corbusier, ligado a um teor primitivista-historicista e seu viés artístico, os Smithsons estavam preocupados com o Paralelo Arte e Vida, com objeto em si da arquitetura e seu reflexo sobre as associações humanas e não com as qualidades abstratas da beleza, buscando coerência visual por meios não-formais e definindo composição de aparente casualidade, mas na verdade determinada por princípios geométricos não euclidianos, topológicos, que incorporam a valorização dos espaços de circulação e movimento que dominariam o mundo contemporâneo. BANHAM, R. The New Brutalism by Reyner Banham. The Architectural Revew. (1955)
} 
Robert Venturi e Denise Scott Brown fizeram a crítica da arquitetura enquanto expressão do gênio criador (arquitetura como "o pato"). Eles defendem a legitimidade do "Galpão decorado", arquitetura voltada para estrada (Strip), desenvolvida espontaneamente pelos comerciantes americanos. A complexidade e a contradição de meios construtivos e da expressão formal seriam os modos adequados de expressão relativos ao mundo contemporâneo ${ }^{19}$. Ainda seguindo a crítica do espaço abstrato moderno e do funcionalismo, podemos citar o arquiteto italiano, Aldo Rossi (1931-1997), que criticará o "funcionalismo ingênuo" dos modernos e defenderá uma arquitetura que expresse formalmente aspectos racionais e irracionais do homem e da sociedade. A Forma não se resumiria a suas premissas abstratas e sim enquanto Fato urbano ${ }^{20}$, cujas referências formais carregam consigo um conteúdo histórico individual e coletivo.

Os anos 1960 assinalam um questionamento acerca das instituições envolvidas na produção arquitetônica: as instituições de Ensino, instituições de Poder, instituições Econômicas. Esse questionamento leva os arquitetos a duvidar da propalada autonomia da arquitetura e a desenvolver diferentes estratégias, inclusive seu abandono como instrumento de resistência. Os integrantes do movimento Situacionista, antes de dissolver-se internamente, propunha nos anos 1950/60 uma série de experiências de apreensão do espaço urbano através de estratégias tais como a Deriva ${ }^{21}$ Queriam com isso oferecer uma dimensão diferente do espaço construído, apreendido de forma alienada através do condicionamento imposto pela configuração setorizada da cidade industrial moderna, que define o traçado da cidade opondo lazer, trabalho, comércio etc. Tais experiências evocam a psicogeografia dos espaços, que seria a revelação da "função psicológica da ambiência" através do comportamento "lúdico-construtivo" de suas proposições.

Os trabalhos dos grupos italianos cunhados pela mídia internacional como Architettura Radicale, composto pelos escritórios Archizoom e Superstudio,

\footnotetext{
${ }^{19}$ Em 1966, publica VENTURI, Robert. Complexidade e Contradição em arquitetura. SP: Martins Fontes, 1995.

${ }^{20}$ Publicado em 1966 : ROSSI, ALDO. Arquitetura da Cidade. SP: Martins Fontes, 1996.

${ }^{21}$ BERENSTEIN, PAOLA, B. (org). Apologia da Deriva: escritos sobre a cidade. RJ: Casa da Palavra, 2003.
} 
também expressava a busca de autonomia ao exacerbar em seus projetos a condição de uniformização da realidade imposta pelo desenvolvimento do capitalismo tardio. Enquanto o Archizoom, nos anos 1960, pensava numa cidade sem arquitetura, o Superstudio propunha a megaestrutura arquitetônica do "Monumento Contínuo". Em ambas as propostas, o uso da alta tecnologia determinaria o espaço arquitetônico contínuo e abstrato. Por outro lado, suas instalações propunham a revisão crítica de tais determinações arquitetônicas.

Para essa geração de arquitetos, radicais ou não, a arquitetura moderna teria sido apropriada pelas economias capitalistas milagrosamente recuperadas no pós-guerra e estaria associada a governos centralizadores e à imagem de um tipo de arquiteto gênio, agora desacreditado. A possibilidade de formulação de novos paradigmas viria da consideração do ponto de vista do usuário, as apropriações feitas pela população que, para esses críticos do moderno, não estavam sendo devidamente ponderadas naquela abordagem do espaço universal, que se pretendia democratizável. O espaço universal não é mais o espaço coletivo dos expressionistas e sim aquele da economia pós-industrial globalizada.

As propostas de resistência às determinantes econômicas remetiam à volta dos paradigmas da Forma e da Técnica ou ao abandono da disciplina. Os historicismos pós-modernos refletem a tentativa de afirmação de autonomia pela estratégia de autoreferência, pelo uso do instrumental tipológico retirado da prática de arquitetura tradicional, e refletem a continuidade do paradigma formal. A rejeição pelo meio dos arquitetos nos anos 1970/80, mas não pelo establishment, do tratamento quantitativo próprio da primeira modernidade, levou-os a resignificarem o paradigma tectônico. A questão da técnica, ou tectônica, será apreendida no seu sentido poético e não científico, progressista, utópico, ou mesmo, meramente econômico conforme tratado pelos modernos, cogitando inclusive a volta a antigos modos artesanais de construir. A valorização de aspectos táteis e materiais da arquitetura funcionaria como um antídoto à realidade do homem metropolitano, calcada em relações mercantis, movimentada pela digitação nos teclados dos computadores, mercadorias escolhidas através de telas, pixels, mundo marcado pela superfície e pelo sentido 
óptico das Formas-mercadorias. Robert Venturi, por sua vez, será acusado de fazer predominantemente uma arquitetura populista, que atuaria como um "signo comunicativo ou instrumental, que sublimaria o desejo de uma experiência imediata através da informação. "22 A arquitetura do Galpão decorado se assemelharia às imagens publicitárias. Para os defensores da ênfase tectônica, ela não seria capaz de estimular um senso crítico do mundo consumista, mesmo através de sua estratégica retórica da ironia. Segundo os defensores do paradigma tectônico, a ênfase na Forma arquitetônica dificilmente deixaria de servir às determinações do mercado:

Escolhi tratar do tema da tectônica por vários motivos, entre os quais a tendência atual de reduzir a arquitetura à cenografia. Essa atitude nasce em resposta ao triunfo generalizado do galpão decorado de Robert Venturi, isto é, à síndrome prevalente de empacotar o abrigo como uma mercadoria gigante. Entre as vantagens da abordagem cenográfica está o fato de os resultados serem inteiramente amortizáveis, com todas as consequências que isso traz para o futuro do ambiente. Estou pensando, é claro, não na doce decadência do romantismo do século XIX, mas na indigência total da cultura do consumo. ${ }^{23}$

Portanto, dever-se-ia concentrar menos nas qualidades superficiais da arquitetura e mais na qualidade do processo da produção arquitetônica, em sua materialidade e materialização, que deveriam incorporar componentes locais e universais. Daí, sim, resultaria uma arquitetura de resistência à massificação cultural. $\mathrm{O}$ arquiteto teria um papel fundamental de destilador da qualidade dos processos, de representante crítico das culturas locais desejosas de uma expressão identitária. O crítico Kenneth Frampton argumenta que a expressão da identidade local contaria com a presença do profissional, não se resumindo a uma expressão espontânea popular.

Frampton afirma que a arte e a arquitetura modernas teriam afinal matrizes figurativas, tais como carros, aviões e navios. Tanto o tropo vanguardista da busca de espaço, como um fim em si, quanto os pastiches históricos e os projetos arquitetônicos escultóricos se baseariam numa dimensão arbitrária. Superfície, planta e volume seriam dados abstratos-representativos. A essência irredutível da forma arquitetônica seria a unidade estrutural, pois o ato de construir não seria representacional, já que "a forma construida é antes uma presença do que

\footnotetext{
${ }^{22}$ FRAMPTON, KENNETH (1983). Perspectivas para um regionalismo crítico.

${ }^{23}$ FRAMPTON, KENNETH (1990). Rappel à l'ordre: argumentos em favor da tectônica.
} 
a representação de uma ausência" "24, é mais coisa que signo. Frampton propõe pensar a arquitetura a partir dos quatro elementos propostos por Semper, alegando que eles romperiam com o paradigma da tríade vitruviana. Isto não se comprova, pois mesmo Frampton mantém sua crítica pautada na questão do espaço, da forma e da estabilidade estrutural, que vence as forças naturais da gravidade e intempéries. A diferença estaria no caráter simbólico atribuído por Semper à estrutura, indo além da interpretação da forma das fachadas. Frampton defende uma interpretação mítica da natureza, que se baseia numa ontologia da construção e na relação do habitar com a noção de preservação das forças da Terra e do Céu, segundo a proposição de Heidegger ${ }^{25}$. A verdade do Ser poderia estar nos objetos orgânicos e inorgânicos. Tal busca de Verdade soaria talvez um tanto anacrônica no mundo da pós-modernidade, ainda mais por sustentar tal relação com a natureza. Talvez haja aí um desejo de manter a autonomia da arte imaculada. Para as vanguardas modernas, a busca da verdade construtiva não cultivava tal sentido escapista para uma natureza originária. $\mathrm{O}$ anti-ilusionismo construtivista, pelo contrário, procurava uma ruptura com qualquer modelo formal, fosse ele a natureza ou a própria arquitetura, por querer introduzir o tempo na concepção da obra, além disso, cultivava a relação com a noção de espaço contínuo:

\begin{abstract}
"Nós rejeitamos a circunferência espacial fechada como expressão plástica da modelação do espaço. Nós afirmamos que o espaço só pode ser modelado de dentro para fora em sua profundidade, não sem o interior através de seu volume. Para que mais é o espaço absoluto além de único, coerente, e de profundidade ilimitada? (...)

Nós rejeitamos a massa fechada como elemento exclusivo para a construção tridimensional e de corpos arquitetônicos no espaço. Em oposição a isso, nós colocamos que os corpos plásticos devem ser construídos estereometricamente. (...)

Nós não estamos mais contentes com os elementos estáticos da forma na arte plástica. Nós demandamos a inclusão do tempo como novo elemento e afirmamos que o movimento real tem que ser empregado na arte plástica, a fim de
\end{abstract}

\footnotetext{
${ }^{24}$ FRAMPTON, KENNETH (1990).

${ }^{25}$ HEIDEGGER, MARTIN. "Construir, habitar, pensar" (1954). "Os mortais habitam, ainda que salvem a terra. Salvar (retten) não é só arrancar de um perigo, é propriamente liberar uma coisa, deixa-la voltar a seu ser próprio. Salvar a terra é mais que tirar proveito dela e. com maior razão, mais que esgotá-la. Quem salva a terra não se torna seu dono, não a converte em súdita." CHOAY, F. O urbanismo: utopias e realidades, uma antologia. São Paulo: Perspectiva, 2013. P.348.
} 
possibilitar o uso dos ritmos cinéticos num modo que não seja meramente ilusionista. (...)"26

$\mathrm{Na}$ arquitetura contemporânea, o paradigma espacial foi retomado sob a égide da "volta da questão do urbanismo", apontada por Rem Koolhaas em 1994 como uma necessidade frente ao inevitável processo de globalização. O agigantamento das edificações dentro da escala metropolitana é associado ao tratamento formalista da arquitetura, tanto como tentativa de afirmação da forma arquitetônica frente a fragmentação da cidade, quanto a estratégias de marketing e de especulação do mercado, já que muitos dos enormes projetos são desenhados por stararchitects. A recuperação da disciplina do urbanismo, abandonada pelos críticos do moderno por seu viés quantitativo, abstrato e totalizante, é retomada a partir de uma revisão desses preceitos. A cidade não será mais pensável como configuração estável. Koolhaas propõe uma abordagem anti-formalista, a enfatizar tanto o tratamento espacial quanto o tecnológico, dado o imperativo de desenvolvimento de infraestruturas em grandes escalas.

(...)não mais interessada no arranjo de menos ou mais objetos permanentes, mas sim com a irrigação de territórios com potencial; (...)não mais obcecada com a cidade, mas com a manipulação de infraestrutura para intermináveis intensificações e diversificações, atalhos e redistribuições - a reinvenção do espaço psicológico. Já que o urbano é agora pervasivo, o urbanismo nunca será novamente sobre o "novo", apenas sobre o "mais" e o "modificado". Não será sobre o civilizado, mas sobre subdesenvolvimento. ${ }^{27}$

O historiador e crítico de arte Hal Foster repotencializa a crítica feita por Kenneth Frampton à arquitetura sob influência da Arte Pop, como mercadoria pronta para consumo. Ao retomar o paradigma tectônico como determinante da autonomia da arquitetura em relação ao mercado, ele não o faz sem ressalvas. A integração da cultura local com a tecnologia contemporânea não teria alcançado aquela qualidade poética que Frampton acreditava ser possível. Foster refuta a exacerbação do caráter high-tech na forma dos edifícios de Richard Rogers, Renzo Piano e Norman Foster. Tais edifícios seriam típicos exemplos de marketing arquitetônico, fomentação de Imagens Pop, nunca a concretização de uma poética do construir ou da evocação do "espírito do lugar". A ênfase no tratamento superficial, o abuso dos acabamentos em vidro e o virtuosismo

\footnotetext{
${ }^{26}$ GABO, NAUM; PEVSNER, ANTOINE. Basic principles of Constructivism. (1920).

27 "What happened to urbanismo?". KOOLHAAS, Rem; SIEGLER; MAU, Bruce. S, M, L, XL: Office for Metropolitan Architecture. New York: Monacelli Press, 1995.
} 
técnico e formal seriam elementos arquitetônicos incapazes de instigar uma experimentação fenomenológica profunda, que escape ao condicionamento determinado pelo sistema mercadológico vigente. Para Foster, a ênfase no tratamento das superfícies dado pelos arquitetos do escritório Diller Scofidio + Renfro repetiria o modelo do galpão decorado, agora aprimorado pela utilização da tecnologia virtual. A exploração da transparência do vidro, tecnologia cultuada pelos expressionistas e modernos, geraria efeitos similares aos utilizados pela mídia contemporânea que estimula o consumo apelando para as neuroses exibicionistas e voyeristas da sociedade contemporânea, criando "máquinas de olhar". A interdisciplinaridade arte, arquitetura e engenharia ("que expõe a exposição", "que conecta imagem e engenharia"), assim como o envolvimento do espectador serviriam apenas para escancarar o comprometimento da cultura contemporânea com o pós-capitalismo; "economia em que somos convidados (aliás, compelidos) a conectar, colaborar, estar em rede. ${ }^{28}$ Os arquitetos que recuperam os experimentos suspensos da arte pósmodernista reiteram o exercício de criação de signos pop. Frank Gehry, por exemplo, faria um híbrido do pato com o galpão decorado graças ao auxílio da tecnologia dos computadores. No Guggenheim de Bilbao, ele privilegia tanto a forma quanto a pele do edifício, sua forma escultórica externa (superficial e decorativa) não revela nenhuma verdade da função interior (contendo espaços mortos, cul-de-sacs), se resume a um envoltório midiático. O uso do programa CATIA enseja a representação de suas formas rebuscadas de modo a que possam ser levadas à execução. Do mesmo modo, tal programa serviu à arquiteta Zaha Hadid e sua experimentação, misturando as formas abstratas suprematistas de Malevich ao materialismo construtivista de Tatlin. A obra realizada, conclui Hal Foster, não passa de "representações concretizadas em edifícios", e revela a exploração de técnicas variadas de perspectiva e projeções - tal como fizera anteriormente Eisenman - como definidoras das distorções da forma e, consequentemente, do espaço. O dinamismo formal, provocado pelas variações de eixos e pelo desafio à verticalidade convencional da arquitetura, é traduzido na obra de Zaha Hadid pela presença de rampas, dobras e espirais, ou seja, floreios estilísticos: "síntese da velocidade futurista congelada com a

\footnotetext{
${ }^{28}$ FOSTER, H. O complexo arte-arquitetura. SP: Cosac \& Naify, 2015.
} 
modelagem expressionista", "que resultam numa imagem estática", "design cenográfico", "perspectiva tornada literal". Floreios tais que não instigam o movimento do observador, nem conformam a experimentação tectônica. Nesse caso, a tecnologia digital viria a minimizar as possíveis restrições materiais e estruturais, redundando seu ímpeto de crítica da arquitetura como representação (no caso, do projeto de arquitetura). Por fim, Foster defende que o expressionismo-futurismo "serve" à economia neoliberal pelo viés da "exaltação sexista de poder". Somente a ênfase ao peso da materialidade tectônica, que dependeria de uma experiência espacial corpórea-tátil-profunda, facultaria à arquitetura proporcionar uma experiência alheia à cooptação promovida pelo sistema mercadológico. A busca de clareza estrutural, leveza e transparência presentes na arquitetura moderna acabaram retraduzidas na estética contemporânea pela transparência fenomênica, ilusória, que revelam um movimento de abstração diferente da pintura, pois trata-se de uma abstração arquitetônico-financeira, bem traduzido nas palavras do arquiteto da ampliação do MOMA em Nova Iorque, Yoshio Taniguchi citadas por Hall: “ "Me arrumem um monte de dinheiro que eu lhes darei uma boa arquitetura”, diz-se que Taniguchi falou aos membros do conselho de administração. "Me arrumem ainda mais dinheiro que eu farei a arquitetura desaparecer,"," 29

Ao que tudo indica, segundo as críticas de Koolhaas e Foster, o paradigma formal vem de tal modo comprometido com as estratégias de mercado que dificilmente estimulariam o desenvolvimento de estratégias projetuais para uma disciplina que almeja algum grau de autonomia. Koolhaas defende uma retomada do urbanismo a partir de estratégias que enfatizam o dinamismo espacial metropolitano. A articulação entre as variadas tecnologias (elevador, arcondicionado, computadores), e não somente a tecnologia civil, constituem as determinantes do espaço. As contraposições entre natureza e artifício não fariam sentido no mundo contemporâneo onde, de certo modo, vacila a própria noção de estabilidade tectônica frente às possibilidades geradas pelos novos materiais. Do mesmo modo, o conceito de escala humana é colocado em xeque em muitos megaprojetos. No entanto, é dada ênfase à percepção fenomenológica, a possibilidade de estimular determinadas nuances psicológicas a partir da

\footnotetext{
${ }^{29}$ FOSTER, H. O complexo arte-arquitetura. SP: Cosac \& Naify, 2015. P. 148.
} 
experiência da cidade. Para Foster, essas experiências fenomenológicas determinadas pelas novas tecnologias virtuais e por outras formas de promover distorções ilusórias abrigam referências formais e tectônicas que desconsideram a presença material do corpo. Eis o que se verifica na maioria dos projetos contemporâneos: atuam com as mesmas estratégias e fins do mercado.

\section{3. \\ Estética do Desaparecimento}

Segundo Andrea Branzi, o crescimento descontrolado da Metrópole desencadearia a condição contemporânea das Cidades sem Arquitetura. Seu surgimento seria efeito tanto do uso crescente da tecnologia eletrônica quanto da impossibilidade, existente desde sempre, de planejar o espaço urbano. A disciplina do urbanismo estivera ancorada numa utopia de controle da realidade. Os urbanistas ignoravam o fato de que, para que o planejamento na escala urbana se concretizasse, supunha-se uma unidade de interesse entre os cidadãos, construtores, fabricantes e instituições governamentais de controle, que jamais foi alcançada e que nenhum projeto poderia assegurar. As tentativas modernistas de controlar o caos urbano com mais arquitetura fracassaram diante dos fluxos dinâmicos atuantes sobre tal espaço. É fácil constatar, a arquitetura da cidade contemporânea não é o que parece: residências se tornaram local de trabalho, antigas fábricas viraram universidade, museus, residências etc. Tal fenômeno resulta do processo frenético de refuncionalização dos espaços interiores, cada vez mais frequente. A presença dos sistemas eletrônicos enseja as alterações dos interiores em tempo real. Uma vasta gama de atividades pode ser desenvolvida internamente sem que se altere "o imóvel contêiner da arquitetura". Assistimos assim a um processo de internalização do espaço urbano, que modifica a atuação dos planejadores: “A cidade do futuro se realiza nos espaços interiores da cidade contemporânea". Tal processo de internalização da cidade torna a noção de tipologia anacrônica, demanda pensar a noção de Forma e Imagem da Cidade. As decisões sobre o espaço se desenvolvem hoje de modo difuso, descentralizado e desarticulado. Cada gesto de design tem um alcance apenas local, um equilíbrio apenas provisório que é a adequação dos espaços interiores, resolvidos através do "universo das microestruturas" dos computadores e móveis. Cada um desses gestos se comunica com a rede global das grandes instituições e suas logomarcas. 
O espaço da cidade remontaria a uma cidade medieval sem catedrais, onde cada elemento isolado ("cultura secular, global e comercial") estaria conectado, configurando, no entanto, uma imagem provisória para ser vista, mais que vivida: "Essa é uma civilização baseada em objetos, tecnologia da informação, dispersa e sem síntese. Poderíamos dizer, uma civilização sem outras metrópoles teóricas que não as das várias Disneylândias espalhadas pelo planeta, as quais, portanto, coincidem completamente com a realidade. "30

Branzi entende que a sociedade contemporânea desacredita em fundamentos, sistemas estáveis e códigos compartilhados, entende-os como cerceamento de sua liberdade. Seus valores seriam baseados na noção de transitório, não necessariamente no sentido espiritual, mas da própria da lógica de liquidez do capital no mundo contemporâneo: "Quando falamos de uma sociedade sem catedrais, nos referimos precisamente à recusa de eternidade na terra. E quando falamos de arquitetura feita de marcas registradas, nos referimos à eternidade relativa, provisória e reversível",31

Se as cidades não têm mais arquitetura, e a arquitetura não tem mais cidade, haveria ainda espaço para discutir o caráter ontológico, ou representacional da arquitetura ou do ato de construir? Ainda poderíamos falar em habitar e ser? Viveríamos vagando na metrópole abstrata? Para Kenneth Frampton, a arquitetura seria antes uma presença do que representação de uma ausência. A autonomia disciplinar da arquitetura residiria exatamente neste caráter ontológico material-construtivo (a tectônica). Segundo o arquiteto italiano Massimo Cacciari, no entanto, seguindo a mesma linha de interpretação heideggeriana, é a forma da ausência que possibilita pensar a arquitetura ontologicamente. Para ele, o ambiente da metrópole não seria necessariamente estéril, pois o problema não estaria nas Formas arquitetônicas em si. Não é a forma construída que faria a Morada (Demora). Na metrópole, são os próprios "moradores" que estão ausentes e, portanto, seria impossível projetar para quem não habita. Há um equívoco interpretativo ao pensar a morada a partir da arquitetura, que reside na identificação própria ao pensamento ocidental entre Ser

30 "Urban Dismissal" em BRANZI, Andrea. Weak and Diffuse Modernity: The World of Projects at the beginning of the 21st Century. NY: Rizzoly, 2006. P.65.

${ }^{31}$ Idem, Ibidem. 
e presença. "No Ser concebido como presença um desvelo fundamental é forçado, o qual, no entanto, o pensamento Ocidental é incapaz de captar. $O$ pensamento Ocidental assume a equivalência do Ser e presença como naturais, $e$ seus esforços são concentrados na análise técnica dessa presença, de seu entendimento, e seu uso"32. Entre o desejo de poder do sujeito (hábil, potente e produtivo) e o habitar existiria um abismo: "Habitar é ser o guardião invisivel de leis invisíveis. "Apenas através da poesia, que é invisível em si, obteríamos as pistas do habitar: "A poesia preserva (no não-ser de suas palavras) o elemento tectônico da arquitetura ao qual o edifício, na medida em que participa da devastação da Terra, pode aludir apenas tragicomicamente. "33. Tal interpretação de Cacciari se baseia na leitura de Heidegger do poema, In leiblicher Bläue, de Hölderlin. Nessa leitura, a poesia seria construção por meio da qual "o homem recebe a medida do tamanho de seu ser" 34 . A medida do Ser é a medida da poesia: manifestação do divino pela ausência. Sua relação com o homem se dá na medida do que está oculto, do desconhecido. A poesia é a Forma que propicia ao homem habitar, "forma que mede a diferença", reconciliando-o com o lugar e com a cidade. O sujeito contemporâneo é alienado, Puro Ser separado do Ser-notempo: "O sujeito ocupa o tempo e não habita“. Nesse contexto, a arquitetura teria, para ele, um papel fundamental no sentido de representar tal separação: “ $A$ Arquitetura seria válida como uma dessas forças (que separam Ser do Ser-notempo) - como o silêncio deve também ser válido, a custódia silenciosa da forma vazia do lar. ${ }^{35}$

Vimos anteriormente como, para Hal Foster, somente a experimentação corpórea, aproximada e tátil, forneceria o antídoto para as mazelas do mundo póscapitalista. A desmaterialização da arquitetura redundaria no ciclo consumista da realidade contemporânea. O remédio para alienação do sujeito metropolitano radicaria na experimentação da arquitetura, enquanto presença material com características definidas: não-ilusionista, pesada, opaca. Ou seja, nada que remetesse ao ilusionismo da tecnologia eletrônica das telas de computadores, suas imagens lusco-fusco, seus painéis de vidro, sua capacidade de, a partir de

32 CASSIARI, M. HAYS, “Eupalinos or Architecture” (verão-1980) em K. Michael (org). Architecture Theory since 1968. NY: MIT Press, 2000.P. 396.

${ }^{33}$ Idem. Ibidem. P. 398.

${ }^{34}$ Heidegger citado por Cacciari. Idem, Ibidem.

${ }^{35}$ Idem, Ibidem. P.400. 
mínimos transístores, produzir imagens ora gigantescas, ora mínimas, confundindo ambiente virtual e real. Tais ambientes híbridos prescindiriam da participação ativa do observador. Não se trataria de uma outra materialidade, conforme define o teórico de arquitetura, Robert Somol, ao identificar a arquitetura tradicional com o princípio do muro ("the wall"), interface vertical, delimitando o espaço público do privado, interior e exterior, figura e fundo; e a arquitetura contemporânea com o princípio da membrana, conforme distinguidos por Gottfried Semper no século XIX. Tal princípio estaria associado às tendas dos povos nômades. Somol explica a importância no mundo contemporâneo da membrana por seu caráter performativo, focado "na troca entre ecologias naturais e artificiais, internas e externas" ${ }^{36}$ e pelo aspecto leve de sua membrana envoltória que permite a passagem dos fluxos metropolitanos. Os limites da arquitetura não são nítidos: ela se encontra diluída enquanto figura e fundo, possibilitando mesmo a inversão da hierarquia tradicional das fachadas sobre os interiores, da arquitetura sobre a paisagem e sobre a infraestrutura (as redes de esgoto, saneamento, circulação, eletrônicas etc.). A infraestrutura, tratada tradicionalmente como elemento invisível e secundário, é trazida à tona.

A imagem propagada da metrópole contemporânea nos faculta, então, remeter ora ao nomadismo dos povos primitivos, ora à planificação e homogeneização máximas próprias à modernidade. A arquitetura contemporânea reflete esse caráter de hibridez do passado com o presente, do orgânico com o inorgânico, da religião com a ciência, do primitivo com a alta tecnologia, do provisório e do altamente estabelecido (é um desastre, por exemplo, faltar energia elétrica). Tal hibridismo faz parte do próprio enunciado do mundo contemporâneo. Talvez a representação atômica que fazemos da realidade propicie tais aproximações e equivalências.

Para Branzi, por exemplo, a Metrópole contemporânea da era da informação não seria somente a capital da tecnologia eletrônica: seria também a capital dos homens, interligados não pelo limite do corpo e sim pela unidade mínima do DNA. Os sistemas biotecnológicos definem a Metrópole da Modernidade Fraca. A comunicação entre os seres se dá de modo muito mais

${ }^{36}$ SOMOL, R., E. “Urbanism without Architecture” em: ALLEN, Stan. Points + lines: diagrams and projects for the city. NY: Princeton Architectural Press, 2012. First Edition Reformatted. 
efetivo, atravessando diferenças de classes, religiões e culturas. Através de tais interconexões se determinariam os estatutos governamentais e sociais do mundo contemporâneo e não através de modelos ideológicos permanentes. A partir da microescala genética os acontecimentos do mundo dos corpos sólidos vêm a ser definidos. A fragilidade do sistema é aparente, pois o efeito em cadeia dos acontecimentos a partir da pequena escala genética alcança a macro escala urbana. A liquefação das antigas estruturas deu lugar à metrópole de espaços não segmentados: "A metrópole contemporânea é uma cama genética, um tipo de aquário cheio de líquido amniótico do qual formas agregadoras da sociedade, baseadas na troca e na informação, tomam corpo e são dissolvidos"37. Esse princípio genético, para Branzi, nada teria a ver com a noção de raça e sim com um modo de agir que não se baseia em um modelo imposto. Significa também que a forma construída da Metrópole é irredutível a uma sucessão de Formas e Espaços. A sociedade atual lembra cada vez mais as civilizações têxteis, que se apresentam numa rede contínua, um tecido flexível e transparente capaz de resistir aos atritos internos e choques com o que há de novo.

As civilizações têxteis, tais como os indianos, pressuporiam uma visão cíclica e cósmica da vida e morte humanas que determina um tipo de pensamento "anti-arquitetural, anti-lógico e anti-construtivo". Eles desenvolveram a ideia de arquitetura como um agregado dos corpos humanos e relações eróticas que correspondem à lógica não-construtiva de sua cultura, que interage com referências variadas da tecnologia aos animais sagrados, do bom e do mau, sem enxergar nesse movimento uma contradição:

"Mahatma Gandhi começou sua revolução voltando ao ato primordial de tecer
algodão como base da radical re-fundação da sociedade. Assim, fugindo de todos
os processos de modernização ligadas às fortes energias da mecânica, a India
decolou no mundo da web pelo caminho religioso, tornando-se em muito pouco
tempo o terceiro maior produtor de software do mundo, atrás apenas dos Estados
Unidos e do Japão. "38
O próprio cenário da metrópole indiana, ainda ligado à presença dos tecidos coloridos e estampados, coincide com o sistema móvel dos corpos num ambiente biotecnológico. Sua paisagem natural não é feita de arquiteturas e sim

37 "Genetic Metropolis" em BRANZI, Andrea. Weak and Diffuse Modernity: The World of Projects at the beginning of the 21st Century. NY: Rizzoly, 2006.

${ }^{38}$ Idem, Ibidem. 
do corpo das pessoas que criam um cenário flutuante em aparência frágil, mas, na realidade, resistente às mudanças sociais. A Metrópole genética seria o modelo teórico proposto por Branzi para um lugar onde as energias vitais e empreendedoras coincidem com a forma da cidade através de um aparato construtivo, reversível e transponível. Ela se aproxima dos sistemas agrícolas ligados às estações climáticas mais do que com os paradigmas do governo urbano, que age através da arquitetura tradicional. A Metrópole genética parece muito mais uma favela high-tech do que com as grandes cidades americanas ou as cidades históricas europeias, rígidas, frágeis e intocáveis. Tendo em vista o adensamento populacional do planeta, tal referencial vem a se tornar bastante relevante. Por um lado, a arquitetura contemporânea remonta ao paradigma têxtil da arquitetura primitiva, por outro, está diretamente ligada às novas tecnologias. Ela evoca o corpo físico do usuário interconectado e, simultaneamente, o desaparecimento das formas fixas do objeto arquitetônico. A ferramenta do computador é potencialmente libertadora por sua configuração instável e de "materialidade fraca", pela possibilidade de expressão individual que inaugura.

Para o arquiteto japonês, Toyo Ito, a realidade não está necessariamente se desmaterializando, ou seguindo o ritmo da liquidez dos produtos comercializados. Evitando as análises deterministas que condenam a arquitetura contemporânea ao desaparecimento, por sua perda propósito e autonomia, ele se propõe pensar num "novo real". Tanto em sua intervenção na Nationalgalerie In Berlin, como no projeto para a Midiateca em Sendai, Ito buscou reverter a ordem formal abstrata da arquitetura através do uso da geometria pós-euclidiana e da injeção de materialidade através da forma construída. Os espaços fluidos, criados com a ajuda da nova tecnologia de computadores, promoveriam o envolvimento físico, a sensação dos "fluxos de tensão dinâmica" que atravessam o lugar, definindo assim “qualidades análogas a cavernas primitivas" (ITO, 2011: 163-171). A complexidade do conhecimento de cálculo estrutural e de tecnologia envolvida no desenvolvimento desses projetos gera um tipo de solução altamente específica, a contradizer e superar a tendência moderna de neutralidade e reprodutibilidade. A facilidade com que as formas fluidas se resolvem estruturalmente é surpreendente e, com certeza, é um dos fatores para que proliferem na arquitetura contemporânea. Outro motivo para justificar tal fenômeno é descrito por Ito. 
Ele analisa a relação estática do homem com a abstração da geometria presente no desenho de Leonardo Da Vinci do homem vitruviano: um corpo parado, inserido com os braços abertos dentro de um quadrado e uma circunferência. O homem estaria em acordo com a verdade eterna das Formas geométricas. A arquitetura se configurou tradicionalmente a partir desta figura ideal e imutável do corpo estático: o corpo do homem moderno e contemporâneo pode ser descrito da mesma forma? Ele sugere um homem contemporâneo dotado de dois corpos, um corpo real e um corpo virtual ${ }^{39}$. O corpo seria fluido e não simétrico, já que incorpora movimentos e transformações materiais. Visando a materialidade de tal corpo, qual arquitetura lhe corresponderia? A arquitetura de vidro, no passado, integrou os espaços habitados com o exterior natural, incorporando o verde e a insolação variada. $\mathrm{O}$ vidro agiu como um filtro mínimo de proteção em relação aos fluidos naturais. Ele correspondia tanto a princípios higienistas-funcionalistas quanto aos ideais de integração coletiva dos expressionistas. A arquitetura de vidro acabou associada à arquitetura corporativa e à geometria euclidiana:

(...) contínuos inorgânicos indistintos de vidro e aço, ambientes completamente artificiais que não estabelecem nenhuma relação com a natureza. Inumeráveis pessoas trabalham ali, dirigidas pelos ditames da economia e da informação, suas vidas gastas, parecendo distantes das coisas materiais reais quando elas consomem seus dias em caixas abstratas mantidas pela maquinação abstrata do dinheiro. ${ }^{40}$

Para Toyo Ito, é claro que a proposta de abstração moderna ("menos é mais") não pretendia submeter as pessoas ao "Vácuo Cartesiano". Durante a obra para Midiateca Sendai, a questão do espaço abstrato ressurgiu, e ele decidiu "mostrar a força de tais espaços abstratos e inorgânicos. " Nessa obra, mistura referências orgânicas e inorgânicas, naturais e abstratas. A essência da arquitetura residiria neste contraponto de "uma ordem formal independente que se origina do mundo natural. $O$ modernismo do século XX substituiu a ordem das colunas redondas e frontões por uma ordem de linhas simples, abstratas e perpendiculares. ${ }^{~} 41 \mathrm{Na}$ Midiateca Sendai, ele tenta inverter tal ordem histórica

\footnotetext{
39 “Ichiro-like Architects", p.143, em: ITO, Toyo. Tarzans In The Media Forest. London: AA Publications, 2011.

${ }^{40}$ ITO, Toyo. "The New "Real": Toward reclaiming materiality in contemporary Architecture" (2006) in Tarzans In The Media Forest. London: AA Publications, 2011.p. 164.

${ }^{41}$ Idem, Ibidem.
} 
da arquitetura. Lá é a natureza que brota da forma construída, injetando materialidade ao espaço abstrato. Tal seria o "novo real", cuja materialidade vai além do modernismo, sem se aprisionar pela nostalgia das aspirações regionalistas em vigor nos anos 1980, e retomadas por Hal Foster. Também para Ito, os elementos estruturais tectônicos tiveram um papel fundamental na defesa da materialidade da obra, agora liberada da geometria estática pensada para o homem vitruviano. A tecnologia dos computadores liberta a arquitetura da geometria euclidiana e permite a realização da fluidez instável do corpo em movimento e o "equilibrio complexo da vida de uma planta em desenvolvimento no espaço arquitetural. "42. A equipe de engenheiros da Midiateca Sendai concebeu a estrutura com base em elementos matemáticos não lineares. A estrutura criada considera a interação de forças dinâmicas, complexas, "arquiteturas de corpo líquido", que não precisam se encaixar em modelos estruturais pré-existentes. Há uma ruptura com o modo tradicional de conceber a estrutura, que dá mais liberdade ao arquiteto para incorporar as referências contemporâneas à materialidade fluida. A mecânica estrutural foi incorporada ao processo de projetação. O desenho de cascas de concreto, por exemplo, pôde ser desenvolvido tridimensionalmente, transferido para uma maquete física, retornando na forma de medidas para serem digitalizadas e produzir uma simulação estrutural. "Como resultado, podemos experimentar um espaço topológico altamente dinâmico". ${ }^{43}$ O edifício da Tod's, por exemplo, é coberto por silhuetas de árvores com ramificações envolventes, que agem como estrutura. Essa imagem foi digitalizada para criar uma simulação. Cada parte da ramificação alterada no estudo, afeta o equilíbrio das outras, ainda que as possibilidades de mudança sejam ilimitadas. Cada elemento estrutural pôde ser dissecado de modo interligado, fato inimaginável sem a tecnologia dos computadores. O engenheiro estrutural, Cecil Balmond, com quem Ito trabalhou no projeto para o Pavilhão da galeria Serpentine em Londres (2002), descreve tais elementos através do seu comportamento molecular. Para Balmond, segundo Ito, o retângulo não seria uma forma estável, pois:

a geometria sempre consiste de trilhas de pontos em movimento: a aplicação de certos parâmetros para a multiplicidade de incontáveis fluxos de pontos e rastros

\footnotetext{
${ }^{42}$ Idem, Ibidem

${ }^{43}$ Idem, Ibidem.
} 
em linha, que eles deixam, determinam direções controladas e intersecções que informam seu conceito de estrutura arquitetônica. O que, até agora, tem sido pura forma - círculos, quadrados e cubos - ele (Balmond) reformulou completamente como momentos congelados nos movimentos em andamento dos pontos. ${ }^{44}$

A superfície operaria como uma malha de circuitos móveis. O volume instável configurado deste modo não adquire limites definidos. $\mathrm{Na}$ galeria Serpentine, a hierarquia das formas arquitetônicas, tais como janelas, portas, vigas e colunas não são distinguíveis visualmente. A experiência do espaço é que se torna preponderante, integrando interior e exterior, dando uma "curiosa sensação flutuante da continuidade espacial abstrata”. Na proposta de Ito e Branzi, para $O$ Forum de Música, Dança e Cultura Visual em Ghent (2003-04), o recurso ao sistema de espaços curvos tridimensionalmente é associado à utilização da grelha regular. Essa associação libera a criação de espaços labirínticos contínuos, que se desenvolvem em múltiplas direções, desvinculando a arquitetura da relação com as estruturas de planos ortogonais e aproximando-a das configurações das cavernas. Tais deformações da grelha são baseadas em princípios que se tornaram simples devido à utilização dos computadores.

Essa tendência à arquitetura fluida e híbrida é efeito do uso da tecnologia, mas também é resultado da imagem da cidade contemporânea que Ito constrói: "Um jardim de microchips". A cidade se conformaria no processo de sedimentação da passagem temporal nas camadas do solo. A camada mais superficial seria produzida pela utilização nanotecnológica. Como as imagens produzidas por microchips não são constantes, não evocam a materialidade pesada da imagem modernista da Era da máquina, mas são fenomenologicamente apreensíveis. A cidade contemporânea não poderia assumir uma expressão morfológica determinada, pois a ela se sobrepõem uma multiplicidade de camadas de fluxos invisíveis de elétrons. Luzes, sons, imagens etc. constituem o estrato sobreposto às camadas de relevo natural e de cidade construída, mas não configuram sua exclusiva materialidade. Para Toyo Ito, a escavação dessas camadas constitui o esforço poético do arquiteto: escavar para revelar e reconfigurar o espaço fenomenologicamente, criando reciprocidade entre natureza e tecnologia.

\footnotetext{
${ }^{44}$ Idem, Ibidem.
} 


\section{3. \\ Abstração}

\section{1.}

\section{Formas e reflexos}

\section{Penso, logo existo}

Etimologicamente definido em contraposição ao termo "concreto" como "separado de" ${ }^{45}$, desde sua introdução no vocabulário da filosofia latina no final da Antiguidade Clássica, teve, por razão da ambiguidade de sua definição, gerado debates inconclusos. A palavra traduzida por Boécio como abstração se referia a dois termos diferentes, usados por Aristóteles: Aphairesis e Chorismus. Os dois remetiam ao processo de separação de um objeto de qualidades do mundo sensível para submeter ao processo de conhecimento. No entanto, as duas palavras mantinham diferentes nuances de grau e tipo de abstração dos objetos; como, por exemplo, do espaço e do movimento, e de qualidades espaciais da geometria. ${ }^{46} \mathrm{O}$

\footnotetext{
${ }^{45}$ Abstrato (FIL): "considerado à parte de suas determinações empíricas ou acidentais (p. ex. A brancura é uma ideia abstrata qundo concebida em separado dos objetos empíricos que apresentam, ou podem apresentar, a cor branca)"

Abstraçãa " (ETIM lat.): "separação, arrebatamento". HOUAISS, A., VILLAR, Mauro de S. Dicionário Houaiss da língua portuguesa. RJ: Objetiva, 2009.

${ }^{46}$ Severino Boécio (Boethius - século V d.C.) teria introduzido em sua tradução o termo em latim "abstractum" para se referir à expressão grega "Aphairesis", que queria dizer "retirar uma parte escolhida". Na Idade Média serviu para conotar a operação de "separar", que no grego tinha outra palavra de referência. Para Aristóteles, "Aphairesis" remetia [1] ao processo pelo qual as entidades matemáticas são constituídas a partir da percepção sensível. "O processo se constituía em excluir através do pensamento a matéria, já que ela atuava como princípio de movimento.(ou seja, não toda matéria envolvida deveria ser excluída, pois as entidades geométricas, por exemplo, possuem matéria espacial também, que é denominada como matéria inteligivel)". Aristóteles nunca definiu a palavra "Aphairesis" propriamente, mas sabe-se que a tradução de Boethius teria usado o mesmo "abstrato" para se referir à entidades matemáticas e físicas, mesmo quando estas, para Aristóteles, não se referiam à ausência de materialidade, própria da contraposição ao termo "concreto" que ficou vulgar nas interpretações posteriores. "Enquanto para Platão a matemática tinha como objeto entidades inteligíveis incondicionadas, Aristóteles tratava de entes físicos, na medida em que somente estas entidades continham em si o momento da espacialidade e da multiplicidade. A matemática diferia da física nisto, já que ela não considerava os entes físicos como fisicos, ou seja, abstraídos do movimento destes entes. O termo [aphairesis] servia no campo da matemática para transpor do objeto geométrico para o aritmético, que é "mais abstrato" que o primeiro. A Aphairesis consiste, portanto, nisto, de excluir no pensamento, o que não obstante ainda se sabe pertencente, na realidade, ao objeto em questão, como no exemplo citado do movimento e da situação do espaço. Trata-se aqui de forma clara do que os escolásticos chamavam de (formal A) [abstratio formalis], ou seja um A, que incide somente sobre a abordagem e não sobre um simples ou total A (abstratio simplex ou totalis), que disto consistia, do sensível extrair uma realidade inteligivel acidentalmente misturada(por exemplo, a ideia ou o geral). Ou seja, para alcançar uma realidade inteligível e incondicionada, Aristóteles tinha um termo especial que era Chorismos, que significava "observar
} 
processo de abstração referido não redundava na simples oposição abstrato/imaterial e concreto/material desenvolvida posteriormente. Os termos gregos, Aphairesis e Chorismus, utilizados por Aristóteles refletiam semelhanças e diferenças em relação à filosofia platônica, referentes aos conceitos de ideia/universal e substância/universal ${ }^{47}$, que foram exatamente as fontes de controvérsias.

Posteriormente, a Querela dos Universais, que marcou a filosofia medieval escolástica, envolvendo os grupos de Realistas e Nominalistas, dependia de uma definição da noção de abstração que eliminasse a contradição que acompanhava as influências platônica e aristotélica incorporadas na fundamentação da doutrina cristã. Para os realistas, o universal era o real. Para estes de maior influência platônica, como os realistas da proto-escolástica ${ }^{48}$, o particular refletiria uma dimensão do Mundo das Formas (transcendente-Ideia Universal), constituindo o particular por isso uma realidade incompleta ${ }^{49}$. Neste sentido, para estes platônicos, abstrato é o mundo dos fenômenos. Para o cristianismo, a terra ${ }^{50}$ em contraposição ao céu $^{51}$. Realistas da Idade Média,

em separado" e que já conteria uma intenção crítica em relação ao platonismo. RITTER, J. (ed.) Historisches Wörterbuch der philosophie. Basel/Stuttgart: Schwabe \& Co, 1971. P.42.

${ }^{47}$ Substância é essência necessária e o que existe necessariamente para Aristóteles. "“se o que é bem por essência não é o bem, então nem o que existe por essência existe, e o que é uno por essência não é uno; e assim com todas as outras coisas (Met., VII, 6, 1031 b 6). Aristóteles aduz. esse argumento contra a separação que Platão faz entre a idéia e as coisas, mas obviamente, esse argumento significa que tudo é o que é em virtude da essência necessária (que é sua causa intrínseca ou extrínseca) e que, portanto, tudo o que há de real ou de cognoscível nas coisas faz parte da essência necessária e existe necessariamente. Assim, para Aristóteles, a S. Constitui a estrutura necessária do ser em sua concatenação causal, porque todas as espécies de causas são determinações da substância.” ABBAGNANO, N. Dicionário de Filosofia. SP: Martins Fontes, 2007. P.1092.

${ }^{48}$ Proto-escolástica: primeiro momento da Escolástica, marcado ainda pela influência de Santo Agostinho e do platonismo. A preocupação em estabelecer uma doutrina que comprove a relação entre a fé e a racionalidade (grega) no caminho da Salvação e elimine conceitos pagãos agregados resultará na Querela dos universais, marcada pela disputa entre os grupos Nominalista e Realista. KLAUS, G., BUHR, M. Philosophisches Wörterbuch. Westberlin: das europäische buch, 1975.

49 " $O R$. afirmava a realidade dos universais (gêneros e espécies), entendendo contudo de maneiras diferentes essa mesma realidade." ABBAGNANO, N. Dicionário de Filosofia. SP: Martins Fontes, 2007. P.979.

50 "Na Cidade de Deus, Sto Agostinho interpreta a história da humanidade como conflito entre a Cidade de Deus, inspirada no amor a Deus e nos valores cristãos, e a Cidade Humana, baseada exclusivamente nos fins e interesses mundanos e imediatistas. Ao final do processo histórico, a Cidade de Deus deveria triunfar." JAPIASSU, H., MARCONDES, D. Dicionário básico de filosofia. RJ: Zahar, 1996.b

51 "Aristóteles distingue três significados do termo: $1^{\circ}$. A substância da circunferência externa do mundo, isto é, o corpo natural que está na extrema periferia do universo: nesse sentido, dá-se o nome de C. à região que se acredita ser a sede da divindade; $2^{\circ}$. O corpo que ocupa o lugar mais próximo da circunferência externa do universo e no qual se acham a Lua, o Sol e alguns astros, 
defendiam que as ideias é que seriam coisas reais. Para os nominalistas ${ }^{52}$, abstratos seriam os conceitos universais, portanto menos reais.

A noção de abstração terá influência em ainda outras dimensões da doutrina cristã, tal como na separação de corpo e alma ${ }^{53}$. O cristianismo adotará a oposição platônica entre a realidade incorpórea e imortal da alma e do corpo corruptível. A tentativa conciliar o conceito de substância aristotélico, que determinava como inseparáveis forma e matéria, com distinção corpo e alma platônica constituiu um paradoxo para a doutrina cristã escolástica, que buscava explicar tanto a imortalidade da alma quanto sua unidade. Segundo Aristóteles, a alma é substância; "o ato final (entelechia) mais importante de um corpo que tem a vida em potência”. Para ele, a alma não poderia existir sem um corpo. A solução escolástica foi justificar a realidade da imortalidade da alma pela fé (Duns Scot, Ockham), ou pela concepção de uma forma corporeitatis ${ }^{54}$ independente da forma da alma imortal (Santo Agostinho).

Deste modo, a capacidade intelectiva autônoma é colocada em questão no período final da escolástica. O escolástico nominalista Ockham (séc. XIV) considerava que a interferência das volições eram comuns ao corpo e à alma e que, deste modo, não haveria garantia de conhecimento a não ser pela fé.

dos quais dizemos que “estão no C. ”(...) (De cael. I, 9, 278 b 10)”. O céu seria incorruptível, feito de éter, diferente das coisas sublunares (água, fogo, terra, ar) e fazia apenas um único tipo de movimento, o circular, que seria ingenerável. ABBAGNANO, N. Dicionário de Filosofia. SP: Martins Fontes, 2007. P.153.

52 "O N. admite que o universal ou conceito é um signo dotado da capacidade de ser predicado de várias coisas . (...)"ABBAGNANO, N. Dicionário de Filosofia. SP: Martins Fontes, 2007. "são nominalistas todos os que acreditam que além das substâncias singulares, só existem nomes puros $e$, portanto, eliminam a realidade das coisas abstratas e universais." LEIBNIZ apud Id. Ib. P.836. A percepção de semelhança entre os objetos induziria à impressão de unidade própria dos universais, conforme atestado pelos empiristas, tal como David Hume.

${ }^{53}$ Agostinho transmite ao mundo cristão elementos do neoplatonismo, conforme elaborado por Plotino, que critica a noção de que alma é corpo: "Plotino não acha que a A. tenha ligação alguma com o corpo, e sua única preocupação é definir essa realidade exatamente nos termos de sua independência em relação ao corpo e a todas as determinações corpóreas. Por conseguinte, Plotino acentua os caracteres divinos da A.: unidade e indivisibilidade, donde a ingenerabilidade e a incorruptibilidade, que são todos os caracteres negativos, assim como, aliás, são negativos os caracteres que Plotino atribui a Deus. Mas qual é a via de acesso à realidade da A, assim entendida? Plotino responde que, para examinar-se a natureza de uma coisa, é preciso considerala em sua pureza, pois tudo o que se lhe acrescenta é um obstáculo a seu conhecimento. Daí para examinar-se o que é A., é preciso retirar-lhe tudo o que é estranho, isto é, convém olhar para si mesmo e recolher-se na própria interioridade." ABBAGNANO, N. Dicionário de Filosofia. SP: Martins Fontes, 2007. P.30. Para o escolástico nominalista, Ockham, tal introspecção não seria suficiente sem a fé, pois a experiência racional poderia ser corrompida pelas volições que afetariam tanto corpo quanto o intelecto. Idem, Ibidem. P.31.

${ }^{54}$ ABBAGNANO, N. Dicionário de Filosofia. SP: Martins Fontes, 2007. P.30. 
Portanto, Ockham defendia que apenas era possível o conhecimento d'alma através de uma "experiência interna", contraposta à experiência sensível de conhecimento do mundo. Este foi o primeiro passo na direção do cogito ergo sum cartesiano $^{55}$ (séc. XVII) no sentido de que seu ponto de partida é própria substância pensante, independente do corpo. Para Kant, esta posição cartesiana, seguida pelos racionalistas, incorria num dogmatismo "matemático-cartesiano" que não resolvia a questão da possibilidade conhecer. O Empirismo, representado por Hume, também não, segundo Kant, pois recaía num ceticismo em relação às representações dos fenômenos devido aos limites impostos por seu subjetivismo. Kant propõe então sua filosofia crítica, que se desenvolveria a partir da verificação dos limites de seus próprios fundamentos, dado o descompasso mostrado historicamente entre o corpo e alma, entre as coisas em si e o fenômeno a que temos acesso através de representações abstratas que sofriam a interferência da imaginação $0^{56}$. Ele se propunha recuperar, através da crítica, o status perdido da filosofia, como caminho para o saber metafísico.

Previamente à constituição de um sistema metafísico, conhecimento pela razão pura das coisas em si, dever-se-á investigar - o que será tarefa da Crítica da Razão Pura - o que pode conhecer o entendimento e a razão, independentemente de toda experiência. Trata-se de criticar, de encontrar os limites de todo conhecimento puro, a priori, isto é, independentemente de qualquer experiência. Deste modo se abrirá se abrirá um caminho certo para a metafísica, que lhe obtenha o consenso dos que se ocupam de filosofia, pois se encontram garantidas a necessidade e universalidade desse saber; estaremos em face de uma ciência. (KANT, MORUJÃO. 2008, P. X)

\section{Revolução copernicana}

Kant buscava para a metafísica o caminho seguro das ciências matemática e física, que vinham se desenvolvendo aceleradamente devido ao estabelecimento de parâmetros que garantiam o método da pesquisa científica. Diferente da lógica, que se ocupa de si própria e pressupõe apenas fazer uso das "regras formais de todo pensamento”, a razão, afirma Kant, lida com objetos que estão além dela, que estão além do sujeito, seja na geometria ou na física.

\footnotetext{
${ }^{55}$ Idem, Ibidem. P. 31.

56 “Assim, a própria física tem de agradecer, tão proveitosa, do seu modo de pensar, unicamente à ideia de procurar na natureza (e não imaginar), de acordo com o que a razão nela pôs (...)", (KANT. 2008, P. 18)
} 
Que a lógica tenha sido tão bem sucedida deve-se ao seu caráter limitado, que a autoriza e mesmo a obriga a abstrair (grifo meu) de todos os objetos de conhecimento e suas diferenças, tendo nela o entendimento que se ocupar apenas consigo próprio e com a sua forma. Seria muito mais difícil para a razão seguir a via segura da ciência, tendo que tratar não somente de si, mas também dos objetos; (...)(KANT. 2008, P. 16)

A grande questão da primeira crítica é, portanto, como sintetizar tais conhecimentos, que se pautam tanto em dados sensíveis da natureza quanto na juízo analítico promovido pela razão. Ele verificou então que desde sempre a geometria fazia tais juízos sintéticos através de um processo de abstração e reconstrução mental dos objetos, a partir de conceitos a priori da razão pura, para que se fixassem os parâmetros a serem tratados analiticamente.

Aquele que primeiro demonstrou o triângulo isósceles (fosse ele Tales ou como quer que se chamasse) teve uma iluminação; descobriu que não tinha que seguir passo a passo o que via na figura, nem o simples conceito que dela possuía, para conhecer, de certa maneira, as suas propriedades; que antes deveria produzi-la, ou construí-la (grifo meu), mediante o que pensava e o que representava a priori por conceitos e que para conhecer, com certeza, uma coisa a priori nada devia atribuir-lhe senão o que fosse consequência necessária do que nela tinha posto, de acordo com o conceito.

De modo similar à matemática, a Física evoluiu, embora de modo mais lento porque pautada em princípios empíricos, a partir de construções de situações feitas com dados separados da realidade, o chamado método experimental: "Quando Galileu fez rolar no plano inclinado as esferas, com uma aceleração que ele próprio escolhera, quando Torricelli fez suportar pelo ar um peso, que antecipadamente sabia idêntico ao peso conhecido de uma coluna de água (...) Compreenderam que a razão só entende o que produz segundo seus próprios planos; que ela tem que tomar a dianteira com principios, (...)”(KANT. 2008, P. 18) . A virada copernicana correspondeu à virada do sujeito que observa a natureza, que se tornou ativo, "deve forçar a natureza a responder às suas interrogações em vez de se deixar guiar por esta”. (KANT. 2008, P. 18). O sujeito não representa a natureza conforme percebe, mas segundo elementos por ele selecionados intencionalmente. Ele constrói a experiência mentalmente, abstraindo o movimento dos objetos e substituindo-o por seu próprio movimento de observador, para depois reconstruir laboratorialmente o que foi mentalizado.

Trata-se aqui de uma semelhança com a primeira ideia de Copérnico; não podendo prosseguir na explicação dos movimentos celestes enquanto admitia que 
toda a multidão de estrelas se movia em torno do espectador, tentou se não daria melhor resultado fazer antes girar o espectador e deixar os astros imóveis. (KANT. 2008, P. 18)

A metafísica deveria encontrar o tal parâmetro fixo, um elemento incondicionado para a razão especulativa. Determinando tempo e espaço como categorias a priori da intuição, posso me limitar tratando apenas dos fenômenos, conforme os representamos, já que a coisa em si desconhecemos. Segundo Kant, podemos pensar os objetos como coisas em si, mas não conhecê-los. O sujeito seria a estrutura fixa que precede a experiência. Os juízos analíticos não trariam dificuldades para o pensamento, pois constituídos da mesma matéria pensante e posto que se pautam em conceitos que já temos das coisas. A dificuldade estaria em fazer juízos sintéticos (pela faculdade do entendimento) a partir de dados incorporados (intuídos) pela experiência sensível (pela faculdade da sensibilidade). A forma como percebemos a matéria, segundo Kant, são o espaço e o tempo, que seriam formas da sensibilidade, consideradas a partir da virada copernicana, como introjetadas no sujeito. Vimos que para Aristóteles, o espaço era uma dimensão material do objeto que poderia ser abstraída em função do que se queria conhecer. Como consequência da inversão kantiana, o espaço será representado como uma grade geométrica e o tempo espacializado ${ }^{57}$. Para Hegel, neste isolamento do sujeito transcendental, Kant não teria escapado da abstração dogmática do racionalismo cartesiano e nem do subjetivismo empirista, pois hipostasiaria o conceito de verdade no de ideia transcendental, mantendo-o alheio à experiência sensível. Efetivamente, Kant toma o conceito de ideia da filosofia platônica para definir as ideias transcendentais como "arquétipos das próprias coisas e não apenas chaves de experiências possíveis." 58 (KANT. 2008, P. 309) e como "totalidade das condições relativamente a um condicionado dado" (KANT.

\footnotetext{
57 Verificar a noção de tempo e espaço descrita por Schiller logo abaixo, como condições do estado do ser (vir-a-ser) inseparáveis da matéria sensível. A partir somente destes limites, o absoluto poderia ser pensado.

${ }^{58}$ As ideias não poderiam ser extraídas, portanto, da experiência que é imperfeita, não é plena do sentido da ideia. Por exemplo, vejamos o desdobramento do conceito de liberdade, se ele pudesse realizar-se for a "do cérebro de um pensador ocioso": "Uma constituição, que tenha por finalidade a maxima liberdade humana, segundo leis que permitam a liberdade de cada um possa coexistir com a de todos os outros (não uma constituição da maior felicidade possível, pois está será a natural conseqüencia), é pelo menos uma ideia necessária (grifo meu), que deverá servir de fundamento não só a todo o primeiro projecto de constituição política, mas também a todas as leis, e na qual, inicialmente, se deverá abstrair dos obstáculos presentes, que talvez provenham menos da inelutável natureza humana do que de terem sido descuradas as ideias autênticas em material de legislação (KANT. 2008, P. 310)
} 
2008, P. 314), que é sempre "absolutamente incondicionada" e inadequadas para uso "in concreto". Elas, segundo Kant, não estariam no Mundo das Ideias, mas "na cabeça do sujeito", que "possui sempre o verdadeiro original com o qual compara o pretenso modelo e pelo qual unicamente o julga” (KANT. 2008, P. $310)$.

É certo que Kant prosseguiu as suas investigações até o ponto de encontrar a unidade naquilo a que chamou o intelecto intuitivo, mas, ainda aqui, não chegou a ultrapassar a oposição entre o subjetivo e o objetivo; por isso, quando nos fala da idéia, Kant transforma tal resolução ou conciliação num caso subjetivo, em vez de a conceber em conformidade com a verdade e o real. Neste aspecto, a Crítica do juízo, que examina os juízos estético e teleológico, é uma obra notável e muito instrutiva. Ao referir-se aos objetos belos da natureza e da arte, aos produtos da natureza que, pelo caráter finalista, lhe abrem o caminho para o conceito do organismo e do ser vivo, Kant só os considera do ponto de vista da reflexão e do juízo subjetivos. É certo que Kant define o juízo em geral como "a faculdade de pensar o particular como participante do geral", e diz que o juízo é refletido "quando está perante só o particular que irá integrar no geral a achar". (Hegel, 2009, P.76 e 77)

O juiz refletido poderia operar do particular para o geral, porque pressupõe, que o juízo do objeto da natureza ou da obra de arte, obedece ao princípio de finalidade, que por sua vez, faz pressupor serem estes objetos racionais, mesmo que escapando à possibilidade de determinação ou conceituação. "O homem, tal qual, é incapaz de formular um juízo sobre o belo, um juízo que possua validade universal. O universal como tal é uma abstração; mas, por isso mesmo, tem o direito de aspirar a uma validade geral cuja determinação geral traz em si." (Hegel, 2009, P.78). A validade geral seria determinada pelo sentimento necessário de prazer despertado pelo objeto, que é independente da consciência que temos de um conceito integrado a ele. No entanto, "Kant vê no belo artístico a realização de uma acordo mediante o qual o particular aparece em conformidade com o conceito. (...) a matéria, em vez de sujeita a uma determinação exterior do pensamento, possui liberdade própria: o natural, o sensivel, os movimentos da alma encontram em si a sua medida, o seu fim, o seu acordo, e, se por um lado a intuição e o sentimento adquirem um caráter de generalidade que lhes permite participar no espírito, o pensamento, por outro lado, não só renuncia à hostilidade contra a natureza, mas nela se expande e se abre”. (Hegel, 2009, P.76 e 80) 


\section{O Absoluto}

Vimos que para Kant o absoluto se define como uma ideia transcendente, "totalidade absoluta na síntese a condições" e "arquétipo, que poderia se fazer real no uso prático da razão, quando se fizesse presente o juízo reflexionante. A razão, no entanto, permaneceria transcendental e abstrata: "Assim, poder-se-ia dizer que a totalidade absoluta dos fenômenos é uma ideia, pois como não podemos nunca realizar numa imagem algo semelhante, permanece um problema sem solução. Em contrapartida, como uso prático do entendimento se trata unicamente de uma execução segundo regras, a ideia da razão prática pode fazer-se real, embora dada só em parte in concreto (...)"(KANT. 2008, P. 317).

A grande contribuição da crítica do juízo, segundo Hegel, teria sido conciliação entre pensamento subjetivo e realidade objetiva, caso Kant tivesse compreendido o absoluto racional através da apreciação artística do belo. Somente através desta experiência com a arte, a filosofia teria transposto a oposição entre os conceitos da filosofia e os da natureza, redefinindo o próprio entendimento do que seria a investigação filosófica:

Para, logo de início, darmos uma definição muito geral, nós a diremos formada pela concepção que vê na arte um meio em que se opera a conciliação do espírito abstrato, descansado em si mesmo, com a natureza, quer nas manifestações exteriores quer nas manifestações interiores, afetivas e psíquicas. Depois de os conciliar, a arte realiza a união, a fusão dos dois termos. (KANT. 2008, P. 75)

Assim como a história e a religião, arte teria como fim último revelar a verdade, "representar, de modo concreto e figurado, aquilo que agita a alma humana”. A obra de arte não seria um meio, mas sim, encerraria em si o absoluto de sua determinação. Sua determinação seria imanente: "em si e para si, segundo sua natureza e conceito. A arte operaria na alta esfera da "conciliação de contrários". A ideia do belo, que é perseguida nas obras de arte, realizaria a conciliação entre realidade sensível e ideal abstrato, sendo, portanto, dotada de individualidade concreta. Para Hegel, o artista partiria sempre de ideias concebidas a partir de uma realidade determinada. Ele critica aqueles que supõem que o artista se inspiraria em puros conceitos racionais: 
$\mathrm{O}$ artista que pretendesse inspirar-se em semelhantes abstrações atuaria como o pensador que fundasse o pensamento em representações indeterminadas e se contentasse com conteúdos também indeterminados. Esta cesura, porém, não abrange aquilo a que nós, filósofos, chamamos de idéia, porque a idéia como tal é concreta em si, é uma totalidade de determinações, e só será belo o que contiver uma adequação direta da idéia à representação objetiva. (Hegel, 2009, P.73)

A arte deveria, portanto, dar acesso à realidade, que para Hegel não se distingue da verdade revelada na unidade realizada entre liberdade e necessidade, entre universal e o particular, entre o racional e o sensível. Schiller seria o pensador responsável por preencher "as lacunas da concepção kantiana”, seu grande mérito seria "ter ultrapassado a subjetividade e a abstração do pensamento kantiano e tentado conceber pelo pensamento e realizar na arte a unidade e a conciliação como única expressão de verdade” (Hegel, 2009, P.80)

Conforme vimos, o belo para Hegel seria resultado da fusão racional com o sensível, constituindo nesta unidade a verdadeira realidade. $\mathrm{O}$ belo considerado por ele, é o belo artístico, que considerado superior ao belo da natureza por ser um produto do espírito de um homem, que por sua vez participa do espirito e da verdade absolutos. Engendraríamos na natureza qualidades do espírito, por isso acharíamos bela a natureza. "O canto do rouxinol apraz-no naturalmente, porque ouvimos um animal emitir, na sua inconsciência natural, sons que se assemelham à expressão de sentimentos humanos. O que nos apraz é, portanto, a imitação do humano pela natureza” (Hegel, 2009, P.28). A natureza seria caracterizada pela necessidade e pela regularidade (a natureza é racional para Hegel); a obra de arte pela atividade livre da imaginação, reflexo da presença do espírito. A natureza, que é objeto de estudo dos cientistas, seria abstrata. Assim como seria abstrata a mera imitação da natureza pelos artistas. Às formas gerais e abstratas retiradas da natureza, ainda que correspondessem à representações figurativas e naturalísticas de então, seria preciso acrescentar um conteúdo, "dar alma”: "No dia do Juizo Final, essas imagens acusarão quem as fez." (MUHAMMAD, Sunna, apud HEGEL, 2009, P.30). A imitação da natureza pelos meios artísticos não levaria ao artístico, mas apenas à demonstração de habilidade do executor.

A natureza, a realidade são fontes que a arte não pode dispensar; como não se pode dispensar o ideal que não é algo de nebuloso, de geral, de abstrato. Mas o fim da imitação consiste em reproduzir os objetos da natureza tais como são em sua existência exterior e imediata, o que só é próprio para satisfazer a lembrança. 
Ora, o que nós esperamos e exigimos, no apelo à totalidade da vida, não é apenas a satisfação da lembrança mas também a sua alma. (Hegel, 2009, P.32)

Toda obra de arte teria uma dupla dimensão, segundo Hegel: como objeto de contemplação e intuição direcionado à sensibilidade e como objeto do espírito. Mesmo o aspecto sensível da obra de arte só deve existir para o espírito, pois, conforme já definia Kant, o juízo de gosto do belo decorre da "complacência pura e desinteressada” (KANT, 2008, P.50). O interesse entraria em contradição com a obra que, dotada de alma, deveria subsistir aos desejos do homem. "O desejo devora, pois, os objetos, caso em que não existe nada mais do que um interesse isolado”. (Hegel, 2009, P.56). Hegel vincula a dimensão natural concreta da obra à necessidade, que seria oposta ao atributo maior do espírito, que é a liberdade. Não será através da necessidade ou desejo que o homem se relacionará com a obra de arte, pois dominado pelo desejo ele não é livre em si; "pois que não se determina pela universalidade e racionalidade essencial da vontade, nem é livre em relação ao mundo exterior, pois que o desejo é essencialmente determinado pelas coisas que o ocupam” (Hegel, 2009, P. 56). A dimensão sensível que interessa no objeto de arte é sua aparência sensível e individual abstraída da materialidade, o que não é redutível ao universal.

Trata-se da aparência puramente sensível ou, com maior exatidão, da forma. Dirige-se a ela, por uma lado, à vista e ao ouvido: simples aspectos e tonalidade das coisas. São estes os aspectos em que o sensível aparece na arte. O reino da arte é o reino das sombras do belo. As obras de arte são sombras sensíveis. Já assim, vemos de mais perto que gênero de sensível pode ser objeto da arte: é somente o sensível que se dirige aos nossos sentidos sublimados. O olfato, o paladar e o tato apenas se referem às coisas materialmente sensíveis: o tato é sensível ao frio, ao calor etc.; o olfato à evaporação de partículas materiais, o paladar à dissociação de partículas materiais. O agradável não participa do belo mas liga-se à sensibilidade tal como existe para o espírito. A matéria sobre a qual a arte se exerce é o sensível espiritualizado. O sensível só entra na arte no estado de idealidade, de sensível abstrato (grifo meu). (Hegel, 2009, P.59)

A atividade artística é, portanto, uma atividade simultaneamente sensível e espiritual que produz imagens para conteúdo absoluto do espírito. A fantasia é o seu modo da expressão, que imprime formas sensíveis imaginíficas. A imaginação criadora, por sua vez, depende do talento artístico que seria um dom natural e corresponderia à dimensão sensível do homem que nasce gênio, e que, diferente da habilidade técnica, não pode ser ensinada. O artista, para Hegel, criaria de modo quase instintivo, exercendo algo entre uma atividade 
natural/animal/necessária e a atividade livre espiritual do pensamento que abstrai a naturalidade. Já o talento científico não dependeria de um dom natural, pois envolveria apenas “uma aptidão de pensar por generalizações” (Hegel, 2009, P.60), sendo, portanto, uma atividade puramente espiritual para ele, mas que não representa o absoluto como a filosofia, a religião e a arte.

No sentido desta fusão entre sensível e racional, Schiller apontaria a importância da educação estética do homem como um acelerador deste processo de fusão, porque ela visa conferir às inclinações, tendências e sentimentos humanos "uma formação que os leve a participar da razão, de tal modo que a razão e a espiritualidade ficam despojadas do caráter abstrato para se unirem à natureza como tal, e da sua carne e do seu sangue se enriquecem” (Hegel, 2009, 82) . Todo homem poderia participar da razão, pois Hegel pressupõe, como Schiller, que contenha "o germe do homem ideal". A representação do homem verdadeiro seria o Estado, que é a forma da unificação dos sujeitos individual e ideal com a moral, segundo o ponto de vista absoluto defendido por Hegel. O Estado realiza uma ideia e é, portanto verdade e real simultaneamente.

\footnotetext{
Ora, a unidade entre o homem no tempo e o homem na idéia pode se realizar de dois modos: de um lado, o Estado, como representação genérica do que é moral, conforme ao direito e à inteligência, pode suprimir todas as encarnações individuais; de outro lado, o indivíduo pode elevar-se ao genérico, e o homem no tempo adquire títulos de nobreza, tornando-se o homem na idéia. (Hegel, 2009, P.81)

O Estado, no entanto, não realiza a ideia absoluta, que Hegel define como
} verdade.

Para darmos da idéia uma definição mais rigorosa, diremos que, enquanto existente em si, é o que participa do espírito de um modo geral, o que é o espírito universal, o espírito absoluto. O espírito absoluto é o espírito enquanto universal e não enquanto particular e finito. Determina-se como o que recebe a verdade de uma verdade universal. (Hegel, 2009, P.120) 


\section{2.}

\section{A Forma Viva}

\section{O Homem artificial e a Forma viva}

\section{A Educação estética da vontade}

\section{O Homem artificial e a Forma viva}

\section{A Educação estética da vontade. O Estado estético.}

As reflexões presentes no livro de Schiller, citado por Hegel, A educação estética do homem foram influenciadas pelo clima europeu de decepção em relação à concretização dos ideais da Revolução Francesa. Um clima de barbárie teria dominado os Estados subsequentes que remetia paradoxalmente à selvageria de povos considerados primitivos culturalmente. Schiller concorda apenas parcialmente com seus contemporâneos nostálgicos que acusam a cultura como responsável pela ambiguidade e dissimulação do comportamento humano, cuja educação não teria evitado o egoísmo e a violência dos ânimos revolucionários, que se acreditava serem propriedades humanas em seu estado natureza; a cultura teria apenas disfarçado tal violência com uma bela aparência. Para ele, a arte, através da experiência estética do belo, teria o potencial de recuperar o homem moderno de seu estado de fragmentação e reconduzi-lo à liberdade e ao absoluto. Schiller acredita que somente uma mente adulta, já devidamente afastada da árdua experiência, descreveria a infância em seu estado natureza como idílio, dando-lhe um sentido exterior já em função da forma final da maturidade. Ele propõe uma revisão das noções sobre a natureza humana para explicar as contradições que a cultura vinha deixando transparecer. Donde se verificaria que o homem em tempos primitivos se impunha pela força. O homem natural seria movido apenas pelas necessidades físicas e não pela ideia de liberdade, agiria em função de sua própria satisfação, usando da violência. Do mesmo modo, Schiller infere que o Estado natural seria o modo "como podemos denominar todo corpo político que tenha sua instalação originalmente derivada de forças e não leis" (SCHILLER, 1990, 28). O Estado moral, que se queria impor por outro lado, seria movido pela mera abstração que ignora a subjetividade individual. Este não conseguiria se estabelecer, seja porque os homens não o respeitariam ou porque ele perderia sua razão moral de ser ao tiranizar. "Se queremos, portanto, contar com a conduta 
ética do homem como seus efeitos naturais, ela tem de ser natureza, e o homem já tem de ser levado por seus impulsos a um comportamento que só pode ser resultado de um caráter ético." (SCHILLER, 1990, 31) Somente o Estado estético propiciado pela arte levaria a esta conduta ética, pois unificaria os impulsos humanos, unindo sua dimensão física à espiritual, fazendo-o capaz de fruir como individuo e como espécie, dando-lhe um "caráter social" (SCHILLER, 1990, 144) e realizando o Ideal da igualdade. Esta igualdade dependeria do desenvolvimento do gosto propiciado pela educação estética do homem, que o libertaria de uma visão instrumentalizada do mundo, que é cega para as belas aparências. O gosto tornaria o homem sensível à aparência das formas de modo independente de seu conteúdo ou da essência real de suas formas, segundo a fruição desinteressada, conforme definido por Kant. A forma se comunicaria diretamente ao espírito; e por isso favoreceria o desenvolvimento no homem da sensibilidade à contemplação de ideias da razão. $\mathrm{O}$ amadurecimento do gosto e da ética caminhariam juntos, pois o gosto fomentaria a alegria da percepção das formas racionais, entre elas a ideia de liberdade, substituindo o estatuto moral, definido antes pela combinação de lei e dever, pela vontade. A educação estética refina, portanto o desejo, tornando-o independente dos instintos da animalidade individual. "Só a beleza faz feliz a todo mundo; e todos os seres experimentam sua magia e todos esquecem a limitação própria” (SCHILLER, 1990, 145). O gosto despertado tanto no belo agradável como no sublime despertaria o espírito para a sensação de liberdade do homem como indivíduo e como espécie, pois ele apaga tal distinção por possuir a dupla dimensão subjetiva e universal.

\footnotetext{
O gosto conduz o conhecimento para fora dos mistérios da ciência e o traz para o céu aberto do senso comum, transformando a propriedade das escolas em bem comum de toda a sociedade humana. Em seu domínio, mesmo o gênio poderoso tem de abrir mão de sua majestade e descer, com gesto familiar, até o senso infantil. A força deixa-se prender pelas deusas das dádivas, o leão altivo obedece às rédeas do Amor. Em troca, o gosto recobre com seu véu suavizante a carência física, ofensiva em sua nudez à dignidade de espíritos livres, ocultando na amável ilusão da liberdade o parentesco desonroso com a matéria. Em suas asas, mesmo a arte degradada pelo ganho escapa ao pó, as correntes da servidão partem-se ao contato de sua vara mágica, liberando tanto o vivo como o inerte. No Estado estético, todos - mesmo o que é instrumento servil - são cidadãos livres que têm os mesmos direitos que o mais nobre, e o entendimento, que submete violentamente a massa dócil a seus fins, tem aqui de pedir-lhe o assentimento. (SCHILLER, 1990, 145)
} 
Schiller estava muito impressionado com a leitura que fizera de Kant, principalmente no tocante às críticas da razão prática e do juízo, a partir das quais pensará a possibilidade de um caminho de desenvolvimento para a ética através das artes, que tanto impressionará Hegel. Para tanto, precisará revisar a concepção de sujeito kantiana, elaborada como virada copernicana, ou mesmo aquela do sujeito reflexivo ${ }^{59}$. O sujeito em Schiller também seria determinado pela vontade, guiada pela exercício livre das faculdades da razão e da imaginação, conforme encontramos em Kant. No entanto, Schiller propõe tratar o objeto do juízo moral como estético, ou seja: que o objeto seja visto de modo espiritualizado e ajuizado como interesse comum da espécie humana e não individual. Deste ponto, a vontade do homem moral não corresponderia ao cumprimento de um dever, estipulado por uma razão abstrata soberana, e acompanhado do sentimento de sacrifício que resultaria num engrandecimento pessoal, conforme se define o comportamento moral sublime proposto por Kant. Schiller acreditava ser possível que o sujeito tivesse uma conduta moral de modo mais fluido, e não através de autoimposições, o que seria possível desde tal sujeito fosse dotado de sentimentos nobres. A educação estética do homem permitiria tal mudança de paradigma do sujeito, que se daria tanto no plano sensível quanto no intelectual. A experiência estética enobreceria os sentimentos humanos, não somente porque a aponta para o mundo espiritual das formas, como também porque permite a vivência do sujeito como além de si, na identificação com os objetos e com os outros, conforme verificaremos adiante.

A cultura estética permitiria o enobrecimento dos desejos e, consequentemente, o apuramento das escolhas humanas. Através da cultura estética, o homem poderia experimentar efetivamente a liberdade que é não ter a vontade determinada por necessidades físicas ou pela moral do sacrifício. A liberdade estética, proporcionada pela prazerosa experiência do belo, refinaria a

59 "Na Carta XXV, Schiller dirá que "a contemplação (reflexão) é a primeira relação liberal do homem com o mundo que o circunda". O tema da reflexão nos estudos estéticos de Schiller tem duas fontes. Para Rousseau, o homem que reflete já deixou, por assim dizer, sua maneira "simples, uniforme e solitária de viver prescrita pela natureza" Discurso sobre a Origem e os Fundamentos da Desigualdade, ed. cit., p.247). Assim, a reflexão não é atributo do homem natural, mas supõe já o convívio social. Por outro lado, a reflexão é, segundo a Crítica do Juízo de Kant, a condição de todo juízo estético: para encontrar beleza numa coisa, diz Kant, "nada mais/é requerido/do que mera reflexão (sem nenhum conceito) sobre uma representação dada."(Primeira Introdução à Crítica do Juízo, ed. Cit., p.188). Nota 83, SUZUKI, M. In SCHILLER. A Educação Estética do homem. SP: Iluminuras, 1990. P. 160 
autoconsciência do sujeito, interferindo assim no resultado de suas escolhas. A vontade seria entendida pela noção de livre-arbítrio ${ }^{60}$ entre dever e inclinação. $\mathrm{O}$ exercício da vontade dependeria de certo grau de liberdade espiritual alcançado pelo homem somente após sua evolução do estado físico para o estado estético. A vontade não seria, portanto, uma determinação puramente racional, mas o efeito de um estado de plenitude humana que envolveria razão e sensibilidade. No inicial estado físico, o homem estaria submetido às leis da natureza material e desconheceria a vontade, que envolve certo grau de espiritualização. A liberdade no plano moral dependeria, portanto, deste processo de passagem de estados: do físico ao estético, e deste ao moral finalmente. Tal fenômeno seria reconhecível tanto no plano individual quanto da humanidade, tomada como espécie. A passagem direta do estado físico/natureza para o moral, seria praticamente impossível, pois somente no estado estético seria suscitada a vontade ${ }^{61}$ e a capacidade humana de emitir juízos universais, atributos que permitem ao homem isolar-se das determinações naturais. A passagem do estético ao moral seria, portanto, bem menos árdua que do físico ao estético.

Para conduzir o homem estético ao conhecimento e às grandes intenções, basta dar-lhe boas oportunidades; para obter o mesmo do homem sensível é preciso modificar-lhe a própria natureza. Naquele, por vezes, é suficiente o desafio de uma situação sublime (que atua do modo mais imediato sobre a faculdade volitiva), para transformá-lo em herói e sábio; este precisa ser posto, antes, sob outro céu. (SCHILLER, 1990, 119)

\footnotetext{
60 "Quanto ao conceito de vontade, pode-se afirmar que muitas vezes ele é usado em seu sentido kantiano, enquanto vontade universalmente legisladora identificada à razão prática (veja-se nota 13). Há passagens, por outro lado, em que o termo Wille (vontade) ou freier Wille (vontade livre) pode exprimir a "faculdade de escolha", vale dizer, o livre arbitrio, como é o caso aqui.

A partir dessa definição da vontade humana (não confundir com "vontade santa") como plenamente livre entre dever e inclinação, passa-se à concepção de que o que caracteriza o homem é justamente a vontade." Nota 64, SUZUKI, M. In SCHILLER. A Educação Estética do homem. SP: Iluminuras, 1990. P.158

"Compare-se, a título de exemplo, (...) com a definição da vontade estabelecida por Kant na Fundamentação da Metafísica dos Costumes (A36/37): "Só um ser racional possui uma vontade ou a faculdade de agir segundo a representação das leis, isto é, segundo princípios. Uma vez que para a dedução das ações a partir das leis exige-se razão, a vontade não é nada mais senão razão prática. Se a razão determina incontornavelmente a vontade, as ações de um tal ser, que são reconhecidas como objetivamente necessárias, são também subjetivamente necessárias, isto é, a vontade é uma faculdade de escolher apenas aquilo que a razão, independentemente da inclinação, reconhece como necessário, isto é, como bom." Nota 13. Idem ibidem. P. 150.

61 “(...), o passo da matéria crua para a beleza, através do qual uma atividade totalmente nova nele deve iniciar-se, tem de ser-lhe facilitado pela natureza, e sua vontade em nada pode comandar uma disposição que dá existência à própria vontade." SCHILLER. A Educação Estética do homem. SP: Iluminuras, 1990. P.118
} 
Os estados do homem, descritos acima, corresponderiam ao desdobramento da existência humana e da humanidade, consideradas segundo seu sentido evolutivo, que rumaria do materialismo ao racionalismo/espiritualismo da moral. A novidade introduzida por Schiller estaria na valorização do estado estético, no qual o homem se tornaria sensível às aparências, percebidas tanto como ideia quanto matéria, e na interpretação da moral como algo além do dever: este entendido como algo limitado à realização de uma finalidade prática estabelecida pela razão; como o cumprimento de ações já moralmente preestabelecidas como fim. Schiller defende a possibilidade de um alargamento destes fins pela "transgressão estética do dever", que significaria buscar o suprasensível e agir com nobreza de alma, renunciando aos apelos materiais individuais e do entendimento (redução do sujeito) para ser capaz da livre contemplação e mesmo da espiritualização dos objetos. A razão moral, resultante da vontade, não resultaria, portanto, no sacrifício sublime definido por Kant, mas sim num enobrecimento do modo de sentir, proporcionado pela experiência do prazer estético como juízo compartilhável e desinteressado que iguala os homens, e que faz a condição de sujeito copernicano oscilar. Razão e sentimento refinam-se e se encontram em harmonia no belo.

\begin{abstract}
Deve ser dita nobre a mente que tenha o dom de tornar infinitos, pelo modo de tratamento, mesmo o objeto mais mesquinho e a mais limitada empresa. É nobre toda a forma que imprime o selo da autonomia àquilo que, por natureza, apenas serve (é mero meio). Um espírito nobre não se basta como ser livre; precisa por em liberdade todo o mais à sua volta, mesmo o inerte. Beleza, entretanto, é a única expressão possível da liberdade do fenômeno. A expressão predominante do entendimento numa face ou numa obra de arte nunca pode ser nobre, como não pode também ser bela, pois acentua a dependência (que é inseparável da finalidade) em lugar de ocultá-la. (SCHILLER, 1990, p. 120)
\end{abstract}

\title{
Impulsos sensível, formal e lúdico
}

\section{Unificação do real pelo belo}

O Homem seria afetado pelas duas tendências de realizar e de formar. Elas corresponderiam aos impulsos sensível e formal, que agem nele como forças opostas. O primeiro leva a realizar no mundo sensível "o que é necessário em nós; o segundo, a submeter a realidade "fora de nós” a leis formais. Quando impulso sensível vigora, homem não é; "pois sua personalidade é suprimida enquanto é dominado pela sensibilidade e arrastado pelo tempo" (SCHILLER, 
1990, p. 68). Este corresponde ao estar fora de si, fora do estado de consciência: "embora esse modo de dizer só ocorra quando a sensação se torna afeto e esse estado seja mais perceptível por sua maior duração, no entanto qualquer um está fora de si enquanto apenas sente" (SCHILLER, 1990, p. 68). O impulso racional, ou formal parte da existência absoluta do homem e move o homem a afirmar sua liberdade e a garantir a conservação do estado de sua pessoa. Suprime o tempo e a modificação: "quer que o real seja necessário e eterno e que o necessário e o real sejam eternos; em outras palavras exige verdade e justiça." Ele fornece leis pela determinação de realidades arrancadas do tempo, que são as afirmações universais sobre objetos eternizados num conceito. Estes impulsos demonstrariam a possibilidade de se definir o sujeito abstratamente a partir de dois limites extremos: aquele que define a pessoa em sua liberdade, que é sujeito no absoluto e que não muda; e aquele que determina sua existência no tempo, seu vir a ser, que ele chamará de estado. Estas duas dimensões humanas justificariam a autonomia do espírito e da sensibilidade como irredutíveis ao cogito cartesiano. "Nós somos não porque pensamos, queremos, sentimos: e pensamos, queremos ou sentimos não porque somos. Nós somos porque somos. Nós sentimos, pensamos ou queremos porque além de nós existe algo diverso." (SCHILLER, 1990, 64)

Espaço e tempo seriam condições externas à pessoa através das quais se percebe a matéria. $\mathrm{O}$ exercício de percepção da matéria demanda a atividade do eu que não se altera, mas que existe no espaço e no tempo. O espírito existiria sem jamais tornar-se matéria, mas sem a sensibilidade a pessoa seria ou "pura forma"; ou "mundo", "mero conteúdo informe do tempo". Por seu potencial pessoal infinito para formar e por sua necessidade de realização, de criação de mundos, o homem tenderia para o divino. Somente a sensibilidade o encaminharia neste sentido, pois somente ela seria capaz de transformar o espírito/personalidade (pura forma espiritual) em matéria (mundo), que é ainda o conteúdo informe do tempo; e somente a personalidade delimitaria o tempo:

Conquanto apenas a sensibilidade faça de sua capacidade uma força real, é apenas sua personalidade que faz de sua atuação algo que lhe seja próprio. Para não ser apenas mundo, portanto, é preciso que ele dê forma à matéria; para não ser apenas forma é preciso que dê realidade à disposição que traz em si. Realiza a forma quando cria o tempo (grifo meu) e contrapõe a modificação ao que 
perdura e a multiplicidade do mundo à eterna unidade de seu eu; forma a matéria, quando suprime de novo o tempo (grifo meu), quando afirma a alternância no que perdura e submete a multiplicidade do mundo à unidade de seu eu. (SCHILLER, 1990, 65)

O homem seria determinado, portanto, por sua dupla natureza sensívelracional. Por seu impulso racional/formal, exige forma (coerência, unidade); por seu impulso sensível, exige tornar realidade a demanda de suas disposições interiores que vislumbram o absoluto: ele "deve exteriorizar todo o seu interior e formar todo o exterior" (SCHILLER, 1990, 65). O primeiro impulso torna a manifestação da existência física possível, submetendo o homem aos limites do tempo e "tornando-o matéria". É o estado da sensação, quando a personalidade é suprimida. Através do impulso sensível, o homem é "dominado pela sensibilidade e arrastado pelo tempo", levado "fora de si" (SCHILLER, 1990, 68). O impulso sensível dá conteúdo ao tempo.

Com ligas indestrutíveis, (o impulso sensível) acorrenta ao mundo sensível o espírito que se empenha pelo mais alto, e faz voltar aos limites do presente a abstração que marcha livremente para o infinito. O pensamento, entretanto, pode fugir-lhe por momentos, e uma vontade firme opõe-se, vitoriosa, à suas exigências; cedo, porém, a natureza subjugada retorna a seus direitos exigindo realidade para existência, um conteúdo para nossos conhecimentos e um fim para nosso agir. (SCHILLER, 1990, 68)

O impulso formal parte da razão do homem (sua existência absoluta) e "está empenhado em pô-lo em liberdade, levar harmonia à multiplicidade dos fenômenos e afirmar sua pessoa em detrimento de toda alternância de estado" (SCHILLER, 1990, 68). Ele fornece leis para os conhecimentos e vontades, arrancando os objetos da jurisdição do tempo, dando-lhe "realidade para todos os homens e todos os tempos, isto é, universalidade e necessidade. (SCHILLER, 1990, 69)

Os impulsos de sensível e formal não poderiam ser sentidos simultaneamente, exceto através da experiência do absoluto, que é alcançada através de um terceiro impulso no homem, o impulso lúdico. Através dele, o homem experimentaria a Ideia de sua humanidade, não como uma mera abstração, mas como sensação da ideia: "Deve sentir por ser consciente e ser consciente por sentir" (SCHILLER, 1990, 77). O impulso lúdico liberaria o homem das contingências impostas pelas leis da natureza, que regem o impulso 
sensível, e que determinam seus desejos e modos de satisfação; e das leis morais, que regem o impulso formal, e que determinariam sua perfeição moral e liberdade. Através desta junção de dois impulsos opostos com o lúdico, os efeitos coercitivos se neutralizariam, provocando a suspenção das imposições físicas e morais determinadas pelos impulsos sensível e formal respectivamente e a compatibilização das ideias da razão com os interesses dos sentidos.

As leis naturais imporiam passividade, as morais, atividade. O lúdico seria ativo e passivo: "O impulso sensivel quer ser determinado, quer acolher seu objeto; o impulso formal quer ele próprio determinar, quer engendrar seu objeto; o impulso lúdico, então, estará empenhado em acolher de modo tal como se ele próprio tivesse engendrado e assim engendrar, como o sentido almeja acolher. ${ }^{\prime 62}$ (SCHILLER, 1949, 287). O impulso lúdico unifica os impulsos sensível e formal e permite que a forma seja experimentada como realidade e que a matéria seja percebida como forma, pois ele leva a "suprimir o tempo no tempo, a ligar o devir ao ser absoluto, a modificação à identidade" (SCHILLER, 1990, 78). Seu objeto seria a forma viva: "um conceito que serve para designar todas as qualidades estéticas dos fenômenos, tudo o que em resumo entendemos no sentido mais amplo por beleza". (SCHILLER, 1990, 81). A beleza, portanto, não se encerraria no mundo da vida, seja num ser vivo ou objeto inerte qualquer; e ela também não seria mera forma abstrata.

Enquanto apenas meditamos sobre a forma, ela é inerte, mera abstração; enquanto apenas sentimos a vida, esta é informe, mera impressão. Somente quando sua forma viva em nossa sensibilidade e sua vida se forma em nosso entendimento o homem é forma viva, e este será sempre o caso quando o julgamos belo. (SCHILLER, 1990, 82)

A gênese da beleza se explicaria por uma exigência da razão frente à "infinitude vazia" (SCHILLER, 1990, 99), "amplo reino do possivel" que se abre em decorrência da alternância dos impulsos contrários de forma e sensível, donde surge uma representação que se afirma como realidade. Através da beleza se conciliaria matéria e espírito e se realizaria a humanidade em seu sentido pleno.

\footnotetext{
62 "Der sinnliche Trieb will bestimmt werden, er will sein Objekt empfangen; der Formtrieb will selbst bestimmen, er will sein Objekt hervorbringen; der Spieltrieb wird also bestrebt sein, so zu empfangen, wie er selbst hervorgebracht hätte und so hervorzubringen, wie der Sinn zu empfangen trachtet.” SCHILLER, F. Ausgewählte Werke. Stuttgart: W. Kohlhammer, 1949. „Ästhetische Erziehung des Menschen“ P. 287
} 
Através da beleza, o homem sensível é conduzido ao pensamento e; o homem espiritual, chamado de volta para o mundo sensível.

A razão, entretanto, diz: o belo não deve ser mera vida ou mera forma, mas forma viva, isto é, deve ser beleza à medida que dita ao homem a dupla lei da formalidade e realidade absolutas. Com isso, ela afirma também: o homem deve somente jogar com a beleza, e somente com a beleza deve jogar.

Pois, para dizer tudo de vez, o homem joga somente quando é homem no sentido da palavra, e somente é homem pleno quando joga. (SCHILLER, 1990, 84)

O ideal do impulso lúdico é estabelecido pela razão que determina a busca do belo ideal: "com o agradável, com o bem, com a perfeição, o homem é apenas sério: com a beleza, no entanto, ele joga”. (SCHILLER, 1990, 82) A seriedade imposta pela necessidade e moral é abandonada diante da experiência do belo, tornando o real pequeno em sua aproximação com a ideia, inspirando no homem a sensação de liberdade que é marcada pelo desaparecimento do desejo e da vontade (legisladora) e numa posterior religação na dimensão da fruição desinteressada.

(Sobre a escultura de Juno Ludovisi:) Toda a figura repousa e habita em si mesma, criação inteiramente fechada que não cede nem resiste, como se estivesse além do espaço; ali não há força que lute contra forças, nem ponto fraco em que pudesse irromper a temporalidade. Irresistivelmente seduzidos por um, mantidos a distância por outro, encontramo-nos simultaneamente no estado de repouso e movimento máximos, surgindo aquela maravilhosa comoção para a qual o entendimento não tem conceito e a linguagem não tem nome. (SCHILLER, 1990, 85)

A fruição do belo liberaria no homem seu Estado Estético, que seria o estado de máxima realidade por ele alcançado. Não corresponderia a um esvaziamento nem de seu impulso sensível, nem do racional. Este estado corresponderia ao equilíbrio de uma "balança vazia" (anulação), estado do ser livre de toda determinação. $\mathrm{O}$ homem não passa do sentir ao pensar imediatamente. Ele volta a um estado equivalente ao estado anterior à impressão, só que agora ligada ao máximo de conteúdo e determinação. Ele deve ter realidade e determinação ilimitada. Esta seria uma disposição intermediária, onde sensibilidade e razão são simultaneamente ativas e a mente não é constrangida nem física nem moralmente. Antes da fruição, que envolve a impressão sensível, o espirito humano vagaria numa infinitude vazia. A manifestação deste espírito no tempo e no espaço é limitada pelo conteúdo finito. É na passagem da indeterminação para determinação por limites que se adquire realidade. Antes 
força ilimitada, agora limitada. A realidade surge então de uma exclusão, simultaneamente acompanhada daquilo de que se exclui e que corresponde à ação da mente, o pensamento imediato.

A beleza ativa os impulsos passivos e ativos, materiais e espirituais respectivamente; e o pensamento é exatamente a resposta do espírito à impressão sensível. O pensamento ou juízo seriam o resultado do "estado-de-ação" 63 do ânimo em oposição à impressão sensível. A impressão sensível dá conteúdo real ao espírito; dá o instante no tempo e um lugar no espaço. O pensamento é, portanto, a ação imediata do espírito "materializado" a liberdade de exteriorizar-se por suas próprias leis (leis formais). O juízo do belo infere a parte no todo e vice-versa, desperta no homem a autoconsciência que unifica as atividades do ânimo, superando a divisão entre o exercício de abstração e a experiência sensível. O belo permite a experiência do supra-sensível nos limites existenciais do homem, conduzindo-o "da matéria à forma, das sensações a leis, de uma existência limitada à absoluta" (SCHILLER, 1990, 100). Ele permite que o homem alcance a liberdade, realizando-se em plenitude, como ser individual. $\mathrm{O}$ belo faz convergir os impulsos contrários sensível e formal que agem no homem, neutralizando suas demandas, oferecendo a possibilidade de liberdade segundo a dupla natureza humana racional e sensível, que é liberdade estética e não puramente intelectual. Neste espaço pleno do embate entre os impulsos, a vontade se afirma como liberdade de poder, como um fundamento de realidade: "Não existe no homem nenhum outro poder além de sua vontade, e

\footnotetext{
63 "Depois de fazer uso de diversos conceitos fichteanos (determinabilidade, negação, posição, oposição etc.), Schiller apropria-se agora do conceito de "estado-de-ação"(Tathandlung). Este $e ́$, para Fichte, o primeiro princípio absolutamente incondicionado de todo saber, "que não aparece nem pode aparecer entre as determinações empíricas de nossa consciência, mas que, muito pelo contrário, está no fundamento de toda consciência, mas que, muito pelo contrário, está no fundamento de toda consciência e é o único que a torna possivel"(A Doutrina-da-Ciência de 1794, ed. cit., $p$. 43. Para a tradução de Tathandlung, vocábulo forjado por Fichte, por "estadode-ação", veja-se a nota de Rubens Rodrigues Torres Fillho). Nota 62 da tradução de Schwarz e Suzuki. (SCHILLER, 1990, p. 157)

${ }^{64} \mathrm{O}$ espirito materializado pode ser entendido como alma, ânima. "Mas de uma mera exclusão nada se tornaria real na eternidade e de uma mera impressão sensivel na eternidade, nenhuma representação surgiria; quando não houvesse algo já dado, do que se pudesse excluir; quando a negação não estivesse relacionada, através de um estado de ação do espírito absoluto (absolute Tathandlung des Geistes), a algo positivo, e quando da não-colocação uma contraposição não surgisse; este manejo da alma/ânimo (Handlhung des Gemüts) se chama julgar ou pensar, e o resultado do mesmo é o pensamento." Tradução da carta XIX de SCHILLER, F. Ausgewählte Werke. Stuttgart: W. Kohlhammer, 1949. „,̈sthetische Erziehung des Menschen“, P. 302.
} 
somente o que suprime o homem, como a morte ou qualquer roubo de sua consciência, pode suprimir a liberdade interior" (SCHILLER, 1990, 102).

A experiência com o belo comprova para Schiller que a liberdade moral não se afirma de modo independente da impressão sensível, e que ela deve se pautar na liberdade estética, compreendendo as determinações tanto materiais quanto espirituais do homem, conforme sua natureza mista. A desconsideração destas forças agindo sobre o temperamento humano é que justificariam a aparente contradição em que se encontrava a sociedade então. A ação das forças sensíveis afetam o estado do homem de modo alheio a sua vontade, interferindo na determinação das personalidades humanas. Somente pelo enobrecimento da vontade pelo belo suavizante ou enérgico o homem se tornaria mais justo. A contemplação estética demandaria certa renúncia do mundo sensível, das inclinações egoístas, orientando o homem para o mundo das Ideias. A vontade que depende do balanço entre os dois impulsos opostos também seria redirecionada, aproximando-se das formas da razão, que correspondem ao absoluto do bem, do belo, do tempo.

\begin{abstract}
O bem sensível faz feliz a um, já que está fundado numa apropriação que implica exclusão; e não o fará mais que parcialmente feliz, pois a personalidade não estará participando. O bem absoluto só pode trazer felicidade sob condições que não podem ser pressupostas em geral; pois a verdade é o prêmio da renúncia, e somente um coração puro acredita na pura vontade. Só a beleza faz feliz a todo mundo; e todos os seres experimentam sua magia e todos esquecem a limitação própria." (SCHILLER, 1990, 144).
\end{abstract}

O mero conhecimento das leis, conforme verificamos, não tornaria o homem mais justo. É preciso que sua inclinação esteja de acordo, pois a autoconsciência humana está submetida a impressões sensíveis que permanecem inconscientes e que alteram a determinação racional e, consequentemente as escolhas humanas segundo sua vontade: "sensibilidade e autoconsciência originam-se sem nenhuma participação do sujeito" (SCHILLER, 1990, 102). A racionalidade pressupõe certa universalidade da consciência que o homem viria adquirindo com a vivência, onde ele poderia ter a experiência de "sua existência absoluta mediante a autoconsciência" e de "uma existência determinada mediante a sensibilidade". Os impulsos da razão e da sensibilidade são reais e a autoconsciência não poderia ser realizada pela mera via da abstração metafísica 
ou do conhecimento, eles precisam ser sentidos: o impulso racional surge da experiência da lei e o sensível da experiência da vida.

O impulso sensível no homem seria anterior ao racional, pois a experiência sensível precede a consciência: "Sabemos que ele começa da mera vida para terminar na forma; que é primeiramente indivíduo e depois pessoa; que caminha das limitações à infinitude” (SCHILLER, 1990, p. 101). A maturidade humana, conforme descrita por Schiller, se fundamentaria na evolução para o estado estético. Na beleza, o homem é livre e experimenta a elevação ao absoluto, como deve ser também no exercício da liberdade moral. Sua liberdade implica em realizar-se dignamente como personalidade e em termos de felicidade. A maturidade moral implica na busca da socialização destes bens. A cultura deve, portanto, contribuir no sentido de educar esteticamente para equilibrar a natureza humana segundo sua dignidade e felicidade, sabendo que na no belo a limitação própria que dá dignidade se realiza no anseio pela razão (que exige o absoluto) e que a felicidade absoluta se encontra no bem comum.

"Numa palavra, não se pode mais perguntar como ele passa da beleza à verdade, pois esta já está em potência na primeira, mas sim como ele abre caminho de uma realidade comum à uma realidade estética, dos meros sentimentos vitais a sentimentos de beleza" (SCHILLER, 1990, 132).

A resposta será: pela "alegria com a aparência, a inclinação para o enfeite e para o jogo." (SCHILLER, 1990, 134). Enfim movido pelo impulso lúdico, que só será despertado no homem que se distanciou do trabalho para sobrevivência e que não mais estaria submetido às mazelas impostas pela natureza; quando ela se torna seu objeto. Ele dá forma a ela, retirando dela qualquer vestígio de seu passado amedrontador. "O monstro divino dos orientais, que governa o mundo com a cega energia do animal de rapina, toma, na fantasia grega, o contorno amável da humanidade, o reino dos titãs é derrotado e a força infinita é domada pela forma infinita" (SCHILLER, 1990, 130).

Antes do advento do impulso lúdico, o homem viveria como um animal; não veria a natureza e nem outros em si, seja como objeto ou existências paralelas, mas apenas como parte inseparável de sua vida que ele consome conforme sua necessidade. Ele seria voraz e viveria limitado a sua individualidade "até que, pela reflexão, ele próprio se distinga das coisas, e os objetos finalmente se 
mostrem no reflexo da consciência" (SCHILLER, 1990, 124). O despertar para a razão o torna independente da realidade sensível, mas conforme vimos a liberdade chega primeiro por meio da aparência estética. $\mathrm{O}$ mundo ideal se torna então a realidade necessária para ele, e sua imaginação se abre para o infinito. O desenvolvimento da capacidade reflexiva é a condição para a apreciação do belo, mas não encerra sua experiência. No belo parecemos sentir a forma:

A beleza, portanto é objeto para nós, porque a reflexão é a condição sob a qual temos uma sensação dela, mas é, ao mesmo tempo, estado de nosso sujeito, pois o sentimento é a condição sob a qual temos uma representação dela. Ela é, portanto, forma, pois que a contemplamos, mas é, ao mesmo tempo, vida, pois a sentimos. Numa palavra: é, simultaneamente, nosso estado e nossa ação. (SCHILLER, 1990, 131).

O interesse pelo belo exigiria o desenvolvimento da sensibilidade pelas aparências. Tanto o homem sensível, movido pela necessidade, quanto o do puro entendimento, que coloca os objetos em repouso para submeter a conceitos, desprezam a aparência em prol da realidade. Somente quando se supera a carência pela abundância material é que o homem desprenderia a imaginação do real, provando sua liberdade exterior e interior: "A realidade das coisas é obra das coisas; a aparência das coisas é obra do homem, e uma mente que aprecia a aparência já não se compraz com o que recebe, mas com o que faz.” A aparência estética é o jogo de livre movimento com as formas, jogo da liberdade no homem. Os diversos sentidos humanos permitem o conhecimento do real, mas somente a visão e a audição propiciariam o desenvolvimento da sensibilidade estética. Ela, por sua vez, depende do desprendimento da realidade e do impulso para jogar com as formas aparentes do mundo. A visão e a audição seriam os sentidos privilegiados no desenvolvimento da sensibilidade estética, porque através deles exercitamos o engendramento dos objetos pelo entendimento e não na passividade da mera sensibilidade tátil. O impulso lúdico seria, portanto, o resultado do desenvolvimento da sensibilidade para a aparência visual, pois a aparência sensível tátil estaria relacionada à relação de apropriação que o homem selvagem tinha com a natureza. A visão permitiria que o homem se mantivesse afastado do objeto material, que é percebido através de imagens. A distância do objeto propiciaria pensá-lo como autônomo, o que será seguido do impulso mimético de criação e posteriormente para a forma, com a qual poderá jogar. "Tão logo comece a fruir com o olho e o ver alcance para ele um valor autônomo, ele é já 
também esteticamente livre, e o impulso lúdico se desenvolveu” (SCHILLER, $1990,135)$.

O homem retiraria a aparência da essência, dispondo dela segundo suas leis formais. Arte seria arte da aparência, que no seu jogo é capaz de ampliar as noções de beleza e de verdade. Não se deveria confundir a aparência com a dissimulação da realidade, falta de solidez e verdade, cuja acusação sofria a arte desde os tempos de Schiller.

Nada mais comum na boca de certos críticos triviais de nossa época do que a queixa de que toda a solidez desapareceu do mundo, e de que a essência é preferida em favor da aparência. (...) Não atacam apenas o verniz enganoso que oculta a verdade e pretende substituir a realidade; desprezam também a aparência benfazeja que preenche os vazios e recobre a indigência - a aparência ideal que enobrece a realidade comum. A falsidade dos costumes ofende-lhes com razão o severo senso da verdade; pena, contudo, contar entre a falsidade também a cortesia.(...) Sentem nostalgia da cordialidade, da autenticidade e da solidez dos tempos passados, mas querem recuperar também o rude e o grosseiro dos primeiros costumes, o tosco das velhas formas, e excesso gótico de outrora. Através de juízos desta espécie revelam um respeito pela matéria em si mesma que não é digna da humanidade, que deve apenas estimá-la na medida em que toma forma e é capaz e é capaz de ampliar o reino das Idéias. (SCHILLER, 1990, 138).

\section{Sombras do belo: belo suavizante e enérgico}

O belo ideal corresponderia ao absoluto indivisível, que seria inalcançável por ser uma "ideia da razão". Ao ser colocado nos limites do tempo, ele se desdobraria nas duplas manifestações do belo enérgico e do suavizante. " $A$ beleza na Idéia, portanto, é eternamente una e indivisível, pois pode existir somente um único equilíbrio; a beleza na experiência, contudo, será eternamente dupla, pois na variação o equilíbrio poderá ser transgredido por uma dupla maneira, para aquém e para além. (SCHILLER, 1990, 87) O belo será, portanto, de natureza enérgica (sublime-monumental ou grotesco), quando age fortalecendo o temperamento/ânimo (das Gemüt) ${ }^{65}$ humano nos planos físico e moral; ou

\footnotetext{
65 "Die energische Schönheit kann den Menschen ebensowenig vor einem gewissen Überrest von Wildheit und Härte bewahren, als ihn die schmelzende vor einem gewissen Grade der Weichlichkeit und Entnervung schützt. Denn, da die Wirkung der ersten ist, das Gemüt (grifo meu) sowohl im Physischen als Moralischen anzuspannen und seine Schnellkraft zu vermehren, (...) „, SCHILLER, F. Ausgewählte Werke. Stuttgart: W. Kohlhammer, 1949. „ësthetische Erziehung des Menschen“ P. 294 „A beleza enérgica pode tampouco prevenir os homens de certo resíduo de selvageria e dureza, assim como a beleza suavizante (schmelzende Schönheit- beleza que funde, derrete) o protege de certo nível de amolecimento e esmorecimento. Pois o efeito do
} 
suavizante (harmonioso-gracioso ou superficial-frívolo), quando seu efeito é de dissolver o temperamento/ânimo, também em dois planos, e aumentar sua receptividade às impressões. Dependendo do momento histórico da humanidade, uma ou outra se faria necessária, reequilibrando a energia harmonizante das forças espirituais e sensíveis que levam o homem a agir e refletir com perfeição. Em determinadas épocas de cultura refinada, o homem estaria mais propenso à "indulgência do gosto", carecendo, portanto, do encorajamento da beleza enérgica. Em outras épocas, o homem estaria enrijecido pela força de seu caráter e temperamento guerreiro, tendendo à natureza bruta e necessitando abrandar-se através da beleza suavizante. "A beleza enérgica não pode guardar o homem de certos resíduos de selvageria e dureza, assim como a beleza suavizante não o protege de certo grau de lassidão e esmorecimento." (SCHILLER, 1990, 88).

A beleza suavizante atuará sensibilizando a percepção da forma abstrata, para aqueles homens tensos sob coerção das sensações; ou da sensação da matéria, para aqueles sob coerção dos conceitos. A beleza teria a função educadora de dar harmonia aos impulsos contrários humanos, expandir as mentes limitadas e dar energia à mentes acomodadas. Para Schiller, a própria razão conclui pela demanda de uma lei moral: "deve haver beleza". A beleza permite passagem da sensação ao pensamento ao liberar a exteriorização da faculdade de pensar de modo autônomo e sensível ao mesmo tempo. A fruição do belo une as duas naturezas do pensamento e da sensibilidade, promovendo a unificação real (SCHILLER, 1990, 132), que é a realização do infinito (o belo) no finito da obra bela.

\section{O homem artificial e o belo enérgico ou sublime}

O homem dos tempos modernos, o homem artificial, teria a característica de ser dominado pela cultura, pela espírito de reflexão crítica que o afastaria da dimensão sensível do "entendimento vivo", que o homem natural possuía. O espírito de abstração dominante levaria o homem artificial à fragmentação de seu Ser, que somente se recomporia através da beleza enérgica ou sublime.

primeiro é tensionar o ânimo (Gemüt) no plano físico e moral e aumentar sua rapidez (...)”. Tradução de trecho da Carta XVI.

Na tradução de Schwarz e Suzuki, a palavra das Gemüt foi traduzida por mente. (SCHILLER, 1990, p. 88) 
A beleza suavizante, afirmou-se, está para uma mente tensa assim como a enérgica para uma mente distendida. Tenso, contudo, chamo o homem que está tanto sob coerção das sensações quanto sob a coerção dos conceitos. Qualquer dominação exclusiva de um de seus dois impulsos fundamentais é para ele um estado de coerção e violência; a liberdade está somente na atuação conjunta de duas naturezas. $\mathrm{O}$ homem dominado unilateralmente por sentimentos ou sensivelmente tenso é dissolvido e posto em liberdade pela forma; o homem dominado unilateralmente por leis e espiritualmente tenso é dissolvido e posto em liberdade pela matéria. A beleza suavizante, para satisfazer a essa dupla tarefa, mostrar-se-á sob dois aspectos. Em primeiro lugar, como forma calma, ela amenizará a vida selvagem e abrirá o caminho das sensações para o pensamento; em segundo lugar, como imagem viva, ela armará de força sensível a forma abstrata, reconduzirá o conceito à intuição e a lei ao sentimento. O primeiro serviço ela presta ao homem natural, o segundo ao homem artificial. (SCHILLER, 1990, 92)

Os hábitos impostos pela mundanidade das atividades humanas não submeteriam a mente enobrecida, que conseguiria exercer a atividade interna espiritual segundo sua liberdade infinita. Para esta mente livre, o belo artístico ultrapassa os limites da recreação (Erholung), conciliando-se com a faculdade da razão. A beleza teria o poder de mobilizar todas as faculdades humanas, exigindo do homem a reunificação perdida entre espírito e sensibilidade. Esta integridade funcionaria como um antídoto contra alienação, na medida em que prepara o homem para a fruição artística mais elevada do sublime estético. A ética nos prepara para apreciação do sublime nas artes. Conforme verificamos, o refinamento do gosto para o belo oferecido pelas artes resulta num enobrecimento moral. Estaríamos acorrentados à fruição passiva da beleza, "nossa guardiã na infância" ${ }^{66}$, enquanto não tivéssemos a ética cultivada segundo os princípios espirituais da razão ${ }^{67}$ no estado estético. A superação do estado natural, físico, infantil se daria através da cultura do belo. A cultura transformaria o homem natural em estético através da exposição às formas. ${ }^{68}$ Até então, o homem estaria limitado pelas contingências estabelecidas pela natureza física, que é condicionada; sendo, portanto, desprovido de vontade e liberdade. O gosto cultivado amadurece e conforme amadurece, expande os limites da capacidade da imaginação e do pensar. A apreciação do sublime requer do homem já certa

66 “(SCHILLER, 2011, p.64)

${ }^{67}$ "A razão, sabemos, dá-se a conhecer no homem pela exigência do absoluto (do que é fundado em si mesmo e necessário), exigência que, não podendo ser satisfeita em nenhum estado isolado de sua vida fisica, constrange a abamdonar totalmente o físico e a passar de uma realidade limitada a Idéias".(SCHILLER, 1990, P.125)

68 "É das tarefas mais importantes da cultura, pois, submeter o homem à forma ainda em sua vida meramente física e torná-lo estético até onde possa alcançar o reino da beleza, pois o estado moral pode nascer apenas do estético, e nunca do fisico." (SCHILLER, 1990, P.119) 
"riqueza de conceitos na cabeça e de um tesouro de princípios no peito para que se desenvolva a partir da razão a capacidade de sentir voltada para o grande e o sublime” (SCHILLER, 2011, p.65). Até então a experiência do sublime não poderia ser apreciada, pois remeteria apenas às limitações físicas ou intelectuais do homem imaturo, correspondentes ao temor à natureza; ou à incapacidade de representá-la seja por sua grandeza além da imaginação ou por ser inapreensível pelas leis do entendimento, respectivamente. $\mathrm{O}$ sublime requereria certa coragem para a livre contemplação dos objetos por um lado e, por outro, a capacidade de elevar o ânimo ao incondicionado mundo das ideias, obrigando o homem entregar-se corporalmente para experimentar a liberdade do espírito. "Sorte dele, portanto, se aprendeu a suportar o que não pode mudar e a abandonar com dignidade o que não pode salvar!” (SCHILLER, 2011, p.70). O sublime artístico por ser artificial prepararia o sujeito para enfrentar o sofrimento real como uma emoção sublime, dando à fatalidade do destino (o sofrimento e a morte inevitáveis) um sentido espiritual (formal) que na natureza em si não existe. " $O$ belo tem o mérito apenas no que diz respeito ao homem, o sublime, no que diz respeito ao puro demônio que o habita." (SCHILLER, 2011, p.72). Belo e sublime se complementariam no sentido de preparar o homem para realização de sua plena humanidade e livre espiritualidade respectivamente.

No caso do belo, a razão e a sensibilidade se harmonizam, de modo que apenas em função dessa harmonia ele tem seu atrativo para nós. Portanto, apenas por meio da beleza nunca experimentamos que estamos destinados a nos mostrar como puras inteligências, e que somos capazes disso. No caso do sublime, em contrapartida, a razão e a sensibilidade não se harmonizam, e justamente nessa contradição entre as duas reside a magia com que ele toma nosso ânimo. Aqui, o homem físico e o moral são separados um do outro do modo mais contundente, pois é exatamente no caso dos objetos nos quais o primeiro sente apenas suas limitações que o outro faz a experiência de sua força, sendo elevado infinitamente por aquilo mesmo que pressiona o outro contra o solo. (SCHILLER, 2011, p.61)

Se o sentimento sublime movia os heróis da Antiguidade submetidos aos confrontos guerreiros e cataclísmicos, agora deve arrancar o homem tanto do alheamento promovido pela rotina tensa de trabalho quanto daquele proporcionado pelo prazer recreativo do belo vulgar. Daí a atualidade do belo enérgico ou sublime nos tempos modernos: este nos arrancaria do deleite relaxado do belo e, ao contrariar o impulso sensível para tal deleite e triunfar sobre a faculdade de imaginação, obriga o homem a colocar sua atividade 
espiritual em plena atividade acima do sentimento de prazer corporal passivo, correspondendo, portanto, à maturidade e ao enobrecimento do gosto para Schiller.

\begin{abstract}
Além disso, é preciso ter os sentidos abertos, um vasto coração, um espírito jovial e não enfraquecido; é preciso ter toda a natureza unida, e este não é de modo algum o caso daqueles que se cindiram de si mesmos pelo pensar abstrato, estreitaram-se pelas fórmulas mesquinhas do ofício, extenuaram-se pelo esforço de atenção. Estes certamente não desejam uma matéria sensível para dar prosseguimento ao jogo das faculdades de pensamento, mas para interrompê-lo. Querem ser livres, mas apenas de um fardo que lhes cansava a inércia, não de um limite que lhes obstruía a atividade.

Pode-se ainda admirar o êxito da mediocridade e do vazio em questões estéticas, e a vingança dos espíritos fracos contra o belo verdadeiro e enérgico? Deste, tais espíritos esperavam uma recreação segundo sua necessidade e seu pobre conceito, e descobrem que aqui primeiramente se exige uma demonstração de força da qual poderiam não ser capazes mesmo em seu melhor momento. (Schiller, 1991, p. 98)
\end{abstract}

\title{
Espiritualização e Desmaterialização/Imaginação
}

\section{A inferioridade do artista plástico na sociedade cultivada}

O homem natural viveria em harmonia com a natureza, no sentido de que suas sensações seriam reações necessárias e imediatas a ela e que suas representações estariam condicionadas pela realidade do mundo exterior. Seus sentidos e razão atuariam como unidade em sincronia com a realidade vivida. $\mathrm{O}$ homem de cultura é um sujeito cindido. Vive oscilando entre os dois polos da sensibilidade material e da abstração. Conforme verificamos, somente o belo é capaz de devolver-lhe a unidade através da imersão do sujeito no estado estético, aproximando-o do Ideal. "Se o homem entrou no estado de cultura e a arte nele pousou a mão, suprime-se a harmonia sensível, e ele ainda pode se manifestar apenas como unidade moral, ou seja, empenhando-se pela unidade" (SCHILLER, 1991, p.60). O homem de cultura fez da natureza e de si próprio objetos de reflexão e jogo. Na busca moral por realizar-se idealmente, precisa reencontrar a natureza perdida, retornar à unidade. O homem moderno vive num mundo criado por ele próprio, onde todas as demandas impostas pela natureza são contornadas por meio de artifícios por ele inventados: a luz elétrica prolonga o dia, os meios de transporte encurtam a distância. O homem moderno teria liberdade para se reinventar conforme lhes desse asas a imaginação, mas esta 
condição de liberdade somente prolongaria a experiência abstrata e cindida da vida. Neste caso, seu espírito estaria tensionado e em plena atividade, conforme Schiller descreve o impulso racional/formal. Para que o homem se reequilibrasse, precisaria sofrer, voltando à natureza. A poesia ingênua, por seu carregado teor sensível, seria o meio privilegiado para distender tal espírito. Se, no entanto, se tratasse de uma mente alienada pelo trabalho repetitivo, ou amolecida pelas comodidades da vida moderna; a poesia sentimental o energizaria. Esta teria seria carregada de teor metafísico, demandando do homem e o esforço do impulso espiritual no sentido de arrancá-lo para além da rotina mundana do mundo sensível. O universo poético para Schiller consistiria, portanto, aos mundos sensível e das ideias, habitados pelo poeta ingênuo e pelo sentimental respectivamente.

A poesia ingênua corresponderia aos primórdios da arte, quando o homem ainda estaria descobrindo o mundo das aparências, começando a se desvencilhar da rudeza real do mundo material. No mundo moderno, tal poesia, cujo conteúdo está centrado na realidade natural como objeto e suas variadas impressões sensíveis, seria reprovada pelo gosto da crítica pela crueza vil de seus personagens. Schiller confessa ter compreendido Homero tardiamente: apenas quando percebeu que os poetas antigos seriam, assim como as crianças, mais livres que os modernos e os adultos para expressarem a verdade de seus afetos com simplicidade. Neste sentido, entendeu como ambos embaraçavam o homem de cultura; este estaria ora perdido em suas extravagantes fantasias, ora amarrado pelas convenções sociais. O poeta ingênuo, por sua verdade transparente, seria um estranho para a sociedade moderna. Para o gosto moderno, a poesia deveria evidenciar o caráter reflexivo do poeta. Ela deveria ter um conteúdo moralmetafísico que, nos poemas dos antigos, não encontramos. Neles, reconheceríamos apenas a pueril sinceridade de intenção, própria da poesia ingênua. Estariam tão próximos da natureza, que seu impulso artístico os instigaria a animar a natureza, atribuindo-lhe vontade de tal forma que acabavam retirando sua pressuposta dimensão condicionada e necessária. Nesta equiparação homem e natureza, eles se deteriam na descrição de objetos deificados ou personalizados, que enfatizam a vivacidade e a liberdade experimentadas em grandes feitos e destinos, que dispensam a inquietante descrição de conflitos 
interiores, resultantes da "razão meditabunda, como a fé eclesiástica das nações modernas" (SCHILLER, 1991, p.56). Eles tratariam seus objetos com tanta verdade que pareceriam insensíveis em sua crueza, o que de fato seria apenas o resultado da identificação direta do poeta com a obra, que formava uma indivisa unidade sensível na qual o coração do poeta parecia diluir-se, ou mesmo desaparecer:

É assim que se mostram, por exemplo, Homero entre os antigos e Shakespeare entre os modernos: duas naturezas sumamente distintas e separadas pela imensurável distância entre as épocas, mas de todo iguais nesse traço de caráter. Quando pela primeira vez, ainda em muito tenra idade, travei contato com este último poeta, indignou-me sua frieza, sua insensibilidade, que lhe permitia gracejar em meio ao pathos mais elevado, interrompendo as cenas lacerantes do Hamlet, do Rei Lear, do Macbeth etc. Mediante um bufão, e que ora o detinha, ali onde minha sensação se apressava, ora o arrastava friamente, ali onde o coração, a refletir junto com ele sobre seu objeto, em suma, a intuir o objeto no sujeito, era-me insuportável que, ali, o poeta não se deixasse apreender em parte alguma e, em parte alguma, quisesse prestar-me contas (SCHILLER, 1991, p.58).

O homem artificial não se deixaria levar pelas sensações imediatas despertadas pela natureza, colocando sempre sua faculdade reflexiva de forma ativa como uma intermediária entre a experiência e suas sensações, onde se experimenta a representação da ideia do natural: “ Eles sentiam naturalmente, nós sentimos o natural.(..) A medida que a natureza foi, pouco a pouco, desaparecendo da vida humana como experiência e como sujeito (agente e paciente), nós a vemos assomar no mundo poético como Idéia e como objeto." (SCHILLER, 1991, p.56) Ainda assim, o poeta sempre teria que se voltar à natureza, de onde retiraria a carga poética da obra. Conforme verificamos, o homem artificial seria um homem cindido da natureza como realidade experimentada e de si mesmo como natureza sensível. Vivendo de modo abstraído, terá que buscar a natureza sensível nos reflexos desmaterializados da realidade que ele pode internalizar de modo livre, segundo o jogo de sua faculdade de imaginação e representação. Suas sensações não estariam condicionadas pela necessidade de subsistência, por isso também suas representações não estariam subordinadas a um conteúdo funcional da realidade a ser incorporada. Movido pela vontade de realizar o conceito de poesia, que é definido por Schiller como o de "dar à humanidade a sua expressão mais completa possível" (SCHILLER, 1991, p.61), o poeta sentimental, que corresponde gênio poético da sociedade moderna cultivada, não poderá efetuá-lo 
por meio da imitação do real, posto que redundaria numa representação da natureza cindida. A harmonia entre o sentir e o pensar se dará apenas idealmente, segundo o empenho moral do poeta em alcançá-la. O poeta sentimental atuaria, portanto, num jogo de concordância e/ou contradição entre a realidade representada e a exposição ao ideal. Uma vez que o ideal tem um conteúdo infinito, jamais esta nova unidade seria alcançada chegaria à perfeição. O poeta ingênuo jogaria com um conteúdo finito da realidade que lhe permitia chegar à perfeição absoluta (ao infinito da forma) ${ }^{69}$ da exposição do seu objeto , que depois de alcançada não seria ultrapassada. O progresso do conceito de humanidade se estagnaria nesse caso. Já o conteúdo do poeta sentimental é ilimitado e parece ser vazio, pois ultrapassa a realidade rumo ao Mundo das Ideias, e é levado pelo ímpeto da extravagância, que a princípio não teria fronteiras. Ou seja, a poesia sempre possui um teor infinito.

Pode ser um infinito segundo a forma, se expõe seu objeto com todos os seus limites, se o individualiza; ou pode ser um infinito segundo a matéria, se afasta todos os limites de seu objeto, se o idealiza; portanto, ou mediante uma exposição absoluta ou mediante a exposição de um absoluto. $O$ peta ingênuo trilha o primeiro caminho; o poeta sentimental, o segundo. (SCHILLER, 1991, p.85)

O sentimental apresentaria um absoluto, ou faria uma apresentação absoluta, porque idealizaria a matéria; ou, no segundo caso, porque não poderia representá-la devido seu material de conteúdo infinito, tal como encontramos no sublime, podendo apenas compará-lo com o Ideal. Alguns artistas desenvolveriam, portanto, a arte do finito e outros a arte do infinito; o que se estenderia aos outros campos artísticos, que, neste momento, experimentavam uma delimitação de fronteiras ${ }^{70}$. O livro Laoconte de Gotthold Ephraim Lessing, definia os limites entre a poesia e a pintura a partir das essências temporal e espacial nelas predominantes. As artes espaciais, arquitetura, escultura e a pintura seriam consideradas limitadas por seu teor imitativo realista. As artes temporais,

\footnotetext{
${ }^{69}$ Schiller utiliza o termo Form e não Gestalt, por isso o conteúdo limitado da poesia ingênua seria infinito como a forma no Mundo das Ideias: "pois, aos ingênuos, não pode nunca faltar conteúdo, já que ele já está contido na própria forma." SCHILLER, F. Ausgewählte Werke. Stuttgart: W. Kohlhammer, 1949. „, Naive und sentimentalische Dichtung “, p.425: ,, denn der naiven kann es nie an Gehalt fehlen, da er hier in der Form selbst schon erhalten ist. "

70 "Lessing observa no Laoconte que, diferentemente da pintura, que expõe simultaneamente objetos no espaço, a poesia se caracteriza por sons articulados em sucessão. Em suas próprias palavras: a imitação poética progride no tempo. Estavam assim demarcados os limites entre a poesia e a pintura." Apresentação de Márcio Suzuki em SCHILLER, F. Poesia Ingênua e Sentimental. SP: Iluminuras, 1991. P.13.
} 
música, teatro e a parte da poesia, seriam ilimitadas devido seu conteúdo incorpóreo, desmaterializado. O conteúdo poético oscilaria entre musical e a pictórico. Estas delimitações impulsionaram um movimento de purificação das artes no sentido de suas especificidades. A poesia seria, não só a arte moderna por excelência, mas também a arte que realizaria a humanidade em seu conceito pleno, que seria a espiritualidade. ${ }^{71}$ A poesia ingênua teria um teor predominantemente plástico-espacial, onde predominariam ainda os elementos corpóreos, figurativos e pictóricos; enquanto a sentimental tenderia para arte sonora, onde vigorariam os elementos abstrato-ideais. A segunda seria superior no sentido da plenitude do seu desenvolvimento. Do mesmo jeito, as artes plásticas modernas seriam inferiores às das Antigüidade, pois não teriam progredido tal qual a humanidade no sentido da espiritualização; a poesia moderna pelo mesmo motivo teria uma posição privilegiada. A indefinição dos objetos tratados na poesia moderna, seu conteúdo informe, era sua vantagem. Muitos dos poetas da época margeavam um exercício abstrato de filosofia metafísica, como o sentimental Klopstock, "que sempre nos leva apenas para fora da vida, convoca apenas o espírito às armas, sem reconfortar o sentido com a presença tranquila de um objeto. Sua musa poética é casta, celestial incorpórea, sagrada (...)"(SCHILLER, 1991, p.76). Para Schiller, as artes predominantemente plásticas não poderiam mesmo progredir, pois sua qualidade corpórea-espacial delimitada, condicionada e necessária consistiria um obstáculo para a aproximação com o Ideal. Tais obras obedeceriam às leis naturais, no caso da arquitetura e escultura; ou, no caso da pintura da época, as representariam. Dependiam essencialmente da apreensão sensível direta propiciada pelo olho, deixando pouco espaço livre para ação da imaginação.

\begin{abstract}
A grande vantagem que as artes plásticas da Antiguidade afirmam sobre as dos tempos modernos e, acima de tudo, a relação desigual de valor em que estão a poesia e as artes plásticas modernas em face desses dois gêneros artísticos na Antiguidade explicam-se justamente pelo fato de a força do artista antigo residir na limitação (e o que foi dito aqui do poeta pode, sob as restrições que se impõem por si, ser estendido ao artista em geral). Uma obra para o olho (grifo meu) só encontra sua perfeição na limitação; uma obra para a imaginação (grifo meu) pode alcançá-la também pelo ilimitado. Por isso, a superioridade do moderno em Idéias pouco o ajuda em obras plásticas; aqui, ele é constrangido a determinar com a maior precisão no espaço a imagem de sua imaginação e, por conseguinte,
\end{abstract}

\footnotetext{
${ }^{71}$ A humanidade chegaria de tal forma à plenitude espiritual que as artes se tornariam chegariam a seu fim em duplo sentido, conforme verificamos em Hegel.
} 
a medir-se com o artista antigo exatamente naquela qualidade em que este tem sua incontestável vantagem. Em obras poéticas, isso é diferente, e se aqui os poetas antigos vencem na simplicidade das formas, naquilo que se pode expor sensivelmente e é corpóreo, o moderno, por sua vez, pode deixá-los para trás na riqueza da matéria, naquilo que não se pode expor e é inefável, em suma, naquilo que nas obras de arte se chama espírito. ${ }^{72}$ (SCHILLER, 1991, p.63)

A matéria de que Schiller trata aqui não poderia ter um corpo ou forma delimitada, ela é apenas a substância sensível infinita de que se constitui o universo. Talvez possamos inferir que se trate de um material atômico ou molecular que tudo constitui, mas que é invisível, ou, como no sublime, o infinitamente grande ou ameaçador. Estas três dimensões ultrapassariam a visão naturalística como referencial das percepções, demandando num dos casos um microscópio, e, para todos eles, a atividade do espírito para interpretar as imagens percebidas. A matéria da realidade não seria interessante para a poesia sentimental, pois ela não deve constituir um afeto direto: "Esse pathos impuro e material, ademais, sempre se revelará por uma preponderância da paixão e por um constrangimento penoso da mente, ao passo que o pathos verdadeiramente poético é reconhecível por uma preponderância da espontaneidade e por uma liberdade da mente que subsiste mesmo durante o afeto." (SCHILLER, 1991, p.65). Para o juízo de gosto de gosto, o valor da obra de arte está na forma e não na matéria. No belo, a forma é uma extensão da matéria natural, como no belo caráter. No sublime, o sujeito deve se elevar acima da matéria.

Na tragédia, muita coisa já ocorre por meio do objeto; na comédia, porém, tudo ocorre por meio do poeta, e nada mediante o objeto. Ora, uma vez que nos juízos de gosto jamais se leva em conta a matéria, o valor estético desses dois gêneros artísticos, naturalmente, tem de estar numa relação inversa à sua importância material. (SCHILLER, 1991, p.67)

A mente enobrecida ou espiritualizada perceberia a forma dos objetos, que para ela se torna preponderante em relação ao conteúdo material das obras de arte e das ações humanas nas obras representadas; pois a forma, diferente da matéria, se comunicaria diretamente ao espírito e não ao corpo. Mesmo a imaginação precisaria enobrecer-se através do estado estético, na busca da forma livre de

\footnotetext{
${ }^{72}$ A palavra utilizada por Schiller é Stoff, que poderia ser traduzida por substância em vez de matéria. Importante lembrar que é matéria sem contornos apreensíveis, é ilimitada. "so kann der neuere sie wieder im Reichtum des Stoffes (hinter sich lassen), in dem, was undarstellbar und unaussprechlich ist, (...)", literalmente: "o novo (poeta) pode novamente deixar (o poeta antigo) para trás de si na riqueza da substância material, no que ela é inapresentável e inexprimivel" Op. Cit. P. 397.
} 
matéria; pois a Imaginação determinada pela coerção da matéria levaria ao grotesco, ao opulento, ao extravagante e ao patético, já que determinada pelo efeito primário do excesso. Embora a imaginação já contenha, desde seu rústico início, vestígios da liberdade de fins que são próprios do jogo estético, seus excessos ainda remeteriam à realidade material condicionada. A plena liberdade da forma é, portanto, resultado de um jogo livre da matéria e não de seu trabalho. Em última instância é a imaginação que deve dar um salto rumo ao mundo espiritual e desmaterializado, donde ela estará submetida à força do espírito legislador: "o espírito legislador intervém pela primeira vez nas ações do cego instinto; submete o procedimento arbitrário da imaginação à sua unidade eterna e imutável, coloca a espontaneidade no que é mutável e sua infinitude no que é sensivel”. (SCHILLER, 1990, p. 141)

\section{3.}

\section{Vontade e representação}

\subsection{1. \\ Nietzsche: a superação da abstração da vontade na valorização da vida}

Tanto para Schiller quanto Hegel, a arte seria o meio propicio para a experiência do absoluto. A arte permitiria a plena realização da humanidade conciliando suas dimensões material e espiritual. Mantinha-se aí, no entanto, o dualismo hierárquico entre a forma e o conteúdo material. A matéria artística mantinha uma conotação de peso que era relacionada ao caráter pouco artístico da obra, correspondentes aos aspectos condicionados humanos tais como a selvageria de seus impulsos. Como consequência, a chamada arte simbólica era então desvalorizada, por corresponder ao estado pouco espiritualizado do homem, submetido à natureza. Hegel apontava nesta arte uma desproporção do conteúdo material em relação ao formal. A arte do mundo grego corresponderia ao estágio de equilíbrio da evolução do espírito humano em seu processo dialético, síntese da dimensão material e espiritual em equilíbrio. As artes plásticas românticomodernas, por sua vez, ocupariam uma escala inferior por não acompanharem materialmente a liberdade etérea do espírito moderno. Os desdobramentos da teologia cristã, como a valorização da vida após a morte ou a desvalorização da dimensão corpórea em prol da espiritualização contemplativa, eram 
compreendidos como um passo adiante na evolução da humanidade em contraposição à animalidade atribuída aos primitivos até então. Ainda que o teor religioso desta desvalorização da dimensão material humana tenha se restringido com a disseminação de ideias iluministas que procuravam separar tais âmbitos, esta tendência de valorizar o espiritual em detrimento do material ainda se manteve num crescendo alimentado pela fé na razão, associada à liberdade espiritual. A síntese do mundo sensível e espiritual neste contexto do movimento de fé na razão e na Revolução Industrial tendeu a realizar-se neste período através das descobertas científicas. As consequências, no entanto, revelaram-se ambíguas. Através delas, começa-se a pensar a liberdade humana tanto como superação quanto como intensificação da dimensão corporal e da submissão à natureza, conquistadas através da aceleração mecânica e da mudança dos ciclos de luz. Quanto ao trabalho associado à máquina, acrescenta-se a equiparação do homem com o artifício e seu processo de alienação. Tais questionamentos enfatizam a dimensão material-corporal, bem como a vida vivida, e forçam uma reavaliação da questão do progresso ocidental, conforme propostos até o romantismo.

A dimensão material da arte e a valorização da vida terrena como fim em si vieram sendo reabilitados pelo pensamento ocidental desde então. Para tanto, foi preciso que se desenvolvesse uma filosofia baseada em valores imanentes à existência. Para o sociólogo Georg Simmel, Nietzche teria dado o passo decisivo de superação da teleologia cristã, valorizando a vida enquanto um fim em si. Nietzche subverteria a moral religiosa ao considerar a existência individual como o grande dever a ser cumprido, livrando a humanidade da mediocridade dos ideais socializantes de igualdade que dominavam sua época. Simmel o considerava um aristocrata da filosofia por isso. Conforme verificamos, Schiller já havia apontado a importância do sentido da individuação, da personalidade na forma viva. Nietzsche radicalizará esta dimensão ao transcender o ideal substancialmente racional imputado ao homem e à natureza em Schiller.

Nietzsche estaria ancorado na metafísica schopenhaueriana da vontade, pela qual se supõe a superação da descrição do homem, como um Ser da razão. Historicamente, o desejo humano e a irracionalidade correspondente estariam associados a um resquício de animalidade primitiva. Segundo Simmel, a 
pressuposição de racionalidade no homem extrapolava os limites do campo epistemológico, contaminando as escalas dos valores morais e determinando as características do par sujeito e objeto, conforme se verificaria na filosofia kantiana. Schopenhauer teria demolido "o dogma de que a razão constitui a mais profunda essência do homem." (SIMMEL, 2010: p. 45). Para Schopenhauer, a lógica racional corresponderia a uma dimensão muito limitada da possibilidade de conhecer correspondente aos fenômenos do mundo, conforme ensinado por Kant. Diferente do kantismo, no entanto, o conhecimento puro da coisa em si seria possível apenas através da eliminação da distinção sujeito e objeto por meio da entrega contemplativa e da renuncia da vontade subjetiva. Esta última se caracterizaria pela determinação de relações lógicas de finalidade responsáveis pela construção de um mundo ilusório de expectativas a serem continuamente frustradas, determinando a falta de sentido da vida em si e, consequentemente, o pessimismo schopenhaueriano. A verdade a ser conhecida seria a coisa em si da vontade absoluta e seu acesso não seria possível pela instrumentalização da racionalidade. A vontade absoluta seria o elemento incondicionado, que não caberia nos limites da razão subjetiva.

\begin{abstract}
Queremos, não porque nossa razão tenha estabelecido fins e valores; ao contrário, porque queremos, estabelecemos fins; e queremos continuamente, sem propósito, desde o mais fundo do nosso Ser. Os fins são a expressão ou a organização lógica dos processos da vontade. Assim, a racionalidade da nossa existência perde o último apoio no conceito de fim, que se sustentava enquanto parecia que o querer era o caminho em direção a objetivos previamente designados pela razão. (SIMML, 2010: p. 49)
\end{abstract}

O pessimismo da filosofia de Schopenhauer seria, para Simmel, reflexo do estado íntimo do homem moderno, que se caracterizaria pelo afastamento cada vez mais radical das possibilidades de realização direta de suas vontades. Simmel defende que para o homem moderno, definido pelo estado avançado de cultura, a clareza do que é desejado se perde no meio do processo de realização. Isto se acentuaria por ele viver apartado de seus fins através de uma cadeia de meios técnicos disponíveis. "Imagine-se, por exemplo, a simplicidade dos procedimentos usados na busca de alimentos - muitas vezes, sem êxito - nas culturas primitivas e compare-se isso com a multiplicação de tão inumeráveis operações, aparatos e meios de transporte para que o homem moderno encontre o pão à mesa." (SIMMEL, 2010: p. 14). 
No mundo moderno, a rede burocrática dos serviços disponíveis tomariam o homem de tal modo que ele acaba perdendo de vista e esquecendo o valor da realização de sua vontade; vive à espera da satisfação parcelada até se dar conta da falta de significado que sua vida apresenta. Nem mesmo os prazeres sensuais momentâneos preencheriam o vazio que vinha sendo cavado pela cultura humana. O apelo para religiões importadas e a inclinação para superstições crescentes demonstraria desde tempos antigos este estado de crise do homem de cultura frente à crescente falta de clareza do mundo que ele mesmo vem construindo. A promessa de salvação da alma e de uma vida no além representariam a última tentativa, oferecida pela doutrina cristã, de dar sentido absoluto à vida, que seria a definição do destino humano como um unitário e claro caminho apontado para o céu.

Nietzche partilharia do mesmo schopenhaueriano descredito num fim absoluto para o destino humano, mas não de seu ideal de ascese pela negação da existência. Ele deixa de legado para o homem moderno uma filosofia que valoriza a vida, cujo fim estaria no seu próprio desenrolar e nos significados associados à dor e prazer experimentados. A vida seria "intensificação, aumento, concentração cada vez maior das forças ambientes no sujeito. Por meio deste impulso- pelo qual se eleva e se enriquece- a vida pode chegar a ser seu próprio fim." (SIMMEL, 2010: p. 17). Deste modo, Nietzche dispensaria uma justificação transcendente e superaria, através da justificação pelo conteúdo vivido (processo vital) em si e por sua valorização, o dualismo entre o espiritual e o corporal; e entre a coisa em si e a representação. Determinadas existências humanas teriam valor em si, valor absoluto, tal como determinadas obras de arte têm significado "evolutivo" para a história da cultura humana. Ao valorizar o absoluto da existência, e não somente das obras primas da arte como Schopenhauer, Simmel aponta como Nietzche superaria a abstração do primeiro, que nega a realidade da existência no tempo e no espaço. Para Schopenhauer, o real é o absoluto da vontade metafísica; a vida, pura ilusão. A evolução da vida, almejada por Nietzche, não seria abstrata porque não seria definida por um fim último, mas como o processo existencial de auto-superação da alma humana que, segundo Simmel, define sua ética e determina o seu absoluto. Nietzche teria tido " $a$ genialidade psicológica de fazer ressoar na própria alma a vida psíquica dos 
tipos mais heterogêneos de homens e a paixão ética pelo tipo humano em geral". (SIMMEL, 2010: p.25). Schopenhauer subtraía qualquer noção de indivíduo, pois este contradiria o dualismo lógico da metafísica da vontade, incluindo um terceiro termo que é a híbrida noção de individualidade. Além disso, Simmel aponta sua tendência psicológica ao pessimismo, que para equilibrar-se, necessitava de explicações totalizantes: "As categorias "fenômeno" e "coisa em si", que permitem compreender a pluralidade dos primeiros na unidade da segunda, eram para Schopenhauer a maneira de transformar o seu mais importante sentimento vital em uma imagem do mundo”. (SIMMEL, 2010: p.31)

Para Schopenhauer, a razão criaria as representações, que corresponderiam apenas ao conhecimento parcial e relativo dos objetos e não ao absoluto que é a coisa em si. Ele negaria com isto o valor da existência, que não passaria de ilusão encobrindo realidade real do absoluto da vontade metafísica.

Para manter a integridade de sua noção Ser, que é a vontade incondicionada e absoluta a unidade do absoluto como vontade. Schopenhauer, segundo Simmel, não teria conseguido superar a rigidez do dualismo de seu sistema, que mantinha a oposição kantiana entre a coisa em si e o fenômeno, como sinônimos da oposição entre a unidade e o múltiplo.

\subsection{2.}

\section{A importância da Estética de Schopenhauer: a matéria como representação da vontade}

\section{A matéria como representação da coisa em si}

Vimos como a contemplação da obra de arte, para Schiller, promove o desprendimento das impressões sensíveis determinadas pelas qualidades materiais da obra em prol da percepção da forma, no caso do belo; e no sentido das ideias da razão, no caso do belo energizante ou sublime. O belo ou o sublime levam, portanto, o homem ao Mundo das Ideias. Tal elevação ao espiritual, no entanto, não incorre numa negação da dimensão sensível-corpórea, não se confunde com um exercício de abstração do pensamento. Ela implica os impulsos humanos em sua totalidade sensível e formal. Deste modo, a arte possibilita a realização máxima do sentido de humanidade; pois promove o exercício da vontade, 
considerada em sua dimensão sensível, em direção ao espiritual. A vontade ética deverá ser também estética. Diferente de Kant, Schiller acredita que a vontade estética, e não a vontade sublime, determinaria a humanidade plena, pois não contrariaria sua dimensão sensível. A vontade estética, estimulada através do desenvolvimento da apreciação artística, prepararia o homem para ter um comportamento heroico-sublime na vida; pois o sublime artístico o tornaria consciente de sua superioridade espiritual em relação à natureza. Portanto, prepararia o homem para sua maior derrota, que seria a morte. Não tendo medo da morte, este ainda seria capaz de aceitar com naturalidade, dado que seu próprio caráter se tornara belo e nobre, o sacrifício real de suas inclinações/necessidades físicas e individuais em prol de uma vontade estética coletiva, correspondente à humanidade.

Schopenhauer amplifica a importância de tal vontade estendida à humanidade, definindo uma existente vontade absoluta como a coisa em si do mundo; diante da qual tudo seria fenômeno, diferentes graus de representação da mesma. Deste modo, ele procura resolver os impasses deixados pelas filosofias de Platão e Kant, que colocaram a ideia e a coisa em si como as invisíveis realidades verdadeiras, formas abstraídas de tempo e de espaço, às quais o homem não teria acesso; pois ora estaria limitado pela teoria das reminiscências no caso platônico, ora pelo dogmatismo racionalista na teoria kantiana. Schopenhauer aproxima, através da vontade originária, os polos historicamente contrapostos da abstração e da concretude, que correspondem aos conceitos de ideia e da coisa em si. Propõe a superação do racionalismo dominante na história da filosofia através da metafísica da vontade, segundo a qual a realidade poderia vir a ser intuída através do conhecimento da vontade; como a coisa em si que se quer conhecer; como sendo a realidade absoluta. Subvertendo a proposta platônica, coloca a ideia num segundo plano que seria correspondente ao domínio das representações ${ }^{73}$, ainda que como ideia não estivessem disponíveis como um fenômeno qualquer.

\footnotetext{
73 Pura representação é objeto para um sujeito. O mundo é objetificação da vontade (representação) em graus variados: "Reconhecíamos as idéias de Platão em tais gradações, na medida em que estas são as espécies determinadas, ou as formas e propriedades invariáveis originárias de todos os corpos naturais, orgânicos ou inorgânicos, como também as forças genéricas se manifestando conforme leis naturais." (SCHOPENHAUER, 1974: 11)
} 
Espero ter sido bem sucedido no livro precedente no formar a convicção de que aquilo que é denominado coisa em si na filosofia de Kant, apresentado em doutrina sobremodo importante, porém obscura e paradoxa, sobretudo devido à maneira pela qual Kant a introduziu, concluindo do efeito para a causa, era encarado como ponto conflitante, e até mesmo como o lado débil de sua filosófica, que isto, assim pretendo, quando atingido pelo caminho bem diverso por nós percorrido, nada mais é que a vontade, na esfera deste conceito ampliada e determinada do modo indicado. Espero, além disto, que não se hesite em reconhecer, feita a exposição precedente, nos graus determinados da objetivação desta vontade, que é o em-si do mundo, aquilo que Platão denominou idéias eternas, ou as formas imutáveis (eidê) que, reconhecidamente o dogma principal, mas simultaneamente mais obscuro e paradoxo de sua doutrina, constitui-se em objeto de meditação, de discussão, de escárnio e de admiração por parte de espíritos numerosos e diversos durante séculos. (SCHOPENHAUER, 1974: 12)

Não somente a humanidade seria determinada pela vontade, mas também o mundo seria representação da vontade absoluta, originária. Tal vontade seria a coisa em si, para a qual as ideias seriam sua objetificação imediata e pura. A vontade seria o em-si não somente da ideia, mas também do próprio sujeito e das coisas individuais. Além do mundo como vontade, nada restaria além do mundo como representação. Como a vontade é absoluta, ela depende das representações humanas para que se faça visível, tornando-se objeto. Caso contrário, permanece como "vontade cega". As ideias, independentes da vontade individuada, seriam a objetificação da vontade, invisíveis para a percepção comum. A percepção comum, aprisionada pela razão abstrata, reconheceria apenas aspectos inferiores das manifestações das ideias, sua realidade aparente e inessencial, nos variados objetos do mundo orgânico e inorgânico. A viva materialidade da realidade orgânica e inorgânica da arte ou da natureza constituiriam, para Schopenhauer, facetas expressivas da ideia, por conseguinte, diferentes graus de representação da vontade.

Quando passam as nuvens, não lhes são essenciais as figuras que elas formam, lhes são indiferentes: mas sim que como névoa elástica, são comprimidas pelo impacto do vento, levadas adiante, dispersas e rompidas; esta é sua natureza, a essência das forças que nelas se objetivam, é a idéia: as figuras ocasionais são somente para o observador individual. Ao córrego rolando sobre pedras, os redemoinhos, as ondas, as formações de espuma que ele mostra, são indiferentes e inessenciais; que obedeça ao peso, se comporte como líquido inelástico, completamente sem rigidez, sem forma e transparente; esta é sua essência, esta é, quando intuitivamente conhecida, a idéia; apenas para nós, enquanto conhecendo como indivíduos, há aquelas configurações. $\mathrm{O}$ gelo na janela se assenta conforme a lei das cristalizações, (...) . O que aparece nas nuvens, no córrego e nos cristais, é o mais débil eco daquela vontade, que se mostra de modo mais perfeito no vegetal, mais perfeito ainda no animal, do modo mais perfeito no homem. (SCHOPENHAUER, 1974: 21) 
Tal como em Platão, as ideias não estariam submetidas ao princípio da causalidade, ou ao tempo e ao espaço, seriam eternas e determinariam os fenômenos deste mundo. Para Schopenhauer, as ideias escapariam à razão humana, pois esta seria seria uma faculdade limitada aos aspectos relativos da existência. A razão apreenderia as ideias segundo a multiplicidade de seus fenômenos, quando as ideias deveriam ser apreendidas em sua essência, segundo seu teor metafísico. As ideias não poderiam ser, portanto, submetidas à razão, como os demais fenômenos apreendidos pelos sujeitos. Elas seriam inacessíveis ao sujeito individual; introduzido no tempo, nas mudanças, não-sendo. Elas demandariam uma suspensão da existência em favor da contemplação do absoluto da ideia, do ser. O tempo ${ }^{74}$ e o espaço, para Schopenhauer, não teriam substância, seriam formas do conhecimento racional ${ }^{75}$, assim como a noção de causalidade. "por isto o fenômeno no tempo também não é: pois o que separa seu começo de seu fim é justamente apenas o tempo, algo essencialmente passageiro, desprovido de substância e relativo, aqui denominado duração" (SCHOPENHAUER, 1974: 17). Ele proporá resolver o impasse das filosofias platônica e kantiana quanto ao acesso à realidade redefinindo a ideia platônica ${ }^{76}$ como um organismo vivo, sujeito à apercepção intuitiva, conforme verificaremos. Deste modo, a ideia não estaria sujeita às deformações das estruturas formais subjetivas como em Kant e também não estaria limitada ao mundo das ideias, pois teria materialidade sensível. A ideia definida como um organismo vivo se assemelha à forma viva de Schiller, apenas a matéria em si não seria considerada como um fenômeno próprio da ideia nesta última. Schopenhauer, conforme verificaremos, elabora sua estética baseada nas qualidades matéria, presumindo sua idealidade.

As ideias seriam passíveis de conhecimento apenas se o sujeito conseguisse libertar-se da vontade, dos sentimentos de dor e da temporalidade, que correspondem a sua existência individual, tornando-se sujeito puro do

\footnotetext{
74 "O tempo, porém, é a forma mais geral de todos os objetos do conhecimento a serviço da vontade e o protótipo das demais formas do mesmo." (SCHOPENHAUER, 1974: 17)

75 "Com efeito, o que Kant diz é essencialmente o seguinte: "Tempo, espaço e causalidade não são determinações da coisa em si, mas pertencem unicamente a seu fenômeno, na medida em que não passam de formas de nosso conhecimento." (SCHOPENHAUER, 1974: 12)

76 "Aproximando ainda mais o enunciado kantiano do platônico, diríamos: tempo, espaço e causalidade são aqueles dispositivos de nosso intelecto graças a que o ser único de qualquer espécie, propriamente existente, se nos apresenta como uma multiplicidade de seres de mesma espécie, num nascer e perecer incessantemente renovado, numa sucessão infinita." (SCHOPENHAUER, 1974: 14)
} 
conhecimento, e podendo se entregar à contemplação: "de tal modo que tudo se passasse, como se existisse unicamente o objeto, sem alguém que o percebesse, não podendo mais distinguir portanto a intuição do seu sujeito, mas ambos se tornaram um, o objeto abandonou toda relação com algo externo a ele, e o sujeito toda relação com a vontade" (SCHOPENHAUER, 1974: 19). Neste momento, o objeto observado é percebido como ideia, como a totalidade absoluta das ideias referentes ao objeto. Sujeito e objeto se tornam indiscerníveis: O "mundo aparece como representação, e ocorre a objetificação perfeita da vontade, já que unicamente a idéia é sua objetividade adequada. Esta encerra em si sujeito e objeto por igual uma vez que são sua única forma" (SCHOPENHAUER, 1974: 19). Somente os gênios teriam a intuição imediata da ideia; as demais pessoas precisariam da mediação das obras de arte, através das quais cada um poderia perceber em conformidade com a própria limitação intelectual.

\section{Não são ideias da razão}

A ideia se distingue do conceito. Este seria objeto do pensar racional, utilizado pelas ciências. "O conceito é abstrato, discursivo, inteiramente indeterminado no interior de sua esfera, determinado somente em seus limites acessível e apreensível por qualquer um, apenas dotado de razão, comunicável através de palavras, sem ulterior mediação, completamente esgotável por sua definição." (SCHOPENHAUER, 1974: 61). A ideia seria comparável a um organismo vivo ${ }^{77}$, também sendo, portanto, intuível. Ela representaria uma infinidade de coisas individuais, sendo ainda assim determinada. As ciências partiriam do exercício de abstração do múltiplo; recolhido como conceito e passível apenas de juízos analíticos, que seriam limitados aos dados representados. A ideia representada nas obras de arte, quando alcançadas pelo estado de contemplação do observador, permitiriam a intuição de sua unidade (unitas ante rem) anterior ao fenômeno da obra, por isso infinita em seus desdobramentos contemplativos, tal como um organismo vivo que se reproduz gerando novos seres:

\footnotetext{
${ }^{77}$ Verificar a similaridade com o conceito, já tratado, de forma viva em Schiller.
} 
A idéia é a unidade decomposta na multiplicidade em virtude da forma espacial e temporal de nossa apreensão intuitiva; por sua vez, o conceito é a unidade reconstituída a partir da multiplicidade, mediante a abstração da nossa razão; esta pode ser denominada unitas post rem, aquela unitas ante rem. ${ }^{78}$ Por fim, é possível exprimir a diferença entre conceito e idéia igualmente, dizendo: o conceito se assemelha a um recipiente inanimado em que tudo o que é ali depositado realmente se encontra lado a lado, mas do qual também não podemos extrair mais (por juízos analíticos) do que nele depositamos (por reflexão sintética); a idéia, porém, desenvolve naquele que a apreendeu representações novas no que diz respeito a seus conceitos homônimos: assemelha-se a um organismo vivo (grifo meu), que se desenvolve, dotado de força reprodutiva, a engendrar o que nele não se encontrava guardado. (SCHOPENHAUER, 1974: $61,62)$

A ideia é original e viva, por isso é fonte para a arte que almeja duração. O artista não seria guiado por uma intenção ou fim definidos, mas pela ideia conforme por ele sensivelmente intuída, "uma idéia que mantém frente aos olhos; por isso não pode justificar a sua atividade. Ele opera, como no dizer popular, unicamente mediante o sentir, e inconscientemente, instintivamente mesmo." (SCHOPENHAUER, 1974: 62) Para Schopenhauer, apenas imitadores, conscientes ou não, seguiriam conceitos, "movidos por astuta intencionalidade. Quais plantas parasitas, absorvem seu sustento de obras alheias, portanto, como os pólipos, a cor do seu alimento.” (SCHOPENHAUER, 1974: 62). Eles não seriam capazes de digerir o que absorvem, porque apreendem por conceitos, usualmente conceitos dominantes marcados pelo espírito da época, e não se tornam aptos a "dotar uma obra de vida interna". Por isso as grandes obras não seriam compreendidas por contemporâneos, que se mantém na maioria engessados por conhecimentos cristalizados. Nesse sentido, a obra não pertenceria à determinada época, mas à história da humanidade como um todo.

Que se leiam os lamentos de grandes espíritos de todos os séculos a respeito de seus contemporâneos, sempre soam atuais, porque a humanidade permanece a mesma. Em todas as épocas e em todas as artes, o medo substitui o espírito, sempre apenas propriedade de uns poucos: o modo, contudo, nada mais é do que a roupa velha e usada da última manifestação do espírito que esteve presente e foi reconhecida. Assim via de regra a aprovação da posterioridade se consegue às custas da aprovação dos contemporâneos; e vice-versa. (SCHOPENHAUER, 1974: 63)

\footnotetext{
${ }^{78}$ unidade antes da coisa, aquela unidade depois da coisa.
} 


\section{A obra de arte como expressão da vontade de (auto)conhecer da vontade}

\section{O sujeito puro do conhecimento}

O verdadeiro conteúdo de todos os fenômenos, as ideias, é examinado pela arte. A arte reproduz ideias eternas nos materiais; e seu objetivo é a comunicação deste conteúdo essencial. As ideias são captadas pela intuição, na entrega à contemplação, por isso dependem da perfeita objetividade do espírito em contraste com subjetividade voltada para a vontade fenomênica. A perfeita objetividade requer uma ampliação da visão do artista. A fantasia amplia seu horizonte para além do referencial da realidade vivida, "situando-o numa posição tal a construir, a partir do pouco introduzido em sua apercepção, todo o restante, desfilando por si assim quase todos os quadros possíveis da vida."(SCHOPENHAUER, 1974: 25).

As ciências em geral obedeceriam ao princípio da razão, limitando-se ao estudo dos fenômenos, constituindo saberes relativos. O homem comum estaria, portanto, mais próximo do conhecimento abstrato-científico, percebendo apenas aquilo que está relacionado com a sua vontade, aquilo que lhe útil segundo o atalho da razão. Uma obra de arte requer a presença do gênio (artista e filósofo), que se caracteriza pela busca do conhecimento puro, que é um exercício dissociado do querer. Ele seria alguém dotado de olhar desinteressado, capaz de se demorar nos objetos e de se entregar à calma contemplação e à pura intuição, que é o oposto da apreensão do objeto segundo um conceito abstrato, próprio de um pensamento utilitário; ou mesmo segundo da agitação promovida pelos pensamentos fantasiosos. Tais pensamentos seriam fruto do capricho próprio e do egoísmo, levando o homem a ilusões e não à arte. O Gênio reproduz as ideias eternas encontradas nos diferentes materiais das artes plásticas, da poesia e da música e os transforma num representante do todo, arrancando-lhe toda condição relativa e temporal. $\mathrm{O}$ artista $^{79}$ compartilha sua visão ampliada com o observador,

\footnotetext{
${ }^{79}$ Para Schopenhauer, os gênios teriam aversão pela matemática, pois esta se restringiria a fenômenos no tempo e no espaço segundo as configurações abstratas da razão. Eles seriam arrastados pela paixão através da experiência de conhecimento intuitivo. Sentidos e entendimento neles predominam sobre o conhecimento abstrato, levando-os à beira da irracionalidade e da loucura. Loucos e sãos não seriam facilmente distinguíveis pela presença da razão: "Nem razão, nem entendimento podem ser negados aos loucos. (...) Visões, assim como os delírios febris não são um sintoma usual da loucura. O delírio falsifica a intuição; a loucura, os pensamentos."
} 
que pode, ou não, através de um exercício de empatia compreender o significado da vontade objetificada pela ideia; que é a serenidade trazida pelo conhecimento desinteressado:

\begin{abstract}
Assim podemos designá-la (a arte) como o modo de encarar as coisas independentemente do princípio de razão, em oposição àquele que a este obedece, que é a via da experiência e da ciência. Este último modo é comparável a uma linha infinita, horizontal; o primeiro, contudo, à vertical que a corta em qualquer ponto desejado. O que se dá conforme o princípio de razão, é o procedimento racional, único válido e útil na vida prática, bem como na ciência; o que abstrai do conteúdo daquele princípio, é o procedimento genial, único válido e útil na arte. O primeiro é o procedimento de Aristóteles; o segundo é, em seu conjunto, o de Platão. O primeiro é igual à tempestade, propagando-se sem origem nem meta, tudo arqueando, agitando e arrastando; o segundo, ao sereno raio de sol, cortando o caminho desta tempestade, sem ser por esta afetado. (SCHOPENHAUER, 1974: 24)
\end{abstract}

A faculdade de conhecimento puro seria inerente a todo ser humano, apenas o gênio seria dotado de um grau maior, por isso tendo a capacidade de comunicar seu conhecimento. De todo modo, os sentimentos de belo e sublime não seriam exclusivos da arte: "o prazer estético é essencialmente único, seja originado por uma obra de arte, ou de forma imediata pela intuição da natureza e da vida. A obra de arte é somente um meio de facilitar este conhecimento em que consiste aquele prazer. (...) O artista nos permite contemplar o mundo por seus olhos." (SCHOPENHAUER, 1974: 31) O artista teria o dom inato de ver o essencial das coisas e dominaria a técnica, através de exercício, de ceder este dom através da obra.

Para se alcançar o estado contemplativo é preciso se afastar dos fluxos de desejo que perturbam a consciência humana e alcançar uma disposição interior que permita à ideia elevar-se. "Então torna-se indiferente contemplar o poente do interior de uma prisão ou de um palácio” (SCHOPENHAUER, 1974: 33). A obra seria acessível a todos a princípio, pois o que é determinante é transladar-se ao estado de conhecimento puro que é totalmente independente do saber formal. O estado contemplativo alcançado pelo sujeito corresponde ao estado de liberdade do próprio querer e por conseguinte da própria individualidade, que continua

(SCHOPENHAUER, 1974: 29). A loucura seria um recurso ficcional utilizado pelo espírito humano para preencher uma memória existencialmente insuportável: "o espírito tão atormentado rompe o fio de sua memória, preenche as lacunas com ficções e se refugia do espiritual que ultrapassa suas forças na loucura, assim como se amputa um membro gangrenado, substituindo-o por um artificial." (SCHOPENHAUER, 1974: 30) 
existindo somente como "a vista única do mundo" de modo que "se torna indiferente o pertencer a vista observadora a um poderoso monarca ou a um atormentado mendigo" (SCHOPENHAUER, 1974: 33). A disposição do gênio contribui para fomentar a experiência artística da obra na medida em que ele compartilha seu olhar ampliado com o observador. Assim como para a poeta sentimental de Schiller, o objeto pode ser experimentado de forma mediada pelo artista, que é capaz de intuir diretamente as ideias. O contraste entre o estado de ânimo do artista e do observador poderiam inclusive amplificar a experiência, como no caso das naturezas mortas e paisagens flamengas. A banalidade do objetos retratados nestas pinturas e a placidez do pintor entregue à contemplação se fariam evidentes na obra, despertando a comoção no observador: a obra revelaria a consciência de que os desejos individuais despertados pela vida não teriam significado real para aquele que, como o artista, elevou-se pela contemplação das ideias e percebeu a insignificância da existência. Neste exercício de empatia com o artista, o observador seria arrancado de sua subjetividade, ainda que por instantes, "e ao solicitar também o quadro a sua participação num tal estado, sua emoção será multiplicada pelo contraste da disposição própria, inquieta, turvada por intenso querer, em que se encontra no momento" (SCHOPENHAUER, 1974: 33).

\section{Belo na arte ou na natureza: prazer estético é único}

\section{Teoria da Empatia com os materiais}

\section{O corpo humano como representação da vontade}

\section{A vontade nos materiais}

Conforme verificamos, os fenômenos correspondem à vontade tornada visível. A materialidade da realidade orgânica e inorgânica seriam representações de ideias e constituiriam, por conseguinte, facetas expressivas de diferentes graus da vontade. Schopenhauer desenvolve uma filosofia estética baseada no conhecimento da expressividade material e na relação de empatia que o homem estabelece com os mesmos, segundo sua apreensão corporal: associando, portanto, sol, luz, clareza, calor ao prazer; e, logo, a noite, escuridão, vazio, frio ao medo e ao desprazer. O corpo, ele mesmo, é entendido como objetificação da vontade, 
tendo papel determinante no ajuizamento do gosto. A visão seria o órgão mais puro, pois o mais aproximado do conhecimento intuitivo. A luz e a transparência seriam as matérias correlatas ao conhecimento puro, portanto, o prazer estético subjetivo que proporcionariam relativas à alegria de conhecer. Os outros sentidos seriam os mais distantes do conhecimento puro e mais próximos da vontade individual $^{80}$.

\begin{abstract}
A luz é a mais contentadora das coisas: constitui-se em símbolo de tudo que é bom e consolador. (...) A ausência de luz nos torna imediatamente tristes; seu retorno alegra: as cores suscitam em encantamento vivo, atingindo seu grau mais elevado, se são transparentes. Isto tudo provém unicamente do ser a luz o correlato do modo de conhecimento intuitivo mais completo, único a afetar em nada a vontade. Pois a visão não é, como afecção dos outros sentidos, em si, imediatamente, e por meio de seu efeito sensorial, capaz de um bem ou mal-estar da sensação no órgão ${ }^{\mathbf{8 1}}$ (grifo meu), i.e., não possui relação imediata com a vontade; mas apenas a intuição originada no entendimento é capaz de possuí-la, localizando-se então na relação do objeto com a vontade. Já com a audição, a situação é diferente: sons podem causar dor de modo imediato, e ser agradáveis aos sentidos de modo imediato, sem referência à harmonia ou melodia. $\mathrm{O}$ tato, uno com o sentir de todo o corpo, está subordinado ainda mais a esta influência imediata sobre a vontade: contudo, existe ainda um tatear privado de dor e de prazer. Odores, porém, são sempre agradáveis ou desagradáveis; sabores ainda mais. Os dois últimos sentidos portanto são os mais inquinados pela vontade: são os menos nobres, e denominados por Kant de sentidos subjetivos. (SCHOPENHAUER, 1974: 35)
\end{abstract}

A hierarquia tradicional dos sentidos auditivo e visual sobre o tátil como receptores sensíveis das obras de arte é redistribuída através da polarização dos órgãos cerebral e genital, que, podemos inferir, relativos à manifestação dos impulsos formal/espiritual e sensível/material, se fizermos um paralelo com a terminologia apresentada por Schiller. Os dois impulsos complementares

\footnotetext{
80 “depois deve ele compreender que a beleza em qualquer corpo é irmã da que está em qualquer outro, e que, se se deve procurar o belo na forma, muita tolice seria não considerar uma só e a mesma beleza em todos os corpos: e, depois de entender isso, deve ele fazer-se amante de todos os belos corpos e largar esse amor violento de um só, após desprezá-lo e considerá-lo mesquinho: depois disso a beleza que está nas almas deve ele considerar mais preciosa que a do corpo, (...)depois dos ofícios é para as ciências que é preciso transportá-lo, a fim de que veja também a beleza das ciências (...) em inesgotável amor à sabedoria, até que aí robustecido e crescido contemple ele uma certa ciência, única, tal que o seu objeto belo é o seguinte. (...) aparecer-lhe-á ele (o belo) mesmo, por si mesmo, consigo mesmo, sendo sempre uniforme, (...) belo, nítido, puro, simples, e não repleto de carnes humanas, de cores e outras muitas ninharias mortais (...)" PLATÃO. O banquete, ou, Do amor. 2aed., Rio de Janeiro: DIFEL, 2003.

${ }^{81}$ A lâmpada elétrica incandescente foi inventada no final do século XIX por Thomas Edison e comercializada a partir de 1879. Eram muito mais poderosas que aquelas a gás ou querosene utilizadas na virada do século XVIII, que Schopenhauer conheceu. Portanto, ele não poderia imaginar quão pavorosa poderia ser a sensação de ofuscamento. $O$ excesso de luz leva ao seu extremo oposto que é a sensação de cegueira. Também não poderia imaginar os efeitos da fotografia, do cinema e do desenho animado, que são bastante sensoriais e imediatos.
} 
corresponderiam à vontade expressa em ideias, que poderiam estar representadas em qualquer ser orgânico ou não. Logo, o próprio impulso poderia ser orgânico ou inorgânico, de tal modo que Schopenhauer contrapõe uma vontade da luz à uma vontade da pedra, por exemplo. A luz, quando refletida n'água por exemplo, sendo: "O mais leve, rápido e sutil modo de interação de corpos." (SCHOPENHAUER, 1974: 35), correspondendo ao impulso espiritual/formal superior e ao prazer do conhecimento. A vontade da pedra correspondendo ao seu grau mais baixo, associáveis ao impulso sensível/material e à ideia de rigidez, peso e coesão.

Schopenhauer apresenta a música como a mais pura das artes, pois independeria da mediação de conceitos da razão e mesmo da ideia, sendo objetificação imediata da vontade. Em contraposição, estaria a arquitetura num status oposto de inferioridade por seu caráter racional/utilitarista e, neste sentido, de pouco conteúdo artístico. O conteúdo artístico é, portanto, definido pela carga de expressão da vontade presente na obra e pela possibilidade dela despertar a vontade do conhecimento puro, considerado uma elevação em relação à ilusão da existência fenomênica. Num primeiro momento, a vontade de conhecer seria dependente da empatia do sujeito com o objeto, ou seja, da identificação do sujeito com a dimensão material do mundo como representação; como submetido ao tempo, espaço e às relações de causalidade. Ela seria seguida da elevação do sujeito que se identifica posteriormente com a vontade absoluta.

A vontade absoluta também se manifestaria no mundo inorgânico segundo a aproximação de aspectos, que podem ser interpretados como sensíveis e espirituais. Esta associação do sensível ao espiritual estendida ao inorgânico é possível na medida em que todos os múltiplos fenômenos, sejam eles a existência individual, uma obra de arte ou a natureza, são sombras das mesmas ideias e não constituiriam um acontecimento verdadeiro, seriam apenas representações. Entre o homem e a natureza existiria apenas um decréscimo do conteúdo objetivado da verdade. O indivíduo em si é considerado um fenômeno como outro qualquer, apenas sua qualidade como representante da ideia de humanidade sendo significativa como acontecimento. 
Mas o espírito do mundo se tomaria de um sorriso e diria: "A fonte de que jorram os indivíduos e suas forças é inesgotável e infinita como o tempo e o espaço; pois aqueles são, justamente como forças de todo fenômeno, também somente fenômeno, visibilidade da vontade. Medida finita alguma pode esgotar aquela fonte infinita; e por isto a todo evento, ou obra, sufocada em germe, ainda se apresenta em aberto para o retorno a infinidade intata. Neste mundo do fenômeno há tão pouco prejuízo verdadeiro possível, quanto verdadeiro lucro. Unicamente a vontade é: ela, a coisa em si, a fonte daqueles fenômenos. Seu autoconhecimento, e a afirmação ou negação decidida a partir deste, é o único acontecimento em si. (SCHOPENHAUER, 1974: 23)

Os fenômenos se apresentariam, portanto, segundo uma hierarquia em relação à proximidade de expressão da vontade. $\mathrm{O}$ homem seria sua representação superior. Nada de novo surgiria em função do decorrer do tempo, pois os seres em si habitariam apenas o mundo das ideias. A objetificação ou representação da ideia de querer-viver humano no mundo fenomênico seriam as paixões humanas: ódio, amor, temor, estupidez, humor, gênio etc. $\mathrm{O}$ espírito dos acontecimentos, no entanto seria sempre o mesmo. A existência não definiria o sentido do ser, assim como a realização ou não de destinos heroicos não alteraria o sentido da humanidade. Os indivíduos atuariam apenas como representações de personagens determinados pela vontade absoluta do espirito do mundo, eles seriam substituíveis. Do mesmo modo, o tempo e o espaço seriam representações da vontade.

A razão humana estaria submetida a um grau bastante inferior da vontade objetificada, pois conforme verificamos limitada à percepção ilusória, relativista do mundo. Ela fundamentaria uma percepção utilitarista, uma visão teleológica do mundo fundamentada nas relações da causa e efeito, que estaria presente na relação do sujeito com o próprio corpo. A razão serviria ao sujeito para ordenar suas percepções do mundo com o corpo segundo os interesses estabelecidos pela vontade. O corpo humano não ultrapassaria os demais objetos existentes em termos de grau de representação da vontade. O corpo seria compreendido pelo sujeito segundo os princípios da razão; conforme as relações espaço-temporais e de causalidade. A vontade humana determina os alvos de interesse que a razão representa segundo seus critérios para consciência. Neste sentido, a razão não teria estatuto de verdade, mas apenas valor instrumental. A vontade estaria mais próxima das paixões e da loucura, ainda que o desvelamento de tal verdade pelo 
conhecimento puro implicasse na sensação de suspensão das mesmas. O corpo humano seria a representação superior desta dimensão da vontade, que é a paixão.

Pois o indivíduo encontra seu corpo como um objeto entre objetos, com todos eles mantendo variadas relações e proporções conforme o princípio de razão, cuja observação, portanto, por vias mais ou menos extensas, sempre reconduz ao corpo, logo à sua vontade. Como é o princípio de razão que situa os objetos nesta relação com o corpo, e por isto com a vontade, o conhecimento servidor desta também se empenhará unicamente em conhecer dos objetos justamente as proporções estabelecidas pela razão, portanto em seguir suas diversas relações no espaço, tempo e causalidade. Pois é somente graças a estas que o objeto é interessante ao indivíduo, i. e., possui uma relação com a vontade. (SCHOPENHAUER, 1974: 17)

\section{O belo e o sublime}

Os sentimentos do belo e do sublime seriam, para Schopenhauer, representações das respectivas ideias no corpo humano, ultrapassando, no entanto, os limites da fisiologia (Sinnenempfindungen) dos juízos respectivos, conforme na exposição de Edmund Burke (1729-1797), que associava o sublime à sensação corporal de calafrio complacente, calma e terror; enquanto o deleite do belo provocaria um amolecimento progressivo do corpo até seu desfalecimento ${ }^{82}$. Verificamos acima a como Schopenhauer descreveu o juízo do belo e do sublime, enquanto objetificações da vontade relacionadas aos membros corporais. A beleza ou o sublime seriam representações da vontade objetificada, constituiriam o organismo vivo das ideias que deveriam ser intuídos a partir de quaisquer representações; seja um artefato, a natureza, ou a obra de arte. Para cada objeto, haveria uma ideia de beleza correspondente. Para Schopenhauer, o juízo do belo não poderia ser dado totalmente a priori, porque, conforme verificaremos dependeria da intuição da ideia, como organismo vivo, que se realiza a partir da contemplação do objeto material. A ideia seria relativa tanto à forma quanto à matéria.

\footnotetext{
82 “(...) o fundamento do sublime fundamenta-se sobre o instinto de autoconservação e sobre o medo, isto é, sobre uma dor que, pelo fato de ela não chegar ao efetivo desmantelamento das partes do corpo, produz movimentos que, pelo fato de purificarem os vasos mais finos ou mais grossos de obstruções perigosas e incômodas, são capazes de provocar sensações agradáveis, na verdade não um prazer, mas uma espécie de calafrio complacente (grifo meu), uma certa calma que é mesclada com terror." Ele (Burke) remete o belo, que ele finda sobre o amor ( e do qual ele contudo quer ver distinguidos os desejos), "ao relaxamento, à distensão e ao adormecimento das fibras do corpo, por conseguinte a um amolecimento (grifo meu), desagregamento, esmorecimento, desfalecimento, a uma morte, um desaparecimento progressivo por deleite." (BURKE apud KANT, 2008: 123)
} 


\section{A condição formal subjetiva do juízo de gosto em Kant}

Kant havia apontado como o fisiologismo de Burke incorria no relato subjetivista da experiência pessoal, inviabilizando o ajuizamento do gosto. Este dependeria de sua qualificação como um universal passível de ser expressado e comunicado. O sentimento de prazer por si não explicaria os juízos de belo e sublime, conforme ele os distingue do agradável e do bom. Sendo estes últimos determinados em função do prazer da satisfação de um interesse determinável, o gozo e a moral, sendo, portanto, alvos de outro tipo de ajuizamento.

Belo é o que apraz no simples ajuizamento (logo não mediante a sensação sensorial segundo um conceito do entendimento). Disso resulta espontaneamente que ele tem de comprazer sem nenhum interesse.

Sublime é o que apraz imediatamente por sua resistência contra o interesse dos sentidos.

Ambas, como explicações do ajuizamento estético universalmente válido, referem-se a fundamentos subjetivos, a saber, por um lado da sensibilidade, do modo como eles em favor do entendimento contemplativo, por outro lado como eles, contra a sensibilidade para os fins da razão prática, e não obstante unidos no mesmo sujeito, são conformes a fins em referência ao sentimento moral. $\mathrm{O}$ belo prepara-nos para amar sem interesse algo, mesmo a natureza; o sublime, para estimá-lo, mesmo contra nosso interesse (sensível).

Pode-se descrever o sublime da seguinte maneira: ele é um objeto (da natureza), cuja representação determina o ânimo a imaginar a inacessibilidade da natureza como apresentação de idéias. (KANT, 2008: 114)

Qualquer outra determinação utilitária do agradável também desqualificaria o objeto do juízo de gosto, assim Kant distingue as belas-artes das artes mecânicas, apesar do caráter intencional no feitio de ambas, considerando-a como parte da natureza: "pelo fato de que na verdade foi encontrada toda a exatidão no acordo com regras segundo as quais, unicamente, o produto pode tornar-se aquilo que ele deve ser, mas sem esforço, sem que transpareça a forma acadêmica, isto é, sem mostrar um vestígio de que a regra tenha estado diante dos olhos do artista e tenha algemado as faculdades de seu ânimo." A apreciação dependeria do gosto, mas a produção da obra de arte requereria o gênio bem dotado nas faculdades da imaginação (que livre associa materiais), entendimento, espírito (que vivifica o material e apresenta ideia estética) e gosto. Kant redefine o belo e o sublime, tentando superar os limites do empirismo de Burke, segundo uma exposição transcendental que aproxima as dimensões sensíveis da estética do gosto da moral. 
Esta redefinição dependia do estabelecimento de um critério a priori dos juízos de gosto que desse validade universal, portanto, a este outro tipo de juízo considerado por Kant sintético. O a priori para os juízos de gosto não poderia ser fundado em conceitos da razão ou em juízos de conhecimento; pois estes os igualariam aos juízos lógicos, desprezando as condições imediatas e sensíveis de prazer e desprazer vividas pelo sujeito no ajuizamento do gosto. "O gosto reivindica simplesmente autonomia. Fazer de juizos estranhos fundamentos de determinação do seu seria heteronomia” (KANT, 2008: 129). Não poderiam também, portanto, ser explicados por regras da estéticas. Por fim, a universalidade e a necessidade presentes também no juízo de gosto se explicariam somente por ele ser fundado na "condição formal subjetiva de juízo em geral” (KANT, 2008: 133), que Kant supõe ser igual em todos os seres humanos, caso contrário, argumenta ele, os homens não conseguiriam comunicar suas representações e conhecimento. Tal condição formal subjetiva comum funcionaria no ajuizamento das representações humanas implicaria a concordância de duas outras faculdades, que seriam a da imaginação e do entendimento, correspondentes à intuição do múltiplo e à conceituação da unidade compreendida respectivamente. Como o juízo de gosto não se pode basear em conceitos conhecidos ou da razão, ele deve emergir diretamente da subsunção da faculdade da imaginação. Ele seria singular, no sentido de que independe de conceitos e liga o predicado da complacência direto a sua representação.

Portanto, não é o prazer, mas a validade universal deste prazer (grifo meu), que é percebida como ligada no ânimo ao simples ajuizamento de um objeto, e que é representada a priori em um juízo de gosto como regra universal para a faculdade do juízo e válida para qualquer um. É um juízo empírico o fato de que eu perceba e ajuíze um objeto com prazer. É porém um juízo a priori que eu o considere belo (grifo meu), isto é, que eu deva imputar aquela complacência a qualquer um como necessária. (KANT, 2008: 133)

Schopenhauer reinterpreta a crítica do juízo kantiana também, retomando a ideia de belo platônica como objeto da intuição imediata e não como condição formal subjetiva. O ajuizamento do belo não dependeria de um juízo a priori, como propunha Kant, mas, pelo contrário, da elevação do sujeito acima de suas contingências subjetivo-individuais. Tais contingências incluíam a estrutura racional do sujeito. Para Schopenhauer, o juízo do belo seria desinteressado somente na medida em que se dissociava da racionalidade humana. No sentido 
pleno, o belo seria uma objetificação da vontade absoluta, portanto, determinado em função dela e interessado. $\mathrm{O}$ que seria antecipado ao artista em relação à realização seria a ideia de si mesmo: que é vontade tal e qual a vocação do material para o belo que define sua obra. $\mathrm{O}$ artista poderia dizer ao pedaço de mármore esculpido; "Eis o que tu querias dizer!” (SCHOPENHAUER, 1974: 52), porque intui a ideia do belo que é a vontade objetificada.

Que todos nós conhecemos a beleza humana, tão logo a percebemos, mas que isto se dá no verdadeiro artista com uma distinção tal, que este a revela de um modo como nunca a viu, superando a natureza em sua apresentação, isto é possível unicamente porque a vontade, cuja objetivação adequada em seu mais alto grau deve ser julgada e apreciada aqui, somos nós mesmos. (SCHOPENHAUER, 1974: 52)

\section{Belo}

Segundo Schopenhauer, tanto o belo quanto o sublime convidariam à contemplação pura, sendo a diferença entre eles relativa à recepção corporal. A beleza seria uma representação da ideia do belo que poderia ser encontrada na natureza ou na arte. Ela despertaria prazer estético através da clareza formal e de significação que livram o homem do conhecimento relativo e dependente da vontade individual. As formas individualizadas do belo suscitariam no sujeito um prazer estético sem resistência, pois não representariam ideias que se traduzem numa ameaça à vontade humana, esta objetificada no corpo humano. O conhecimento puro seria despertado sem luta, pois a beleza facilitaria o esquecimento da vontade e o despertar do puro sujeito do conhecimento. A natureza bela teria o poder de forçar mesmo pessoas insensíveis à entrega, quando a consciência individual é deixada, e à contemplação estética. $\mathrm{O}$ sentido objetivo da beleza é a revelação da ideia, que é possível apenas fora das condicionantes do tempo e do espaço. A visão objetiva exigida pela para a contemplação do belo, pressupõe não submeter o objeto ao princípio da razão. Pois, conforme verificamos, para Schopenhauer, as formas do pensamento racional, tempo e espaço, determinariam o objeto como condicionado; que seria incompatível com a noção de ideia.

Por isto, ao contemplar, p. Ex., uma árvore esteticamente, isto é, duma vista artística, conhecendo não a ela, mas a sua idéia, não possuía menor importância o se tratar desta árvore ou sua antecessora de há mil anos, e também o ser observador este indivíduo, ou outro existido num lugar qualquer, numa época 
qualquer;(...) E não só ao tempo, mas também ao espaço se furta a idéia: não é a configuração espacial aos meus olhos, mas a expressão, o significado puro da mesma, sua essência mais íntima, que se revela e me provoca, constitui propriamente a idéia, podendo permanecer idêntica apesar da grande diversidade das condições espaciais de sua conformação. (SCHOPENHAUER, 1974: 43)

Já no sublime, o conhecimento puro seria alcançado através de violenta ruptura da relação do objeto desfavorável com a vontade. Tal ruptura é constantemente ameaçada pela recordação do objeto desfavorável, provocando continuamente o movimento de despertar da vontade (sentida como resistência ao objeto). O despertar da vontade renovaria o sofrimento, o sentimento da insignificância de nossa existência; "como corpo animado, como fenômeno transitório da vontade, como gota no oceano, sumindo e se perdendo no nada"(SCHOPENHAUER, 1974: 39). Contra tal pensamento nos elevaríamos através da consciência de que o mundo existe apenas em nossa representação, que tal sofrimento que nos causa terror depende de nós. Sentiríamo-nos elevados nessa unidade com o mundo. $\mathrm{O}$ despertar da vontade/sofrimento e a elevação se repetem continuamente através da recordação diante do sublime, operando como "princípio vivificador" genérico. A lembrança do frio, do vazio, da aridez, por exemplo, refrescariam a sensação corporal

\footnotetext{
Esta elevação não deve somente conscientemente ser conquistada, mas também mantida, sendo assim acompanhada de uma constante recordação da vontade, não de um querer isolado, individual, como o temor ou o desejo, mas do querer humano em geral, enquanto expresso de um modo geral por sua objetividade, o corpo humano. (SCHOPENHAUER, 1974: 37)
}

O observador diante de representações do sublime, abstém-se do sentimento de ameaça proporcionado por determinados tipos de objetos, eleva-se acima de suas vontades e relações individuais e entrega-se à contemplação prazerosa do mesmo. Este processo de elevação e distanciamento conscientes diante do objeto ameaçador despertam um sentimento de engrandecimento, um estado de exaltação (Erhebung). Assim, belo e sublime seriam idênticos quanto à determinação principal do conhecer puro e abandono da vontade em prol da contemplação.

$\mathrm{O}$ belo e o sublime se distinguiriam de fato pelo grau de empatia provocada no sujeito pelo sujeito. O objeto sublime ressoa as carências, conforme representadas no corpo humano, enquanto o belo faz esquecê-las. Para cada parte 
do corpo haveria uma ideia de sofrimento correspondente. Em cada órgão corporal, a ideia do belo e do sublime seriam representadas de maneira própria; sendo possível estabelecer a gradação de um sentimento ao outro, ou de um sublime fraco ao forte. A luta entre a vontade, o prazer e o desprazer determinariam o jogo estético:

Do mesmo modo que o homem é simultaneamente impulso impetuoso e sinistro da vontade (designado pelo pólo dos órgãos genitais como seu foco) e sujeito eterno, livre e sereno do conhecimento puro (designado pelo pólo do cérebro), também, em correspondência a esta oposição, o sol é ao mesmo tempo fonte da luz, a condição para o conhecimento perfeito, e portanto da mais agradável das coisas, e fonte de calor, a primeira condição da vida, i.e., de todo fenômeno da vontade em seus graus mais elevados. Assim, o que é para a vontade o calor, é para o conhecimento a luz. (SCHOPENHAUER, 1974: 37)

Então se o corpo procura o calor, o sublime é determinado pelo frio. Se a mente busca a clareza das formas, a luz reforça o belo. Uma paisagem vazia pode ser um convite para à contemplação serena, mas também uma fonte de angústia por remeter à suspensão do desejo de algo que nos sirva e ocupe. Uma paisagem árida tem um teor sublime maior que uma paisagem coberta de vegetação. $\mathrm{O}$ sentimento sublime é ainda maior se a natureza se torna atuante (vontade adversa da natureza), como numa tempestade.

Tal como apresentado por Kant em sua definição do sublime, este sentimento estaria associado à dupla consciência do sujeito; a do sentimento de fragilidade diante da natureza hostil e da inaptidão a de nossa faculdade da imaginação para representar a relatividade dos fenômenos naturais vividos que envolvam uma enorme medida de grandeza, "que ultrapassa todo padrão de medida dos sentidos", apontando para o infinito (sublime-matemático); ou nos parecem ameaçadores (sublime-dinâmico), tanto no sentido da integridade física, diante de uma paisagem, quanto moral, diante de Deus. O sublime seria, para Kant, alvo de um prazer negativo, isto é, sentido como uma violência contra nossa faculdade de imaginação perante o objeto que não pode ser percebido como uma forma em sua totalidade. Não é, no entanto, a ameaça real o agente determinante de tal sentimento, mas a necessidade de evocação de ideias da razão pelo objeto ameaçador ou incomensurável, visto que nenhuma forma sensível se mostra adequada à representação de tais objetos. O prazer corresponderia ao reconhecimento de superioridade de nossa faculdade espiritual em relação à 
natureza hostil (interna ou externa ao homem). A sublimidade estaria diretamente relacionada com a ideia de liberdade em Kant, por isso sua dimensão moral. O exercício da liberdade entendido como a superação das determinações naturais, tais com os desejos humanos. A guerra, portanto, teria algo da qualidade sublime naquilo que move as pessoas a renunciarem a suas vontades individuais, enfrentando o medo e arriscando a vida por um ideal de bem coletivo. O sublime estaria, deste modo, relacionado com um sentimento de grandeza moral (razão prática) em relação ao sujeito consigo e com seu entorno.

Tudo o que suscita este sentimento em nós, a que pertence o poder da natureza que desafia nossas forças, chama-se então (conquanto impropriamente) sublime; e somente sob a pressuposição desta idéia em nós e em referência a ela somos capazes de chegar à idéia da sublimidade daquele ente, que provoca respeito interno em nós não simplesmente através de seu poder, que ele demonstra na natureza, mas ainda através da faculdade, que se situa em nós, de ajuizar sem medo esse poder e pensar nossa destinação como sublime além dele. (KANT, 2008: 110)

Schopenhauer rejeita o teor moral (e conformista?) da definição kantiana de tais juízos reflexionantes. Para ele, o sublime se expressaria no contraste entre a vontade humana e sua capacidade de se colocar acima da natureza não pela razão, mas através da contemplação e do conhecimento puro de ideias tais como o ilimitado e o ameaçador. Entretanto, o conhecimento puro, entendido por Schopenhauer como intuição imediata do absoluto, que levaria o sujeito a perceber a insignificância e ausência de sentido de sua existência enquanto ser individual, opõe-se diametralmente à definição kantiana do sublime relacionada com ideias da razão e com o consequente sentimento moral de grandeza d'alma. O prazer do sublime em Schopenhauer decorreria da suspensão dos prazeres e dores individuais através da entrega na contemplação, donde há uma identificação do indivíduo com "sujeito eterno do conhecimento puro", que fora da experiência do belo e do sublime estaria acima do mundo das meras representações das vontades. No sublime, o sujeito se identificaria com a incomensurabilidade do mundo, formando com ele uma unidade acima de si próprio. "É exaltação, engrandecimento acima do próprio indivíduo, sentimento do sublime" 83 (SCHOPENHAUER, 1974: 38). O sujeito resistiria no sublime a pressões contraditórias, despertando nele tanto a consciência do medo diante de

\footnotetext{
${ }^{83}$ Schopenhauer cita um Upanichade dos Vedas.
} 
determinadas situações da vida como a consciência da falta de sentido de tal medo:

Então a duplicidade da consciência do espectador impassível desta apresentação atinge sua maior clareza: ele se sente simultaneamente como indivíduo, frágil fenômeno da vontade, passível de destruição pelo mais débil daqueles golpes, impotente frente à poderosa natureza, dependente, abandonado ao acaso, um nada incomensuravelmente pequeno, frente a poderes colossais; e ao mesmo tempo como eterno e sereno sujeito do conhecimento, que, como condição do objeto, é precisamente o portador de todo este mundo, e a terrível luta da natureza somente sua representação, ele próprio na percepção tranquila das idéias, livre e alheio a todo querer e a todas necessidades. É a sensação total do sublime. Aqui produzido pela visão de um poder que ameaça de destruição o indivíduo, incomparavelmente superior que lhe é. (SCHOPENHAUER, 1974: 39)

O belo e o sublime seriam em essência, portanto, indistintos, pois o objeto da contemplação estética é ideia a ser revelada. O princípio da razão é que estaria relacionado com o conhecimento do objeto individual, que se define por manter relacionado com a vontade individual e exterior a ele. A ideia é autônoma, portanto, não está submetida às condições do espaço e do tempo.

\section{As representações humanas como mais alto grau de objetificação da vontade}

\section{Dimensões espaço-atemporal e temporal: Figura/ espaço e tempo/movimento}

O objetivo da arte seria a comunicação da ideia apreendida. $\mathrm{O}$ artista compartilharia a ideia de modo purificado, tornando-a mais acessível ao observador, que consegue intuí-la apenas desta forma mediada. A obra de arte permite que o observador partilhe da condição de sujeito do conhecimento puro, que se identifica com o mundo. A contemplação de ideias configuraria uma experiência estética, que fosse feita através da arte ou da observação da natureza envolveria o exercício da empatia. O objeto de empatia pode ser mais ou menos artístico, conforme objetividade da ideia nele presente. $\mathrm{O}$ homem sente empatia pelo objeto de contemplação estética seja natureza ou arte, porque sua essência é a vontade. A vontade, por sua vez, teria seu grau mais alto de objetificação na ideia de humanidade.

Todas as coisas possuiriam algum grau de beleza na medida em que permitem sua contemplação pura, isto é; a contemplação objetiva e exterior a todas as relações. Elas representariam uma ideia, sejam elas do mundo orgânico 
ou inorgânico. "Porém, uma coisa é mais bela do que outra, por facilitar esta pura observação objetiva, lhe vir ao encontro, forçando-a mesmo, quando então a denominaremos muito bela”. (SCHOPENHAUER, 1974: 43) A beleza poderia seria apreendida de modo mais objetivo, por impelir o sujeito de modo imediato à intuição estética da ideia; ou subjetivo, por levar o sujeito a fazer correlações desta concepção, arrancando-o do modo individual e racional de conhecimento, possibilitando o conhecimento puro de modo indireto. A beleza objetiva é, portanto, superior e se realizaria de modo pleno na escultura e na pintura histórica; enquanto a pintura de paisagem e natureza morta implicariam também a experiência do belo/prazer subjetivo:

\begin{abstract}
(na natureza morta e pintura de arquitetura), nosso prazer não consiste principalmente na apreensão imediata das idéias apresentadas, mas muito mais na correlação subjetiva desta concepção, no conhecimento independente da vontade, já que, ao mostrar o pintor as coisas através de seus olhos, adquirimos uma sensação póstuma e partilhamos de um sentimento de profunda paz espiritual e de completo silêncio da vontade, indispensáveis para mergulhar o conhecimento inteiramente nestes objetos sem vida e apreendê-los com tal dedicação, i. e., com tal grau de objetividade. (...).”(SCHOPENHAUER, 1974: 49)
\end{abstract}

A vontade subjetiva seria apenas um grau mais baixo da representação da vontade que a ideia da beleza humana. A perfeita objetificação da vontade em seu mais alto grau é a beleza humana: "Beleza humana é uma expressão objetiva, que designa a mais perfeita objetivação da vontade no mais alto grau de sua cognoscibilidade, a idéia do homem em geral, expressa inteiramente na forma intuída". As belas representações humanas nos impelem "tão subitamente à pura intuição estética", que "um prazer indescritivel se apropria de nós, elevando-nos acima de nós mesmos e tudo que nos oprime”. (SCHOPENHAUER, 1974: 51). A beleza humana seria superior à dos demais seres por expressar a ideia de humanidade, sendo esta a ideia mais próxima da coisa em si que é a vontade.

Nas representações de seres vivos, o caráter genérico é sinônimo de toda ideia de beleza: "o leão, lobo, cavalo, carneiro, touro mais característico sempre também foi o mais belo." (SCHOPENHAUER, 1974: 51). Nas representações humanas, entretanto, a expressão da individualidade acrescenta uma dimensão subjetiva e particular à beleza que corresponderiam à plenitude da manifestação da ideia de humanidade. As representações artísticas humanas devem conseguir expressar a ideia de humanidade, que se realiza quando correspondem tanto ao 
belo genérico quanto à ideia de individualidade, que não deve ser confundida com uma qualidade acidental, "totalmente peculiar ao indivíduo em sua individualidade, porém, como uma face da idéia da humanidade justamente aparente de modo particular neste indivíduo, cuja apresentação, portanto é de utilidade para a revelação daquela idéia."(SCHOPENHAUER, 1974: 54). O ideal de indivíduo deve ser apreendido através destas representações, sendo ele a face particular da ideia de humanidade.

Nas representações humanas, corpo e fisionomia expressariam a dimensão espaço-atemporal do homem, seu caráter genérico; movimento e expressão facial, a dimensão temporal dos sentimentos passageiros das paixões e afeições e as mudanças do querer e conhecer humanos, seu caráter individual ao longo dos tempos. O monopólio das características genéricas (a beleza, por exemplo) pode resultar numa representação insignificante; por outro lado, o exagero das características individuais em detrimento da beleza, em caricatura ${ }^{84}$. Do mesmo modo, a graça dos movimentos deve equilibrar-se com a forma corporal, para evitar a caricatura dos movimentos que geram distorções e contorções estranhas à pintura, escultura e mesmo ao teatro.

\begin{abstract}
$\mathrm{Na}$ escultura, a beleza e a graça permanecem o principal. O caráter do espírito propriamente, que se mostra na afeição, na paixão, na alternância do conhecer e do querer por meio da expressão da face e dos gestos unicamente, é de preferência propriedade da pintura. Pois embora os olhos e a cor, situados fora do âmbito da escultura, muito contribuam para a beleza, são ainda muito mais essenciais para o caráter. Além disto, a beleza melhor se desdobra à observação a partir de vários pontos de vista; mas a expressão, o caráter permite ser apreendido perfeitamente a partir de um ponto. (SCHOPENHAUER, 1974: 55)
\end{abstract}

84 "Por ser a beleza, aparentemente, o objetivo principal da escultura, Lessing procurou explicar o fato de que Laoconte não grita, dizendo que o grito não se concilia com a beleza." Para Schopenhauer, as respresentações do grito na expressão facial tornariam a escultura ridícula, pois mostrariam um esforço físico em vão, não resultando obviamente em som. (SCHOPENHAUER, 1974: 55) 


\section{Desmembramento da beleza humana}

\section{O belo ideal como modelo e não as formas da natureza}

\section{$O$ belo ideal como objeto de interesse da vontade}

Nas representações humanas, a diversidade de formas que as compõem despertariam interesse particular em si por possuírem "vita propria”, tais como mãos, cabeças e pés; diferente das representações vegetais cujas suas partes apenas compõe o agregado que resulta na forma natural. A beleza não poderia derivar do processo de imitação da natureza, pois "alguma vez a natureza produziu um homem de beleza perfeita quanto a todas as suas partes?" (SCHOPENHAUER, 1974: 52). A escolha daquelas partes da natureza que fossem as mais belas para elaborar uma composição artística como somatório, pressuporiam saber de antemão o que é a beleza. Porém, para Schopenhauer o belo não é passível de conhecimento racional, pois é ideia "como organismo vivo". A beleza humana é a vontade objetivada em seu mais alto grau e somente pode ser conhecida através do domínio do conhecimento puro, que é autoconhecimento e descoberta.

Este é sempre, ao menos parcialmente, a priori, muito embora de modo inteiramente diferente, do que das formações do princípio da razão, que também nos são conscientes a priori. Estas se referem à forma geral do fenômeno como tal, como esta fundamenta a possibilidade do conhecimento, o como geral, sem exceção, do fenômeno, conhecimento que produz a matemática e ciências naturais puras; aquele outro modo de conhecimento, a priori, porém, que possibilita a apresentação do belo, atinge o conteúdo e não a forma dos fenômenos, o que e não o como do fenômeno. Que todos nós conhecemos a beleza humana, tão logo a percebemos, mas que isto se dá no verdadeiro artista com uma distinção tal, que este a revela de um modo como nunca a viu, superando a natureza em sua apresentação, isto é possível unicamente porque a vontade, cuja objetivação adequada em seu mais alto grau deve ser julgada e apreciada aqui, somos nós mesmos. (SCHOPENHAUER, 1974: 52)

A beleza na natureza ou na obra de arte pode ser antecipada pelo artista gênio porque a essência do belo conforma o artista e o observador, enquanto vontade objetificada: “apenas a natureza pode entender a si mesma, apenas a natureza pode se aprofundar em si mesma, mas também somente pelo espírito, o 
espirito pode ser aprofundado." 85 (SCHOPENHAUER, 1974: 53) O artista imprime a beleza na forma, porque reconhece a ideia nas coisas individuais: "compreende a natureza em meia palavra, proferindo claramente o que ela apenas balbucia. (...), lhe diz ao mesmo tempo: "Eis o que querias dizer!”, e retruca o conhecedor: "Sim, era isto!"” (SCHOPENHAUER, 1974: 52). A ideia antecipada é o ideal, que já é parte da obra que se completa na execução prática da arte, onde a ideia atinge sua maior clareza.

As representações do mundo vegetal estariam limitadas à beleza ou ausência dela, que se exprimem através de formas no espaço. Homens e animais, dependeriam ainda de um outro modo de expressão que revelasse toda sua essência, que seria expressa tanto pela forma quanto pelo movimento. Assim, o fenômeno da vontade manifestado nos homens e animais incluiria, além da dimensão espacial da forma, também uma dimensão temporal correspondente às suas ações. À perfeição da forma atribui-se beleza, à dos movimentos corporais, graça.

A graça pressupõe uma proporcionalidade de todos os membros, um corpo regular e harmonioso; pois somente assim é possível a leveza perfeita e a conveniência transparente em todas as posições e movimentos; portanto a graça nunca existe sem um certo grau de beleza do corpo. Ambas perfeitas e reunidas constituem o fenômeno mais nítido da vontade no grau mais elevado de sua objetificação. (SCHOPENHAUER, 1974: 54)

Beleza e graça seriam as características principais da escultura, enquanto na pintura, na histórica sobretudo, a ideia de humanidade possui maior importância, principalmente no que tange as suas ações.

Como a forma do belo e a graça, que é movimento relacionado ao belo, são as qualidades essenciais da escultura; ela procura a nudez, a evidência de suas formas sem interferências, excessos, ou artifícios que a encubram, obscurecendo seu significado real que é a ideia. Se aparecem vestimentas, devem ser abreviadas e insinuar a forma causal de suas pregas, como aparece no drapejado de tais vestimentas. O drapejado seria, portanto, apenas uma apresentação mediada da forma, que não impede a intuição da mesma.

\footnotetext{
${ }^{85}$ Schopenhauer deixa uma nota referindo sua citação a Helvétius (il n'y a que l'espirit qui sent l'espirit), reforçando que não se trata da oposição entre Espírito e Natureza propagada pela "influência da daninha sabedoria sedal hegeliana". (SCHOPENHAUER, 1974: 53)
} 


\section{Significado real e nominal}

Quanto às pinturas históricas, Schopenhauer considera fundamental a distinção entre o significado nomimal e o real nelas, muitas vezes, presentes simultaneamente, ainda que sejam independentes. É o significado real que define a qualidade da obra de arte, pois somente ele se refere às significações internas das ações representadas.

A significação externa é a importância de uma ação em relação às consequências da mesma para o e dentro do mundo real; portanto conforme o princípio de razão. A significação interna é o alcance da visão na idéia da humanidade, que revela apresentando facetas mais raras de sua idéia, ao permitir o desdobramento das peculiaridade de individualidades que se mostram de modo claro e decidido mediante circunstâncias convenientemente dispostas. Somente a significação interna tem valor na arte: a externa vale na história. (SCHOPENHAUER, 1974: 58)

A importância exagerada as grandes narrativas (bíblicas ou da história universal) teriam levado à incompreensão da pintura da escola flamenga, por elas relatarem aspectos apenas da vida comum. Valorizava-se unicamente os aspectos da destreza técnica. A arte não diz respeito aos acontecimentos acidentais da vida de alguns indivíduos, mas pode falar desses acontecimentos, se eles se elevam à múltipla ideia da humanidade, conforme na pintura de genre. Sua qualidade residiria no significado real que o quadro traria através da intuição imediata da idéia revelada pela pintura. A significação nominal ou histórica do mesmo dependeria das relações com o contexto temporal e espacial, inferidas pela razão.

Até a rapidez do momento fixada pela arte num tal quadro (atualmente denominado quadro de genre), possui um contato leve, peculiar: o mundo fugidio, transformando-se constantemente em acontecimentos individuais, representativos do todo, requer, para ser captado num quadro permanente, duma realização da pintura, pela qual esta parece parar o próprio tempo, elevando o individual à idéia de seu gênero. Por fim, os propósitos históricos e de significação externa da pintura trazem frequentemente o inconveniente de que justamente o que neles é significativo não permite apresentação intuitiva mas deve ser acrescentado pelo pensamento. Neste sentido deve se distinguir entre a significação nominal de um quadro e a real: aquela é a externa, que se constitui apenas como conceito; esta é a parte da idéia da humanidade, que se revela à intuição mediante o quadro. (SCHOPENHAUER, 1974: 58)

No sentido desta distinção entre o conteúdo artístico e o histórico presentes na pintura, é importante verificar os fundamentos adotados por Schopenhauer para afirmar ser o conteúdo artístico aquele que corresponde à realidade e o mais 
próximo da verdade. O conteúdo histórico teria um fundamento teleológico, relativo e conceitual, quando o artístico é a ideia tomada como um organismo vivo, autônomo e intuível.

A distinção entre os significados real e nominal contraria a estética hegeliana que, primeiro, contrapõe forma e conteúdo, sendo o conteúdo da obra de arte interpretado relativamente à história do espírito. Também a dimensão material da obra estaria subordinada a tal leitura histórica. A arte simbólica seria inferior, para Hegel, à arte grega, porque não haveria nela um equilíbrio entre o conteúdo material e o espiritual da obra. As obras seriam grandes demais para o espírito de uma civilização pouco desenvolvida: a forma aparente seria inadequada ao conteúdo histórico-espiritual.

Para Schopenhauer, não haveria contradição entre forma aparente e conteúdo espiritual na obra de arte, porque ambos seriam representações da vontade, representada no organismo vivo da ideia. No entanto, a arte simbólica seria inferior devido à carga de conteúdo conceitual nela presente, que seria inversamente proporcional à carga artística, que deve ser estética e intuída e não decifrada. Os símbolos não teriam valor artístico, sendo comparáveis à hieróglifos, ideogramas e emblemas; dotados de caráter informativo-utilitário. As produções artísticas primitivas, chamadas simbólicas, não alcançariam o status de arte propriamente: "A escultura grega se dirige à intuição, por isto ela é estética; a hindu se dirige ao conceito, por isto é apenas simbólica." (SCHOPENHAUER, 1974: 65)

A arte simbólica carregaria o mesmo entrave que a alegoria. O problema da alegoria, para Schopenhauer residiria, no fato dela também exprimir um conceito, pois remete a algo que estaria fora da obra apresentada à intuição: " $a$ alegoria pretende designar um conceito e consequentemente dirigir o espírito do observador da representação intuitiva apresentada para outra, abstrata, não intuitiva, localizada inteiramente fora da obra de arte; aqui portanto quadro ou estátua devem realizar o mesmo que, de modo mais perfeito, é realizado pela escrita" (SCHOPENHAUER, 1974: 63). A alegoria opera, muitas vezes, como símbolo, quando a relação entre o objeto apresentado intuitivamente e o conceito 
abstrato referido é uma mera convenção de sinais, que ocorre de modo acidental e sem o conteúdo de associação de ideias subsumido.

Algumas obras, conforme verificamos anteriormente, algumas pinturas, como determinadas pinturas históricas, possuíam significado nominal e significado real. A qualidade artística seria relativa apenas ao conteúdo real, que é a ideia. Para Schopenhauer, a alegoria na pintura remeteria ao significado nominal, conceitual e representaria "uma queda" na apreensão. "Este significado nominal, este intuito alegórico pode perturbar o significado real, a verdade intuída" (SCHOPENHAUER, 1974: 64). A alegoria como parte da obra, funcionaria, para ele, como "uma jocosidade divertida", que torna "um quadro apto a servir de inscrição, como hieróglifo, inventado para deleite dos que são inacessíveis à verdadeira essência da arte. Tudo se passa como se a obra de arte fosse simultaneamente um instrumento utilitário, quando serve a dois fins". (SCHOPENHAUER, 1974: 64).

\section{A palavra como material abstrato da poesia}

\section{A poesia como meio mais propício que a história para expressão da verdade}

A poesia como apresentação da ideia humanidade. A ideia de humanidade como história das paixões em batalha, alegria e sofrimento, das lutas entre tombar e se levantar.

Quanto mais elevado for o grau da vontade objetificada, maior a clareza da ideia e a beleza do objeto. $\mathrm{O}$ homem seria a mais bela das coisas, cuja natureza se desvelaria na poesia e nas artes plásticas. As artes plásticas descreveriam sua figura espaço-temporalmente, conforme verificamos; enquanto a poesia trataria das atividades humanas, entendidas como objetivações da ideia de homem. Por seu teor humano, corresponderiam ao grau mais alto da vontade. As artes visam o conhecimento puro, o esclarecimento e o desdobramento da ideia: no grau mais alto, tem como objeto o homem; e no mais baixo, o mundo inorgânico. "O que o artista hidráulico realiza com a matéria líquida, o arquiteto realiza com a matéria rígida, e justamente isto o poeta épico ou dramático faz com a idéia da humanidade." (SCHOPENHAUER, 1974: 76) 
A vida do homem, como com frequência maior se revela na realidade, se assemelha à àgua como esta se apresenta no lago ou em fluxo; mas na epopeia, no romance ou na tragédia, caracteres eleitos são dispostos em situações tais, em que todas as suas peculiaridades se desdobram, as profundezas do espírito humano se revelam e se apresentam em ações extraordinárias e significativas. Assim, a poesia objetiva a idéia do homem, a quem é peculiar a apresentação por caracteres altamente individuais. (SCHOPENHAUER, 1974: 76)

A poesia segue o caminho oposto ao das artes plásticas, pois não partiria do intuitivo dado, mas de conceitos que, via metáforas, parábolas e alegorias estimulam a fantasia do ouvinte a apresentar os dados à intuição. "Na poesia, o conceito é o material, o dado imediato, que pode muito bem ser abandonado, dando lugar a um intuitivo inteiramente diferente, em que o objetivo é atingido." (SCHOPENHAUER, 1974: 66). Também a poesia se guiaria pela verdade da ideia, apesar de partir da generalidade abstrata da palavra e dos conceitos. Ela seria mais adequada para a expressão dos graus superiores de expressão da vontade objetivada por ser capaz de relatar todos os afetos e pensamentos e feitos humanos. Tanto a poesia quanto a narrativa histórica descreveriam as atividades do homem, no entanto, a poesia seria o meio mais adequado para a expressão da verdade, pois somente o poeta apreenderia a ideia "fora de toda relação, de todo tempo, a objetividade adequada da coisa em si em seu grau mais elevado" (SCHOPENHAUER, 1974: 70). O historiador, obedecendo ao princípio da razão, buscaria apenas a verdade fenômenos; verdade que é individual e relativa às relações aparentes dos acontecimentos e das pessoas, conforme aparecem encadeados com os fatos de seus próprio tempo. "Assim, não fará pouco caso de uma ação pouco significativa, em si ordinária, de um rei; pois ela possui consequência e influência. Mas ações em si altamente significativas de indivíduos singulares destacados, quando permanecem sem consequências, sem influência, não serão por ele mencionadas." (SCHOPENHAUER, 1974: 69). No entanto, é impossível que o historiador tenha acesso a todos os dados necessários e que estes tenham sido totalmente esclarecidos, de modo que se pode supor que, na história, "o falso seja mais presente que o verdadeiro". Já o poeta apreendeu a ideia da humanidade, que é também objetivação de seu próprio eu e pode ser alvo de conhecimento a priori e que é, portanto, dotada de verdade interior e incondicionada. O poeta teria, por isso, a possibilidade de antever a ideia de humanidade que o fenômeno representa, enquanto o historiador colecionaria dados acidentais que ele tenta reunir racionalmente: 
A relação entre ambos a este respeito também pode ser elucidada pela comparação seguinte: o historiador estrito, puro, a trabalhar somente conforme os dados, se assemelha a alguém que, desprovido de todo conhecimento matemático, busca por meio de mediações obter as relações de figuras encontradas acidentalmente, cujos resultados empíricos estão portanto dotados de todos os erros da figura desenhada; o poeta, ao contrário, se assemelha ao matemático a construir a priori aquelas relações, mediante pura intuição, expressando-as não como a figura desenhada realmente as possui, mas como se encontram na idéia, que o desenho pretende tornar possível. Por isto Schiller afirma:

"Was sich nie und nirgends hat begeben,

Das allein veraltet nie ${ }^{\prime 86}$. (SCHOPENHAUER, 1974: 71)

A ideia de humanidade importa na medida em que representa a vontade em grau superior. Então, as autobiografias teriam vantagem sobre os relatos históricos, pois elas considerariam a relação das ações humanas com seu significado interno. Delas seria possível uma visão mais aproximada e nítida do homem que da história, pois esta última trata de nações e exércitos. O significado de ambas vem da relação dos fatos descritos com a vontade. "Assim como uma circunferência de uma polegada de diâmetro e uma de quarenta milhões de milhas de diâmetro gozam totalmente das mesmas propriedades geométricas, os processos e a história de uma aldeia e de um império são essencialmente os mesmos, e num ou noutro pode-se estudar e conhecer a humanidade." (SCHOPENHAUER, 1974: 72)

A poesia lírica, apesar de seu teor subjetivo, também apresentaria a ideia de humanidade. A ideia, neste caso, se confundiria com a do próprio poeta, que intui e descreve seu próprio estado, desaparecendo como indivíduo simultaneamente. O poeta seria o espelho da humanidade: "na poesia lírica de poetas verdadeiros se reproduz o interior de toda a humanidade, e tudo o que milhões de homens passados, presentes e futuros sentiram ou sentirão em situações idênticas, em constante retorno, ali encontra a expressão correspondente." (SCHOPENHAUER, 1974: 73). Para Schopenhauer, sendo o poeta o espelho da humanidade que reflete todos os sentimentos humanos, não se poderia cobrar dele um comportamento moral. "Pois o poeta é propriamente o homem geral; tudo que agitou o coração dum homem qualquer e que é produzido pela natureza humana em qualquer situação, que habita e fervilha num peito

86 "O que nunca e em lugar algum aconteceu, /Somente isto jamais envelhece. (N. do T.) (SCHOPENHAUER, 1974: 71) 
humano, constitui seu tema e sua matéria, como a seu lado também a totalidade da natureza. (SCHOPENHAUER, 1974: 73). A poesia se constituiria, portanto, de certo conteúdo subjetivo, assim como ambiental, que seriam intuídos. O contraste entre as intuições do espirito humano, da ideia de natureza e o impulso do querer individual é que definiria o estado lírico, conforme se verifica no cantor:

É o sujeito da vontade, i. e., o próprio querer, que preenche a consciência do cantante, muitas vezes como um querer liberto, satisfeito (alegria), com frequência provavelmente e maior ainda como um querer impedido (luto), e sempre com afeição, paixão, disposição espiritual agitada. Ao lado disto, contudo, e simultaneamente, mediante a visão da natureza em torno (grifo meu), o cantante se torna consciente de si como sujeito do conhecimento puro, independente da vontade, cuja inabalável paz espiritual se situa agora em contraste com o impulso do querer (grifo meu), sempre limitado, sempre carente: a sensação deste contraste, deste jogo de alternativas é propriamente o que se exprime no todo da canção e que constitui o estado lírico. (SCHOPENHAUER, 1974: 74)

No estado lírico, o sujeito do conhecimento puro e do querer se misturam, alternam-se. O efeito poético resulta dessa mistura de ambiente e sujeito, de contemplação e querer, conhecimento objetivo e impressão subjetiva. Esta mistura de estados afetivos seriam aprimorados pela vivência: a criança não se distinguiria do ambiente; o jovem se entregaria aos seus próprios sentimentos e sensações; e o homem maduro, dotado de maior discernimento e menor ímpeto, poderia voltar-se com mais facilidade para a introspecção. "Precisamente por isto o jovem se prende tanto ao lado exterior das coisas, justamente por isto se presta somente à poesia lírica, e apenas o adulto à dramática. $O$ ancião, no máximo podemos pensá-lo como épico, como Ossian, Homero, pois relatar pertence ao caráter da velhice. (SCHOPENHAUER, 1974: 75).

O mais alto grau da realização poética seria, portanto, a tragédia, pois ela revelaria o terror da vontade em conflito consigo mesma, na perfeição de sua objetivação. A tragédia revelaria a constituição do mundo e da existência: "o sofrimento inominável, a miséria da humanidade, o triunfo da maldade, o cínico domínio do acaso, a queda sem salvação do justo e inocente." (SCHOPENHAUER, 1974: 76). O desfecho da tragédia revelaria sempre a ilusão de sentido da vida. Após o cumprimento do destino de sofrimento provocado por erros e maldades individuais, ou pela casualidade de um destino cego e desgraçado, o indivíduo alcança a consciência da própria impotência e percebe a 
forma do fenômeno e conhece finalmente a essência do mundo, que funciona como um calmante da vontade (Quietiv des Willens), conduzindo à resignação e renúncia da vontade de viver. A lógica da tragédia não residiria numa expiação de culpa particular relativa ao herói, mas à culpa de existir da própria humanidade, que carrega consigo o peso do pecado original.

As ações humanas corresponderiam ao desdobramento da ideia de humanidade que as expressões fisionômicas apresentam. Elas corresponderiam a um grau mais alto da objetificação da vontade. Tanto a inércia como o movimento humano são representações da vontade, mas o movimento corresponderia às paixões do homem despertadas pela ideia de querer viver. A inércia humana poderia estar associada ao reconhecimento da falta de sentido da vida, tanto num sentido da bela serenidade quanto da resignação sublime frente à falta de sentido do sofrimento. De qualquer modo a presença humana se traduziria melhor pela ação e pelo sentido trágico, ou, ao menos, pela relevação do mesmo. Também as matérias inorgânicas revelam-se plenamente quando colocadas em movimento, pois aí melhor se observaria as ideias que nelas confluem. Com relação às Ideias presentes em um material tal como a água, por exemplo, "não é suficiente observá-la no lago tranquilo ou no curso uniforme, porém, estas idéias se desdobram por inteiro, quando a água aparece sob todas as circunstâncias e obstáculos, que agindo sobre ela, a induzem à expressão total de todas as suas propriedades. Por isto achamos bonito sua queda, seu estrondo, seu espumar, seu arremessar ao alto e tornar em forma de vapor, (...)" (SCHOPENHAUER, 1974: 75).

A ideia de humanidade se objetiva na vida em muitos graus conforme a variação do fluxo de eventos da vida, mas o artista deverá eleger determinados caracteres em sua obra que possuem tanto traços genéricos da ideia como aqueles altamente individuais que melhor representem as ideias. Tal essencialismo também encontraremos em relação ao material inorgânico da arquitetura, que para ele deveria descartar o que não fosse definitivo para sua estabilidade estrutural, expressos na relação entre rigidez e gravidade. 
Nos gêneros literários, portanto, determinadas situações vividas pelo homem e determinados aspectos do seu caráter humanos seriam propícios para apresentar a ideia de humanidade de maneira desdobrada e significativa.

A significação contínua das situações deve distinguir o romance, a epopéia, o drama da vida real, do mesmo modo como a conjugação e escolha de caracteres significativos; em ambos os casos, porém, a veracidade rigorosa é condição indispensável de sua atuação, e a carência de unidade nos caracteres, a oposição dos mesmos contra si mesmo ou contra a essência da humanidade em geral, como a impossibilidade, ou inverossimilhança próxima a esta, nos eventos, mesmo que em circunstâncias secundárias, chocam a poesia, do mesmo modo como figuras mal traçadas, perspectiva falsa ou iluminação errada na pintura, pois ali como aqui exigimos o espelho fiel da vida, da humanidade, do mundo tornado claro unicamente pela apresentação, e significativo pela combinação. (SCHOPENHAUER, 1974: 75)

\section{Teoria da empatia com os materiais}

\section{A bela matéria}

\section{A Demonização dos materiais.}

Todas as coisas são representações da vontade, logo ideia. Todas elas, se permitirem o estágio de contemplação pura, são belas. Apenas umas são mais belas que outras, apresentando de modo mais claro a vontade objetivada. A escala da representação da vontade apresenta o homem no topo e vai descendo até a natureza inorgânica e vegetal. Na contemplação dos graus inferiores, o prazer do conhecimento independe da vontade, contendo pouca amplitude de significação e conteúdo. Na contemplação da beleza humana e animal, o prazer do conhecimento está na concepção das ideias, revelando de modo mais nítido a essência da vontade como violência, horripilância, satisfação e rompimento. Tal essência afetiva da vontade teria uma correlata inorgânica que se expressariam " $n a$ afinação pelos contrabaixos" da natureza, que representariam as ideias de gravidade, rigidez etc., própria da arquitetura.

Contudo, toda coisa possui sua beleza específica: não apenas tudo o que é orgânico e se apresenta na unidade de uma individualidade, mas também tudo que é inorgânico, disforme, inclusive todo artefato. Pois tudo isto revela as idéias, pelas quais a vontade se objetiva nos graus mais inferiores, constituindo a afinação pelos contrabaixos mais retumbantes da natureza. Gravidade, rigidez, luz, etc., são as idéias que se exprimem em rochas, edifícios, correntes de água. (SCHOPENHAUER, 1974: 43) 
As ideias corresponderiam tanto à forma quanto a matéria dos objetos existentes. Os artefatos criados pelos homens seriam distinguidos das obras de arte por derivarem de um conceito humano (forma accidentalis) e não da objetivação da vontade (forma substantialis) ${ }^{87}$. A forma artificial dos artefatos encobriria a ideia do material ainda reconhecível neles. Para Schopenhauer, no entanto, as representação artísticas estariam mais próximas da ideia do que para Platão, que colocava os elementos naturais acima das obras de arte em termos desta proximidade ${ }^{88}$ e condenava as artes plásticas e a poesia por desviarem os homens da busca da verdade, reduzindo-as à imitação da ideia no seu grau mais baixo, pois intermediadas pela representação de artefatos. "Seja mencionado ainda nesta oportunidade um outro ponto, em que nossa doutrina das idéias diverge da de Platão: Ensina este (De Rep., X., p.288) que o objeto que a arte pretende produzir, constitui o modelo da pintura e da poesia, não a idéia, mas a coisa individual" (SCHOPENHAUER, 1974: 44)

A matéria em si não apresentaria uma idéia, pois "seu ser é agir", seria, portanto, princípio de causalidade e substrato para o fenômeno individual. Neste sentido de incompletude, a matéria seria abstrata: "Mas isto se confirma a posteriori por não ser possível da matéria como tal representação intuitiva alguma, mas somente um conceito abstrato; nela se apresentam apenas as formas e as qualidades, cuja portadora é a matéria, e em cujo interior se revelam as idéias." (SCHOPENHAUER, 1974: 45). A matéria seria principium individuationis $^{89}$, princípio da razão, distinta da forma e de seu fenômeno.

\footnotetext{
${ }^{87}$ Schopenhauer faz referências à terminologia escolástica de forma accidentalis e forma substantialis.

${ }^{88}$ Schopenhauer alega que Platão consideraria apenas os seres naturais como reflexos da idéia, citando Aristóteles (Metafísica XI, cap.3): "ho Pláton éphe, hóti eíde estìn hóposa physei".(SCHOPENHAUER, 1974: 44)

${ }^{89} \mathrm{O}$ problema da individualidade teria sido posto como dependente da material desde Aristóteles, passando por Avicena e os escolásticos. "Tomás de Aquino apresentou uma variante dessa solução ao afirmar que o princípio de I. não é matéria comum (já que todos os homens têm carne e rosto e portanto não se diversificam nisso), mas a matéria signata ou, como ele diz, "a matéria considerada sob determinadas dimensões"(De ente et essential,2). Em outros termos, um homem é diferente de outro porque unido a determinado corpo, diferente pelas dimensões, ou seja, por sua situação no espaço e no tempo, dos corpos dos demais homens (S. Th., III, q. 77, a.2). Esse mesmo tipo de solução é reproduzido na modernidade por Schopenhauer, que, considerando a vontade como a substância única comum de todos os seres, viu o princípio da I. no espaço e no tempo: "De fato, por meio do espaço e do tempo, aquilo que é uno na essência e no conceito mostra-se diversificado, como pluralidade justaposta e sucessiva"(Die Welt, I, S 23)" ABBAGNANO, N. Dicionário de Filosofia. 5a ed. SP: Martins Fontes, 2007.
} 
O indivíduo, como fenômeno de uma idéia, é sempre matéria. E também toda qualidade da matéria é sempre fenômeno de uma idéia, e como tal também apto a uma contemplação estética, i.e., conhecimento da idéia nela apresentada. Isto tem validade mesmo para as qualidades mais gerais da matéria, sem as quais não existe, e cujas idéias são a objetividade mais débil da vontade. Tais são: gravidade, coesão, rigidez, liquidez, reação contra a luz, etc. (SCHOPENHAUER, 1974: 46)

\title{
A batalha das paixões na arquitetura: gravidade versus rigidez
}

\section{A vontade da pedra e o impulso espiritual}

\section{O impulso material-sensível massudo e opaco}

A dimensão utilitária da arquitetura não seria uma representação da vontade absoluta, logo não seria objeto do conhecimento puro. A dimensão artística da arquitetura corresponderia apenas aos graus mais baixos da vontade objetificada em ideias tais como: gravidade, coesão, rigidez, dureza e luz. Elas estariam relacionadas com os materiais utilizados de modo que a intuição de tais idéias descreveriam a estética presente na obra de arquitetura. Portanto, o jogo descrito pelos elementos com funções estruturais arquitetônicas constituiriam sua essência artística.

\begin{abstract}
Mesmo neste grau inferior da objetivação da vontade, vemos sua essência se revelar em ambiguidade, pois em verdade a luta entre a gravidade e a rigidez é a única matéria estética da arquitetura. Fazer com que ressalte com inteira clareza de maneira diversificada é sua tarefa. Ela a resolve, privando estas forças indestrutíveis no caminho mais curto de sua satisfação, retendo-as por meio de um desvio, pelo qual a luta é prolongada e o esforço inesgotável de ambas as forças se torna visível de maneiras variadas. (SCHOPENHAUER, 1974: 46)
\end{abstract}

A força estética da arquitetura estaria manifesta nos esforços de resistência à força da gravidade, conforme se verificaria na rigidez com que a massa arquitetônica se assentaria no solo, com que as vigas suportam a tendência a cair mediatizadas por pilares. Os desvios promovidos pela mediação de elementos de estruturais de resistência à força da gravidade constituem o dispositivo que faz com que o material constituinte destes elementos revele sua potência efetiva, que é a vontade enquanto manifesta no seu grau inferior (vontade do material). Tal vontade do material é autônoma em relação a vontade humana, disto resulta sua dimensão estética passível de contemplação e busca do absoluto. A beleza

Conforme verificamos, Schiller também considerava o tempo e o espaço como princípios da individualização. 
funcionalista da arquitetura, que se traduz na "finalidade visível de toda parte" $\mathrm{e}$ ausência de ornamentos, é restrita ao reconhecimento da essência estrutural do edifício. Ela não se estende às características de interação utilitária do homem com ele. As funções utilitárias não seriam artísticas. Somente as funções estáticas seriam estéticas e passíveis de intuição. Tal função estática seria expressão da vontade da pedra, sua resistência à força da gravidade corresponderia à objetificação mais baixa da vontade e, portanto, relativa aos impulsos materialsensíveis:

Em consequência a beleza de uma edificação consiste na finalidade visível de toda parte, não em relação ao fim exterior casual do homem (nesta medida a obra pertence à arquitetura utilitária); porém imediato à constituição do todo, em relação a que a posição, dimensão e forma de toda parte deve manter uma relação tão necessária, que, no possível, retirada uma parte, ruiria o todo. Pois apenas enquanto cada parte sustenta tanto quanto pode, e cada parte é escorada num lugar e dum modo tal, como é necessário, se desdobra aquele antagonismo, aquela luta, entre rigidez e a gravidade, que perfazem a vida, as exteriorizações da vontade da pedra, para sua completa visibilidade, e se revelam com clareza estes graus mais inferiores da objetividade da vontade. Igualmente as formas de frisos, vigas, arcos, cúpulas são inteiramente determinadas por seu fim imediato e destarte esclarecem a si mesmas. Os ornamentos dos capiteis, etc., pertencem à escultura e não à arquitetura, que somente admite como ornamentação suplementar, podendo ser suprimidos. Conforme o que foi dito é indispensável à compreensão e ao prazer estético de uma obra da arquitetura, possuir um conhecimento intuitivo, imediato de sua matéria, quanto a peso, rigidez e coesão, e nosso prazer em uma tal obra seria repentinamente mui reduzido pelo esclarecimento de que o material de construção é pedra-pones, pois nos pareceria então uma edificação imaginária. (SCHOPENHAUER, 1974: 47)

Os impulsos material-sensíveis não seriam os únicos determinantes do conteúdo estético da obra de arquitetura. Os impulsos espirituais, representados pela materialidade da luz, permitiriam o desdobramento da ideia estética presente na obra. Esta deveria ser avaliada por seus elementos sem ornamentos de modo que ficasse clara as relações dinâmicas entre os impulsos, ultrapassando a tradição disciplinar baseada na análise das proporções estáticas, na noção de forma e simetria. A relação entre a parte e o todo deveria ser funcional, a fim de favorecer a percepção visual e do espaço. Os jogos de luz desempenhariam o importante papel de embelezar a arquitetura, desdobrando a aparência de sua estrutura, operando num sentido oposto ao da gravidade e rigidez e estendo o processo de visão através dos efeitos de reflexão e absorção da mesma sobre as diferentes superfícies. Seria "correlato objetivo do modo de conhecimento intuitivo mais perfeito" (SCHOPENHAUER, 1974: 48). Diferente de outras artes plásticas e da 
poesia, a arquitetura não seria uma cópia da ideia, mas a construção de um objeto real que é apresentado ao observador. Nestas outras artes, a apreciação geraria uma "sensação póstuma" (SCHOPENHAUER, 1974: 49), onde se partilha do olhar subjetivo do artista e não propriamente da apreensão imediata das ideias apresentadas.

\begin{abstract}
A arquitetura possui em relação às artes plásticas e à poesia o distintivo de não formar uma cópia, mas a coisa mesma; não reproduz, como aquelas, a idéia conhecida, com o que o artista empresta seus olhos ao observador, mas aqui o artista apenas apresenta o objeto ao observador, facilitando-lhe a apreensão da idéia, ao tornar o objeto individual real na expressão clara e perfeita de sua essência. (SCHOPENHAUER, 1974: 48)
\end{abstract}

A essência da arquitetura seria a expressão das vontades de gravidade e rigidez pertinentes ao material por ela apresentado, que Schopenhauer reduz à pedra necessariamente, que se caracteriza pela massa e opacidade. Outros materiais, como a madeira, não desempenhariam o potencial arquitetônico pleno no sentido estético "da luta ente rigidez e gravidade" (SCHOPENHAUER, 1974: 47). O material deveria contribuir com a ideia de peso e consistência que seriam pertinentes à arquitetura, reforçando o ideal de clareza e beleza que lhes são próprios. A clareza proporcionada pela simetria, apesar de facilitar a leitura do edifício, teria muito menos importância que a coerência material para revelação da ideia de beleza arquitetônica. A essência da beleza não estaria na regularidade da forma, mas na expressão da vontade, "pois até as ruínas são belas." (SCHOPENHAUER, 1974: 47)

Já os chafarizes, espelhos d'água, que apesar de complementarem o espaço arquitetônico, definiriam-se pela fluidez, ausência de forma, mobilidade e transparência da água em sua luta com a força da gravidade, constituindo o que ele chama de arte hidráulica. Representariam, portanto, um outro grau da vontade.

\title{
A leveza e a transparência da vontade na música. A arte abstrata.
}

\section{A Música faz mundo}

\section{A objetificação imediata da vontade}

A música ocuparia, para Schopenhauer, um status diferenciado entre as, assim por ele chamadas, belas-artes. A tragédia corresponderia a representação 
visível da ideia em seu mais alto grau, a arquitetura, em seu mais baixo. A música não apresentaria nenhuma ideia, por isso também não configuraria uma representação, pois não imita ou repete ideias, mas apresenta sempre a essência do mundo e dos homens, que é a vontade. A música comunicaria a todos os homens com tamanha clareza, causando um impacto maior no interior do homem que as obras de arte intuíveis, que muitas vezes tentou-se explicá-la comparando à precisão aritmética. "Também sua relação reprodutora com o mundo deve ser muito íntima, infinitamente verdadeira, precisamente correta, porque é compreendida instantaneamente por qualquer um dando a conhecer uma certa infalibilidade, por permitir remeter sua forma a regras bem determinadas, de expressão numérica, de que não se pode desviar sem deixar de ser música." (SCHOPENHAUER, 1974: 79). A precisão da música decorre do fato dela ocupar o mesmo grau de distância em relação à vontade que a ideia. Nas outras artes, a ideia é o meio de expressão da vontade apresentada através dos fenômenos artísticos. O mundo fenomênico e o mundo das ideias seriam o resultado de objetivações da vontade, sendo os fenômenos dependente da ideia e a ideia, da vontade. A música expressa a vontade de modo imediato e independente do mundo fenomênico, tal como as ideias, constituindo um lugar próprio:

\begin{abstract}
A música é de fato uma objetivação e um reflexo tão imediatos de toda vontade, como o mundo mesmo é e, sim, como as ideias também são, das quais a aparição múltipla determina o mundo das coisas individuais. A música não é de modo algum, igual às outras artes, o reflexo das ideias, mas sim o reflexo da vontade mesma, cuja objetidade (die Objektität) $)^{90}$ também são as ideias, por isso mesmo o efeito da música é tão mais poderoso e penetrante que o das outras artes: já que elas falam somente das sombras, ela, porém, do ser. Aqui entrementes, a mesma vontade é objetivada, tanto nas ideias quanto na música, apenas de modo totalmente diferente; assim é necessário que, certamente não haja nenhuma semelhança imediata, mas sim um paralelismo, e que exista uma analogia entre a música e as ideias, cuja aparição na multiplicidade e imperfeição constituem o mundo visível. A demonstração desta analogia facilitará o esclarecimento desta difícil explicação devido à obscuridade do assunto. ${ }^{91}$ (SCHOPENHAUER, ????: !!)
\end{abstract}

\footnotetext{
${ }^{90}$ Mantive a diferenciação existente nas duas palavras objetivação (Objektivation) e objetidade (Objktität), presentes no texto original em alemão.

91 "Die Musik ist nämlich eine so unmittelbare Objektivation und Abbild des ganzen Willens, wie die Welt selbst es ist, ja wie die Ideen es sind, deren vervielfältigte Erscheinung die Welt der einzelnen Dinge ausmacht. Die Musik ist also keineswegs, gleich den andern Künsten, das Abbild der Ideen, sondern Abbild des Willens selbst, dessen Objektität auch die Ideen sind: deshalb eben ist die Wirkung der Musik so sehr viel mächtiger und eindringlicher, als die der andern Künste: denn diese reden nur vom Schatten, sie aber vom Wesen. Da es inzwischen der selbe Wille ist, der sich sowohl in den Ideen, als in der Musik, nur in jedem von Beiden auf ganz verschiedene Weise,
} 
A música seria objetivação da vontade como a ideia. A ideia para Schopenhauer incluía seus múltiplos desdobramentos no tempo e no espaço, seu movimento. A música também poderia ser descrita segundo seu vir a ser, apresentando graus da vontade superiores e inferiores, correspondentes aos sons agudos e graves respectivamente.

\begin{abstract}
Reconheço nos tons mais graves da harmonia, no baixo fundamental, os graus mais inferiores da objetivação da vontade, a natureza inorgânica, a massa do planeta. Todos os tons mais agudos, de grande mobilidade e rápido ocaso, como é sabido, devem ser considerados como originados por vibrações concomitantes do baixo fundamental, cuja emissão sempre acompanharam suavemente, e constitui lei da harmonia, que devem acompanhar uma nota grave somente aqueles tons agudos que efetivamente ressoam simultaneamente com aquela (seus sons harmoniques) por meio de vibrações concomitantes. Isto forma analogia com o fato de que o conjunto dos corpos e organizações da natureza devem ser considerados como originados pelo desenvolvimento gradual a partir da massa do planeta; esta, como é seu portador, também é sua fonte, e a mesma relação possuem os tons mais agudos com o baixo fundamental. (SCHOPENHAUER, 1974: 80)
\end{abstract}

O tons graves corresponderiam, portanto à massa informe e de pouca sugestão de movimento, comparável à arquitetura (movimento sublimado na luta interna entre rigidez e gravidade) e também ao mundo vegetal. Tons intermediários corresponderiam ao mundo animal, que já se moveriam lentamente e ainda um tanto sem forma. "O movimento desconexo e a determinação regular de todas as vozes intermediárias é análogo com o fato de, em todo o mundo irracional, do cristal ao animal mais perfeito, nenhum ser possui propriamente uma consciência conexa, capaz de tornar sua vida um todo significativo, nenhum ser experimenta uma sucessão de desenvolvimentos espirituais, (...)”(SCHOPENHAUER, 1974: 81) Os tons muito graves seriam praticamente inaudíveis e, tanto eles como os intermediários, dependeriam de um agudo, único dotado de força e vontade, que lhe desse forma e qualidade. A melodia seria este tom agudo que dá sentido e conecta o início ao fim, correspondendo ao mais alto grau de objetivação da vontade que é pensamento e aspirações humanas sobre a vida.

objektivirt; so muß, zwar durchaus keine unmittelbare Aehnlichkeit, aber doch ein Parallelismus, eine Analogie seyn zwischen der Musik und zwischen den Ideen, deren Erscheinung in der Vielheit und Unvollkommenheit die sichtbare Welt ist. Die Nachweisung dieser Analogie wird als Erläuterung das Verständniß dieser durch die Dunkelheit des Gegenstandes schwierigen Erklärung erleichtern. “ K.52

http://www.zeno.org/Philosophie/M/Schopenhauer, + Arthur/Die + Welt + als + Wille + und + Vorstellu ng/Erster+Band/Drittes + Buch . 
Ela relata, em consequência, a história da vontade iluminada pela reflexão, cuja impressão na realidade efetiva constitui a série de seus atos; ela diz mais, porém, relata sua história mais secreta, descreve toda a agitação, todo impulso, todo movimento da vontade, tudo o que a razão reúne sob o amplo e negativo conceito de sentimento, e que não pode continuar recebendo em suas abstrações (grifo meu). É também por isto que sempre se afirmou ser a música a linguagem do sentimento e da paixão, assim como as palavras são a língua da razão; (...)(SCHOPENHAUER, 1974: 82)

A melodia corresponde ao eterno vagar dos desejos humanos insatisfeitos, renovados, frustrados e alimentados, que se desdobram numa "ansiedade vazia". O gênio ao inventar a melodia, revelaria os segredos do querer e do sentir humanos. Sua obra não nem de reflexão e nem de intenção. "O conceito aqui, como em toda parte na arte, é infrutífero; o compositor revela a essência mais íntima do mundo assim como sonâmbulo magnético fornece informações sobre as coisas, de que em vigília não possui noção alguma." A melodia pode conduzir à felicidade imediata, se é ligeira e direta, como a vontade rapidamente satisfeita, traz alegria. "O retardamento do novo movimento da vontade, o languor, não permitiria expressão outra senão o prolongado tom fundamental, cujo efeito em breve se tornaria insuportável; desde já se aproximam de melodias vazias, muito monótonas. Os motivos curtos e palpáveis da rápida música de dança parecem se referir apenas à felicidade fácil e comum”. (SCHOPENHAUER, 1974: 82) Apesar da semelhança dom os efeitos dos fenômenos que trazem tristeza e alegria, jamais a música se teria outra referencia além da vontade, que é a coisa em si de todos os fenômenos do mundo. A música se corporifica na fantasia humana, sem corresponder verdadeiramente a nenhum sentimento individual. E ela deve manter esta dimensão genérica e abstrata mesmo num meio híbrido de expressão musical como a ópera. $\mathrm{Na}$ ópera, a parte falada seria por demais relacionada aos acontecimentos, que seriam estranhos à música, não devendo sobressair-se. Somente a execução instrumental expressaria de modo puro a música, correspondendo a sua essência abstrata.

Por isto, ela não exprime esta ou aquela alegria individual e determinada, esta ou aquela aflição, ou dor, ou espanto, ou júbilo, ou humor, ou serenidade, mas a alegria, a aflição, a dor, o espanto, ou júbilo, o humor, a serenidade ela própria, por assim dizer in abstracto, o que neles há de essencial, sem qualquer acessório, portanto também sem os seus motivos. (SCHOPENHAUER, 1974: 83)

A linguagem da música seria dotada de tão alto grau de generalidade quanto os conceitos. Enquanto estes, no entanto, referem-se a uma genérica 
abstração vazia, relativa à representação de objetos individuais; a música possuiria a nitidez das figuras geométricas, que poderiam ser representadas a priori como formas abstratas e, ao mesmo tempo, serem aplicáveis e intuíveis como objetos da experiência. A música seria cópia imediata da vontade em todas as suas manifestações e aspirações, entendidas pela razão pelo conceito de sentimento: "porém sempre na generalidade da simples forma, sem a matéria, sempre apenas conforme o em-si, e não conforme o fenômeno, assim como a alma mais íntima da mesma, sem corpo”. (SCHOPENHAUER, 1974: 84) A música não seria como as outras artes, representação da ideia, objetidade adequada da vontade, mas a representação imediata da própria vontade ${ }^{92}$, que é a coisa em si e a essência metafísica do mundo; por isso a música é paradoxal: possui tanto uma dimensão abstrato-genérica quanto a dimensão vívida pulsante de coração do mundo. $\mathrm{O}$ coração do mundo é a vontade inconsciente. Nenhuma determinação intencional levaria à criação musical de fato, mas apenas a um tipo de música imitativa, desenvolvida a partir da reprodução de um fenômeno do mundo visível, tal como na composição “"As quatro estações do ano” de Haydn”. (SCHOPENHAUER, 1974: 85) A música seria por sua generalidade de forma e vazio de sentimento, abstrata; e por ser expressão do conteúdo mais íntimo do homem (e que não é a representação ilusória de sofrimento), coisa em si.

\begin{abstract}
Pois as melodias são, de certo modo, assim como os conceitos gerais, uma abstração da realidade, esta, o mundo das coisas individuais, fornece o intuitivo, o particular e o individual, o caso isolado, tanto para a generalidade dos conceitos, como para a generalidade das melodias, generalidades, porém, que são reciprocamente opostas numa certa medida, na medida em que os conceitos contêm apenas as formas abstraídas principalmente da intuição, a casca exterior das coisas, sendo portanto propriamente abstrações; a música contudo fornece a semente interna anterior a todas as formações, ou o coração das coisas. Esta correspondência permitiria expressão bem apropriada na linguagem dos escolásticos, que afirmavam: os conceitos são os universais post rem, a música porém constitui as universaliza ante rem, e a realidade a universaliza in re. (SCHOPENHAUER, 1974: 85)
\end{abstract}

\footnotetext{
92 "Denn die Musik ist, wie gesagt, darin von allen andern Künsten verschieden, daß sie nicht Abbild der Erscheinung, oder richtiger, der adäquaten Objektität des Willens, sondern unmittelbar Abbild des Willens selbst ist und also zu allem Physischen der Welt das Metaphysische, zu aller Erscheinung das Ding an sich darstellt. Man könnte demnach die Welt eben so wohl verkörperte Musik, als verkörperten Willen nennen: daraus also ist es erklärlich, warum Musik jedes Gemälde, ja jede Scene des wirklichen Lebens und der Welt, sogleich in erhöhter Bedeutsamkeit hervortreten läßt; freilich um so mehr, je analoger ihre Melodie dem innern Geiste der gegebenen Erscheinung ist.” K. 52 http://www.zeno.org/Philosophie/M/Schopenhauer, + Arthur/Die + Welt + als + Wille + und + Vor stellung/Erster + Band/Drittes + Buch .
} 
Assim, a vontade expressada pela música é abstrata na medida em que é destituída de realidade e sofrimento. Estas corresponderiam não corresponderiam a dimensões verdadeiras da existência humana, seriam ilusões acima das quais o sujeito deveria elevar-se. A música propiciaria esta experiência da elevação de forma ainda mais pura que as artes visivelmente sensíveis. Schopenhauer aproxima a definições conceituais de música e filosofia, pois ambas revelariam a verdade: "a filosofia nada mais é do que uma perfeita e correta repetição e expressão da essência do mundo, mediante conceitos muito gerais" (SCHOPENHAUER, 1974: 85) e a música, citando Leibniz, seria "um exercício oculto de metafísica, sem que o espírito saiba que está filosofando” (N. do T., SCHOPENHAUER, 1974: 86). Tanto pelas relações numéricas apontado por Pitágoras e Leibniz, quanto pelo sentido ético-socrático, musicar seria filosofar. Nas relações entre harmonia e melodia (física e metafísica para Schopenhauer), poderia se determinar um procedimento ético: "consideraremos uma pura filosofia moral sem explicação da natureza, como almejava introduzir Sócrates, inteiramente análoga a uma melodia destituída de harmonia." (SCHOPENHAUER, 1974: 86). A música objetiva a vontade pela harmonia, que equivaleria às manifestações da ideia em graus inferiores e superiores. A harmonia perfeita seria a expressão da vontade única e extratemporal, mas esta não pode realizar-se de fato, como se verifica no mundo que é "arena constante de todos aqueles fenômenos de uma vontade única, revelando assim sua contradição interna consigo mesma.(...) Os próprios números, pelos quais os tons permitem expressão, ostentam irracionalidades insolúveis". (SCHOPENHAUER, 1974: 87).

\begin{abstract}
A música seria percebida de forma totalmente independente do entendimento, pois a impressão estética do som não depende de uma manifestação sensível no espaço que demande buscar sua origem. O tempo seria seu único meio de expressão: "pois os tons criam a impressão estética como simples efeitos, e sem retorno à causa, como no caso da intuição. ”(SCHOPENHAUER, 1974: 87)
\end{abstract}

Para Schopenhauer, a arte não muda o mundo, ela o torna mais visível e nítido, porque representa a vontade de modo concentrado na obra, e o torna mais agradável por alguns instantes àquele que for capaz de contemplação, oferecendo a este um consolo na beleza e um momento de esquecimento das mazelas da vida. 
A arte seria a representação do mundo, uma repetição do que o mundo já é ${ }^{93}$, que nos torna conscientes da vontade, permitindo-nos libertar do querer individual buscar redenção: "Se o mundo todo, como representação, é apenas a visibilidade da vontade, a arte é o esclarecimento desta visibilidade, a Camara obscura, a mostrar os objetos com mais pureza, e permitir uma melhor visão do conjunto e combinação dos mesmos, o teatro no teatro, o palco sobre o palco no Hamlet." (SCHOPENHAUER, 1974: 88)

\subsection{3.}

\section{Abstração e Empatia}

\section{A Linha abstrata}

Vimos até aqui discutindo a relação da abstração com a filosofia, com as ciências e com as artes. Em todos os seus espectros, a abstração esteve ligada à separação de determinadas qualidades formais, seja no caso da forma tomada como ideia ou conceito, representação ou mesmo como forma viva.

Para Wilhem Worringer, a abstração tomará um sentido diverso daquele adotado anteriormente. Worringer trata o significado da abstração, tomando como referência o espaço existencial do homem e sua Vontade de Forma (Kunstwollen). O conceito de Vontade de Arte teria contribuído para o desenvolvimento do psicologismo da arte do qual ele se declara participante, tendo sido elaborado por Aloïs Riegl nos seguinte termos: "Por "absoluta volição artística" é para ser entendida aquela latente demanda interior, a qual existe per se, inteiramente independente do objeto e do modo de criação, e comporta-se como Vontade de Forma.". (WORRINGER, 2014: 9) Da relação entre Kunstwollen e a psicologia do espaço resulta o desenvolvimento de dois impulsos artísticos, que ele distingue

\footnotetext{
93 "Este aspecto puro de reconhecimento do mundo e a repetição do mesmo em toda obra de arte é o elemento do artista." K. 52

"Diese rein erkennbare Seite der Welt und die Wiederholung derselben in irgend einer Kunst ist das Element des Künstlers.” K. 52

http://www.zeno.org/Philosophie/M/Schopenhauer, + Arthur/Die + Welt + als + Wille + und + Vor stellung/Erster + Band/Drittes + Buch .
} 
como: o de Empatia, já anteriormente definido por Theodor Lipps ${ }^{94}$, e o de Abstração, que ele desenvolve.

Para Worringer, as teorias estéticas vinham historicamente relegando boa parte da produção artística da humanidade, pois consideravam apenas as produções resultantes do impulso de Empatia. No entanto, o belo empático não daria conta de grande parte das obras de arte, pois descreve "somente um polo do sentimento humano artístico" (WORRINGER, 2014: 4). O outro polo seria o impulso para a abstração.

Os impulsos antitéticos de Abstração e Empatia funcionariam como estimuladores psicológicos para o homem no sentido da busca de auto-satisfação na experiência estética, que seguiria em duas direções representativas; uma dominada pela linha vívida e orgânica, e a outra abstrata, inorgânica e neutra. Esta última significando "negação-da-vida".

Assim como o impulso para a empatia como um pressuposto da experiência estética encontra gratificação na beleza do orgânico, o impulso para a abstração encontra sua beleza na negação-da-vida inorgânica, na cristalina ou, em termos gerais, em toda lei abstrata e necessidade. (WORRINGER, 2014: 4)

A Empatia é determinada pelo prazer estético proporcionado pela obra, entendido como autocontentamento objetificado. "Fruir esteticamente significa me contentar de modo sensual com um objeto diferente de mim mesmo, empatizar-me com ele. " (WORRINGER, 2014: 4). Identifico minha energia vital neste objeto, que é atividade interior, minha vontade em ação. Tal conceito da sensação de empatia vai além das noções de prazer, envolvendo uma dimensão aperceptiva: o objeto sensual desperta em mim uma atividade à qual posso ou não resistir. Somos sempre levados a nos contrapor interiormente com o objeto. Se correspondo ao objeto, sinto liberdade e prazer. Se preciso me defender dele, sinto inibição e desprazer, e considero o objeto como feio (Empatia Negativa).

Para Worringer, a teoria da empatia se limita à Arte Greco-Romana e à Arte Moderna Ocidental. A Arte desenvolvida antes do florescimento clássico e a Arte Oriental seriam explicadas pelo processo psíquico da abstração. As teorias

94 Theodor Lipps (1851-1914) foi dos mais importantes representantes do Psicologismo na Alemanha. Naquela época, Psicologia era estudada no curso de Filosofia, sendo então complementada com disciplinas das Ciências Naturais. 
materialistas vigentes no século XIX, que tentaram explicar os movimentos artísticos a partir da disponibilidade dos recursos técnicos e da habilidade das civilizações, fomentaram um tipo de determinismo histórico que ignorou as complexas dimensões psicológicas do processo de criação artística e contribuíram para a disseminação de uma perspectiva narrativa progressista e eurocêntrica, conforme verificamos em relação às artes greco-romanas. Este privilégio do naturalismo significou um rebaixamento da expressão geométrico-abstrata, associada ao nível mais baixo do desenvolvimento cultural, mesmo quando alcançado o mais alto grau de aperfeiçoamento da forma pura regular.

Para os defensores da pertinência do conceito de Vontade de Arte, a destreza técnica é considerada uma consequência do querer e não a razão de ser de um fenômeno artístico. Propósitos utilitários, matéria-prima e técnica apenas modificariam a o princípio da Vontade de Arte ao longo dos tempos. Para eles, a História da arte é a história das volições artísticas. E para Worringer, ainda assim excluiu-se a arte produzida anteriormente ao florescimento greco-romano da narrativa histórica das volições. Isso se deveu pela ignorância da Vontade de Abstração e por uma série de interpretações distorcidas que surgiram em consequência da valorização da arte naturalista e empática greco-romana. A redução do princípio geral da volição à empatia e esta última ao conceito de mímese, interpretado de forma duplamente equivocada como busca de realismo imitativo e propósito único da arte, determinou a incorporação de um critério de juízo predominante, que seria o naturalismo.

O critério de julgamento ao qual nos apegamos como algo axiomático, é, como eu disse, aproximação da vida orgânica em si. Nossos conceitos de estilo e beleza estética, os quais, em teoria, declaram ser o naturalismo um elemento subordinado na obra de arte, são na realidade inseparáveis do referido critério de valor. (WORRINGER, 2014: 10)

A determinação do conceito de belo na arte a partir da aproximação com o modelo natural, incorre no vício da determinação de estilo como "uma influência reguladora, modificadora da reprodução das verdades da vida orgânica.".(WORRINGER, 2014: 11). No entanto, para Worringer, estilo corresponde ao impulso de abstração, assim como o conceito de naturalismo ao impulso de empatia e nada tem a ver com o impulso da imitação. A imitação da natureza em si não é arte. Seria preciso distinguir o naturalismo, como um tipo de 
arte, do mero impulso de imitação. O impulso artístico serve para satisfazer a necessidade psíquica de encontrar felicidade. Nesse sentido, a história da arte encontra paralelos com a história da religião. Elas expressam a relação do homem com o mundo exterior, com o cosmo. "Assim, as várias gradações do sentimento de mundo podem ser aferidas pela evolução estilística da arte, bem como da teogonia dos povos." (WORRINGER, 2014: 13). As expressões artísticas de outros tempos, que podem nos causar um enorme estranhamento, corresponderam ao fundamento de belo e à vontade de arte da época de sua criação. Para compreendê-los, precisamos nos desvincular da herança clássica da Antiguidade e do Renascimento, onde predominou o impulso pela empatia.

Para Worringer, o impulso para a abstração dominou todo o início das histórias da arte ${ }^{95}$, bem como determinadas culturas orientais. Na cultura ocidental, a tendência abstrata retraiu-se com o florescimento da cultura grecoromana, sendo revitalizada pela arte moderna do século XIX e XX, quando se alicerçou em parâmetros psíquicos modificados, que discutiremos adiante. Conforme verificamos, entre os gregos dominava o impulso para empatia, que era ativado pela relação alegre de confiança que o homem demonstrava em relação ao mundo. O sentimento de mundo dos egípcios e bizantinos era movido pelo medo, que, para Worringer, estaria na origem de todas as criações artísticas e religiões.

(...), o impulso de abstração é o resultado de uma grande inquietude interior inspirada no homem pelo fenômeno do mundo exterior; num domínio religioso, ele corresponde a um forte matiz transcendental para todas as noções. Nós podemos descrever este estado como um imenso medo do espaço (grifo meu). "(WORRINGER, 2014: 15)

Tal medo de espaços abertos presente no processo de criação seria um resíduo traumático arquetípico da época em que o homem se tornou finalmente bípede, mas não sentia confiança para caminhar baseado nas informações que captava visualmente, ansiando ainda tatear como um quadrúpede. "No curso de sua evolução posterior, todavia, o homem se livrou deste medo primitivo do espaço expandido através do hábito e da reflexão intelectual. " (WORRINGER, 2014: 15). O mesmo medo do espaço estende-se ao mundo desconexo e arbitrário

\footnotetext{
${ }^{95}$ Worringer considera as representações naturalistas encontradas nas cavernas como meramente imitativas. Tal instinto de imitação permearia toda a história da arte, mas deveria ser descrito a partir de uma história da destreza manual.(Worringer, 2014: 11)
} 
dos fenômenos. O desenvolvimento racionalista do homem ocidental e suas invenções, tais como o telescópio, os meios de transportes e de comunicação, progressivamente promoveram a impressão de apequenamento do mundo e fizeram com que este medo drasticamente se retraísse. O conhecimento racional é inversamente proporcional à sensibilidade para as coisas em si, que movia o homem em tempos primevos. De tal modo, que o impulso abstrato ficou restrito a determinadas culturas, que resistiram à homogeneização da percepção promovida pela visão cientificista racionalista. A visão distanciada e a objetificação do mundo promoveram a condição alienada do homem moderno.

Os povos civilizados do Leste mantiveram um sentimento de mundo que se opunha à tendência racionalista ocidental. Para os povos orientais, é aceitável que os fenômenos do mundo permaneçam relativamente desconhecidos. "Seu profundamente-enraizado conhecimento instintivo da problemática natureza do fenômeno e da insondabilidade da existência evita o surgimento de uma crença ingênua nos valores do mundo físico." A apreensão intelectual racionalista propagada pelo Ocidente não afetou profundamente sua esfera cultural, que mantém o espírito transcendentalista.

\begin{abstract}
"Aqui nenhum conhecimento foi capaz de abafar a consciência da limitação humana e sua indefesa situação perdida no universo. Aqui nenhum conhecimento foi capaz de matar sua angústia inata no mundo. Pois esta angústia não permaneceu como no homem primitivo, frente à cognição, mas acima dela. Há um último grande critério para a relação da humanidade com o cosmo: sua necessidade de salvação. A forma tomada por esta necessidade é um guia infalível para as qualitativas variações nas predisposições psíquicas das pessoas individuais e raças. Onde as noções religiosas assumiram um matiz transcendental, este é um sinal seguro da forte necessidade de salvação determinada pelo mais profundo instinto de mundo. Então, um lento arrefecimento da necessidade de redenção corre paralelamente com o caminho do rígido transcendentalismo para a concepção de Deus como imanente. (...). Ao transcendentalismo da religião sempre corresponde um transcendentalismo da arte, para o qual não temos o órgão de compreensão somente, porque nós obstinadamente insistimos em apreciar a vasta massa de material de fato no campo de arte total a partir do estreito ângulo de visão de nossa concepção clássico-europeia." (WORRINGER, 2014: 131, 132).
\end{abstract}

Os povos orientais eram dominados pela busca de tranquilidade que compensasse a aguda sensibilidade que tinham para o fluxo dos fenômenos do mundo exterior. A felicidade, portanto, não poderia ser alcançada na identificação com o mundo externo, na empatia com as coisas ali encontradas. A felicidade, 
para eles, consistia em retirar a coisa individual do mundo da multiplicidade fortuita fenomênica, eternizando-a através da aproximação com as formas abstratas. Worringer atesta que, neste processo, os orientais experimentavam a mesma felicidade que os povos ocidentais sentem com a beleza da forma orgânico-vital.

\begin{abstract}
"Seu impulso mais poderoso era, por assim dizer, tirar o objeto do mundo externo para fora de seu contexto natural, para fora do fluxo contínuo da existência, purificá-lo de toda dependência da vida, i.e. de tudo sobre ele que era arbitrário, torná-lo necessário e irrefutável, aproximá-lo do seu valor absoluto. (WORRINGER, 2014: 17).
\end{abstract}

Em comum com os povos orientais, os povos primitivos de uma maneira geral buscaram a expressão geométrica regular como forma de encontrar a felicidade frente a obscuridade do mundo. Eles tinham o impulso de abstração como condição inata, uma predisposição psicológica para lidar com a aparente hostilidade do mundo que não compreendiam. A linha abstrata inorgânica não se referia à observação da realidade, como se poderia supor ao associá-las às formas minerais. Segundo a interpretação psicológica de Worringer, eles estariam buscando uma forma absoluta e transcendental.

Para a cultura Ocidental, no entanto, a conquista do mundo pela razão e o conhecimento significaram progresso e um afastamento desse estado instintivo para o mundo das coisas, além do estabelecimento de uma relação de paridade com o divino. Deus é imanente para o homem moderno e a obra de arte também. Então, qual seria o significado da arte abstrata para ele? Qual o sentido de busca de transcendência? Há busca de transcendência?

\footnotetext{
"Somente depois que o espírito humano passou, em milhares de anos de sua evolução, ao longo de todo curso do conhecimento racionalista, ressuscitou o sentimento para a "coisa em si" nele como a resignação final do conhecimento. Aquilo que era anteriormente instinto é agora o produto final do conhecimento. Tendo decaído do orgulho do conhecimento, o homem está agora tão perdido e indefeso vis-à-vis à visão de mundo como homem primitivo, uma vez que reconheceu que "este mundo visível no qual estamos é a obra de Maya, trazida por mágica, um semblante transitório e insubstancial em si, comparável com a ilusão e o sonho, do qual é igualmente falso e igualmente verdadeiro dizer que é, assim como que não é" (Schopenhauer, Kritik der Kantischen Philosophie). " (WORRINGER, 2014: 18).
}

Para Worringer, no entanto, o retorno ao impulso de abstração seria impossível nas condições modernas. Além de afastado do mundo das coisas em si 
através da apreensão racional do mundo, o homem moderno vive desgarrado do grupo. Somente a massa do conjunto dos homens teria força para criar formas abstratas a partir do instinto comum. "O homem por si só era muito fraco para tal abstração”. A abstração artística nada tem a ver com uma busca intelectual por regularidade, mas com a criação instintiva. Portanto, entre o homem moderno e o homem primitivo que se expressam através da linguagem geométrico-abstrata reside "a mesma diferença essencial que verificamos existir entre o sentimento pela "coisa em si" e a especulação filosófica relativa à "coisa em si".

Os povos movidos pelo impulso de abstração não se enxergavam como indivíduos distintos por uma suposta interioridade de seu ser. Segundo Worringer, eles se viam como individualidades de diferentes tamanhos aplastradas numa vertiginosa unidade indivisível do real. Como consequência buscavam na arte uma ordem formal que isolasse as coisas do entorno ambiental, criando certa distinção visual que não remetesse à profundidade do espaço. A linha abstrata, por eles desenvolvida, pode ser entendida como que este gesto de retirada da coisa do fluxo natural, tornando-a absoluta. A forma absoluta era alcançada através da clara individualidade de suas entidades abstratas, tais como o plano e a forma pura isolada. "Uma consequência crucial desta volição artística era, por um lado, a aproximação da representação ao plano, e por outro lado, estrita supressão da representação do espaço e a execução da forma isolada (grifos meus) ". (WORRINGER, 2014: 21).

A representação tridimensional era evitada pelos povos primitivos por comprometer a percepção do objeto individualizado ao exigir a percepção em sucessivas dimensões, remetendo à temporalidade do mundo natural. Além disso, a profundidade criada através de sombras e projeções sobre o plano envolveria a contraposição da percepção subjetiva relativa com o fato objetivo, remetendo à indistinção individual que os angustiava. A representação do espaço devolvia a condição relativa do objeto representado, dissolvendo sua individualidade material. "Supressão da representação de espaço era ditada pela necessidade de abstração pelo simples fato que é precisamente o espaço que liga as coisas uma à outra, o que transmite a elas sua relatividade na representação de mundo, e 
porque espaço é uma coisa impossível de individualizar." (WORRINGER, 2014: 22).

A essência derradeira da experiência estética seria satisfazer a necessidade humana de auto-alienação. $\mathrm{Na}$ arte abstrata, o ego cerceia a possibilidade de felicidade; na arte empática, é a união do ego com a obra que traz felicidade. Em ambos os casos, a experiência artística é descrita por Worringer como autoalienação. No processo de empatia, a obra é alienação da existência individual e auto-afirmação simultaneamente.

\footnotetext{
"Ao empatizar esta vontade de atividade em outro objeto, entretanto, nós estamos no outro objeto. Nós somos enviados de nosso ser individual desde que nós somos absorvidos num objeto externo, uma forma externa, com nosso impulso interno para a experiência. Sentimos, como se fosse, nossa individualidade fluir dentro de limites fixos, em contraste com a falta de diferenciação de limites da consciência individual. Nesta auto-objetificação está a auto-alienação. " (WORRINGER, 2014: 24).
}

Se na abstração o sujeito se aliena da vida orgânica, na empatia o sujeito "se perde"(se aliena) na contemplação da obra de arte. Ou seja, a experiência estética, bem como a sensação geral de felicidade, seria essencialmente uma autoalienação.

\section{Arquitetura e Escultura em função dos impulsos de Abstração e Empatia}

O princípio absoluto da volição artística de um povo, conforme descreve Worringer, é fruto de sua disposição psíquica, o que explica as tendências artísticas como naturalistas ou abstratas, seja no tratamento do ornamento, da escultura, pintura ou arquitetura. No princípio de todas as artes estava a abstração. No entanto, alguns povos têm uma maior ou menor disposição para desenvolver uma ou outra tendência, dando um caráter peculiar para os impulsos de abstração e empatia, conforme a cultura local. Assim, a arte abstrata teria sido colocada em segundo plano rapidamente entre os gregos, que preferiam, devido ao seu caráter alegre, fruir o orgânico. A suplantação gradativa da arquitetura dórica pela jônica revela como a tendência naturalista predominou entre os gregos.

"O templo dórico representa o produto de uma volição artística ainda direcionada pelo abstrato. Sua constituição interna, se podemos assim chamar, é ainda baseada numa pura regularidade inexpressiva geométrica, ou melhor, estereotômica, acima de cujos limites claros ela não desejaria ir. As leis de sua 
construção são ainda nenhuma outra que as leis da matéria (grifo meu). Esta constituição interna dá a ele aquele peso sincero, aquela compacidade, falta de vida, aquela sujeição imutável ao feitiço da matéria, a qual vai constituir sua solenidade sem paralelo." (WORRINGER, 2014: 79)

No templo dórico, apenas alguns detalhes individuais anunciavam a tendência naturalista que os gregos viriam a desenvolver, tais como " $a$ alternância de linhas retas e sinuosas, as curvas, as ligeiras dilatações nas vigas e as dilatações e afunilamento das colunas (êntase), a leve inclinação para dentro das colunas externas, o estreitamento das vigas de canto e a irregularidade na disposição dos tríglifos". (WORRINGER, 2014: 80) No templo jônico, a matéria se torna subserviente à Vontade de Arte, que é movida pelo sentimento do orgânico, pela empatia. Apesar da monumentalidade do templo jônico, ele é mais próximo do homem, tanto em suas proporções quanto em seu significado mais mundano.

\begin{abstract}
"As colunas ficaram mais altas e mais esbeltas, parecem levantar pela própria força e nas extremidades mais altas voluntariamente permitirem-se serem apaziguadas pela construção do frontão. Enquanto no templo dórico, a grandiosa, inexpressiva lei da matéria em sua exclusividade afugentava toda empatia humana, no templo jônico, todas as sensações da vida fluem nele sem inibições, e a alegria destas pedras irradiadas com vida se tornam nossa própria alegria. " (WORRINGER, 2014: 80)
\end{abstract}

Para Worringer, seus contemporâneos se equivocavam ao ignorar o fundamento primordial psicológico nas artes e também na arquitetura, ao ressaltarem dimensões técnicas que supostamente estariam colocadas anteriormente à Vontade de Arte. Para ele ornamento, as diversas concepções utilitárias do espaço, bem como as concepções tectônicas envolvem muito mais que o conhecimento técnico e científico de cada época.

Mencionamos anteriormente, que a abstração correspondia ao medo do espaço, que as primitivas representações artísticas tendiam ao plano, por este manter o nexo da apreensão da matéria individual isolada de modo imediato e tátil. As representações superficiais dominam, portanto, na arte egípcia, seja pela presença da sisuda matéria ou pelos relevos. $\mathrm{O}$ relevo grego primitivo não tem a mesma rigidez abstrata do egípcio, tendo incorporado a representação do espaço e da perspectiva na época após o Cristianismo, quando a vocação naturalista é assumida. A escultura e arquitetura abstratas pressupõem, portanto, uma 
contradição de princípios, pois dependem da experiência no espaço e da incorporação da dimensão temporal que eram incompatíveis com a volição abstrata. Uma das consequências dessa incompatibilidade será a estilização, o surgimento da ideia de estilo escultural. $O$ impulso abstrato se realiza na individualidade material do objeto separado do mundo fenomênico e na busca pela forma absoluta eternizada. A arquitetura e a escultura misturam-se facilmente ao mundo natural e foi preciso inventar um novo modo de dar impressão unidade e nexo tátil que não fosse através do plano, o que foi alcançado na escultura pela "compacidade cúbica":

"Esta lei fundamental da escultura permaneceu inalterada das mais antigas estátuas arcaicas até Michelangelo, Rodin e Hildebrandt. Pois não há, em princípio, nenhuma diferença entre uma estátua arcaica e uma das figuras de túmulo de Michelangelo. Na anterior, a figura parece crescer laboriosamente a partir da coluna, os braços aderidos firmemente ao corpo, o quanto possível toda divisão da superfície é evitada e divisões que são inevitáveis são ou sugeridas somente num modo geral ou ainda meramente pintadas, a fim de alcançar a máxima impressão de compacidade material (grifo meu). Em contraposição a isto, com Michelangelo a compacidade da matéria é tornada perceptível não de fora, mas de dentro. Neste caso, os limites estritamente terminais da matéria não são reais mas imaginários, ainda que não sejamos, entretanto, o claramente conscientes deles. Nós não podemos tocá-los mas os sentimos em sua compacidade cúbica. (...). Dentro do espaço cúbico fechado, um máximo de movimento; aqui temos uma das fórmulas da arte de Michelangelo." (WORRINGER, 2014: 85)

Muitas vezes, tal compacidade foi interpretada como inabilidade do artista para vazar os membros do corpo esculpido, ou como limite de resistência da matéria. Posteriormente, os gregos abandonarão esta acomodação forçada à forma cúbica e em prol do ritmo orgânico, ainda assim restará o pedestal geométrico das estátuas para distingui-las do mundo da vida. Para Worringer, a escultura só alcança o grau de arte através do processo de abstração que dá à forma criada a impressão de plano, ainda que seja cúbica. Isto seria alcançado pelo que ele chama de estilização. "As duas leis do estilo escultural" seriam, para ele, a máxima compacidade do material e a compressão forçada do objeto na regularidade geométrica ou cúbica: "porque escultura, conforme já afirmado, é, através de sua tridimensionalidade, menos capaz de dispensar a estilização e é consequentemente, entre todas as artes, aquela que carrega as mais distintas marcas da necessidade de abstração”. (WORRINGER, 2014: 89) 
As pirâmides do Egito são o exemplo paradigmático do impulso de abstração arquitetônica para Worringer. A questão da tridimensionalidade novamente se coloca. Sua forma dá a perfeita impressão de individualidade material e unidade fechada. A função de fornecer espaço para as câmaras mortuárias, investem-nas daquela qualidade de "espaço ameaçador", que os egípcios conseguiram subtrair: dos quatro lados, somente se vê os planos uniformes do triângulo retângulo, cujos limites afiados de suas arestas limitam de forma que não se percebe a profundidade volumétrica. "Até o ponto em que o cubo pode ser transmutado em abstração, isto foi feito aqui. A transformação da individualidade material, severa regularidade geométrica, transposição da superfície cúbica em impressões de superfície (grifo meu): todos os ditados de um extremo impulso para a abstração são preenchidos aqui. " (WORRINGER, 2014: 91)

O tratamento decorativo em representações verossimilhantes tais como estátuas, através de padrões geométricos nos cabelos e nos drapeados das vestimentas ou mesmo nos hieróglifos, eram uma forma criar superfícies planas através da linha abstrata. A arte bizantina seria, segundo Worringer, a maior herdeira dessa tendência de estilizações, que vieram da Antiguidade e da Arte dos cristãos primitivos. 


\section{4. \\ Real}

4.1.

Vontade

\section{O Expressionismo nas artes plásticas}

\section{Realismo, evasão e utopia- Arte de evasão e engajada}

Não somente a ascensão do Nazismo na Alemanha, onde se encontrava um dos berços do movimento expressionista com o grupo Die Brücke, contribui para o seu fim. Também a crítica no interior do próprio meio artístico e a condenação do seu legado cultural fomentaram sua dispersão. A perseguição política teve como marco a exposição “Arte degenerada”, montada em 1937 com a combinação de obras modernas de variadas correntes que foram desapropriadas dos museus e, depois da exposição, condenadas à destruição ou comercializadas fora do país. A exposição incluía obras de outros movimentos além do expressionista, tais como obras cubistas e das Vanguardas Russas. Tal perseguição não impediu que o Expressionismo fosse associado à propaganda nazista pela exaltação do seu teor nórdico e anticlássico, tendo tido efetivamente a participação de artistas que ao regime aderiram. Assim como também foi associado ao capitalismo imperialista e retratado como obra da burguesia boêmia e alienada, que servia de massa de manobra dos poderes instituídos contrarrevolucionários. Para esses críticos, o subjetivismo exacerbado nas obras através da expressão do sentimento de angústia e vazio refletiriam a alienação pequeno-burguesa e sua falta de propósito e comprometimento com a realidade revolucionária que animava o humanismo do movimento socialista. O subjetivismo era considerado ora um desvio da luta por justiça social, ora um reflexo da realidade brutal que se estaria experimentando, devendo ser considerado como uma revelação legítima do sentimento de crise, conforme atestavam os defensores das vanguardas modernas. Este era o argumento favorável do filósofo marxista Ernst Bloch no debate que se desenvolveu na revista literária internacional e antifascista Das Wort ${ }^{96}$ de 1937 a 1940, quando é interrompido pela guerra. O debate sobre o expressionismo foi travado na forma de artigos para a revista, envolvendo ainda Bertold Brecht e

\footnotetext{
96 Revista alemã de exilados de literatura, publicada de 1936 a 1939, inicialmente em Moscou.
} 
Lukács. Este defendia uma arte engajada que se baseasse no princípio de realismo, centrado na questão da luta de classes, como alternativa ao "pseudorrealismo" que mimetizava a desordem do entreguerras e a alienação dos vanguardistas. Lukács é acusado por Brecht e Bloch de defender, sob o signo da "totalidade da forma", um tipo de formalismo classicista como único meio de exprimir ("refletir") a realidade do momento. O realismo de Lukács implicava renegar todo modo de expressão associado à vanguarda sob a égide da abstração associada à fragmentação formal. O debate seria retomado nos anos 1950 através da querela entre Adorno e Lukács ${ }^{97}$, recaindo novamente sobre a questão da legitimidade da obra abstrata de vanguarda, enquanto expressão da realidade decadente e da solidão humana na sociedade individualista. Para Adorno, Lukács não teria percebido o conteúdo social das obras de vanguarda por se equivocar quanto ao conceito de arte, quanto à especificidade da arte enquanto realidade da aparência estética.

\begin{abstract}
A arte encontra-se na realidade, possui sua função nela, é também em si multilateralmente mediada pela realidade. Porém, enquanto arte, segundo o seu próprio conceito, contrapõe-se também antiteticamente em relação a este, como é o caso. A filosofia fez disso objeto de reflexão com o nome de aparência estética. Lukács também não poderia passar por cima do fato de que o conteúdo das obras de arte não é real no mesmo sentido da sociedade real. Se esta distinção fosse eliminada, logo todo esforço em estética perderia seu substrato. (ADORNO, MACHADO, 2016: 328)
\end{abstract}

Para Adorno, o conteúdo subjetivo das obras vanguardistas seria histórico, mas, ao ser mediado esteticamente, cristalizaria-se na aparência da forma fragmentária. O que Lukács entendia como subjetivismo e alienação da realidade corresponderia, na verdade, à qualidade do processo artístico da produção de imagens. Esta produção suporia conciliação e irreconciliação entre sujeito e mundo, a partir dos quais a obra artística resultante se manteria como objeto diferenciado esteticamente; não podendo ser igualado nem às coisas usuais nem ao sujeito.

\footnotetext{
${ }^{97}$ Para Jordão Machado, o debate entre Lukács e Adorno sobre as vanguardas históricas teria como base o debate sobre o expressionismo, incluindo na retomada dos conceitos artísticos retomados, tais como a abstração, a montagem e o conceito de decadência e autonomia na arte. “(...) o debate sobre o expressionismo marcou toda reflexão estética posterior, principalmente de Lukács e Adorno, - como se este fosse a "proto-história" do debate realizado vinte anos depois". Em MACHADO, Carlos E. J., Um capítulo da história da modernidade estética: debate sobre o expressionismo. SP: Unesp, 2016.
} 
Certamente que a arte mesma possui diante do mero existente, na medida em que não se limita simplesmente a duplicá-lo de modo estranho à arte, essência e imagem. (...) Apenas na cristalização da própria lei formal, não no passivo recolher dos objetos, a arte converge com o real. (...) Como imagem o objeto é acolhido no sujeito ao invés de petrificar-se reificadamente contra, obedecendo ao comando do mundo alienado. Por força da contradição entre objeto reconciliado na imagem, isto é, espontaneamente acolhido no sujeito, e aquele externo irreconciliado, a obra de arte critica a realidade. É decorrente disso o conhecimento negativo. Segundo a analogia ao discurso filosófico corrente hoje em dia, poderia se fala da diferença estética do existente: apenas graças a esta diferença, e não negando-a, torna-se a obra de arte ambas as coisas, obra de arte e consciência justa. (ADORNO, MACHADO, 2016: 329)

Lukács estaria excessivamente amarrado ao conteúdo "narrado" em vez de focar-se na lógica da técnica artística, que para Adorno definiria o modo ser da obra tanto na produção quanto na recepção da obra. Lukács não compreenderia " $o$ gesto do não reconhecimento do mundo" que envolve o processo artístico das vanguardas, que resulta numa perda de perspectiva e na tendência ao subjetivismo; solipsismo; alienação; individualismo do monólogo interior. Tal perda de perspectiva envolveria também a recepção das obras. A experiência das obras vanguardistas demandaria um tipo de apreensão monadológica, que se contraporia ao estado de contemplação apropriado à experimentação da obra clássica. Lukács entenderia que a imersão na obra envolveria um processo de apreensão solipsista, que supõe a alienação do contexto espaçotemporal/socioeconômico. Daí decorreria o fato de Lukács não perceber o substrato social e estético de tais obras imanente à aparência informe das obras vanguardistas.

Para Adorno, a deformação vanguardista estaria associada à angústia existencial do homem moderno e à sua consciência do tempo despertada, refletida numa nostalgia em relação a tempos primordiais. As obras expressionistas refletiriam o questionamento da divisão do tempo relacionada ao mundo do trabalho mecânico, reveladas como deformadoras e alienantes do sujeito. $\mathrm{O}$ tempo como dimensão da realidade existencial passa a ser interpretado como tempo vivido em contraste com o tempo instrumentalizado pela ciência e pelo trabalho. Tal dimensão do tempo permaneceria relegada por Lukács, porque este estaria preso a um idealismo-objetivista hegeliano cristalizado, que determinava sua rejeição desta dimensão subjetiva e singular da realidade. 
(Na comparação das obras de Joyce e Thomas Mann) A controvérsia deflagrada por Bergson sobre o tempo é tratada como o nó Górgio. Uma vez que Lukács é um bom objetivista, o tempo objetivo precisa partout ter razão, pois o tempo subjetivo é meramente distorção da decadência. O que induziu Bergson a formular a sua teoria do tempo vivido não foi o espírito subjetivista da subversão, como a mente burocrática embrutecida tende a acreditar, independentemente de suas convicções políticas, mas a simples incapacidade de suportar a passagem vazia de sentido do tempo reificado alienado, que o jovem Lukács descreveu uma vez de modo tão penetrante para a Education sentimentale. (ADORNO, MACHADO, 2016: 341)

Para Georg Lukács, conforme veremos em sua resposta na revista, o subjetivismo se refletiria na tendência que ele considera abstrata e alienada do movimento expressionista. Sua militância é decisiva para chegar a tal conclusão. Ele acredita que a expressão da temática existencial nas artes seria indissociável da social, portanto, a dimensão existencial, entendida como uma abstração desta, desviaria o foco da luta revolucionária para um combate espiritual-subjetivo. $\mathrm{Na}$ medida em que a revolução social a favor dos operários somente poderia ser feita através do combate físico e da violência da guerra, a tendência democráticopacifista defendida pela intelectualidade burguesa representava um atraso e um enfraquecimento do movimento que estaria beneficiando a burguesia ligada ao imperialismo. Somente a ditadura do proletariado representaria o progresso e a aceleração do tempo objetificado que interessava à Lukács. Nada escaparia à realidade homogênea determinada pelo sistema socioeconômico, portanto, não existiria nem a especificidade da obra de arte tal como descrita por Adorno e nem a especificidade existencial da vivência humana. Um sociedade dominada pela exploração capitalista determinaria a qualidade das obras e da existência como patológicas, retroalimentando o sistema capitalista ao representar a realidade exterior como reflexo da impressão subjetiva imediata e fragmentada. A obra revolucionária, para Lukács, seria realista na medida em que distinguisse a partir da elaboração da realidade apreendida pelo sujeito, segundo o contexto de causa e efeito das relações socioeconômicas. Isso se refletiria na forma clara e fechada da obra, em sua totalidade. Lukács relegava a dimensão inconsciente tanto no plano individual quanto no da estrutura social conforme construída pelos homens. Desse modo, ele chega à conclusão contraditória de que as relações socioeconômicas constituem a realidade determinante, mas que por outro lado as determinações do singular-individual canalizadas nas obras expressionistas 
serviram para a manipulação das forças revolucionárias e enfraquecimento do movimento social.

Para Ernst Bloch e Brecht, Lukács não escapa de um rígido formalismo em sua defesa do realismo e na acusação de esvaziamento de conteúdo das obras expressionistas. Essas obras se relacionariam com o conteúdo da nova realidade social demandando uma diferente forma de representação. Para Brecht, a fragmentação expressionista seria reflexo na nova realidade social experimentada pelo homem. Na literatura isso se manifestaria tanto pela fragmentação e heterogeneidade, pela colagem da escrita que configuram inicialmente falta de sentido, própria da linguagem inconsciente revelada por Freud e que serviram de herança para o Surrealismo. "Num grande romance satírico, o Ulisses de Joyce, havia, além da utilização de vários modos de escrita e de outras coisas insólitas, o chamado monólogo interior. Uma pequena-burguesa meditava, de manhã, na cama. Os seus pensamentos foram representados em desordem, entrecruzados e confundindo-se. Sem Freud, o capítulo dificilmente poderia ser escrito. "(BRECHT, MACHADO, 2016: 297)

Certamente, a disseminação da psicanálise posteriormente fez com que o subjetivismo patológico, associado às "poéticas metropolitanas" do expressionismo, tivesse sua dimensão psicológica explicada como parte inseparável da experiência com o real. Nesse sentido, o texto de Lukács teria perdido sua atualidade. O próprio homem não podendo mais ser descrito segundo uma relação de transcendência em relação à realidade, ou mesmo, uma distinção interior e exterior. Não apenas o relativismo proporcionado pelas infinitas possibilidades de reflexão sobre as formas percebidas, conforme propunham os Românticos, como a descoberta daquilo que escapa à representação ${ }^{98}$ e, que movimentaria a estrutura do inconsciente, se oferece como tema da pesquisa estética dos artistas expressionistas. Para Bloch, a arte do expressionismo teria

\footnotetext{
${ }^{98}$ Nesse sentido, as alusões ao desenvolvimento da psicologia, da sociologia e da antropologia são recorrentes nos textos críticos de arte da época, influenciando também na incorporação de outros critérios novos trazidos pela "descoberta" de artes de outras partes do mundo, que não a ocidental, bem como dimensões humanas comuns tais como os impulsos worringerianos. "O próprio texto de Worringer aponta sua gênese no contexto artístico bem diferente do Expressionismo. Esse contexto se sugere bem poderosamente na introdução que Worringer forneceu para a edição de 1948 de Empatia e Abstração. Ele relata aqui como as primeiras ideias para sua dissertação surgiram durante uma visita a Paris. Estando no Musée de Trocadéro, ele viu o grande sociólogo alemão Georg Simmel entrar no museu. "(DONAUE ed., JENNINGS, 1995, p.90)
} 
contribuído para nos revelar tal realidade invisível do homem, deixando o caminho aberto para o desenvolvimento de movimentos tão divergentes como o Surrealista e o Abstracionista. Tal realidade se revelaria através do esvaziamento de conteúdo da obra, inicialmente sem sentido devido seus "traços maus, vazios e estagnados", que chocavam e permitiam o desdobramento de significados tanto do pavor quanto da revolta expressos através da extravasão do EU. O teor de desespero próprio ao movimento não seria apenas expressão da percepção da decadência do mundo, mas também da esperança ambígua de um futuro utópico pacífico e de um passado mítico.

E a força que fazia a guerra era o puro sujeito, a necessidade e a selvageria emocionais do sujeito, que, com sua lanterna mágica, se projetava num mundo aparentemente sem objeto. Numa mescla só possível na Alemanha - Alemanha de Ossian, do romantismo, e depois também do Jugendstil, com suas flores de pântano e os seus sonhos de liberdade -, os próprios quadros foram precisamente buscar, recuperar algo ao mesmo tempo arcaico e utópico, sem tivesse sido possível dizer exatamente onde acabava o sonho originário, onde começava a luz do futuro. (BLOCH, MACHADO, 2016: 233)

Apesar da imagem onírica, elas ressoariam como sinais reais, promessas de uma existência futura, na "integração do não-mais-consciente (Nicht-mehrBewussten) no ainda-não-consciente (Nochnicht-Bewussten), do passado distante no ainda não revelado sob forma alguma, do enclausuramento no arcaico numa liberação pela utopia, que é finalmente a sua forma de expressão mais adequada." (BLOCH, MACHADO, 2016:p. 235). A aparência de montagem a partir de fragmentos ${ }^{99}$ de figuras e transplantadas, tais como nas colagens vanguardistas, operariam como objetos "desreificados e trazidos para a fabulação”. Os objetos espelham o movimento do homem, ganham aspecto fisionômico. A selvageria das pinturas, a expressão do irracionalismo, o informe, o animismo dos objetos, a deformação das figuras seriam as marcas do humano que envolvem o observador e o arrastam para dentro do quadro. "A coisa torna-se máscara, conceito, fórmula completamente deformada, desnaturalizada, do secreto prazer no objetivo a atingir, o interior do homem no interior do mundo se

\footnotetext{
99 O processo de fragmentação, no entanto, não era propriedade das vanguardas artísticas modernas, conforme verificaremos. Pressupõem a quebra do paradigma da forma plástica pelo de signo e levam à noção de construção/montagem. O realismo impressionista é construção no sentido também da técnica empregada, a estrutura de cores e seu sistema de valores. O problema colocado pelo Impressionismo era o do realismo integral: "liberar a sensação visual de qualquer experiência ou noção adquirida”. Ver o capítulo "A Realidade e a Consciência” em ARGAN, Giulio C. Arte Moderna. São Paulo: Cia das Letras. 1992.
} 
aproximam”. (BLOCH, MACHADO, 2016: p. 233). O Expressionismo corresponderia a um desvio do classicismo, que Bloch associa ao conceito de realidade "fechado-objetivista", que Lukács evocaria com nostalgia romântica "por causa da regularidade e do belo acabado" (BLOCH, MACHADO, 2016: 225). A realidade decadente seria explorada pelos expressionistas que aproveitariam seus espaços vazios de sentido, sua decomposição, para revelar alguma nova dimensão do homem. "No lugar da eterna "análise formal" do objet d'art, ele voltou-se ao homem e a seu conteúdo que se esforça por encontrar sua expressão mais autêntica possível”. (BLOCH, MACHADO, 2016: 227). O expressionismo teria se voltado para situações da vida do homem comum, revelando seu humanismo revolucionário e pacifista na relação com o oprimido através de releituras das artes populares, dos desenhos infantis, dos doentes mentais e da arte primitiva.

(...) a vanguarda de então também no selvagem se referia ao Homem, sem dúvida ao Homem oculto ou que apenas se anunciava; em resumo, explorava os segredos do humanismo. Ampliava o mundo no Homem e o Homem no mundo muito além da expressão até aí conhecida, procurava o grito, que não passava primeiro através de uma harpa das classes dominantes e das suas euforias desonestas e devastadoras. (BLOCH, MACHADO, 2016: 236)

Uma vertente contemporânea retoma o texto de Lukács para apontar a alienação promovida pelos meios digitais ao disseminarem imagens abstraídas da realidade do mundo. A presença pervasiva da nova tecnologia alteraria inclusive a sociabilidade dos homens ao substituir a presença física corporal nas relações pela comunicação digital. Tal abstração remeteria à alienação do homem e não à tomada de consciência de sua própria estrutura na relação com a realidade do mundo. As mídias ainda promoveriam certa desmobilização da dimensão política ao alterar a relação do homem com o espaço público, que antes seria marcada pelas experiências da presença corporal e do olhar não intermediadas pelas imagens fragmentadas das telas. A perda da visão da totalidade do real implicaria numa perda de perspectiva e tomada de posição política. 


\section{Lukács: O Expressionismo como “ideologia de intermediação” preparatória para a manutenção do Imperialismo}

Lukács descreve o movimento expressionista como tendo surgido num círculo de intelectuais radicais anticapitalistas e pacifistas no final da Primeira Guerra que acabou se tornando a expressão literária da ideologia do USP (Partido independente da socialdemocracia alemã, que se separou do SPD/ MSPD no final da Primeira Guerra em função do pacifismo), quando este se tornou então, apesar da presença inicial da esquerda intelectual, uma asa da direita no caminho para estabilização do capitalismo. Os proletários e a esquerda radical do partido USP teriam migrado pro partido comunista emergente, quando o período de tentativas revolucionárias terminou frustrado. Os métodos expressionistas, no entanto, teriam sido mantidos pelos partidários remanescentes no USP, coincidindo com uma estratégia de disseminação da "ideologia de intermediação" que se disseminou no contexto dividido da burguesia ${ }^{100}$ intelectual alemã e que favoreceria o desenvolvimento do imperialismo alemão.

O Expressionismo teria disponibilizado métodos desviantes de esvaziamento de conteúdo da realidade através da abstração do contexto histórico social, que permitiram a disseminação da tal ideologia da intermediação. Worringer seria um dos precursores e fundadores do movimento expressionista através de sua contribuição teórica acerca do conceito de abstração. Lukács acusa Worringer de manter uma visão alienada e elitista ao diagnosticar o desmoronamento das aspirações do movimento expressionista como uma mera crise da visão de mundo então experimentada pelo homem em geral e refletida na arte e não reconhecer que o colapso do Expressionismo refletiria um crise mais geral da arte quanto à possibilidade de enfrentamento da nova realidade do “Imperialismo, da Guerra Mundial e da Revolução Mundial” (LUKÁCS, 1971: p. 109) do ponto de vista conceitual e artístico.

Segundo Lukács, através da abstração, as relações de causa e efeito relativas ao conceito da revolução socialista, por exemplo, permaneceriam ocultas

\footnotetext{
${ }^{100}$ Segundo Lukács, tal divisão seria reflexo da contradição social mantida desde a transformação da Alemanha dos grandes proprietários nobres capitalistas agrários burgueses, unidos pelo capital financeiro, que passaram a ter influência sobre o Estado, transformado numa monarquia parlamentar que aproximava esquerda e direita a favor dos interesses burgueses.
} 
de modo a poderem ser usadas tanto pelos oportunistas políticos de direita quanto de esquerda. Assim, foi possível que se canalizasse o ímpeto revolucionário para fins menores que não alteravam a estrutura do todo, tal como a revolta familiar. Do mesmo modo, o discurso pacifista teria sido apresentado como uma ideia abstrata, desvinculada de suas implicações com o sistema imperialista, ofuscando as razões para a legitimidade da luta. $\mathrm{O}$ retrato da guerra se reduzia à denúncia da violência das mortes em massa e da falta de esperança nas trincheiras sem relacioná-las com os interesses de classe envolvidos na guerra. Com isso, o USP pretenderia apenas desviar as massas da revolução, mobilizando as massas através de um discurso radical pacifista que levaria para um chauvinismo social. Tal discurso de oposição acabou servindo à política guerra e, por conseguinte, ao estabelecimento da direita. O fundamento real, o ser verdadeiro do fenômeno da guerra permaneceria ofuscado desviando as massas da possibilidade de reflexão espontânea e da práxis correta. Somente a forma superficial abstraída e superficial da guerra se revelava.

\section{O método expressionista na literatura como formalismo vazio e ideologia moral}

\section{A ditadura do proletariado $\mathrm{X}$ utopia democrático-pacifista}

\section{Forças de ação $X$ alienação}

\section{Luta de classes X luta moral subjetiva}

Embora a crítica ao Expressionismo lukácsiana se estenda ao movimento como um todo, em “”Ascensão e Queda” do Expressionismo” (1934), Lukács toma como base para a condenação exemplos literários ${ }^{101}$. O título do texto se refere ao ensaio de Worringer "Künstlerische Zeitfrage" (1921) sobre o panorama das artes naquele momento e é descrito por Lukács como o tributo fúnebre do movimento expressionista. Retomarei Lukács, ainda que vise as artes plásticas, porque seus argumentos se conectarão com a leitura benjaminiana do Expressionismo e ao conceito de abstração.

\footnotetext{
${ }^{101}$ Somente nos textos posteriores, tais como “Trata-se de realismo”(1938) mencionará questões das artes plásticas, talvez porque suscitadas pelo debate expressionista.
} 
Para Lukács, a literatura expressionista promoveria o desvio do campo de batalha da luta de classes para o campo privado da moral, onde a batalha é restrita aos efeitos deformantes promovidos no homem. Tal desvio resultaria na mudança do foco sobre as coisas para a relação entre as coisas. O idealismo-subjetivo dos expressionistas propagaria o afastamento do foco sobre as coisas reais através do discurso abstrato que situa as determinantes do real na cabeça dos homens. Os próprios homens seriam os responsáveis pelas catástrofes sociais, de tal modo que o problema central da revolução dependeria de sua educação no sentido de formar o "novo homem" e não uma mudança do sistema econômico. Daí se daria, segundo Lukács, o parentesco entre o USP e os Expressionistas em termos de forma e conteúdo. A contraposição de força e espírito serviriam à falta de compromisso revolucionário, conforme se verificaria nos discursos pacifistas de ambos. A defesa de uma democracia de proletários no lugar de sua ditadura encobriria a necessária força do movimento de tomada de poder, indiretamente clamando a rejeição à violência abstraída de suas causas na guerra e ignorando a violência corriqueira das relações de exploração. $\mathrm{O}$ discurso utópico dos expressionistas seria de um radicalismo aparente e reacionário, que santificaria o sofrimento da força do capital, levando à resignação. O USP usaria a poética pacifista do Expressionismo para manipular o pequeno burguês através de seu medo do caos revolucionário, assegurando o domínio da burguesia. A manobra consistia, portanto, num esvaziamento dos fenômenos da violência, da guerra e da revolução, tratando-os de um ponto de vista meramente formal e abstraído da realidade social e econômica. Deste modo, restringindo o campo de ação ao campo espiritual individual, segundo uma ideologia do espírito moral. De um lado, o proletário era manipulado pelo medo da violência da guerra identificandose com o USP, de outro, o pequeno burguês pelo medo do caos revolucionário resignava ao apoio moral à "democracia proletária”. O conceito de revolução substituiria a realidade do movimento, que pressupõe a violência pela causa socialista. Lukács conclui que a revolta expressionista nunca se objetivava por desconsiderar as dimensões socioeconômicas, permanecendo limitadas à forma do manifesto. 


\section{A fragmentação como método de esvaziamento da totalidade (da realidade)}

Tal efeito se estenderia nas técnicas de linguagem, onde os escritores vinham valorizando a palavra isolada em detrimento da frase. A palavra escolhida espelharia o contexto da realidade segundo a árbitro pessoal do escritor e dominaria a obra que é fragmentária. O método expressionista levaria a uma contradição insuperável entre forma e conteúdo. Por um lado, o escritor parte de um subjetivismo solipsista e pressupõe que o conceito abstraído poderia se tornar apreensível sensivelmente. A forma "refinada" em sua essência, no entanto, fica aberta à arbitrariedade e à falta de conteúdo objetivo. A totalidade de movimentos aparentes e fragmentários acumulados terminaria por determinar um resultado meramente superficial, que é formal e vazio. O Simultaneísmo seria um desses meios formais utilizados pelos expressionistas que levam à justaposição de elementos que determinariam uma totalidade vazia. O vazio de conteúdo foi encoberto pela expressão do patético de pavor da guerra, pela histeria. A expressão do conflito de classes é mencionada desligada de seu contexto social, como mera expressão do desolamento humano. A revolução é eternizada como movimento eterno ("revolução eterna da Humanidade") do homem, no entanto, desligado da luta de classes. O movimento torna-se, portanto, um elemento vazio do artista pequeno-burguês, não correspondendo ao movimento revolucionário ou a qualquer compromisso com resultados históricos reais. A revolução se dissocia da luta de classes, torna-se uma propriedade do homem moderno, definido como temporalmente em eterno movimento. A histeria se estabelece com a interrupção do estímulo real exterior, determinando a estabilização do artista no caminho vazio da "Nova Objetividade" da inteligência burguesa que se afasta do operariado.

\section{O homem blasé metropolitano e o histérico expressionista: dois modos de reação abstrata?}

\section{O conteúdo de verdade da luta}

Lukács acusa o misticismo, o irracionalismo e a falta de comprometimento com a realização, como fatores determinantes da inconsistência expressionista. Ele propõe uma abordagem realista em seu lugar, que considerasse o contexto 
específico da Alemanha no desenvolvimento do capitalismo imperialista. Os métodos expressionistas incorriam em relativismo e resignação, sabotando o ímpeto revolucionário emergente naqueles anos. Lukács associa o utopismo expressionista à filosofia pós-kantiana do "como se" que estava em voga e "que se propunha a experimentar o absoluto a partir do singular e nunca chegava lá". Os filósofos do "como se" tenderiam ao ilusionismo por conservarem os fundamentos agnósticos, que, segundo ele, deveriam ter sido superados no processo histórico de transformação almejado do Idealismo subjetivo para o objetivo. O agnosticismo seria uma herança da filosofia kantiana, representada pela distinção entre fenômeno e coisa em si como limites para o conhecimento. Esses filósofos teriam ignorado a crítica hegeliana. "Visto que Hegel, um século antes, concluía que a passagem do subjetivo para o objetivo, pressupunha uma ruptura radical com todo tipo de agnosticismo como base de conhecimento teórico dessa passagem (crítica da concepção kantiana de coisa em si)" (LUKÁCS, 1971: p.112). Dado que, para os agnósticos, o acesso à coisa em si estava limitado, eles teriam se resignado no irracionalismo místico do "como se". Este seria caracterizado pelo posicionamento ético-formalista, sendo desnecessário o enfrentamento revolucionário real. $\mathrm{O}$ tal retrato do comprometimento social compunha a visão de mundo que funcionava como uma aparente crítica do presente, mas que, de fato, se afastava dos concretos problemas econômicos; encobrindo a relação entre economia, sociedade e ideologia.

\begin{abstract}
A filosofia do Romantismo vivenciou uma renovação. Simultaneamente, Goethe é trazido como filósofo, como criador da visão de mundo de uma "filosofia da vida", ao lado de Kant como ponto central da Herança. A filosofia extremamente relativista se desenvolve sempre de modo mais forte num irracionalismo místico, sobretudo também pela conservação das bases agnóstico-relativistas (Simmel, com influência de Bergson). Vaihinger ligado ao chão de um extremo, mas "mítico-formativo", relativismo de Kant com Nietzsche ( "Philosophie des "Als ob"”, surgida em 1911). (LUKÁCS, 1971: p.114)
\end{abstract}

A “poesia da metrópole" expressionista corresponderia à superficial crítica capitalista romântica atribuída aos intelectuais boêmios dos cafés. Estes burgueses intelectuais teriam se afastado dos movimentos operários, limitando suas questões ao âmbito do idealismo subjetivo ou do idealismo objetivo místico. A oposição expressionista contra a burguesia havia se tornado abstrata, totalmente afastada da relação de classes. Esta fragilidade no escopo teórico da crítica à 
burguesia teria permitido sua apropriação pela direita e pelo fascismo traduzida numa crítica demagógica contra o capitalismo. Lukács alerta como muitos escritores expressionistas teriam se tornado fascistas, demonstrando o papel de ideologia preparatória (tais como a pseudo-crítica, distorção abstrata, o modo místico) para o reacionarismo. O reflexo dessa abstração ideológica se refletiria na linguagem da arte expressionista como um problema de contradição entre a pobreza do seu conteúdo o pathos subjetivo sobressaltado de sua apresentação. A visão de mundo subjetiva-idealista seria compartilhada com a filosofia do Imperialismo. A estratégia expressionista de distorção e negação da realidade seja pela ironia, pelo grotesco, pela expressão labiríntica teria significado uma “ideologia de fuga” mascarada de revolta e distorção da realidade.

\section{A auto-elevação fausto-gótica expressionista}

O Expressionismo esvaziado do conteúdo revolucionário teria se tornado conveniente para a expressão do fascismo após os anos 1920, tendo sido usado por Goebbels para propaganda fascista. Sua apropriação teria sido facilitada pelo viés idealista mistificante da abstração, que no expressionismo inicial se traduzia na estilização da apreensão da realidade. Goebbels estende o conceito para a descrição da realidade como deformada em si, "realidade expressionista em si". Ele tentaria ressuscitar o movimento já morto para fins de propaganda, recaindo num ecletismo estilístico grandiloquente da auto-elevação (sich erheben) "góticafaustica", que mascarava a realidade obscura. O Expressionismo teria se tornado um patrimônio do fascismo através da cristalização desse teor romântico transformado na "nova objetividade" da realidade distorcida. Artistas como Nolde, Barlach, Stefan George teriam se perdido na procura por uma expressão plástica germânica no gótico, desviando-se da figuração da realidade atual. Tal desvio satisfazia os propósitos fascistas apoiados na determinação de obscuridade. Goebbel teria apoiado as aspirações mítico-irracionalistas associadas ao góticofaustico para manter o expressionismo afastado das ideologias realistas marxistas. A suposta nova objetividade do expressionismo seria, portanto, ainda mais descolada da reprodução da realidade socioeconômica, permanecendo como expressão da superfície do período Imperialista. O esvaziamento de conteúdo e afastamento da realidade permitiam que o expressionismo fosse incorporado à 
ordenação e alinhamento necessários para o funcionamento do sistema totalitarista do fascismo.

Para Lukács o embasamento psicologizante dos impulsos de empatia e abstração, fornecido por Worringer, culminaria com a tendência decadente de um impressionismo psicológico que vinha assolando as artes e que as estava desviando da busca revolucionária. O princípio desta teoria seria a experiência de medo que o homem sente pelo espaço. No homem primitivo seria maior e teria diminuído com o desenvolvimento do conhecimento do mundo pelo homem. Aqueles anos de guerra, revoluções e vida metropolitana, no entanto, implicariam uma regressão, despertando o mesmo medo do espaço, a mesma sensibilidade para a coisa em si no homem moderno que o homem primitivo teria experimentado e que, portanto, segundo a lógica de Worringer, despertariam seus impulsos para a abstração. Tal associação já havia sido feita por Simmel, ao associar a reação blasé do sujeito ao estresse metropolitano. Na verdade, conforme veremos, a abstração dos primeiros expressionistas (Die Brücke) corresponde mais à histeria do homem gótico que ao blasé simmeliano. Ambos reagiriam à experiência metropolitana com o choque, que danificaria o aparato cognitivo humano. Ao sujeito blasé, no entanto, está implícito o silêncio de desdém; aos primeiros expressionistas, o grito. A tendência gótica ao transcendentalismo pode ser associada ao utopismo expressionista. O transcendentalismo expressionista poderia implicar, além do subjetivismo, numa abnegação do indivíduo. Esta abnegação, que tanto foi cultivada na tendência totalizante e homogeneizante do fascismo como também no humanismo utopista do expressionismo, pode ser associada à herança da mística na religiosidade do gótico, conforme descrita por Worringer. Este aponta como a mistura da escolástica à mística no medievo levou o gótico à internalização da agorafobia, revertida numa síntese do medo de espaço primitivo associado à angústia pelo processo de individuação em andamento, a refletir-se na necessidade do êxtase. A cultura nórdica manteria tal diferença em relação às culturas clássicas, onde o indivíduo encontrará amparo no próprio eu personalizado.

O homem nórdico sente também o negativo desse processo de individualização, quer dizer não se torna consciente de seu desamparo individual imediatamente; já que através da negação desse eu, ao qual ele pertence, ele procura se salvar de um abandono individual. O movimento da Renascença sulista com sua crescente 
consciência de personalidade leva à autoafirmação, para auto aceitação, autoglorificação, o processo de individuação do nórdico em contraposição leva à negação de si, ao desprezo de si. O ser individual é aqui sentido como algo negativo, sim, como algo diretamente pecaminoso. $\mathrm{O}$ individualismo da mística prega: negue sua individualidade. Ou como na linguagem mística proclama: "Sua essência comprimida. Quem insiste em si, não pode reconhecer Deus". Essa é justamente a ambivalência da mística: nascida do individualismo, ela direciona sua pregação justo contra a própria origem. Enquanto o homem renascentista reflete sobre seu eu e torna-se consciente de sua personalidade para tornar-se totalmente livre interiormente, independente e em clara autoafirmação tomar o mundo como próprio; considera o homem nórdico somente sobre o seu eu, para novamente de imediato renunciá-lo na ávida busca por Deus. Ele é justamente apenas um indivíduo, não se tornou nenhuma personalidade. Assim permanece a mística transcendental como a escolástica e o elemento da embriaguez, a necessidade de redenção desempenha em ambos o mesmo papel; o processo de individuação não deixa desaparecer a dilaceração dualista, apenas ela toma outras formas através dele. (WORRINGER, 1912: 125)

Nesse sentido, a referência de Lukács ao primeiro livro de Worringer não é suficiente para explicar a abstração segundo a vertente mais sensualista e subjetivista do expressionista histérico, ligado ao grupo Die Brücke, que mais se aproxima do gótico ou do subjetivismo barroco, descrito por Benjamin. Para Lukács, as referências ao gótico não passarão de estilizações (abstrações) da "realidade descrita como expressionista em si". Ele rejeita qualquer dualismo do sujeito em relação ao mundo, como ceticismo para a coisa em si que é, para ele, a realidade socioeconômica.

Para Lukács, a legitimação da relação dualista de medo do espaço determinaria a representação da realidade como caos e labirinto, como fenômenos inapreensíveis. O impulso para a abstração nas artes legitimaria a representação mistificada da realidade, levando o homem à resignação e alienação. O gesto superficial de revolta expressionista apenas encobriria a resignação, a fuga do confronto com as forças do Imperialismo e a fuga frente à escolha entre o proletariado e a burguesia. Nesse sentido, o expressionismo somente poderia estar dando prosseguimento à arte burguesa do Impressionismo, estando limitado à representação de uma visão de mundo subjetiva e fragmentária, à forma superficial do relativismo; estando afastado tanto do conflito de classes quanto de sua solução. Os Impressionistas teriam dado início a tal processo de alienação nas artes ao tomarem a impressão sensória pelo todo do mundo exterior. $\mathrm{O}$ reflexo subjetivo superficial da vivência seria considerado como a essência da realidade 
poética, que excluiria, segundo Lukács, o contexto espaço-temporal que o provocou.

\title{
A contribuição de Worringer no método criativo do Expressionismo
}

\section{A realidade como caos, a imersão na realidade e a abstração}

A contribuição teórica de Worringer refletiria em três aspectos problemáticos do método de criação do movimento: a realidade seria descrita como caos incompreensível e degradante; o único modo de se relacionar com ela seria através de uma imersão patológica, irracional, impulsiva, apaixonada; a coisa capturada deveria ser isolada de suas relações que reconduzem ao caos através da abstração, tipificação. A abstração implicada no método resultaria numa expressão da revolta vazia do pequeno-burguês desmoralizado, perdido e esmagado pelas engrenagens capitalistas.

\begin{abstract}
A conexão como o conceito worringeriano de "abstração" é imediatamente visível. Na conexão com ele é, porém, notável de três formas: primeiro, que a realidade é interpretada de antemão como caos, assim como algo não reconhecível, sem lei existente; segundo, que o método para compreensão da essência (aqui chamado de "coisa") precisa ser o isolamento, o recorte, a destruição das conexões, cujo emaranhado sem lei determina justamente o "caos"; terceiro, que o "órgão" para essa compreensão da essência, a paixão, aqui algo de antemão irracional, é contraposto rígido e exclusivamente ao intelectivo.

Quando nós observamos agora esses três momentos do método criativo um pouco mais de perto, então fica claro neste momento, por que a realidade tinha que parecer como "Caos" para os Expressionistas. Eles estavam numa oposição romântica ao capitalismo, embora a partir de um lado ideológico puro, a visão em sua legalidade econômica nunca procurados. A realidade lhes parece de tal modo "sem sentido", "desalmada", que não compensa penetrá-la, como também é degradante.( LUKÁCS, 1971: p. 138)
\end{abstract}

\section{Gestos vazios}

Tal como o Naturalismo, Impressionismo e Simbolismo, o Expressionismo teria se limitado aos "fenômenos de superfície", acrescido de uma elevação no sentimento de estranhamento, desenraizamento, vazio e desespero mundanoboêmio. Para esses artistas, o reflexo subjetivo da vivência é tomado como a essência da realidade poética, que exclui o contexto espaço-temporal que o provocou. $\mathrm{O}$ embate das forças dominantes do mundo descrita em obras realistas é reduzido ao embate entre sujeito e realidade. No processo criativo expressionista, o " gesto soberano do poeta para forma"(p.141) refletiria um medo abstrato e 
resignação diante do confronto com o mundo. A própria incapacidade de ordenação e combate traduzidas no subjetivismo ocupam o centro da cena expressionista. Tenta-se apreender a realidade por viés subjetivista, taquigraficamente. Os gestos de um elevado subjetivismo são vazios de objetividade. A abstração de Worringer significaria um empobrecimento de conteúdo de formação da realidade.

\section{A Vontades de Arte e os dois modos de percepção do mundo segundo Riegl Do Tátil ao Óptico}

\section{Do Tátil à abstração}

Ao considerar a abstração como um impulso artístico legítimo, Worringer reabilita períodos, tais como o gótico e o barroco e as artes africana e oriental, que não correspondiam aos seus critérios estéticos classicistas dominantes, sendo descritos como períodos de decadência, ou de primitivo desenvolvimento espiritual respectivamente. Worringer vinha seguindo um caminho de abertura promovido pelos românticos na valorização do gótico e pelo teórico e arquitetorestaurador, Viollet Le Duc (1814/1879), que passava pelo elogio da "selvageria" do artesão medieval através do crítico de arte John Ruskin (1819/1900) ${ }^{102} \mathrm{e}$ chegava na psicologia dos estilos de Aloïs Riegl (1858/1905), onde este reconhecia o estado psíquico-perceptivo diferenciado das diferentes épocas, e não a inabilidade artística ou a disposição de materiais, como explicação para os resultados formais variados.

Para Riegl ${ }^{103}$, “A história da arte desde o Egito antigo até a antiguidade tardia é a história da mudança do tátil (Riegl diz háptico) ao modo de percepção

\footnotetext{
102 John Ruskin foi crítico da arte e da estrutura da sociedade industrial emergente. Ele era um crítico da máquina, das imitações baratas por ele produzida, de sua interação com o homem. A beleza ou se pareceria com as formas naturais orgânicas ou viria através do reconhecimento das marcas imperfeitas do trabalho e do cuidado humano. "Afinal, ele mesmo enalteceu a "selvageria" dos artesãos góticos medievais e assim chegou à relutante conclusão que o dom decorativo que ele chama de "tipo mais baixo" é inseparável da crueldade e que aquela civilização tem um efeito adverso nessa forma de talento artístico. A restrição da agressividade (nós podemos acrescentar de toda repressão) tem que ser paga com uma perda de espontaneidade e prazer sensual." GOMBRICH, E.,H., The sense of order. A sudy in the psychology of decorative art, London: Phaidon Press, 1984.

${ }^{103}$ Riegl (1858-1905) desenvolveu suas ideias teóricas no período entre 1897 e 1898, quando esteve licenciado do Museu de Arte e Indústria de Viena. Suas notas foram produzidas para um curso proferido no ano seguinte. Depois de revisão, elas deveriam se compor o livro Historische Grammatik der bildenden Künste, que foi publicado postumamente por seus alunos somente em 1966.
} 
visual ou "óptico"” (GOMBRICH, 1984: p. 196). As artes dominadas pela sensibilidade óptica corresponderiam aos períodos mais desenvolvidos da arte e aos homens antigos. Para Riegl, foi a passagem para a percepção óptica, que envolveria uma apreensão dos objetos de forma distanciada e totalizante, que possibilitou o desenvolvimento da representação do espaço e da atmosfera, culminando com o advento da perspectiva renascentista. A apreensão tátil envolveria uma apreensão aproximada que iria das partes da superfície tátil ao todo, dando impressão aos olhos do homem moderno de falta de coesão, de uma colagem, conforme prevalece na representação planar e na arte os egípcia. A supressão da tridimensionalidade representava para aqueles artistas um modo de ordenamento da imagem, baseado na sensibilidade que tinham mais desenvolvida e no apaziguamento proporcionado pela clareza de tal ordem a partir da observação que também deveria ser aproximada. "O artista Egípcio acreditava que ele estava reproduzindo as figuras como elas eram, não como elas pareciam aos olhos através das ilusões espaciais." (RIEGL, 2004: 403) . A representação da profundidade seria possível apenas porque temos a memória da sensibilidade tátil que é a única a fornecer a terceira dimensão no tato. Na representação bidimensional, ela corresponderia a um efeito ilusório. A sensibilidade háptica, que Worringer associará à abstração, determinaria uma arte mais "realista” que aquela correspondente ao ilusionismo óptico, este dependente da memória. Tal efeito ilusório, no entanto, não nos provoca a vertigem que deveria provocar nos antigos.

Ao observar o mundo a sua volta, o homem primitivo se encontrava confrontado pelo caos. Àquele caos, ele procurava trazer ordem. O primeiro passo era trazer para a frente as coisas que detinham atração especial, de tal modo que, no lugar de uma massa confusa e caótica, ele tinha diante dele entidades individuais.(...) A abordagem óptica lhe mostrava o caos; a tátil lhe oferecia uma suficiente convicção da integridade individual das coisas. As artes visuais, consequentemente, tinham que começar com a superfície tátil. Deste ponto, podemos reconstruir todo o desenvolvimento a priori. O mais antigo período era governado pela percepção tátil na visão aproximada. Hoje, como todos sabemos, a percepção óptica na visão distanciada prevalece. Estes representam extremos opostos. A percepção da visão normal tem que, portanto, residir no meio, durante os períodos de equilíbrio. De fato, nós encontramos a visão normal mais prontamente na arte grega clássica e na Alta Renascença italiana. (RIEGL, 2004: 401)

As tendências à percepção planar (mesmo numa arquitetura escultural como a pirâmide egípcia), à bidimensionalidade e ao tratamento individualizante 
(através da busca de qualidades geométricas absolutas nas coisas); que Riegl aponta como qualidades da arte egípcia corresponderiam à Vontade de arte marcada pela percepção tátil, inerente à relação dualista do homem com o mundo, comuns também ao homem primitivo e no gótico. Worringer associará a arte produzida sob o predomínio da percepção tátil ao impulso para a abstração e aquela associada à percepção em equilíbrio do óptico-tátil, atribuída ao grego clássico, ao impulso para a empatia. O impulso para a abstração, no entanto, implicaria um acréscimo de conteúdo conceitual ao sentido riegliano ${ }^{104}$.

\section{As vontades e o direito do mais forte}

Riegl parte do pressuposto de que o homem compete com a natureza através da arte. A criação artística corresponderia à versão melhorada da natureza que o homem lhe impõe. Tal concepção teria se desenvolvido na Antiguidade e corresponderia à vontade de fazer valer o direito do mais forte. "Assim, o povo antigo passa a esperar regularidade, o estabelecimento de harmonia por meio do mais forte - o triunfo do mais forte. A lei natural da Antiguidade, como suas leis morais, era fundamentada no direito do mais forte - mais especificamente, o tangivelmente e materialmente mais forte.” (RIEGL, 2004: 57). Esta concepção não seria a única, embora tenha prevalecido, determinando o sentido conhecido da história da arte na direção do clássico: "somente a forma humana poderia aparecer digna de uma força superior aos seres humanos. Assim nasceu o politeísmo antropomórfico, que os gregos iriam levar a sua plena perfeição" (RIEGL, 2004: 58). A outra tendência descrita por Riegl corresponderia ao conceito de forma mais rudimentar por não se determinar pelo direito do mais forte e pelo sentimento humano de superioridade em relação à natureza. Ela

\footnotetext{
104 "Não se parece demais sublinhar que as considerações de Riegl estão muito modificadas - $e$ não para melhor - na obra de Worringer. Quando Riegl diz, "toda arte deseja representar o mundo", Worringer diz, "Arte (como arte "orgânica") ou quer representar o mundo ou (como "abstrata") não quer representá-lo". Riegl destina assim um conceito de "simples natureza" no qual ou a arte imita ou não imita e tem, deste modo, tentado reivindicar para toda arte sua própria visão de mundo ou seu próprio mundo de visões. Ou seja, ele desarraigou a antiga antítese entre arte natural, e arte que deforma a natureza. Worringer, essencialmente, eterniza esta antiga antítese, com a exceção que deriva da "inaturaleza" de certos estilos não do Nichtkönnen ["ser inapto"] mas do Nicht-Wollen ["não desejar que"] e então chega à mistura da tônica de valores [Werkakzente]. É precisamente no sentido de Riegl que não podemos dizer com Worringer, "este estilo abstrai da realidade natural"; mais propriamente, teríamos que dizer, "a realidade deste estilo não corresponde ao nosso conceito da essência do natural"." (WÖLLFLIN apud PANOFSKY: 1912, 463).
} 
estaria associada ao "politeísmo infinito" que teria sobrevivido em algumas culturas. "Tudo na natureza era, portanto, um deus;(...) Se é possível, à luz da atitude temerosa do homem em relação à natureza, falar de qualquer tipo de competição com aquela força é no mínimo problemático." (RIEGL, 2004: 57). O povo germânico seria um deles e a tendência a espiritualizar os motivos naturais vegetais e animais no gótico teriam fundamento nesse panteísmo mais radical que o grego, este refletido no antropomorfismo.

As obras de arte seriam uma manifestação do desejo humano de um sentido de ordem. O reconhecimento da ordem no mundo proporcionaria prazer ao homem, portanto a obra de arte teria uma função de aperfeiçoamento do seu habitat, descrito como natureza. As obras primitivas ou as clássicas, portanto, seriam representações do mundo como ele deve ser em sua versão melhorada, desenvolvida a partir da sensibilidade que lhe fosse contemporânea; tátil ou óptica respectivamente. Worringer, por outro lado, pressupõe no impulso para a abstração do homem primitivo a necessidade de negação da dimensão vívidaorgânica da realidade, pois esta lhe parecia amedrontadora em sua arbitrariedade. A expressão abstrata refletiria uma atitude negativa, um gesto que vai além das limitações impostas pela percepção tátil e que nos permite questionar o caráter representativo apontado por Riegl na arte primitiva.

\section{Vontade de Arte, industrialização e ornamento}

\section{Vontade de arte}

A descoberta da arte "desviada", feita por Riegl, deveu-se em parte ao uso de outras fontes de pesquisa, que não as grandes artes da pintura, escultura e arquitetura. Riegl foi curador de 1886 a 1896 do Museu Austro-húngaro de Arte e Industria, sendo responsável do departamento têxtil. Além disso, fora contemporâneo das descobertas arqueológicas pré-históricas da cultura de Hallstatt, feitas a partir de meados do século XIX. A organização do acervo do museu dependia da atenção sobre a ornamentação nas variadas épocas, que não se justificavam por uma explicação materialista, tal como apresentava o historiador G. Semper, mas de uma predisposição da vontade que se manifestava nos 
variados estilos de forma reconhecível, mesmo nas civilizações mais antigas, primordialmente na ornamentação.

O reconhecimento do impulso "desviado" como abstração por Worringer, torna o critério da habilidade técnica, que era considerado um dos fundamentos para avaliação das artes miméticas, obsoleto. A valorização crescente das artes chamadas primitivas no início do século XIX foi o resultado desta mudança de paradigma e da busca de novos critérios que se verificava nos movimentos de vanguarda artística. Por outro lado, a exposição "Arte degenerada", montada em 1937 na Alemanha nazista, é um exemplo do movimento de retaguarda e de que a questão da habilidade artística retorna ciclicamente. No caso, ela estava associada ao mote de "retorno à ordem", cujo caráter investigaremos adiante. A exposição ridicularizava as obras dos artistas expressionistas, e de outros associados a esses, ao equipará-las aos trabalhos de doentes mentais através de comentários ou dos desenhos paralelamente expostos.

A manutenção do critério de habilidade comprovava o lastro deixado pelo predomínio da cultura artística greco-romana, associada à representação mimético-naturalística e ao impulso de empatia. Além disso, a valorização do realismo imitativo implicava numa diminuição do valor artístico abstrato associado à ornamentação, como algo que requereria menor desenvolvimento de capacidades manuais e intelectuais e que não estaria associado à essência da obra de arte. Com o desenvolvimento do processo de industrialização da arquitetura, a questão da ornamentação é recolocada, associando-se a ela a velha questão da perda de qualidade artística/manual, bem como de expressão. Primeiramente se manteve a linguagem clássica nos elementos ornamentais, para então colocar em pauta a adequação à produção mecanizada ${ }^{105}$. A mecanização dos processos, certamente, abre espaço para o caminho alternativo da abstração.

\footnotetext{
105 Sobre a questão do ornamento, lembro 3 pontos desenvolvidos por Gombrich sobre o ornamento: 1. A questão do ornamento volta à tona com o desenvolvimento dos produtos industriais no início do século XIX. Lembrando que o ornamento carrega consigo a pecha moral de opor-se ao elemento metafísico essencial e racional, acrescenta-se agora a falta de critério da produção seriada.

2. No século XIX, o desenho de padronagem torna-se uma disciplina artística emancipada da decoração. (GOMBRICH, 1984: p.59)

3. Os estilos gótico e barroco eram considerados como excessivamente ornamentados, assim como os templos hindus. O período neoclássico mostra uma preocupação purista, uma busca da essência
} 
Enquanto as academias de arte ensinavam aos pintores a imitar a realidade até o ponto da ilusão, as escolas de design preveniam seus estudantes para nunca imitar a arte dos períodos ilusionistas, mas preferivelmente escolher como seus modelos as decorações dos períodos da arte europeia os quais ainda não tinham "ultrapassado o encantador balbucio infantil da representação estilizada. (GOMBRICH, 1984: p.195).

A superação do critério de habilidade associado à imitação e a valorização das representações estilizadas ${ }^{106}$. como expressões adequadas aos ornamentos e, posteriormente, como elementos artísticos em si implicaram no interesse por culturas não-eurocêntricas como fontes de pesquisa, traduzindo-se na admiração crescente pelas artes orientais, africanas e da Oceania. As gravuras japonesas são um exemplo do interesse dos pintores impressionistas e simbolistas desde o final do século XIX por um tipo de representação que se assemelha à ornamentação em seu caráter de figuração estilizada. As esculturas africanas e da Oceania fazem parte da pesquisa cubista, assim como a arte asteca para os surrealistas. Em comum, estas artes têm o fato de poderem ser consideradas como resultantes do impulso para a abstração.

\section{2.}

\section{A linha abstrata gótica}

\section{Do pathos histérico da linha abstrata gótica ao Expressionismo}

O conceito de abstração worringeriano oferecia um escopo teórico alternativo aos artistas do início do século $\mathrm{XX}$, tornando-o extremamente popular. Além de serem, os livros de Worringer, inúmeras vezes reeditados, sua teoria da abstração se alarga no livro, Formprobleme der Gothik, publicado, pela primeira vez, em 1910. Este segundo livro coloca em pauta a controversa questão da germanidade, apresentada como Vontade de arte do povo nórdico. Worringer não apresenta esta vontade como a essência fechada de um povo, mas como um corpo que manteve elementos comuns da humanidade primitiva e que foi sofrendo mutações e incorporando elementos de outros povos ao longo do caminho. $\mathrm{O}$ período do Entreguerras tencionará a interpretação do conceito de abstração

clássica. Riegl descobre o caráter evolutivo do ornamento estudando o precioso acervo de tapeçaria do museu austro-húngaro e reavalia este critério do purismo.

${ }^{106}$ A representação estilizada é associada ao desenho de ornamentação aplicada à arquitetura ou inerente a ela; distinguindo-se da pintura e da estrutura arquitetônica . 
nórdica tanto para um pacifismo humanista, na tradição do romantismo, quanto para o nacionalismo fascista e a alienação capitalista.

Seus livros, Abstração e Empatia e Formprobleme der Gothik, serão associados imediatamente ao movimento expressionista, e Worringer será tratado como seu apologista. O segundo livro verifica as raízes do gótico na ornamentação nórdica primitiva. Em contraposição à busca de simetria e harmonia da ornamentação desenvolvida no mediterrâneo, esta seria caracterizada pela repetição de elementos fantasmagóricos que não buscam alcançar equilíbrio, mas sim uma movimentação crescente, que nunca termina e que leva à sensação de embriaguez. "O homem nórdico tem em vista a melodia infinita da linha na sua ornamentação; essa linha infinita, que não alegra, mas atordoa e nos obriga à abnegação involuntária. Quando nós, na consideração da ornamentação nórdica, fechamos os olhos, permanece apenas a impressão reverberante de uma movimentação infinita incorpórea." (WORRINGER, 1912: 36). O tom eloquente e labiríntico, que ele aponta existir tanto na poesia como na arquitetura e ornamentação gótica futuras, teria germinado nos primórdios da arte nórdica, como fenômeno da mesma Vontade de Arte marcada por uma patologia histérica, que ele denomina sublime histeria. Tal patologia, no passado nórdico, seria o sintoma de uma cultura ainda em processo de espiritualização, que mantinha uma relação dualista com o mundo, própria dos homens primitivos, embora menos fatalista que eles. O primitivo, conforme explicado em seu primeiro livro, não teria a mediação da cultura com o mundo. A cultura atenuaria a sensação de medo do desconhecido, intermediando a relação com a realidade através de representações estáveis e tranquilizadores. Ele confrontava-se com o caos. Conforme demonstrado por Riegl, este estado psíquico agorafóbico implicava na busca de felicidade através da aproximação dos objetos, tornando-os discerníveis na visão aproximada, tátil. Para Worringer, estaria aí implicado o impulso para a abstração, ou negação da vida, que corresponderia a uma vontade de arte com teor transcendentalista. Tal vontade de arte se caracterizaria pela linha geométrica inexpressiva, que em seu valor absoluto representaria o oposto da arbitrariedade da vida. O caráter transcendental da arte primitiva residiria, portanto, nessa necessidade de redenção pela arte que nega a existência do mundo orgânico através da linha abstrata inorgânica. 
Dos primitivos até os modernos, dois caminhos foram seguidos com o desenvolvimento da espiritualização: a arte abstrata oriental e a arte empática dos povos mediterrâneos. A abstração dos orientais estaria relacionada com o transcendentalismo metafísico de sua religiosidade, que é colocado acima do conhecimento. Já seu sofrimento com o mundo é convertido em resignação fatalista e veneração. A linha abstrata oriental é, portanto, morta como a primitiva e reflete um tipo de resignação contemplativa, que Worringer associa ao quietismo do idoso. Em contraposição, a linha abstrata gótica mostra vitalidade expressiva, conforme se verifica no entrelaçamento de linhas e animais fantásticos de sua ornamentação. Worringer associa tal vitalidade ao estado patológico da histeria adolescente. O pathos da linha gótica seria expressão de um dualismo agorafóbico suavizado pelo conhecimento, cuja necessidade de redenção transcendental não se caracteriza mais pelo silêncio da linha abstrata primitiva e orientais. "Sua essência singular (da vontade de forma na linha gótica) parece, na verdade, um impulso para inquietação, que em sua procura por apaziguamento, em sua busca de redenção, nenhuma outra satisfação pode encontrar, que aquela do anestesiamento, que aquela da embriaguez." (WORRINGER, 1912: 49)

O povo nórdico ocuparia uma posição intermediária entre a necessidade de negação da vida do primitivo e o sentimento de harmonia com o mundo dos mediterrâneos. Ele ainda não teria a autoconfiança destes últimos, que através do conhecimento foram capazes de superar o dualismo e o transcendentalismo absolutos, valorizando a imanência da vida. O nórdico experimentaria uma existência angustiada e que somente era aliviada na sensação de embriaguez e êxtase, promovida nos cultos e na arte. Ele manteria vestígios da religiosidade panteísta que não permitiria purificar sua angústia em veneração. Tenta superar seu sentimento interno de desarmonia com o mundo pelo acionamento do transcendental, através de inebriante e assustadora fantasmagoria. Tal sentimento de desarmonia seria o oposto do que sentem os homens clássicos, que experimentariam uma relação de coesão orgânica e harmoniosa com o mundo, descritas em formas artísticas felizes e harmoniosas, espelhando a segurança que o conhecimento do mundo lhes proporcionava. Assim, resta ao nórdico evocar o sobrenatural. 
Ele resiste à fatalidade dualista e tenta superá-la através da elevação artificial das sensações. Isso não é superado nem através do conhecimento racional sensível no sentido clássico, nem é suavizado através da profunda visão metafísica do oriental, e o sentimento transfigurado do conflito dualista o faz inquieto e atormentado. Sente-se como o escravo de um poder superior, que ele somente pode temer e não venerar. Entre a devoção ao mundo do grego elevada a partir do racionalismo e da sensibilidade ingênua orgânica e a negação do mundo dos orientais refinada no religioso, ele se situa com seu infeliz temor do mundo, um produto da falta de paz terrena e da angústia metafísica. E aqui privado de tranquilidade e clareza, resta-lhe nada mais, que elevar sua inquietação e confusão até o ponto, onde elas o anestesiam, onde elas lhe trazem a redenção. (WORRINGER, 1912: 53)

A expressão geométrico-abstrata da arte nórdica refletiria este caráter híbrido de uma geometria vivificada através de elementos que apontam para o sobrenatural, para a vida espiritual. Suas linhas torcidas, curvadas, espiraladas, em zigue-zague ou em forma de "s" foram trançadas, treliçadas, grampeadas e depois aleatoriamente cortadas e amarradas de modo a amplificar a turbulenta movimentação sem fim, deram origem a emaranhados padrões fantásticos. Seriam um exemplo da "geometria tornada vívida", que, no entanto, desafia a apreensão sensível na medida em que parecem romper tanto com a movimentação orgânica quanto com a nossa percepção do que seriam as formas naturais. Mesmo os ornamentos animais perdem aí a clareza de sua estrutura orgânica no entrelaçamento de suas linhas torcidas.

O essencial da expressão singular dessa linha é que não é representada com o valor sensual-orgânico, mas como valor não sensual, quer dizer, de modo espiritual. Não é a atividade da vontade orgânica que se manifesta nela, mas sim uma atividade da vontade psico-espiritual que está longe de toda ligação e reconciliação com os complexos sentimentais. (WORRINGER, 1912: 34)

\section{Realidade X Natureza}

Para Worringer, o primitivo não reconheceria na realidade uma forma estável, que lhe permitisse descrevê-la segundo uma natureza. Vimos como sua experiência com o mundo era dualista, baseando-se numa relação de medo do desconhecido. Dado que não tinha uma percepção abrandada e distanciada pelo conhecimento, ele se confrontava diretamente com o caos da realidade. Este fenômeno se prolongaria nos povos nórdicos, contemporâneos aos gregos clássicos, chegando ao Gótico. 
Conforme se verificaria no processo de desenvolvimento dos cultos de religião da natureza, que era próprio aos primeiros nórdicos, a relação de medo foi se restringindo com o tempo a alguns elementos do real, mas não se dissipou. $\mathrm{Na}$ verdade, como real e irreal eram indistintos na medida em que os nórdicos não tinham uma visão do cosmo constituída, a fantasmagoria podia ser compreendida como elemento do real. A tendência ao panteísmo evocaria traços da maior sensibilidade para a realidade, implicada no predomínio da percepção tátil, conforme verificamos no primitivo, e que se relacionaria com o impulso para a abstração. Nos cultos nórdicos, os deuses surgiam segundo figuras informes, impalpáveis, impessoais, fugidias, assustadoras, vindas das florestas escuras. Nenhum vestígio da simetria orgânica ou da regularidade rítmica apareciam em suas representações. $\mathrm{O}$ nórdico ainda não teria introjetado um conceito de natureza, pois este envolveria certo grau de racionalização que ele ainda não possuía. O mundo, para ele, não configuraria um cosmo, uma ordem em si, pois seria dominado pela arbitrariedade dos espíritos que o dominam. Portanto, mesmo os motivos orgânicos encontrados em sua ornamentação não estariam relacionados com uma atividade mimética de representação da natureza, mas sim com uma atividade construtiva, que se dava a partir de elementos genéricos e pedaços de corpos, imagens retiradas de reminiscências da realidade, e entrelaçados segundo uma configuração linear plástica. “Originalmente, estas construções são apenas monstruosidades de uma fantasia linear, fora deste fantástico linear não possuem existência, também não existem na vida imaginativa do homem nórdico”. (WORRINGER, 1912: 40) No gótico, com o desenvolvimento do naturalismo óptico, destes pedaços de corpos reunidos surgirão animais fabulosos. No momento inicial, no entanto, domina o impulso abstrato. O processo de representação da natureza não seria possível; tanto por pressupor como ponto de partida um ponto de partida pessoal, "um olhar ativo, reconhecedor", como por pressupor no mundo uma relação de ordem com a qual este olhar poderia se relacionar. Isto somente seria alcançado no período clássico, onde este duplo reconhecimento se dá pelo impulso da empatia.

Nós dizíamos, que, com estas fabulosas construções animais, incluem lembranças da natureza no jogo abstrato da linha. Isto não foi disto de maneira precisa. Já que não trata aqui de lembranças da natureza, mas de lembranças da realidade. Esta diferença tem para todo o problema do gótico um significado decisivo. Pois a realidade não é idêntica à natureza de forma alguma. Pode-se registrar a natureza 
de modo nítido, sem assim se aproximar da natureza. Na verdade, antes de tudo reconhecemos a natureza dentro do real, quando a representação do orgânico se tornou vívida em nós e com isto nós nos tornamos aptos para o olhar ativo, reconhecedor. Então somente se dissolve para nós o caos da realidade no cosmo da natureza. A representação da lei orgânica, porém, pode somente aqui se tornar vívida, onde é alcançada uma relação de identidade ideal entre o homem e o mundo, como foi alcançada nas épocas clássicas. Desta relação resulta a purificação da visão de mundo de si, pois a empatia, este resultado da consciência da identidade, ela é, aquela que fixa para nós todas os chamados desarticulados da realidade e que forma uma estrutura orgânica clara. (WORRINGER, 1912: 41)

A própria linguagem utilizada por Worringer no texto sobre o gótico reforça a vitalidade eloquente nórdica, pois faz uso dos mesmos elementos descritos como atributos desta vontade de arte e que, concluímos, poderiam evidenciar uma associação extensiva à literatura e arte expressionistas emergentes, que ele não faz claramente nestes dois livros. Tal associação extensiva com o expressionismo, atribuída à Worringer, não é unívoca ${ }^{107}$.

Também em outros campos o patético se permitia comprovar como elemento fundamental da Vontade de Forma nórdica. O cruzamento totalmente singular da palavra com a frase na poesia nórdica antiga, o caos ornamental de suas representações reciprocamente tortuosas, que através da aliteração de determinada rítmica expressiva com a tortuosa repetição do som inicial (da repetição dos motivos na ornamentação compreendida e igual a ele produzindo o caráter de uma melodia desordenada, interminável) tudo isso análogo inconfundível da ornamentação nórdica A poesia alemã não conhece a expressão de tranquilidade e equilíbrio, tudo gira em torno do movimento. (WORRINGER, 1912: 51)

\section{Lukács e a crítica do impulso de abstração no Expressionismo}

Lukács defendia um tipo de realismo ${ }^{108}$ que confrontasse as relações de produção consideradas como a totalidade que define o mundo capitalista. As estratégias abstratas vanguardistas se pautavam no fragmento e na montagem

\footnotetext{
${ }^{107} \mathrm{O}$ autor associa a teoria worringeriana da abstração ao Cubismo. JENNINGS, Michael W., "Against Expressionism: Materialism and Social Theory in Worringer's Abstraction and Empathy" in DONAHUE, Neil H. (ed.), Invisible cathedrals: the expressionist art history of Wilhelm Worringer, EUA: Pennsylvannia State University, 1995.

${ }^{108}$ A afirmação da negatividade, própria da abstração como vontade de arte autônoma, será criticada por Lukács como uma atitude de esvaziamento e alienação do próprio conteúdo artístico, relacionada com tendências utopistas, que ele aponta existir na teoria do jogo como fundamento estético em Schiller; na substituição do trabalho pelo jogo em Fourier ${ }^{108}$ e nas estratégias abstratas expressionistas relacionadas à arte Vanguardista e associadas à Worringer. Lukács considera que estas teorias subavaliam o papel do trabalho nas relações humanas e na teoria estética. A reação de isolamento da arte para garantir sua autonomia em relação à alienação promovida pela divisão do trabalho, defendida por estas teorias, levaria ao esvaziamento de conteúdo da mesma. LUKÁCS, G. Die Eigenart Des Ästhetischen. Werke, 1. Halbband. LUCHTERHAND, 1965, 1971. P. 354.
} 
como meio de expressão da negatividade e de um transcendentalismo de tendências utópicas, dado o pacifismo em tempos de guerras, confrontando apenas uma dimensão parcial e aparente da realidade. Elas se baseavam numa apreensão espontânea, imediatista, evocando a simultaneidade dos acontecimentos de modo tal que apenas uma impressão caótica da realidade seria fixada. Tais estratégias estariam, portanto, restritas à expressão da sensação patológica do homem moderno e à expressão abstrata da realidade. Sua abstração seria comparável à fetichização capitalista.

Segundo Lukács, nas teorias vanguardistas, a tentativa de autonomização artística pela via da abstração implicaria num desligamento das relações sociais do trabalho. Essas relações sociais deveriam fornecer o conteúdo para a relação dialética com a arte no capitalismo. Tal dialética expressaria a essência da realidade como um todo. A fragmentação corresponderia ao movimento incompleto da relação do artista com a realidade, seria resultado do seu processo de abstração que deveria ser superado no momento da composição da obra, deixando transparecer a essência realista e artística através da coesão interna de seus elementos. Montagem e fragmentação corresponderiam a uma tendência moderna de intensificar a unilateralidade na arte explícita através acomodação de elementos díspares na obra.

Esta monotonia é a consequência necessária do abandono do reflexo objetivo da realidade, do abandono do esforço artístico de configurar a rica e entrelaçada diversidade e unidade das mediações e da superação nas personagens. Já que este modo de sentir o mundo não admite nenhuma composição, nenhum crescendo e decrescendo, nenhuma estruturação a partir de dentro, da natureza real da matéria viva configurada. (LUKÁCS, JORDÃO: 2016, p. 279)

Assim, a abstração, conforme exigida por Lukács, configuraria apenas parte do processo de representação mimética da natureza, que determina o realismo na arte. "Pois nossa análise das chamadas formas abstratas já mostraram que mesmo estas são modos de reflexo da realidade objetiva" (LUKÁCS, 1965, 1971: 352). Ela seria própria do processo intelectivo de percepção da realidade, que não poderia ser apreendida como totalidade imediata, mas apenas como conclusão do jogo dialético hegeliano que dá primazia "ao 
universal substancial"109 (ADORNO, JORDÃO, 2016: 340). Ainda que afirme um equilíbrio no processo de composição da obra, o processo de composição demandaria uma tomada de consciência que se confunde com a determinação do sentido de totalidade: "Sobretudo precisa ser dito, que aparência e ser são igualmente momentos da realidade objetiva; que assim sendo, todas as considerações do conhecimento teórico erram ao tentarem gerar uma hierarquia entre eles do ponto de vista da realidade e da irrealidade respectivamente". (LUKÁCS, 1965, 1971: 361). Podemos concluir que o universal substancial seria o elemento metafísico que dá sentido de coesão e continuidade à evolução histórica e que aponta os caminhos de seu suposto progresso a partir de elementos retirados da realidade como exemplos de conteúdos essenciais. "Mas a história é a unidade dialética viva da continuidade e da descontinuidade, da revolução e da evolução. (...) Neste ponto, como em todas as coisas, tudo depende da correta apreensão do conteúdo" (LUKÁCS, JORDÃO: 278). Tais conteúdos devem ser acessíveis ao povo. Os elementos retirados da herança cultural, seja da arte popular ou burguesa, deveriam ser apresentados de modo a clarificar as vivências do observador e a alargar "o seu horizonte humano e social" de modo a sensibilizá-lo para o humanismo político, democrático e progressista.

E, enquanto no caso do grande realismo o acesso mais fácil propicia também uma grande riqueza de conteúdos humanos, com a literatura "vanguardista" as grandes massas do povo não podem apreender nada.(...) A compreensão da arte de "vanguarda", só é alcançável à custa de um grande esforço, proporciona, pelo contrário, reminisc6encias tão subjetivas, deturpadas e deformadas da realidade, que o homem do povo jamais as poderá traduzir para a linguagem das suas próprias experiências. (LUKÁCS, JORDÃO: 278).

109 "A convicção lukacsiana empregada à maneira de Hegel, total e viril, da primazia do universal substancial sobre a aparente, deteriorada "má existência" da mera individuação, lembra aqueles procuradores de estado, que exigem o extermínio daqueles inaptos para viver ou que se desviam da norma." ADORNO, Theodor W., Reconciliação extorquida. A propósito da Significação atual do realismo crítico de Georg Lukács. Der Monat: novembro, 1958. Em MACHADO, Carlos E. J., Um capítulo da história da modernidade estética: debate sobre o expressionismo. SP: Unesp, 2016. P.340. 
Neste caso, a produção artística se confunde com outras formas de conhecimento, que estariam limitadas a um predomínio da atividade da racionalidade e da consciência, ${ }^{110}$ e despreza parte das conclusões benjaminianas, retiradas da teoria dos primeiros românticos, entre eles Schlegel e Novalis.

Ainda que o jovem Lukács tivesse um entendimento mais aberto da obra de arte que teria em sua maturidade, verificaremos que, em ambos os casos, estava condicionado à determinada concepção de forma, que mais facilmente se associa ao romantismo de Goethe e Schiller. Em função da radicalização de sua adesão ao marxismo a partir dos anos 1930, Lukács fará uma revisão autocrítica a partir da qual afirmará sua defesa do realismo e rejeição do formalismo de suas obras dos anos 1910, tal como "Die Seele und die Formen”. Para o crítico literário, Luiz Costa Lima, o Lukács maduro teria atrofiado o conceito de mimese, apenas implícito em sua obra inicial, relacionando-a com o "dogma do reflexo" e desarticulando com isso do poder transformador da forma: "no Lukács das primeiras obras, a forma terá uma identificação específica e determinante da forma, ao passo que, em suas obras marxistas, ela se confundirá com os conteúdos derivados da realidade social” (LIMA, 2017: 95). Lukács associou a fragmentação à abstração vanguardista em sua defesa do Realismo. Aqui cabe verificar, se o conceito de mimese, associado ao conceito de forma, ainda descreveria tais processos de fragmentação dos primeiros românticos e da arte moderna.

\section{O fragmento não serve para Lukacs}

A abstração como vontade de arte, aquela oposta à mimese, é associada por Lukács à decadência e ao esteticismo burgueses, denotando um sentido de desorientação ou mera vontade de perda-de-perspectiva. (LUKÁCS, 1965, 1971: 366). O impulso para a abstração implicaria, para Lukács, num ato de abstenção

\footnotetext{
110 "De maneira extremamente adialética, o dialético oficializado condenou aqui todas as tendências irracionalistas da filosofia moderna, varrendo-as todas para o campo da reação e do fascismo, sem perdoar o fato de que nessas correntes o pensamento, diante do idealismo acadêmico de rebelava contra si mesmo e, sobretudo, contra aquela reificação de ser e pensamento, cuja crítica constituía a causa específica de Lukács. Nietzsche e Freud tornam-se para ele simplesmente fascistas (...)". ADORNO, Theodor W., Reconciliação extorquida. A propósito da Significação atual do realismo crítico de Georg Lukács. Der Monat: novembro, 1958. Em MACHADO, Carlos E. J., Um capítulo da história da modernidade estética: debate sobre o expressionismo. SP: Unesp, 2016.
} 
diante da realidade e não numa outra predisposição psicológica, conforme sugeria Worringer. A defesa de tal vontade de arte corresponderia, para Lukács, a um culto do patológico, próprio do artista burguês. Sua melancolia não passaria de uma atitude regressiva, que este não se esforçaria em transpor, acomodando-se com a aparência imediata da realidade: "com base na imediaticidade, só pode surgir um pensamento abstrato" (LUKÁCS, 1965, 1971: 259). O trabalho do artista envolveria o trabalho de reconhecimento da realidade, que seria tanto artístico como filosófico, e também o de "recobrimento artístico" das "conexões de realidade a que se chegou por meio da abstração - a superação da abstração" (LUKÁCS, 1965, 1971: 260). Somente através da dialética artística da essência e da aparência, apresentada na "unidade viva da contradição de riqueza e unidade das determinações sociais" se chegaria à obra realista, escapando do subjetivismo do "sujeito cindido" expressionista e da "imediaticidade abstrata" do naturalismo e do impressionismo. Ainda que a arte expressionista em seu aspecto disforme tivesse a conotação de denúncia da ordem social e econômica, ele não levaria a Aufhebung, apenas imitando o mundo em decomposição e vazio.

O que significa, em oposição a isso, a "via de abstração para fora da realidade"? A superfície opaca, refletida em estado de desagregação, de aparência caótica, incompreendida, vivida apenas imediatamente, é fixada como tal, num processo que elimina mais ou menos conscientemente e não contempla as mediações objetivas, sem qualquer tentativa de se elevar intelectualmente acima deste nível (LUKÁCS, 1965, 1971: 260).

\section{3.}

\section{A alegoria como abstração}

\section{Arquétipo e Ideia}

As experiências românticas permitiram o questionamento da mimese como mera imitação ${ }^{111}$ da realidade ao levarem à reavaliação do conceito de forma artística a partir do procedimento de reflexão. Para os românticos, o homem moderno é qualificado como sujeito reflexivo. Enquanto imerso na cultura e

111 “A psicanálise, podemos dizer, nasce do horizonte da experiência aberto pelos românticos. Experiência decisiva no sentido de mostrar que a razão, tal como concebida pelo pensamento $e$ pela poética clássicas, não servia como critério de explicação da arte. A razão erige modelos conscientes a serem direta ou sublimadamente internalizados. Por isso mesmo ela os confunde com o real a ser imitado. Substituindo o modelo da imitatio consciente pela reflexão ante as cenas experimentadas da vida, os românticos implicitamente revelaram que a realidade não se torna um Da pelo simples fato de ser formada por objetos que se põem à minha frente - Gegenstände." (LIMA, 1989: 65) 
distanciado das formas da natureza, estaria como condenado a experimentá-la de modo apenas indireto através da reflexão. Ao lado deste sentimento de desenraizamento e de perda da percepção forma orgânica do mundo promovida pela reflexão, o sujeito moderno romântico descobriria a liberdade infinita do espírito em contato com as ideias da razão. A reflexão, que até Kant ${ }^{112}$, estaria condicionada a uma estatuto lógico e racional e ligada ao juízo do belo, encontra nos primeiros românticos uma abertura infinita e ambígua no absoluto, tendo por meio o Eu e a arte. Estes Eu e arte configurariam os meios para se pensar a ideia originária destas formas, segundo certo vestígio platônico que identifica a realidade com o Mundo das Ideias. Schlegel, no entanto, subverte o sentido platônico ao defender de modo paradoxal a afirmação da individualidade da unidade da arte (formas em devir) como parte do continuum que constitui a forma de arte absoluta que é a Ideia de Arte. A Ideia de arte "não seria uma abstração das obras de arte empiricamente dadas" (BENJAMIN, 1993, p. 96), mas sim o resultado de um processo de realização infinita da reflexão e que constitui a unidade orgânica da Ideia. "O princípio deles (do filosofo e do artista), a ideia que os une, é um germe orgânico, que se desenvolve livremente, toma uma forma que contém indivíduos indeterminados e que constitui uma figura infinitamente individual, omniconformadora - uma Idéia pródiga em Idéias”. O “médium absoluto" para a elaboração das Ideias seria o caos. "Mas a beleza suprema, sim, a suprema ordem, é portanto, decerto, apenas a do caos que espera apenas o toque do amor para desdobrar-se num mundo harmônico..." (SCHLEGEL, BENJAMIN, 1993, p. 98).

Para Walter Benjamin, a mudança do estatuto da reflexão através dos primeiros românticos implicou tanto na mudança do conceito de forma, como do próprio conceito de obra de arte. A obra de arte passa a ser tomada como um centro de reflexão, livre do racionalismo das regras que mediam a produção imitativa e de um ideal de conformação.

Os românticos não compreendiam, como a Aufklärung, a forma como uma regra de beleza da arte e sua observância como uma precondição necessária para o

112 "Neste contexto pode-se indicar sem dificuldade uma diferença entre o conceito kantiano de juízo e o romântico de reflexão: a reflexão não é, como o juízo, um procedimento subjetivo reflexivo, mas antes, ela está compreendida na forma de exposição da obra, desdobra-se na crítica, para finalmente realizar-se no regular continuum das formas." (BENJAMIN,1993: p. 94) 
efeito agradável e edificante da obra. A forma mesma não valia para eles nem como regra nem como dependente de regras. (BENJAMIN, 1993, p. 84)

A reflexão é um processo infinito, portanto, a obra de arte não pode ser entendida como meio de expressão de conteúdo determinado e nem de um percurso vazio ${ }^{113}$. A reflexão, definida como "pensar do pensar do pensar" (BENJAMIN, 1993, p. 36), envolveria um processo infinito de conexões que se abrem do objeto observado ao absoluto das ideias. Num primeiro grau, a forma seria o pensar de algo (pensar material); a reflexão, o pensar do pensar (pensar a forma). A forma pensada é conteúdo da reflexão. Refletir é conhecer o pensar, compreender os modos de conexão das formas. No último estágio da reflexão, a forma deve dissolver-se diante da totalidade do absoluto. A forma estética constituiria um meio para a reflexão absoluta. A arte é o meio absoluto da reflexão. "A crítica de arte é o conhecimento do objeto neste médium-dereflexão” (BENJAMIN, 1993, p. 71). A crítica eleva o pensamento acima das conexões. "Abstração, e particularmente abstração prática, no fim, não é realmente nada senão crítica" (BENJAMIN, 1993, p. 59). O procedimento reflexivo se confundiria com o crítico e este com a abstração e a fragmentação: "qualquer fragmento é crítico" (BENJAMIN, 1993, p. 59). O fragmento seria, como a obra de arte, um "médium-de -reflexão", que concilia condicionado e incondicionado. "A obra de arte não pode ser torso, deve ser um momento em movimento e transitório na forma transcendental vivente. Na medida em que ela se limita em sua forma, se faz transitória numa configuração casual, numa configuração passageira torna-se, no entanto, eterna, via crítica." (BENJAMIN, 1993, p. 119). A crítica de arte é tanto parte do processo reflexivo que produz a obra e o conhecimento da obra. A crítica dá acabamento à obra, distingue-se do ajuizamento, pois este pressupõe a obra completa para o desfrute. A crítica deve ser imanente e, portanto, prolongar o próprio conteúdo estético da obra. "Toda obra é necessariamente incompleta diante do absoluto da arte, ou - o que

\footnotetext{
${ }^{113}$ Friedrich Schlegel daria continuidade à filosofia de Fichte, apropriando-se do aspecto da infinitude reflexiva, o pensar do pensar. Fichte entende a consciência como uma ação do Euduplicado na representação de um objeto, como não-Eu, segundo um processo de derivação infinita da reflexão. O pensar, como consciência de si, interromperia a reflexão. Ele seria imediato, fazendo coincidir sujeito e objeto. Para Fichte, a derivação da consciência seria resultado de um modo de representar livre e inconsciente: "todo produzir consciente é determinado por motivos e, por isso, pressupõe sempre novamente um conteúdo particular de representação. O produzir originário pelo qual, de início, o Não-Eu é obtido no Eu, não pode ser consciente, mas somente não-consciente". (BENJAMIN, 1993, p. 34)
} 
significa o mesmo - ela é incompleta diante de sua própria Idéia absoluta." (BENJAMIN, 1993, p. 78).

Segundo Walter Benjamin, os primeiros românticos, Schlegel e Novalis, teriam colocado em questão o conceito de obra de arte, definido na tradição formalista a partir de um ideal de conformações que se traduziria em beleza e apreciação. "As obras de arte superiores são pura e simplesmente desagradáveis; são Ideais, que podem e devem agradar apenas aproximando, imperativos estéticos" (BENJAMIN,1993: p. 111). A obra de arte é fragmento e crítica imanente. Sua forma (médium-de-reflexão) representaria o dado a priori que possibilita o exercício de reflexão infinito realizado no Eu-absoluto ${ }^{114}$, que é a "essência da reflexão infinitamente realizada" (BENJAMIN,1993: p. 44). Além de proporem um tipo de formalismo livre e não dogmático, que configuraria a tradição formalista da arte, contraporiam-se ao Ideal de arte goetheano, a Ideia da forma. "A forma é, então, a expressão objetiva da reflexão própria à obra, que forma sua essência. Ela é a possibilidade da reflexão na obra, ela serve, então, a priori, de fundamento dela mesma como um princípio de existência: através de sua forma a obra de arte é um centro vivo de reflexão." (BENJAMIN,1993: p. 81). A forma-de-exposição da obra singular é o um limite casual e momentâneo da reflexão que deve superá-la. A obra de arte elevada ao absoluto, transcendental, é arte da arte e forma simbólica: "aquela forma que dura no absoluto após a destruição das formas profanas" (BENJAMIN,1993: p. 102). A forma da obra de arte é simbólica pela qualidade da ironia e da reflexão que dissolvem a materialidade da forma-de-exposição, colocando-a em contato com a verdade do eterno que revela seu significado superior na ligação com a Ideia da arte: "ela indica, primeiramente, a ligação com os vários conceitos que recobrem o absoluto poético, sobretudo com a mitologia. (...) ela é a expressão do puro absoluto poético na forma” (BENJAMIN,1993: p. 102)

Para os primeiros românticos, a poesia moderna romântica seria Ideal, enquanto a grega seria Real. A moderna seria ideal-transcendental na medida em que implica um pensamento sobre si que também é arte, arte elevada ao absoluto,

114 O pensamento do Eu se confunde com o conceito do mundo, conforme a citação de Schleiermacher: "Auto-intuição e intruição do universo são conceitos intercambiáveis; daí por que cada reflexão é infinita" (BENJAMIN,1993: p. 44) 
arte da arte. "Como já dissemos, através da reflexão na obra de arte mesma sua rigorosa coesão formal (tipo grego), que permanece relativa, torna-se, por um lado, formada, e por outro, no entanto, livre de sua relatividade e elevada ao absoluto da arte através da crítica e da ironia (tipo moderno)" (BENJAMIN,1993: p. 101). O romance como "poesia desleixada e dependente de objetos" seria sua expressão maior, pois sua forma prosaica possibilitaria a fluidez, a coexistência da pluralidade de formas e a destruição da matéria pela ironia, permitindo a elevação ao transcendental. Além disso, a forma prosaica seria marcada pela sobriedade que favorece a clareza de exposição em contraposição às exacerbações extáticas e ornamentais. Para Schlegel e Novalis a arte se definiria por ser Ideia, expressa na relação dialética entre infinidade ${ }^{115} \mathrm{e}$ unidade proporcionada pela forma. "Pois a unidade romântica é uma infinidade. Tudo o que os românticos declararam acerca da essência da arte é determinação de sua Idéia, assim como a forma, que conduz à expressão da dialética da unidade e da infinidade na Idéia, através daquela da autolimitação e autoelevação" (BENJAMIN,1993: p. 115).

Os primeiros românticos teriam valorizado a forma em detrimento do conteúdo na teoria da arte, enquanto Goethe seguiria o caminho inverso. Os primeiros românticos teriam dado mais valor à crítica que à obra. Para os primeiros românticos, a obra de arte delimitaria uma forma crítica, cujo conteúdo seria a possibilidade de reflexão. E tal conteúdo seria infinito, por isso a obra, "momento em movimento e transitório", poderia ser definida apenas no fragmento a ser completado e eternizado pela via crítica. "Na medida em que ela (a obra de arte) se limita em sua forma, se faz transitória numa configuração passageira torna-se, no entanto, eterna, via crítica." (BENJAMIN,1993: p. 119).

Goethe teria canonizado as obras da Antiguidade grega ${ }^{116}$, tomando-as modelo do Ideal e do conteúdo da natureza verdadeira e arquetípica. Para Goethe,

\footnotetext{
115 "Os românticos determinam a relação das obras de arte com a arte como uma infinidade na totalidade - ou seja: na totalidade das obras realiza-se a infinidade da arte; Goethe a determina como unidade na pluralidade - ou seja: na pluralidade das obras sempre novamente se encontra a unidade da arte. Aquela infinidade é a da forma pura, esta unidade é a do puro conteúdo". (BENJAMIN, 1993: p. 121)

116 "Eles não podiam reconhecer modelos, obras autônomas fechadas em si, configurações cunhadas de modo definitivo e subtraídas à progressão eterna. Novalis foi quem se revoltou contra Goethe do modo mais atrevido e espirituoso: "Natureza e intelecção da natureza surgem
} 
a Ideia da natureza seria o arquétipo dado a priori, que a arte torna visível. A natureza verdadeira, não uma natureza visível, corresponderia, portanto, ao conteúdo da obra de arte.

De um tal a priori parte a filosofia da arte de Goethe. Seu motivo central é a questão do Ideal da arte. Também o Ideal constitui uma unidade altamente conceitual, a do conteúdo. Sua função é, portanto, totalmente distinta da Idéia. Não é um médium que abriga em si a conexão das formas, conformando-as a partir de si, mas, antes, uma unidade de outro tipo. Só é abarcável dentro de uma multiplicidade limitada de conteúdos puros nos quais se decompõe. Nesta concepção, Goethe encontra-se com os gregos. (...) A soma dos conteúdos puros, o Ideal da arte, deixa-se portanto designar por musal. (...) Os puros conteúdos como tais não podem ser encontrados em obra alguma. Goethe denomina-os arquétipos. As obras não podem atingir aqueles arquétipos invisíveis - mas intuíveis - cujos guardiões os gregos conheciam sob o nome de musas, elas podem apenas em maior ou menor grau assemelhar-se a eles. Não pode, em princípio, conduzir à similitude, e não pode ser atingido via imitação. (BENJAMIN,1993: p. 116)

Assim, para Walter Benjamin, a relação entre forma e conteúdo da arte não teria sido resolvida por nenhum deles. Ele conclui que faltou até então um pensamento sistemático da filosofia da arte acerca da relação entre Ideia e Ideal da arte, entre forma e conteúdo.

Pois forma e conteúdo não são substratos da conformação empírica, mas, antes diferenciações relativas, encontradas em razão de diferenciações puras e necessárias da filosofia da arte. A Idéia da arte é a Idéia de sua forma, assim como seu Ideal é o Ideal de seu conteúdo. A questão sistemática fundamental da filosofia deixa-se portanto formular também como a questão acerca da relação entre Idéia e o Ideal da arte. (BENJAMIN,1993: p. 121).

\section{Alegoria e forma simbólica}

Podemos encontrar o sentido filosófico para a relação entre forma e conteúdo na arte moderna através do conceito de alegoria de Walter Benjamin e inferir que a alegoria opera como o fragmento crítico dos românticos. Este teria permitido a ruptura com o conceito de forma (mimética-empática), pois a alegoria pressupunha o reconhecimento do impulso para abstração como Vontade de Arte associada aos períodos de decadência, tais como a Antiguidade Romana tardia, o Barroco, o Gótico e o Expressionismo.

ao mesmo tempo, assim como a Antiguidade e o conhecimento da Antiguidade; pois erra-se muito quando se acredita que existe a Antiguidade. Apenas agora a Antiguidade começa a surgir [...]. Com a literatura clássica se passa como com a Antiguidade; ela não é propriamente dada a nós ela não é existente -, mas, antes, ela deve ser produzida apenas por nós”. (BENJAMIN,1993: p. 119). 
Verificamos com os românticos a ruptura do conceito de forma artística associado aos paradigmas clássicos, definidos pela tríade "imitação, perfeição e Ideal" em contraposição ao significado superior simbólico da tríade proposta por Schlegel como "necessidade, infinidade e Idéia" (BENJAMIN,1993: p. 118). Cabe notar que mesmo na teoria goetheana, associada ao clássico, a imitação não redundaria numa cópia, mas sim na produção de diferença tanto em relação ao visível quanto em relação ao conteúdo Ideal. Examinaremos a seguir a relação da forma com o conteúdo presente nas noções benjaminianas de forma simbólica e alegoria, conforme apresentado em sua obra sobre o "decadente” Drama Barroco alemão.

Walter Benjamin defende que a experiência estética do Expressionismo teria permitido a abertura para as obras das épocas de decadência de modo imanente, ao menos é o que lhe teria permitido a releitura tanto do Barroco quanto da obra de Baudelaire. No caso do Barroco, pela ressonância do sentimento comum para o exagero; a pompa patética que revestiria a impressão de esvaziamento de sentido das coisas e do mundo. A forma artística encontrada pelo Barroco não seria plástico-expressiva como a clássica. Ela determinaria a mudança de foco da forma acabada para os processo de construção ${ }^{117}$ e de "apreensão" (reflexão) infinita de seus signos fragmentários; para suas molduras reduplicadas e desdobramentos meditativos e não para o objeto.

De fato, o Barroco, como o Expressionismo, é menos uma época do genuíno fazer artístico do que um obstinado voluntarismo artístico. É o que sempre acontece com as chamadas épocas de decadência. A realidade suprema da arte é a obra isolada e completa. Por vezes, no entanto, a obra acabada só é acessível aos epígonos. São as épocas da "decadência" das artes, da afirmação do seu "voluntarismo". Isto explica que Riegl tenha cunhado este termo com referencia à arte da última fase do império romano. Este voluntarismo consegue chegar apenas à forma como tal, mas não à obra singular e bem construída. (BENJAMIN, 2013: p. 194)

A apropriação das obras barrocas tornava-as objeto de crítica filosófica. Elas seriam alvo de um subjetivismo vazio relacionado à melancolia mundana do

117 "O que a Antiguidade lhes legou são os elementos com os quais, um a um, amassam a nova totalidade. Melhor: a constroem. Pois a visão acabada do "novo" era a ruína." (BENJAMIN, 2013: p. 190). "Mas a eles ela (a natureza) não se mostra no botão e na flor, mas na extrema maturidade e na decadência de suas criações. O seu sonho é o de uma natureza como eterna caducidade, na qual apenas o olhar saturnino daquela geração reconheceu os sinais da história" (BENJAMIN, 2013: p. 191) 
barroco, da linguagem meramente especulativa e abstrata. "No mal absoluto, a subjetividade apropria-se do seu real e vê-o como mero reflexo de si mesma em Deus" (BENJAMIN, 2013: p. 252). Crítica não no exato sentido da elevação romântica da forma viva, mas no sentido da determinação de um emblema esvaziado e arruinado, a alegoria, cujo significado mutável é preenchido por aquele que se apropria. "A beleza que perdura é um objeto de saber" (BENJAMIN, 2013: p. 194). A beleza barroca dura na busca do saber destituído de fim (a verdade), dura na mera curiosidade, segundo promessas satânicoespirituais de redenção da teologia barroca118. "Aquilo que atrai é a ilusão de liberdade - na busca do proibido; a ilusão de autonomia - na secessão em relação à comunidade dos crentes; a ilusão do infinito - no abismo vazio do mal." (BENJAMIN, 2013: p. 248).

Segundo o crítico literário Michael W. Jennings, o livro "Origem do Drama trágico alemão" sintetizaria influência de Riegl e Worringer ao voltar-se para arte de um período considerado degenerado, ou seja ao qual não corresponderia a coerência entre forma e conteúdo da obra simbólica. A alegoria maior do Barroco, seria o cadáver, um corpo esvaziado de vida, reificado, correspondendo à condição existencial melancólica do período e também à abstração das referências orgânicas contemporâneas ao desenvolvimento do capitalismo. Para Benjamin, o luteranismo se traduziu na ética do trabalho dos pequenos e no desprezo pelo cotidiano em prol da entrega à fé sem transcendente nos grandes, que se transformou numa desolação contemplativa da banalidade da vida de onde emergia o sentimento de luto e a alienação melancólica: "fuga cega para uma natureza desprovida de Graça” (BENJAMIN, 2013: p. 78). A alegoria, enquanto emblema enigmático, servia à necessidade de contemplação do barroco.

O estado de apatia melancólica não seria exclusividade barroca, ressurgindo como falha do aparato sensório do homem moderno, provocado pela experiência de choque devido à superestimulação da vida urbana e à pervasão da abstrata lógica monetária e produtiva. A poesia de Baudelaire ecoaria tal estado de

118 "O importante para o drama trágico foi o fato de a Idade Média cristalizar na figura de Satanás a ligação entre o elemento material e o demoníaco. Foi sobretudo possível, com a concentração das diversas instâncias pagãs num único Anticristo teologicamente bem definido, atribuir à matéria, de forma mais clara do que através de muitos demônios, essa aparência sombria e dominadora." (BENJAMIN, 2013: p. 245) 
tédio e melancolia. "Produção mecânica, a divisão do trabalho, e acima de tudo a ascendência do commodity trouxe um "esvaziamento da vida interior" idêntico àquele analisado no livro Trauerspiel. A alegoria representa, então, o modo poético mais adequado para revelar o funcionamento do capitalismo" (JENNINGS, DONAUE, 1995: p. 98). A alegoria corresponderia à necessidade meditativa de ultrapassar os limites da coisa percebida e estaria relacionada ao desprezo pelo mundo das aparências, comum ao príncipe barroco e ao sujeito metropolitano. Nas duas experiências, ela operaria como um fragmento crítico, "“un pessimisme debordant”- que rompe com a aparência fetichizada da mercadoria" (JENNINGS, DONAUE, 1995: p. 99). A alegoria enquanto abstração se presta ao exercício meditativo do sujeito melancólico e despersonalizado, cuja satisfação reside tentar desvendar seus hieróglifos. Em contraposição a ela, estaria a forma simbólica ligada à beleza clássica e empática. A alegoria e a forma simbólica estariam relacionadas aos impulsos worringerianos de abstração e empatia respectivamente.

Em vez de opor o par geminado abstrato/empático, Benjamin opõe épocas culturais que produzem obras simbólicas e alegóricas. Certas qualidades formais das obras simbólicas seguem a definição do símbolo em si. Em vários pontos de sua carreira Benjamin refere-se a esse tipo de obra como simbólica, clássica, autônoma, ou finalmente, aurática. Baseado em suas pretensões a uma referencialidade privilegiada, a obra de arte clássica clama tais atributos como totalidade, completude, organicismo e integridade. Como tal, perpetua falsas noções da estrutura da história e sobre a natureza da experiência humana. Benjamin opõe à obra simbólica outra forma, a qual ele geralmente denomina alegórica, embora a palavra moderno apareça crescentemente como um sinônimo. Alegoria tem para Benjamin pouco a ver com a compreensão tradicional do conceito, (...) Em vez disso, Benjamin vê a alegoria como forma particular de escrita, séries de significantes rigorosamente codificados que não têm necessariamente relação com uma série de significados. Na alegoria, a produção de significado se rompe, somente para ser substituída pela "história natural do significado": alegoria é a concreta e precisa representação da decadência da linguagem. A característica fundamental da alegoria é seu quebrantado e, assim, sua resistência à representação mimética das coisas como elas parecem ser. (...) Em vez da relação integral entre significante e significado requerida pela obra simbólica, arbitrariedade e frequentemente, caos marcam o texto alegórico. A imagem alegórica como "fragmento amorfo" permanece em forte contraste com o símbolo plástico. (DONAUE ed., JENNINGS, 1995: p. 96)

Segundo Jennings, as obras de Worringer e Riegl teriam servido de substrato para a determinação do conceito de alegoria benjaminiano em dois sentidos: Riegl teria contribuído com a democratização da história cultural, regenerando a valorização das artes anticlássicas, associadas à decadência e à 
barbárie; Worringer, ao incorporar a moderna teoria social simmeliana, teria conseguido descrever as complexas determinações sociais associadas à Vontade de Arte riegliana, que justificariam as tendências empáticas e abstratas no mundo contemporâneo. A atualização de tais tendências pela sensibilidade moderna permitiram a releitura do Barroco e a definição do conceito de alegoria como desdobramento do conceito do fragmento crítico romântico, que serviu de chave para sua historiografia benjaminiana. Ele tomará os momentos de decadência como momento superiores para a reflexão da história por não falsearem numa ideia de totalidade e progresso. "Somente arte como tal (da decadência) nos dá uma percepção privilegiada da condição verdadeira da história. Seu quebrantado, sua rejeição de consolo, e, especialmente, seu fervor retórico, o Trauerspiel é uma "reflexão responsável" de sua época." (JENNINGS, DONAUE, 1995: p. 101). A alegoria, como emblema que demanda contemplação e reflexão, é paradoxalmente esvaziado de verdade e meio para o desvelamento da história por meio da apropriação. Assim transformando os tais conteúdos históricos em conteúdos de verdade filosóficos. Assim, nas "formas-escombro da obra de arte" (BENJAMIN, 2013: p. 260) se encontraria a possibilidade de no fenecer da beleza efêmera fazer surgir a ruína do passado que esclarece e salva.

\footnotetext{
Somente se o passado pode ser reconstelado com o presente, pode ele alcançar uma "progressiva concentração (integração) da realidade na qual tudo no passado pode alcançar um mais alto grau de relevância contemporânea - Aktualität - do que tinha no momento de sua existência. No conhecimento do passado está contido os meios de julgar - e talvez de mudar - qualquer presente dado. (JENNINGS, DONAUE, 1995: p. 101)
}

E qual seria a alegoria da era digital? Qual seria a relação da impressão de desmaterialização com o luto barroco? Haveria uma ligação entre o lixo produzido pela modernidade e os corpos desencarnados góticos ou barrocos?

\section{4. \\ Do Expressionismo à realidade virtual}

\section{A materialidade da realidade virtual}

\section{Guerra intersubjetiva na internet}

Em "Depois da realidade virtual worringeriana: Videodromos e Cinema 3, MassCult e guerra Cyber", o literato Geoffrey Waite compara dois momentos da recepção de Wilhelm Worringer: a época da querela sobre o Expressionismo e 
quando se inicia a popularização do Ciberespaço ${ }^{119}$. A ponte entre os dois momentos já viria sendo construída pelos filósofos pós-estruturalistas, resgatando Worringer do ostracismo ao qual fora relegado junto do movimento expressionista. A associação de Worringer ao movimento havia sido feita por Georg Lukács, tomando como ponto em comum a teoria da abstração, que Waite associará, contemporaneamente, às tecnocultura e tecnofilia da era digital, estas conforme interpretadas por Paul Virilio e Gilles Deleuze. A mudança da recepção de Worringer decorreria em parte devido à assimilação acrítica e inconsciente da teoria da abstração worringeriana. Para Waite, Worringer teria valorizado os movimentos artísticos abstratos em detrimento dos empáticos e, deste modo, sua influência teria restringido o desenvolvimento de expressões alternativas, que não estivessem subjugadas à tecnocultura como dimensão determinante da realidade. A assimilação acrítica propiciara o fato estarmos vivendo efetivamente numa "realidade abstrata worringeriana". No mundo contemporâneo, o impulso para abstração, descrito por Worringer, como uma reação ao medo do espaço no primitivo, seria o resultado do processo de comodificação da realidade e de alienação das relações de corporais devido ao uso da tecnologia cibernética. A abstração dos objetos reduzidos ao valor de mercadoria e a mudança da percepção do mundo no sentido da abstração dos sentidos operariam de modo determinante na concretização do próprio espaço real como se fosse virtual, tornando indiscerníveis as fronteiras entre vida cotidiana, arquitetura, cinema e guerras. Uma realidade estaria retroalimentando a outra. A estética informando a política;

119 "Redes das Redes, baseando-se na cooperação "anarquista” de milhares de centros informatizados no mundo, a Internet tornou-se hoje o símbolo do grande meio heterogêneo $e$ transfronteiriço que aqui designamos como ciberespaço. A cada mês, o número de pessoas com "endereço eletrônico" no mundo aumenta em 5\%. Em 1994, mais de 20 milhões de pessoas, essencialmente jovens, estavam “conectados"”. (LEVY, 1999: 12) Em 2018 chegam a mais de 3 bilhões de usuários.

"A palavra "ciberespaço" foi inventada em 1984 por William Gibson em seu romance de ficção científica Neuromancer. No livro, esse termo designa o universo das redes digitais, descrito como campo de batalha entre multinacionais, palco de conflitos mundiais, nova fronteira econômica e cultural.(...) O termo foi imediatamente retomado pelos usuários e criadores de redes digitais. Existe hoje no mundo uma profusão de correntes literárias, musicais, artísticas e talvez até politicas que se dizem parte da "cibercultura".

Eu defino o ciberespaço como o espaço de comunicação aberto pela interconexão mundial dos computadores e das memórias dos computadores. Essa definição inclui o conjunto dos sistemas de comunicação eletrônicos (aí incluídos os conjuntos de redes herzianas e telefônicas clássicas), na medida em que transmitem informações provenientes de fontes digitais ou destinadas à digitalização. Insisto na codificação digital, pois ela condiciona o caráter plástico, fluido, calculável com precisão e tratável em tempo real, hipertextual, interativo e, resumido, virtual da informação que é a marca distintiva do ciberespaço." (LEVY, 2010: 94) 
a economia, à estética. Para Waite, na experiência da realidade virtual, o corpo estaria alienado pelos equipamentos, impossibilitando o exercício da empatia com o Outro. Daí a propagação de um nível de violência encoberta na pasteurização ("eufemização") das imagens que dominam a realidade subjugada pela realidade virtual (VR).

Waite associa a estética "tecno-sublime" de filmes e da literatura de ficção científica distópicos do Cyberpunk e do emergente fenômeno de culto à cultura de massa sob o nome de Masscult à linha abstrata gótico-worrigeriana. O sublime do Gótico e do Egípcio se aproximariam esteticamente dos ambientes dominados pela realidade virtual através do caráter comum da indeterminação de conteúdo, devido à impossibilidade de apresentação da Ideia (de algo absolutamente grande). A abstração seria o resultado da impossibilidade de expressão do sentimento do sublime, cujo esvaziamento permitiria a variação de seus conteúdos ideológicos ao longo do tempo. O expressionismo abstrato de Kandinsky, ligado ao movimento do Blaue Reiter, também é associado à distopia sublime por Waite. Tais produções estéticas teriam em comum o fato de promoverem o espaço abstrato, um tipo de espaço reprimido ou suprimido em representações geométrico-abstratas planificadas. À falta de espaço tridimensional corresponderia uma falta de empatia entre os homens e também seu silêncio. O ponto geométrico corresponderia ao ser imaterial do signo abreviado da linguagem humana para Kandinsky. "Assim, a forma geométrica (do ponto geométrico) encontra sua forma material em primeira instância - ela pertence ao discurso e significa silêncio." (WAITE, DONAHUE, 1995: 183). Para Waite, no entanto, o ponto geométrico da arte abstrata corresponderia ao olho enucleado, ao desmembramento humano, reimplantado nas estruturas de poder. "Conforme vemos de Blade Runner e do Masscult em geral, todas as lentes são pontos intraoculados (e ocultados), agências encarnadas e desencarnadas, implantes (proto) cyberpunk em matrizes de poder (de classe). E, portanto, de luta (de classe)." (WAITE, DONAHUE, 1995: 184)

A teoria worringeriana seria, portanto, uma proto-teoria da realidade virtual e, por configurar uma teoria do espaço abstrato, também seria proto-teoria da Ciberguerra que dominaria a realidade de desigualdades sociais e econômicas 
pós-capitalistas. Para Waite, a realidade virtual disseminada pelo uso da tecnologia levaria o homem ao abandono do espaço público, à perda de empatia, ao isolamento e à perda de força política: “Mas "meu” ponto aqui é que quando nós estamos sozinhos "nós” somos "todos" incapazes. Coletivamente, ação comunal - ao lado da ação individual, singular - é necessária para combater o que já é a coletividade deformada da VR, a alucinação consensual do ciberespaço." (WAITE, DONAHUE, 1995: 188). O texto de Waite, escrito em 1992, estava limitado à influência da TV, cinema, da internet e das redes incipientes (anos 1990 nos EUA), dos computadores pessoais e portáteis (anos 1970 e 1980). Ele não poderia estimar a onipresença dos smartphones (anos 1990) iOS e androids (anos 2000). Ele também não poderia prever que, contra suas expectativas, dali a apenas alguns anos (1999), aconteceria o movimento de volta às manifestação nas ruas contra o encontro da OMC (Organização Mundial do Comércio), organizado por ONGs, sindicatos, estudantes, religiosos e anarquistas com ajuda do uso da tecnologia digital. A insatisfação desse grupo heterogêneo com a divulgação da manifestação levou ao desenvolvimento da mídia alternativa através da internet como forma de organização coletiva voltada para política. $\mathrm{O}$ espaço cibernético também veio a ser ocupado de modo permanente e prolífero com as mídias independentes e baratas que serviram para a divulgação de informações e ideias que não eram bem-vindas nos meios estabelecidos ligados às grandes corporações. O efeito da manipulação de conteúdos alternativos e de informação dos usuários, por outro lado, operará como efeito de rebote.

A disseminação das tecnologias digitais capitalizadas reforçariam um processo de abstração da realidade material, seja no sentido da alteração da percepção do próprio corpo como da experiência com o espaço, inserindo o sujeito contemporâneo num estado de alienação profunda. Tal abstração levaria à percepção da realidade como representações geométricas pontual-fragmentadas, que comprometeriam a formação de uma perspectiva histórica e de um posicionamento político.

A recepção deleuziana de Worringer não contribuiria para a tomada de consciência política por reproduzir a defesa do espaço abstrato worringeriano, não empático, da realidade virtual; por informar a cultura de massa, a teoria estética e 
a arquitetônica, apresentando Worringer como "guerreiro cyberpunk" (DONAUE ed., 1995, p. 161); por reforçar, com a contribuição de Paul Virilio, a indistinção entre a Guerra cibernética e o Masscult, ambos apresentados no espaço abstrato da realidade virtual, arenas de Videodromes; por rejeitar o paradigma humanístico orgânico corpo-mente-subjetividade e estar defendendo certo tipo de tecnofilia sublime, que seria consequência da adoção do paradigma mecanicista da linha abstrata gótica worringeriana.

Waite sugere que uma visão crítico-histórica das determinações econômicas demandaria um tipo de experiência empática da qual o sujeito contemporâneo está alijado por não buscar confrontar-se diretamente com o espaço material real situado fora do espaço cibernético e por ter se tornado dependente de "cérebros biomecânicos", dos quais estará livre somente se eles falharem. Estes retroalimentariam o estado de alienação implicadas na percepção do mundo como uma grande pista de corrida de imagens televisivas de violência e pornografia e no Masscult. A Guerra tendo se tornado mais um espetáculo televisivo a ser consumido entre outros produtos da cultura de massa. A mais profunda influência de Worringer não teria sido sobre a arte, conforme Lukács já apontava, mas sobre a perda do espaço público e político. De fato, as novas tecnologias deslocaram parte do palco de combate, determinando um espaço público ambivalente definido pelo equipamento eletrônico usado tanto na praça quanto na ambiente doméstico. Verificaremos a seguir se esses meios são meramente reprodutores do sistema de poderes políticos e econômicos existentes, ou se poderiam operar como a máquina abstrata que recorta fragmentos críticos, ruínas, alegorias produtores de novos espaços e novas realidades.

\section{A mídia polifônica e polisemântica}

As fronteiras entre o virtual e o real são constantemente testadas no ciberespaço. O meios de comunicação por computadores em rede amplificam a tendência à virtualização da realidade ${ }^{120}$; tanto no sentido da antecipação de realidades acordadas por esses meios, quanto no sentido da configuração de um

120 “Contudo, a rigor, em filosofia o virtual não se opõe ao real mas sim ao atual: virtualidade e atualidade são apenas dois modos diferentes da realidade. Se a produção da árvore está na essência do grão, então a virtualidade da árvore é bastante real (sem que seja, ainda, atual)." (LEVY, 2010: 49) 
mundo imaterial paralelo ao real. Para o filósofo Pierre Levy, eles abririam um espaço desterritorializado, independente de lugar e tempo, através da universalização da cibercultura ${ }^{121}$, que tanto poderia se manter virtual como atualizar-se no real. As redes criariam um universo de expectativas com as quais as pessoas tomam decisões sobre a realidade política e econômica que têm influência sobre a realidade material. Se as transações financeiras tinham caráter abstrato, este foi amplificado com a virtualização.

O que nos conduz diretamente à virtualização das organizações que, com a ajuda das ferramentas da cibercultura, tornam-se cada vez menos dependentes de lugares determinados, de horários de trabalhos fixos e de planejamentos a longo prazo. Da mesma forma, ao continuar no ciberespaço, as transações econômicas e financeiras acentuam ainda mais o caráter virtual que possuem desde a invenção da moeda e dos bancos. (LEVY, 2010: 51)

As redes construídas pelas mídias eletrônicas definiriam um espaço universal ${ }^{122}$ que não se fecha numa totalidade abstrata. As mídias eletrônicas possibilitariam desatar a qualidade totalizadora da comunicação universal existente, conforme promovida pelo princípio de "fechamento semântico" com que a informação é transmitida na mídia tradicional do rádio ou da TV: seja ele a racionalidade ou a espetacularização. O efeito dinamizador do tempo real das transmissões (como a linguagem oral) e sua interconexão permitiriam tornar o hipertexto móvel, interativo, vivo. O universal não se confundiria com a massificação, mas com a participação de muitos homens. "O principal evento cultural anunciado pela emergência do ciberespaço é a desconexão desses dois operadores sociais ou máquinas abstratas (muito mais que conceitos!) que são a universalidade e a totalização." (LEVY, 2010: 120).

121 "O ciberespaço se constrói em sistema de sistemas, mas, por esse mesmo fato, é também o sistema do caos. Encarnação máxima da transparência técnica, acolhe, por seu crescimento incontido, todas as opacidades do sentido. Desenha e redesenha várias vezes a figura de uma labirinto móvel, em expansão, sem plano possível, universal, um labirinto com o qual o próprio Dédalo não teria sonhado.

Essa universalização desprovida de significado central, esse sistema da desordem, essa transparência labiríntica, chamo-a de "universal sem totalidade”. Constitui a essência paradoxal da cibercultura." (LEVY, 2010: 113)

${ }^{122}$ A escrita teria dado início à comunicação universalizada permitindo a disseminação do texto no espaço e no tempo, fora do contexto limitado da emissão oral. "Grande parte das formas culturais derivadas da escrita tem vocação para a universalidade, mas cada uma totaliza sobre um atrator diferente: as religiões universais sobre o sentido, a filosofia (incluindo a filosofia política) sobre a razão, a ciência sobre a exatidão reprodutível (os fatos), as mídias sobre uma captação em um espetáculo siderante, batizado de "comunicação. Em todos os casos, a totalização ocorre sobre a identidade da significação. ”. (LEVY, 2010: 119) 
As redes sociais deram espaço para um tipo de guerra que, muitas vezes, se desenvolve no plano intersubjetivo com o posicionamento direto que elas permitem, conforme manifestado nas expressões: "Somos todos CharlieHebdo"(2015); “Somos todos Marielle"(2018); “Ele não” (2018). À violência no espaço da vida corresponderam também ameaças nas redes, desdobrando-se numa encenação de guerra da qual participaram os internautas. Refiro-me a um posicionamento direto e pontual, que cada uma dessas declarações pode representar e que difere do posicionamento ideológico como um todo. Posicionamentos ideológicos convivem com os enunciados coletivos na rede, ordenando-os segundo palavras de ordem que servem à polarização política e ao emudecimento de vozes múltiplas ${ }^{123}$.

\section{A fábrica de subjetividades e o labirinto branco}

No início do anos 1990, o filósofo Pierre Levy acreditava que o ciberespaço poderia constituir uma ágora virtual, o lugar de uma nova forma de democracia direta em grande escala e em tempo real, que permitisse a cada um contribuir continuamente para a colocação de problemas comuns, formulação de argumentos e adoção de posicionamentos independentes de modo a construir “uma paisagem política qualitativamente tão variada quanto quisessem” (LEVY, 1999: 65) sem a amarração partidária ou de palavras de ordem. "A manifestação, como o voto, só possibilita aos indivíduos construir para si uma subjetividade política pela pertença a uma categoria ("os que retomam as mesmas palavras de ordem” ou os que se reconhecem em tal partido" etc.)." (LEVY, 1999: 66). O Ciberespaço permitiria a formação de sujeitos de enunciação que não ecoariam em uníssono como no caso do voto e da manifestação, mas como um “coral polifônico improvisado": "O ciberespaço poderia abrigar agenciamentos de enunciação produtores de sintomas políticos vivos que permitiriam aos coletivos humanos inventar e exprimir de modo contínuo enunciados complexos, abrir o leque das singularidades e das divergências, sem por isso inscrever-se em formas fixadas de antemão." (LEVY, 1999: 67). O Ciberespaço configurou então a esperança de um espaço democrático, livre do controle do Estado e das demarcações territoriais, um espaço comunitário que permitiria a disponibilização

${ }^{123}$ No Brasil, operando num sentido de suposto apagamento de ideologias contrapostas, num movimento propalado como desideologizador, anti etc. 
do conhecimento e a interação entre as pessoas através do laço social pelo saber $^{124}$. Ele promoveria o oposto do que Waite afirmou quanto à alienação política e empática. Hoje, no entanto, o ciberespaço mostrou-se menos transparente e pacífico do que se acreditava possível ser.

$O$ projeto da inteligência coletiva supõe o abandono da perspectiva do poder. Ele quer abrir o vazio central, o poço de clareza que permite o jogo com a alteridade, a quimerização e a complexidade labiríntica. Ora, o palácio de luz, labirinto branco, traço arquitetônico de uma alegria de viver, de uma beleza, de uma leveza soberana, torna-se aos olhos da polêmica, que só sabe reconhecer-se em toda parte, o labirinto negro, armadilha mortal que abriga um monstro devorador de homens. A lenda do labirinto manifesta a incapacidade de encontrar saída pacífica. (...) Em vez de tornar mais espessas as fortalezas do poder, refinemos a arquitetura do ciberespaço, o último labirinto. Sobre cada circuito integrado, sobre cada chip, vê-se e não se sabe ler a cifra secreta, o emblema complicado da inteligência coletiva, mensagem irênica dispersa a todos os ventos. (LEVY, 1999: 212)

Para o filosofo Pierre Levy, as novas tecnologias permitiram a reorganização do mundo do trabalho segundo uma estrutura móvel e cooperativa que permitiria compartilhar o que Levy chama de "inteligência coletiva". Elas teriam promovido a "industrialização" do setor terciário desta nova fase do capitalismo, desenvolvida a partir dos anos 1960. O capitalismo teria entrado na era do conhecimento ${ }^{125}$, tendo como infraestrutura o software. O regime de trocas se daria segundo a transversalidade de sua distribuição molecular. Os governos comunistas totalitários não teriam conseguido acompanhar o novo processo de industrialização, a demanda de atualização constante das identidades profissionais, das técnicas e da dinâmica de produção e teriam ruído. "O puro econômico ou a mera eficácia perdem em eficiência." (LEVY, 1999: 21). O engajamento subjetivo $^{126}$, incluido nas dimensões cultural, de lazer e social, se

124 "É da mais alta necessidade trilhar outros caminhos quando a produção de comunidade por pertença étnica, nacional, ou religiosa conduz aos sangrentos impasses que conhecemos. Basear o laço social na relação com o saber consiste em encorajar a extensão de uma civilidade desterritorializada, que coincide com a fonte contemporânea da força, ao mesmo tempo em que passa pelo mais íntimo das subjetividades. ” (LEVY, 1999: 27)

125 "É como se já navegássemos no quarto espaço, em meio às ondas e correntes da inteligência coletiva. Na Terra, o homem é um micro cosmos; no Território, é uma micro polis; no Espaço mercantil eis que ele se torna um micro oikos, uma pequena casa; no Espaço do saber, o humano se restringe ainda mais: não é mais do que um cérebro. Mesmo seu corpo se torna um sistema cognitivo. Ora, o cérebro entra em contato e compõe-se com outros cérebros, sistemas de signos, (...) criam mundos múltiplos (...). No espaço do saber, o ser humano volta a tornar-se nômade, pluraliza sua identidade, explora mundos heterogêneos, é ele próprio heterogêneo e múltiplo, em devir, pensante.” (LEVY, 1999: 135)

126 "De que grãos serão compostas as imagens de seres vivos e criadores de sentido? Existe uma quântica da liberdade? Como medir a subjetividade? Desde já, sabemos que esses quanta de 
torna peça fundamental para a atualização da rede, apagando a fronteira entre o social e o profissional. A produção contínua de subjetividades é considerada " $a$ principal atividade econômica” (LEVY, 1999: 21).

\begin{abstract}
Além disso, as novas condições da vida econômica conferiram uma vantagem competitiva à organizações em que os membros eram capazes de adotar individualmente iniciativas de coordenação em lugar de se submeter a uma planificação vinda de cima. Ora, essa mobilização constante das capacidades cognitivas e sociais supõe necessariamente uma forte implicação subjetiva. Doravante, não basta mais identificar-se passivamente com uma categoria, uma profissão, uma comunidade de trabalho; é necessário ainda engajar a singularidade, a própria identidade pessoal na vida profissional. É precisamente essa dupla mobilização subjetiva, bastante individual, de um lado, mas ética e cooperativa, de outro, que o universo burocrático e totalitário era incapaz de suscitar. (LEVY, 1999: 21)
\end{abstract}

\title{
Luta de classes, ideologia de fuga e Máquina de Guerra
}

\section{Subjetivismo alienante em Lukács e Presentismo e espaço topológico alienantes}

Waite situa seu texto, tomando como referência a queda do Muro de Berlim, período que qualifica como aquele da derrota do socialismo e vitória do neoliberalismo. "No nosso caso aqui - neste livro e neste ensaio - o tópico é Wilhelm Worringer no centro do neocapitalismo global, no momento de seu altivo autoproclamado triunfo sobre todas as possibilidades - um mundo neocapitalista caracterizado pela tecnologia de informação transicional $e$ por um anticomunismo pós-industrial, pós-fordista, pós-sindical” (WAITE, DONAHUE, 1995: 160). Para elaborar sua crítica ao neocapitalismo dessa era da revolução Cibernética, Waite retoma a crítica de Lukacs feita ao Expressionismo de que este seria um movimento da classe burguesa que promoveria em seu discurso literário e teórico uma "ideologia de fuga" através da teoria da abstração worringeriana,

subjetividade não serão jamais módulos funcionais ou "partes" de sistemas ( por mais "complexos" que sejam concebidos esses sistemas), pois isso seria o mesmo que reificar e, em última instância, aniquilar as subjetividades que se pretende exaltar. Os quanta de qualidades humanas serão signos, e apenas isso. (...) Imaginemos os sujeitos, em vez disso, como concentrações caóticas de quanta, zonas ardentes suscetíveis de engendrar novos signos. (...) Os quanta de subjetividade são como passos, cujos traços desenham a imagem trêmula e inacabada de uma dança. (...) A engenharia do laço social possibilita o surgimento de outro tipo de subjetividade. Ela pulveriza os signos do saber ou da identidade, mas para permitir-lhes fluir, mesclar-se, reencontrar-se, valorizar-se, delatar-se e trocar-se...Ela não implode as identidades, mas as libera: entrega a cada um o poder de forjar suas imagens." (LEVY, 1999: 137) Subjetividades por quanta (Identidades quânticas) se contrapõe à subjetividades por pertença, que são territorializadas e cristalizadas em raízes, raças, religiões etc. As Identidades quânticas nasceriam em quatro espaços simultâneos: família, do território, da Terra e do cosmo. 
que teria contribuído para desarticular o movimento operário revolucionário e facilitado o funcionamento da engrenagem fascista rumo ao Poder. Lukács aponta que a abstração da realidade socioeconômica nas obras expressionistas limitava-as a um mero subjetivismo alienado. A crítica de Lukács teria importância no mundo contemporâneo devido à repetição desse processo de esquecimento, que Waite associa ao senso de tempo e espaço exercitado na teoria pós-moderna como “presente perpétuo" ${ }^{27}$ : "Esqueça a pré-história socioeconômica, a história atual, toda a história. Nada além de sonhos. É tudo nostalgia pós-moderna não pela história social vivida mas pelo momento quando primeiro se decidiu embrenhar na matriz de mídia" (WAITE,1995:187). A teoria pós-moderna estaria permitindo a instrumentalização de métodos abstrato-alienantes pelos poderes econômicos e políticos da era pós-fordista do capitalismo globalizado.

\begin{abstract}
Há, por exemplo, uma óbvia "negligência" das determinações, condicionantes e pressões econômicas sobre todo desenvolvimento cultural em Worringer (como apontado por ninguém melhor ou mais obsessivamente que Georg Lukács). Tal "negligência" existe não somente na obra de Worringer, contudo, mas também na maior parte de sua recepção subsequente. Ela tende a reduzir tanto os escritos de Worringer $e$ aqueles de seus críticos ao status de objeto transicional irrefletido. (...) Mais propriamente, é, em seus próprios termos, uma faceta bem racional da hegemonia capitalista (no sentido gramsciano ou althusseriano de "coerção nãocoercitiva") (WAITE, 1995: 169)
\end{abstract}

As dimensões da realidade socioeconômica estariam sendo negligenciadas, permitindo o desenvolvimento de uma prática política desarticulada, que desconsideraria a presença e a importância da classe trabalhadora, que ainda operaria segundo os moldes do capitalismo industrial. "E todos esses seres humanos podem todos ainda fazer greve, incluindo greves gerais que poderiam fazer qualquer governo se curvar tão rápido quanto qualquer hacker cyberpunk esoterrorista de HD” (WAITE, 1995: 180). As teorias abstratas que estariam configurando a onipresença da realidade virtual contribuiriam também para a desarticulação política dos trabalhadores ao subverterem a representação do espaço de luta para um espaço desmaterializado. Waite desacredita que a estratégia da "máquina de guerra", conforme definida por Virilio e Deleuze,

127 "Frederic Jameson desenvolveu uma linha conceitual no Capitalismo e Esquizofrenia de Deleuze e Guattari para sugerir que este tipo de fascínio com o "presente perpétuo" é uma terrivel indiciamento do capitalismo de consumo em si" e "no mínimo, um alarmante e patológico sintoma da sociedade que se tornou incapaz de lidar com o tempo e com a história”. (WAITE, 1995: 169) 
substituiria a luta de classes no sentido de alcançar a justiça social. Deste modo, o movimento revolucionário teria perdido sua força. Para Waite, a máquina de guerra redundaria na chamada realidade virtual, pois não operaria no horizonte traçado pela perspectiva histórica, segundo as determinações do espaço geométrico e dimensionável que configuraria o cenário revolucionário. A revolução pela máquina de guerra não encontraria mais esse cenário fixo, operando como um vetor em perpétuo movimento arbitrário. A percepção do espaço seria agora associada à geometria pós-euclidiana, topológica, que as tecnologias de guerra e cinema ajudaram a disseminar. Para Waite, no entanto, os novos parâmetros teriam se desenvolvido a partir da apropriação indevida da noção leninista de "pontos estratégicos onde se aplica força", incorrendo numa perda de discernibilidade da realidade devido sua fragmentação e na impossibilidade efetiva de transformação social.

\begin{abstract}
Então, tudo isso começa a soar como Worringer no final; ao menos parece para Deleuze e Guattari citando Virilio citando Lenin - Lenin contra quem todas realidades virtuais parecem ser contrapostas.(...) Lenin é retratado aqui e pela realidade virtual worringeriana como seu - somente - Outro radical; sua - única possibilidade alternativa. Como realidade virtual worrringeriana, a política pósmoderna torna-se não somente outra política nômade ou abstrata e teoria da guerra, mas especificamente uma política pós-leninista a priori. (WAITE, 1995: 179).
\end{abstract}

\title{
Sobre a máquina de guerra pós-estruturalista
}

Voltemos à máquina de guerra pós-estruturalista. Deleuze e Guattari retiraram o termo da análise, apresentada pelo filólogo Georges Dumézil (18981986), das estruturas de Poder e da religião dos povos indo-europeus. A estrutura de Poder desta sociedade seria composta pelos polos opostos do déspota e do legislador, conformando o aparelho do Estado separadamente do exército a princípio. A noção de "máquina de guerra", que interessou aos pósestruturalistas, descreveria, portanto, um elemento exterior ao aparelho de Estado. Esta separação se devia pela natureza de sua constituição e modo de agir. O Estado agiria "por captura mágica imediata, "agarra" e "liga", impedindo qualquer combate” (DELEUZE, GUATTARI, 1997, Vol. 5: 12). O aparelho do Estado definiria "sujeitos de enunciação" que propagam a estrutura de Poder em contraposição aos elementos indefinidos da máquina de guerra, que poderiam ser "um homem, uma mulher, uma pulga ou um elefante" e que operariam de modo 
não institucionalizado, regrado e codificado. "Estado é soberania. No entanto, a soberania só reina sobre aquilo que ela é capaz de interiorizar, de apropriar-se localmente" (DELEUZE, GUATTARI, 1997: 23). A guerra, não sendo apropriada pelo Estado, não se desenvolveria conforme o teatro do jogo de Xadrez com seus papéis pré-determinados, mas como peças do jogo de Go. “Os peões do go são os elementos de um agenciamento maquínico não subjetivado, sem propriedades intrínsecas, porém apenas de situação." (DELEUZE, GUATTARI, 1997, Vol. 5: 13). Do mesmo modo, o espaço de combate se desenvolveria segundo um movimento perpétuo no espaço aberto, “liso", que é territorializado e desterritorializado, sem destino definido. A máquina de guerra é pensada, portanto, como um agente desestabilizador do Estado. "Faz valer um furor contra a medida, uma celeridade contra a gravidade, um segredo contra o público, uma potência contra a soberania, uma máquina contra o aparelho. Testemunha de uma justiça, às vezes de uma crueldade incompreensível (...)”(DELEUZE, GUATTARI, 1997, Vol. 5: 13). Ela pode ser apropriada pelo Estado e perder sua qualidade de força transformadora e de afirmação de segmentos sociais não controlados. O interesse de Deleuze e Guattari é pela noção de máquina de guerra enquanto mecanismo que se mantém exterior ao Estado, como nas sociedades bárbaras indo-germânicas, como agente de desestabilizador de poderes. As novas tecnologias da era digital poderiam se configurar como tal ou não, dependendo do modo como se dá tal interação.

Mas a forma de exterioridade da máquina de guerra faz com que esta só exista nas suas próprias metamorfoses; ela existe tanto numa inovação industrial como numa invenção tecnológica, num circuito comercial, numa criação religiosa, em todos esses fluxos e correntes que não se deixam apropriar pelos Estados senão secundariamente. Não é em termos de independência, mas de coexistência e de concorrência, num campo perpétuo de interação, que é preciso pensar a exterioridade e a interioridade, as máquinas de guerra de metamorfose e se os aparelhos identitários de Estado, os bandos e os reinos, as megamáquinas e os impérios. Um mesmo campo circunscreve sua interioridade em Estados, mas descreve sua exterioridade naquilo que escapa aos Estados ou se erige contra os Estados. (DELEUZE, GUATTARI, 1997, Vol. 5: 24)

\section{$O$ culto da cultura de massa}

A recepção pós-estruturalista, segundo Waite, teria permitido que a teoria da abstração fosse também usada como política cultural alienante do sistema vigente. Para ele, tanto a cultura popular quanto a cultura de massa não se 
refeririam à expressão popular de fato, mas ao modo de manipulação de sua produção e consumo pelas elites. No meio acadêmico, tal fenômeno de massa estaria se desenvolvendo como objeto de culto, traduzido na produção de livros de ficção científica e cyberpunk, bem como filmes.

Finalmente, MassCult é preferível à "indústria de cultura" na medida em que designa o objeto contra o qual a cultura é direcionada: especificamente, aquelas "massas" cuja possibilidade de alguma ver obter algo como o momento empático uma vez conhecido como "consciência de classe" é precisamente o que é eliminado preventivamente de antemão da sua formação potencial pelos mecanismos de comodificação e abstração de ambas as "alta" e "baixa" cultura igualmente. (WAITE, 1995: 171)

Confirmando o impacto das tecnologias modernas no modo de percepção do homem, os filósofos pós-estruturalistas, Virilio e Deleuze, teriam mostrado sua interferência tanto no modo de sentir corporalmente quanto na nova concepção de mundo a partir das extensões fornecidas pelos aparatos técnicos da modernidade. A tecnologia teria amplificado a hibridização de realidades provocando uma mudança no próprio sistema perceptivo e sensório humano. As tecnologias do cinema e da guerra seriam um exemplo desse desenvolvimento integrado que teria um fim de uso documental e estratégico inicialmente, mas que acabaram determinado as referências dos filme de guerra para entretenimento e mesmo de arte. No sentido inverso também, pois as imagens cinematográficas passaram a servir de referência para soldados em tanques e pilotos. As imagens tanto da guerra quanto do cinema acabaram por definir um modo de perceber, comunicar e existir do homem moderno. Haveria, portanto, uma inversão do aparato perceptivo, que antes valorizaria a dimensão racional, em prol da dimensão sensível. Para Waite, a estética teria se estendido do campo das artes e da cultura para tornar-se a determinante maior do campo da percepção humana. A estética controlaria as interfaces entre o organismo e o ambiente no mundo dominado pela realidade virtual. Desse modo, os limites entre realidade e ficção estariam sendo redefinidos através de computadores. Efetivamente, podemos verificar a presença pervasiva dos computadores seja para experimentar projetos arquitetônicos antecipadamente ou definir determinados aspectos de fato no modo interativo, seja no treinamento médico ou para o entretenimento.

Cirurgiões cerebrais fazem operações simuladas pelo computador sentindo o calor da glândula pineal, o peso do bisturi a laser. A Luva Poderosa da Mattel 
Corp. de Brinquedos: uma prótese para transmitir movimentos da mão em sinais eletrônicos que "controlam" os jogos Nintendo. Fones de ouvido, luvas Ciber , capacetes Ciber, vestimentas Ciber. Ter sexo teledildônico (sexo bom, sexo ruim, qualquer sexo) com o "pequeno objeto a" lacaniano de sua escolha: "pele inteligente", "tecnologia abrangente", "fucksuits com pele ciber". E ainda assim relativamente fácil de lavar. (WAITE, 1995: 163).

Assim a ciência, as artes e a guerra configurariam, segundo Waite, o cenário contemporâneo da vida identificada com uma única Videodromo. Para Waite, tais aparatos tecnológicos representariam uma forma de alienação do humano no homem e não um modo de extensão de suas possibilidades. Este estaria se afastando de seu corpo, do corpo dos outros, do espaço real e, assim, da dimensão pública e política.

E a estética alcançou o ponto de designar a prótese cyberpunk: uma extensão do corpo material e da mente impulsionados para a morte, uma extensão potencial, todavia, de todos os sentidos e órgãos. (...) Nos termos de Haraway ${ }^{128}$ : "No final do século XX...somos todos quimeras, híbridos teorizados e fabricados de máquina e organismo; resumindo, nós somos ciborgues. O ciborgue é nossa ontologia; ele determina nossa política." Metafísica e estética estão ambos se tornando formas de psicoplasma e vice versa. Psicoplasma refere-se a (teoricamente senão realmente) operação psicanalítica transferencial envolvendo a auto-replicação (inclusive póstuma) de projeções sem corpo dos medos subconscientes e conscientes, ódios, e desejos em corporações materializadas, incorporadas de seres gerados transexualmente ou assexuadamente ou "incubados" - com certos benefícios saudáveis para o indivíduo projetado e com consequências imediatas desastrosas para as vítimas dos últimos e potencialmente para a sociedade como um todo. (WAITE, 1995: 166)

Sabemos que a crítica aos efeitos da interação do homem com os equipamentos tecnológicos é contemporânea ao seu nascimento, mas as mutações promovidas pela disseminação das tecnologias da realidade virtual precisam ser constantemente atualizadas. Vimos como, para Pierre Levy, a tecnologia se definiria de modo ambivalente: homem não interagiria apenas de modo passivo com as tecnologias.

\section{Cinema}

Tal predomínio da estética sobre a razão determina a necessidade de avaliar de que modo essa estetização da realidade viria se atualizando nesse

\footnotetext{
${ }^{128}$ Donna Haraway é filósofa e autora de "Um manifesto ciborgue", ensaio escrito em 1985. A autora colocava em questão os limites do corpo e da identidade de gêneros através da demonstração das relações humanas hibridizadas com animais e máquinas já ocorridas historicamente.
} 
contexto interativo da modernidade. Waite aponta como a valorização da dimensão estética, paradoxalmente, resultaria na alienação da própria dimensão corporal, que passa a ser percebida de modo desmembrado, sem a hierarquia tradicional orgânica. Tal desmembramento resultaria também numa perda de perspectiva histórica e de classe, que ele associa à estética surrealista e que remete à enucleação ocular e à cegueira da abstração. Para Bataille, no entanto, o significado da enucleação tinha relação com retirar o privilégio da razão relacionada ao olho e colocar em pauta a questão do erotismo, invertendo o sentido tradicionalmente valorizado.

Mas é esse ato (de tomar o olho como cosmo) virtualmente violento esgotável com a enucleação obscenamente eufemizada (o termo suave de Bataille para a auto-infligida exfoliação do olho humano para fora do seu soquete, seu desincorporamento) que foi sugerido por cowboys de farmácia ciberpunks como Worringer, nos seus impulsos compensatórios para se "livrarem" dos reais horrores da história, parar de pensar sobre qualquer coisa que não seja o próprio espaço, a própria classe - mesmo quando negando que esse era um espaço, que essa era uma perspectiva de classe? (WAITE, 1995: 183)

Para Waite, o cinema e a teoria sobre o cinema, conforme tratados pelos filósofos Gilles Deleuze, Guattari e Virilio, naturalizaria a perda de perspectiva e clareza sobre a realidade. A perda de clareza estaria relacionada com a interpretação deleuziana do impulso para a abstração que passou a dominar a produção de cinema contemporâneo. Tal crítica de Waite é contraditória com a tese de Worringer que afirma que a abstração se refere à busca de clareza na realidade confusa no primitivo, podendo, talvez ser relacionada ao êxtase religioso no gótico. Nesse caso, uma busca de dissolução do eu subjetivo.

Deleuze teria relacionado o neorrealismo ${ }^{129}$ de Fellini e Antonioni aos conceitos worringerianos de empatia e abstração. O neorrealismo seria descrito por ele como "cinema do tempo" em contraposição ao "cinema movimento", que o antecedia cronologicamente no realismo. O cinema do tempo seria descrito

129 "O que define o neorrealismo é essa ascensão de situações puramente ópticas (e sonoras, embora não houvesse som sincronizado no começo do neorrealismo), que se distinguem essencialmente das situações sensório-motoras da imagem-ação no antigo realismo. Talvez isso seja tão importante quanto a conquista de um espaço puramente óptico na pintura, ocorrida com o impressionismo." (DELEUZE, 2018: 13) Para Deleuze, além disso, as imagens da realidade passariam a estar relacionadas ao pensamento e não mais à ação, necessitando então de novos signos. "Trata-se, para ele, de uma nova forma de realidade, supostamente dispersiva, elíptica, errante ou oscilante, operando por blocos, com ligações deliberadamente fracas e acontecimentos flutuantes. O real já não era representado ou reproduzido, mas "visado"”, (DELEUZE, 2018: 11). 
segundo dois tipos fundamentais de signos visuais produzidos, segundo a proximidade ou distância dos opsignos e sonsignos ${ }^{130}$, que tenderiam aos impulsos de empatia ou abstração. O sistema de signos visuais substituiria a imagem-ação motora, relacionada às funções do corpo, resultando num novo tipo de imagem, onde a distinção sujeito e objeto perde a importância, porque real e imaginário, físico e mental se tornaram indiscerníveis. Para Waite, tal abstração do corpo, não mais concebido como estrutura funcional-orgânica, experimentada no cinema tempo teria se tornado pervasiva no mundo contemporâneo devido à disseminação das tecnologias cibernéticas. Tal como nos filmes Videodrome e Total Recall, a tela teria se tornado uma prótese corporal real, bem como uma máquina de guerra real, tornando sujeito e objeto indiscerníveis. Nessa indiscernibilidade, a guerra de fato estaria sendo apresentada como um programa de TV transmitido em tempo real para o espectador doméstico e também para os soldados que lá lutavam e recebiam as imagens do local. Devo ressaltar, no entanto, que para Deleuze não se trata de uma abstração do corpo no caso do cinema tempo, como Waite interpreta, mas numa desorganização deste que experimenta as sensações ópticas, sonoras e táteis. A oscilação entre sujeito e objeto inaugurada com a participação do espectador no filme determinaria a desorganização das sensações. O espectador teria iniciado sua participação ao se identificar com os personagens e teria evoluído no sentido de ser assistido. "Mas só agora a identificação é subvertida efetivamente: a personagem tornou-se uma espécie de espectador." (DELEUZE, 2018: 13). A participação do espectador definiu a indiscernibilidade entre sujeito e objeto, real e imaginário. Tal indiscernibilidade tanto poderia levar para a empatia quanto para a abstração, distintas apenas pelo grau de proximidade do olhar que pertence tanto aos objetos quanto aos personagens.

No antigo realismo ou de acordo com a imagem-ação, os objetos e os meios já tinham uma realidade própria, mas se tratava de uma realidade funcional, estreitamente determinada pelas exigências da situação, (...) Ao contrário, desde Obsessão já aparece o que nunca mais deixará de se desenvolver em Visconti: os objetos e os meios conquistam uma realidade material autônoma que os faz valerem por si mesmos. É preciso, portanto, que não somente o espectador, mas também os protagonistas, invistam os meios e os objetos pelo olhar, que vejam e

130 "Não sendo mais induzida por uma ação, nem se prolongando em ação, a situação óptica e sonora não é, portanto, um índice, nem um synsigno. Falaremos de uma nova raça de signos, os opsignos e os sonsignos." (DELEUZE, 2018: 18) 
ouçam as coisas e as pessoas, para que a ação ou a paixão nasçam, irrompendo em uma vida cotidiana preexistente. (DELEUZE, 2018: 15)

\section{CYBERWAR : A Guerra}

As Guerras constituiriam um cenário da realidade virtual a ser consumido como espetáculo na Videodromo, que corresponde tanto ao espaço real onde se desenvolve o evento quanto ao espaço do inconsciente no mundo contemporâneo. Ambos se fundiram segundo suas respectivas dimensões abstratas, conforme descreveriam seus sobreviventes. O termo Videodromo, retirado do título de um filme de David Cronenberg de 1983, é assim definido:

Em comparação como o "velódromo" das classes trabalhadoras modernistas de corridas de bicicletas concretas em múltiplos dias , "Videodrome" é muito mais abstrata, a arena propriamente pós-moderna do combate com as interfaces e metamorfoses mente-corpo do ciborgue, dentro e por meio do qual a luta pela hegemonia total capitalista é sadomasoquisticamente desenvolvidas em - e como - acesso-público a TV e outras práticas "estéticas". (...) E assim estética vem referir-se à prótese cyberpunk: uma extensão do corpo material e mende propulsionada para a morte, extensão, todavia, de todos os sentido e órgãos. (WAITE, 1995: 166)

Para Waite, as guerras corresponderiam ao melhor exemplo relativo às teorias políticas pós-modernas, estas descritas por Deleuze e Guattari em Mil Platôs e Paul Virilio. Waite se apropria da análise que Virilio faz do desenvolvimento interdependente das tecnologias de guerra e do cinema e da conclusão de que tal interação determinaria uma mudança no modo de percepção do homem. Isso teria sido possível porque, segundo Virilio, tanto o cinema quanto a guerra têm em comum a dimensão espetáculo e da magia. Estes relacionados aos rituais das antigas religiões e reuniões tribais. ${ }^{131}$ Waite, no entanto, despreza tal dimensão antropológica para acusar "a recepção acrítica do teoria da abstração" praticada pelo pós-estruturalismo.

A propaganda, a encenação dos próprios ataques, a competição armamentista são descritas por Virilio como dimensões do teatro da guerra que criam torpor psicológico, êxtase, agonia e medo. Virilio aponta como os gastos envolvidos na corrida armamentista não justificariam o seu pouco uso e nem a necessidade de inovação tecnológica, mas apenas a encenação de Poder. O

${ }^{131}$ Bataille já apontava a relação entre a religião, a guerra e o erotismo, como formas de canalizar o impulso de morte humano, de organizá-lo nas sociedades que se civilizam. 
próprio vocabulário militar usado para descrever as estratégias de combate remetem à encenação implicada. O termo "teatro de operações", por exemplo, remete ao espaço físico onde ocorrem as batalhas.

Ou seja, a guerra consiste menos em obter vitórias materiais (territoriais, econômicas...) do que em apropriar-se da imaterialidade dos campos de percepção. À medida que os modernos combatentes estão decididos a invadir a totalidade destes campos, impõe-se a idéia de que o verdadeiro filme de guerra não deve necessariamente mostrar cenas de guerra em si ou de batalhas. $\mathrm{O}$ cinema entra para a categoria das armas a partir do momento em que está apto a criar a surpresa técnica ou psicológica. (VIRILIO, 1993: p. 15)

Virilio teria apontado a mudança das estratégia de campo para as de concepção como relacionadas à automação e abstração no campo de percepção relativo à guerra. Waite associa a abstração ao decréscimo de empatia entre os soldados. Ela levaria à equívocos inesperados, dado a crença na alta-tecnologia investida, que se verificaria desde o treinamento dos soldados em simuladores que representam a situação da guerra de modo teoricamente idêntico ao que será experimentado nas telas dos aviões posteriormente. Nos simuladores, no entanto, todo "alvo mole", em contraposição aos "alvos duros" correspondentes aos edifícios, tanques e mísseis, é representado como possível inimigo a ser destruído. Tal representação abstrata dos alvos teria precitado a morte de compatriotas ao tornar a imagem do inimigo indistinta. Além disso, o próprio jargão utilizado revela a falta de empatia e a patologia de um olhar reificado e comodificado ao ser modelado pela cultura de consumo e "ciborgueificado" ao ser alterado pelas tecnologias.

O resultado da Guerra do Golfo foi que alguns dos últimos (compatriotas) foram ocasionalmente "desligados" por "fogo amigo". "Esta Bud é para você!" gritava um artilheiro de tanque confuso, cego pela poeira no Kuwait como ele relutantemente obedecia a ordem técnica de lançar um projétil opticamente guiado num alvo mole que revelou, como ele temia, ser seu próprio companheiro. Confrontado pelos seus superiores (com intenção de tomá-lo como bode expiatório), o jovem artilheiro replicou: "Ninguém sabe o quão abstrato (the fuck how fucking abstract) é lá fora" - tomando por "lá fora" não somente nas areias em redemoinhos das Tempestades do Deserto mas também "lá dentro" fundo na matriz, no cérebro do ciborgue da Guerra Cyber worringeriana. (WAITE, 1995: 177)

O olhar perverso do soldado, "literalmente comodificado, reificado, ciborgueificado", que se esconde para espiar e que toma o projétil por uma cerveja, estaria associado ao voyeurismo desenvolvido pela necessidade de 
organizar caos visual promovido pela síntese entre a arquitetura e a tela de cinema. Cinema e aviação surgem simultaneamente e, a partir da Primeira Guerra, os voos de observação fazem parte da estratégia militar contribuindo para determinar um "novo modo de ver" (VIRILIO, 1993: 33). O novo olhar mecânico explode a continuidade espacial das imagens através do movimento ininterrupto que as aproxima e afasta numa rapidez tamanha que faz romper a noção de escala, fornecendo apenas fragmentos. A visão em movimento rompe com visão homogênea e engendra "a heterogeneidade dos campos de percepção" (VIRILIO, 1993: 37). Com a aproximação dos poderes industriais e comerciais dos meios de comunicação nos anos 1920, imagens de atrizes figuram equipamentos de guerra. Estas imagens corresponderiam ao olhar obsceno proporcionado pelo olhar mecânico aéreo, aquele que aproxima, fragmenta e coloca em evidência o invisível da realidade penetrada.

A publicidade do cinema industrial não se equivocará: se a estrela pode ser chamada de "corpo" e sua imagem é pintada sobre as bombas e os aviões de caça, este corpo desprovido de dimensões estáveis logo será oferecido "em pedaços" aos espectadores, repetindo ainda mais uma vez a percepção heterogênea do Vouyer militar. De Jean Harlow a Betty Grable, a atenção será dirigida a um detalhe exageradamente ampliado: as pernas, o olhar, as ancas etc. A exposição cinemática - reveladora de formas exteriores à percepção imediata renova a dissecação da anatomia antiga. (VIRLIO, 1993: 47)

A mudança nos modos de percepção, promovido pelas novas tecnologias, incorreriam na mudança da percepção do espaço, que era outrora dimensionaleuclidiano e corresponde agora à geometria topológica. Virilio descreve como no final da Primeira Guerra há uma mudança radical no modo de combate, que não é mais corpo a corpo. O soldados passam a ficar imóveis e escondidos, de onde recebem imagens do inimigo que lhes são transmitidas de modo indireto e fragmentário. Através do uso de telescópios e das fotografias aéreas, atira-se num alvo abstrato. Os voos para o reconhecimento do lugar, que eram inicialmente pilotados, passam a ter controle remoto. "A partir de então, não mais existe a visão direta: em um espaço de 150 anos, o campo de tiro transformou-se em campo de filmagem, o campo de batalha tornou-se uma locação de cinema fora do alcance dos civis." (VIRILIO, 1993: 24). A aviação determina um novo modo de ver, através de "loopings", "folha-seca", grande-oito", que determinam a perda das referências polares homogêneas do continuum espacial antes utilizadas. 
A partir de então a visão aérea escapa à visão euclidiana tão fortemente experimentada pelos combatentes nas trincheiras. A aviação abre túneis endoscópios, é o acesso mais surpreendente possível à visão topológica, ao "ponto cego" antevisto nas atrações dos parques de diversões do século anterior, nas rodas-gigantes e mais tarde nas montanhas-russas e em outras diversões presentes, por exemplo, na Berlim do pós-guerra. (VIRILIO, 1995: 35)

Waite associa tal mudança da percepção a uma política econômica do espaço: "não somente do espaço em abstrato mas virtualmente do espaço real" (WAITE, 1995: 178). Citando Henri Lefebvre, ele associa a visão topológica, descrita por Virilio, ao espaço abstrato, o que constituiria um equívoco que vale esclarecer.

Para Lefebvre, o espaço abstrato estaria efetivamente relacionado às políticas institucionais e teria sido estabelecido historicamente às custas de violência e guerra. Ele não seria homogêneo em si, mas provocaria um esvaziamento ilusório na heterogeneidade e na multiplicidade da matéria multiforme que constitui o espaço social. Para Lefebvre, o espaço social viria sendo tratado de modo reducionista pelos diversos campos do conhecimento, que privilegiariam ora o aspecto mental, ora o físico, reforçando a qualidade abstrata. A ênfase no mental e no físico levaria à ilusões; seja da transparência da verdade ou da realidade (substancialidade/naturalidade) do espaço, sendo esta última assim definida: "De acordo com os filósofos da boa velha escola idealista, a credulidade peculiar no senso comum leva à crença equivocada de que "coisas" tem mais existência que o "sujeito", seus pensamentos e desejos." (LEFEBVRE, 1991: 27). Para ele, a produção do espaço pleno dependeria tanto do aspecto perceptivo, quanto do conceptivo e do vivido. O ponto de partida para a necessidade da determinação desta tríade (percebido-concebido-vivido) teria sido despertado pela investigação de três momentos da filosofia. O primeiro marcado pelo dualismo cartesiano (pela oposição entre substância pensante e extensa) e os outros, pelas duas tentativas de superação de tal dualismo, que configuravam o privilégio do mental, através das dialéticas hegeliana e marxista. O hegelianismo teria recaído no ilusionismo da transparência, determinado pela racionalidade de seu sistema.

Tal sistema não pode nem ter fins materiais e nem fins perdidos, é um "perfeito" sistema cuja racionalidade é suposta, quando sujeitada ao escrutínio mental, para ser auto-evidente. Este paradigma aparentemente tem o poder mágico de 
transformar obscuridade em transparência e de tirar o "objeto" das sombras para a luz meramente por articulá-lo. Resumindo, tem o poder de decifrar. Assim conhecimento (savoir), com notável ausência de consciência, coloca-se aprisionado ao poder, suprimindo toda resistência, toda obscuridade, no seu próprio ser. (LEFEBVRE, 1991: 40)

O momento marxista, por sua vez, teria se desvirtuado ao confundir-se com uma ideologia do crescimento que também resultou em alienação e não na produção do espaço social diferenciado, aberto à experiência da vida. Para Lefebvre, se a luta de classes ainda permanece latente e pode ganhar feição revolucionária, esta seria bem diferente daquela do "marxismo empobrecido", centrado na derrubada do Estado e na tomada de posse dos meios de produção, conforme sugerido por Waite. "De todos os eventos, tudo sugere no presente que os trabalhadores nos países industrializados não estão optando nem pelo crescimento indefinido nem pela revolução violenta, levando ao desaparecimento do Estado, mas antes pela atrofia do trabalho em si” (LEFEBVRE, 1991: 24).

Verificaremos que Waite se restringe ao aspecto representacional (em termos lefebvrianos) do espaço, à política que determinava a concepção de tal espaço, por isso insiste no movimento revolucionário das lutas de classe como única saída contra a exploração e alienação do homem. Ele ignora a dimensão apropriativa do espaço, proposta por Lefebvre. Além disso, Waite se equivoca quanto ao caráter abstrato worringeriano do suposto ciberespaço. Ainda que descreva-o corretamente segundo a geometria topológica, em contraposição à pressuposta relação de hierarquia entre as partes e a totalidade do espaço euclidiano e empático. O equívoco é gerado pela diferença da referência do conceito de abstração que serve de fundamento para Deleuze e Guattari, cujo caráter é worringeriano; e aquele que serve à Lefebvre e que se aproximaria da empatia worringeriana; e, por fim, o conceito de abstração, utilizado por Waite, que retoma a crítica de Lukács e é worringeriano. Então, ao tomar como referência Lukács e Lefebvre, Waite cai em contradição. Vimos como o realismo lukácsiano pressupunha a determinação da totalidade da forma, em contraposição à fragmentação abstrata das vanguardas que ele criticava. Por outro lado, para Lefebvre, o espaço abstrato é explicado preponderantemente como fenômeno sociológico, que, no entanto, também inclui dimensões do inconsciente, conforme refletido no corpo social. Entretanto, permanece antagônica em relação a 
Worringer e os pós-estruturalistas a noção de abstração. Para Lefebvre, a abstração reduziria a dimensão corporal, seria mais mental e visual, e, assim, terminaria por se parecer com a visão distanciada associada ao clássico e à empatia worringeriana, que ele, porém, não menciona. $\mathrm{O}$ espaço abstrato, definido por Lefebvre, deve ser compreendido segundo uma tríade afetiva, para que não se recaia no equívoco de Waite, conforme podemos acompanhar a seguir.

A tríade percebido-concebido-vivido se traduziria em termos espaciais em "práticas espaciais, representações do espaço e espaços representacionais", respectivamente. A prática espacial se refere às relações desempenhadas pelos indivíduos no espaço, conforme seu domínio e apropriação. "Ela incorpora uma associação íntima, dentro do espaço percebido, entre a realidade diária (rotina diária) e realidade urbana (as rotas e redes que ligam os lugares colocados em separado para o trabalho, vida "privada" e lazer)" (LEFEBVRE, 1991: 3). A prática pressupõe que a fragmentação do espaço abstrato, próprio da disciplina de zoneamento urbano moderno, poderia ser superada através da apropriação dos usuários. A apropriação do espaço corresponderia à liberação das predeterminações que o dominavam, tornando espaço e tempo instrumentalizáveis. A experiência do tempo ficaria reduzida à quantificações relacionadas às necessidades estruturadas segundo funcionamento urbano, segundo lógicas itinerárias e dos modos de transportação. Na cidade moderna, a separação entre o espaço e o horário do prazer daquele do trabalho implica na divisão e no esvaziamento do próprio sujeito em cada momento. O espaço seria um meio ambíguo capaz de alienar ou despertar o sujeito em sua integridade mental e erótica. O desejo despertado é o efeito da reversão do espaço abstrato em espaço diferencial, reavivando a heterogeneidade própria do processo de sedimentação do espaço que as determinações funcionais abstraem. "Espaço é suscetível de ser erotizado e restaurado em sua ambiguidade, como local de nascimento de necessidades e desejos, por meio da música, por meio de sistemas diferenciais e valorizações que ultrapassam a estrita localização de necessidades e desejos no espaço especializado, seja psicologicamente (sexualmente) ou socialmente" (LEFEBVRE, 1991: 391). As necessidades são, portanto, a abstração do desejo humano. O desejo precede as necessidades e vai além delas ao não permitir a estagnação das determinações de necessidade. O desejo impulsiona 
as mudanças e é ambíguo. As necessidades resultam de desejos objetivados, por isso são determinadas. "Conforme aplicada à realidade anterior à emergência de necessidades, “desejo" se refere às energias disponíveis para o ser vivo, energias que tendem a ser descarregadas explosivamente, sem objeto definido, de modos violentos, destrutivos ou autodestrutivos." (LEFEBVRE, 1991: 394).

O espaço social se desenvolveria, portanto, a partir de três dimensões da experiência corporal no espaço, determinando três momentos no desenvolvimento do espaço: As representações do espaço estão relacionadas com a ordem que a produção do espaço impõe como desdobramento de conhecimento, signos, códigos e "relações frontais" (de fachada); que são predominantemente abstratos. Seria o espaço dos técnicos, cientistas e arquitetos.

O espaço representacional incorporaria associações simbólicas, muitas vezes, relacionadas à vivencia dos "subterrâneos" do espaço social, do qual a imaginação quer apropriar-se: "memórias infantis, sonhos, ou imagens uterinas e símbolos (buracos, passagens, labirintos)" (LEFEBVRE, 1991: 42). É o espaço de usuários, mas também dos artistas, antropólogos e psicanalistas que fazem o exercício de ir além de descrever objetivamente o espaço apesar de referirem-se à história. "(Tal espaço) Tem um núcleo afetivo ou centro: Ego, cama, banheiro, habitação, casa; ou: praça, igreja, cemitério. Abarca o local da paixão, da ação $e$ das situações vividas, $e$ assim imediatamente implica o tempo. Consequentemente deve ser qualificado em muitos modos: deve ser direcional, situacional ou relacional, porque é essencialmente qualitativo, fluido e dinâmico." (LEFEBVRE, 1991: 42).

Lefebvre define o ato conceptivo da abstração como predominantemente mental e visual, determina a abstração das outras instâncias do percebido e do vivido e a subordinação do espaço representacional à figuras simbólicas esvaziadas, as referências originalmente religiosas (céu, inferno, anjos etc.). O período da Renascença corresponderia a tal momento de subordinação e abstração, facilitada pelo estabelecimento da representação pela perspectiva linear como um código da lógica de percepção que privilegia a visão. "A linha de fuga, $o$ ponto de fuga e o encontro das linhas paralelas "no infinito" eram determinantes da representação, ao mesmo tempo mental e visual, que promoveu 
a primazia do olhar num tipo de "lógica da visualização" (LEFEBVRE, 1991: 43). Vale ressaltar aqui, que para Worringer a tendência geométrica hierarquizante do renascimento corresponderia ao impulso de empatia, que envolve uma visão de mundo subjetiva autocentrada, e não o de abstração. Para Worringer, tanto o gótico como o primitivo não partilhariam de tal condição existencial do sujeito, mesmo no Gótico ainda bastante referendado no coletivo.

Tal privilégio da abstração teria se perpetuado na prática de arquitetos e urbanistas, determinando uma tendência na prática social que trata de modo reducionista a multidimensionalidade do corpo; sejam as relações do sujeito com seu próprio corpo, como do corpo com o espaço e com a sociedade. "Considerada na totalidade, a prática social pressupõe o uso do corpo: o uso das mãos, membros e órgãos sensórios, e os gestos do trabalho como atividade não relacionada ao trabalho." (LEFEBVRE, 1991: 40) As representações do corpo, no entanto, derivam da introjeção de conhecimento, ideologia e de modos de relação com o ambiente que não correspondem à experiência do corpo vivido. Este seria tratado de modo inconsciente devido à repressão de sua dimensão erótica que a herança da cultura judaico-cristã promove.

\begin{abstract}
A experiência do corpo vivido, por sua parte, talvez tanto altamente complexa e bastante peculiar, porque "a cultura" interfere aqui, com imediação ilusória, através de simbolismos e através da longa tradição judaico-cristã, certos aspectos da qual das desvelados pela psicanálise. O "coração" como vivido é estranhamente diferente do coração como pensado e percebido. O mesmo é válido a fortiori para os órgãos sexuais. Localizações não podem absolutamente ser tomadas como certas quando se trata da experiência vivida do corpo: sob a pressão da moralidade, é mesmo possível se chegar ao estranho resultado de um corpo sem órgãos - um corpo castigado, como se estivesse, no ponto de ser castrado. (LEFEBVRE, 1991: 40)
\end{abstract}

É neste ponto que a teoria da abstração de Lefebvre levaria à uma contradição com a teoria da abstração de Worringer e dos pós-estruturalistas. Verificaremos que a teoria da diferença proposta por Lefebvre coincide com a teoria da abstração dos supracitados. "A teoria formal da diferença abre a partir de si para o desconhecido e mal entendido: para ritmos, para circulações de energia, para a vida do corpo (onde repetições e diferenças dão origem uma a outra, harmonizando e desarmonizando por sua vez)" (LEFEBVRE, 1991: 373). A contradição reside, portanto, na contraposição logos-erótica proposta por Lefebvre, pois esta determinaria o logos como extensão do estado mental, que 
excluiu a princípio a dimensão erótica, e é associado ao espaço abstrato. A tendência dos arquitetos a projetarem os espaços segundo as necessidades funcionais e não segundo uma abertura para o desejo refletiria a preponderância do logos em detrimento do erótico.

Para Worringer, no entanto, o impulso para a abstração seria uma resposta corporal que derivaria da sensibilidade extremada para as coisas em si no homem primitivo e gótico. Tal sensibilidade seria mais tátil que visual. Este impulso corporal corresponderia ao impulso psíquico do medo e demostraria a falta de controle da consciência sobre a vontade.

\footnotetext{
Quando nós somos tomados por uma forte agitação interna, que nós não podemos mais que externar no papel, então irão as garatujas sair de modo totalmente diferente. A vontade da nossa articulação da mão não é de modo algum questionada, mas o lápis dirige-se selvagem e veemente sobre o papel e em vez das bonitas curvas redondas organicamente temperadas, surge uma linha rígida, angulosa, constantemente interrompida, pontiagudo de forte ímpeto expressivo. Não é a articulação da mão que automaticamente cria, mas nossa rigorosa vontade de expressão, que dominantemente prescreve seu movimento. $\mathrm{O}$ impulso de movimento uma vez estabelecido não pode, como se encontra na tendência natural expirar em si, mas é abafado continuamente por um novo impulso de movimento. (WORRINGER, 1912: 33)
}

Tal sensibilidade seria expressão da condição coletiva e de uma visão de mundo não determinada pelo conhecimento racional. O impulso para a abstração worringeriano corresponde a uma atividade volitiva relativa à necessidade psíquica específica de alienar-se do fluxo da vida por medo do espaço no caso do primitivo e por tormento interior no caso do gótico. A geometrização e a estilização primitivas refletiriam uma busca de contentamento psíquico através da expressão de formas tornadas unitárias, cristalinas (inorgânicas) e absolutas pela supressão de qualidades espaciais. No gótico, a linha abstrata geométrica ganha vitalidade com a introdução de elementos da realidade, tais como animais e vegetais, e valor expressivo "inorgânico", uma vez que seria tomada por uma movimentação que excede a direção dada pelos sentimentos subjetivos. Ela teria expressão própria: "não representa com o valor sensual-orgânico, mas com valor não sensual, quer dizer, de modo espiritual. Não manifesta a atividade da vontade orgânica que se manifesta nela, mas sim uma atividade da vontade psicoespiritual que está longe de toda ligação e reconciliação com os complexos sentimentais.” (WORRINGER, 1912: 34) 
Worringer acentua ao apontar a sensibilidade para a coisa em si, conforme vimos anteriormente, a diferença entre o impulso abstrato primitivo e a atitude blasé ou cientificista do homem moderno. A sensibilidade moderna ressurgiria a partir da consciência, despertada pela filosofia e pela ciência, de que os fenômenos seriam apenas a aparência transitória e insubstancial daquilo à que não se tem acesso e que é a coisa em si, conforme apresentavam Kant e Schopenhauer. Para este último, a coisa em si entendida como vontade. "Apenas depois que o espírito humano passou, por milhares de anos de sua evolução, ao longo de todo curso de conhecimento racionalista, o sentimento para a coisa em si ressuscitou como a resignação final do conhecimento." (WORRINGER, 1953: 18) A sensibilidade para a coisa em si do homem moderno é, portanto, relacionada a uma visão distanciada e totalizante proporcionada pelo conhecimento; enquanto, para o primitivo, ela implicaria na necessidade de estabelecer um nexo tátil e fragmentário a ser recomposto na imaginação e não visualmente: "proporcionando ao espectador a consciência tranquilizante de apreciação do objeto na necessidade irrefutável de sua individualidade material fechada “(WORRINGER, 1953: 41).

No homem da modernidade, no entanto, a vontade de arte não seria mais expressão do coletivo que dá origem ao impulso abstrato (na modernidade digital, conforme propõe Levy existiria a possibilidade da configuração de uma sujeito coletivo polifônico). As expressões geométricas e a busca de regularidade do sujeito moderno, enquanto distinto da massa, seriam reflexo de cálculo e intelectualismo, que nada conteriam da religiosidade transcendentalista do primitivo, do oriental e do gótico.

Seria uma interpretação equivocada das precondições psicológicas para a gênese dessa forma abstrata de arte, dizer que uma ânsia por regularidade levou o homem a buscar a regularidade geométrica, pois isso pressuporia uma penetração espirito-intelectual da forma abstrata, faria parecer produto de reflexão e cálculo. Nós temos mais motivos para assumir que o que vemos aqui é uma criação puramente instintiva, com necessidade elementar e sem a intervenção do intelecto. Precisamente porque o intelecto ainda não tinha ofuscado o instinto, a disposição para a regularidade, a qual depois de tudo já está presente na célula germinal, foi capaz de encontrar expressão abstrata apropriada. (WORRINGER, 1953: 19)

O impulso para a abstração contrapõe-se ao hedonismo e ao sentimento imanente implícitos no impulso para a empatia e representa um desejo de 
alienação da arbitrariedade do mundo orgânico no primitivo e, no gótico, a anulação de si no êxtase religioso. Ele pressupõe uma relação dualista com o mundo e uma busca de transcendência em relação à realidade existente. A empatia pressupõe a alienação do sujeito na identificação com o objeto, pressupõe a identificação com a forma e a apreciação estética dela decorrente. Para o homem clássico, o mundo é "o complemento vívido de seu próprio eu”; "assimilado em sua pequena humanidade”. (WORRINGER, 1953: 24)

Pois isto implica que o processo de empatia representa uma autoafirmação, uma afirmação da vontade geral de atividade que está em nós. (...) Somos transportados de nosso ser individual desde que sejamos absorvidos num objeto externo, uma forma externa, com nosso ímpeto de experiência. (...) Nessa autoobjetificação está uma autoalienação. (...) "Na empatia, portanto, eu não sou o eu real, mas estou intimamente liberado do último, ou seja, estou liberado de tudo o que eu sou fora da contemplação da forma. Sou apenas este ideal, este eu contemplador" (Lipps, Aesthetik, 247). (WORRINGER, 1953: 24)

A abstração gótica pressuporia portanto, segundo Worringer, um outro

modo de abordagem da obra de arte que não passaria pela apreciação estética da forma, pois o Gótico não atende aos critérios do juízo do belo, mas de conteúdo expressivo. Sua psicologia dos estilos pretenderia considerar este outro querer, capaz de justificar momentos relegados pela incompreensão da vontade de arte abstrata.

\begin{abstract}
A essência da arte Cis-Alpina consiste precisamente no fato de que ela é incapaz de expressar o que tem a dizer apenas pelos meios formais, mas que ela degrada esses meios em suportes de um conteúdo literário que se encontra fora do efeito estético e assim os despoja da própria qualidade específica. (...) Uma obra de arte desse tipo não pode mais, portanto, ser aproximada esteticamente, mas apenas individualmente; assim seu efeito não é comunicável, e consequentemente não pode ser tratada com a ciência estética. Isso tem que ser dito com toda admiração. Pois não é menosprezo dizer de uma obra de arte que ela é inacessível. Pois seu valor humano e pessoal deve residir na própria inacessibilidade, enquanto o estético é sob todas as circunstâncias o não-individual. (WORRINGER, 1953: 24)
\end{abstract}

\title{
A Qualidade corporal-erótica da abstração
}

Para Worringer as representações naturalísticas pré-históricas não seriam movidas pela vontade de arte e, portanto, não passariam de meras imitações, distintas da mimese naturalística empática ou da abstração-ornamental ${ }^{132}$. Bataille

132 “A tese de que o estilo geométrico da arte foi o mais remoto é, portanto, é abalado por estes vestígios. Pois onde quer que mais sucedamos em ter um lampejo dos princípios artísticos desses povos que possam mostrar um desenvolvimento artístico, nós encontramos o pressuposto 
discorda de tal veredicto sobre a arte pré-histórica ao reconhecer, num sentido de prolongamento ao levantado por Worringer, uma tendência artística que não se confunde com a tradição clássica do belo e racional, e que teria sido silenciada em função de um processo de repressão erótico-religiosa inerente ao desenvolvimento da humanidade. Bataille reconhece nas representações pré-históricas o derradeiro momento de nascimento da arte. Nas cavernas de Lascaux, ele reconhece um espaço sagrado cujas pinturas já expressariam uma definida vontade de arte marcada pelo contraste entre as figurações naturalísticas dos animais e a deformação quase abstrata do humano. Tal contraste expressaria o sentimento de culpa do caçador, despertado pela transgressão do interdito da morte então instaurado.

As imagens das cavernas teriam tido por finalidade figurar o momento em que, o animal aparecendo, o assassino necessário, ao mesmo tempo condenável, revelava a ambiguidade religiosa da vida: da vida que o homem angustiado recusa, que, no entanto, ele consuma na superação maravilhosa de sua recusa . Essa hipótese repousa sobre o fato de que a expiação consecutiva ao assassinato do animal é de regra entre os povos cuja vida se assemelha sem dúvida àquela dos pintores das cavernas. E tem o mérito de propor uma interpretação coerente da pintura do poço de Lascaux, em que um bisão moribundo encara o homem que talvez o tenha matado, a que o pintor deu o aspecto de um morto. O tema dessa célebre pintura, que suscitou explicações contraditórias, numerosas e frágeis, seria o assassinato e a expiação.

Ao menos, essa maneira de ver tem o mérito de substituir a interpretação mágica (utilitária), evidentemente pobre, das imagens das cavernas, por uma interpretação religiosa, mais condizente com um caráter de jogo supremo, que geralmente é próprio à arte e ao qual corresponde o aspecto dessas pinturas prodigiosas que nos chegaram do fundo das eras. (BATAILLE, 2013: 59)

Para Bataille, a arte, o erotismo, as religiões e a guerra seriam resultantes do processo de organização e retardamento dos violentos instintos humanos demandados pela experiência do trabalho. O trabalho implicaria uma contenção do dispêndio de excessos próprios à natureza em função da racionalização dos resultados almejados; implicando, portanto, num adiamento da realização dos instintos.

Desde os tempos mais remotos, o trabalho introduziu um intervalo, graças ao qual o homem cessava de responder ao impulso imediato comandado pela violência do desejo. É arbitrário, sem dúvida, sempre opor o desligamento, que está na base do

corroborado que a arte não começa com constructos naturalísticos, mas como aqueles ornamental-abstratos." (WORRINGER, 1953: 55). Talvez Worringer tenha se equivocado sobre a precedência das representações abstratas primitivas sobre as naturalísticas porque seu livro antecederia a descoberta das pinturas de Lascaux. 
trabalho, a movimentos tumultuosos cuja necessidade não é constante. O trabalho começado cria, entretanto, uma impossibilidade de corresponder a essas solicitações imediatas que podem nos tornar indiferentes a resultados desejáveis, mas cujo interesse diz respeito tão somente ao tempo ulterior. (BATAILLE, 2013: 64)

O rituais sagrados e o erotismo seriam também o resultado da estruturação social promovida pela influência do trabalho. Para Bataille, o erotismo seria o resultado "do um jogo de equilíbrio do interdito e da transgressão" (BATAILLE, 2013: 59), que se institui quando o homem se distingue dos outros animais pelo desenvolvimento da atividade do trabalho. O ser que trabalha é um descontínuo, que se diferencia dos outros e da natureza, constituindo-se como indivíduo. Ele é devolvido à continuidade e ao ciclo natural pela violência da morte. $\mathrm{O}$ erotismo refletiria a nostalgia dessa continuidade perdida, que se desdobra nas três formas de superação do isolamento: "erotismo dos corpos, erotismo dos corações e, enfim, o erotismo sagrado”. (BATAILLE, 2013: 39) As três formas seriam indissociáveis, unindo "desejo e o pavor, o prazer intenso e a angústia" (BATAILLE, 2013: 62). Elas correspondem à interiorização do desejo que determinará a escolha de seu objeto de modo não objetivo, porque complicadas na vida interior do homem: "O erotismo, já o disse, é a meus olhos o desequilíbrio em que o próprio ser se coloca em questão, conscientemente. Em certo sentido, o ser se perde objetivamente, mas então o sujeito se identifica com o objeto que se perde." (BATAILLE, 2013: 55). As obras de arte também revelariam a ambiguidade da vida interior humana despertadas pelo erotismo, refletindo os sentimentos de nostalgia da continuidade, o medo da morte e desejo de superá-la na duração artística. "A poesia conduz ao mesmo ponto que cada forma do erotismo, à indistinção, à confusão dos objetos distintos. Ela nos conduz à eternidade, nos conduz à morte e, pela morte, à continuidade: a poesia é a eternidade." (BATAILLE, 2013: 48)

Assim, para Bataille, as deformações nos desenhos de crianças e primitivos refletiriam o instinto reprimido do homem, que seria primordialmente destrutivo, e não um estágio subdesenvolvido. O impulso destrutivo seria de tal forma reprimido pela cultura, que teria relegado movimentos artísticos não identificados com a representação naturalística e com a empatia à momentos de decadência na história da arte. A representação da violência como inerente à 
humanidade nas artes tenderam a ser silenciadas, permanecendo como um ponto obscuro ou inconsciente. A vida civilizada teria se fundado sobre uma mentira que a contrapõe à violência explicita daquela dos bárbaros. "Com efeito, os civilizados falam, os bárbaros se calam, e aquele que fala é sempre civilizado. Ou, mais exatamente, a violência é silenciosa, já que a linguagem é, por definição, a expressão do homem civilizado." (BATAILLE, 2013: 214). Sade teria tido o mérito de tornar o homem consciente da ligação do erotismo com a violência, ainda que se mantenha o afastamento das religiões outrora sacrificiais: "ninguém poderia negar hoje que existem impulsos que ligam a sexualidade à necessidade de fazer o mal e de matar" (BATAILLE, 2013: 210). A linguagem humana teria evoluído no sentido de abafar a relação da cultura com a violência sublimada. As artes teriam acompanhado esta busca de ascese, tornando-se cada vez mais abstrata, incorpórea e desnecessária em contraposição aos excessos da natureza animal. No entanto, se ela mantém algo do teor erótico-sagrado, ele se manifesta como violência corpórea.

As marcações das crianças nas paredes, seus rabiscos no papel, tudo procederia de um desejo de destruir mutilar o suporte. Em cada estágio subsequente do desenvolvimento traçado por Luquet ${ }^{133}$, Bataille vê a encenação de um novo desejo de alterar e deformar o que está diante do sujeito: "Arte, desde que é incontestavelmente arte, procede desse modo por sucessivas destruições. Assim, na medida em que ela libera instintos, esses são sádicos.” (KRAUSS, 1985: p.54)

O impulso humano para destruição determinaria uma tendência "não naturalista", que seria precedente à representação mimético-naturalista, como primeiro impulso artístico. Isso aconteceria tanto na criança como no homem primitivo, pois, para ele, o realismo naturalístico (visual) não dependeria da evolução intelectual ou das habilidades humanas, mas de uma mudança de comportamento promovida pela experiência do trabalho e, consequentemente, da sociedade. Através do trabalho, a intenção sádica dos humanos seria retardada em função da busca de resultados do mesmo, segundo o processo de concepção e execução (das ferramentas à caça; do plantio e colheita da agricultura). A razão deve cada vez mais prevalecer sobre a violência, coibindo excessos em função da

\footnotetext{
133 Para o etnógrafo George-Henri Luquet (1876-1965), estudioso dos desenhos infantis, as crianças evoluiriam de um realismo intelectual, caracterizado pela interpretação de rabiscos aleatórios aos quais daria um sentido conceptivo, para um realismo visual de reconhecimento das semelhanças entre o representado e o visto, justificando sua evolução para o desenho intencional e mimético. Bataille discorda dessa evolução rumo à intenção mimética. (KRAUSS, 1985: p.53)
} 
eficácia produtiva, do cálculo de esforço investido na ação em contraposição aos movimentos tumultuosos dos momentos agora delimitados de festa e jogo. O erotismo, cuja alma é a violência, também é reprimido. O homem consciente de sua constante transgressão, encontra-se divido.

\begin{abstract}
De modo que a vida humana é feita de duas partes heterogêneas que nunca se unem. Uma sensata, cujo sentido é dado pelos fins úteis, consequentemente subordinados: essa é a parte que aparece à consciência. A outra é soberana: quando a ocasião se apresenta, ela se forma graças a um desregramento da primeira, é obscura, ou antes, se ela é clara, cega; furta-se, assim, de toda maneira à consciência. Consequentemente, o problema é duplo. A consciência quer estender seu domínio à violência (quer que uma parte tão considerável do homem cesse de escapar). Do outro lado, a violência, para além de si mesma, busca a consciência (a fim de que o gozo que atinge seja refletido, e assim mais intenso e mais decisivo, mais profundo). Mas, sendo violentos, nos afastamos da consciência e, do mesmo modo, esforçando-nos por apreender distintamente o sentido de nossos movimentos de violência, nos afastamos desses desgarres e desses arrebatamentos soberanos que ela comanda. (BATAILLE, 2013: 220)
\end{abstract}

A produção e a reprodução do espaço abstrato constituiriam um instrumento político de perpetuação do poder das classes hegemônicas. A estratégia de abstração no sentido de Lefebvre se desenvolveria em três vertentes formantes; a geométrica, a visual e a fálica. Estas vertentes formantes de abstração do espaço teriam iniciado sua implementação no final da Idade Média, quando as cidades se definiram a partir de um centro mercadológico e local de trabalho coletivo sustentados pela produção excedente do campo. O espaço absoluto da vida monástica desaparecia e surgia o espaço da vida secular e, posteriormente, o das nações. A verticalização das catedrais, que marcavam a paisagem urbana aérea, proclamariam a autonomização da razão. A lógica visual arquitetônica evidenciaria o proeminência da razão. Ela ficava evidenciada na forma mais leve das estruturas nervuradas que eram iluminadas pelos vitrais, frisando suas funções estruturais segundo a clareza da lógica visual. "Em contraste com a maléfica utopia do mundo subterrâneo, proclamava uma utopia benevolente e luminosa onde o conhecimento seria independente, e em vez de servir ao poder opressor contribuiria para o fortalecimento de uma autoridade baseada na razão." (LEFEBVRE, 1991: 256). Corpos, animais e plantas são trazidos para a superfície aparente na arquitetura medieval. A tendência à visualização se juntará à abstração geométrica do espaço homogêneo euclidiano e da lógica, determinando 
a espetacularização de uma arquitetura fálica, segundo Lefebvre, que serve às autoridades que querem se impor.

A verticalidade e a arrogância política das torres, seu feudalismo, já aprofundava a aliança vindoura entre Ego e Phallus. (...)

O Phallus é visto. O órgão genital feminino, representando o mundo, permanece escondido. O prestigiado Phallus, símbolo do poder e da fecundidade, força caminho para se tornar ereto. No espaço por vir, onde o olho usurparia tantos privilégios, calhou do Phallus recebê-los ou produzi-los. O olho em questão seria aquele de Deus, aquele do Pai, ou aquele do Líder. Um espaço no qual o olho lança mão do que quer que sirva aos seus propósitos seria assim um espaço de força, de violência, do poder contido por nada além das limitações de seus meios. Esse era para ser o espaço do Deus trinitário, o espaço dos reis, não mais o espaço dos signos crípticos mas antes o espaço do mundo escrito e o regime da história. $\mathrm{O}$ espaço, também, da violência militar - e consequentemente um espaço masculino. (LEFEBVRE, 1991: 262)

Para Lefebvre, portanto, o final da Idade Média marcaria o início da disseminação do espaço abstrato, porque seria o período em que sua estrutura de reprodução se estabeleceria. Esta seria marcada pela centralização do Poder, do mercado e do sujeito, este identificado com a figura de Poder vigente (masculino, racional, violento e autocentrado). A autonomização da razão promovida pelo cristianismo favoreceria o estabelecimento da lógica abstrata do capitalismo monetário, que também operaria de modo desencarnado segundo o valor de troca e não de uso. A reprodução de tal espaço se dá pela violência, pela hierarquização e homogeneização das qualidades encontradas, agora disponibilizadas pela lógica da quantificação e da visualidade. Em contraposição ao espaço abstrato estaria o espaço a ser produzido com o corpo tomado em sua plenitude sensória. Vimos que para Worringer, a abstração corresponderia à preponderância da sensibilidade tátil, da visão aproximada e da imaginação capaz de recompor a fragmentariedade decorrente de tal modo de apreensão da realidade. Para ele, o gótico corresponderia ao momento de passagem da cultura, que era marcada pela sensibilidade para a coisa em si dos povos nórdicos, à tendência do vitalismo empático, trazido pela escolástica. Tal momento não corresponderia ao autocentramento do sujeito, conforme se verificaria no Renascimento, mas ao momento de individuação sem centro que se traduzia na angústia e no medo de separação do coletivo. Nesse sentido, temos uma diferença em relação à angústia do primitivo que era limitada ao espaço e vivida coletivamente. A arquitetura gótica apresentaria, portanto, um equilíbrio entre sensibilidade e razão, decorrente 
da expressão do cristianismo sob influência da mística e da escolástica que lhe foi característica. Para o ensaísta Otavio Paz, tal equilíbrio entre razão e sensibilidade corresponderiam também à rara situação de equilíbrio entre o corporal e espiritual, corpo e não-corpo. Somente a arte budista do primeiro século depois de Cristo teria compartilhado um momento de equilíbrio equivalente, só que invertido. As duas religiões postulariam a relação da realidade ontológica com o vazio, mas em direções opostas. O corpo e espírito são tomados como graus de realidade, signos que aparecerão na fantasmagoria de monstros e santos das duas religiões que acompanha a gradação.

\footnotetext{
Na primeira (budista indiana) acentua-se o corpóreo, por oposição complementar ao intelectualismo crítico e ao rigor ascético do budismo: frente ao catolicismo medieval - mais corporal e menos radical em sua crítica do mundo e da existência - as figuras das virgens e dos santos, pela mesma lei da oposição complementar, afirmam o elemento espiritual e incorpóreo.(...) Entre o infra mundo e o mundo superior há uma gradação de modos de ser - ou de modos da vacuidade. Nos dois casos, o equilíbrio consiste, como já disse, num leve desequilíbrio: corporeidade e sensualidade do budismo e, no catolicismo medieval, transfiguração espiritual dos corpos. Uma religião que nega realidade ao corpo, o exalta em sua forma mais plena: o erotismo; outra, que fez da encarnação seu dogma central, espiritualiza e transfigura a carne. (PAZ, 2018: 49 a 51)
}

Assim, podemos afirmar que existe um momento especial que corresponderia ao medievo. Esse não seria qualificado como aquele momento da primazia do intelecto e da autonomização da razão de fato, mas de equilíbrio entre corpo e mente. Segundo Worringer, a arquitetura Gótica evidenciaria aspectos estruturais tornados expressivos de um movimento para o alto, e daria também a impressão de desmaterialização, ou "espiritualização da matéria". Ela uniria a lógica à extática, que corresponderiam às influências da Escolástica (no exterior) e à Mística (no espaço interior) respectivamente. (WORRINGER, 1912: 69)

\section{O espaço gótico, o expressionista e o ciberespaço seriam equiparáveis?}

O equívoco de Waite reside na apreensão unidimensional das qualidades do espaço apresentadas por Lefebvre. O que, de início, seria uma divergência de nomenclatura, torna-se um erro de sentido. Lefebvre está criticando a homogeneidade do espaço abstrato, que ele associa à geometrização euclidiana, ao falocentrismo inerente ao verticalismo (das torres, dos edifícios altos, das praças de poderes), à fragmentação do espaço própria da divisão dos espaços de trabalho 
e lazer e da consequente deterioração da vida cotidiana assim determinada. Tal espaço, chamado de abstrato por Lefebvre, já estaria se dissolvendo desde o início do século XX, ainda que no pensamento epistemológico continuasse dominante, conforme se verificava na conduta dos arquitetos modernos.

O fato é que por volta de 1910 um certo espaço se estilhaçou. Esse era o espaço do senso comum, do conhecimento (savoir), da prática social, do poder político, um espaço até agora consagrado no discurso cotidiano, como no pensamento abstrato, como ambiente de e canal para comunicações; o espaço, também, da perspectiva clássica e geometria, desenvolvida da renascença em diante com base na tradição grega (Euclides, lógica) e incorporada adiante pela arte Ocidental e filosofia, como na forma da cidade (KRAUSS, 1985: p.54)e cidadela. (...) Espaço euclidiano e perspectivista desapareceram como sistemas de referência, junto com outros antigos "lugares comuns" tais como a cidade, história, paternidade, o sistema tonal na música, moralidade tradicional e assim por diante. (KRAUSS, 1985: p.25)

Para Virilio, Deleuze e Guattari, o espaço determinado pelo impulso abstrato (espaço liso para últimos) corresponderia à geometria pós-euclidiana e, efetivamente, não suporia um corpo que percebe segundo sua estrutura natural orgânica. Nesse sentido, a tentativa de mudança da primazia logocêntrica para o erotismo é comum a Lefebvre, Bataille e os pós-estruturalistas. À essa mudança corresponde a deformação do corpo nas narrativas iniciadas com o Expressionismo, como efeito do pathos histérico do homem moderno, e que culminarão no Surrealismo. Virilio associa a disseminação na modernidade de imagens corporais fragmentadas e deformadas à experiência de velocidade do avião nas guerras, compartilhada no cinema e por ele mesmo apropriado esteticamente. Waite permanece preso à estética do realismo de Lukács. O espaço que surge a partir de 1910 é associado à transparência, que é o tema do próximo capítulo. 


\section{5. \\ Transparência}

5.1.

\section{O mito da sociedade transparente}

O ideal de uma sociedade transparente não se realizou a partir da boa educação, do progresso científico e tecnológico, conforme previam pensadores iluministas e modernos. Nem mesmo a democratização dos meios de comunicação, tais como jornais, televisão e, contemporaneamente, das redes de alcance mundial que transmitem informações em tempo real levaram o homem à "autoconsciência de toda a humanidade, a coincidência entre aquilo que acontece, a história e a consciência do homem." (VATTIMO, 1992: 12). Para o filósofo Gianni Vattimo, o efeito da multiplicação das mídias de massa levaram ao efeito contrário àquele da transparência, promovendo o atrito e a contaminação entre as imagens, interpretações e reconstruções da realidade apreendida. De tal modo, que a própria ideia de transparência teria perdido seu fundamento estável e levado à noção de que a busca de clareza e distinção evidentes que a acompanhavam não passaria de fabulação. Mesmo as ciências não deteriam mais o estatuto da objetividade do conhecimento em relação à exterioridade de um "real já constituído e ordenado" da natureza. Elas participariam, através do desenvolvimento tecnológico, não só com a manipulação e tentativa de domínio dessa realidade como com a produção e transmissão de imagens do mundo. Nesse sentido, constituindo-se também como as demais ciências humanas em estreita ligação com a sociedade da comunicação: "esta sociedade em que a tecnologia tem o seu apogeu na "informação" é também, essencialmente, a sociedade das ciências humanas - no duplo sentido, objetivo e subjetivo, do genitivo: aquela que é conhecida e construída, com seu objeto adequado, pelas ciências humanas; e aquela que se exprime (...) nestas ciências” (VATTIMO, 1992: 23).

A amplificação dos meios de comunicação, sejam eles as expedições científicas, a imprensa de Gutenberg ou a rede mundial de internet, teriam contribuído para o surgimento de novos campos de experiência e conhecimento, que determinariam o surgimento de novas instituições, formas simbólicas e culturas e novos campos das ciências humanas tais como a sociologia, a antropologia e a psicologia. Tais novos campos não deixaram, no entanto, de 
serem movidos por uma utopia de transparência e emancipação do real (pressupondo o sujeito central contraposto) herdada do Iluminismo por serem alimentadas pela metafísica que dominou historicamente o pensamento ocidental.

(...) a metafísica é ainda uma forma violenta de reagir a uma situação de perigo e de violência; procura, de facto, apoderar-se da realidade com um "golpe de mão", alcançando (ou imaginando alcançar) o princípio primeiro de que tudo depende (e assegurando-se assim ilusoriamente o domínio dos acontecimentos). Heidegger, prosseguindo nesta linha de Nietzsche, mostrou que pensar o ser como fundamento, e a realidade como sistema racional de causas e efeitos, é apenas uma forma de alargar a todo o ser o modelo da objetividade "científica", da mentalidade que, para poder dominar e organizar rigorosamente todas as coisas, as deve reduzir ao nível de puras presenças mensuráveis, manipuláveis, substituíveis - reduzindo por fim a este nível também o próprio homem, a sua interioridade, a sua historicidade. (VATTIMO, 1992: 14)

O iluminismo teria estendido a busca do conhecimento das novas realidades humanas a um projeto de emancipação e transformação das mesmas segundo um ideal de liberdade e transparência proporcionada pelo "“cientismo" positivista" que o acompanhava: "sociedade livre é aquela em que o homem se pode tornar consciente de si numa "esfera pública", a da opinião pública, da livre discussão, etc., não ofuscada por dogmas, preconceitos, superstições”. (VATTIMO, 1992: 25). Tal ideal de transparência de comunicação persistiria na teoria social contemporânea através da pressuposição de uma "comunidade ilimitada da comunicação”, que corresponderia à idealização da sociedade de comunicação como sujeito transcendental da ciência.

A sociedade da comunicação ilimitada, aquela em que se realiza a comunidade do socialismo lógico, é uma sociedade transparente, que precisamente na liquidação dos obstáculos e das opacidades, mediante um procedimento que se forma largamente a partir de uma certa ideia de psicanálise, chega a também reduzir radicalmente os motivos de conflito. (VATTIMO, 1992: 27)

A intensificação da troca de informações na modernidade não teria tornado o homem mais plenamente autoconsciente ou livre de manipulações ideológicas, mas apenas evidenciado a impossibilidade de uma hipótese unificante para descrever a realidade que não correspondesse à fabulação da mesma, do sujeito de enunciação transcendental (seja ele relacionado às ciências humanas ou a algum domínio de político ou econômico) e da transparência da linguagem. A pósmodernidade seria marcada, portanto, pela ruptura com a perspectiva unitária da realidade e da história e pela tentativa de enfrentamento da mesma segundo 
perspectivas fragmentárias, oscilantes e plurais. Como decorrência de tal fato, a crença nos projetos de emancipação e progresso também teriam ruído. A possível desmobilização social, nesse sentido, não decorreria necessariamente dos efeitos de alienação e manipulação dos desejos, promovidos pelas mídias de massa ou pela fragmentação da visão de mundo, conforme apontavam hegelianos tais como Adorno e Lukács respectivamente. Para Vattimo, pelo contrário, o efeito de fragmentação da realidade poderia abrir caminho para a experiência "de “confusão" dos dialetos" (VATTIMO, 1992: 16) e para o Outro: outros mundos e outras formas de vida. A consciência da fabulação do mundo despertada pela fragmentação e multiplicação de perspectivas levaria a transparências e liberdades oscilantes, a um tipo de verdade fraca. As narrativas pós-colonialistas, não-eurocêntricas e as subculturas seriam exemplos de abertura da experiência com impacto sobre a vida política na era da comunicação disseminada.

\begin{abstract}
Mas em que consiste, mais especificamente, a possível capacidade de emancipação, de libertação, da perda do sentido da realidade, do verdadeiro desgaste do princípio de realidade no mundo dos mass media? Aqui a emancipação consiste mais no desenraizamento, que é também, e ao mesmo tempo, libertação das diferenças, dos elementos locais, daquilo que poderíamos chamar, globalmente, o dialecto. Derrubada a ideia de uma realidade central da história, o mundo da comunicação generalizada explode como uma multiplicidade de racionalidades "locais" - minorias étnicas, sexuais, religiosas, culturais ou estéticas - que tomam a palavra, finalmente já não silenciadas e reprimidas pela ideia de que só exista uma única forma de verdadeira humanidade a realizar, com prejuízo de todas as peculiaridades, de todas as caracterizações limitadas, efémeras, contingentes. (VATTIMO, 1992: 15)
\end{abstract}

Para Vattimo, o período pós-moderno corresponderia ao momento de desmistificação da desmistificação deflagrada por Nietzche através do questionamento da metafísica e desenvolvida ao longo da modernidade. O primeiro momento de desmistificação teria levado a uma legitimação dos mitos como saber primitivo e se identifica ainda com os processos emancipatórios promovidos pela razão iluminista. Nesta acepção, o mito era concebido como saber anterior ao científico relacionado a narrativas fantásticas e emocionais que encobriria a realidade fenomênica, que estaria relacionado à religião, arte, rito e magia e que seria desvelado pela ciência. $\mathrm{O}$ segundo momento corresponderia à desmistificação da razão associada ao pensamento metafísico. A carência de uma concepção filosófica da história desvinculada da noção unitária de origem e progresso, no entanto, entravaria tais processos de desmistificação da metafísica, 
incorrendo em tendências à distopia ou à utopia. Vattimo descreve o predomínio de três tendências delas: arcaísmo, relativismo cultural e irracionalismo mitigado. A primeira resvalaria numa atitude nostálgica e escapista de recusa da cultura tecno-científica e de volta àquelas primitivas e não-ocidentais. Ela estaria relacionada às vanguardas artísticas do Surrealismo e do Expressionismo, bem como às preocupações ecológicas atuais, para ela: "o mito não é uma fase primitiva e superada da nossa história cultural, mas antes uma forma de saber mais, não devastada pelo fanatismo puramente quantitativo e pela mentalidade objetivamente própria da ciência moderna, da tecnologia e do capitalismo." (VATTIMO, 1992: 39). A segunda tendência do relativismo equipararia mito e ciência, considerando que a base de tais saberes escaparia igualmente do saber racional e da demonstração, posto que seria a representação da experiência vivida incorporada na forma de crenças. A hermenêutica heideggeriana e a antropologia deslizariam nesse sentido problemático da impossibilidade de isolar objetos de estudo, mundos culturais, que elas próprias enunciam.

O estudo das "outras" culturas acontece já sempre num contexto que torna impossível, e artificialmente falsa, a pretensão de as representar como objetos separados; elas são, pelo contrário, interlocutoras de um diálogo que, no entanto, uma vez reconhecido, coloca o problema do horizonte comum em que de facto acontece, tornando inútil a separação pressuposta pelo relativismo. (VATTIMO, 1992: 45)

E a terceira tendência seria o irracionalismo mitigado, que identificaria o mito com o sentido etimológico da estrutura de narração e que se contraporia ao caráter descritivo, demonstrativo e objetivo da ciência. Ela se encontraria na psicanálise, nas teorias da historiografia que aceitam a pluralidade da narratividade histórica e na análise sociológica dos produtos das mídias de massa segundo uma mitologia de conteúdos. Tal tendência, no entanto, pressuporia uma distinção de campos entre as ciências naturais e do espírito que não se poderia mais comprovar, pois "também a ciência exata é uma empresa social: (...) os métodos objectivantes das ciências da natureza são um momento no interior de um contexto que, como tal, entraria de pleno direito no campo das ciências histórico-sociais." (VATTIMO, 1992: 45)

A filosofia historiográfica proposta por Vattimo dependeria das três tendências no sentido de definir um contexto narrativo entre a pluralidade 
existente, que não busca uma origem e nem presume um sentido determinado de progresso. Aceita-se certo grau de arbitrariedade associado aos mitos da razão e do progresso das ideias por parte do narrador, entendendo a verdade como provisória. A interpretação histórica promoveria, portanto, tanto o esvaziamento quanto a distorção de sentido do que é tomado como fato histórico, num sentido que Vattimo associa à secularização das narrativas. Tal movimento de secularização permitiria vislumbrar tanto o sentido de continuidade quanto de transformação dos fatos descritos, porque não seria dissociado da consciência do mito e de sua desmistificação enquanto verdade enfraquecida.

O espaço que se abriria para o suposto desvelamento e transparência nebulosa do ser não seria o do passado originário e nem o do futuro utópico ou distópico, mas aquele heterotópico aberto pela experiência da arte. A arte na era da sociedade da cultura de massa seria modificada pelas novas formas de produção e fruição. Tal modificação teria implicado numa tendência a encará-la como em processo de decadência, conforme já apontava a crítica de Lukács ao Expressionismo, sendo rejeitada. Para Vattimo, a tendência à aceitação de tais obras, que seriam expressões do sujeito metropolitano e da cultura de massa, representada por Adorno e Ernst Bloch, também não teria conseguido dissociar-se de um ideal de conciliação e perfeição utópico associado à metafísica ocidental.

Quando Adorno nega que a arte possa realmente (ou deva) perder sua aura que a isola da quotidianidade, defende certamente o poder crítico da obra em relação à realidade existente; mas adopta também, e mantém, a concepção da arte como lugar de conciliação e de perfeição que se exprime em toda a tradição metafísica ocidental, de Aristóteles a Hegel. (VATTIMO, 1992: 52)

Para Vattimo, a grandeza da obra de arte na sociedade de comunicação residiria no seu poder de desenraizamento e oscilação e não de conciliação. Para ele, a noção de conciliação seria dependente de uma definição metafísica de interioridade e exterioridade humanas associadas à ideia do belo, à catarse e ao sentimento de proteção, segurança e abrigo. "Desde a doutrina de Aristóteles da catarse ao livre exercício das faculdades de Kant, ao belo como perfeita correspondência entre interior e exterior em Hegel, a experiência estética parece ter sido sempre descrita em termos de Geborgenheit - de segurança, de “enraizamento” ou "reenraizamento". (VATTIMO, 1992: 58). 
A conciliação não definiria a experiência estética no pós-moderno porque pressupõe um critério estético tal que seria comum a toda humanidade e que, na verdade, estivera historicamente restrito à comunidade estética europeia. O eurocentrismo de tais concepções teria sido colocado em questão com os processos de desmistificação e multiplicação de narrativas promovidos pela crítica ao pensamento metafísico, dando espaço e voz para outras comunidades culturais. A multiplicação de comunidades na sociedade de comunicação se caracterizaria pela pluralização de critérios de beleza e formais. $\mathrm{O}$ belo teria perdido seu lastro metafísico e se definiria então como ornamental devido seu caráter existencial, superficial e aberto. "O belo não é o lugar de manifestação de uma verdade que nela encontra expressão sensível, provisória, antecipadora, educativa, como muitas vezes pretendeu a estética metafísica da tradição”. (VATTIMO, 1992: 76). A tentativa de tomar como cânone a teoria estética da conciliação com o belo na identificação com um objeto ou estrutura de objeto esbarraria na experiência do Kitsch e não numa experiência estética. "Kitsch é, (...), apenas aquilo que, na época do ornamento plural, pretende ainda valer como monumento mais perene que o bronze, reivindica ainda a estabilidade, o "caráter definitivo", a perfeição da forma "clássica" da arte" (VATTIMO, 1992: 77). O belo pós-moderno não estaria aderido às relações de composição da obra traduzidas em sua forma. Também o sujeito tardo-moderno não se configuraria como sujeito centrado, capaz de experimentar a obra contemplativamente, segundo a conciliação de mundo interior e exterior; mas sim, conforme apontaria Benjamin, distraidamente e superficialmente. A própria experiência de excesso de estímulos metropolitana teria alterado sua sensibilidade para a experiência, marcando-o pela alienação, pelo espírito blasé e calculista etc.

Segundo Vattimo, o ideal de conciliação do homem e com o ambiente, da felicidade e de recuperação da essência do homem pela arte teria sido conservado nas utopias de salvação pela aproximação da experiência estética do quotidiano, que marcaram os movimentos artísticos das primeiras vanguardas até a dos anos 1950. A suposta ruptura das vanguardas com o esteticismo em função de um projeto social não teria sido, portanto, integral. O que se poderia verificar tanto na ideologia do design relacionada à Bauhaus, passando pelo Surrealismo e chegando no Situacionismo. Além disso, tal ideal de conciliação incorria no 
ajuizamento da obra em relação ao que seria a essência da arte. Tal essência se definiria a partir do horizonte utópico das diferentes correntes e em função da definição de um curso histórico unitário a ser seguido.

Vattimo retoma o ensaio de Walter Benjamin de 1936, A Obra de Arte na Época da sua Reprodutibilidade Técnica para reintroduzir o conceito de Choque comparativamente ao conceito heideggeriano de Stoss, apresentado no ensaio A Origem da Obra de Arte de 1936, e através dessa comparação colocar a questão do ser no mundo contemporâneo transformado pela presença das mídias de massa, da ubiquidade do mercado, da instrumentalidade técnica e da institucionalização da arte. Segundo a leitura que Vattimo faz de Heidegger, a experiência estética abriria um tipo de espaço favorável para colocar a questão do ser diante do sujeito fragmentado e desenraizado da modernidade e pós-modernidade, assim considerado tanto na identificação com os primeiros metropolitanos como com aquele da era da comunicação mundial em rede. Embora Heidegger fosse um crítico dos efeitos da razão instrumentadora disseminada pela técnica, assim como Adorno e Benjamin, também não teria a priori uma concepção da obra de arte associada à forma orgânica. Benjamin e Heidegger identificariam a possibilidade de libertação das imposições das lógicas de mercado e da técnica numa impossibilidade de conciliação com a obra que não pressuporia sua autonomia dos valores de uso e troca, conforme defendia Adorno ${ }^{134}$. Para eles, o valor da obra na era da reprodutibilidade técnica se dava no plano dos efeitos de desenraizamento promovidos pela obra através do choque. Para Benjamin, os meios técnicos de produção da arte, tal como é o cinema, provocariam o afeto do medo da morte, necessário para despertar o espectador alienado pela rotina enervante daquele que se defronta com o tráfego e com a multidão nas grandes cidades. "O cinema é feito, também ele, de projécteis, de projecções: logo que uma imagem é formada, já é substituída por outra, à qual o olho e a mente do espectador se devem readaptar”. (VATTIMO, 1992: 55)

\footnotetext{
134 "Quando Adorno nega que a arte possa realmente (ou deva) perder a aura que a isola da quotidianidade, defende certamente o poder critico da obra em relação à realidade existente; mas adopta também, e mantém, a concepção da arte como lugar de conciliação e de perfeição que se exprime em toda tradição metafísica ocidental, de Aristóteles a Hegel." (VATTIMO, 1992: 52)
} 
Os meios técnicos de reprodução também não constituiriam um empecilho para a experiência estética conforme entendida por Heidegger, pois a técnica compreendida por sua noção de Ge-Stell, aponta Vattimo, é simultaneamente uma “im-posição" e uma provocação para o homem pensar o ser: "a essência da técnica moderna assim definida não é apenas o ponto de chegada supremo do esquecimento metafísico do ser: para Heidegger, o Ge-Stell é também "um primeiro e premente brilhar do Ereignis", isto é, do evento do ser, para além do seu esquecimento metafísico.". (VATTIMO, 1992: 61). A provocação do GeStell possibilitaria repensar as contraposições engessadas pela metafísica, tais como os pares natureza e artifício; liberdade e necessidade; homem e Cyborg. Afinal o mundo da técnica não tornou o homem necessariamente escravo ou mais livre das determinações naturais, sociais ou mesmo técnicas. Tais domínios estariam intrinsecamente misturados e seu isolamento recairia naquelas tendências escapistas alimentadas por vestígios metafísicos da ideia de homem, natureza e da própria técnica, apontadas por Vattimo em sua análise sobre arcaísmo, relativismo e irracionalismo mitigado. A liberdade deveria ser pensada não a partir do paradigma maior da falta de liberdade possível, que é a morte, mas do medo desta demonstrado no sentimento de angústia e desenraizamento. Estaríamos novamente diante do pathos histérico: a provocação de êxtase que Worringer associava ao gótico (individuado, mas ainda não um sujeito centrado conforme vimos) e ao impulso para a abstração?

Assim o Ge-stell e a obra de arte seriam fenômenos do mundo contemporâneo que "realizariam a verdade", porque seriam acontecimentos (Ereignissen) do ser processados na "exposição do mundo e produção da terra". O desenraizamento não espelharia apenas a crise do homem moderno nas grandes cidades, mas o fato de o homem ter desaprendido a habitar, morar. Para Heidegger, a técnica de construir constituiria o meio de habitar do homem, porque prefiguraria "sob um mesmo teto a marca de sua passagem através do tempo. Um negócio, também nascido do "habitar" e que ainda usa suas ferramentas $e$ andaimes como coisas, construiu a morada" (CHOAY, HEIDEGGER, 2013: 348). O sentido da construção teria caído no esquecimento, bem como o ser do homem no habitar. Morar seria tanto cuidar e proteger, como livrar: devolver alguma coisa a seu próprio ser. 
Os mortais habitam, ainda que salvem a terra. Salvar (retten) não é só arrancar de um perigo, é propriamente liberar uma coisa, deixá-la voltar a seu ser próprio. Salvar a terra é mais que tirar proveito dela e, com maior razão, mais que esgotála. Quem salva a terra não se torna seu dono, não a converte em súdita. (CHOAY, HEIDEGGER, 2013: 348)

Para Heidegger, o pensamento e o construir constituem o habitar. O habitar das grandes cidades refletiria o modo de pensar do homem moderno. Se pensar e habitar não significam aderir ao mundo estabelecido, devolver o homem a seu próprio ser denotaria mais do que liberá-lo das intempéries da terra ou dos efeitos da estrutura do mundo de mercado e da técnica. Pensar levaria ao reconhecimento da crise do saber habitar como desenraizamento. "Assim que o homem, entretanto, passa a considerar o desenraizamento, este já deixa de ser uma miséria (Elend). Justamente considerado e mantido, ele é o único apelo que convida os mortais a habitar" (CHOAY, HEIDEGGER, 2013: 349).

A origem técnica da obra, portanto, comporia o acontecimento da obra de arte no mundo moderno. A técnica determinaria tanto a dimensão do acontecimento quanto a da submissão ao consumo. $\mathrm{O}$ desenraizamento que convida a pensar seria provocado pelo efeito do choque que as grandes obras de arte sempre provocariam. O Stoss não implicaria em abstrair o mundo de consumo na obra, mas pelo contrário, através do choque, revelar a insignificância dessa lógica estabelecida (remontando a Schopenhauer). O Stoss da arte seria vivido como a angústia descrita por Heidegger em $O$ Ser e o Tempo, como experiência de não se sentir em casa: "a angústia registra esta insignificância, a gratuidade total do facto do mundo existir. A experiência da angústia é uma experiência de “desenraizamento" (de Un-heimlichkeit, de Un-zu-Hause-sein)" (VATTIMO, 1992: 56). É nessa atmosfera de crise, ansiedade e medo provocado pelo choque que a obra provocaria espanto e fundaria mundo, "dado que se apresenta como uma nova “abertura" histórico-eventual do ser" (VATTIMO, 1992: 56).

(O significado do Stoss) é, essencialmente, o mesmo: colocar em estado de suspensão a evidência do mundo, suscitar um espanto preocupado pelo facto, em si insignificante (em sentido rigoroso, que não remete para nada: ou que remete para o nada), do mundo existir. (VATTIMO, 1992: 57)

A experiência estética corresponderia, nesse caso ao oposto da conciliação, corresponderia ao estranhamento sem retorno. $\mathrm{O}$ desenraizamento provocado pelo 
estranhamento da obra de arte é mantido em contraposição à familiaridade e segurança proporcionadas pelos objetos de uso. A obra de arte seria mais "desfundante" de mundo que fundante.

\begin{abstract}
Fundação e "desfundamento" são o sentido dos dois aspectos que Heidegger indica como constitutivos da obra de arte, isto é, exposição (Auf-stellung) do mundo e pro-dução (Her-stellung) da "terra". O mundo exposto pela obra é o sistema de significados que ela inaugura; a terra é produzida pela obra quando é apresentada, mostrada como o fim obscuro, nunca totalmente consumável em enunciados explícitos, sobre a qual o mundo da obra se radica. Se, como se viu, o desenraizamento é o elemento essencial e não provisório da experiência estética, deste desenraizamento é responsável muito mais a terra que o mundo: só porque o mundo de significados alargado à obra surge como obscuramente radicado (portanto, logicamente, não "fundado") na terra, a obra produz um efeito de desenraizamento: a terra não é o mundo, não é sistema de relações significativas, é o outro, o nada, a geral gratuidade e insignificância. A obra só é fundação enquanto produz um contínuo efeito de desenraizamento, nunca recomponível numa Geborgenheit final. A obra de arte nunca é tranquilizante, "bela" no sentido da perfeita conciliação de interior e exterior, essência e existência etc. (VATTIMO, 1992: 59)
\end{abstract}

A obra produz o outro, o nada, a insignificância e, assim, produz a terra. $\mathrm{O}$ espaço que a obra abre também reflete tal insignificância, por isso não poderia ser identificado com aquele da utopia atrelada à narrativa historiográfica como curso unitário e universal. Segundo Vattimo, o mundo da cultura de massa favoreceria estranhamente a realização de utopias estéticas sonhadas desde o Iluminismo, como a espiritualização da vontade humana em Schiller ou do cotidiano na Bauhaus. A difusão comunicativa multicultural promoveria a dissolução da concepção metafísica da obra de arte que teria dominado a cultura Ocidental, demandando um novo modo de experimentação que é baseado no sentimento de desenraizamento. As obras se realizariam como a acima citada abertura obscura na terra, como o espaço "Outro", insignificante e não apaziguador, da heterotopia. A experiência estética se desenvolveria como acontecimento indissociável da vida e da perspectiva de morte, mas não abarcável segundo valores estéticos (humanos) presumidamente universais. A experiência estética se daria na multiplicidade dos mundos heterotópicos que podem surgir nas diversas comunidades de fruidores. 


\section{2.}

\section{Transparência abjeta}

\section{A obscenidade do real}

A experiência do desenraizamento, associada à obra de arte e à arquitetura desenvolvidas posteriormente à revolução industrial e tecnológica e ao desenvolvimento da sociedade de comunicação em massa, não é comumente, contrariamente à leitura de Vattimo, associada à abertura para a experiência do habitar e para realização da verdade. Conforme verificamos no debate Expressionista e nas outras leituras embasadas no pensamento simmeliano, o desenraizamento experimentado pelo sujeito fragmentado moderno é comumente associado à alienação e a diversos sintomas neuróticos e psicóticos. O ápice de tal desenraizamento seria simbolizado pela ameaça representada pelos robôs e ciborgues, manifestado primeiramente na literatura de ficção científica e no cinema, e pela disseminação da realidade virtual na era digital. A experiência do desenraizamento seria levada assim da relação com o ambiente para o presumido limite do corpo sadio ou não, natural ou protético. Os sintomas neurastênicos corresponderiam ao lado reverso da busca de transparência iniciada pelos Iluministas sob a égide da razão, clareza e distinção; e da identificação destas com uma percepção visual imediata. Eles demonstrariam tanto o lado sombrio do homem quanto do espaço produzido por ele na sociedade de comunicação. A busca de transparência seria assim revertida em opacidade e numa distopia.

A arte pós-1960 hiper-realista, descrita por Hal Foster no livro $O$ retorno do real é descrita como um fenômeno do sintoma traumático de repetição, que reelabora experiências relacionadas às primeiras vanguardas, tais como a desmistificação da desmistificação do sujeito de criação e da obra de arte já levantadas pela arte Pop (de tendência representativo-ilusionista esvaziada ou com referencial engajado) e pelo Minimalismo (de tendência abstrata). No lugar do sujeito vazio, a obra hiper-realista se referiria ao sujeito traumatizado pelo choque. A obra estaria relacionada ao realismo traumático, que seria definido por Lacan como encontro faltoso como o real, aquele que não podendo ser representado, geraria o impulso para a repetição que encobre um choque traumático primário. $\mathrm{O}$ sujeito do trauma estaria destituído do anteparo que o 
separa do mundo através do jogo entre percepção e consciência, experimentaria assim a confusão entre o dentro e o fora, de si com o mundo. A teoria da arte elaborada por Foster, derivada de princípios psicanalíticos, também evidencia o papel da visualidade e do olhar ao relacioná-las à questão da repetição traumática, não mais estritamente relacionados à transparência do conhecimento ou à contemplação estética, mas segundo a tese apresentada no seminário de Lacan sobre o olhar. Lacan, retomaria a fenomenologia de Merleau-Ponty, ao considerar o olhar como preexistente ao sujeito, mas iria além ao considera-lo uma ameaça vinda de todos os lados: "de acordo com Lacan, esse "olhar, enquanto objeto a, pode vir a simbolizar a falta central expressa no fenômeno da castração" (FOSTER, 2014: 132). O domínio do sujeito da visão autoconsciente seria sobreposto pelo olhar que emana do objeto, sentido como sendo "visto vendo". A contemplação estética implicada na arte operaria como uma proteção contra tal troca de olhares entre sujeito e objeto. $\mathrm{O}$ universo simbólico disponibilizado pela arte serviria como anteparo de mediação com o real, transformando-o em imagens e fornecendo imagens. A arte contemporânea hiper-realista recusaria esta domesticação do olhar através da mediação do anteparo, evocando o olhar ameaçador do real que leva a experiência ao sublime, obsceno e grotesco, conforme se verificaria na tendência desenraizante da arte abjeta. Abjeto, definido por Julia Kristeva como não-ser, seria relacionado ao corpo antes da separação da mãe e do cadáver e traduziria a condição do sujeito contemporâneo.

(...) o abjeto é aquilo de que devo me livrar para me tornar um eu (mas o que é esse eu primordial que primeiro lugar expulsa?). É uma substância fantasmática não só estranha ao sujeito, mas também íntima dele - íntima demais, até, e esse excesso de proximidade produz pânico no sujeito. Nesse sentido, o abjeto afeta a fragilidade de nossas fronteiras, a fragilidade da distinção espacial entre nosso interior e nosso exterior bem como a da passagem temporal entre o corpo materno (mais uma vez, o domínio privilegiado do abjeto) e a lei paterna. (FOSTER, 2014: 132)

A obra da artista Cindy Sherman operaria tanto no sentido do desprezo pelo anteparo quanto no foco dado ao olhar-objeto. Suas fotografias aparecem como que capturadas pelo olhar, vindo de outro sujeito, do mundo espetacularizado da propaganda e do cinema ou de dentro do próprio sujeito desenraizado. 
Aqui Sherman mostra seus sujeitos femininos como auto-observados, não na imanência fenomenológica (vejo-me vendo-me), mas no estranhamento psicológico (não sou o que imaginava ser). Logo, na distância entre a jovem maquiada e seu rosto refletido no espelho em Sem título \#2 (1977), Sherman captura a lacuna entre as imagens do corpo, imaginado e real, que se abre em cada um de nós, a lacuna do (ir)reconhecimento em que as indústrias da moda e do espetáculo operam dia e noite. (FOSTER, 2014: 142)

Ela retrataria o estranhamento psicológico provocado pela comparação entre a autoimagem e a imagem produzida pela indústria cultural, entre o corpo imaginado e o corpo real através de um processo de des-idealização e dessublimação que levariam ao terror e à repulsão próprios da arte abjeta, com cenas de decadência, morte e "corpos virados pelo avesso". Imagens de corpos que aparecem fraturados, informes, e do sujeito que aparece dissolvido no espaço remeteriam ao estado de indistinção e descentramento esquizofrênico, descrito por Roger Callois: "O corpo, então, se separa do pensamento, o indivíduo rompe a fronteira de sua pele e habita do outro lado dos seus sentidos. Ele procura se ver de um ponto qualquer do espaço. Ele mesmo se sente virar espaço, espaço negro onde não se podem pôr coisas" (CALLOIS, FOSTER, 2014: 155). Tal dissolução de figura e fundo, sujeito e o outro apontariam o obsceno do real evocado pelo olhar-objeto sem nenhum anteparo, sem uma "moldura da representação para contê-lo" (FOSTER, 2014: 144).

\section{O espaço paranoico}

Para o crítico de arquitetura, Anthony Vidler, o renascimento da busca por transparência na arquitetura seria um indício tanto da mudança de seu significado quanto da patologia esquizoide do sujeito contemporâneo. O desenvolvimento dos Grands Projets desenvolvidos durante os governos François Miterrand a partir dos anos 1980 dariam o testemunho de um fenômeno de retorno da transparência que se distanciaria do paradigma moderno da máquina. Além disso, apesar desses projetos responderem a programas simbólicos associados à história de Paris e seus monumentos e à representação do Estado francês, tais como a pirâmide no museu do Louvre e a Biblioteca Nacional nos arredores da Torre Eiffel, os projetos em sua massa vítrea almejavam desaparecer no contexto. O desaparecimento da arquitetura no contexto da cidade corresponderia ao movimento oposto àquele do sujeito universal, metafisicamente concebido, ao qual correspondeu a arquitetura 
transparente, monumental e disciplinar associada ao período do Iluminismo e também, em certo sentido, ao modernismo em sua vertente funcionalista. A tendência ao desaparecimento dos novos edifícios contradiria sua função de monumento urbano.

Para Vidler, a arquitetura do desaparecimento dos novos edifícios de Paris espelhariam a condição do sujeito metropolitano pós-moderno. O sujeito contemporâneo viveria a sensação de perda da unidade orgânica do corpo e a fetichização desse corpo-cadáver perdido. As bio-tecnologias e a cibernética teriam contribuído para confundir os limites entre os corpos orgânicos e inorgânicos que determinariam a perversão contemporânea. O Surrealismo já operaria uma estética da fetichização biotecnológica, que teria sido antecipada pelos Frankenstein e outros monstros do romantismo até chegar nos ciborgues contemporâneos $^{135}$.

Agora, os limites entre orgânico e inorgânico, borrados pela cibernética e biotecnologias, parecem menos acentuados; o corpo em si invadido e reconfigurado pela tecnologia invade e permeia o espaço exterior, mesmo se este espaço assume dimensões que em si confundem o interior e o exterior, visualmente, mentalmente e fisicamente. "L'homme-type", o modulor musculoso, apareceu através de uma combinação de aparatos protéticos, drogas, e escultura corporal despontada como ciborgue, um mutante potencialmente sem gênero, e seu lar não é mais uma casa. (VIDLER, 1992: 147)

A arquitetura contemporânea desenvolveria um desdobramento da transparência fenomênica inaugurada pelas pintura e arte abstratas no início do século XX, conforme definido por Colin Rowe e Robert Slutzky (ver item adiante). Para Vidler, a arquitetura da transparência contemporânea, no seu esforço em romper com o paradigma antropomórfico herdado da tradição clássica, viria desenvolvendo uma arquitetura Unheimlich, que incitaria o sentimento do desenraizamento levado a extremo tal que o sujeito extático experimentaria o próprio desmembramento corpóreo e a diluição de sua consciência no espaço. Tal como na arte abjeta descrita por Hal Foster, a transparência opaca da arquitetura contemporânea refletiria como um olhar que alcança o sujeito sem a proteção do anteparo das representações. O projeto do arquiteto Rem Koolhaas (Fig. 21, 22 e

135 "Proponho o conceito de cyborg, um ser que desconhece a nostalgia associada ao nascimento, mas que apresenta todos os efeitos espectrais do duplo, como manifestação típica do estranhamente familiar que continua a assombrar a cultura contemporânea." (VIDLER, 2006: $620)$. 
23), que integrou a competição para a Biblioteca Nacional Francesa em 1989, ilustraria a noção de espaço paranoico desenvolvida por Vidler. Podemos comparar tal projeto, conforme a interpretação vidleriana, à arte abjeta por reconhecer em ambas as narrativas os seguintes pontos em comum: o pressuposto pathos alienado/desenraizado do sujeito moderno metropolitano, a espetacularização promovida pelos meios de comunicação e a explicação psicanalítica lacaniana traduzida na introdução do objeto $a$.

Koolhaas descreve seu projeto como uma estratégia de vazios que substitui o procedimento da construção, "abortando" os procedimentos usuais de projeto que visam a determinação de uma forma a priori. O edifício se configuraria como resíduo de um processo de eliminação. Sua transparência, ora tornada transluzente ou opaca é assim interpretada: “misteriosa, reveladora, ou muda...Quase natural - como um céu nublado à noite, como um eclipse..." (KOOLHAAS; MAU, 1995: 654)

\begin{abstract}
A própria Grande Biblioteca é interpretada como um sólido bloco de informação, um repositório de todas as formas de memória - livros, discos laser, microfilmes, computadores, banco de dados. Nesse bloco, a maior parte dos espaços públicos é definida como "ausências de edificação", vazios escavados no sólido na informação. Flutuando na memória, eles são embriões múltiplos, cada qual com sua própria placenta tecnológica.
\end{abstract}

Já que são vazios- eles não precisam ser "construídos" - bibliotecas individuais podem ser configuradas estritamente de acordo com sua própria lógica, independente uma da outra, do envelope externo, das dificuldades usuais da arquitetura, até mesmo das leis da gravidade. (KOOLHAAS; MAU, 1995: 616)

A gigantesca biblioteca (250.000) não abrigaria apenas impressos em papéis, mas incluiria todas as imagens além das palavras produzidas desde 1945, que poderiam ser acessadas em tablets ou na salas de cinema. O programa já pressupunha o sistema eletrônico de comunicação integrada que, para o arquiteto, contradiria a necessidade colecionadora materializada num espaço de tamanha grandeza, exceto pela possibilidade de acomodar o "persistente desejo de coletividade” num espaço simbólico.

Anthony Vidler descreve o projeto de Koolhaas para a biblioteca como um bloco cúbico de vidro com órgãos internos flutuantes escavados "tal como um modelo anatômico" (VIDLER, 1992: 221). Sua transparência seria configurada a partir de um volume vítreo sólido escavado e não como a forma usual da 
membrana transparente encobrindo um espaço vazio interior. Os vazios escavados se sobreporiam e apareceriam como densidades flutuantes planificadas na fachada, reduzindo a transparência a uma translucidez sombria que encobriria o interior num simulacro.

A inerente qualidade da transparência absoluta de se transformar no oposto, refletividade, é lançada em dúvida; o sujeito não pode mais se perder em l'espace indicible da razão infinita ou encontrar-se no narcisismo de sua própria reflexão. Em vez disso, é suspenso num momento difícil entre o conhecimento e o bloqueio, empurrado para uma experiência de densidade e amorfismo, mesmo se é deixado diante de uma superfície que é, para todos os propósitos e objetivos, nada mais que um simulacro bidimensional do espaço interior. (VIDLER, 1992: 221)

Para Vidler, o estranhamento despertado pela transparência sombria da fachada remeteria ao sentimento do Unheimlich, o sentimento do estranhamente familiar ou do "desenraizamento" (para Vattimo e Heidegger), comum à "experiência de espelhamento e aparição de um invisivel outro", conforme descrita na literatura fantástica do romantismo e estudada por Freud. Anthony Vidler reconhece o Unheimlich, como a qualidade que viria assolando a arquitetura contemporânea em sua tendência à fragmentação, que ele associa à mutilação e ao biotecno-morfismo, manifestado na tendência animista de “"paredes que vêem” e devolvem o olhar passivo de cyborgs domésticos, seus espaços vigiados por olhos em constante movimento e que simulam transparência" (VIDLER, 2006: 619). O reconhecimento de dimensões agorafóbicas associada à noção psicanalítica do Unheimlich permitiram que ele elaborasse uma fenomenologia espacial arquitetônica, que conta ainda com a leitura da sociologia urbana ${ }^{136}$. Para ele, o sujeito contemporâneo, considerado no desenvolvimento dessa arquitetura, seria tomado como híbrido de corpo e artifício tecnológico, sendo definido como um ser destituído da experiência intrauterina e de nascimento, tal como os ciborgues. Tal sujeito híbrido seria metralhado por imagens eletrônicas fornecidas pelos meios de comunicação, tendo se tornado incapaz da experiência corporal plena devido à "eliminação da profundidade fenomenológica" (VIDLER, 2006: 620) que tais meios impõem, determinando assim o estado de alienação do homem moderno.

136 "Selecionando algumas das inúmeras "casas mal assombradas" do período romântico, elaboro uma fenomenologia do uncanny espacial, que estendo para a cidade como um locus de medo do espaço a partir de uma leitura de vários sociológos e patologistas urbanos, de Legrand du Saule a Georg Simmel, Siegfried Kracauer e Walter Benjamin." (VIDLER, 2006: 620) 
O Unheimlich da transparência na arquitetura estaria associado a uma determinada fase do processo de desenvolvimento do Eu no Estádio do espelho da teoria lacaniana. A teoria lacaniana pressupõe a formação do Eu a partir do reconhecimento de si no olhar do outro, que funcionaria como um espelho. A fase do estranhamento corresponderia a um período intermediário do processo sadio que deverá fornecer uma imagem da totalidade corporal do sujeito e que servirá de base para o seu desenvolvimento posterior socialmente. Essa fase intermediária, seria definida pela sobreposição de imagens corporais vistas e refletidas no jogo entre sujeito e objeto-olhar-do-outro, que informariam ao sujeito aquilo que ele é e não é na redução da projeção bidimensional da imagem rebatida no espelho/olhar do outro. Tal situação de ambiguidade, que é vivenciada em associação com a suspeita de se possuir na realidade um corpo despedaçado (aparece e não aparece, é a visão ou o olhar), seria deflagradora de angústia; tal como no estranhamento provocado pelas fotografias que Cindy Sherman tira de si, contrapondo à idealização glamorosa das fotos de propaganda a imagem do que seria real (sem anteparo), com o abjeto incluído. A arquitetura de Koolhaas cristalizaria tal momento de angústia, provocada pelo estranhamento no reconhecimento de si, através imagem ambígua produzida pela transparência que não espelha, que seria absorvida pela imagem dos vazios e na reflexão exterior, gerando um estado de suspense e ansiedade paranoica relacionada ao Unheimlich. "O arquiteto não permite nem parar na superficie nem penetrar nela, capturando-nos num estado de ansiedade” (VIDLER, 1992: 222). O sujeito contemporâneo identificado com tal estado de fragmentação experimentaria nessa ansiedade o suspense com a chegada daquilo que lhe é estranhamente familiar, o "seu interior biológico", e que, não fosse por seu regresso paranoico, teria permanecido oculto e protegido pelo anteparo da representação.

A ansiedade do sujeito confrontado com o espaço "liso" das superfícies de Koolhaas é então a manifestação de um estranho baseado nas recém-formuladas condições de interioridade e exterioridade, onde as "aparições" do "interior" funcionalista no exterior espelha não a aparência exterior do sujeito mas seu próprio, agora-transparente interior biológico. O espaço paranoico é transformado então em espaço do pânico, onde todos os limites se tornaram borrados numa substância espessa, quase palpável, que substituiu ela mesmo, quase imperceptivelmente, a arquitetura tradicional. (VIDLER, 1992: 225) 


\section{3.}

\section{Transparência sublime}

\section{O lado sombrio da transparência}

Na metafísica ocidental, a escuridão é associada ao fim e à morte, por isso assombrada com toda fantasmagoria que decora o cenário do maior atentado contra a vontade do homem. A morte não tem razão, não faz sentido do ponto de vista da vontade humana. A angústia provocada pelo medo do fim, pelo sentimento de desenraizamento forçado, pode ser interpretada, conforme acompanhamos na exposição de Vattimo, como instigadora da revelação da verdade. Tal verdade seria libertadora. Num caminho oposto ao de Vattimo estaria a leitura do Unheimlich feita por Vidler. Este interpreta a ansiedade despertada pelo Unheimlich como sintoma da condição alienada do homem moderno. O Unheimlich teria se tornado a condição disseminada do espaço moderno ao ser instrumentalizado pelos arquitetos através da estética do sublime para representar o Poder. A arquitetura da transparência sublime, herdada do Iluminismo, levada ao extremo se converteria num opacidade sombria e numa estética do desaparecimento.

No ensaio "Transparency and Utopia: Constructing the Void from Pascal to Foucault”, Anthony Vidler revela o triunfo das sombras, produzidas pela interação de luz e escuridão, deixado como legado reverso da utopia de transparência no Iluminismo. A metáfora da transparência teria se desenvolvido em função da presunção de superpoderes visionários de seus pensadores que queriam dar conta do mundo através da "coleção e organização taxonômica de seus elementos num espaço organizado racionalmente segundo a verdade matemática”. Tamanha evidência tornaria a natureza disponível ao espirito iluminista.

(...) "O espaço iluminista" parece simples o suficiente para ser descrito: ele é geométrico, racional, reticulado e, acima de tudo, transparente, universal e contínuo. Igualmente iluminado e iluminador. Os objetos permanecem nesse espaço como tantas entidades claramente definidas, separadas uma da outra, taxonomicamente organizados em séries e hierarquias, tão conhecido e reconhecível quanto o espaço que as cerca. (VIDLER, 2011: 131) 
Não somente os enciclopedistas, mas também os arquitetos teriam buscado realizar tal espaço, adotando como arquétipo da clareza o Panóptico, o modelo de arquitetura penitenciária desenvolvido pelo filósofo e jurista Bentham. Tal ideal de clareza e transparência espacial teria dominado a teoria da arquitetura do modernismo em pleno século XX até Michel Foucalt apontar o lado sombrio dessa arquitetura desenvolvida para "fabricar virtudes" e detonar uma série de pesquisas que evidenciavam a política implicada nos espaços institucionais. $\mathrm{O}$ Panóptico associaria a clareza geométrica do espaço iluminista ao obscuro terror provocado pelo estado permanente de vigilância e controle. Foucault revelaria como a utopia da transparência teria se desenvolvido desde sempre cercada por um espaço de certezas sombrias.

Segundo Vidler, desde o princípio, a utopia de construir uma sociedade transparente teria se desdobrado na revelação de obscuridade e perversões viabilizadas por "superpoderes visionários", tais como o voyeurismo e a libertinagem. Assim, enquanto as visões negras de Goya revelavam os monstros da razão; Sade "utilizava os poderes do espaço hermético em nome da "liberdade ao infinito"," (VIDLER, 2011: 132). Os superpoderes visionários seriam, portanto, bifocais; revelando lado a lado as possibilidades de uso da razão técnica em prol do desenvolvimento social e a escuridão escondida no interior do homem.

\begin{abstract}
Em termos espaciais nós podemos caracterizar essa escuridão como relacionada às similares evocações sádicas e aterrorizantes - a natureza fundamentalmente intrusiva da visão iluminista, sua relação com a versão do progresso tecnológica e anti-humanista todo-determinante, assim como também às mais profundas implicações psicológicas das indagações rousseauescas sobre a personalidade e suas forças escondidas. Nesses termos, o sonho da transparência iluminista é revelada como uma falsa promessa de redenção, dialeticamente situada entre a verdade absoluta e o terror absoluto, e dedicada à instalação da máquina em conformidade com a produção e suas leis sociais. O olhar poderoso do Iluminismo foi fundado desse modo (VIDLER, 2011: 132)
\end{abstract}

Foucault teria revelado o lado escuro da política espacial implicada na arquitetura iluminista como aparato disciplinar. Vidler considera, no entanto, que ele caiu num formalismo reducionista que se tornou deveras influente nas geração de historiadores ligados à geração de 1968, críticos da institucionalização do espaço, tais como Henri Léfebvre. A determinação do espaço como instrumento poderoso, capaz de definir de modo imediato e transparente a vida das pessoas e da sociedade, seria o efeito da simplificação reducionista a que o pensamento de 
Foucault teria chegado, traduzido na equação: "Panóptico = circular, espaço centralizado = vigilância" (VIDLER, 2011: 134). Tal equação refletiria uma caricatura da própria teoria da arquitetura moderna resumida na fórmula, "a forma segue a função”, que redundaria na própria fórmula e excluiria a percepção da instrumentalização da estética sublime como instigadora do horror. Esta instrumentalização do sublime sombrearia as dimensões disciplinar e de uso, revelando o modo ambíguo do mecanismo de Poder.

\section{O teatro do Poder}

A obra do arquiteto Claude-Nicolas Ledoux para uma fábrica de sal construída em Arc-et-Senans entre 1774 e 1779 seria uma das obras visitadas por Foucault, das quais a pronta identificação com a estrutura do Panóptico incorreria na desconsideração da experiência estética do sublime. Tal desconsideração o teria levado à interpretação do espaço como extensão do objeto arquitetônico, como estruturas que homologariam as instituições políticas de modo disciplinar. Para Vidler, esta interpretação, que alimentou a crítica ao funcionalismo da arquitetura modernista, ignoraria o sentido aberto pela arquitetura iluminista para a representação do espaço infinito, através da estética do sublime, como instrumento instigador de medo e angústia utilizado por parte do Poder. "Ledoux estava, então, como a maioria dos arquitetos de sua geração, tão fortemente investido na representação do Poder através de formas simbólicas e efeitos sublimes, como ele estava na real, empírica distribuição e implementação do controle gerencial'”(VIDLER, 2011: 137). Foucault teria enxergado nessa fábrica apenas o aparato disciplinar pré-panóptico, relacionado à planta centralizada e semicircular. Vidler associa a planta semicircular da fábrica de Ledoux aos anfiteatros antigos e à busca por efeitos sublimes apropriados à representação do Poder.

O sentimento de espaço aberto por essas obras promoveria o efeito sublime através da dissolução da arquitetura no contexto do território. $\mathrm{O}$ efeito de desaparecimento da arquitetura pela ênfase no sentimento de espaço teria sido ignorado pelos críticos da arquitetura panóptica, que permaneceriam aderidos à crítica do monumento arquitetônico em detrimento da identificação de outras estratégias da política espacial utilizada pelo Poder. No projeto de Ledoux, por 
exemplo, a forma semicircular da fábrica de sal ficaria disposta no centro da configuração oval do complexo industrial, que se integraria futuramente ao projeto da cidade ideal de Chaux ${ }^{137}$, cujo desenho em perspectiva olho de pássaro é assim descrito: "(é sublime) na contemplação das imensas distâncias reunidas pela expansão econômica e comercial das salinas e sua prevista transformação em um centro de negócios do mundo, ligando os polos e atravessando as latitudes, (...) com seus eixos se estendendo - como aqueles de Versalhes similarmente representados - até o infinito"(VIDLER, 2011: 141). Em outros projetos de Ledoux, no entanto, o sublime do espaço infinito não estaria representado pelo prolongamento de retas que ameaçam se encontrar no infinito, mas através da representação do vazio pela luz e escuridão absolutas. "O espaço não é mais uma verdade universal construída pela geometria, mas é transformada numa projeção contínua e introjeção de luz” (VIDLER, 2011: 142). Segundo Vidler, tal estética do desaparecimento da arquitetura, associada ao sublime espacial, será utilizada na política espacial das cidades modernas como instrumento de alienação do sujeito associado aos ambientes unheimlich, que as grandes cidades nos oferecem: "estacionamentos vazios abandonados à volta, centros comerciais decadentes, no espaço simulado trompe l'oeil exibido, no, que é, as margens desperdiçadas e aparências superficiais da cultura pós-industrial", (VIDLER, 1992: 3).

\section{O sublime na arquitetura}

A voga do sublime teria dominado a cena de atuação dos arquitetos iluministas, tendo sido herdada da poesia. $\mathrm{O}$ sublime seria traduzido como efeito das formas nos sentidos que provoca um tipo de elevação sentimental comparável à poesia. $\mathrm{O}$ filósofo empirista Edmund Burke teria contribuído com a dissociação entre o sublime e os efeitos de retórica, associados à poesia, ao relacionar o sublime à sensação; como "princípio da percepção estética fundado na psicologia da sensação" (VIDLER, 2011: 138). A arquitetura da sublimidade

\footnotetext{
${ }^{137}$ Ledoux desenvolveu uma tipologia de edifícios limitada que deveriam compor a cidade ideal. A cidade contava com o primeiro complexo industrial já desenvolvido, que incluía alojamentos para os operários além dos galpões de trabalho. A tipologia de edifícios desenvolvida para a cidade deveria expressar sua função social segundo a utopia de equilíbrio social almejada. Assim, um edifício da cidade, a Oikema, dedicado a estimular "a virtude por meio da saciedade sexual", tinha como planta-baixa a forma de um pênis. (FRAMPTON, 2003: 8)
} 
seria recomendada pela tratadística iluminista como adequada às obras monumentais que precisassem expressar grandes propósitos e surpreender o observador, tais como templos, edifícios públicos e tumbas. Burke teria acrescentado o fator medo ao sublime grandioso e listado detalhadamente todos os elementos da arquitetura capazes de instigá-lo. O sublime na arquitetura equivaleria ao da natureza no sentido de estar relacionado à evocação do "horror ao medo do sofrimento" que a lembrança de um fenômeno natural pode provocar. Ele seria o resultado de uma interação do objeto percebido com a mente que produz ou acrescenta imagens ameaçadoras, que também podem ser lembranças e que despertam o medo. "Já que uma cadeia continua de associação trabalhou do sofrimento real ao sofrimento e horror e medo antecipados ou imaginados; de algum modo a "apreensão do sofrimento e morte" trabalhou na mente analogamente ao ferimento físico real" (VIDLER, 2011: 138). Paredes e penhascos; a noite e a escuridão poderiam se equivaler. Do mesmo modo que imagens ou relacionadas a ela poderiam evocar o sublime, também poderiam as ideias religiosas, as abstratas ideias da razão e estados psicoemocionais. Burke teria especificado a técnica do sublime detalhadamente, disponibilizando uma cartilha para os arquitetos.

\begin{abstract}
Escuridão, confusão, incerteza; tudo adicionado ao senso de sublime como necessariamente conectado à prática do domínio religioso. Similarmente, a experiência imaginativa do infinito, eternidade, do supremo e ilimitado poder, tal como deve ser atribuído a uma divindade, levaram inevitavelmente ao sentimento do sublime. Assim, impressões ou experiências de vacuidade, escuridão, solidão e silêncio, todas conectadas com um sentimento geral de privação: vastidão em todas as dimensões, altura, largura, comprimento, e profundidade; magnitude e esplendor; todas são causas do sublime e devem igualmente ser estimuladas pela natureza ou arquitetura (VIDLER, 2011: 138)
\end{abstract}

O efeito sublime deveria ser criado através de artifícios tais como a repetição de colunas iguais e uniformemente distribuídas levariam à imagem do infinito; a magnificência associada aos efeitos de grandeza e ao esforço executivo requisitado; o dramático no contraste de sombras; o absoluto na absoluta clareza ou escuridão; e o vazio associado à experiência meditativa do espaço infinito, também representado pela luz e escuridão absolutas.

O projeto de Ledoux para o cemitério de Chaux de 1785 metaforizaria o flagelo da alma perambulando pelo universo infinito depois da morte. As almas rumariam 
através de vias dispostas radialmente na planta circular do edifício subterrâneo, que corresponde à cidade dos mortos, até a grande esfera semienterrada: "caverna dos mortos...viaja-se no vazio do terror, nunca se chega" "(LEDOUX, VIDLER, 2011: 142)

\section{Unheimlich - o estranhamente familiar da arquitetura do desaparecimento}

Um dos efeitos da estética do sublime, associados ao vazio e ao espaço infinito na arquitetura, seria o efeito reverso de dissolução do monumento arquitetônico. A técnica utilizada para tal dissolução seria o jogo de luzes e sombras ao longo do dia e da época do ano. "O edifício é tanto constituído para revelar esse jogo (o sólido objeto sobre o qual a luz incide como modo de revelar a luz) como constituído por esse jogo (em si uma coisa de gradações de sombras, um fenômeno puramente visual)" (VIDLER, 2011: 142). Outro aspecto do sublime promovido pelo jogo de luzes seria o surgimento de uma arquitetura da negatividade, que se apresentaria pelo espaço negativo da arquitetura que surgiu na escuridão. O arquiteto Étienne-Louis Boullé (1728-1799) se declarava o inventor de tal arquitetura feita de sombras, que Vidler associa ao sentimento estranhamente familiar, o Unheimlich da psicanálise. Boullé queria desenvolver uma arquitetura que falasse da morte e do luto; da melancolia experimentada na visão de sua própria sombra projetada, surgida num passeio à luz da lua. A arquitetura do Templo da Morte deveria ser enterrada, "absorvida pela terra"; e destituída de ornamentos, "mostrando o esqueleto da arquitetura por meio de uma parede absolutamente nua" (BOULLÉ, VIDLER, 2011: 143). Sua fachada deveria parecer ter espessura ínfima e sem substância, definida em função da variação na posição das sombras projetadas. As sombras projetadas representariam espaços criados com vazios escuros que funcionam como um "agente da dissolução monumental”. A arquitetura de sombras de Boullée seria, portanto, uma arquitetura do desaparecimento.

Boullee criou a imagem de uma arquitetura não apenas sem profundidade real, mas uma que deliberadamente joga com as ambiguidades entre a planaridade absoluta e profundidade infinita, entre sua própria sombra e o vazio. $\mathrm{O}$ edifício como o duplo da morte do sujeito traduz esse desaparecimento em experiência da incerteza espacial. (VIDLER, 2011: 145) 
Tal arquitetura romperia com o paradigma clássico de imitação baseado na imagem do homem vitruviano, para tomar como referência a " "forma morta” do corpo, sombreado no chão" (VIDLER, 2011: 144), o fantasma da morte que é interpretado freudianamente como sendo o duplo estranhamente familiar (Unheimlich ou Uncanny) que retorna para mostrar que o sujeito não é o que pensa ser segundo seu ideal narcísico. O Unheimlich revelaria "essa transformação do signo algébrico do duplo, sua ligação com o narcisismo e a morte como punição por ter procurado imortalidade (...) duplo não duplica uma presença mas a suplementa, permitindo que se leia, como num espelho, a originária "difference", castração, morte, e ao mesmo tempo a necessidade de apagá-las”(VIDLER, 2011: 145).

A arquitetura da negatividade, que metaforiza o desaparecimento do sujeito através da dissolução do monumento no espaço infinito pelo jogo de luz e sombras, visaria operar como um instrumento dos Poderes instituídos no sentido de desestabilizar o sujeito e controlá-lo socialmente. Para Vidler, a vasta literatura sobre a fobia do espaço, que foi associada à figura mítica e melancólica do "teórico do vazio" Blaise Pascal ${ }^{138}$, refletiria o estado de ânimo que vinha sendo instalado pela arquitetura das grandes cidades. A patologia instalada e identificada por psicólogos e sociólogos teria um caráter espacial e revelaria o sentimento do estranhamento e assombramento do homem que não se sentiria mais em casa nem no mundo e nem em si.

(A arquitetura das sombras) nos permite estender nossa compreensão do espaço no período moderno, e preparar para a profunda revolução em nosso olhar que iria seguir a conclusão aforística de Freud, alcançada no final de sua vida, de que "o espaço pode ser a projeção da extensão do aparato físico. Nenhuma outra derivação é provável. Em vez das determinantes a priori de Kant do nosso aparato físico. A Psique é estendida; não sabe nada sobre isso". (VIDLER, 2011: 146)

A angústia e o sentimento de desenraizamento despertados pelo sublime espacial, para Vidler, não implicariam numa "verdade posta em ação" no sentido heideggeriano; mas apenas na fragmentação do sujeito e na produção que, no mundo contemporâneo, se traduziu numa arquitetura de transparência sombria e abjeta. A ansiedade vivida no contemporâneo espelharia, para ele, esse sentimento de estranhamento e teria remetido o sujeito para a busca ou retorno a lugares no passado e no futuro, "dilema da temporalidade, ligado ao contexto

138 "Em qualquer evento, Pascal era vinculado à imagem do teórico ideal e exemplar dos efeitos do sublime especial, teórico do vazio, do "l’horreur du vide”, do “l'infini", “l'néant"”. (VIDLER, 2011: 141). 
inóspito do aqui-e-agora ao mesmo tempo que o lá-e-então" (VIDLER, 1992: 5); segundo uma patologia traumática que se reflete numa repetição assombrosa dos eventos vividos. Vidler supõe existir uma ordem no tempo que separaria o passado e o futuro e que viria sendo desrespeitada pela instrumentalização técnica de um lado e pelo poder do outro. A sombra da morte, que seria prenúncio do futuro e do fim dos tempos, teria se tornado a marca subjetiva do ser às raias da hibrização "homem-ciborgue". Escuridão, fim, vazio, natureza e o homem seriam os elementos da metafísica ocidental aos quais Vidler se manteve vinculado em sua interpretação do sublime espacial.

A ansiedade do tempo, conforme exprimidas nas tentativas intelectuais de imaginar futuros impossíveis ou retornar aos igualmente impossíveis passados, foi acompanhada pela fascinação com as consequências dos erros do tempo - os efeitos distópicos da interferência insólita no desenvolvimento natural das coisas, por um lado, e os efeitos psicológicos de choque do passado e do futuro por outro." (VIDLER, 1992: 5).

\section{4 . \\ O mito da japonidade}

\subsection{1.}

\section{A moda da Japonnerie}

\section{A abertura forçada para o mercado ocidental}

Desde a expulsão dos negociantes portugueses e missionários jesuítas no século XVII até a chegada do Comodoro Perry e sua ostensiva frota em meados do século XIX ${ }^{139}$, o Japão vivia em relativa paz ${ }^{140}$ e quase completamente isolado do mundo através da política de relações internacionais denominada Sakoku ${ }^{141}$. Alguns poucos países mantinham relações comerciais com o Japão, tais como a Holanda, China e Coréia ${ }^{142}$. Nenhum estrangeiro entrava no país, nenhum japonês saía.

\footnotetext{
${ }^{139}$ Em 1853 chegaram os "navios negros" do comandante americano Matthew Perry, ostentando poderio militar e bélico-tecnológico, obrigando os japoneses a reabrir o comércio com o Ocidente e a aceitar acordos desiguais.

${ }^{140}$ Conceito de paz no Japan, heiwa, foi influenciado pelo conceito chinês Ho P'ing e relaciona-se com a ideia de ordem política (e cósmica), harmonia, estado mental tranquilo. As batalhas entre os Samurais poderiam fazer parte do contexto de paz, já que o que estaria em jogo seria a morte heroica e não a violência contra o inimigo. ISHIDA, Takeshi. Japanese Political Culture. New Jersey: Library of Congress, 1989. p. 124, 125.

${ }^{141}$ Era Sakoku (país fechado), durou de 1640 a 1853, entre os ocidentais, apenas os holandeses puderam manter negócios com o Japão. GOODMAN, Grant K. Japan: The Dutch Experience. London: The Athlone Press, 1986. P. 5.

${ }^{142}$ Os estrangeiros foram restritos à cidade de Nagasaki, ficando aquartelados, depois de 1641, na ilha artificial de Deshima, construída nas imediações para os portugueses. Eles tinham a circulação controlada e pagavam uma taxa de aluguel pela terra. Os japoneses temiam os métodos da Inquisição cristã, sua influência sobre o povo, bem como desaprovavam as práticas escravocratas dos ocidentais. GOODMAN, Grant K. Japan: The Dutch Experience. London: The Athlone Press, 1986. P. 18 a 24.
} 
A superioridade militar do Comodoro americano impôs uma revisão das estruturas do Xogunato Tokugawa (1542-1868), que eram até então baseadas numa política ditatorial e militar de senhores feudais (Bankufu). A política do Bankufu, exercida pelo Xógum, se baseava na presença de subordinados Senhores da terra, Daimyoo, e no enorme contingente de Samurais e seus últimos subordinados que garantiam a guarda armada. Tal estrutura altamente hierarquizada destinava-se a manter a ordem política que se estabelecia tanto pela força quanto pela educação.

O evento da chegada do Comodoro Perry, no final do período feudal, é interpretado como momento da imposição de modernização ao país e de integração ao sistema capitalista. No entanto, do ponto de vista da estrutura política interna, os processos de "Modernização Japonesa" estão também associados ao fenômeno da chamada "Restauração Meiji" (1868) ${ }^{143}$, que foi paradoxalmente o momento de recuperação de poder pelo imperador, tomado com o apoio de classes descontentes ${ }^{144}$, marcando o fim do Xogunato. A antiga estrutura Imperial reinstaurada se comprometeu com os processos de reforma, tentando recolocar o Japão em igualdade de forças em relação a outras nações ${ }^{145}$. O período Meiji (1868-1912) é caracterizado pela acelerada incorporação de elementos ocidentais, que inicialmente fora imposta através de transações comerciais desiguais, instaurando um sentimento xenófobo que teria permanecido latente no Japão. No entanto, a novidade da tecnologia industrial destes produtos, fabricados pelos "bárbaros" (ban), terminou por ser identificada como símbolo de progresso e Poder que poderiam vir a ser apropriados e quiçá superados. Uma “oligarquia Meiji”, oriunda das antigas elites de samurais e senhores, será responsável por promover as reformas institucionais necessárias para o processo de modernização do país. Esses líderes darão início aos processos de transformação através da presença de consultores e empresas estrangeiras selecionadas criteriosamente segundo a lógica de reconhecimento do melhor que cada país tem a oferecer. A influência de culturas estrangeiras nunca foi um tabu para a cultura japonesa, com a exceção da disseminação do cristianismo pelos

\footnotetext{
${ }^{143}$ BEASLEY, W. G. The Meiji Restoration. California: Stanford University Press, 1972.

${ }^{144}$ Samurais de mais baixo escalão e comerciantes emergentes.

145 WESTNEY. D. Eleanor. Imitation and Innovation: The transfer of Western

Organizational Patterns to Meiji Japan. Massachusetts: Harvard University Press, 1987.
} 
missionários jesuítas, expulsos no século XVII ${ }^{146}$. O Japão se desenvolveu em grande parte pela assimilação do que vinha da China e através dela.

\section{A busca por uma expressão de transparência nas artes}

Se nos séculos XVII e, principalmente, XVIII, a porcelana japonesa chegara no mercado europeu na onda orientalista a esteio das Chinoiseries, no final do século XIX, a chegada dos produtos japoneses despertam uma febre colecionadora na Europa.

Na Inglaterra do século XIX, a moda dos produtos japoneses levou ao desenvolvimento de um novo estilo de mobiliário, o "Anglo-japonês", que foi distribuído em versões comerciais lado a lado com estilos históricos como o Chippendale. Versões de melhor qualidade também circularam, como aquelas desenvolvidas pelo arquiteto Edward Godwin, que antecipavam a linguagem do Art Nouveau e que caminhavam para a ruptura do referencial clássico. No contexto do Arts and Crafts, foi a simplicidade e a leveza do mobiliário japonês que encantou os artistas. Tais qualidades coincidiam com o movimento em prol da recuperação do status e da ética do trabalho artesanal medieval, promovido por William Morris e Ruskin, que levou muitos arquitetos e artistas a se voltarem para a produção de mobiliário. O próprio termo Art Furniture, que passa a ser utilizado nas revistas de decoração, reflete a voga da reaproximação entre a arte e artesania. Alguns arquitetos e artistas tomaram como referência os pré-rafaelistas (Pugin, Carlyle) ou a vertente medievalista (Ruskin e Morris), que são escolhidas na busca por expressão de simplicidade, rusticidade e leveza em contraposição ao rebuscamento do período vitoriano. Essas duas últimas vertentes espelham o viés nostálgico e moral, do qual outros artistas tentarão escapar através da arte japonesa. $^{147}$

\footnotetext{
146 “(...) a Igreja Católica tinha até o seu próprio Estado, o Vaticano, com papas que se envolviam frequentemente em política. Tudo isto dava a entender que a Igreja Católica não era apenas espiritual(...) a Cristandade acabou por simbolizar a presença e a ameaça do Ocidente ao poder e à autoridade do xogunato.(...) Esta acção não tinha por objeto apenas os ocidentais, mas também os Japoneses que se tinham convertido ao cristianismo. ”(HENSHALL, 2004:85)

147 "Whistler manteve com os pré-rafaeleistas tardios uma relação de oposição tão aguda que culminou numa ação judicial contra o crítico Ruskin. Motivo do litígio: o caráter social dos prérefaelitas, com sua honesta técnica artesanal, e o suposto arbítrio de Whistler, para quem a arte consistia na intuição instantânea de um inefável instante de harmonia entre o indivíduo e o
} 
A primeira onda da Japonnerie se deu através descoberta das gravuras japonesas em madeira, que foi feita em 1856 pelo também gravador Bracquemond em Paris ${ }^{148}$. Ele e um grupo de artistas envolvidos na pesquisa da sensação visual pura se surpreenderam com as cores claras e luminosas de tais gravuras. Alguns anos depois, lojas e armazéns foram abertos com produtos orientais japoneses e chineses, tanto na Inglaterra como em Paris. Os produtos eram embrulhados em gravuras baratas, desconsideradas no próprio Japão por sua temática marginal. Elas também podiam ser compradas em lojas de chá por um preço módico e passaram a ser avidamente colecionadas por artistas do movimento Impressionista ou ligados a ele ${ }^{149}$, tais como Degas, que "Foi dos primeiros a estudar as estampas japonesas, não por gosto ao exotismo, e sim pela novidade desse sistema de figuração que, eliminando a corporeidade do volume e da cor, fundia no mesmo gesto-signo o movimento dos corpos e do espaço. "150

Whistler pintou a "Princesse du Pays de la Porcelaine" em 1864. Sua casa, White House, foi desenhada pelo arquiteto Edward Godwin, que havia desenvolvido uma linha de sóbrios móveis anglo-japoneses, em 1877. Whistler complementa a decoração de sua casa pintando suas paredes com uma delicadeza de cores até então desconhecidas: amarelo limão, branco e rosa. Assim como os pintores do grupo Impressionista e Simbolista, Whistler frequenta a casa do poeta Mallarmé ${ }^{151}$. Sua teoria da poesia pura, baseada na valorização dos sons das palavras e sua capacidade de evocar imagens, influenciou a busca impressionista da pintura pura. Para Mallarmé, os significados não estariam aderidos às palavras, que seriam signos vazios: "O som adquire valor a partir das pausas $e$ da ausência de um significado dado das palavras; daí uma necessária

mundo. Foi também através do estudo da arte japonesa que Whistler chegou a esta idéia da continuidade do todo." ARGAN, Giulio C. Arte moderna na Europa: do Iluminismo aos movimentos contemporâneos. SP: Cia das Letras, 1992. P.152.

${ }^{148}$ PEVSNER, N. Estudios sobre Arte, Arquitetura y Diseño: del maneirismo al romantismo, era Victoriana y siglo XX. Barcelona: Gustavo Gili, 1983.

${ }^{149}$ GOMBRICH, E. H. The History of Art. London: Phaidon Press Limited, 1995.

150 ARGAN, Giulio C. Arte moderna na Europa: do Iluminismo aos movimentos contemporâneos. SP: Cia das Letras, 1992. P.106.

151 "Mallarmé gostava de se definir como "poeta impressionista e simbolista”, e assim os neoimpressionistas como Gauguin não excluem uma síntese das duas tendências, pelo contrário, aspiravam a ela. (...) A pintura, de fato, perdendo sua função social tradicional, torna-se um instrumento de pesquisa da mente humana, se seus conteúdos e processos, da qual a sensação visual é decerto um segmento, e exatamente o consciente, aquém e além do qual, porém, existe um subconsciente e um sobreconsciente. "ARGAN, Giulio C. Arte moderna na Europa: do Iluminismo aos movimentos contemporâneos. SP: Cia das Letras, 1992. P.84. 
ambiguidade, pela qual as palavras adquirem um significado novo. "' Whistler se utiliza da gama de cores dos japoneses e pinta " "sinfonias" em prateado, azul, cinza", que "não depende de impressões visuais, nasce da palavra poética"152. Ele não estava preocupado com o conteúdo em si representado, mas com as relações de cores e formas.

Manet também partilhou do interesse pelas gravuras japonesas, tendo pintado o escritor Zola em 1868, sobre um fundo com gravuras e um painel japoneses. Seu propósito era pintar apenas o que via, desconsiderando conteúdos narrativos e tratando os objetos apenas como material compositivo. Esse propósito o afastava da pintura realista, dando margem para composições inverossímeis, que não utilizavam o chiaroescuro, mas zonas de cores lisas. Para ele, a pintura é sensação visual, portanto não distingue as coisas do espaço, a luz é a própria cor. A sensação visual se distingue da noção intelectual, refletida e convencionada, e é nesse sentido que as gravuras japonesas parecem tão instigantes para os artistas dessa época. Também elas se baseiam na valorização da sensação visual e não em regras compositivas intelectuais. A sensação visual independe do realismo da representação de profundidade e da impressão de massa a ele associado. As gravuras japonesas apresentavam uma interpretação do espaço que valorizava a relação entre os tons das cores transparentes e vaporosas e não o efeito de massa dado pelo efeito sombreado. Assim como para os impressionistas, eles estariam atentos aos jogos das formas e da luz sobre a realidade cambiante do mundo.

Para o historiador Henri Focillon (1881-1943), os gravuristas japoneses pintariam a vida das formas, sem imobilizá-las e sem sobrecarregá-las de símbolos ou pensamentos. "Deve-se chamá-los pintores dos fenômenos terrestres. Porque é na variedade dos fenômenos que eles aplicam todos os recursos de uma arte onde o princípio é a curiosidade e onde uma síntese expressiva é o termo" (FOCILLON, 1914: 148). Os pintores ocidentais teriam se encantado com a poesia da arte japonesa com a qual entraram em contato na exposição universal de 1878, modificando seus hábitos visuais e fonte de inspiração, afastando-se da concepção de espaço tridimensional e da "tirania do relevo".

${ }^{152}$ Idem, Ibidem. P. 152. 
O Ocidente demanda dos artistas gráficos uma imagem do relevo e da profundidade: na representação das formas, ele dá um lugar preponderante ao modelado das massas, que ele obtém por uma distribuição harmoniosa de sombra e luz. Mesmo os mestres menos solicitados pelo efeito, o desenho não é um simples limite, ele é acompanhado de uma gama de valores. A pintura enfrenta os problemas do espaço e não simplifica os dados. (...) ele mostra os volumes, e não as superfícies. Sem dúvida, seu objetivo não é fazer crer que os seres ou os objetos pintados "saem do quadro". Mas eles devem se destacar sobre horizonte e sobre o terreno e, de acordo com os planos onde estão estabelecidos, apresentar um relevo proporcional ao seu afastamento. (FOCILLON, 1914: 3)

A profundidade se apresentaria na arte japonesa como representação gráfico-linear ou por manchas de elementos atmosféricos carregados de água; tais como as névoas, as nuvens e a chuva (Fig. 1 e 2). Nos vazios de pintura deixados entre as manchas ou entre os primeiros e segundo planos surgiria o espaço transparente e luminoso que "simboliza o distanciamento e a atmosfera". A profundidade seria alcançada através da sensação visual, e não pela técnica da perspectiva com ponto de fuga ou com o apego realista-imitativo. Sua pintura é fluida tanto pelo pincel carregado d'água, quanto pelo traçado. O efeito de tal técnica e da profundidade, alcançada através da variação tonal, é a transparência e a leveza vaporosas, que comparadas à arte ocidental parecem fazer a imagem desmaterializar-se. Mesmo o efeito decorativo, alcançado pela fluidez de linhas no desenho e nos complementos caligráficos, compartilharia o caráter límpido das aguadas. Podemos afirmar que tal decorativismo é o fundamento oposto ao elemento transcendental e essencial buscado pela arte acadêmica ocidental. Foram os experimentos no campo da pura visualidade ${ }^{153}$, dos quais os impressionistas participaram, que ajudaram a promover a mudança necessária para receber a arte oriental com admiração.

As paisagens de grandes linhas simples, atravessadas pelas longas faixas de nuvens, nos parecem puras indicações topográficas quase exclusivamente lineares, sem solidez, mas não sem poesia. Iguais ao cego operado, nós ficamos felizes de ver a luz, mas nós não pudemos de início conhecer esse universo que como uma associação de linhas e de tons combinados num mesmo plano, comparáveis aos desenhos de um tecido. (FOCILLON, 1914: 4)

\footnotetext{
153 Além do problema colocado por ser a fotografia uma técnica reprodutiva (realista) da impressão pela luz, que não "deveria” superar a função da arte, também a descoberta científica das teoria ópticas contribuíram para a mudança do conceito de arte. Ente outros pontos, constaria no programa impressionista: "o trabalho en-plein-air, o estudo das sombras coloridas e das relações entre cores complementares. Quanto a este último ponto, há uma referência inegável à teoria óptica de Chevreul sobre os contrastes simultâneos; a tentativa deliberada de fundar a pintura sobre as leis científicas da visão ocorrerá apenas em 1886, como o Neo-Impressionismo de Seurat e Signac" (ARGAN, 1992: 76)
} 
As gravuras coloridas japonesas se desenvolveram a partir da gravura chinesa, tendo pouco se modificado ao longo de 1000 anos. Inicialmente, influenciadas pelo confucionismo, os rolos de gravura apresentavam exemplos ilustrados e escritos para orientar a conduta do povo. Já se verificaria o traço leve e a tendência a incorporar movimento e linhas ondulantes nessas representações chinesas do século IV. A introdução do Budismo na China coloca o pintor num patamar elevado, devido ao importante papel que as gravuras tinham para o desenvolvimento da meditação. $\mathrm{O}$ exercício da meditação era considerado mais importante que o conhecimento da vida de Buda, por isso a temática das gravuras não era exatamente religiosa. Os artistas representavam limitados motivos da natureza, como rochas e hastes de bambu, em rolos de seda que somente eram abertos durante o ritual que poderia durar horas. Esses motivos não eram pintados in loco, mas a partir do estudo de antigos mestres. Depois de dominar o desenho dos motivos com destreza, eles viajavam para contemplar a natureza e voltavam para refazer as imagens que capturaram, evocando o espírito dos lugares. Essa técnica implicava manusear o pincel com facilidade, rapidez e simplicidade, para não perder o frescor da sensação experimentada. Elas vinham acompanhadas, muitas vezes, de poemas. No século XVIII, os artistas japoneses abandonam os temas da natureza de inspiração chinesa e passam a representar cenas cotidianas em composições, que do ponto de vista da arte acadêmica, seriam consideradas arrojadas por seu casualismo. Por exemplo, na gravura em madeira de Katsushika Hokusai, Mount Fuji behind a cistern (1835), o Monte Fuji aparece atrás de um guincho, cuja inclinação é a mesmo do relevo, e que está sendo manuseado por um trabalhador. A relações formal abstrata, marcada pela linha igualmente inclinada, tornava os objetos representados visualmente equivalentes. Na gravura de Utamaro, Rolling up a blind for the plum-blossom view (1790), o artista "não hesitaria em mostrar algumas de suas figuras cortadas pela margem de uma impressão ou pela cortina de bambu. Era esse ousado descuido da regra elementar da pintura europeia que tocou os impressionistas. Eles descobriram nessa regra um último esconderijo da antiga dominação do conhecimento sobre a visão" ${ }^{\prime 154}$.

${ }^{154}$ GOMBRICH, E. H. The History of Art. London: Phaidon Press Limited, 1995. P. 525. 

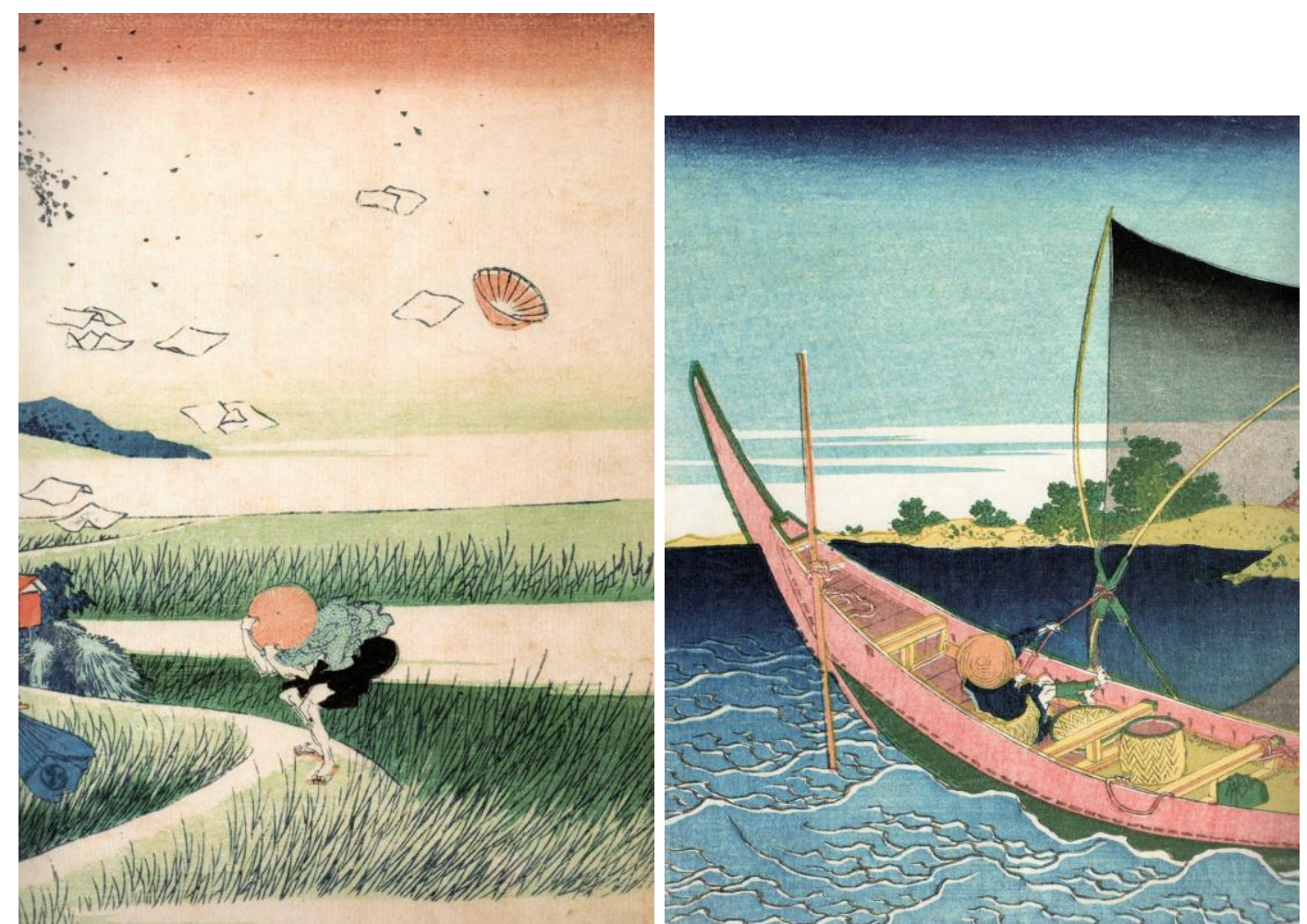

Figuras 1 e 2: Obras de Hokusai (detalhes): "Il vento"(1830-32) "Cose che scorrono veloci"'(1833).

Na primeira gravura, a pintura dos fenômenos naturais sem retirar o movimento. Na segunda gravura, movimento e transparência na vela do barco.

Fonte: SHÔNAGON, Sei; RUDOLF, Geneviève; BEAUJARD, André. Note del guanciale: illustrate con le opere di Hokusai. Italia: Electa, ?

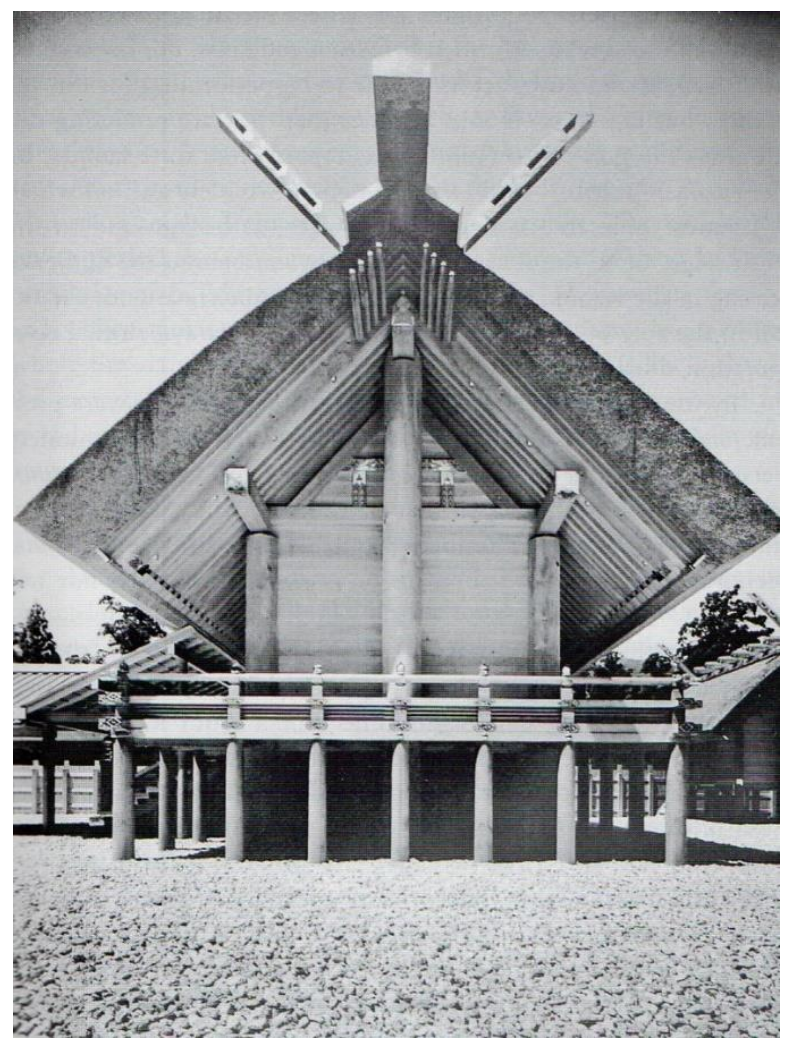

Figura 3: Vista Frontal Santuário Principal de Ise, século VII, Foto de Yasuhiro Ishimoto. Fonte: ISOZAKI, Arata. Japan-ness in Architecture. London, MA: The MIT Press, 2011. 


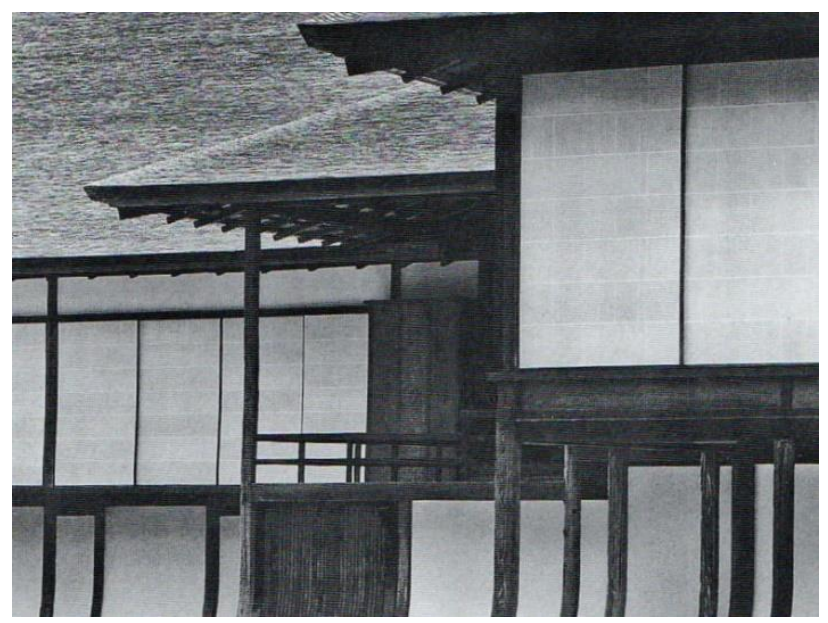

Figura 4: Palácio Katsura, Quioto. Fotografia de Yasuhiro Ishimoto.

Fonte: ISOZAKI, Arata. Japan-ness in Architecture. London, MA: The MIT Press, 2011.

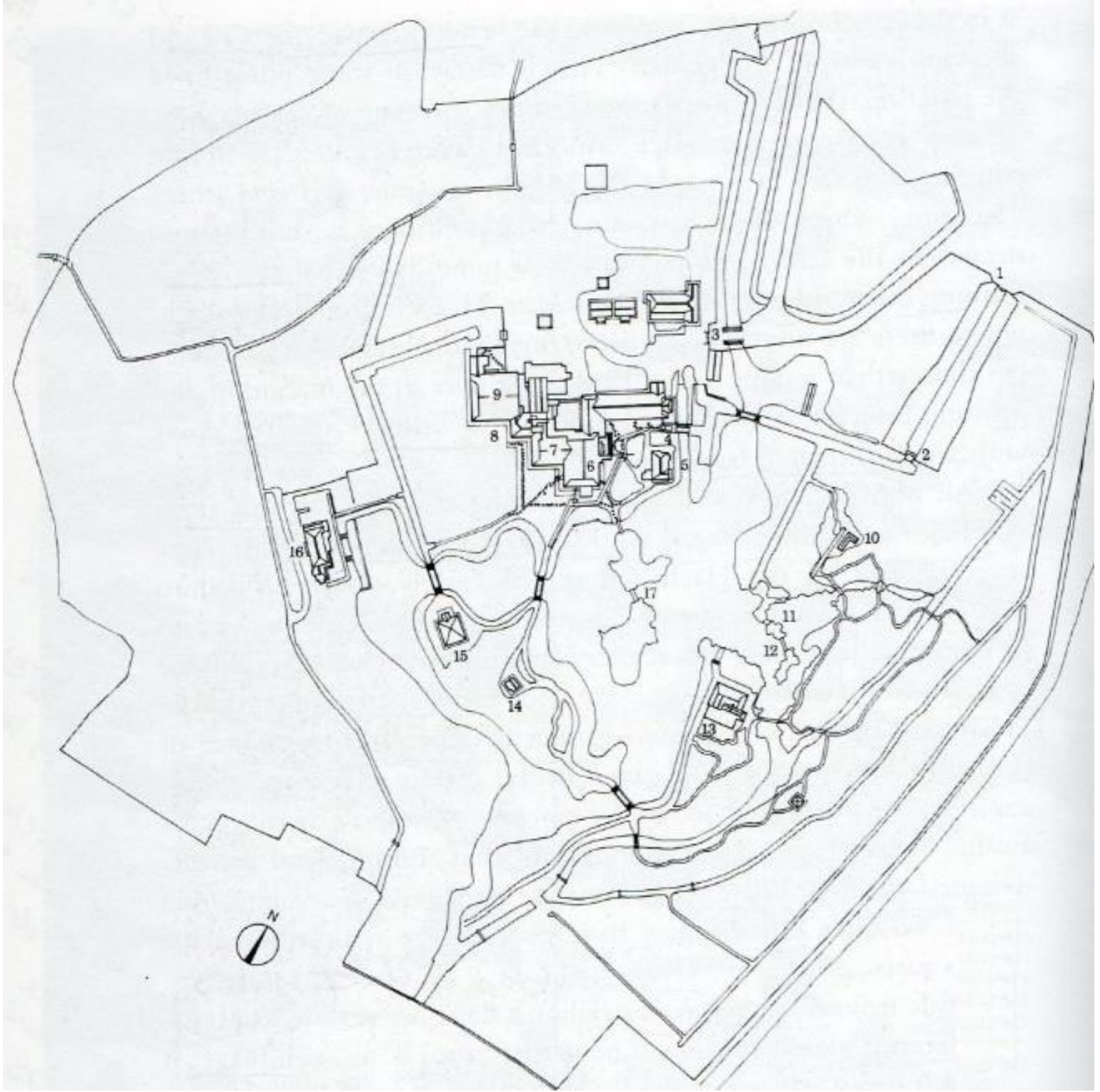

Figura 5: Planta de situação, Palácio Katsura, meados século XVII.

Fonte: ISOZAKI, Arata. Japan-ness in Architecture. London, MA: The MIT Press, 2011. 


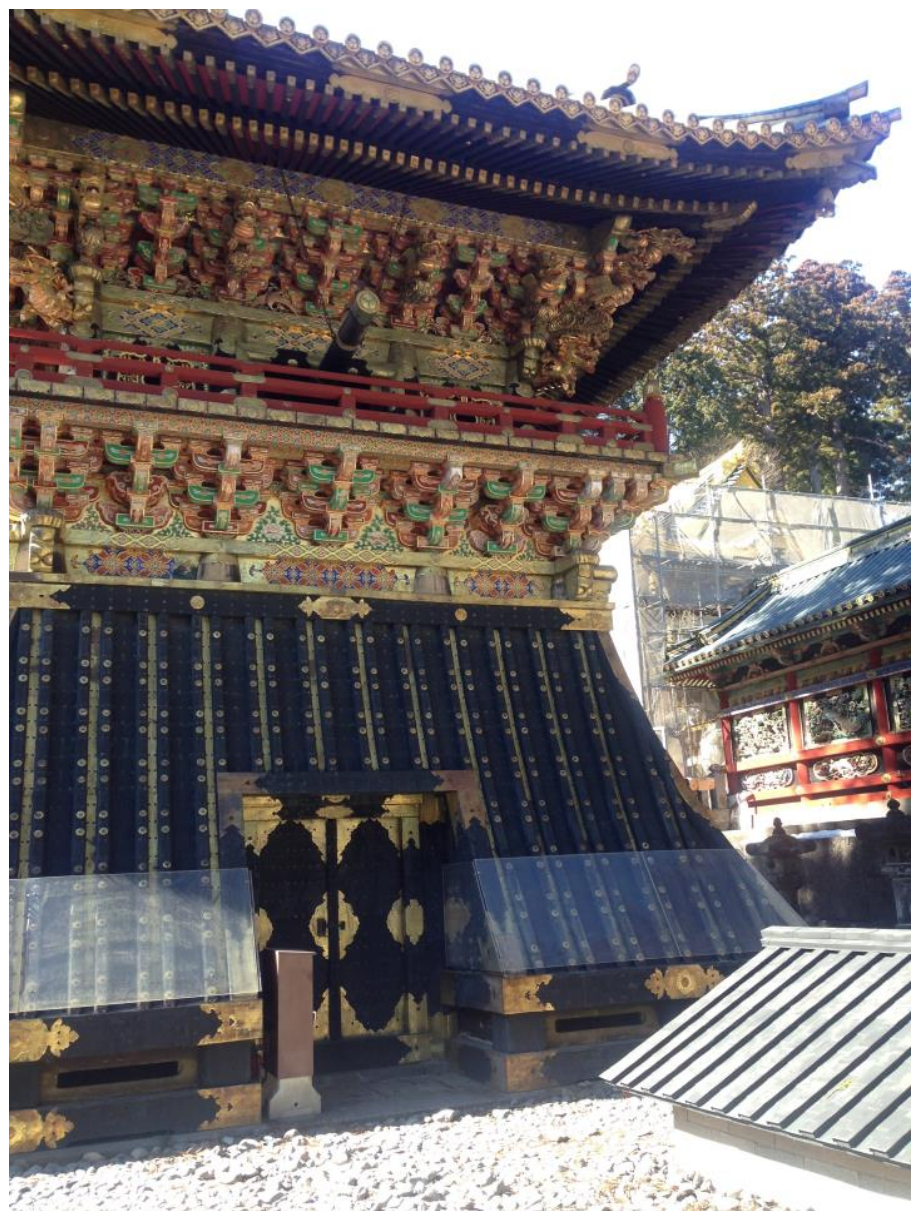

Figura 6: "Barroco Japonês" do século XVII. Tosho-gu Shrine, Nikko. Foto: Silvana Nicolli

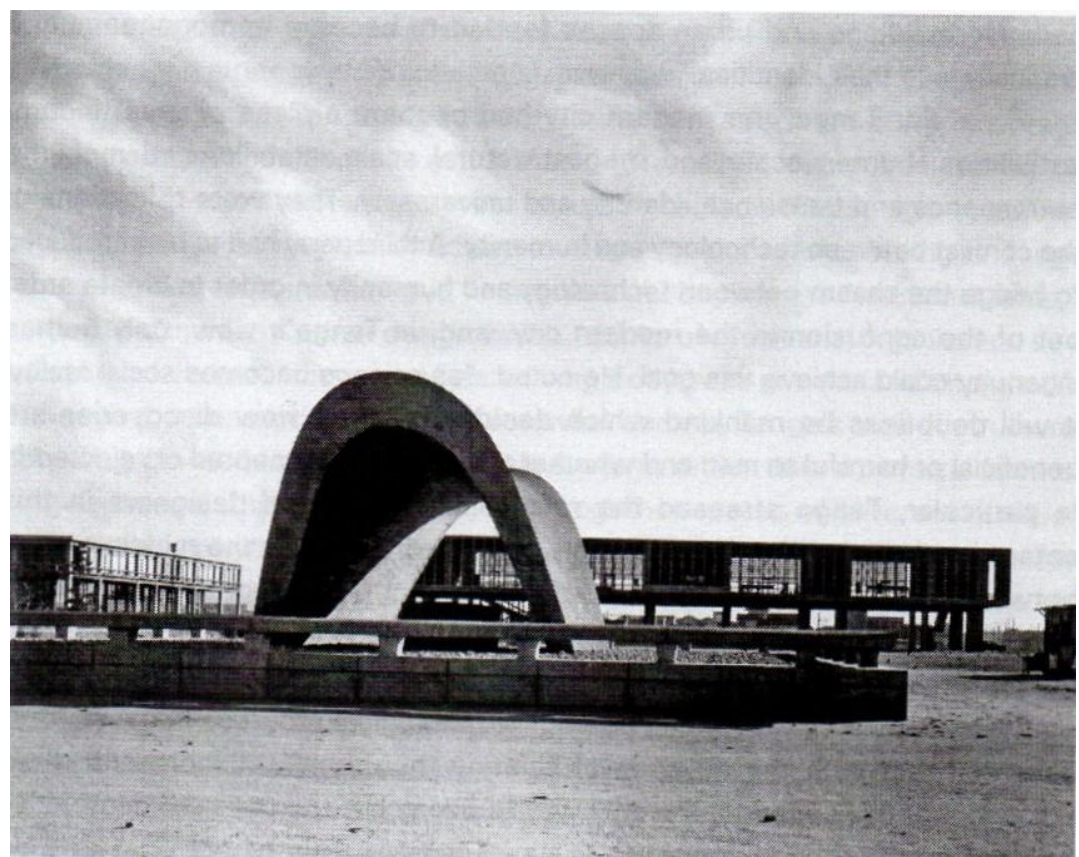

Figura 7: Memorial da Paz em Hiroshima, Kenzo Tange (1949-1955)

Fonte: ISOZAKI, Arata. Japan-ness in Architecture. London, MA: The MIT Press, 2011. 


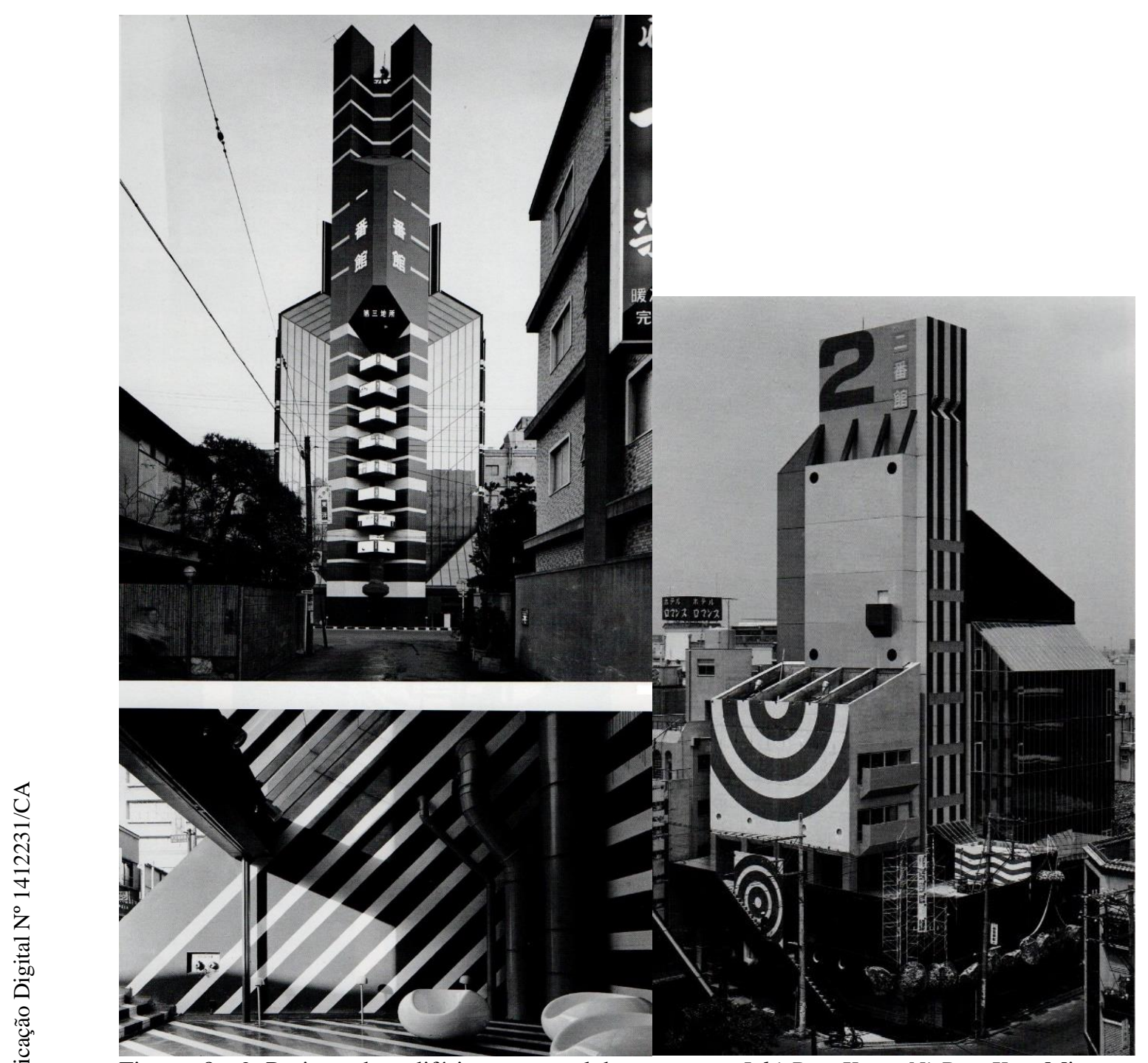

Figuras 8 e 9: Projetos dos edifícios para os clubes noturnos Ichi-Ban-Kan e Ni-Ban-Kan, Minoru Takeyama, 1969 e 1970.

Fonte: BANHAM, Reyner; KOBAYASHI, Katsuhiro; SUZUKI, Hiroyuki. Contemporary Architecture of Japan 1958-1984. London: The Architectural Press, 1985. 


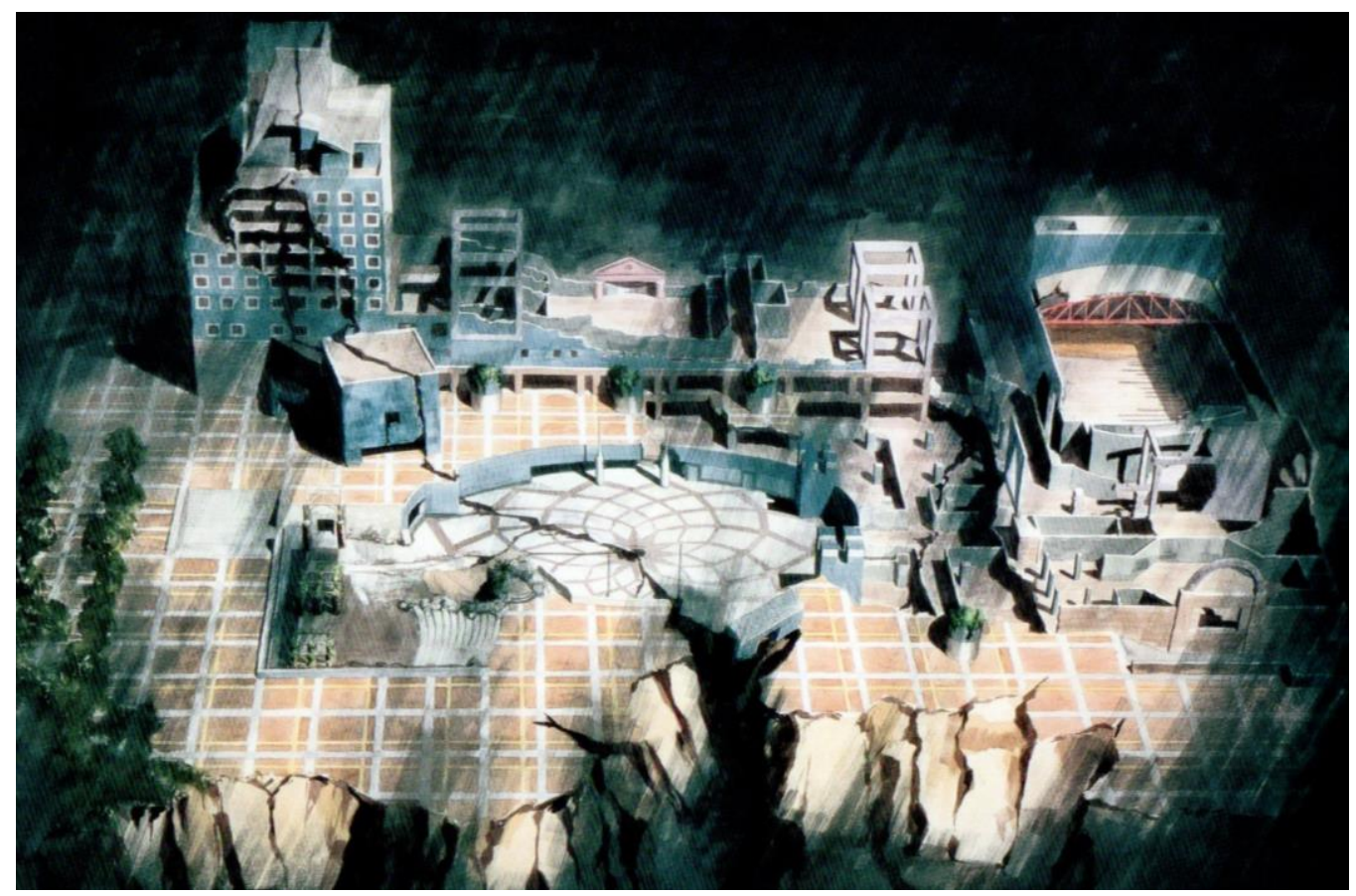

Figura 10 : Arata Isozaki: Aquarela da Praça do Tsukuba Centre em ruínas, Ibaragi no Japão (1979-83).

Cidade Nova desenvolvida como parte do projeto em escala nacional no início dos anos 1960. Fonte: ISOZAKI, Arata; OSHIMA, Ken T.. Arata Isozaki. London: Phaidon Press, 2009.

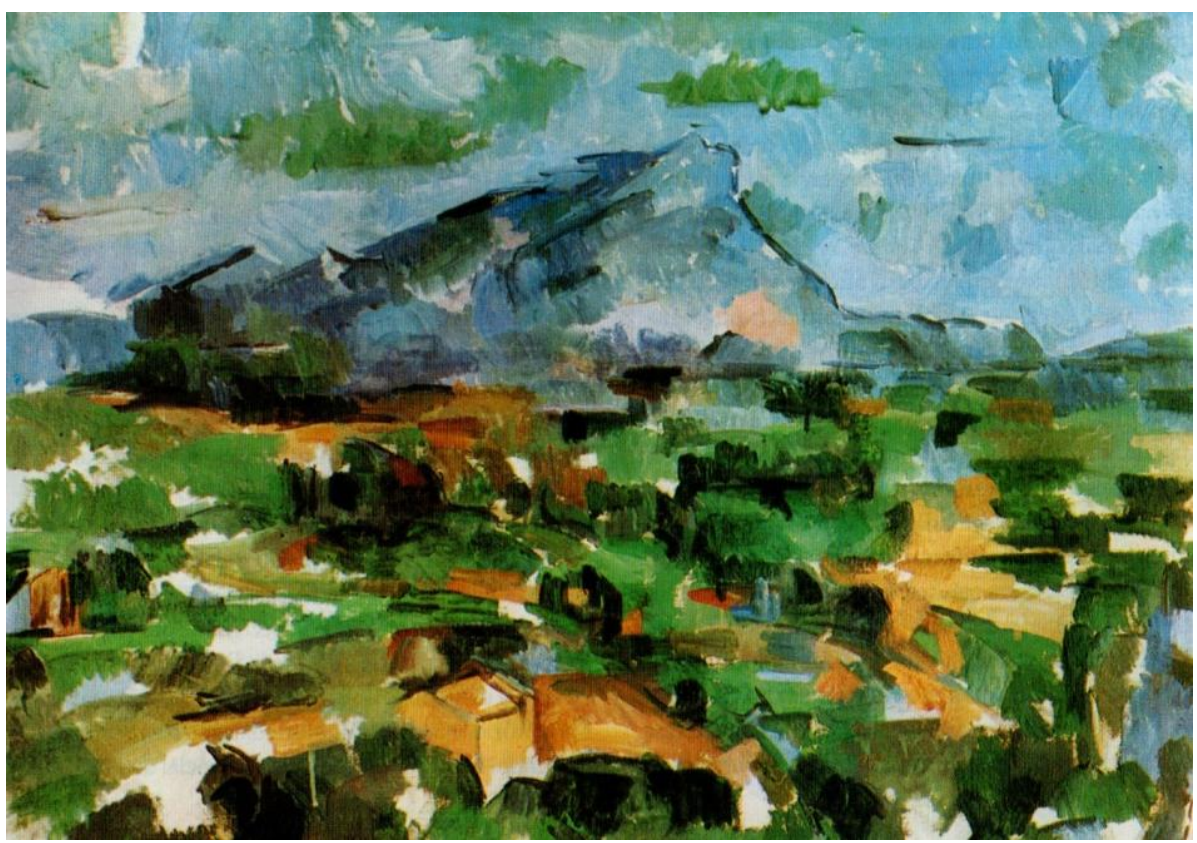

Figura 11: Paul Cézanne: O Monte Sainte-Victoire (1904-6)

Fonte: ARGAN, Giulio C. Arte Moderna. São Paulo: Cia das Letras. 1992. 


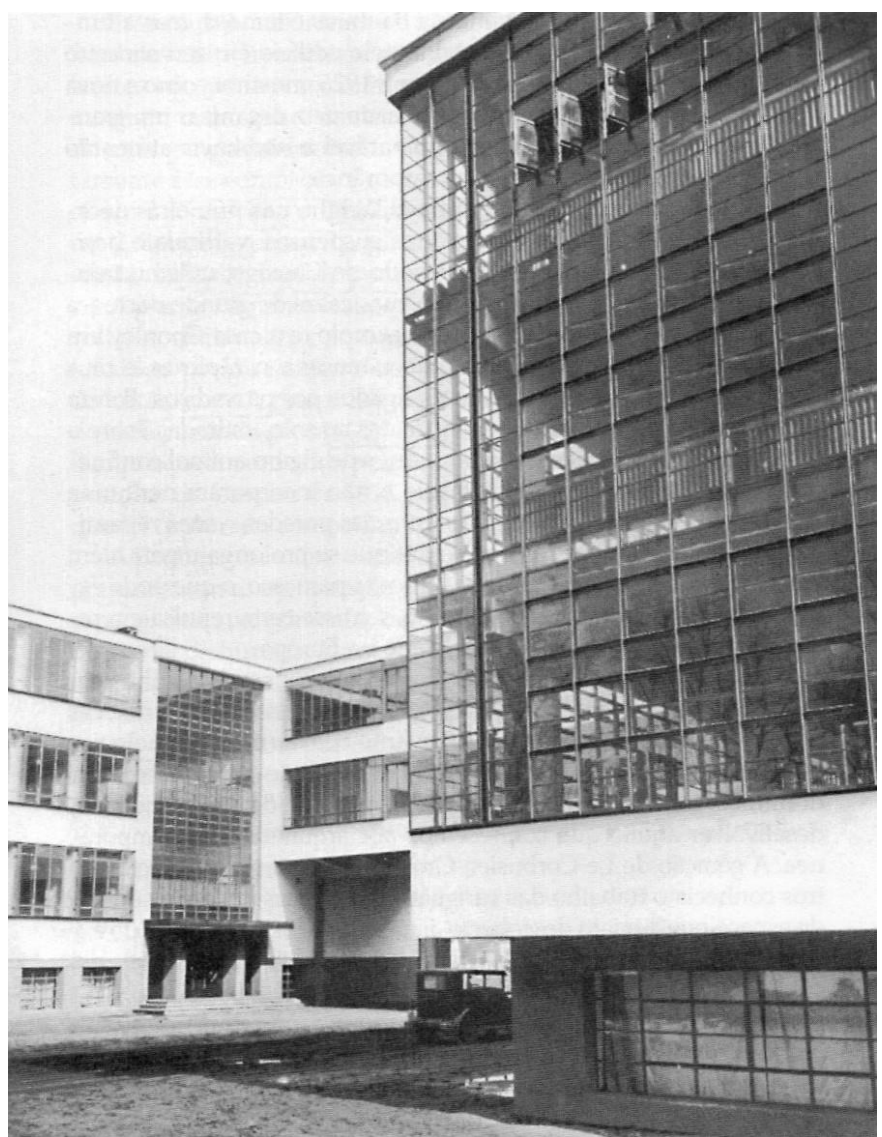

Figura 12: Walter Gropius: Bauhaus, Dessau, 1926.

"Angulo da sala de oficinas. Nesse caso, o interior e o exterior do edifício são apresentados simultaneamente. As superficies transparentes e contínuas desmaterializam os cantos (...)"

(GIEDEON, 2004: p. 523)

Fonte: GIEDEON, S. Espaço, tempo e arquitetura: o desenvolvimento de uma nova tradição. São Paulo: Martins Fontes, 2004.

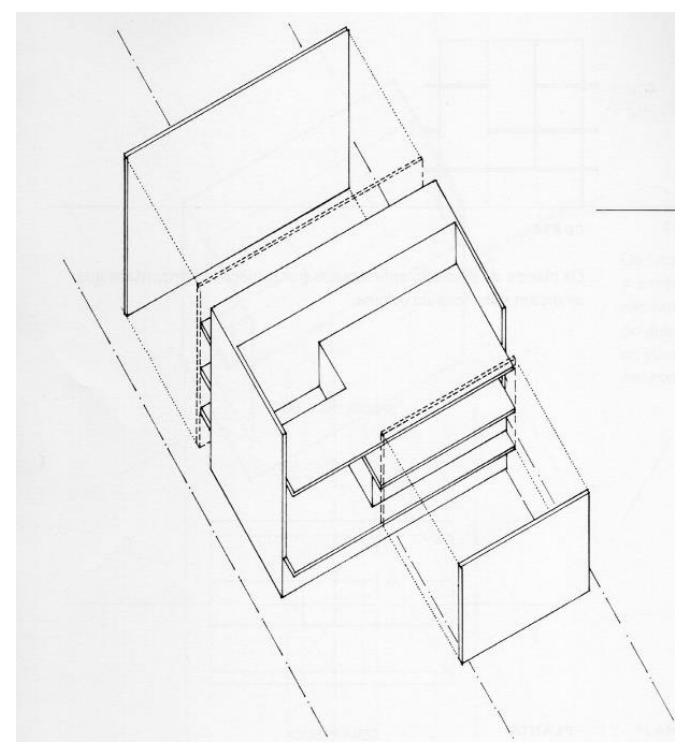

Figura 13:Projeto de Le Corbusier para Villa Stein de Monzie 1926-29

Fonte: BAKER, Geoffrey H. Le Corbusier: uma análise da forma. São Paulo: Livraria Martins Fontes, 1998. 


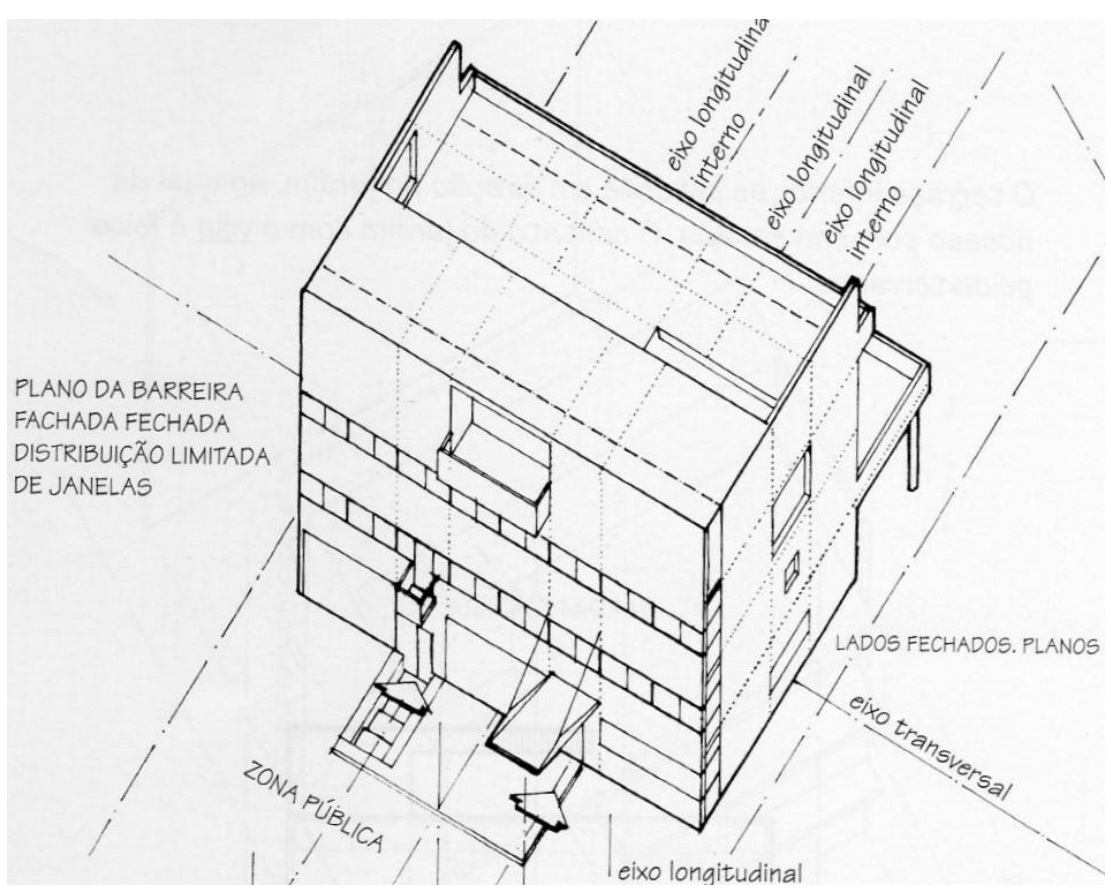

Figura 14: Projeto de Le Corbusier para Villa Stein de Monzie 1926-29

Fonte: BAKER, Geoffrey H. Le Corbusier: uma análise da forma. São Paulo: Livraria Martins Fontes, 1998.

\subsection{2.}

\section{A escuridão e o vazio como princípios da vida}

A narrativa da história do Japão como Estado até pouco se manteve fundamentada na descrição mítica que faz parte dos registros Kojiki e Nihongi, encomendados pelo imperador Temmu no século VII. O imperador pretenderia assim "legitimar a supremacia da família imperial, atribuindo-lhe origem divina” (HENSHALL, 2004: 16). O primeiro imperador apontado no Kojiki, Jimmu, seria o tetraneto da deusa Amaterasu ("Luz do Céu”) e estaria incumbido por ela de governar a terra. Os descendentes de Amaterasu conviveriam com descendentes de outras divindades na terra e juntos determinariam a origem divina do povo japonês. A origem divina da linhagem imperial determinaria o estabelecimento do sistema tennô, que é marcado pela descrição da realidade japonesa segundo sua relação com as divindades espirituais residentes de outro mundo. Apesar da ordem estabelecida por esse sistema e a família imperial, o divino do sistema poderia se incorporar nos mais variados elementos.

O sistema tennô é sempre redutivo signo zero, e assim onipresente. Como o hi ou deuses animísticos, ele pode aparecer em qualquer lugar - em todo detalhe, mesmo no interior de uma folha de grama. Uma vez que o visualizado o centro de seu ser é removido ou descartado, ele, no entanto, permanece como elusiva bruma aglutinada no lugar de todo evento. (ISOZAKI, 2011: 77) 
A premissa para a incorporação das entidades divinas é um centro vazio que passa a ser temporariamente ocupado. Os lugares nos santuários montados para o ritual de incorporação são tradicionalmente alternados, permanecendo temporariamente como espaços vacantes sagrados. O sistema tennô não se encerra no objeto mas no "mecanismo de construir uma ficção em torno do signo zero, assim produzindo um não-lugar a-histórico" (ISOZAKI, 2011: 77). Tal marco zero seria o vazio e a escuridão associados ao sistema tennô. A presença divina do imperador, portanto, também seria marcada por esse paradoxal vazio.

Em O Império dos Signos, o livro de Roland Barthes sobre o Japão e a japo(nês)idade, um vazio central é o suposto indicador da presença do imperador japonês e da corte imperial como cifra zero, conforme implícito na metáfora da escuridão no coração da floresta. (ISOZAKI, 2011: 77)

A harmonia do sistema Tennô dependeu da incorporação da tradição animista herdada do xintoísmo, mesmo quando o budismo, trazido junto da Rota da Seda no século VI, se tornou a religião oficial do Estado Yamato. Um dos fatores que facilitou a recepção do Budismo foi a presença de coreanos entre alguns clãs ligados ao império. O clã dos Soga teria promovido a prática do sincretismo religioso, pois ela permitiria a incorporação de elementos da estrutura política chinesa que facilitaria o estabelecimento do Estado Yamato. "(O Budismo). Ele oferecia uma ideologia unificadora à nova nação. A sua identificação com a família imperial também significava que a difusão do budismo ajudava a alargar a aceitação da autoridade imperial" (HENSHALL, 2004: 16). A fusão de concepções políticas e religiosas variadas fundamentava, portanto, a visão cósmica e de mundo herdadas do período Yamato, determinando também uma prática espacial no Japão.

Conforme verificamos na concepção animista do sistema Tennô, o espaço na concepção japonesa é prenhe da divindade que o pode ocupar, define-se como intervalo $M a$, tendo tempo e espaço simultaneamente subentendidos. O espaço definido como intervalo compreende a referência dos eventos acontecidos antes e depois e é, portanto, definido através da mediação do tempo. Isso poderia ser verificado pela observação da transitoriedade na aparência dos fenômenos naturais. As mudanças observadas na natureza evidenciariam sua qualidade 
espacial e temporal simultâneas, pois seriam o testemunho visível do evento de passagem das divindades por seu suposto centro espacial vazio.

Para o antigo japonês, a percepção do espaço surgiu sobretudo do esforço antigo para visualizar e formalizar as divindades (kami) com seus comportamentos singulares que se pensava difundidos em todo o cosmo. O modelo para as divindades era o sol, o qual poderosamente articulava tempo e espaço através de seu movimento. Sua presença era descoberta no contraste entre noite e dia, luz e escuridão, o mundo divino e o submundo. Montanhas sagradas, rochedos e árvores simbolizavam essas crenças; espíritos habitavam esses objetos e o espaço ao redor numa escala microscópica. Pelo delineamento de locais abertos por quatro postes e uma simples corda, acreditava-se que as divindades kami desceriam e habitariam o espaço. Essas ações de preparar espaço para kami tiveram subsequentemente uma grande influência na cognição do espaço. (ISOZAKI: 2009, 156)

A estética japonesa é dominada por esse conceito de espaço vazio, que implica, em sua condição de intervalo, a potencial abertura para o acontecimento da vida. As marcas deixadas no modo singular da ocupação do espaço refletem a manifestação dessa noção de vazio potencial sob os mais variados temas das artes plásticas, da música e da arquitetura. Exemplos variados da arte japonesa, segundo o arquiteto Arata Isozaki, refletiriam essa noção do termo como passagem não redutível a um fluxo absoluto; como a composição espontânea da música, onde cada músico segue seu ritmo intuitivo; como nos jardins de passeio japoneses, onde não há um eixo dominante de visão, mas o jogo de aparição e desaparição de variados cenários que surgem ao longo do caminho seguido; como na arquitetura, onde a ondulação topográfica é incorporada para a determinação de um eixo ondulante na arquitetura e na predominância do eixo diagonal, do tipo ganko, na disposição planar. Nessas composições, o espaço se revela apenas através do movimento e, portanto, tempo. Não é possível a apreensão imediata da totalidade do espaço no arranjo ganko, que supõe o desenvolvimento temporal em eixos sucessivamente variados. O ganko difere, portanto, da composição hierarquizada segundo um ponto de vista central único, onde as cenas se desenvolvem num fluxo contínuo de tempo, que é associada à concepção do espaço geométrico, uniforme e contínuo que dominou a concepção ocidental.

(O arranjo não-simetricamente ou não-axialmente centralizados) Essa mesma abordagem apareceu no período Muromachi (1338-1573) na disposição dos palácios de estilo shoin nos quais um número de construções são reunidas numa sucessão ao longo do eixo diagonal. Essa disposição, chamada ganko, retirou esse nome do padrão de voo de gansos selvagens ( $\mathrm{gan}$ ), onde os pássaros formam um 
recuo em "V" escalonado atrás de seu líder. Enquanto cada ala da construção preserva seu próprio senso de frontalidade, ele se torna dinamicamente multifacetado conforme o eixo muda baseado na visão diagonal. Em outras palavras, os múltiplos planos sobrepostos (experimentados através do tempo) mudam o eixo, assim divergindo do tempo e espaços absolutos. (ISOZAKI: 2009, 157)

A contemplação dos fenômenos de transitoriedade, que são derivados do conceito de intervalo $M a$, dominam a estética japonesa. $\mathrm{O}$ arquiteto Arata Isozaki relaciona nove sub-temas dele decorrentes, que ainda são desdobráveis. Por exemplo, o conceito de Sabi se relacionaria com o estado do corpo deixado pelo espírito, portanto, tanto com o movimento quanto com a corrosão das coisas. Expressaria a necessidade de viver cada momento, dado o fim inexorável da existência.

Na raiz dessa ideia se situa o senso de dissolução de todas as coisas. Assim todo fenômeno pode ser olhado como existindo num estágio temporário a partir da aproximação com a extinção. Os objetos visíveis gradualmente desaparecem em sombras de si. O ser humano vivente é transformado pelo tempo em cadáver e, finalmente, no esqueleto sem carne. (...) desprovido de toda esperança desse destino, o homem não tem senão uma opção - viver de momento a momento. (ISOZAKI: 2009, 160)

A gravura ukiyo-e de Katsushika Hokusai (1760-1849), Ono no komachi no Kusô-zu, é um exemplo claro da estética sabi. Ela retrata os seguidos estágios da poetiza Ono no Komachi (século IX) que iam do auge à decadência de sua beleza, até sua morte e depois dela quando foi reduzida a um esqueleto. Outro modo de fruição de tal estética seria a contemplação das cores desbotadas nos objetos; “" "patinados” pela passagem do tempo" (ISOZAKI: 2009, 160). No romance Genji Monogatari (século XI) de Murasaki Shikibu, que narra a história do filho do imperador e se passa no contexto da corte japonesa, menciona-se várias vezes a prática do mono no aware que é a contemplação dos aspectos melancólicos da natureza, associados à dimensão da efemeridade da vida. $\mathrm{O}$ poema de Ono no Komachi também revelaria a estética sabi.

Os botões em flor morreram,

Enquanto eu envelheço ociosamente,

Olhando a chuva. (HENSHALL, 2004: 16)

Outro tema relacionado ao vazio animável do $M a$ é o lugar do Utsushimi. Ele se relacionaria à projeção do corpo na realidade e suas marcas singulares 
deixadas no lugar vivido: "a sala de estar extravagante de uma famosa superstar, uma cabana deserta numa área de mineração, uma casa de fazenda tradicional, uma casa de gueixa sofisticada, uma habitação com cobertura de palha num clima húmido do sul, uma casa de taipa num distrito ao norte" (ISOZAKI: 2009, 160). Já o tema do Utsuroi corresponderia à contemplação na iminência de mudança do fenômeno, quando o vulto do espírito primeiro emerge do espaço vazio e projeta sua sombra, conforme se verificaria nas sombras lançadas na água e na terra; no movimento das flores murchando.

(A visão do movimento na natureza) se reflete no espaço arquitetural, onde planos lisos e móveis, tão finos a ponto de ficarem transparentes, são colocados um em frente ao outro, controlando a transmissão de luz e linhas de visão e produzindo um espaço ambíguo e indefinido. Em tal espaço, o cintilar das sombras e a transitoriedade dos planos móveis aludem ao mundo em transformação da natureza; $m a$ é a quietude expectante do momento de espera por esse tipo de mudança. (ISOZAKI: 2009, 159)

\section{Espaço para Arata Isozaki}

O espaço não corresponderia a um lugar fixo, segundo a concepção japonesa. Ele varia conforme a percepção incorporada no movimento, que é gerador de imagens. O espaço arquitetural somente pode ser experimentado através da percepção com o corpo. Este determinaria a produção de imagens cintilantes que os cinco sentidos teriam posto em andamento. Assim, Arata Isozaki conclui que o espaço também surgiria cintilando em função das imagens que vão surgindo na consciência. Tal produção de imagens poderiam ser divididas em dois eixos: um eixo determinaria o espaço da escuridão, relacionado ao espaço psicológico profundo e ao espaço mágico e simbólico; o outro, o espaço do vazio associado ao espaço abstrato e multidimensional da semiótica. Esses dois eixos decorreriam de projeções de imagens interiores. $\mathrm{O}$ espaço trabalhado pelos arquitetos dependeria da compreensão desta dupla dimensão que transforma o espaço em lugar e o tempo em ocasião, conforme proporia a fenomenologia do espaço desenvolvida pelo arquiteto Aldo Van Eyck.

Pelo reconhecimento do espaço como sendo uma imagem projetada do interior, pode-se descobrir um outro espaço fora da imagem. O espaço arquitetural pode ser entendido pela identificação dos modos através dos quais um fenômeno específico é gerado. Projetar o espaço é equivalente a tornar real esses fenômenos. (ISOZAKI, 2009: 151) 


\section{O espaço das ilusões}

O desejo de criar ilusões espaciais determinaria as formas dissolvidas e fluidas da arquitetura religiosa barroca. Diferente da arquitetura renascentista ou gótica, que seriam determinadas por um único ponto de vista, a arquitetura barroca duplicaria os pontos de vista. O efeito da duplicação estaria implicado no modo de fazer referência ao mundo etéreo, transcendente ao mundo físico. $\mathrm{O}$ instrumento para a duplicação de mundos no espaço seria o jogo de luzes, que se polariza nos contrapontos de luz e escuridão, "preenchendo o espaço com arabescos de sombras" (ISOZAKI, 2009: 152), e determina um espaço dramático. Assim, na arquitetura barroca, o jogo de luzes criaria a ilusão de dissolução das formas, através da sobreposição de sombras de modo contrastante com a fonte de luz vinda do exterior. A luz transformaria o espaço determinando o espaço simbólico da escuridão.

Os parques de diversões e as discotecas também determinariam espaços ilusórios, que se tornariam evasivos devido o excesso de imagens projetadas, ultrapassando o limite da visão ordinária. "Hiper-percepções como ilusões, por outro lado, existem no ambiente ou na presença. Alucinação, levitação, e regressão são gerados dentro do corpo. O espaço externo primeiro transmuta. Aparece apenas quando foi percebido. Uma prova disso, é uma percepção instantânea; no momento seguinte mudou. ”(ISOZAKI, 2009: 159)

Outro espaço de ilusão seria determinado por sobreposição ou disjunção de códigos do espaço. Este dependeria da introjeção de determinados códigos espaciais, tal como aconteceria em joguinhos eletrônicos e no espaço urbano, para que o sujeito conseguisse se mover nele.

Os Pilotos de aeronave voando à noite ou em mau tempo tem que contar totalmente com instrumentos assegurar sua localização no espaço. impossibilitado de confiar em sua própria percepção, ele tem que botar fé nos mostradores da cabine, os quais são um código para o espaço. Espaços modernos, especialmente os urbanos, são compostos de uma grande variedade de tais signos. Por exemplo, sinais e sinalizadores de trânsito transmitem sistemas específicos e eventos. (...) Várias redes de código para transmissão de comunicados cobrem nossas cidades e são indispensáveis para a leitura dos espaços urbanos. (ISOZAKI, 2009: 154) 


\section{O elogio da escuridão}

A procura por desenvolver uma arquitetura que se aproximasse mais do paradigma fenomenológico do corpo em detrimento da concepção de espaço abstrato geométrico fez com que ele se voltasse à procura de fontes na própria cultura. A obra do escritor Junichirô Tanizaki, No elogio das Sombras, que analisa as características do espaço arquitetônico japonês, serviu de base. Conforme Isozaki também pensava, espaço e tempo não seriam entidades distintas e separadas, conforme definido pela ciência newtoniana. Além disso, Tanizaki enfatizaria a importância da escuridão como elemento que compreende tais entidades. Ele teria, através de sua obra literária, revelado o poder estético relacionado ao jogo de luzes e sombras da arquitetura japonesa. A escuridão é descrita por ele como adquirindo substância, espessura e cor.

\footnotetext{
"Há muito tempo atrás, palácios e bordéis tinham teto alto, corredores espaçosos e vastos espaços sempre permeados com uma névoa de escuridão, em cuja acre ambiência, damas bem-nascidas eram inseridas. (...) Mas naquela escuridão cintilante e tremeluzente do interior, visível ao olho, as fantasias prontamente surgiam. Algumas vezes, a escuridão desse tipo é mais ameaçadora que a escuridão do exterior." (TANIZAKI, ISOZAKI, 2009: 153)

O espaço se definiria pela distribuição de sombras, produzidas pela passagem de luz. O elemento a priori do espaço seria a escuridão. As luzes e as sombras desapareceriam na escuridão, que "traga tudo e permeia todos os lugares" (ISOZAKI, 2009: 153), porque elas seriam elementos secundários que apenas fazem a escuridão cintilar. O espaço da arquitetura seria definido, portanto,
} pelo monismo da escuridão.

Nos espaços tradicionais japoneses, entretanto, a luz é algo que cintila na escuridão primordial. No ambiente à luz de vela que Tanizaki descreve, as sombras não nascem quando a luz é projetada mas sim tudo que sobrou quando a luz cortou através da escuridão. Por essa razão, a luz não pode ser um absoluto. Ela é efêmera e tem que passar. O espaço se manifesta como densidade de luz, mas a intensidade sofre mudanças e se torna a inevitável escuridão dos interiores japoneses. A escuridão não pode ser interpretada na base da lei de oposições. Escuridão absoluta é o pano de fundo para a manifestação de todo fenômeno. Ela sustenta por dentro minha filosofia da arquitetura (ISOZAKI, 2009: 153).

O espaço escuro seria a ideia do espaço levado ao extremo. A absoluta escuridão (Yami) possibilitaria a manutenção do $M a$. A morte e a destruição associadas à escuridão fazem parte do processo que define o espaço japonês como performativo e não segundo uma metafísica do construído. Por isso, Isozaki enfatiza a importância da estética do sabi, que retrata a paisagem da morte como espaço transitório $(M a)$. A matéria destruída seria o último estágio da dimensão 
de coisa dos seres; o último estágio antes do desaparecimento. O espaço da escuridão de onde surgiria um vazio produtivo $(M a)$.

Os antigos japoneses acreditavam que os espíritos chamados kami permeavam todo o cosmo. Eles eram conscientes do movimento do sol, que dividia o tempo e o espaço. O sol criava o dia e a noite, e a vida na terra; assim como o mundo da escuridão, yami. Os espíritos moravam no mundo das sombras; eles apareciam na terra em momentos específicos, então desapareciam novamente na escuridão.(...)

Yami- yo, a raiz da palavra "yami", significa o reino dos mortos ou a noite. De yami foi gerado o verbo "yamu”(acabar). (ISOZAKI, 2009: 159)

\subsection{3. \\ Japonnerie, Japonica e Japonidade}

$\mathrm{O}$ arquiteto Arata Isozaki descreve três momentos da construção do que caracterizaria a japonidade. Os três momentos estariam relacionados com o olhar estrangeiro lançado sobre os elementos culturais japoneses, que teriam evoluído no sentido da reciprocidade até o enevoar das fronteiras atual. $\mathrm{O}$ primeiro momento teria correspondido ao Japão acuado pela exigência de abertura e imposição de tratados desiguais associados à chegada da frota do comandante Perry em 1854, colocando o sistema do xogunato em crise e restaurando o poder do imperador em 1868. A corrida por uma equiparação dessa relação com o estrangeiro teria correspondido a uma corrida tecnológica e de conhecimento em geral, que marcou a Era Meiji (1868-1912).

A Japonnerie correspondeu à febre colecionista na Europa possibilitada pela abertura do país. O interesse se direcionava para o objetos considerados exóticos, tais como gravuras ukiyo-e, pinturas em rolo, armaduras de samurai. Tal febre implicaria um olhar "pitoresco" vindo de cima. O exotismo do gosto japonês pontuava os produtos selecionados para serem consumidos. Tal mercado não teria sido interrompido até hoje, mas apenas teria mudado de foco dos objetos para os conceitos que caracterizariam sua produção: "simplicidade, humildade, pureza, luminosidade e shibusa (sofisticada austeridade). Mesmo hoje em dia esses conceitos se referem ao gosto japonês e continuam a guiar a seleção e o julgamento dos objetos japoneses" (ISOZAKI, 2011: 4).

O livro de Tenshin Okakura sobre a cerimônia do chá, Book of Tea, escrito em inglês corresponderia a um segundo momento dentro da Japonnerie, quando um japonês com formação também na cultura ocidental fez um esforço de 
atualização da própria cultura. No mais das vezes, tal esforço correspondeu a um tipo de Ecletismo, certa quimerização das culturas em dois sentidos. Para Isozaki, nem o Hotel Imperial (1913-1923), projetado pelo arquiteto Frank Lloyd Wright, e nem o estilo Crown (teikan-heigô-shiki), desenvolvido pelo arquiteto Kitutaro Shimoda (1866-1931) escapariam desse Ecletismo. "A ideia de Shimoda fora projetar um telhado como elemento tradicional sobre um edifício construído com as novas técnicas e materiais, como união da estrutura racional e do símbolo tradicional, assim dispondo um emblema simples o suficiente para ser amplamente apreciado. ”(ISOZAKI, 2011: 8). Já o projeto de Wright para o hotel Imperial, além de ter rendido uma acusação de plágio por parte de Shimoda, não passaria de uma composição acadêmica, que careceria totalmente do sentido da planaridade própria do espaço japonês. Além disso, cometeria um equívoco ao utilizar um material pesado e poroso, típico de uma cidade do Japão, mas raramente utilizado na arquitetura como acabamento. "Para um ocidental, o Hotel Imperial pode ter parecido asiático ou japonês, mas não para um olho japonês" (ISOZAKI, 2011: 6). Wright ${ }^{155}$ não teria entendido o conceito de vazio sobre o qual lera no livro de Okakura, proferindo palestras em que associava a destruição do volume fechado da arquitetura, que marcava a arquitetura ocidental, ao desenvolvimento do espaço interior concebido como vazio.

Ao chamar a atenção para esse conceito taoísta do vazio onipresente, Okakura salientava o ponto de que a casa de chá, bem como seus utensílios de chá, têm significado somente em termos desse vazio. Mas Wright interpretou mal essa questão chave, não como vazio onipresente, mas como um espaço interno teleologicamente construído. Wright tinha começado a teorizar seu modo singular de destruir a caixa ou fechamento, como forma de salientar seus "conteúdos", mas, assim, objetificando-os. (ISOZAKI, 2011: 5)

O estilo Crown (Teikan), além de fragilmente concebido como ecletismo formal, teria servido como expressão do nacionalismo e na campanha

\footnotetext{
155 "A casa japonesa impressionou Frank Lloyd Wright como "um estudo sublime sobre a eliminação - não só da sujeira, mas também do irrelevante". Para a casa americana, Wright havia conquistado a mesma eliminação, uma rejeição do confuso e fútil. Porém fez mais do que isso. Ele começou a considerar aqueles elementos que passam despercebidos em toda parte elementos provenientes de soluções puramente utilitárias - e descobriu nesta matéria-prima sua expressividade oculta, da mesma maneira como a geração seguinte descobriria a expressividade oculta na engenharia e na estrutura. " (GIEDION, $2004: 433)$.

Como resultante do tratamento elementar, segundo Gideon, a arquitetura de Wright adquiriria unidade espacial. A partir da destruição do volume, ele chegaria à planta flexível e aberta do "estilo da pradaria", marcado pelo jogo de superfícies planas que será retomado pelos neoplasticistas.
} 
expansionista empreitada no continente asiático pelo próprio Japão a partir dos anos 1920. Nessa época, o Japão já teria alcançado um surpreendente desenvolvimento da produção industrial, apoiado pela política estatal, ainda que fosse reprimido no quesito da militarização. "Uma das resoluções de Washington (Conferencia de Washington em 1921/22) obrigava o Japão a concordar com um limite de três navios de primeira linha, a América a cinco e a Grã-Bretanha a cinco também" (HERSHALL, 2004: 154). A partir dos anos 1930, no entanto, a situação política se inverte, quando o Japão inicia a invasão da Ásia: “uma tentativa de expandir sua influência político-econômica sob o pretexto de liberar a Ásia da dominação ocidental. O objetivo era construir uma comunidade supraasiática - a assim chamada Grande Esfera Leste-asiática de Coprosperidade com patrocínio japonês.” (ISOZAKI, 2011: 14) Tal momento teria coincidido com uma revisão crítica da expressão de conteúdo da japonidade do estilo Crown (Teikan).

A revisão teria sido promovida por arquitetos japoneses que haviam ido estudar e trabalhar na Europa nos anos 1920, entrando em contato com a arquitetura moderna da Werkbund de Viena, da Bauhaus e de Le Corbusier. O processo de revisão teria contado ainda com a ajuda de um possível porta-voz da japonidade, que teria sido o arquiteto expressionista, ligado à Bauhaus, Bruno Taut. Este teria chegado no Japão em 1933 à procura de refúgio contra a perseguição nazista. Segundo Isozaki, Taut provavelmente desconhecia a arquitetura japonesa. Ele foi prontamente acolhido por um grupo de arquitetos japoneses, que tivera contato com a arquitetura moderna e era crítico do ecletismo do estilo Crown (Teikan). “(...) O grupo queria demonstrar que os elementos “puros" japoneses e racionalistas (ou, para eles, funcionalistas) da arquitetura moderna poderiam coexistir sob uma e mesma égide" (ISOZAKI, 2011: 10). O caminho para tal sincretismo entre o tradicional e o moderno já havia sido aberto pelo arquiteto Sutemi Horiguchi (1895-1984), que havia praticado em projeto a mistura de elementos do estilo wayô com o moderno. A escolha pelo wayô se devia pela simplicidade de seus detalhes, presente também nas casas de chá, e também pelos elementos em comum com o racionalismo; tais como a ortogonalidade e as divisões espaciais flexíveis. Os estilos budistas importados que não se encaixassem nesse padrão eram rejeitados ou associados à 
monumentalidade que, teoricamente, esse primeiro modernismo racionalista rejeitava. "Além dessa tipologia (da simplicidade racionalista) surgiu o costume de opor o santuário xintoísta ao templo budista, e de colocar o minka (habitação rural pré-moderna) e a casa de chá como espaços do cotidiano versus o castelo feudal e o mausoléu como símbolos de autoridade” (ISOZAKI, 2011: 12). Esses arquitetos, críticos do ecletismo, levaram Taut para visitar duas obras da arquitetura japonesa tradicional em Quioto: a Vila Imperial de Katsura e o Santuário Ise.

\section{A eterna atualização do santuário de Ise}

Os arquitetos que levaram Taut para visitar o santuário de Ise (Fig. 3) estariam em busca de um juízo do arquiteto que desse um argumento para a incorporação da arquitetura moderna Internacional, cuja linguagem tenderia à universalização, num país em franco movimento nacionalista. Arata Isozaki aponta a insólita comparação que Taut faz do Ise com o Parthenon. Este seria arquétipo da linguagem clássica, relacionada à tendência da cultura universalista ocidental, ao pensamento metafísico, à arquitetura como monumento perene. $\mathrm{O}$ Ise, por outro lado, um monumento ao mito, à obscuridade do segredo, à arquitetura que é transitória, sendo desmontada, remontada e atualizada conforme a repetição do ritual e atualização das crenças.

A origem do santuário é cercada de mistério, pois associada ao momento em que o sistema imperial se instalou no século VII, legitimado pelo mito da ancestralidade divina do imperador. Falar de sua origem se manteria um tabu até o século XX. A continuidade do obscurecimento da origem do Ise, como prolongamento do mito da ancestralidade, seria garantida através do ritual de desmontagem e remontagem do santuário em lugares alternados a cada vinte anos. Tais remontagens incluiriam algumas alterações ao longo dos séculos ${ }^{156}$, de tal modo que seria impróprio defini-lo como arquitetura "pelo modo do conceito ocidental de materialidade perene" (ISOZAKI, 2011: X). As alterações se

156 "Mas, em vez de reconhecer o esquema espacial existente, o arranjo espacial e a escala foram intencionalmente formalizados de acordo com a nova tendência medieval em direção à frontalidade. Nesse caso, seria impreciso dizer que reconstrução de vinte anos de intervalo manteve uma estrita identidade da forma. Em vez disso, temos que admitir que no gesto de repetição, certa vontade de ajustar o desenho na direção de uma autenticidade percebida." (ISOZAKI, 2011: 138) 
dariam em função das mudanças no entendimento das crenças e das práticas rituais promovidas pela influência de novas seitas budistas ${ }^{157}$ que incrementavam o sincretismo já reinante. Elas corresponderiam ao esforço de atualização da forma, determinando uma noção de eternidade que contradiria àquela do progresso que preserva a identidade. "Esse desejo persistente de criar uma eternidade, uma eternidade diferente certamente, é algo como o que o filósofo Heidegger chamou "temporalidade da queda", ou o modo temporal de uma queda vertical no presente. Cada repetição é a repetição de um começo compelido à similitude." (ISOZAKI, 2011: 146). A repetição do ritual de reconstrução do Ise também estaria associado à encenação da incorporação da divindade no imperador, quando este é entronado, garantindo a preservação do sistema Tennô. "É dito inclusive que há uma implicação sexual - já que dizem que a deusa visita tennô para dormir com ele. Esse tratamento do corpo físico do imperador é análogo ao tratamento das construções no Ise - segundo a reconstrução/ relocação, o novo santuário é hospedeiro para o hi (espírito)."

(ISOZAKI, 2011: 132)

\section{A busca por transparência}

Taut teria comparado o Ise ao Parthenon e prognosticado como o destino final de futuras peregrinações internacionais para conhecimento de mais um “clássico" da arquitetura mundial. Ele teria identificado, na planta retangular, simétrica, avarandada (e elevada sobre colunas de madeira sem embasamento) do santuário principal de Ise, a pureza formal que também se encontraria nas arquiteturas clássica e moderna.

\footnotetext{
"Os santuários de Ise são a maior e mais completamente original criação do Japão em termos de arquitetura mundial. (...) O Parthenon na Acrópoles é até hoje um sinal visível dos dons de beleza que os homens de Athenas atribuíram ao seu símbolo de sabedoria e inteligência, Athena. Ele é esteticamente o maior e mais sublime edifício em pedra, como os santuários de Ise são em madeira. Mas há uma grande diferença. Mesmo que o Parthenon não tenha caído em ruínas ele seria hoje apenas um monumento dos tempos antigos, já que falta vida a ele. Como são diferentes os templos de Ise! Não apenas são os ritos religiosos e os
}

\footnotetext{
${ }^{157}$ O budismo na China teria se misturado ao confucionismo e ao taoísmo. No Japão, as seitas budistas, desenvolvidas na China, teriam disponibilizado um componente metafísico ao xintoísmo. "Naquele contexto, o taoísmo foi empregado para o estabelecimento do ritual, o budismo para seus aspectos doutrinários e o ideal de um estado moderno em si para a propagação da nova ideologia religiosa inclusiva." (ISOZAKI, 2011: 144)
} 
fluxos intermináveis de adoradores uma presença vívida, os santuários possuem ainda outra qualidade, a qual é inteiramente original em seus efeitos, intenção e percepção. Esse é o motivo porque os santuários são sempre novos." (ISOZAKI, 2011: 124)

A intervenção de Taut teria feito com que mesmo especialistas japoneses mudassem sua visão do Ise, tal como Chûta Itô, que teria questionado Taut sobre a sobrevalorização do santuário: "Ele respondeu que era difícil listar os pontos reais, mas o principal critério era sua pureza. Apesar de não possuir nem ornamentação nem complexidade, a pureza de forma e estrutura atesta certa espiritualidade. (...) A pureza dessa arquitetura é como a de uma criança, sua inocência tem um caráter divino”. (ISOZAKI, 2011: 122)

Assim, Taut na companhia de seus anfitriões, Ueno e Shimomura, também identificaria no Palácio Katsura (Fig. 4 e 5) a expressão do funcionalismo. Para Isozaki, este seria apenas o primeiro estágio de um processo de mitificação da arquitetura do Katsura, que contaria ainda com as leituras feitas pelos arquitetos Sutemi Horiguchi e Kenzo Tange. As primeiras leituras modernistas estariam centradas na leitura do jogo de suas vigas e paredes brancas como composição planar modrianesca, assim como o jogo das camadas de espaço que se abriam ao longo da disposição diagonal e assimétrica. Essas leituras ignoravam certos "excessos", considerados por Taut como Kitsch. Horiguchi e Tange farão uma revisão desse purismo inicial em função de um novo contexto da discussão da japonidade, que verificaremos posteriormente. Assim, Taut associa a disposição diagonal aparentemente espontânea ambientes do Palácio às necessidades cotidianas do uso.

$\mathrm{O}$ arranjo inteiro, de qualquer parte que se tome para olhar, sempre seguiu elasticamente em todas as suas partes um propósito o qual cada uma delas, assim como também o todo, teve que cumprir. O objetivo poderia tanto ter sido aquele da banal e regular utilidade, ou a necessidade de uma representação mais digna, ou de uma elevada espiritualidade filosófica. E o grande mistério foi que todos os três propósitos tinham sido unidos num todo, suas fronteiras apagadas. (ISOZAKI, 2011: 258)

Taut desconheceria a mistura de estilos pertinentes ao palácio, executado durante cinquenta anos em meados do século XVII sob comando de duas gerações de príncipes. As qualidades de pureza, simplicidade e nobreza que ele encontrou na arquitetura do Katsura estariam mais predominantemente associadas ao 
primeiro estágio de seu desenvolvimento, relativo ao ambiente do Ko-shoin. Todos os três estágios de desenvolvimento juntos determinariam a diagonalidade da disposição (gan-kô ou zigue-zague), que cria um ritmo assimétrico e introduz iluminação e ventilação. O primeiro estágio, no entanto, seria o mais transparente de todos, pois manteria a unidade de sistema modular homogêneo e oferecia um ponto focal determinado no início. Teria sido o espaço que mais agradou aos modernistas: "sua composição puramente linear e sem qualquer detalhe representacional deve ter parecido ideal pros modernistas, na intenção de conjurar um espaço abstrato a partir de meros planos e linhas”. (ISOZAKI, 2011: 279). A japonidade havia se traduzido então nessa transparência iluminada, de uma geometria flutuante, leve, de uma simplicidade funcionalista e, simultaneamente, espiritualizada.

Do momento que entramos no Ko-shoin, nós nos impressionamos com a transparência de seu interior. Os shôji circundantes suavizam a luz do sol recebida, agora gentilmente tentando alcançar os cantos e ambientes traseiros da estrutura. (...) As linhas índigo das bordas azuis do tatame, as bordas laqueadas de preto do fusuma, e a escuridão das colunas envelhecidas e lintéis entrecruzam esse volume reluzente. $\mathrm{O}$ todo resulta em algo como uma impressão de espaço variável baseado num módulo homogêneo que a arquitetura modernista tomou como premissa. Não é surpresa que os modernistas tenham demonstrado um apreço particular pelo Ko-shoin. (ISOZAKI, 2011: 279)

O reconhecimento da arquitetura japonesa feito por Taut não estaria livre dos critérios de prazer estético herdados da cultura clássica ocidental, baseados em elementos puramente visuais, tais como a pureza da linhas, proporção e harmonia; o que teria determinado um estereótipo relacionado à noção de composição que teria servido, no entanto, para superar a noção de gosto que norteava a japonidade (exótica) do ecletismo Teikan. Taut endossaria a ideia de uma possível transposição de elementos, esvaziados de seus aspectos particulares, desenvolvida por seus anfitriões japoneses. Assim, os elementos pertencentes à arquitetura moderna e à tradicional japonesa foram identificados por sua universalidade. "Esse encontro discursivo promoveu uma crença de que existia uma série de princípios universais do funcionalismo que iam além das particularidades históricas e geográficas” (ISOZAKI, 2011: 12).

Por outro lado, Taut teria classificado o mausoléu do xógum Tokugawa em Nikko, como um tipo de "estilo excessivamente decorado, um tipo de barroco 
japonês” (ISOZAKI, 2011: 13), como vulgar, kitsch, inautêntico e descartável ${ }^{158}$ (Fig. 6 ). Para Isozaki, Taut teria tido também motivações político-ideológicas ao classificar a arquitetura ligada ao sistema imperial como autêntica e essa do período do xogunato como kitsch: ele precisava de refúgio no país. Desse modo, estaria endossando a legitimidade do sistema Tenno sustentada pelo espírito nacionalista reinante e, simultaneamente, disponibilizando uma leitura da arquitetura moderna como perpetuadora desse sistema para aqueles arquitetos japoneses ávidos por mudanças e para o público.

\section{Transparência moderna}

Apesar dos esforços iniciais, a revisão crítica da arquitetura eclética somente seria colocada em prática no Japão após a Segunda Guerra, devido ao desvio da produção para o aparelhamento bélico e à limitação do uso de materiais, tais como o aço, para a construção civil. Verificamos como a noção de transparência havia se tornado o paradigma da japonidade na arquitetura. $\mathrm{O}$ desenvolvimento do método para uma presumida arquitetura moderna, baseada na japonidade, teria sido feito por Hideto Kishida (1899-1965) durante os anos 1930. Ele se basearia na captura de imagens da arquitetura do passado através do enquadramento moderno, resgatando assim elementos destituídos da distância temporal. Kishida tinha uma posição privilegiada como professor da universidade de Tóquio e juiz de concursos estatais. Ele tentava subverter o predomínio dos arquitetos ecléticos através de sua posição influente.

Ele estava assim bem colocado para promover seu objetivo de realizar um espaço transparente para o xintoísmo - um espaço ritualístico originando no Xinto que é austero, reducionista e único e é, de certo modo, compatível com o desenho moderno. Ele procurou as características dessa transparência entre os instrumentos ritualísticos usados nas cerimônias religiosas, assim como também

\footnotetext{
${ }^{158} \mathrm{O}$ juízo em função dos critérios de autenticidade e não-autenticidade acabou sendo incorporado também pelo olhar estrangeiro, que conforme apontou Isozaki, ignorou o movimento interno dos próprios japoneses para superação do ecletismo Teikan. Assim, o historiador Leonardo Benévolo descreve, em 1960, a passagem de Taut no Japão. "Taut fica no Japão e dá uma contribuição decisiva para o estudo da tradição local, nela distinguindo os aspectos caducos e os permanentes, ainda suscetíveis de desenvolvimento. (...)

Taut insiste nessa distinção, que é ainda fundamental para o desenvolvimento da cultura arquitetônica japonesa: uma verdadeira continuidade com o passado não pode ser estabelecida através de imagens ligadas às situações contingentes, mas através dos métodos, generalizáveis por meio da reflexão crítica.” BENEVOLO, Leonardo. História da arquitetura moderna. SP: Editora Perspectiva, 1989.
} 
no espaço da vida diária. Ele não apenas compôs essa imagem (...) mas também procurou desenvolver uma nova arquitetura a partir dela. (ISOZAKI, 2011: 15)

O aluno de Kishida, Kenzo Tange, venceu três concursos em que ele foi juri, dois não executados em função da guerra. Apesar do uso de elementos comuns à linguagem moderna, teoricamente desprovida de conteúdo histórico, esses projetos refletiam a ideologia nacionalista em três contextos diferentes da história do Japão. "Essas três mensagens - a unificação japonesa da Asia, dominação cultural das colônias pelo Japão e comemoração de um derradeiro apesar de auto-infligido desastre - todos, no entanto, representavam temas primordiais para o estado." (ISOZAKI, 2011: 17)

Kishida somente teria êxito na realização efetiva do seu intento após o fim da guerra, quando Kenzo Tange seria o vitorioso do projeto para o Memorial de Hiroshima em 1950 (Fig. 7).

Seria difícil afirmar uma linhagem outra que o estilo Internacional para a linguagem arquitetural desenvolvida por Tange em Hiroshima. Pilotis, um telhado plano, o espaço flutuante, a estrutura exposta e transparência são plenamente utilizadas. Ao mesmo tempo, os pontos de referência à arquitetura tradicional japonesa - o plano Hô-ô-dô do Byôdô-in, a relação entre as colunas baseada no Katsura - eram inconfundivelmente e claramente expressos. O Centro Memorial da Paz é tanto uma obra modernista quanto japonesa. E até incorpora o espaço xintoísta da transparência que é considerado frequentemente como epítome da estética tennô. (ISOZAKI, 2011: 17)

\section{A decadência da transparência como reação ao olhar configurado pela japonica}

Para Arata Isozaki, a identificação da arquitetura japonesa como sinônimo da transparência viria a ser questionada em função de dois aspectos que se tornaram complementares. $\mathrm{O}$ primeiro seria relativo à configuração da japonidade da transparência como expressão do modernismo da arquitetura internacional, que era associado à vertente americana e à ocupação no pós-Segunda Guerra. O segundo seria consequência do questionamento da essência da japonidade transparente face à "descoberta" da arte pré-histórica Jômon. Esta associável à onda primitivista, suscitada pelo movimento surrealista europeu e alimentada no Japão pelo sentimento anticolonialista que foi despertado pela ocupação americana. 
A presença de dois personagens japoneses, mas em contato com o olhar americano e europeu, retratariam esse novo momento tornado ainda mais decisivo pelo deslocamento do centro de influência das artes da Europa para os Estados Unidos. Os dois teriam ficado retidos em campos de concentrações americanos. A imigração de muitos artistas da vanguarda moderna europeia, fugidos do fascismo, também teria contribuído para a mudança do eixo de influência para os Estados Unidos. Os personagens cruciais para o argumento de Isozaki sobre esse momento de virada de critério da japonidade seriam o artista Isamu Noguchi, que estudara escultura com Brancusi em Paris, e o fotógrafo Yasuhiro Ishimoto, que havia frequentado os ateliês da Bauhaus em Chicago. A arquitetura moderna que teria se determinado agora como um método racional baseado no estabelecimento de uma linguagem universal, conforme proposto pela Bauhaus, e não um estilo, recebia a alcunha de Estilo Internacional a partir da exposição do MOMA de 1932. Assim, é a partir dessa pretensão de universalidade da linguagem moderna que Noguchi e Ishimoto olharão para o próprio país de nascimento. As referências da japonidade se tornariam ainda mais abstratas, permitindo o completo afastamento do gosto japonês que determinava o estilo eclético.

\begin{abstract}
A partir da experiência de modernismo determinada pela japonidade surgiu uma forma de composição abstrata e sofisticada. Aqui novamente precisamos notar que um olhar externo desempenhou o papel determinante. Depois da Guerra, Noguchi veio ao Japão como a encarnação do modernismo americano, tendo abstraído a beleza japonesa do ponto de vista privilegiado do modernismo. (...) Não somente o que era chamado internacional foi considerado válido - mas novamente o mecanismo de apreciação se transformou em japonidade. (ISOZAKI, 2011: 36)
\end{abstract}

A japonica teria se tornado uma moda nos EUA, depois abandonada, contribuindo para que Noguchi se debruçasse na busca de um olhar mais próprio, longe dos colabores americanos com os quais trabalhou ${ }^{159}$. Os dois artistas, o fotógrafo e o escultor, viveriam um momento de virada da Japonica. Tal momento corresponderia ao desenvolvimento de uma debate sobre as raízes da japonidade, sustentado pela mudança de paradigma teórico proposto pelo historiador Ryûichi Hamaguchi e interpretado pelo artista Taro Okamoto (19111996).

\footnotetext{
${ }^{159}$ Isamu Noguchi desenhou uma mesa para a marca fabricante de móveis modernos Herman Miller, fez cenografia para Martha Graham e intentou colaborar com os arquitetos Louis Kahn e Buckminster Fuller. (ISOZAKI, 2011: 37)
} 
As ideias de Ryûichi Hamaguchi teriam como base a crítica proferida pelo arquiteto Kunio Maekawa de que o Memorial da Paz em Hiroshima não corresponderia de fato à vontade construtiva oriental, que seria pautada pelo devir (jinen) e não pela vontade de construir (sakui) ${ }^{160}$. Tal noção permitiria a superação da oposição entre moderno e tradicional na síntese performativa, mas o movimento de busca dos elementos comuns teria transformado a almejada japonidade num objeto, redundando na tendência ocidental (sakui).

Não obstante, os métodos que encontraram para si eram nesse momento mais ocidentais que aqueles da geração anterior que experienciou o Ocidente diretamente, no sentido de que essa nova geração tinha por fim tentado internalizar as ideias modernistas. Assim, equipados, eles fizeram do Japão o objeto de sua própria pesquisa e projeto. Em outras palavras, eles extraíram a própria interioridade, tendo desviado via um olhar externo. Desse modo, escaparam do ciclo vicioso da auto-referência, já que o vetor criativo antes alcançou uma alteridade por meio da qual poderia viajar internamente. (ISOZAKI, 2011: 25)

A consciência do papel do Estado ao longo do desenvolvimento do chamado gosto japonês teria determinado, segundo Isozaki, a procura de Hamaguchi por outros critérios estéticos em substituição ao gosto exótico, mas também em relação ao juízo de gosto que teria se mantido associado ao critério composicional moderno. Ambos alicerçados na busca por expressão de Japonidade, que, de certo modo, havia se definido de modo descontextualizado das contingências políticas. Tal critério seria o conceito de Kunstwollen (vontade de forma), desenvolvido por Aloïs Riegl e Wilhelm Worringer e interpretado por Ryûichi Hamaguchi através da comparação dos métodos ocidentais e orientais (ISOZAKI, 2011: 26). A arquitetura ocidental seria baseada em princípios compositivos, categorizados como objetivos e construtivos. A vontade de forma na arquitetura japonesa seria caracterizada pelos aspectos de performatividade, seguindo como princípio o método intersticial $(M a)$, que foca nos intervalos vazios e não nos elementos construídos. Tal mudança de enfoque do gosto para uma dimensão performativa teria impacto sobre a estética da transparência e da pureza formal abstrata. O artista Isamu Noguchi, por exemplo, muda seu ateliê para o Japão, onde desenvolve um processo de criação escultórica em que "deixa a pedra falar". Tal processo seria próprio da colocação das pedras no paisagismo

\footnotetext{
${ }^{160}$ Os conceitos de sakui e jinen foram desenvolvidos por Masao Maruyama no livro Estudos na história intellectual do Japão Tokugawa (1952).
} 
tradicional japonês e refletiria o desvio de Noguchi da abstração de tendência “internacional” para uma volta às raízes locais. Ele diminui ou elimina a distância temporal entre o projeto e a execução no espaço, fundindo nesse sentido duas dimensões.

O design subjetivamente orientado (e assim arbitrário) é deixado para trás. O designer precisa se identificar com a objetidade da natureza diretamente, sem mediação. Essa norma de apagar a distância que separa sujeito e objeto - de se tornar um com a natureza - é comum a inúmeras artes japonesas: as técnicas de diversas artes performáticas, o ensino secreto do budô (espadachim), desenho de jardim e muitas outras práticas. Que Noguchi tenha alcançado a ideação da arte tradicional por meio de um longo desvio foi para o artista mesmo a marca final da maturidade. (ISOZAKI, 2011: 36)

O fotógrafo Yasuhiro Ishimoto daria testemunho de uma volta às origens a partir do olhar do modernismo internacional, associado ao centro americano de influência, e desdobrado na forma da Japônica. Seu papel como fotógrafo de arquitetura teria tido importância na determinação da imagem e do imaginário, disponibilizado na época, e que viria, após sua guinada pelo performativo, a evidenciar o reflexo da crítica ao olhar moderno da japônica. Ishimoto foi o fotografo do livro escrito pelo arquiteto Kenzo Tange sobre o Katsura em 1960, que seria prefaciado pelo arquiteto da Bauhaus, Walter Gropius. Devido à influência da formação na Bauhaus de Chicago, seguida por Ishimoto, suas fotos teriam sido marcadas por uma estética materialista ${ }^{161}$. A orientação de tal estética no sentido da opticidade determinaria a evidência de elementos que remetiam a planos e linhas e à eliminação dos elementos curvos dos telhados e do jardim pitoresco, que não se adequavam a tal estética.

A câmara bravamente elimina tudo isso, focando nas superfícies que definem o espaço arquitetural. Superfícies de piso (tatame ou madeira assim como bambu), divisórias deslizantes ${ }^{162}$ (byôbu ou shôji e painel de madeira), paredes (de areia e cal e gesso), e forros de kasa-buchi (...) Ishimoto focou nas composições abstratas derivadas dessas divisões, usando somente a moldura de sua câmera, de tal modo que seus disparos vieram parecer-se muito com as composições do De Stijl ou do Construtivismo do início do século XX. (ISOZAKI, 2011: 38)

A reação contra a japônica teria contado ainda com o esforço de contextualização social a partir da contribuição do artista Taro Okamoto (1911-

\footnotetext{
${ }^{161}$ A Bauhaus de Chicago (1937) contou com os artistas europeus da Escola Bauhaus, ligados ao movimento Construtivista, tais como Lásló Moholy-Nagy e György Kepes

162 byôbu ou shôji : biombos ou portas de correr.
} 
1996), que tendo entrado em contato com os surrealistas e com figuras do Collège de Sociologie em sua estada em Paris, introduziria na interpretação da japonidade a contraposição de duas "vontades de forma" retiradas da pré-história japonesa: Jômon ( ? - 300AC) e Yayoi (300AC - 300DC). A cerâmica produzida em cada período ilustraria duas tendências; a primeira primitiva, dinâmica e popular, a outra de beleza elegante. Isozaki compara esse binômio ao nietzschiano dionisíaco e apolíneo, que teria sido tomado como estratégia por parte de Okamoto para olhar para a história estruturalmente, de modo a poder ser aplicada no presente. Okamoto promoveria a tendência Jômon por representar para ele a expressão popular em contraposição à elegância Yayoi associada ao colonialismo.

Fazendo a leitura da campanha de Okamoto pelo Jômon num contexto social, deve ser dito que enquanto a beleza do Yayoi era o que o modernismo americano levou do Japão para Nova Iorque como um troféu da ocupação (inspirando a linha da arquitetura que resultou na Shôfu-sô de Junzô Yoshimura [Casa das brisas de pinheiro] no Moma em 1954), a beleza do Jômon encorajada pelo olhar modernista europeu de Okamoto secretamente nutriu um dinamismo nativo em oposição ao olhar do ocupante. (ISOZAKI, 2011: 39)

Tal mudança de paradigma teórico levaria à crise da estética associada à japônica, traduzida nas noções de transparência e de abstração levadas ao extremo, que passaram a ser associadas à política colonialista americana e ao próprio passado japonês imperialista. A mudança de ótica não significou um fechamento sobre si, pois coincidia com uma tendência da arquitetura moderna que se disseminava apoiada na estética brutalista, que tanto apontava uma inspiração regionalista e primitivista ligada a figura de Le Corbusier quanto uma estética da decadência associada à paisagem de destruição do pós-guerra e ao caos urbano associada aos arquitetos ingleses Alison e Peter Smithson. O modernismo europeu brutalista teria chegado no Pós-guerra por meio da obra de Corbusier na Índia: "ele foi bem recebido como tática para confrontar e contrariar o japonismo americano.(...) Vivacidade, brutalidade, aspereza, a exposição do trabalho interior, as entranhas - tais elementos facilmente se sobrepuseram e entraram em acordo com a estética derivada da cerâmica Jômon” (ISOZAKI, 2011: 44). A valorização do Jômon teria permitido também a reconsideração de várias obras históricas que haviam sido taxadas de Kitsch e inautênticas, ou simplesmente ignoradas, disponibilizando outros dispositivos retirados da tradição. A obra do próprio arquiteto Kenzo Tange teria se modificado em função 
da crítica a sua tendência Yayoi. O debate sobre o Jômon ainda teria servido de base para manifestações estudantis contra a política da Guerra Fria ${ }^{163}$, entre outras coisas, que vieram a se desenrolar ao longo dos anos 1960.

De forma geral, durante o período é possível teorizar dois tipos de japonidade. De um lado, a sofisticada habitação sobre plataforma, tranquila transparência do Yayoiesco/apolínea/aristocrática - correspondente ao gosto japonês em geral, ou à base-japônica do modernismo americano. Por outro lado, a opacidade dinâmica da habitação semi-subterrânea, Jômonesca/dionisíaca/populista, a qual coincidia com a versão do modernismo europeu brutalista. (...) Os discursos Jômon não foram irrelevantes para o movimento que culminou na demonstração dos Zengaku-ren (Federação Nacional da Associação autônoma de Estudantes) contra o tratado de segurança Japão-EUA no Edifício Nacional da Dieta em 1960, sustentada como estava por um disseminado sentimento antiamericano em toda nossa nação. (ISOZAKI, 2011: 44)

Os dispositivos associados à valorização do Jômon se baseariam no princípio da performatividade espacial e visariam um tipo de transparência opaca, própria da abertura para o tempo, que a espacialidade por camadas da arquitetura japonesa propiciaria. A transparência opaca revelaria um tipo de profundidade espacial, insinuada e não revelada, que havia sido ignorada nas primeiras leituras da Japonidade. Tal espacialidade teria se desenvolvido mais caracteristicamente no período do xogunato, conforme atestaria a diagonalidade do Palácio Katsura. No entanto, Isozaki aponta que o gosto pelo velamento $(\mathrm{Oku})^{164}$ e pela escuridão é que estariam presentes desde o seu indecifrável início, conforme atestaria a arquitetura do Ise.

Ocultamento em si foi a origem. Entretanto, diferente do taisha-zukuri ${ }^{165}$, Ise adota a forma de um eixo central - o objeto sagrado no centro foi inevitavelmente aberto a vista, de tal modo que, paradoxalmente, um número de camadas capazes

\footnotetext{
${ }^{163}$ Em função da Guerra da Coreia (1950-53) se aproximando foi assinado um tratado de paz com o Japão, cessando a ocupação. Os EUA pretendiam permanecer indefinidamente no Japão como forma estratégica de disputa de Poder com a União Soviética e luta contra o comunismo: "Apenas algumas horas depois da assinatura do tratado de paz, o Japão e os Estados Unidos assinavam um tratado de segurança conjunta que garantia indefinidamente a manutenção de bases americanas no Japão, sobretudo em Okinawa." (HENSHALL, 2004: 216)

164 "Tendo viajado para muitas cidades no exterior, estou inclinado a acreditar que os espaços em muitas camadas estão entre os poucos fenômenos observáveis apenas no Japão. Os japoneses sempre postularam a existência do que é chamado oku (a área mais interior) no núcleo desse espaço de alta-densidade organizado em múltiplas camadas como uma cebola, e o conceito de oku permitiu a eles elaborar e dar profundidade mesmo a uma área limitada. (...) Evidente no uso de todas essas palavras (compostas com o termo Oku) é uma tendência a reconhecer e estimar o que está escondido" (MAKI, 2008: 153-154). Oku seria uma profundidade sem centro para Maki. 165 "A principal característica desse estilo de arquitetura de santuário é que, com a empena da entrada e a coluna central que suporta a cumeeira do telhado, entrada e escadas estão descentradas para a direita. Em adição, o altar está localizado imediatamente atrás da parede pero da coluna" (ISOZAKI, 2011: 315)
} 
de obscurecê-lo teve que ser introduzido. Ise assim exibe tendências conflitantes na direção da transparência e opacidade. Todos esses elementos na direção da transparência - o portão do recinto, o portão central, o pilar sagrado central abaixo do piso, e a cadeira do divino (minashiro) -foram cortadas do nosso olhar por uma bem-definida série de intervenções. A noção de transparência havia recentemente derivado no Japão do planejamento urbano da China antiga centrado na posição do Imperador. Respaldado pela estrela polar, o filho do céu foi entronado num eixo central, faceando o sul. Dessa posição, acreditava-se que ele podia ver todo o mundo que estava sob seu comando. Essa lógica foi imaginada como espaço perfeito, transparente, hierárquico sem obstáculo.(...) Devido à essa formação desfavorável da transparência espacial, a arquitetura no Ise teve que introduzir deliberadamente um meio de fechar-se: a sebe que o cerca , os portões que fecham, e as portas mantidas firmemente fechadas. As coisas podem se "abrir" somente na escuridão e obscuridade. (ISOZAKI, 2011: 156)

\section{5 . \\ Literal e fenomênica}

Vimos que na concepção japonesa de espaço, que toma como princípio a ideia de intervalo e impermanência $(M a)$, espaço e tempo não se configurariam como entidades distintas. O efeito da concepção arquitetônica baseada no princípio de impermanência é a ênfase na dimensão performativa da construção ${ }^{166}$, no seu tornar-se, e nas qualidades espaciais mais que na materialidade do construído. A diagonalidade, a planaridade e a profundidade dessa arquitetura, conforme apresentada na disposição Ganko ${ }^{167}$, são experimentadas segundo a interação com o movimento corporal e foram desenvolvidas segundo esse mesmo desejo de movimento. Não há visão de profundidade, mas a sensação de profundidade porque o espaço se mostra de modo estratificado, vai se revelando através dos painéis móveis que conservam a visão frontal limitada aos eixos ortogonais. Para Mitsuo Inoue, tal característica, predominante na arquitetura japonesa, determinaria um tipo de espaço, "espaçomovimento", cuja apreensão é topológica e aproximada.

(No espaço-movimento) Relatando suas características, é importante notar que, diferente dos espaços geométricos, as posições (i.e., as coordenadas) dos elementos composicionais relativas a alguma estrutura geral são desimportantes ; em vez disso, como na topologia, o que é importante são as posições dos elementos relativos um ao outro; os componentes espaciais são observados sucessivamente, o que é induzido pela dobra do caminho de movimento ou pela

\footnotetext{
166 “(Ryûichi Hamaguchi-1944) Em sua base, ele distinguiu a vontade arquitetônica do ocidente"construtiva e objetiva”- daquela do Japão - "espacial e performativa" [kôi-teki]" (ISOZAKI, 2011: 24)

${ }^{167}$ Disposição da planta-baixa em ziguezague/ganso no estilo shoin, relacionada à ala cerimonial das residências feudais japonesa, conforme se verifica no Palácio Katsura em Quioto. (INOUE, 1985: 153)
} 
obstrução da linha de visão; a observação do espaço movimento; portanto, é sempre postulada pela visão do movimento, quer seja real ou intelectualizada. (INOUE, 1985: 147)

As características do espaço geométrico são identificadas com a noção de transparência, "simplicidade e luminosidade", conforme a leitura que arquitetos modernos tais, como Bruno Taut e Sutemi Horiguchi, fizeram do espaço japonês na tentativa de encontrar pontos em comum com a arquitetura moderna. No entanto, a diagonalidade da disposição em planta-baixa (Ganko) abrigaria a obstrução da visão estática, demandando o movimento corporal associado ao espaço-movimento e a requalificação de tal transparência opaca, conforme examinaremos a seguir.

Também verificamos como Vidler critica tanto a suposta transparência cristalina da arquitetura moderna quanto as arquiteturas da transparência opaca iluminista e pós-moderna. As sombras produzidas em tais arquiteturas espelhariam a morte do sujeito, a angústia e o sentimento de desenraizamento do homem moderno. Enquanto duplo do sujeito pós-moderno, tais sombras também espelhariam seu lado abjeto, seu estado de ansiedade e pânico. Tal efeito patológico teria sido provocado pela dissolução do monumento arquitetônico através do "sublime espacial", relacionado à concepção de espaço infinito e do vazio desenvolvidos no Iluminismo. Tentaremos a seguir, identificar a transparência da arquitetura japonesa, assim como aquelas apontadas por Vidler, segundo a proposta de distinção entre Literal e Fenomênica proposta pelos teóricos Colin Rowe e Robert Slutzky.

No artigo, "Transparency: Literal and Phenomenal" (1963), os teóricos Colin Rowe e Robert Slutzky já haviam apontado as contradições implicadas no conceito de transparência associado à arquitetura moderna. $\mathrm{O}$ artigo foi escrito antes de Vidler apontar supostas raízes de tais contradições no Iluminismo. Na maioria dos textos especializados, a transparência da arquitetura moderna estaria relacionada à influência que a Teoria da Relatividade e as descobertas de Hermann Minkowski teriam tido nas vanguardas modernas. Minkowsky concebia espaço e tempo como contínuo indivisível, assim como, conforme verificamos, era pressuposto na concepção de $M a$. 
Em 1908, o grande matemático Hermann Minkowski concebeu um mundo em quatro dimensões, unindo espaço e tempo de modo a formar um continuum indivisível. Sua obra Space and Time [Espaço e tempo], daquele ano, começa com a célebre afirmação: "De agora em diante o espaço em si, e o tempo em si, estão fadados as esvanecer em meras sombras, e somente uma espécie de união entre os dois preservará uma realidade independente." Exatamente nesse momento os pintores cubistas e futuristas, na França e na Itália, desenvolviam o equivalente artístico do espaço-tempo, em busca de meios que expressassem sentimentos puramente contemporâneos. (GIDEON, 2004: 41)

Rowe e Slutzky são céticos em relação à associação do conceito científico com o espaço arquitetônico, pois percebem contraditórios níveis de significados associados à transparência, nem todos associáveis à nova concepção espaçotempo. Diferentes níveis de significado da palavra transparência já estavam contidos no verbete do dicionário, que apontava dois sentidos: um que corresponderia à qualidade material de ser permeável à luz e ar; outro que seria resultado de um imperativo moral e intelectual, demanda pela evidência perfeita, ausência de dissimulação. Na arquitetura, no entanto, além da identificação com materiais translúcidos, a transparência vinha sendo descrita e associada com os seguintes termos: "espaço-tempo"; "interpenetração"; "sobreposição"; "ambivalência". Tais ambivalências seriam o resultado de uma nova opticidade, conforme teorizava Gyorgy Kepes no livro Language of Vision, que seria proporcionada pelos novos materiais e pelas consequentes alterações na percepção do espaço: "Transparência significa uma percepção simultânea de diferentes localizações espaciais. O espaço não simplesmente recua, mas flutua numa atividade continua. A posição das figuras transparentes têm significado ambíguo, já que tanto se vê cada figura agora, como a mais próxima e a mais distante." (ROWE, SLUTZKY, 1963: 45)

Os autores sugerem então que se faça uma distinção entre dois tipos de transparência na arte e na arquitetura. A primeira se limitaria às inovações trazidas para opticidade pelos novos materiais, sem grandes impactos na percepção da organização do espaço. Esta seria a transparência literal e seria configurada através das qualidades inerentes desses materiais translúcidos, disponibilizados pelas novas técnicas de fabricação. A outra, chamada fenomênica, seria baseada nas qualidades organizacionais do espaço. Esta segunda corresponderia a uma inovação com impactos muito mais profundos na própria concepção de arquitetura. Para compreendê-las, o estudo da influência de técnicas associadas à 
estética cubista teria sido muito mais relevante em ambas as transparências que as das novas concepções científicas, pois, na verdade, se trataria mais de compreender a dimensão metafórica e ilusionista que a realização de fato de uma flutuação de espaços através "da sobreposição de planos". Nesse sentido, ele retoma a comparação, feita pelo pintor Moholy-Nagy, com os efeitos de transparência nas aglutinações de múltiplas palavras em James Joyce (Joycean pun-trocadilhos). Pelo processo de distorção, recomposição e duplo sentido gerado pelas aglutinações surgiria uma forma de transparência linguística que seria o equivalente literário da "interpenetração sem destruição óptica" descrita na arte e na arquitetura. Joyce proporcionaria através das aglutinações de palavras planos de sensações transparentes que seriam apreciados simultaneamente em vez de linearmente: "quem experimenta uma das "aglutinações” de Joyce apreciará a sensação de olhar através de um primeiro plano de significação para outros dispostos através dele." (ROWE, SLUTZKY, 1963: 45). Tal como em Joyce, a ambiguidade de sentidos promovida pelas aglutinações é que corresponderia à inovação.

É a pintura, no entanto, que revelaria o procedimento técnico que permitiu a elaboração de uma imagem análoga à ambiguidade joyceana, que sintetizaria a transparência fenomênica e que poderia ser utilizada na arquitetura. Tal recurso técnico teria sido antecipado por Cézanne. Na pintura de Cézanne (Fig. 11), Mont Sainte-Victoire de 1904-06, já se verificariam determinadas qualidades que marcariam o cubismo posteriormente desenvolvido, tais como: o ponto de vista frontal, a supressão de elementos sugestivos de profundidade e a retração dos planos primeiro, médio e de fundo. Certas áreas seriam mais iluminadas que outras e algumas pinceladas incompletas deixam vazar o fundo da tela, dando a impressão de sobreposição de planos transparentes, que variariam segundo a cristalinidade, translucidez opalina e a opacidade. A direção inclinada ou ortogonal das pequenas pinceladas de cores opacas e contrastantes determinariam a configuração de dois grids (malha) que se sobreporiam, determinando certo grau de homogeneização da superfície tela, e que introduziriam um interesse periférico. Tais recursos técnicos teriam sido incorporados pelo Cubismo Analítico, determinando a ambiguidade de leitura apreciada. Esta ambiguidade de leitura teria derivado da multiplicação do ponto de vista da representação, quando este 
foi colocado em movimento, produzindo imagens que são apresentadas simultaneamente.

\begin{abstract}
Nessas telas, além do desmantelamento e da reconstituição dos objetos, do retração da profundidade, talvez acima de tudo estamos conscientes de um encurtamento da profundidade e da crescente ênfase que agora é conferida ao grid. Descobrimos o enlaçamento de dois sistemas de coordenadas. (...) Genericamente falando, as linhas obliquas e curvas possuem uma significação naturalística, enquanto as retilíneas mostram uma tendência geometrizante a qual serve para reafirmação do plano pictórico. Ambos os sistemas de coordenadas proporcionam a orientação das figuras simultaneamente num espaço estendido e numa superfície pintada: enquanto suas configurações sobrepostas, interligadas e seu desenvolvimento maior numa configuração flutuante permite a gênese do motivo cubista tipicamente ambíguo. (ROWE, SLUTZKY, 1963: 46)
\end{abstract}

Os dois recursos, tanto o do grid quanto o do efeito de transparência pela incompletude dos traçados e interpenetração consequente dos elementos figurados, serão amplamente utilizados na arquitetura moderna, que Rowe e Slutzky identificam com a transparência fenomênica. São esses os dois elementos fundamentais para determinar a ambiguidade relativa à transparência fenomênica. Tal ambiguidade se caracterizaria tanto por exigir do observador o exercício intelectual de completar mentalmente a imagem apreendida, prolongando o grid ortogonal imaginário que a arquitetura insinuaria através de suas linhas; quanto através do jogo estabelecido entre a abertura para o espaço profundo e sua supressão, promovido pela estratificação do espaço em camadas rasas definidas por trechos de planos de paredes construídas (coulisse) intermitentemente que vazam outro ambiente. O gridding, que envolveria tanto a demarcação das linhas de forças dos elementos quanto a estratificação, permitiria a leitura da flutuação e interpretação dos espaços ao apontar tanto para o espaço raso (grid ortogonal) quanto para o profundo (aberturas). O efeito de jogo dos planos seria o equivalente à sobreposição e aproximação de planos transparentes na pintura, mas, dado que na arquitetura não se poderia retirar completamente a profundidade tridimensional, esta teria sido a estratégia desenvolvida para desviar o olhar de um possível foco no infinito. Na obra de Le Corbusier (13 e 14), Villa Stein de Monzie (1928), em Garches, se poderia verificar como o gridding cubista permitiria a marcação da frontalidade e o desenvolvimento da espacialidade rasa também na arquitetura. 
Em Three Faces, Léger concebe sua tela como um campo modelado em baixo relevo. De seus três principais faixas (as quais sobrepõem, articulam, e alternadamente comprimem e excluem um ao outro), duas são estreitamente implicadas numa quase equivalente relação de profundidade, enquanto a terceira constitui uma coullisse (corrediça), revelando um lugar que tanto avança como recolhe. Em Garches, Le Corbusier substitui a preocupação de Léger com o plano pictórico por um olhar mais altamente desenvolvido para o ponto de vista frontal. (as visões preferidas incluem somente os desvios mínimos da perspectiva paralela);(...); e o espaço profundo é então elaborado de modo parecido com a coullisse (bastidor-coxia), com a fachada cortada e a profundidade inserida na abertura decorrente. (ROWE, SLUTZKY, 1963: 50)

Rowe e Slutzky apontam que, embora, identificado com a transparência fenomênica cubista pelos historiadores, tais com Gideon, a obra do arquiteto Walter Gropius (Fig. 12) para os edifícios da escola de arquitetura da Bauhaus (1926) não corresponderia de fato àquelas qualidades espaciais ambíguas supracitadas, sendo considerada por eles uma obra de transparência literal. A Bauhaus, apesar da transparência material não teria se dissociado do espaço profundo da representação clássica, tendendo a ser associada com o efeito trompe l'oeil do edifício transluzente sobre o espaço profundo naturalístico; enquanto a transparência fenomenológica demandaria a ruptura com tal espaço, inaugurando um espaço superficial e abstrato.

Gropius estaria preocupado com a expressão do vidro e do metal por suas qualidades materiais intrínsecas, tais como a luminosidade, reflexividade e cristalinidade. $\mathrm{Na}$ ala de oficinas da Bauhaus, por exemplo, a principal preocupação de Gropius seria o desejo de que os planos de paredes internas fossem visíveis através da cortina de vidro. Na Bauhaus, citando Giedion, o envidraçamento conferiria ao edifício uma "translucidez cristalina" e desmaterializante: "O vidro foi convocado em virtude de sua qualidade desmaterializante; a geração precedente o havia utilizado para fins práticos, ou (em casas particulares) o havia colorido ou pintado" (GIDEON, 2004: 525). A utilização da cortina de vidro como uma membrana que envolve o edifício, sem a interferência do esqueleto estrutural recuado e de suportes nas quinas, reforçaria o caráter desmaterializante do edifício e o enfraquecimento das referências superficiais planares e ortogonais. Assim, o olhar atravessaria o edifício e alcançaria a profundidade do espaço natural, apesar da composição de edifícios do tipo laminar, cuja forma sugeriria a leitura do espaço por camadas de planos. 
A planta do complexo em forma de cata-vento, "com três braços em forma de gancho prolongando-se a partir do centro” (GIDEON, 2004: 525), demandaria a execução do percurso entorno para se apreender a visão do todo. Teoricamente, tal demanda resultaria numa percepção fragmentada das visadas sucessivas. Rowe e Slutzky afirmam que não é o que fato acontece, pois os contra-movimentos das alas ("pás do cata-vento") enfraqueceriam a predominância da visada frontal numa única direção, fazendo com que se olhe para direção resultante diagonal. Além disso, as quinas de vidro permitiriam que o olhar as atravessasse, reforçando diagonalidade imposta pela planta. A diluição do edifício em função da linearidade diagonal predominante e dos materiais translúcidos se traduziria numa visualidade literal, embora simultânea, dos múltiplos planos de composição. Nesse projeto, tal sucessão de espaços não configuraria "uma contradição de dimensões espaciais", associada à transparência fenomênica.

\begin{abstract}
Apoiando-se no ponto de vista diagonal, Gropius externou os movimentos opostos de seu espaço, permitiu-lhes escaparem para o infinito; e, ao ser relutante em atribuir para cada um qualquer diferença de qualidade significativa, ele impediu as possibilidades de uma ambiguidade potencial. Assim, somente os contornos deste edifício assumem um caráter do tipo em camadas; mas estas camadas do edifício raramente atuam na alusão de uma estrutura em camadas, seja do espaço interno ou externo. Negado, por estes meios, a possibilidade de penetrar um espaço estratificado definido tanto pelos planos reais ou suas projeções imaginárias, o observador é vetado da possibilidade de experimentar aqueles conflitos entre um espaço que é explícito e outro que está implicado. Ele pode desfrutar da sensação de olhar através da parede de vidro e assim ser capaz de ver o interior e o exterior do edifício simultaneamente; mas, ao fazer isto, ele será consciente de poucas daquelas emoções ambivalentes que derivam da transparência fenomênica. (ROWE, SLUTZKY, 1963: 52)
\end{abstract}

A Villa Stein de Monzie (1926), em Garches, desenvolvida por Le Corbusier, poderia ser comparada à Bauhaus pela utilização de elementos da linguagem moderna comuns, servindo de exemplo para evidenciar as diferenças espaciais. A fachada do jardim de Garches e as alas de oficinas na Bauhaus se parecem. Ambas empregam lajes em balanço e o recesso do pavimento térreo. Ambas fazem uso marcação de horizontalidade do envidraçamento, além de enfatizarem a janela de quina. Apesar das semelhanças, no entanto, para Rowe e Slutzky, Le Corbusier trabalharia as qualidades planares do vidro e Gropius os seus atributos transparentes. As divisões horizontais na vidraça sugeririam a continuidade imaginária no espaço. A fachada de Garches não se dissolveria pela 
transparência do vidro, como a cortina de vidro na Bauhaus, pois teria sua planaridade reafirmada pelo jogo alternado de faixas de vidro e parede, dotando-a de rigidez e tensão de superfície geral. Além disso, a fachada de Garches pareceria contraditória com o espaço interno, que "parece um grande e único volume seguindo de modo paralelo por trás de suas vidraças”, o que, no entanto, suas divisões internas negariam. Pela rigidez da fachada e pela contradição com o interior é que o plano vertical de fachada se afirmaria. A transparência, portanto, não seria evidente, como na Bauhaus. Ela dependeria tanto de um ato mental de projeção imaginária de linhas de forças, quanto da percepção desenvolvida ao longo do percurso bem marcado, que atravessa a estratificação do espaço determinado pelos planos verticais e que impedem a visão em profundidade. $\mathrm{O}$ resultado do vazamento espacial nos planos verticais não equivaleria ao sublime espacial descrito por Vidler, mas ao jogo contraditório entre o espaço "dutado" da "promenade arquitetural" ["sequencia de movimentos em pequena escala com pretensão de acentuar a experiência do espaço" (FRAMPTON, 2001: 43)] e o deslizamento da atenção para as laterais. Tal efeito de ambiguidade espacial seria o equivalente à sobreposição de grids ortogonal (artificial e superficial) e diagonal (naturalístico) na pintura de Cézanne. Esta estratégia de sobreposição de grids seria recorrente na obra de Le Corbusier. Kenneth Frampton aponta como, em Garches, Corbusier sobreporia a axialidade clássica palladiana do volume prismático à elementos relacionados à estética máquina, que seria exprimida pela ordem planar assimétrica e dinâmica da fachada livre e do espaço interno estratificado. Já no projeto para o complexo de edifícios para a Liga das Nações de 1927, segundo Frampton, Corbusier combinaria o programa palaciano traduzido na axialidade clássica simétrica com os desvios de um racionalismo que remontaria à tradição Francesa Greco-Gótica. Em ambos, portanto, repetiria o embate entre as referências espaciais naturalísticas e as abstrato-superficiais, promovendo a ambiguidade própria da transparência fenomênica.

Por um lado, havia ali uma fileira retirada da tradição clássica, consistindo de elementos marcados na planta como um "peristyle" (pórtico), uma "scala regia" (grande escadaria) e uma "salle de pas perdus" ( um grande foyer correndo embaixo e envolta do auditório), enquanto por outro, havia ali um esqueleto estrutural de aço estruturalmente hierarquizado carregando o telhado do hall. (FRAMPTON, 2001: 82) 
O projeto para a Liga das Nações apresentaria o mesmo tipo de transparência fenomênica de Garches. Ela seria determinada pela sobreposição de grids, indicados nos planos verticais, com direções contraditórias: "uma série de planos paralelos e entalhes que corriam perpendicularmente à orientação principal da perspectiva Leste-Oeste” (FRAMPTON, 2001: 83). Tais planos correspondente aos grids seriam, portanto, atravessados pela promenade que se estenderia do percurso atravessando o edifício percurso do jardim também marcado por camadas reais ou imaginárias que desviariam o olhar lateralmente para elementos da paisagem, definindo a corbusiana conception paysagiste; “combinação da abordagem axial clássica com o grupamento irregular de árvores na tradição do Pitoresco inglês” (FRAMPTON, 2001: 83). Tal combinação de partidos arquitetônicos contraditórios disponibilizariam tanto o recurso técnico da geometria relacionada à cada um deles quanto o imaginário metafórico correspondente, que combina o monumental palaciano ao maquinismo-funcionalista, que, naquele momento, era descrito como correspondente à realidade, mas que, de fato, havia já se confundido com um ideal (estético) traduzido na superficialidade espacial.

\begin{abstract}
Mas novamente, como em Garches, as insinuações de profundidade inerentes nesta forma são consistentemente retraídas. Um corte, um deslocamento, e um deslizamento pelas laterais acontecem ao longo da linha de seu eixo principal; e, como um espaço, é repetidamente pontuado e derrubado nas séries de referências laterais - pelas árvores, pelas circulações, pelo dinamismo dos edifícios em si de tal modo que finalmente, por séries de implicações positivas e negativas, toda o esquema se torna uma espécie de debate monumental, uma disputa entre espaço real e ideal. (ROWE, SLUTZKY, 1963: 53)
\end{abstract}

Rowe e Slutzky constroem uma imagem selvagem para retratar o espaço altamente direcionado aberto segundo a concepção paisagista corbusiana para o Palácio da Liga das Nações: "são como facas para o racionado fatiamento do espaço." Assim evidenciando paradoxalmente a associação da transparência fenomênica tanto com a distinção e clareza dos elementos formais quanto com a ambiguidade de sentidos. A arquitetura da Bauhaus, por outro lado, seria dotada de um ilusionismo óbvio e de uma determinação do espaço que seria frouxa. $\mathrm{O}$ envidraçamento não seria fundamental no projeto da Liga das Nações, mas sim a força com que os elementos visuais bem marcados propulsionariam a sequência de um caminho que tanto não deixa focalizar a direção do horizonte, desviando 
obrigatoriamente o olhar tanto em função das movimentações topográficas do percurso dinâmico, quanto das atrações laterais da arquitetura ou do paisagismo.

Se nós pudéssemos atribuir ao espaço as qualidades da água, então este edifício é como uma represa por meio da qual o espaço é contido, confinado, dutado, canalizado e finalmente derramado nos jardins informais ao lado do lago. Enquanto por contraste, a Bauhaus, isolada no mar do contorno amórfico, é como um recife suavemente coberto pela plácida maré. (ROWE, SLUTZKY, 1963: 53)

A imposição do espaço dutado no projeto corbusiano permitiria o exercício da apreensão fenomenológica, conforme conceituado por Isozaki, envolvendo o corpo como um todo de modo intenso. Podemos nos perguntar pelo sentido desta orientação por uma vivência bucólica em um edifício cuja função é representativa e também pelo teor pitoresco em ambos os projetos corbusianos. $\mathrm{Na}$ arquitetura japonesa, a valorização do percurso e da frontalidade correspondiam também à intensificação da vivência, que estava relacionada ao exercício de contemplação do movimento e da transitoriedade da natureza. A visada frontal do Palácio Katsura é direcionada para o jardim. A promenade corbusiana, descrita como um fluxo represado que derrama no jardim, parece inverter o sentido da contemplação e da introspecção, sendo traduzido para: intensificação de movimento do observador na direção do jardim e frontalidade marcada pelo jogo entre o olhar direcionado pelo caminho e o periférico voltado para os elementos da arquitetura e do jardim.

\section{O Poder da arquitetura}

No livro, Por uma arquitetura de 1923, Le Corbusier afirma que a casa seria uma máquina de morar; que a máquina daria ao homem o exemplo lógico da economia necessária para o desenvolvimento da casa e acrescentava: "Há no sentimento mecânico, sentimento moral" (CORBUSIER, 2014: 81). Contradizendo o imperativo moral da economia mecânica, no entanto, estaria a preocupação corbusiana, também moral, de retirar a família do tédio doméstico e da vontade de circular socialmente. Tal preocupação o levou a escrever um extenso manual de caráter higienista, que não deixou, entretanto, de referendar o caráter pitoresco de sua concepção. A reprodução abaixo visa salientar que a ambiguidade perceptiva da transparência fenomênica na obra corbusiana se estende ao significado, pois tanto se verifica aspectos da arquitetura disciplinar e 
higienista quanto da dimensão lúdica do habitar. Esse habitar estaria associado a uma imagem de vida doméstica que não acompanha o sentido da modernização da cultura urbana, e não somente pela questão do ordenamento e caos urbano, mas pela complexificação dos laços sociais e seus reflexos.

Uma casa é feita para ser habitada. Não é possível! - Mas sim! - Você é um utópico!

Para dizer a verdade, o homem moderno se entedia mortalmente em casa então vai ao círculo. A mulher moderna se entedia fora da alcova; vai ao chá das cinco. $\mathrm{O}$ homem e a mulher modernos se entediam em casa: vão ao dancing. (...)

A planta das casas rejeita o homem e é concebida como guarda-móveis. Essa concepção favorável ao comércio do subúrbio Saint-Antoine é nefasta à sociedade. Ela mata o espírito de família, de lar; não há lar, família e crianças, porque é demasiado incômodo viver. (...)

\section{Manual da Habitação}

Exijam uma toilette com boa iluminação, uma das maiores peças do apartamento, o antigo salão por exemplo. Uma parede toda de janelas abrindo, se possível, para um terraço para banhos de sol; pias de porcelana, banheira, duchas, aparelhos de ginástica.

Peça contígua: guarda-roupa onde vocês se vestirão e tirarão a roupa. Não tirem a roupa no quarto de dormir. É pouco higiênico e isso cria uma desordem penosa. (...)

O gramofone ou a pianola lhes dará interpretações exatas das fugas de Bach e lhes evitará a sala de concerto e as gripes, o delírio das virtuoses.

(...) (CORBUSIER, 2014: 81)

A transparência literal também deu margens a arquiteturas que escapam da questão da ordem, da higiene social e do controle no sentido punitivo e disciplinar. Ao menos, enquanto manifesto, a proposta de Yves Klein e Werner Ruhnau de 1960, Projeto para uma arquitetura aérea, dá continuidade à utopia expressionista da transparência cristalina. Os expressionistas propunham ultrapassar os muros opacos do mundo privado em prol de uma comunidade solidária. A cidade idealizada por Bruno Taut, A City Crown (1919), teria edifícios públicos (teatro, ópera, assembleias) como o ponto central, que comporia "a nova catedral". O novo cristianismo seria o pensamento social. O entretenimento não é descrito por ele como efeito da alienação social, mas como busca por um prazer elevado. "O outro lado dos desejos do povo, o qual leva para os estabelecimentos públicos, é também baseado num nobre traço interior. É o desejo de se moldar no interesse comum e ter a sensação de união no ambiente, 
como um homem entre outros" (BENTON, SCHARP, 1980: 84). A cidade de Taut seria coroada por uma casa de vidro que serviria de passagem aos edifícios públicos. A casa seria o suporte para uma experiência cósmica, religiosa e artística. $\mathrm{O}$ arquiteto seria, assim, o arquiteto do todo artístico, social e religioso. $\mathrm{O}$ vidro representaria automaticamente uma ruptura com a arte imitativa e seu referencial naturalista, sendo este substituído pela expressão do reflexo de metais e pedras preciosas coloridas e pelo jogo de luzes e sombras. "Toda ternura e todas as grandes sensações deveriam ser despertadas aqui quando toda luz do sol verter sobre o espaço e se decompor em numerosas e tênues reflexões (...) Aqui a arquitetura renovará sua ligação maravilhosa com escultura e pintura”. (BENTON, SCHARP, 1980: 85)

Tanto as propostas expressionistas quanto a apresentada no manifesto do artista Yves Klein (1928-1962) e do arquiteto Werner Ruhnau (1922-2015) sugerem a ideia do desenvolvimento de uma nova sensibilidade humana, alcançada pelo uso do vidro, que modificaria a própria cultura. Os órgãos sensórios evoluiriam e a cultura também. "Se quisermos elevar nossa cultura para um nível superior, somos forçados para o melhor ou para o pior a transformar nossa arquitetura. E isso só será possível se removermos a qualidade enclausurada dos espaços onde vivemos" (SCHEERBART, CONRADS, 1971: 32). Klein e Ruhnau associam à arquitetura transparente o fim da estrutura patriarcal, a desinibição, a liberação da "vertigem psicológica da composição, aos limites do prestigio incomensurável da vida ela-mesma, da vida em si, onde a personalidade em caso algum pode se inscrever" (KLEIN, 1959). Habitar dependeria de intensificar a sensibilidade, viver com a imaginação o espaço imaterial da vida. Para Klein, a imaginação seria o veículo da sensibilidade posta em ação de modo cooperativo e não pessoal pela arquitetura aérea. O homem porvir viveria integrado no espaço total da vida no universo. A arquitetura aérea rumaria nesse sentido do desenvolvimento da sensibilidade para o imaterial. "Liberado da falsa interpretação da intimidade psicológica, ele viverá num estado de concordância absoluta com a natureza invisível e imperceptível pelos sentidos, isto é com a vida tornada ela mesma concreta pela inversão de papéis." (KLEIN, 1959). A arquitetura aérea seria transparente pelo uso de ar, gás, fogo, odores, forças magnéticas, eletricidade, eletrônica e vidro. A transparência dos 
materiais, no entanto, não redundaria num espaço profundo naturalístico e nem na literalidade do sentido espacial: "penso que o Ocidente europeu compreenderá o valor de nosso empreendimento imaterializante a tempo, para viver sem tardar o puro, vivaz, belo agora." (KLEIN, 1959). Abaixo, um trecho do manifesto Por uma arquitetura aérea de 1960.

Nós propomos proteger a cidade com um telhado de ar em movimento. Uma estrada central leva ao aeroporto, dividindo a cidade em duas: um bairro residencial e um bairro para trabalho, dispositivos industriais e mecânicos. O telhado de ar simultaneamente condiciona e protege os espaços privilegiados.

Um piso de vidro transparente. Armazenagem no subsolo (cozinhas, banheiros, armazéns e planta de produção).

O conceito de sigilo, o qual ainda nos é conhecido, terá desaparecido dessa cidade inundada de luz e completamente aberta para o mundo exterior. Uma nova condição de intimidade humana existirá. Os habitantes vivem nus. $\mathrm{O}$ antigo sistema da família patriarcal não existirá mais. A comunidade será completa, livre, individual, impessoal. A principal ocupação dos habitantes: lazer. (CONRADS, 1971: 171) 


\section{6. \\ Obra analisada com estudo de campo}

\section{1.}

\section{A Japonização do mundo da arquitetura}

\section{Preâmbulo}

Num ensaio para a introdução do livro "Contemporary Architecture of Japan 1959-1984", o historiador e crítico da arquitetura Reyner Banham (19221988) descreve o que ele denomina como processo de japonização do mundo da arquitetura. Tal processo teria produzido um efeito rebote de ocidentalização da arquitetura japonesa, que, por um lado, teria frustrado as expectativas dos seus sucessivos "descobridores", por outro, teria feito com que ao longo desse processo que já durava 50 anos, a arquitetura japonesa, através da apropriação singular da arquitetura ocidental, continuasse a provocar estranheza e espanto.

Banham descreve três estágios desse processo de japonização do mundo que estava a se desenvolver até 1985, quando publicou seu ensaio. O primeiro estaria associado aos arquitetos da vanguarda moderna europeia aportada no Japão, que teria descoberto na arquitetura tradicional japonesa, transparente, simples e pura, a vocação para a linguagem universal moderna. O segundo estágio, estaria associado à decepção dos primeiros, ao encontro com os arquitetos Brutalistas do Team X e à descoberta da vocação japonesa para o expressionismo estrutural e técnico. Tal estágio coincidiria com o lançamento do primeiro movimento de vanguarda moderna japonês em 1960 através do grupo megaestruturalista chamado Metabolismo e correspondeu ao momento de intensificação do diálogo com o exterior e à posterior internacionalização da arquitetura japonesa através das obras metabolistas. O terceiro estágio, que contou com a decepção dos segundos, corresponderia ao momento de desilusão com as utopias visionárias do momento anterior e ao questionamento contracultural ligados ao Maio de 1968. Esse estágio estaria associado à descoberta da vocação japonesa para se apropriar de signos históricos ou da cultura Pop e desenvolver sua própria arquitetura de forma altamente simbólica. A figura chave da disseminação desse estágio seria o arquiteto Charles Jencks, que teria incluído 
vários arquitetos japoneses para ilustrar seu livro sobre a arquitetura pós-moderna em 1977.

Poderíamos acrescentar um quarto estágio relativo ao momento contemporâneo. Ele corresponderia ao retorno da linguagem das vanguardas modernas dos anos 1920, retomando aqueles valores da abstração, da leveza e da transparência. Desta vez, tal linguagem não estaria associada à estética mecânica, mas à estética eletrônica da Era digital. $\mathrm{O}$ arquiteto Toyo Ito seria sua figura chave. A exposição, "A Japanese Constellation", montada no MOMA em 2016 espelharia o reconhecimento de um grupo que se formou em torno de Ito; seja por serem colaboradores, protegidos ou colaboradores de colaboradores. Esse é o caso de Kazuyo Sejima, Ryue Nishizawa, Sou Fujimoto, Akihisa Hirata e Junya Ishigami. Ito assume sua ascendência sobre a mais nova geração, ressaltando a importância de que a associação à estética abstrata, pura e transparente não fosse experimentada como esvaziada do comprometimento social. Segundo a crítica de Isamu Hasegawa, publicada em fins dos anos 1990, os jovens arquitetos japoneses, influenciados por Ito, teriam sido vítimas da "síndrome $d a$ transparência": eles estariam sendo levados a buscar luminosidade, efemeridade e transparência através da linguagem moderna, tal como Ito, mas redundariam numa expressão de neutralidade e apatia. Estas qualidades marcariam essa geração mais nova de craques nos computadores.

Os novos arquitetos, por exemplo, ainda que desenvolvessem uma arquitetura extremamente sofisticada esteticamente devido o domínio no uso do computador, teriam perdido a referência de escala e da proporção corporal. Sua sensibilidade teria se tornado mais tátil, não se estendendo ao todo da percepção visual. Eles não teriam o ímpeto do debate, da troca de ideias, da revolta contra o sistema estabelecido; estariam movidos por impulsos de elétrons sobrepostos aos impulsos orgânicos e configurariam a geração de arquitetos Ichiro ${ }^{168}$ que ele reconhecia entre seus próprios colaboradores: "Seja Ichiro ou uma criança mergulhada num vídeo game, eles não estão simplesmente confrontando a bola ou a tela através do sentido da visão. Eles entraram num espaço virtual que

\footnotetext{
${ }^{168}$ Ichiro Suzuki é o nome do jogador de beisebol, perfeito nas manobras e inexpressivo facialmente, que foi o primeiro japonês contratado como titular pela Liga Principal de futebol americano.
} 
envolve todos os seus sentidos: audição, tato, e assim por diante." (ITO: 1989, 2011, 153). As mídias eletrônicas seriam responsáveis pela mutação do aparato sensório humano, obscurecendo as fronteiras entre o dentro e o fora. A inexpressividade do Ichiro estaria relacionada à preponderância de seu corpo digital/virtual sobre o corpo físico/substancial: "poderíamos dizer que o anterior é um tipo análogo do corpo que não é transparente, enquanto o último é um corpo digital e transparente" (ITO: 1997, 2011, 122). Sem o feedback do olhar e da presença do outro, esses arquitetos teriam se tornado seres demasiado frágeis para enfrentar a dimensão pública. "Ocasionalmente deve ser necessário se expor o corpo vulgar à visão do público e debater" (ITO: 2002, 2011, 153). A introversão associada à concentração técnica do Ichiro resultaria na tendência à padronização, ao abstracionismo e ao fraco realismo de seus projetos. Seus projetos não promoveriam o atrito necessário com o outro, fazendo com que a crítica social implícita se diluísse muitas vezes num esteticismo vazio. "Eles dominam uma metodologia inteligente, racional que pode ser chamada "coolismo"” (ITO: 2002, 2011, 148). Um concurso com concorrentes europeus teria evidenciado tal sintoma do desligamento da realidade material como predominante entre os japoneses. A apresentação de projetos na exposição, “ $A$ Japanese Constellation", é introduzida por textos onde os pupilos de Ito descrevem a busca, instigada por ele, pela ativação do corpo físico no encontro com o ambiente natural, na interação comunicativa e na manifestação pública da diversidade de seres. A arquitetura deverá estar aberta à existências porvir, funcionando como organismo vivo e ecológico. A dimensão pública não corresponderia à monumentalização da arquitetura associada ao exibicionismo tecnológico, ou à auto-expressão do arquiteto, mas à consciência da dimensão do impacto social da arquitetura enquanto espaço físico vivido no cotidiano e no pensamento. "Hoje somos capazes de criar arquitetura baseada em normas do mundo natural através do uso de computadores. Entretanto, nos deveríamos usar essas normas não para fazer formas que imitam a natureza, mas, em vez disso, criar arquitetura que respire e seja congruente com o meio-ambiente" (GADANHO, ITO: 2016, 21). 


\section{A morte da Utopia}

Até a crise do petróleo em 1973-1974, o Japão foi palco de um surto de crescimento econômico acompanhado do surto construtivo em grandes escalas, além dos eventos em escala nacional tal como as Olimpíadas de 1964 e a exposição Osaka em 1970. A valorização do solo nas grandes cidades a níveis inimagináveis, no entanto, dará origem a um desenvolvimento urbano descontrolado que foi efeito tanto do crescimento demográfico, estimulado pelo projeto político-econômico de industrialização do país como um todo, como do problema da escassez e custo do solo. Até meados dos anos 1960, a figura de Tange teria dominado o cenário e garantido a coerência e a qualidade das obras em grandes escalas, que pressupunham a integração do país segundo um projeto infraestrutural. As obras da rodovia Metropolitana e do trem de alta-velocidade, Schinkansen, ligando Tóquio a Osaka seriam exemplo dessa escala de projetos que culminaria com a realização da Olimpíada em Tóquio em 1964, passando pela construção de cidades artificiais e cidades dormitório na periferia das metrópoles, cujo impacto social será avaliado posteriormente. A partir desse período, no entanto, as grandes construtoras e tecnocratas assumem a qualidade do desenvolvimento das cidades, excluindo o experimentalismo em grandes escalas que era próprio ao grupo de Kenzo Tange. A força do tecno-expressionismo das obras disseminadas se torna rotina, perdendo sua força produtora de imagens da cidade do futuro. Para o crítico Hiroyuki Susuki, por um lado, tal expressionismo seria uma reação auto-expressiva (subjetiva) da impotência inconsciente frente ao sistema da arquitetura que teria sido sugado na onda de crescimento econômico, tornando a arquitetura um produto consumível da moda; por outro, a estética expressionista não conseguia competir consigo própria.

Não tanto a despeito de seu vanguardismo como por causa dele, a maioria dos arquitetos futuristas recebeu sanção da sociedade para se tornar provedora dos modos sociais. A expressão de vanguarda assim foi reconhecida sem muita oposição. Como resultado, a maioria dos arquitetos de vanguarda foi imediatamente ultrapassada por formas revolucionárias que eles próprios haviam criado. Assim foi que os arquitetos dissiparam seu status revolucionário ao deixarem de ser aqueles que denunciam e processam a sociedade para serem aqueles que são objetos populares de sua fantasia. (KOBAYASHI, SUSUKI, BANHAM, 1985: 9) 
Outro fator que teria promovido $\mathrm{o}$ isolamento dos arquitetos experimentalistas e seu afastamento da escala urbana seria o próprio questionamento da dimensão utópica dos megaprojetos urbanos, que pressupunham um fundamento teleológico associado à perspectiva do futuro. A noção de projeto como fim determinado associada àquelas utopias passa a ser relegada entre os próprios arquitetos, colocando em crise a legitimidade da atividade do planejador urbano como influente na vida social. Ou este estaria a serviço das grandes corporações, tal como um tecnocrata, ou deveria procurar outro meio de atuação.

O ideal teleológico como um todo morreu, e com isso estagnou o planejamento orientado a um fim. Em vez disso, uma rede de singularidades - quer dizer, de individualidades nas cidades através do mundo desenvolvido - foi gerada. Nós tivemos que esperar até o fim do século para que a rede de alcance mundial suplantasse esses indivíduos por terminais mais impessoais; entretanto, no final dos anos 1960, nós tínhamos uma premonição de que isso iria acontecer. No meio do processo, estava o desvio de vinte-anos do pós-modernismo. (ISOZAKI, 2011: 85)

O desenvolvimento caótico das cidades teria tornado as megaestruturas metabolistas obsoletas, e a qualidade de vida associada a elas também não corresponderia ao esperado. O contexto contracultural do final dos anos 1960 também contribui para que se incorresse na desarticulação das vanguardas visionárias. A atividade dos arquitetos liberais ficou assim restrita a projetos em menor escala e tendeu a estratégias de projeto que expressavam a rejeição ao contexto de caos urbano. O arquiteto Arata Isozaki, teria sido uma figura importante nessa transição pós-utópica, mantendo contato com os arquitetos de movimentos visionários internacionais através de conferências que contavam com a participação de gerações ainda mais jovens que o Team $\mathrm{X}$, tais como o Archigram, Superstudio, Hans Hollein e Archizoom. Isozaki partilhou assim com eles o processo de desilusão com as utopias. Isozaki se ligaria mais tarde à vanguarda pós-moderna dos radicais neorracionalistas, RATS ${ }^{169}$. Para Suzuki,

169 "Esses (arquitetos mais jovens que o Team X) seriam mais tarde chamados de RATS (um nome cunhado pelo holandês Aldo van Eyck para significar arquitetos radicais neorracionalistas." (ISOZAKI, 2011: 82). Conscientes da morte da utopia e se declaravam a favor de uma arquitetura crítica e política com base "realista". Grupo de arquitetos encabeçados na Itália (La Tendenza) por Aldo Rossi nos anos 1960, que criticava o "funcionalismo ingênuo" da arquitetura moderna e propunha uma releitura da noção de tipologia para repensar o espaço da cidade. Sobre a crítica tipológica: a forma seria o elemento imutável que permanece (arquétipo): "A reformulação desse conceito no caso de Aldo Rossi estava relacionada com a importância outorgada ao tecido 
esta mudança de estratégia projetual estaria relacionada na obra de Isozaki ao enfraquecimento da dimensão visionária em prol de um método retórico, através do qual os elementos estruturais são compostos como uma montagem (assemblage) a partir de formas autônomas. De modo similar às vanguardas artísticas modernas, a forma da montagem expressaria a perda da função social do arquiteto como aquele que vislumbra ou prevê o futuro melhor para a cidade. Apesar da identificação de Isozaki com os neorracionalistas, que exercitavam a releitura dos monumentos históricos, o contexto das grandes cidades japonesas e a experiência de destruição do Pós-guerra ensejaram em Isozaki a noção do contexto urbano como construção, ruína e diferença simultaneamente, como partes do ciclo natural das cidades ${ }^{170}$. Nesse sentido, Isozaki estabeleceria outro modo de relação com o contexto da realidade, que, no Japão, seria praticamente destituído de referências históricas construídas (Fig. 10). Isozaki, no entanto, compartilha com os RATS a busca por autonomia da obra em relação ao ciclo capitalista de produção e consumo através da especulação com a forma pura (tipológica) ${ }^{171}$, tal como Isozaki empregou no Museu de Arte Moderna de Gunma (1971-74).

Isozaki rejeita o contexto urbano. Ele aparentemente percebeu que era impossível para a visão digladiar com uma cidade inteira, uma sociedade inteira, reconhecendo os limites do poder destrutivo da visão contra a sociedade. Em vez de implementar um relacionamento com a sociedade e a cidade, ele fez da arquitetura algo isolado, completo, um objeto à parte. (KOBAYASHI, SUSUKI, BANHAM, 1985: 11)

É no contexto de morte da utopia do projeto e da tecno-utopia, que o Japão apresentaria o terceiro momento do processo de japonização do mundo da arquitetura, chocando os arquitetos do Team $\mathrm{X}$ ao incorporarem elementos tanto da cultura pop americana como elementos da tradição clássica ocidental e

urbano _ cada tipologia arquitetônica deve ser entendida em função da morfologia urbana - com a vontade de sinalizar que o elemento que está mais próximo da essência da arquitetura é a forma e a estrutura dos espaços". (MONTANER, 2001: 139). Sobre o racionalismo de Rossi: "Trata-se do conceito de tradição que deve ser entendido como uma ordem a partir da qual podemos alcançar a outra mais ampla e nova por meio da crítica racional” (MONTANER, 2001: 139)

${ }^{170}$ Ver capítulo 6 desta tese, ítem 6.4.2., sobre a importância do vazio e da transitoriedade para a estética japonesa. E também "Ma [interstice] and Rubble" em Isozaki, Arata. Japan-ness in Architecture. London: MIT, 2011.

${ }^{171}$ Os RATS trataram da pura forma da arquitetura destilada de utopia, como tipologia. Sobre a descrença no desenho para realizar utopias, bem como na ideologia, ver TAFURI, Manfredo. Architecture and Utopia. Design and Capitalist Development.London: MIT, 1976. Sobre o conceito de tipologia, ver o texto de Anthony Vidler, “A terceira tipologia”, em NESBITT, Kate (org). Uma Nova agenda para a Arquitetura. SP: Cosac Naify, 2006. 
japonesa $^{172}$. Banham aponta como a história se repete, quando o teórico da pósmodernidade Charles Jencks, que ilustrou dois de seus livros com os edifícios “pop" Ichi e Ni-ban-kan ${ }^{173}$ (1969 e 1970) de Minoru Takeyama (Fig 8 e 9), descreve a importância da arquitetura japonesa a partir do abertura para o passado e para a tradição. Ele estaria, assim como Gropius, buscando uma correção para os erros cometidos pelos arquitetos modernos ocidentais, que desprezaram os conteúdos históricos ao buscarem a pureza da expressão estrutural e funcional. Por outro lado, Jencks estaria revelando o quanto a arquitetura pós-moderna teria se desenvolvido a partir da influência da arquitetura japonesa moderna e não apenas de uma revisão das arquiteturas europeia e americana. A riqueza de conteúdo metafórico suscitado pelas obras japonesas seria seu grande manancial e agente provocador do estranhamento na arquitetura no final dos anos 1960 .

Como Las Vegas, portanto, o moderno japonês - inocentemente sem vergonha num grau que poderia somente ser igualado pelo despudor de Las Vegas poderia mostrar aos arquitetos ocidentais um caminho, ou mesmo vários caminhos, longe das rotinas formais fossilizadas de sua costumaz modernidade tão logo eles vieram a entender que alguma forma de libertação era necessária. No final dos anos sessenta, a necessidade de libertação estava sendo crescentemente compreendida, e como as tentativas imensamente sofisticadas dos New York Five para recuperar a suposta pureza dos primeiros dias do antigo Estilo Internacional congelaram em um padrão de rotina cortês que faria o ritual japonês mais elaborado parecer improvisado, o Pós-modernismo inevitavelmente surgiu, muito sob a influência japonesa. (KOBAYASHI, SUSUKI, BANHAM, 1985: 21)

Para Reyner Banham, a diferença da arquitetura japonesa em relação à ocidental estaria fundamentada na liberdade de uso que demonstra esta ter tanto em relação aos materiais quanto em relação aos elementos arquitetônicos incorporados de outras culturas. Banham aponta que as diferenças abstratas usualmente apontadas como diferenças características da arquitetura japonesa, tais

\footnotetext{
${ }^{172} \mathrm{O}$ arquiteto Togo Murano (1891-1984) é considerado um pós-moderno antes do tempo pela justaposição de elementos modernos, históricos e fantasiosos (ocidentais e orientais); pelo tratamento de superfície nas fachadas; e esforço contextualização de urbana. Teria sido redescoberto no final dos anos 1960. Ver Togo Murano em MAKI, Fumihiko. Nurturing Dreams. Collected Essays on Architecture and the city. London: MIT, 2008. O projeto de Arata Isozaki para o edifício do centro de Tsukuba (1983) e a praça fazem referência à arquitetura clássica demonstra preocupação com o desenho urbano, baseado no Campidoglio de Michelangelo.

173 "Dispositivos gráficos exagerados no vernáculo comercial...supergráficos gigantescos, padrões ópticos, sinais escritos...[ele] combina esses códigos comerciais com a disciplina geométrica e expressão volumétrica mais comuns no jogo elevado da arquitetura séria...pura geometria". Descrição por Charles Jencks do Ni-Ban-Kahn de Minoru Takeyama. (KOBAYASHI, SUSUKI, BANHAM, 1985: 21)
} 
como a impermanência; a capacidade de mudança e de absorver culturas variadas e a valorização dos espaços intermediários teriam raízes num dado literal que é o fato de terem sido pensadas em relação às construções em madeira. Os edifícios representativos, tais como os templos, seriam de madeira, enquanto a alvenaria estaria restrita às fortificações e obras de engenharia civil. No ocidente, os edifícios seriam de alvenaria, conforme herdado da cultura humanista mediterrânea, que se tornou dominante em relação a cultura arquitetônica do norte em madeira. Se não eram de alvenaria, buscavam parecer-se com ela. "Por mais refinada que tal obra de madeiramento ocidental pudesse tornar-se ela não era ainda uma arquitetura merecedora de respeito cultural na tradição europeia depois da Renascença." (KOBAYASHI, SUSUKI, BANHAM, 1985: 23). Para Banham, no entanto, não seria a leveza do estilo sukyia, e das casas de chá que melhor caracterizariam a arquitetura japonesa, mas a arquitetura massivamente elaborada em madeira. "Arquitetura séria - na medida em que esse termo essencialmente ocidental é transferível para o Oriente - era madeira, massiva e elaborada" (KOBAYASHI, SUSUKI, BANHAM, 1985: 23). Isso se verificaria na transferência da lógica construtiva da madeira para o concreto, conforme se verificaria desde August Perret até os modernistas europeus que repetiriam a leveza da estrutura em madeira e a distinção lógica entre o elemento de vedação e estrutural, enquanto os japoneses utilizariam o concreto de modo ambíguo, pesado, completamente distinto do trabalho que eles próprios poderiam ter feito em madeira tradicionalmente. Eles não imitariam no concreto o tratamento dado à madeira, usando-o num nível mais abstrato e ousado esteticamente: apesar de ser um material pesado, o concreto armado, podia ser explorado por suas qualidades elásticas para vencer grandes vãos. Para Banham, nas tradições da arquitetura europeia a exploração abstrata de tais qualidades dos novos materiais, tal como o concreto, permaneceriam sendo associadas à dificuldade que as construções em pedra ofereciam. Balanços e grandes vãos mesmo em concreto sempre seriam associados aos lintéis de pedra que rachavam no meio do vão devido ao próprio peso. Já a tradição em madeira da arquitetura japonesa os teria fornecido uma outra expressão da lógica estrutural, bem como da harmonia entre as partes, que resultariam nessa expressão que nos pareceria ousada e radical. 
$\mathrm{Na}$ tradição japonesa nunca existiu qualquer desses dilemas (apesar de ter provavelmente outros que são lhes próprios) sobre vãos e aberturas, e os olhos japoneses pouco provavelmente veriam um grande balanço ou amplo vão como sendo notável o suficiente para comentar; qualquer um que olhe um templo japonês, palácio, ou mesmo algumas casa privadas provavelmente verá madeiramentos muito maiores que o cálculo estrutural requereria, não apenas rasgando grandes aberturas mas também equilibrados em membros subsidiários bem mais esbeltos do que pareceria decente aos olhos ocidentais. (KOBAYASHI, SUSUKI, BANHAM, 1985: 23)

Banham aponta que o mesmo estranhamento que se tem da expressão estrutural se verificaria no tratamento das formas enquanto valor simbólico. As formas incorporadas do ocidente sempre adquiririam sentidos dissociados dos originários, estratégia de projeto que se verificaria no Ocidente somente com a revisão da arquitetura moderna e com a arquitetura pós-moderna. Tal mudança decorreu da observação de que as formas modernas da arquitetura internacional ultrapassavam, mesmo que involuntariamente, a mera expressão da verdade da função ou estrutura. Elas estariam sempre associadas à qualidades estéticosimbólicas.

No Japão, a tendência à interpretar a verdade segundo o fluxo da vida, e não segundo uma ontologia da permanência de origem metafísica, modificaria as supostas clareza e distinção associadas à geometria da arquitetura moderna funcionalista. Mesmo o tratamento das formas puras geométricas ganharia novo sentido, sendo elas utilizadas como motivos disponíveis, tomados conceitualmente de modo não literal, e destituídos do conteúdo originário metafísico da arquitetura ocidental.

$\mathrm{Na}$ linguagem ocidental que ele menciona (o arquiteto Mayumi Miyawaki, que toma como partido as "formas primárias"), poderia apenas referir-se a cilindro, esfera, cone, retângulo etc., da tradição platônica, sólidos geométricos elementares dos quais todas as outras formas são nocionalmente construídas. Contudo, quanto mais se olha para a arte e arquitetura japonesas tradicionais, mas se tem que duvidar de que essas formas, onde quer que elas surjam, podem ter tido alguma vez o mesmo significado de ser ou os blocos edificantes do universo (como no pensamento de Le Corbusier) ou as imagens da divindade (como no misticismo da Renascença - a ideia de Deus como uma esfera cujo centro está em todo o lugar em sua superfície infinita é um paradoxo que parece muito chocante para ser apreciado por algum mestre Zen, sabe-se lá qual!) (KOBAYASHI, SUSUKI, BANHAM, 1985: 24)

A japonização do mundo contemporâneo, portanto, decorreria da disseminação desse processo de relativização da ontologia tradicional, que o 
Japão teria apresentado na arquitetura e em sua confusa paisagem urbana de modo antecipado. A sobreposição de imagens religiosas aos produtos de consumo em massa e à alta tecnologia configurariam o espaço contemporâneo nesse início de pós-modernidade japonesa. Essa sobreposição impura de imagens na paisagem urbana viria de tal modo se disseminando que talvez não produzisse mais o estranhamento que antes parecia separar cidades do Ocidente e do Oriente. Tal impureza seria própria ao uso de uma língua estrangeira, corresponderia à marca da diferença, ou às inexplicáveis "reticências" que separariam uma cultura de outra. "É o padrão do pensamento costumeiro e do costumeiro impensável, as coisas sobre as quais nunca se precisa pensar, que importam, porque as mais significantes diferenças derivam de coisas que não podem ser feitas, as reticências costumeiras nascidas do hábito social - e a arquitetura do Oriente tem sido conspicuamente reticente” (KOBAYASHI, SUSUKI, BANHAM, 1985: 21). Essas reticências determinariam o modo particular de apropriação de elementos arquitetônicos estrangeiros e mesmo um modo de declarar o estranhamento nesse processo, tal como se encontraria na Casa de Cinquenta e Quatro Janelas de Kazuhiro Ishi, criticada pela arbitrariedade de seu ecletismo ou possível chiste. A aceitação de tal obra confirmaria a reciprocidade do processo de japonização das arquiteturas mundiais e da ocidentalização da japonesa, sendo que o segundo movimento seria mais fácil de aceitar, conforme se verificava nos encontros iniciais enunciados por Gropius e pelo Team X e rejeições posteriores.

\begin{abstract}
A janela, como entendemos aqui - a janela ocidental como um buraco na parede não tem lugar na tradição histórica japonesa de paredes como telas corrediças, de tal modo que cada janela de Ishi é uma declaração numa língua estrangeira, quer dizer, e pela constante repetição com variação se torna parte de uma declaração sobre a língua estrangeira. (KOBAYASHI, SUSUKI, BANHAM, 1985: 26)

Conforme verificamos, os anos 1968 corresponderam ao momento de reconhecimento da morte da utopia no meio arquitetônico internacional, ambiente compartilhado por Arata Isozaki. No contexto japonês, ele não foi o único a perceber que as soluções megaestruturais foram assimiladas pelo sistema político e econômico, além de estarem majoritariamente sendo definidas pelas construtoras e tecnocratas. As gerações mais novas não conseguiam se inserir nesse sistema já estruturado, ficando restritos à escala doméstica. Outra razão para
\end{abstract}


se ater na escala doméstica seria a possibilidade de experimentação, como é o caso da escolha de Kazuo Shinohara.

\section{A Escola Shinohara - um platonismo nipônico?}

A atuação inicial do arquiteto Kazuo Shinohara (Fig. 17), que foi concomitante com a da vanguarda Metabolista, é caracterizada pela distância que ele mantém em relação ao movimento. Shinohara discordava da visão do arquiteto como missionário do projeto nacional de democratização no pós-guerra. Ele se manteve, portanto, afastado da orientação sociológica e se voltou para a experimentação com o espaço doméstico que é tratado como obra de $\operatorname{arte}^{174}$. O hermetismo de suas investigações é entendido frequentemente como falta de consciência social. Para o arquiteto Shin-ichi Okuyama, no entanto, tal juízo resultaria de um desconhecimento da profunda crítica da sociedade implícita em sua obra. Assim como Kenzo Tange, mentor dos metabolistas, a quem ele é contraposto frequentemente, ele também possuía um laboratório na Universidade de Tóquio e é responsável pela formação de um grupo de arquitetos, tal como Toyo Ito, onde a questão social é tratada de modo julgado ambivalente frente à importância dada para a experimentação formal.

Shinohara é crítico da transparência lógica associada às megaestruturas, concebidas como metáfora e determinantes de um futuro claro e distinto. Para ele, o planejamento urbano moderno levaria as cidades a um ponto em que ela se tornaria inapreensível pelas estratégias modernas. "Em vez disso (clareza e distinção), vórtices tempestuosos e ardentes de desejo reporiam a fase sucessiva. Ademais, estava claro que a abordagem de Shinohara não seria orientada logicamente, mas, pelo contrário, através do radicalmente corpóreo." (OKUYAMA, Ja 93, 2014: 4). O desenho de suas casas pressupõe sua teoria social urbana, que reconheceria nas grandes cidades japonesas um caos frutífero (Tóquio é tomada como referência), conforme encontrado na teoria do caos relacionada à biologia e às supertecnologias. As relações entre a arquitetura e a cidade se estabeleceriam segundo componentes arquitetônicos aparentemente

\footnotetext{
${ }^{174}$ Shinohara repetiria o seguinte aforismo: "Uma casa é Arte” (OKUYAMA, Ja 93, 2014: 4).
} 
indiferentes que se ligam ao todo da cidade numa "Progressiva anarquia". (SHINOHARA, Ja 93, 2014: 119).

Suas experimentações seriam inicialmente baseadas numa investigação matemática, dado sua formação inicial na disciplina, e na tradição japonesa, desdobrando-se em função dos teoremas que surgiriam no processo de projetação $^{175}$. O resultado de sua estratégia projetual seria o desenvolvimento de uma metalinguagem arquitetônica, que não deixaria de ser crítica da linguagem abstrata e padronizada e do culto à tecnologia propagados pelo movimento moderno em função de fatores econômicos. A investigação de Shinohara sobre o espaço abstrato resultaria na determinação de espaços reservados minimalistas, ainda assim dotados de referências tradicionais e singularidade.

Conforme descarto estilos espaciais japoneses e tento dar forma à espaços abstratos, estou constantemente impulsionado pelo desejo de voltar esses espaços para o cotidiano. Não é fácil fazê-lo. Estou possuído pela busca da abstração baseada numa forma completa, e dentro de mim está nascendo o senso real de um aspecto diferente de espaço. (SHINOHARA, Ja 93, 2014: 30).

Sua obra arquitetônica construída é acompanhada de ensaios, que configurariam juntos o que Shinohara denomina de ficcionalidades. "Procurando sua própria independência hipotética dos esquemas urbanos, das condições do lugar impostas, das obrigações com a orientação familiar, e de outros inconvenientes com as instruções do cliente, Shinohara afirma que sobretudo tem-se que tentar "fazer na beleza um espaço de ficção"," (SHINOHARA, Ja 93, 2014: 5). Na verdade, a obra determinaria uma rede ou camadas de ficção que incluiriam a determinação do programa arquitetônico, sua documentação, os pósescritos, os registros etc. Que poderiam ir além da obra construída em termos de existência. A sociedade de consumo estenderia tal rede de ficções ao multiplicar as possibilidades de realização dos ambientes movidas pelo desejo, que determinaria as cadeias de imagens reais e virtuais convivendo simultaneamente. Os meios de comunicação também participariam desse enredo ficcional que

175 “As transições de seu estilo podem ser resumidas como a seguir. No primeiro período, ele criou espaço simbólico, tirando sua inspiração das casas japonesas tradicionais. No segundo período, ele criou casas antitéticas àquelas do primeiro período e composições tais como "cubos" e "fissuras" predominavam. O terceiro periodo foi caracterizado pela dissonância dos elementos arquitetônicos, os quais ele descrevia enigmaticamente como "selvageria", "máquina espacial", ou "coisas nuas". Agora está entrando em nova fase, que ele prevê irá reinterpretar o movimento moderno dos anos 1920, ou Sachlichkeit” (KOBAYASHI, SUSUKI, BANHAM, 1985: 84) 
embasa a arquitetura doméstica. Para Okuyama, a noção de ficcionalidade associada às tecnologias de comunicação, proposta por Shinohara já no contexto dos anos 1960, pervertia a ideia de que a tecnologia seria sinônimo de progresso social e material ao valorizar exatamente sua dimensão insubstancial e, ao mesmo tempo, antecipar a condição contemporânea da realidade virtual determinada pela tecnologia digital. "Um mundo prestes a ser inundado pelo banho de informação da internet e envelopado na visualização dos smartphones, com suas mínimas distinções entre realidade e falsidade, pode provocar uma situação paradoxal na qual certo grau da assim chamada ficcionalidade poderia servir para melhorar e intensificar o real." (SHINOHARA, Ja 93, 2014: 6). A ficcionalidade romperia com as demandas dos referenciais relativos da realidade imediata, que é condicionada por questões político-econômicas, para alcançar a duração da obra de arte. Através da ruptura com o espaço real, a linguagem circularia no mundo ficcional da auto-referencialidade ao qual Shinohara se ateve.

E assim, as construções metalinguísticas e auto-referentes de Kazuo Shinohara, conceitualmente isoladas do espaço real como elas podem parecer por vezes, contudo, fornecem uma dimensão implícita em contraste com a autoproclamada metalinguagem arquitetural de seu rival Arata Isozaki. Já que o último, possui uma impressionante visão de Jano e é limitado pela expressão material sem a atribuída conquista do tempo, a qual, como uma impressionante construção social, investe a aparição etérea de Shinohara quando ficcionalidade austera. (SHINOHARA, Ja 93, 2014: 6).

\section{2 . \\ 0 arquiteto Toyo Ito}

\section{Morfemas corporais e utopias tecnológicas}

O arquiteto Toyo Ito (1941) é formado pela Universidade de Tóquio (1965). Apesar de ter trabalhado até 1969 com o arquiteto megaestruturalista Kiyonori Kitutake, é descrito, junto com os arquitetos Itsuko Hasegawa e Kazunari Sakamoto, como pertencente à Escola Shinohara. Sua passagem pelo escritório de Kitutake teria representado o oposto da racionalidade projetiva megaestrutural apresentada por integrantes do Movimento Metabolista nos Seminários de Kenzo Tange de pós-graduação. A experiência no escritório de Kitutake (Fig. 15 e 16) colocará para ele a necessidade de superação da teoria através do desenvolvimento do senso corporal. 
Mas assim que ingressei no escritório de Kitutake, percebi quão ridículo era tudo isso. Aí, sim, eu vi do que a arquitetura é feita. Nenhuma teoria, nenhum sentido. (...)

Tudo isso me fascinava cada vez mais. Na realidade, ele intuía seus projetos com todo o seu corpo, confiando em uma espécie vocabulário físico. Para dar um exemplo, ele desenhou puxadores de porta que pareciam lagartos. Não por alguma razão lógica, mas apenas porque eles aderiam às portas. $\mathrm{E}$ aquilo parecia estranhamente convincente. Ele sempre abordava tudo por um viés físico.

$\mathrm{Eu}$ nunca fui avesso a palavras e a escrever, motivo pelo qual eu suponho Kitutake tenha me encarregado de fazer isso para ele, embora, inversamente, eu não tivesse a menor confiança no meu próprio vocabulário físico, e estivesse dolorosamente consciente da necessidade de desenvolver o meu "senso corporal", se de fato quisesse me tornar um arquiteto. (ITO, 2005: 74)

A certeza de que a arquitetura ultrapassava o conhecimento teórico deve ter encaminhado Ito na direção da concepção de arquitetura como ficcionalidade, proposta por Shinohara. Afinal, mesmo uma metodologia de projeto arquitetônico racionalmente determinada pressupõe uma condição hipotética, que se torna consciência do problema colocado como ficção. A linguagem da ficção, Ito proporá, deve ser construída através de morfemas abstraídos da memória corporal: "formas abstraídas das cenas urbana e natural contidas na minha própria memória e consciência. (...)" (ITO, 1976, 2011:37). Esses morfemas não corresponderiam a representações analógicas da cidade, mas à expressão de sensações incorporadas através da alteração do ritmo corporal e senso de movimento no choque com a realidade. "Para mim, expressar esse tipo de sensação incorporada na arquitetura é simbolizar a cidade” (ITO, 1976, 2011:37). Ito não esteve interessado nos elementos simbólicos abstraídos da narrativa histórica, tal como na tendência pós-moderna de fazer citações, nem nos morfemas metalinguísticos, tal como os utilizados pelos arquitetos americanos do New York Five, "que tentaram decompor a arquitetura de Le Corbusier em formas puras das quais eles então extraem vários elementos e recompõem na própria arquitetura" (ITO, 1976, 2011:37).

Em 1971, ele abriu seu próprio escritório, chamado Urban Robots (URBOT), apenas renomeado com seu próprio nome em 1979. Simultanemamente, publica o ensaio "The Logic of Uselessness" que apresenta seus três primeiros projetos. O ensaio corresponderia ao registro dos anos de "observação muda da cidade" feita pelo "robô urbano" e ao manifesto teórico elaborado em tom de ficção-científica. No ensaio, a cidade de Tóquio estaria 
tomada por robôs, cápsulas, psicodelia, arquitetura pop e por sistemas de informação integrados que estariam definindo a "mecano-história", o que deixaria o próprio robô URBOT, que é produtor de arquitetura habitacional e portal de informação, infeliz: "a imagem da cidade informacional "mecanohistórica" nada mais era que a ilusão coletiva do mundo homogêneo, ao passo que ele poderia sentir realidade apenas naqueles espaços que transmitiam o calor da respiração e a corporeidade humana." (ITO, 1971, 2011:24). A arquitetura do URBOT seria influenciada pela linguagem do vernáculo pop do Oeste americano, exemplificado pelos supergrafismos de Charles Moore, associado ao utopismo tecnológico disfuncional "no estilo de ficção científica" do Archigram e do Superstudio. As duas tendências arquitetônicas críticas da supremacia da civilização tecnológica, que se expressariam antiteticamente, determinariam a patologia do URBOT. Esta seria resumida no desejo de "retornar à natureza enquanto idolatrando a tecnologia" (ITO, 1971, 2011:24), o que tornaria o URBOT inoperante como membro da sociedade. Ele prevê, portanto, sua própria destruição e reestruturação. Tal destino, no entanto, traria sentido a sua inutilidade: "a natureza essencial da arquitetura reside precisamente na apreciação da absurdidade da vida real para um ser humano individual." (ITO, 1971, 2011:26). Ele conclui que a intensificação da fricção com a realidade estéril metropolitana, que se traduz no sentimento de alienação e de inutilidade, permitirá paradoxalmente a simbolização do vivido, tal como no fenômeno de exaptação ${ }^{176}$ da teoria da evolução biológica, determinando a arquitetura por esse mesmo processo.

No princípio de sua vida profissional, Ito assume uma postura crítica em relação à cidade que se assemelha a de Shinohara e não ao otimismo metabolista. A busca de um modo singular de expressão artística em pequena escala dominaria o experimentalismo dessa geração mais jovem que inicia o trabalho autônomo no momento das revoltas estudantis e da na iminência da crise do Petróleo. Vimos que para os arquitetos da geração imediatamente anterior, Kazuo Shinohara e Arata Isozaki, a cidade se tornara uma referência negativa da especulação e da

\footnotetext{
${ }^{176}$ Distingue-se do fenômeno de adaptação e seleção natural das determinações genéticas em função de uma necessidade atual, operando como um desdobramento do efeito previsto. "Exaptação é a consequência de uma adaptação excessivamente direta ao ambiente, manifesta no fenômeno que excede o nível da função e enfatiza seus significados simbólicos, tal como o chifre do veado" (ITO, 1971, 2011:27)
} 
tecnocracia contra a qual a experimentação formal fechada, segundo o estabelecimento da metalinguagem arquitetônica, se tornara estratégica. Para Ito, assim como para outros arquitetos japoneses de sua geração, a liberdade conceitual vinha acompanhada de uma crítica da realidade, que se traduziam numa tendência a bloquear o envolvimento com o exterior (KOBAYASHI, SUSUKI, BANHAM, 1985: 12). Assim como Shinohara e Isozaki, Ito voltaria as costas para a cidade e "focaria na criação de utopias pessoais em miniatura" (DANIELL; ITO, 2011: 7).

\section{A abertura para a realidade da cidade}

Ito renomeia seu escritório em 1979, quando também sua orientação arquitetônica é redirecionada em torno do esforço de abrir o espaço da casa para a cidade, de recuperar a relação com o contexto urbano. "Ele também deixa a órbita de Shinohara, mesmo que temporariamente, formando um grupo "antiShinohara”, com colegas tais como o crítico Koji Taki." (DANIELL; ITO, 2011: 10). A recuperação da relação com o contexto urbano, não significou para Ito um abandono da crítica da realidade, mas sim a busca de um princípio e de estratégias que permitissem a experiência do habitar nesse contexto corrompido. Ito associa o sentimento de alienação experimentado nas metrópoles tanto aos espaços abstratos do modernismo quanto aos espaços caóticos da cidade informal, que emergem espontaneamente marcados pelas disponibilidades mercadológicas. Em Tóquio, devido à bolha econômica relacionada à escassez de solo, cujo ápice foram os anos 1980, a paisagem urbana teria se tornado efêmera e caótica, dado a curtíssima vida útil dos edifícios.

A primeira solução de Ito para a questão da deterioração do espaço da cidade correspondeu incialmente a um fechamento da casa, retomada como mito ao qual os arquitetos davam forma como modelo do mundo: "Se o telhado ou cúpula que formam a casa simbolizam o céu, os suportes que seguram o telhado conectam céu e terra, e representam o centro do mundo. Assim, o mito do mundo mostra que a ação de fazer uma casa cria ordem a partir do caos e dá estrutura forma, e normas pelas quais configurar o universo." (ITO, 1978, 2012: 102). Seu projeto residencial White $U$ (1976), corresponderia à realização desse mito do habitar (Fig. 18, 19 e 20): "fazer arquitetura é ainda o ato de procurar o sentido 
do habitar, e assim, no primeiro passo retirada da atividade cotidiana, eu quero averiguar o que as pessoas querem e o que lhes causa dor, e fazer arquitetura como campo que pode tocar em tais emoções. " (ITO, 1976, 2011: 34). A casa deveria ultrapassar o condicionamento das atividades cotidianas em prol de uma experiência sensual que desse sentido ao habitar. A forma de um corredor descrevendo um percurso semicircular foi escolhida. $\mathrm{O}$ exterior em concreto aparente contrastava com o interior totalmente pintado de branco, iluminado com lâmpadas fluorescentes e alguns poucos rasgos de luz natural que, na verdade, enfatizavam o efeito variado das sombras. Ele descreve o projeto dessa casa como um campo onde agem forças contrastantes de fluxo ("corredor" interior branco e inorgânico) e estagnação (exterior de concreto no interior do semicírculo, formando um pátio interno "subterrâneo"). No espaço interior do fluxo, os "morfemas corporais", memórias abstratas das cenas urbanas, demarcariam o ritmo de passagem pontuada de elementos variados, tais como superfícies curvas, paredes escalonadas, pontos de luz variados etc. "A superficie curvada é um morfema que causa uma variedade de efeitos imprevistos" (ITO, 1976, 2011: 38). A forma interior abobadada e branca serviria como local para projeção de sombras cambiantes em função dos focos de luz que substituiriam quadros, enfatizando sua linguagem formal paradoxalmente abstrata e sensível. "Como pessoa que tenta apreender a arquitetura em termos de forma somente, isso me parece mais natural" (ITO, 1976, 2011: 40).

O significado pleno do contraste entre a forma simbólica da White $U$ com a cidade somente teria se revelado para Ito em leituras posteriores, onde comentadores evidenciariam sua "singularidade como bolsa-de-ar" na cidade. $\mathrm{O}$ crítico de arquitetura Koji Taki, por exemplo, teria apontado que a aparência subterrânea da casa corresponderia à realização do conceito de escuridão, que é associado às habitações primitivas, tais como as cavernas e pirâmides. A enorme carga simbólica, trazida por seu espaço de escuridão e sombras, contrastaria com o entorno caótico, pontuado por edifícios altos e linguagem moderna abstrata, fazendo-o desaparecer. "Para os arquitetos, o espaço de sombra tem um charme particular, misterioso: entrando, o arquiteto cai, como se deslizando em buracos de formiga-leão, e a conexão lógica com esse mundo, ou mesmo a conexão lógica 
com a sensibilidade dessa época, pode ser inteiramente perdida." (ITO, 1978, 2012: 98).

O reconhecimento do potencial da dimensão mítica de White $U$, como purificadora da lógica urbana contemporânea capaz de fazer a cidade desaparecer, permitiu que ele repensasse a questão de seu fechamento radical. A questão do contexto urbano seria elaborada a partir da contraposição de dois mundos: o sagrado da casa e o profano da cidade. Sua integração determinaria a realização mais plena do sentido de habitar. A chave para abertura da casa estaria na definição de um espaço de transição entre esses dois mundos, um espaço sagrado devolvido ao culto coletivo inserido no contexto urbano. O mundo profano incluiria tanto o espaço planejado moderno quanto a arquitetura informal e comercial que se desenvolvem espontaneamente. Ele se baseia na distinção proposta pelo Filósofo romeno Mircea Eliade (1907-1986), que contrasta o espaço planejado moderno; determinado segundo uma estrutura homogênea, plana e indiferenciada com o espaço sagrado; que depende da existência de "um ponto fixo absoluto, um centro" a ser "envelopado pela reencarnação sagrada" (ITO, 1978, 2012: 101). O espaço profano corresponderia a "fragmentos do universo", sendo determinado de forma instrumentalizada, segundo critérios funcionais. $\mathrm{O}$ sagrado seria determinado segundo um processo de abstração ${ }^{177}$, baseada na discussão sobre o ser.

Se fôssemos pensar no White $U$ em termos de lugar sagrado e profano, nós iríamos encontrar espaço centrífugo em vez de homogêneo, ordem em vez de desordem, a palavra universo como oposta ao caos: esse é tipo de espaço com o qual nós estamos lidando. Em vez de uma discussão de funcionalidade, há um discussão de abstração. Em vez de uma discussão de relatividade, há um mundo da ontologia. (ITO, 1978, 2012: 101)

O desejo de habitar corresponderia ao anseio pelo sagrado, que alguns arquitetos modernos teriam correspondido, tais como Le Corbusier em La Tourette e Louis Kahn. Tal anseio estaria manifestado na propensão arquitetônica à escuridão, centralidade e axialidade. De um modo geral, no entanto, a arquitetura moderna teria descartado tal questão. "Do momento de sua formação, a arquitetura moderna exaustivamente descartou o conceito da casa como

177 O sentido de abstração dado por Ito tem a ver com o sentido de espiritualizar. O Kanji de abstração tem um sentido de elevação do pensamento e não de redução de qualidades sensíveis. 
modelo do mundo. A fim de se livrar da palavra casa das conotações históricas havia uma tentativa de eliminar o ícone da casa e substituir pelo recipiente vazio. Esse é um verdadeiro iconoclasmo." (ITO, 1978, 2012: 103)

A procura de leveza na arquitetura, desenvolvida em projetos posteriores por Ito, seria o resultado da preocupação com a abertura do sagrado no contexto urbano. Tal preocupação teria sido revigorada pela ampliação do debate arquitetônico a discurso cultural nos anos $1960^{178}$, como esforço de reinseri-la também no contexto social, do qual a arquitetura moderna havia terminado por dissociar-se. A mudança do debate arquitetônico para o âmbito das discussões culturais teria permitido a revisão de princípios racionalistas e cientificistas que teriam dominado a arquitetura desde o Iluminismo, introduzindo novos significados que determinariam sua técnica: "uma por uma, palavras como superfície, indefinição, duplicidade, discrepância, e ambiguidade tomaram a arquitetura do interior de seu gênero fechado; a levantaram e jogaram num domínio cultural mais amplo” (ITO, 1978, 2012: 99).

O espaço sagrado somente poderia ser recuperado através de uma experiência holística e não como experiência pessoal, por isso o compromisso de Ito de abrir a casa para a cidade: para que o espaço se tornasse propriedade comunal e experiência de todos (ITO, 1978, 2012: 104). O espaço comum corresponderia aos desejos contraditórios de casa e de recipiente. A casa sem a contaminação pelo profano se isolaria no tempo e no espaço. $\mathrm{O}$ recipiente que não fosse tocado pelo sagrado desapareceria no caos da cidade. "Através disso, o arquiteto tem um modo de relacionar as pessoas à cidade que eles habitam. E a fim de retirar o mundo profano das profundezas do subconsciente - restabelecer sentimentos como o sagrado e a propriedade comunal que sustentem o espaço da cidade - nós criamos uma arquitetura que é inerentemente ambígua" (ITO, 1978, 2012: 108). O sagrado flutuaria dentro do espaço profano como sombra trepidante e vice-versa numa ordem intercambiável e complexa. A arquitetura espontânea

\footnotetext{
178 "Venturi foi o primeiro arquiteto que me mostrou que a arquitetura que os modernistas acreditavam ser o pináculo do abstrato e sagrado estava na realidade proliferando subconscientemente através do mundo profano" (ITO, 1978, 2012: 108) . O ensaio de Venturi, Complexidade e Contradição em arquitetura: trechos de um livro em preparação, é de 1966. Ver também ROWE, Colin; KOETTER, Fred. Cidade Colagem. (1975) em (NESBITT, 2008: 293).
} 
teria um potencial vital que pode ser incorporado na arquitetura planificada. " $A$ vitalidade do espaço misto do sagrado e do profano é derivada do senso de perigo no momento do movimento de um para o outro. Esse é também o processo de incorporação e ativação da periferia ambígua - a fronteira entre os territórios da cultura e não-cultura." (ITO, 1978, 2012: 111)

A experiência da forma simbólica no mundo contemporâneo, dominado pela abstração e universalismo das formas modernas e nivelado culturalmente pela abstração da mercadoria, no entanto, demandaria uma nova técnica que permitisse a experiência do habitar. A nova técnica não corresponderia totalmente nem à recuperação mítica do habitar, que permanecia isolada e velada como no White $U$, mas à recuperação da manifestação pública que se daria apenas na ambiguidade espacial, onde profano e sagrado se misturam. O espaço da arquitetura habitacional comercial demonstraria o desejo de habitar manifestado em imagens icônicas do que seria uma casa, reduzidas ao efeito decorativo que o modernismo dispensava.

É possível dar um brilho no espaço polindo todo vocabulário que preserva o ícone, e recombinando aquele vocabulário polido num sistema especial flexível que aumente a utilidade do container sem perder algo do seu vigor. Esse tipo de brilho não é certamente capturado pelo realismo; ele somente é obtido pelo seu poder simbólico, e quando isso se torna possível, as casas seriadas alcançam valor cultural como casa. (ITO, 1978, 2012: 111)

Os elementos da arquitetura, tal como a malha estrutural da arquitetura moderna, quando tratada de modo distorcido e instável também deixaria de ser meramente funcional, contaminando o espaço homogêneo com o sagrado, sem a necessidade da referência icônica.

(...) por causa da tendência da estrutura em direção ao sagrado, a ação de centralizar forças cria uma fricção com a estrutura que gera um espaço instantâneo. (...) Depois de contínua liquefação, a estrutura essencialmente desaparece, e somente uma colagem dos elementos coloridos pela sombra do ícone permanece. Essa arquitetura é uma estrutura não-visual, e flutua como uma bruma quente no espaço homogêneo. (ITO, 1978, 2012: 111)

Toyo Ito sugere o desenvolvimento de dispositivos que permitam a movimentação mútua da relação profano-sagrado no espaço. A dimensão profana do cotidiano tal como ele se desenvolve na realidade contemporânea seria superficial; tanto porque determinada pela lógica mercadológica abstrata quanto 
pela banalidade cotidiana. Assim, a superfície vulgar configuraria o cenário da realidade, onde o drama da vida se desenrola. Também a arquitetura compartilharia dessa superficialidade que permite revelar a profundidade do drama, a própria superfície se tornou a arquitetura onde o sagrado se comprime. A estrutura que teria a vocação para o sagrado também se comprime na superfície. "A profundidade não é revelada através da ruptura de superficie". (ITO, 1978, 2012: 113)

Por causa do ímpeto para a profundidade, o efeito estrutural da superfície emerge como choque elétrico, e, num momento subconsciente, a profundidade aparece como superfície. Esse movimento instantâneo, elétrico e do tipo de uma corrente é o dispositivo que cria um mecanismo para a retroalimentação flexível, tanto em novelas quanto na arquitetura. (ITO, 1978, 2012: 113)

A aparência e a essência teriam perdido a distinção. $O$ dispositivo criado por Ito de explorar a superficialidade da arquitetura se traduz no mascaramento do interior, tal como na aparência exterior telúrica do White $U$. Seu exterior, ao negar a cidade através de sua forma fechada, abstrato-geométrica, não-icônica (contrastava com todas as casas do entorno imediato também) e pesada, paradoxalmente, se comportava como uma habitação no sentido sagrado do termo utilizado por Ito. O interior fluido, em contraposição ao exterior centralizado, seria profano como uma "máquina que fabrica espaço". Tal ambiguidade determinaria o surgimento de um espaço intersticial nem dentro e nem fora que seria habitável.

No White $\mathrm{U}$, no entanto, a casa estaria separada da cidade. O dispositivo permitiria romper de modo não-literal a contradição entre a universalidade da linguagem moderna e o contexto, tal como as referências diretas fariam. $\mathrm{O}$ jogo de intensificação da discrepância entre estrutura e fachada, entre a superfície e a fachada, entre o ornamento e a superfície permitiria o desenvolvimento de uma linguagem ambígua no âmbito da arquitetura que se relaciona com o contexto.

Como tal, mesmo quando o ornamento é uma forma de arte em si, ele também tem a capacidade de atrair as pessoas para outro universo através de sua universalidade. Isso é porque o ornamento já é inerentemente superficial, mas é também uma estrutura para guiar as pessoas na compreensão de sua profundidade. Esse tipo de ornamento, decorativamente estratificado na superfície da arquitetura, atribui significado ao espaço arquitetural, revela significado a partir da superfície e revela nova expressão ao espaço de outro 
modo estático. (...) Mas, de fato, a pele é nada mais que uma imagem aplicada que irradia alguma ressonância no observador (ITO, 1978, 2012: 116)

As verdades construtivas que norteavam a arquitetura moderna, tais como a estrutura independente da parede, fachada que segue o interior ("a forma segue a função") e solidez material que garante a estrutura e abrigo, poderiam recair numa ilusão de profundidade. Tais verdades não corresponderiam ao habitar no tempo, que está representado pelo espaço efêmero da cidade e pela tendência à superficialidade. O sagrado estaria comprimido na superfície da arquitetura contemporânea.

Há uma propensão hoje em dia de exigir do espaço arquitetônico que seja pesado e substancial, com a capacidade de proteger, mas esse espaço arquitetural não pode simplesmente ser rejeitado como superfície, ou como algo frívolo e duvidoso. (ITO, 1978, 2012: 113)

\section{A realidade envolvida em "filme plástico": a cidade fenomênica}

Conforme verificamos, a arquitetura moderna em sua obsessão por pureza teria perdido a capacidade de proporcionar habitação, porque mimetizaria a própria condição de alienação abstrata do sujeito contemporâneo. Este estaria dominado pela instrumentalização da realidade através das lógicas da racionalidade técnica e de mercado. A realidade se apresentaria para esse sujeito como se estivesse enrolada em "filme plástico" (ITO:1992, 2011, 96). A arquitetura moderna teria buscado, segundo Ito, através da pureza de sua linguagem de aço e vidro se contrapor à realidade heterogênea e extremamente substancial, "de tijolo e pedra”, das cidades do início do século XX. Já as cidades contemporâneas teriam incorporado o grid homogêneo, fluido e fragmentário, sobrepondo as duas dimensões substancial e fenomênica. Uma dimensão seria substancial e hierarquizada segundo a centralidade da estrutura social, indo do indivíduo ao estado. A outra seria a da “cidade como fenômeno”, cuja presença teria se intensificado após os anos 1980 com o desenvolvimento das mídias eletrônicas. Seus cidadãos consumiriam signos e não os objetos em si; eles viveriam sob a égide da fragmentação das relações. "Essa é a cidade como informação, a cidade virtual como evento. (...) que se estende topologicamente no espaço e no tempo" (ITO:1992, 2011, 94). Nela, as relações sociais seriam mais importantes que as familiares, deslocando a centralidade do "estar" das casas para os restaurantes. O indivíduo não se comunicaria mais através da família com 
a sociedade, mas diretamente nos "espaços comunitários efêmeros e acidentais" (ITO: 1992, 2011, 94). Vale ressaltar, que a cidade de Ito é Tóquio ou qualquer outra grande metrópole, e não Sendai que está por vir. "Não importa o quanto as obras de arquitetura tentem fazer valer sua originalidade, no instante que são colocadas na cidade, começam a parecer com aqueles produtos alimentícios cobertos com filme plástico dispostos nas vitrines de lojas de conveniência." (ITO:1992, 2011, 96). A arquitetura teria perdido substância e o homem teria atrofiado a sensibilidade corporal que a experiência do espaço ambíguo poderia proporcionar. A cidade contemporânea teria se tornado um "jardim de microchips", determinando um espaço marcado menos pela substancialidade material que por sua aparência. Esse espaço fenomênico poderia ser expresso de maneira concreta na arquitetura pela sobreposição dos dois sistemas, o informacional e o substancial. Ele seria caracterizado pela fluidez inorgânica dos elementos artificiais visíveis e invisíveis (fluxos de elétrons), pela multiplicidade de camadas sobrepostas do real e virtual e pela busca de efeitos fenomênicos desmaterializados, tais como luzes, sons e imagens. A informação se tornaria ambiente (ITO:1993, 2011, 112).

\section{O espaço puro como espaço sagrado do habitar}

Ito associa a dimensão abstrato-conceitual à arquitetura sagrada que permitiria a experiência do habitar (ITO, 1978, 2012: 108). A expressão pessoal da arquitetura de Ito estaria manifestada nessa busca de pureza espacial e abstração, conforme entendidas pelos arquitetos japoneses (KOBAYASHI, SUSUKI, BANHAM, 1985: 24). No caso de Ito, seria uma estratégia radical herdada da escola Shinohara, que desprezava qualquer influência externa, seja dos clientes ou das demandas sociais. Ito buscava através da abstração o espaço sagrado, conforme verificamos. Para o arquiteto Yamamoto, no entanto, sua busca de pureza estaria relacionada à incapacidade de ouvir os outros, que ele somente superaria no desenvolvimento participativo da biblioteca Sendai. "Ito era da opinião que um arquiteto deveria ser estritamente fiel a sua própria imaginação interna; e, acima de tudo, a pureza daquelas imaginações deveria ser defendida e mantida" (ITO; BUNTROCK, IRAGASHI, YAMAMOTO: 2009, P.31). Sua busca por pureza espacial não se traduziria numa busca da geometria da tradição platônica (KOBAYASHI, SUSUKI, BANHAM, 1985: 24), mas numa busca de ordem que poderia se traduzir em formas dinâmicas da geometria topológica e na 
configuração de espaços puros a serem experimentados corporalmente segundo o movimento e os demais sensos. A estratégia da superficialidade, conforme verificamos, corresponderia paradoxalmente à busca de pureza e ambiguidade espacial decorrente da mistura dos espaços sagrado e profano, da passagem de um a outro. O sagrado estaria, portanto, relacionado com a estética da transitoriedade, com a noção de Ma e com a contemplação das marcas deixadas pela passagem da vida (ITO, 2012: 111).

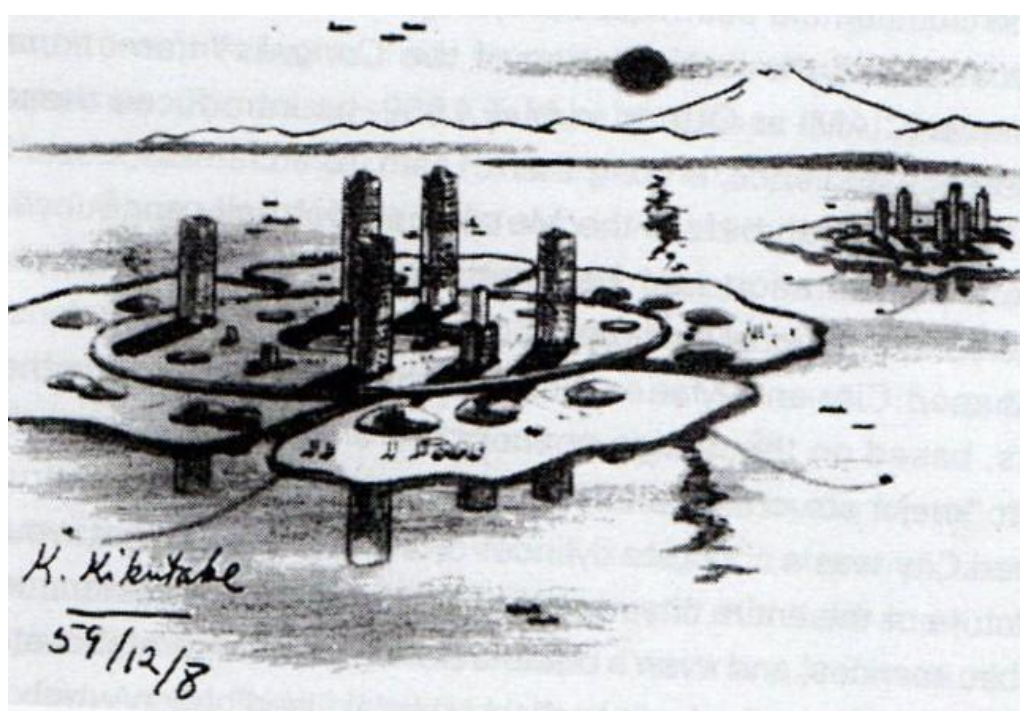

Figura 15: Kiyonori Kitutake, Croqui Cidade Marinha, 1959.

Fonte: LIN, Zhongjie. Kenzo Tange and the Metabolist Moviment: Urban Utopias of Modern Japan. New York: Routledge, 2010. 


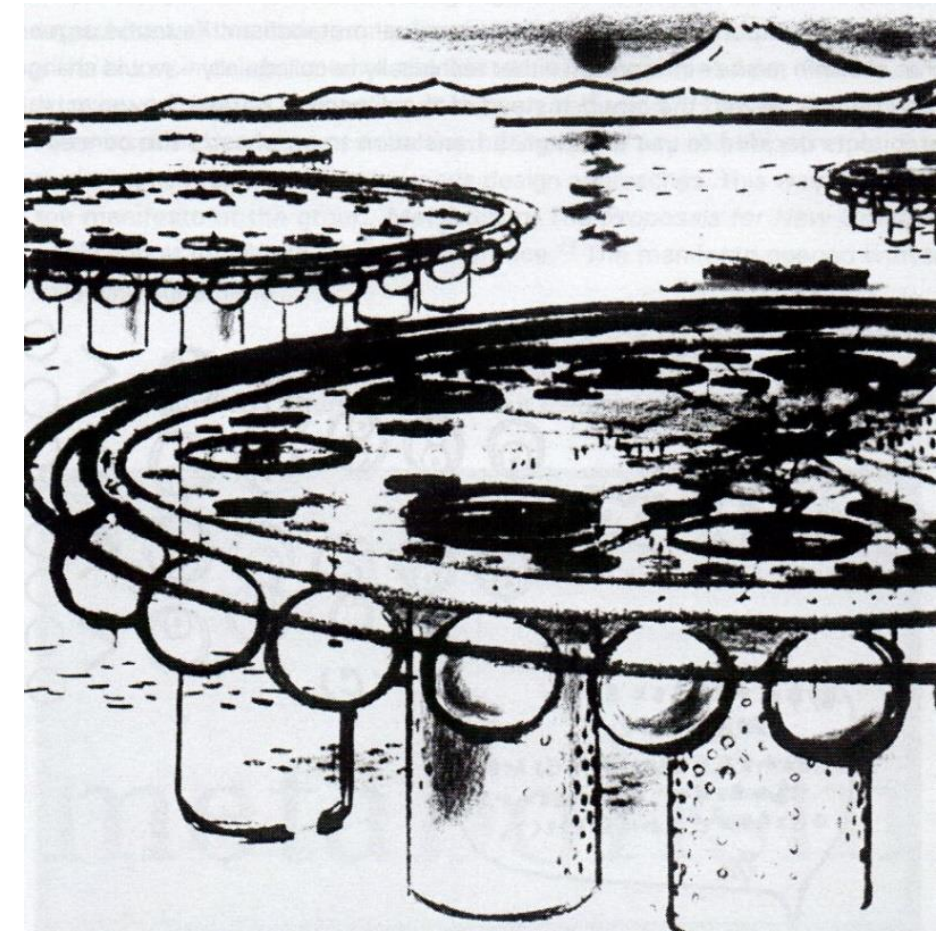

Figura 16: Kiyonori Kitutake, Croqui Cidade Marinha, 1959.

Fonte: LIN, Zhongjie. Kenzo Tange and the Metabolist Moviment: Urban Utopias of Modern Japan. New York: Routledge, 2010.

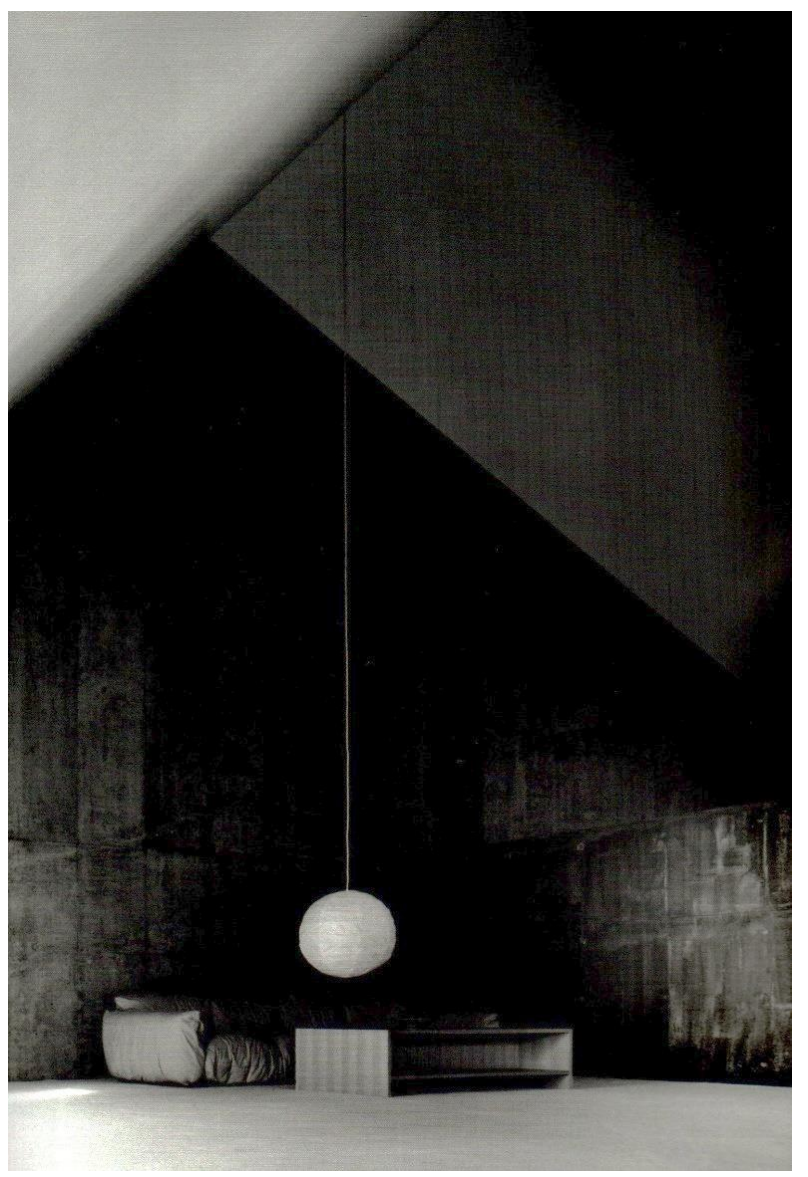

Figura 17: Projeto de Kazuo Shinohara, Casa em Seijo, 1973.

Fonte: Kazuo Shinohara: Complete Works in Original Publications. Ja: The Japan Architect. Tóquio: Schinkenchiku-sha Co Ltd., n.93, Spring, 2014. 


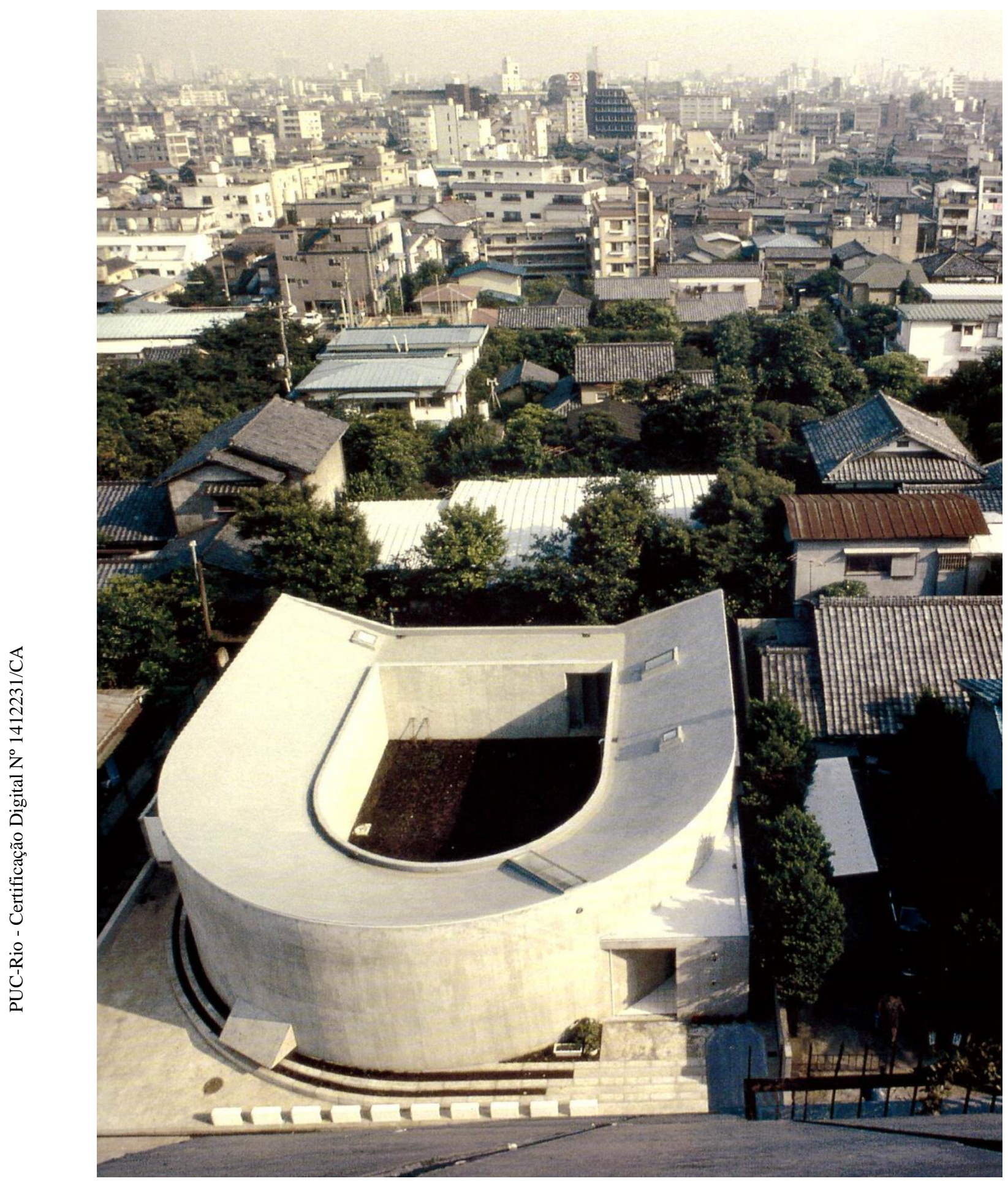

Figura 18: White U- Toyo Ito, Tóquio, 1976.

Fonte: ITO, Toyo; BUNTROCK, Dana; IRAGASHI, Taro; YAMAMOTO, Riken. Toyo Ito. London: Phaidon Press, 2009. 


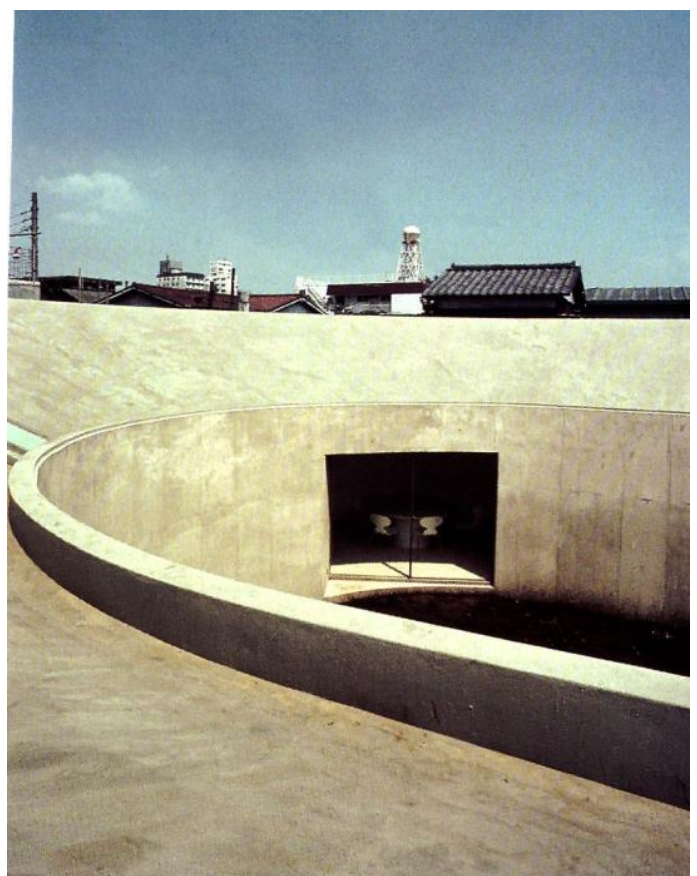

Figura 19: White $U$ - Toyo Ito, Tóquio, 1976 Fonte: ITO, Toyo; BUNTROCK, Dana; IRAGASHI, Taro; YAMAMOTO, Riken. Toyo Ito. London: Phaidon Press, 2009

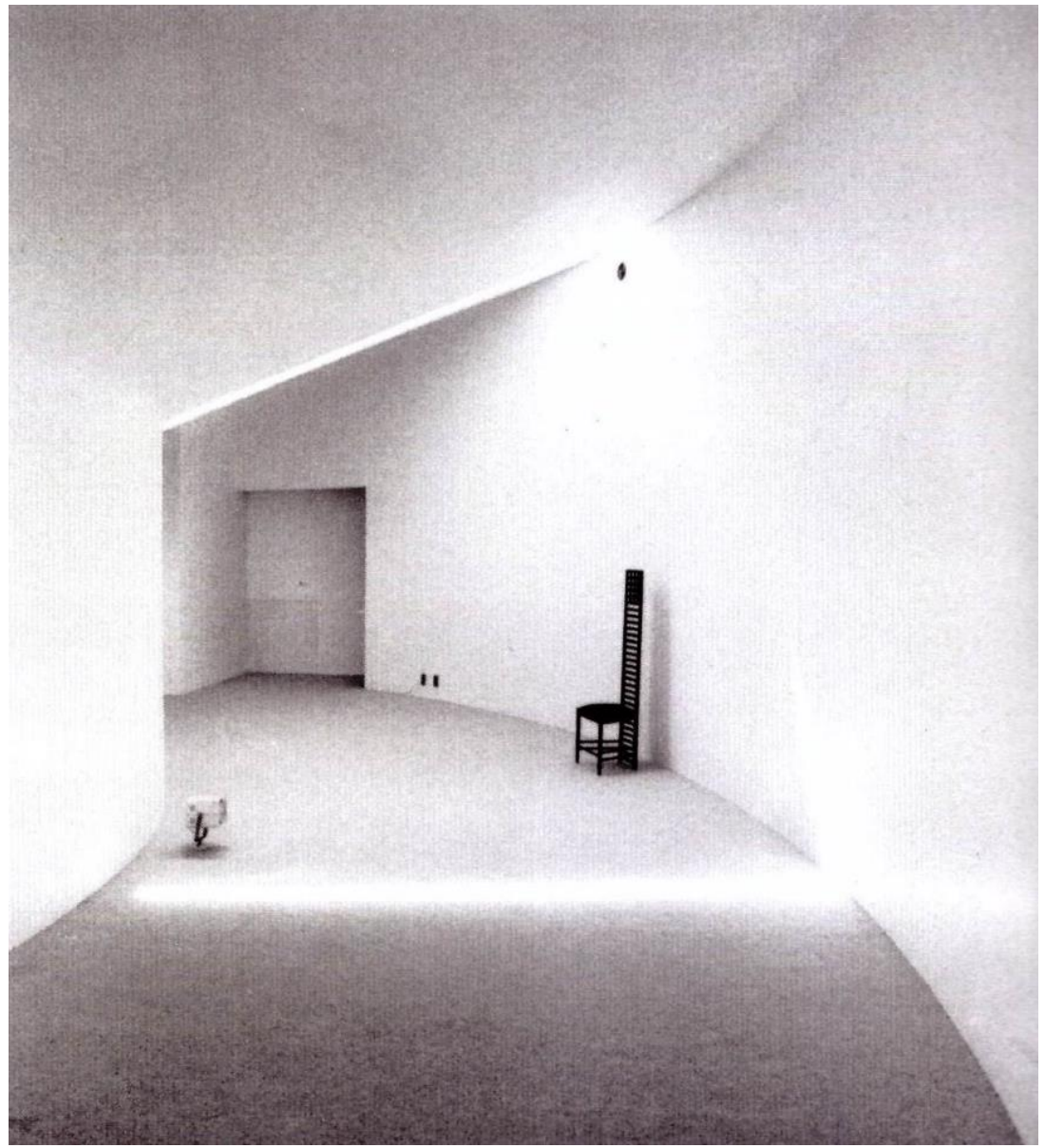

Figura 20: White $U$ - Toyo Ito, Tóquio, 1976.

Fonte: ITO, Toyo; BUNTROCK, Dana; IRAGASHI, Taro;

YAMAMOTO, Riken. Toyo Ito. London: Phaidon Press, 2009. 


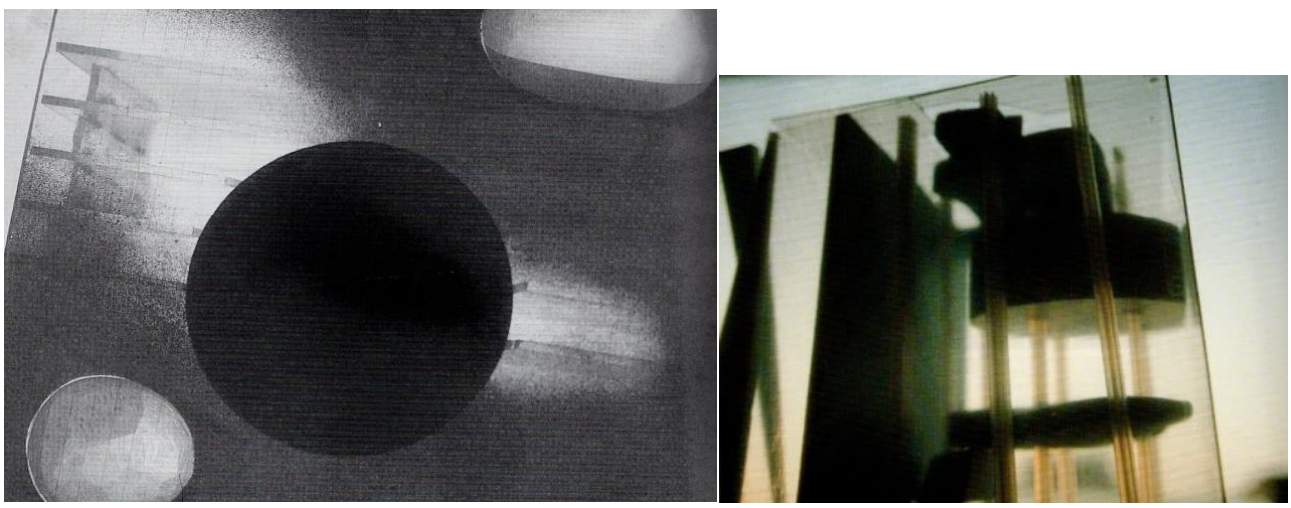

Figuras 21 e 22: Projeto do OMA para a Trés Grande Bibliotèque 1989 Fonte: KOOLHAAS, Rem; SIEGLER; MAU, Bruce. S, M, L, XL: Office for Metropolitan Architecture. New York: Monacelli Press, 1995.

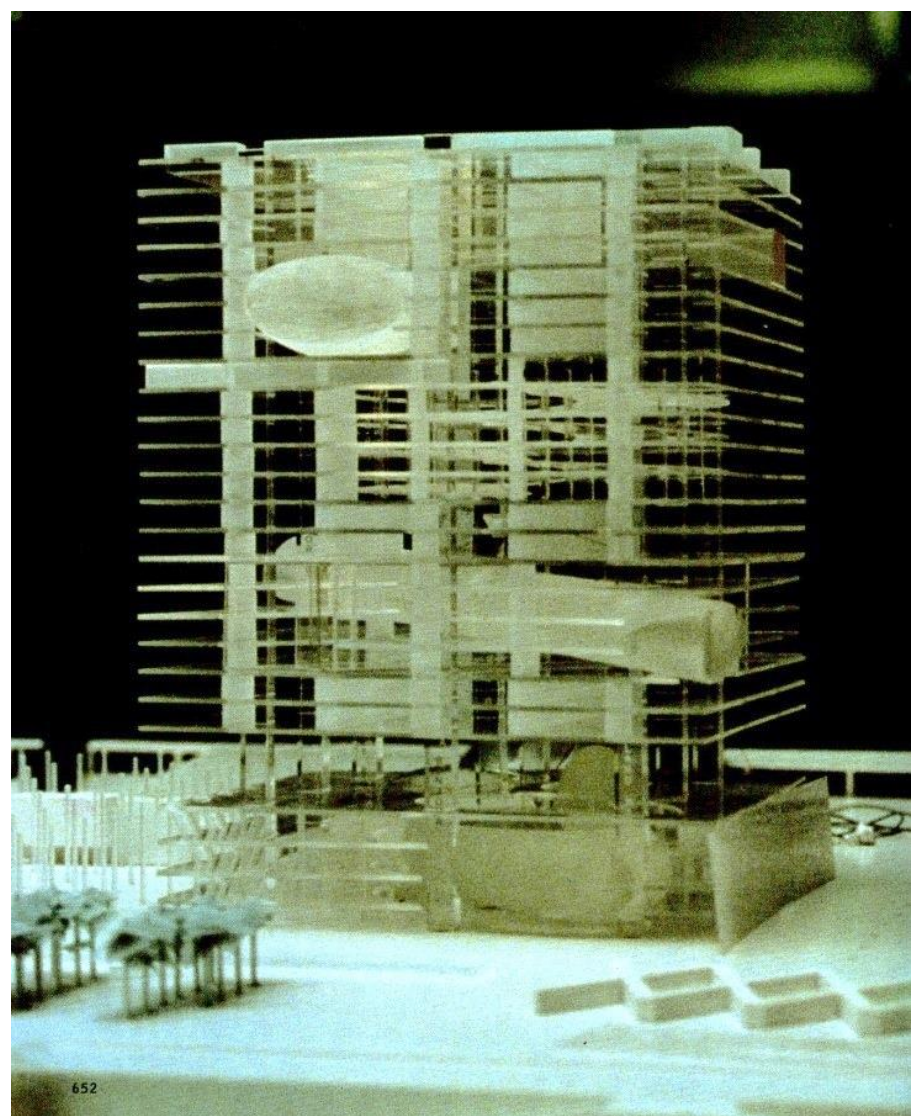

Figura 23: Projeto do OMA para a Trés Grande Bibliotèque 1989.

Fonte: KOOLHAAS, Rem; SIEGLER; MAU, Bruce. S, M, L, XL: Office for Metropolitan Architecture. New York: Monacelli Press, 1995. 


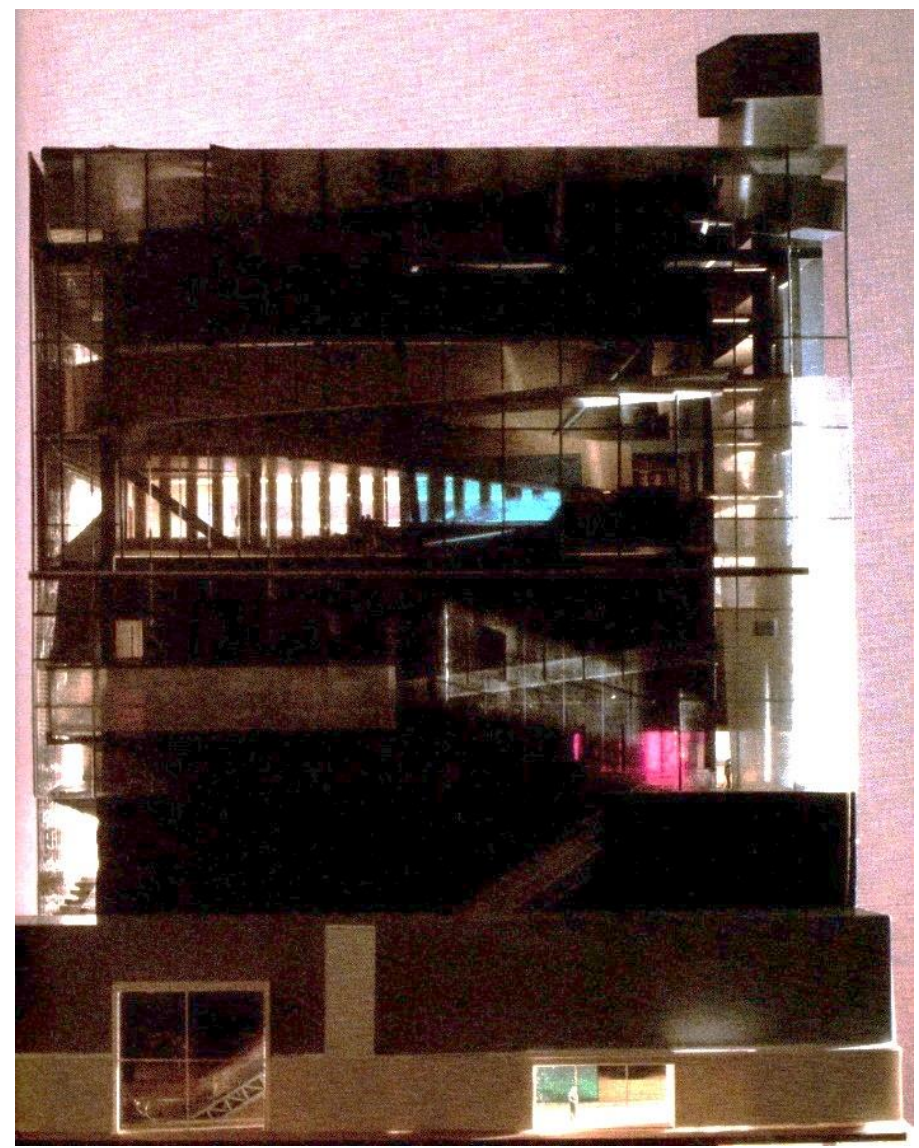

Figura 24: Projeto do OMA para o Zentrum für Kunst und Medientechnologie 1989-92. Fonte: KOOLHAAS, Rem; SIEGLER; MAU, Bruce. S, M, L, XL: Office for Metropolitan Architecture. New York: Monacelli Press, 1995.

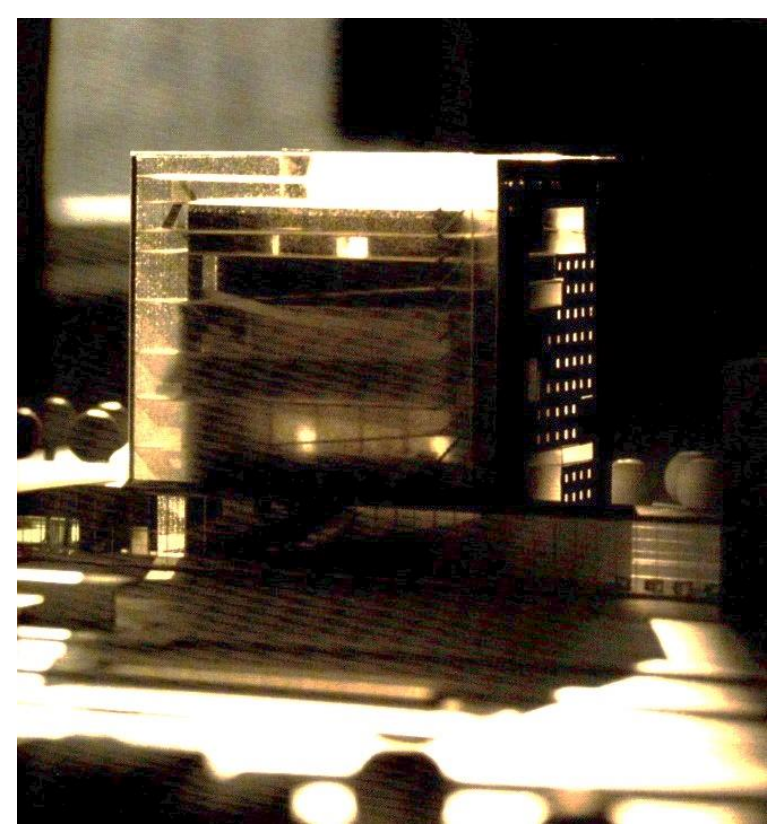

Figura 25: Projeto do OMA para o Zentrum für Kunst und Medientechnologie 1989-92 Fonte: KOOLHAAS, Rem; SIEGLER; MAU, Bruce. S, M, L, XL: Office for Metropolitan Architecture. New York: Monacelli Press, 1995. 

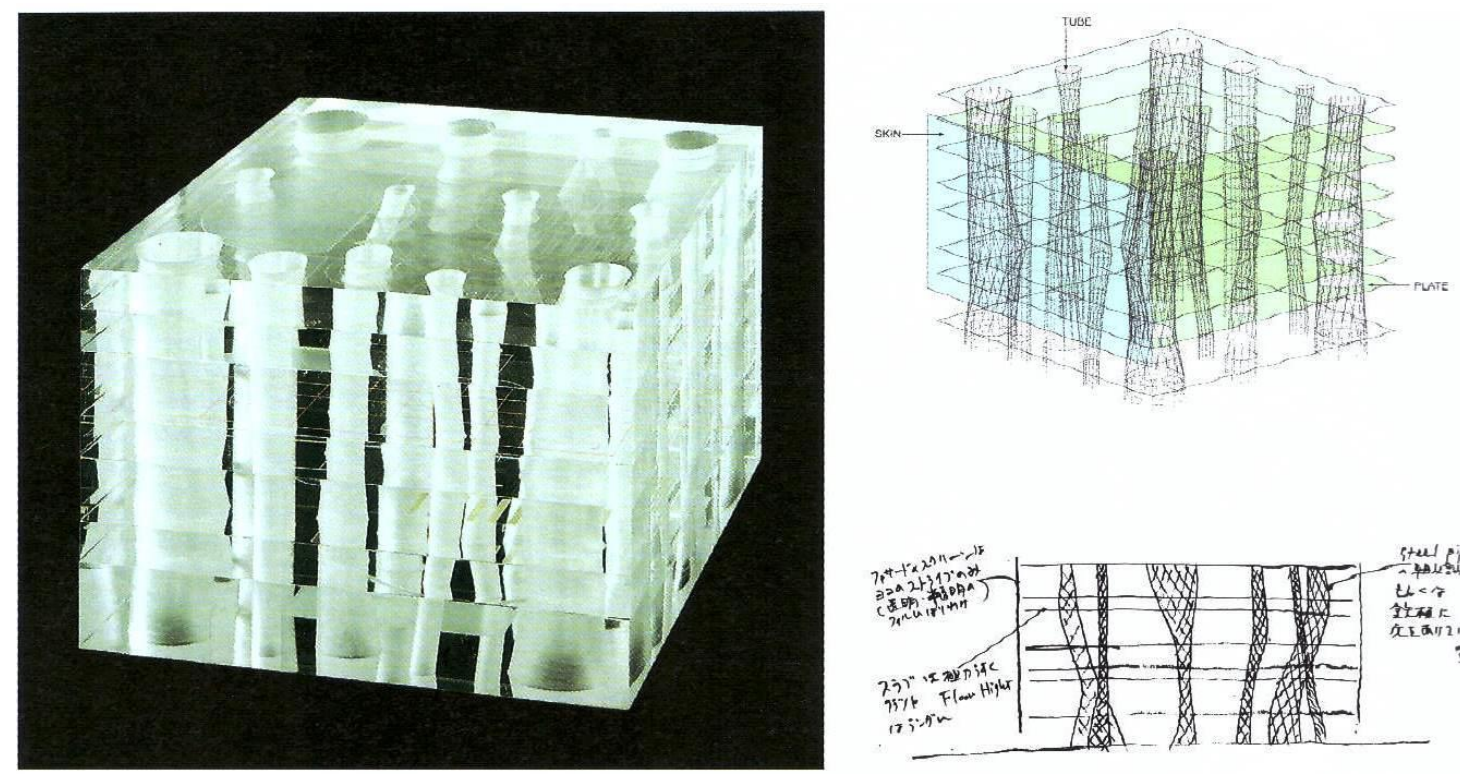

Maqueta conceptual / Concept model

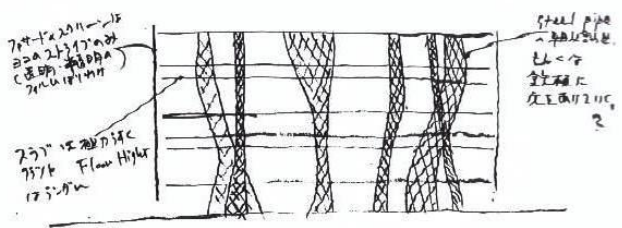

Croquis conceptual / Concept sketch

ป
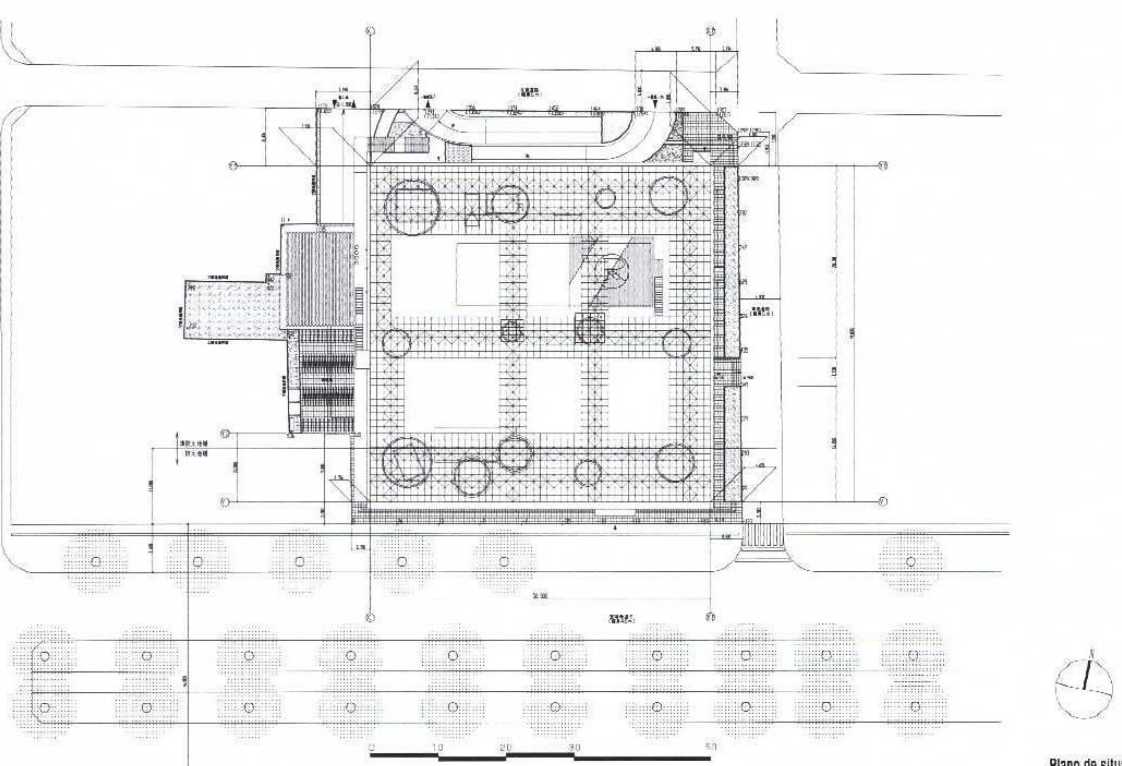

Figura 26: Planta de situação, maquete e croquis conceituais Midiateca Senda 2000, Toyo Ito Fonte: EL CROQUIS. The very best works at the turn of the century. Madrid: El croquis editorial, 2011. 


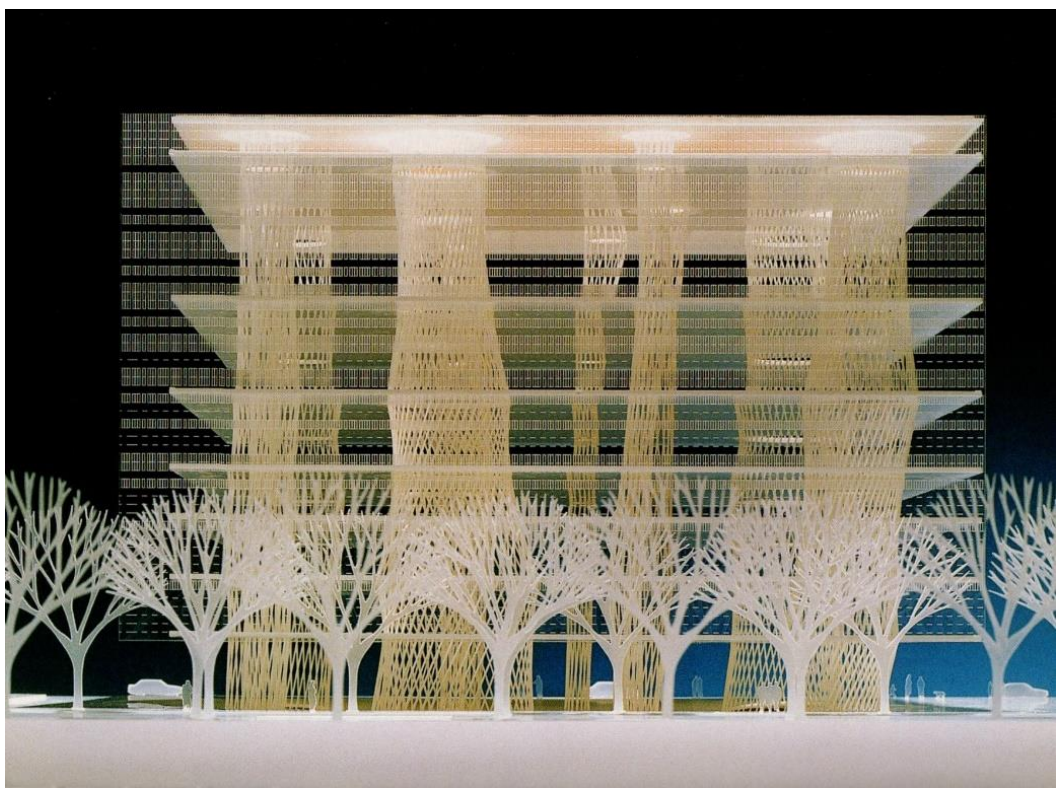

Figura 27: Maquete da competição, Midiateca Sendai 2000, Toyo Ito Fonte: TO, Toyo; SASAKI, Mutsuru. Sendai Mediatheque, Myagi, Japan, 1995-2000. Barcelona: Actar, 2003.
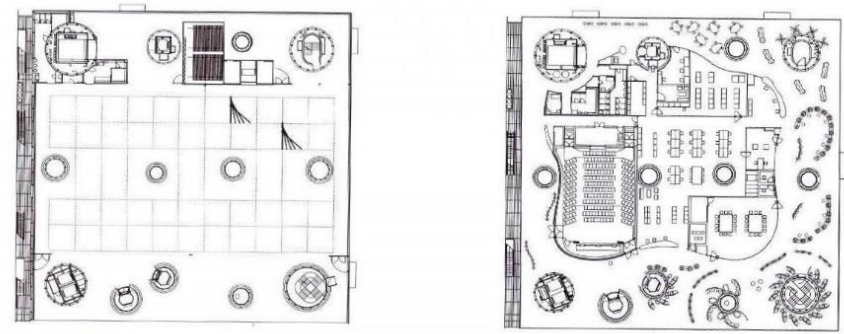

Sixth-floor plan

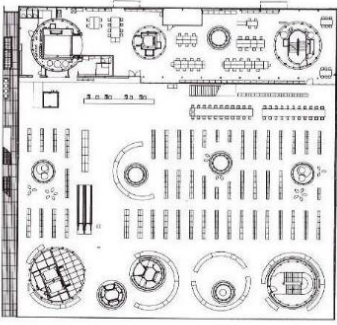

Second-floor plan

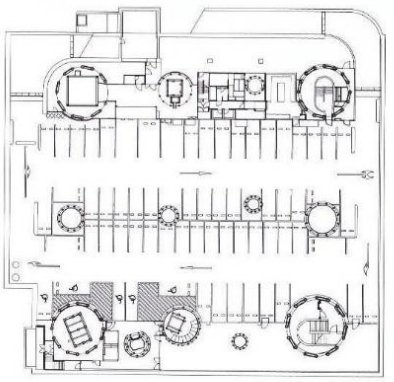

Basement plan

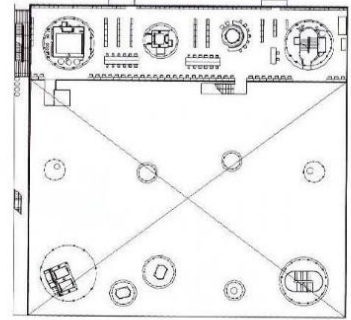

Third-floor plan

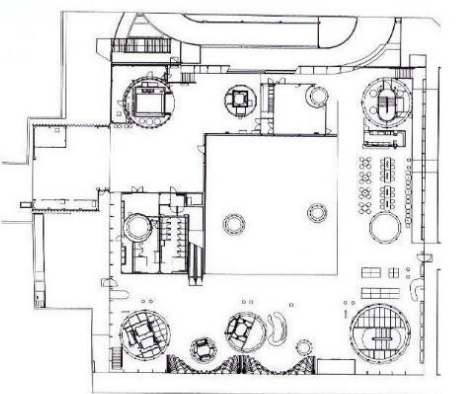

Ground-floor plan

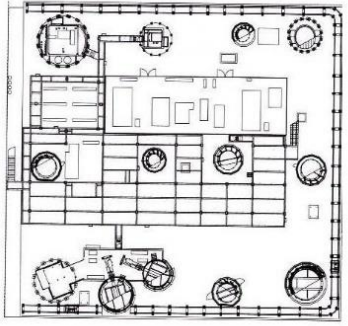

Roof plan

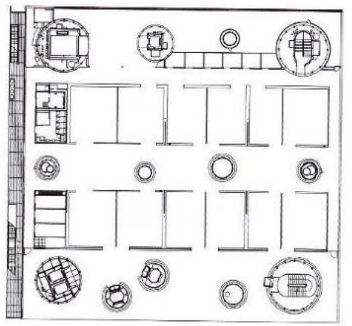

Fourth-floor plan

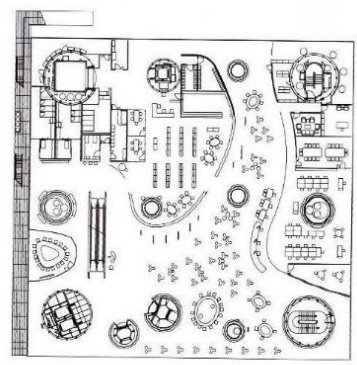

First-floor plan

Figura 28: Planta-baixa andares. Midiateca Sendai- Toyo Ito, 2000.

Fonte: ITO, Toyo; BUNTROCK, Dana; IRAGASHI, Taro; YAMAMOTO, Riken. Toyo Ito. London: Phaidon Press, 2009. 


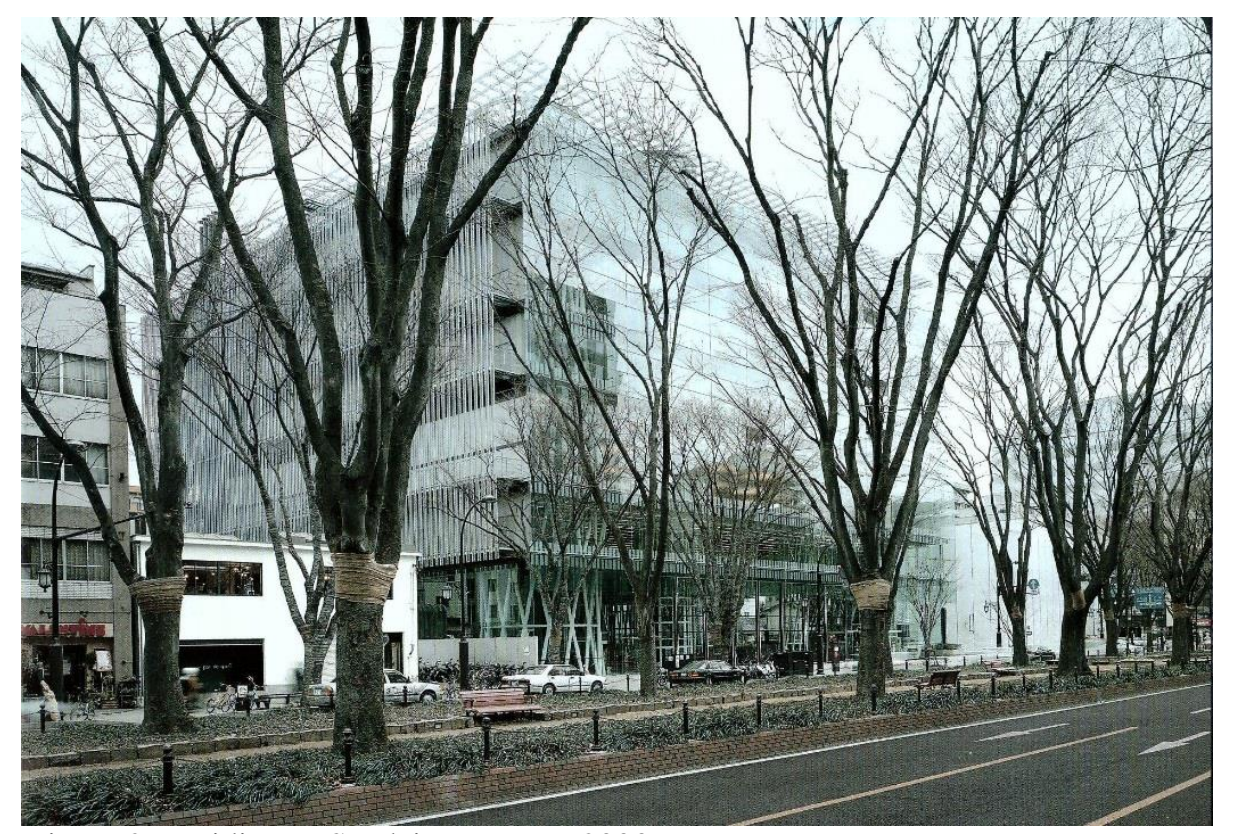

Figura 29: Midiateca Sendai- Toyo Ito, 2000.

Fonte: EL CROQUIS. The very best works at the turn of the century. Madrid: El croquis editorial, 2011

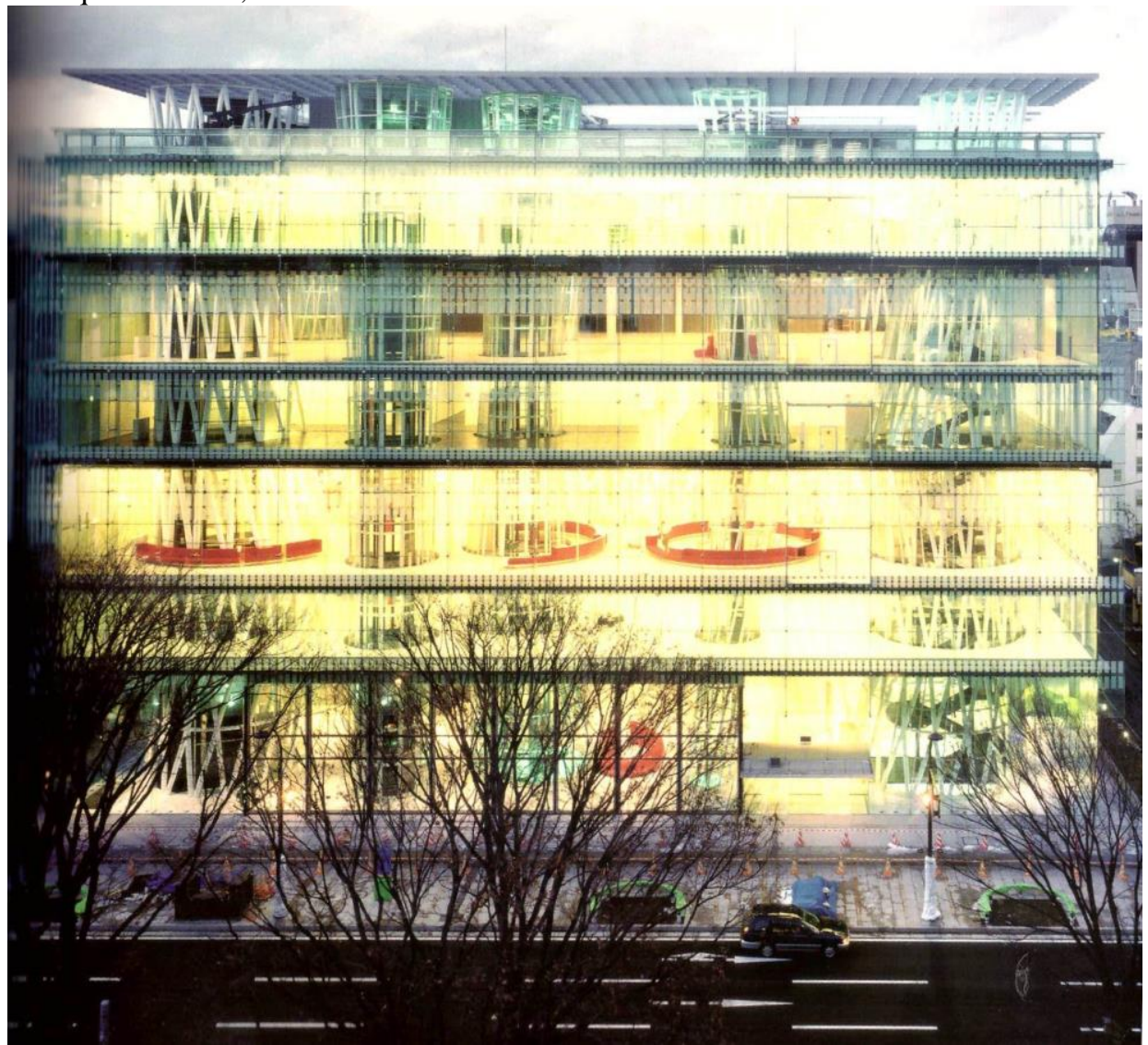

Figura 30: Fachada Principal, Midiateca Sendai- Toyo Ito, 2000.

Fonte: ITO, Toyo; BUNTROCK, Dana; IRAGASHI, Taro; YAMAMOTO, Riken. Toyo Ito. London: Phaidon Press, 2009. 


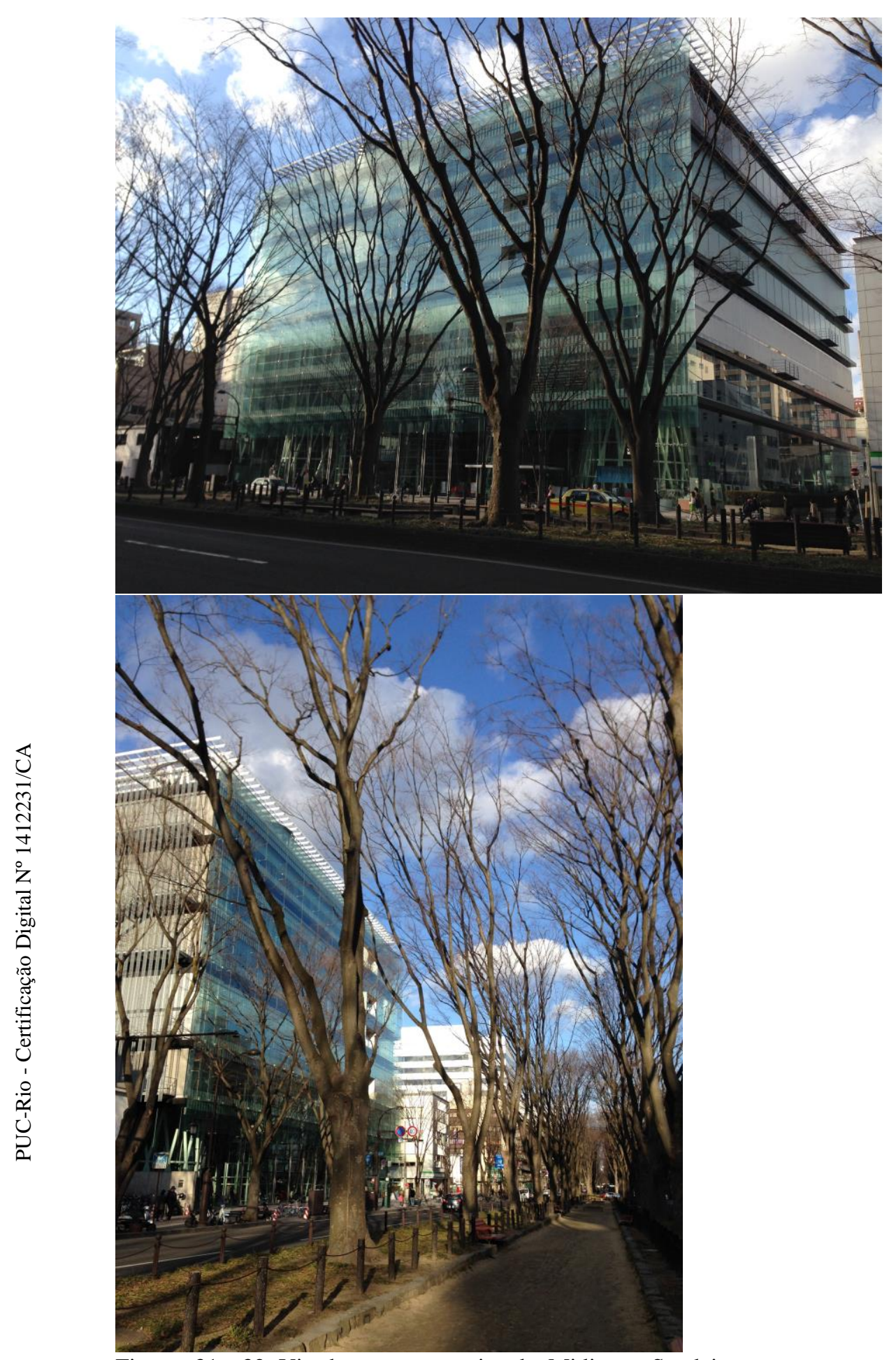

Figuras 31 e 32: Visadas em perspectiva da Midiateca Sendai Fonte: Silvana Nicolli 


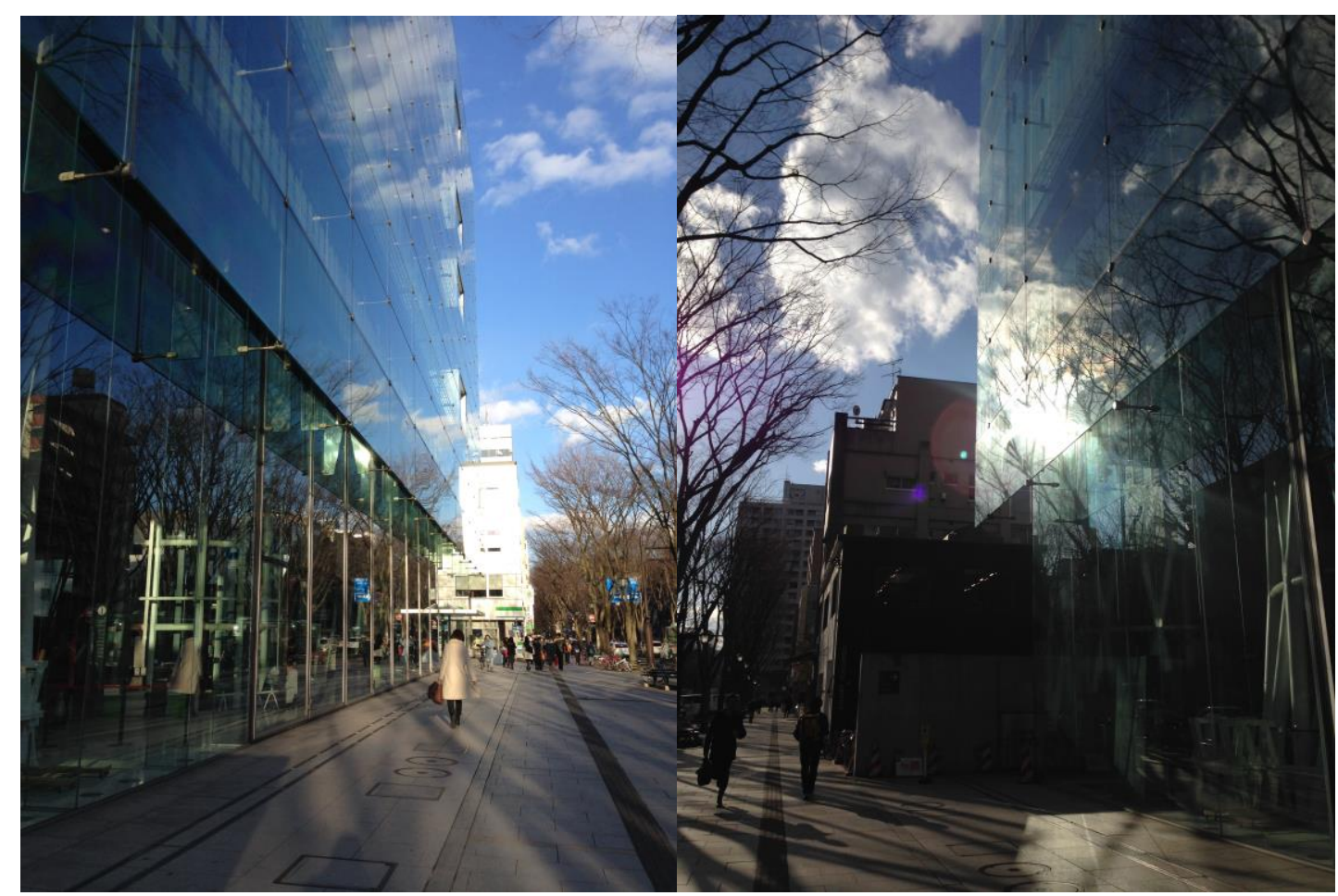

Figuras 33 e 34: Fachadas Midiateca Sendai Fonte: Silvana Nicolli

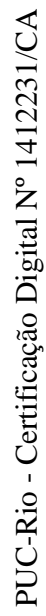

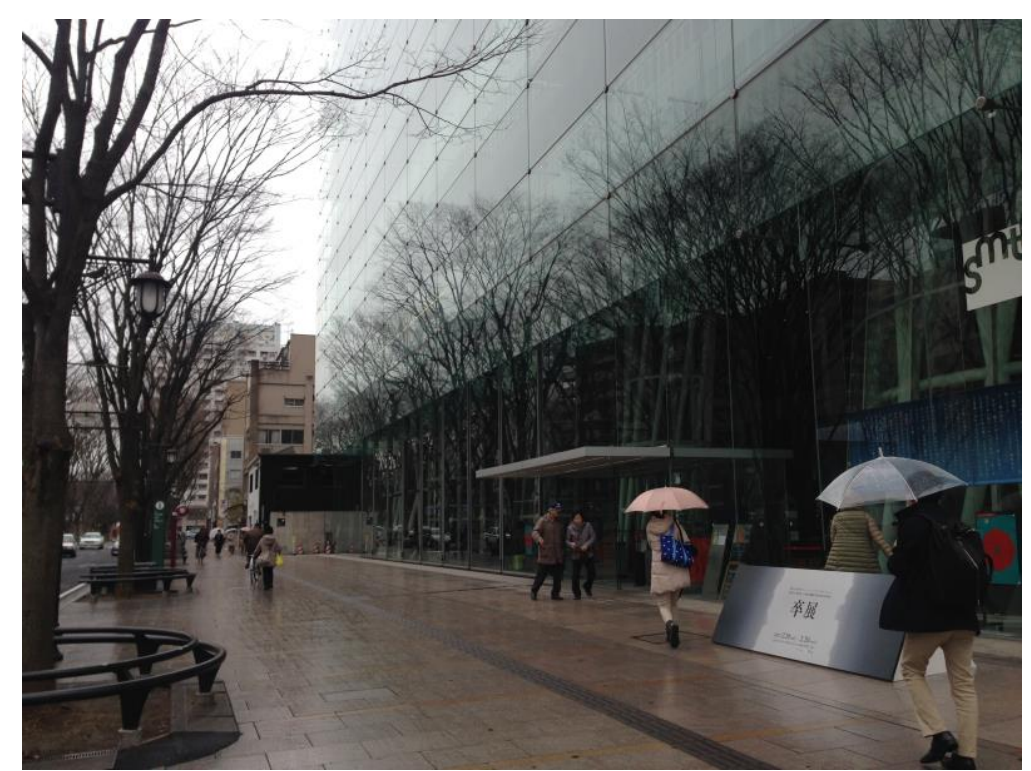

Figura 35: Fachada Midiateca Sendai

Fonte: Silvana Nicolli 


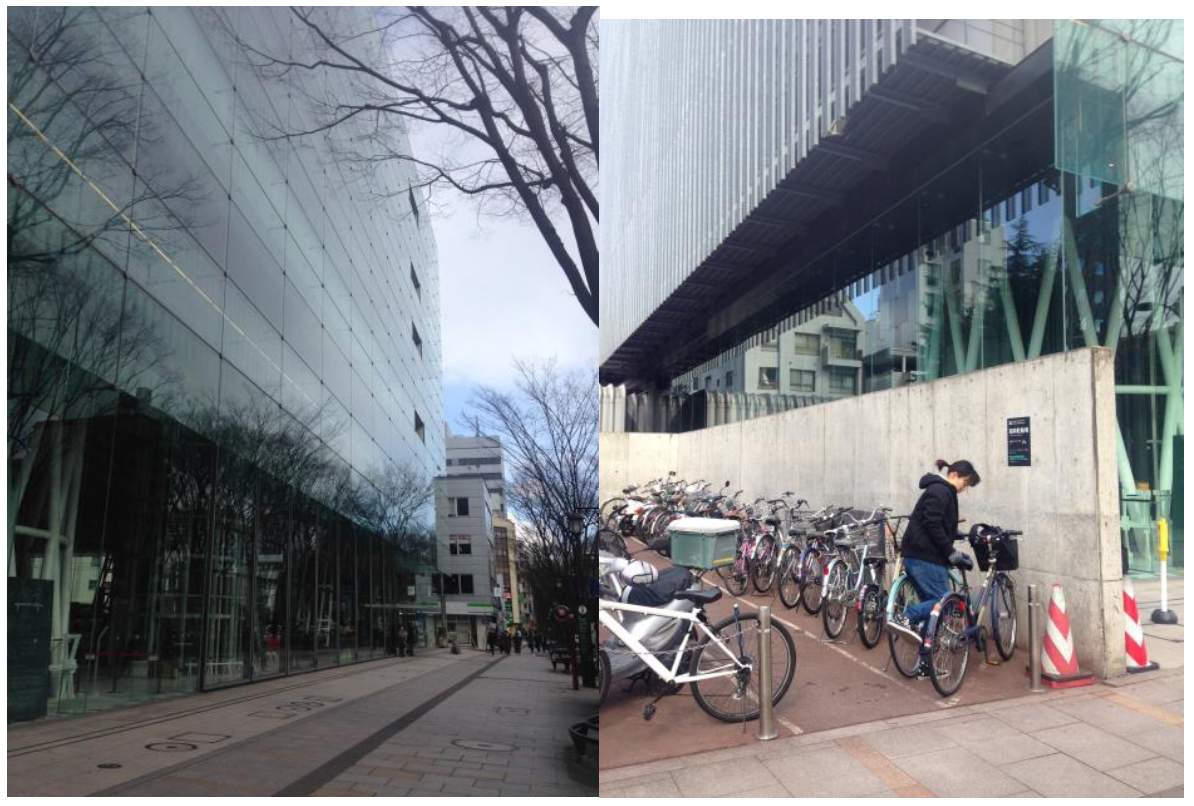

Figuras 36 e 37: Fachada principal da Midiateca Sendai à esquerda e fachada lateral com tela metálica.

Fonte: Silvana Nicolli

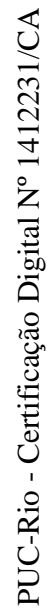

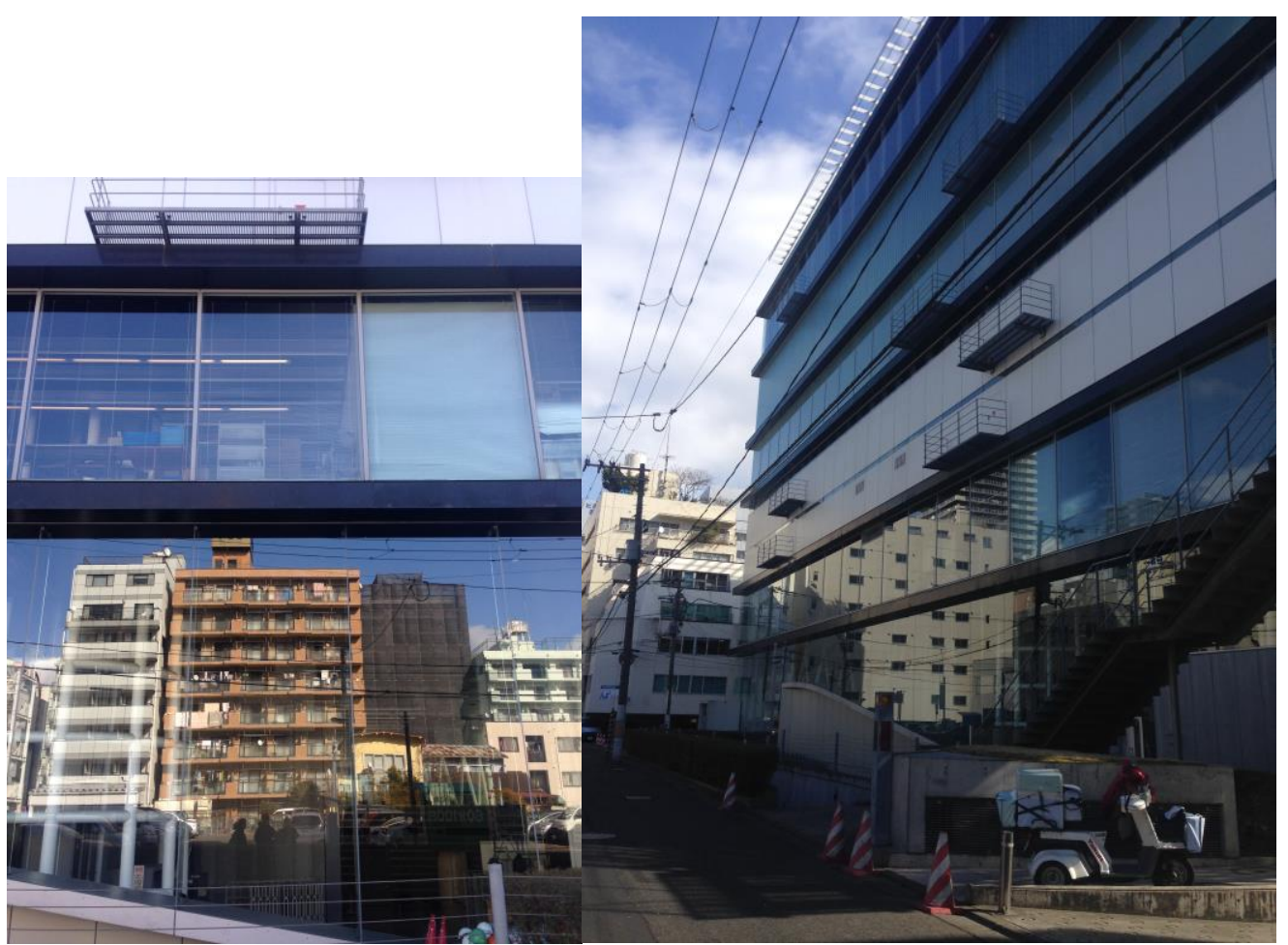

Figuras 38 e 39: Fachada de fundos da Midiateca Sendai.

Fonte: Silvana Nicolli 


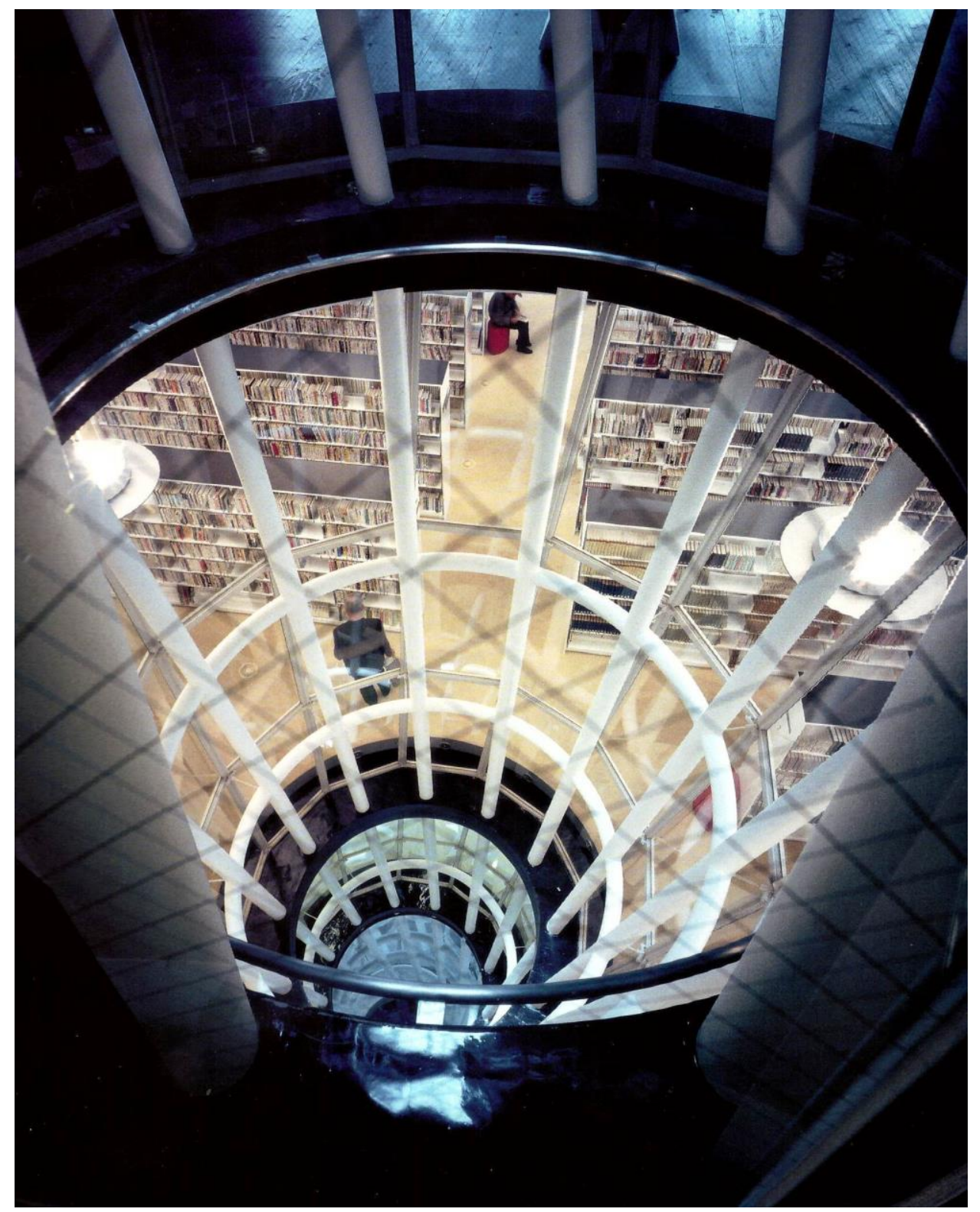

Figura 40: Vista interior estrutura vazada. Midiateca Sendai- Toyo Ito, 2000.

Fonte: ITO, Toyo; BUNTROCK, Dana; IRAGASHI, Taro; YAMAMOTO, Riken. Toyo Ito. London: Phaidon Press, 2009. 


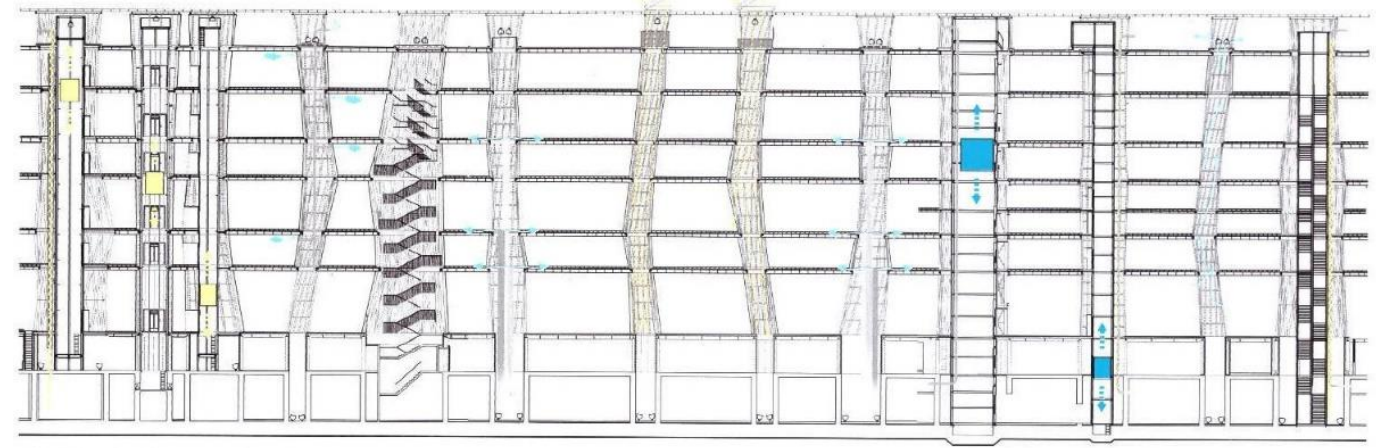

The tubes function variously as housing for stairs and lifts, air conditioning and light wells.

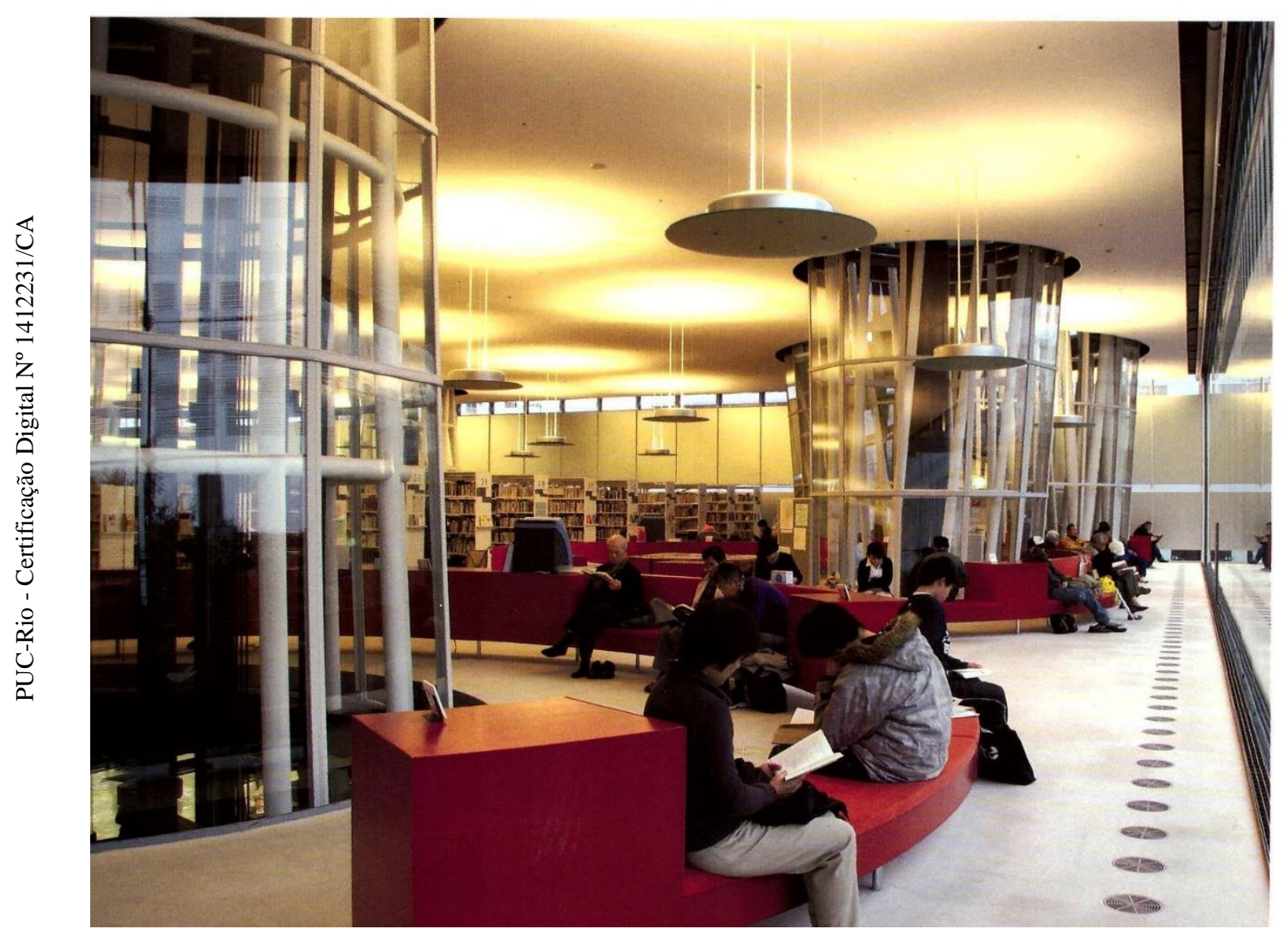

Figura 41 e 42: Corte acima e Visada do pavimento da biblioteca, Midiateca Sendai- Toyo Ito, 2000.

Fonte: ITO, Toyo; BUNTROCK, Dana; IRAGASHI, Taro; YAMAMOTO, Riken. Toyo Ito. London: Phaidon Press, 2009. 


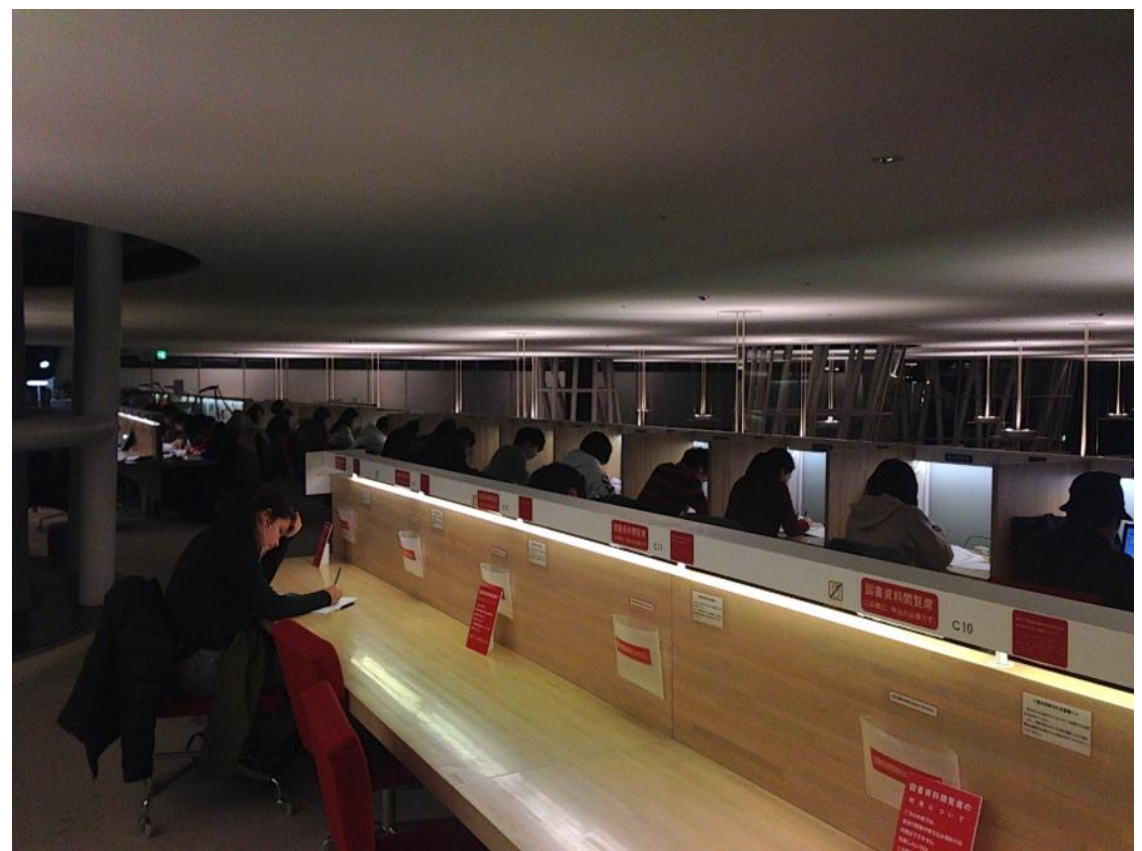

Figura 43: Pavimento da Biblioteca. Mezanino com área de estudos Midiateca Sendai Fonte: Silvana Nicolli

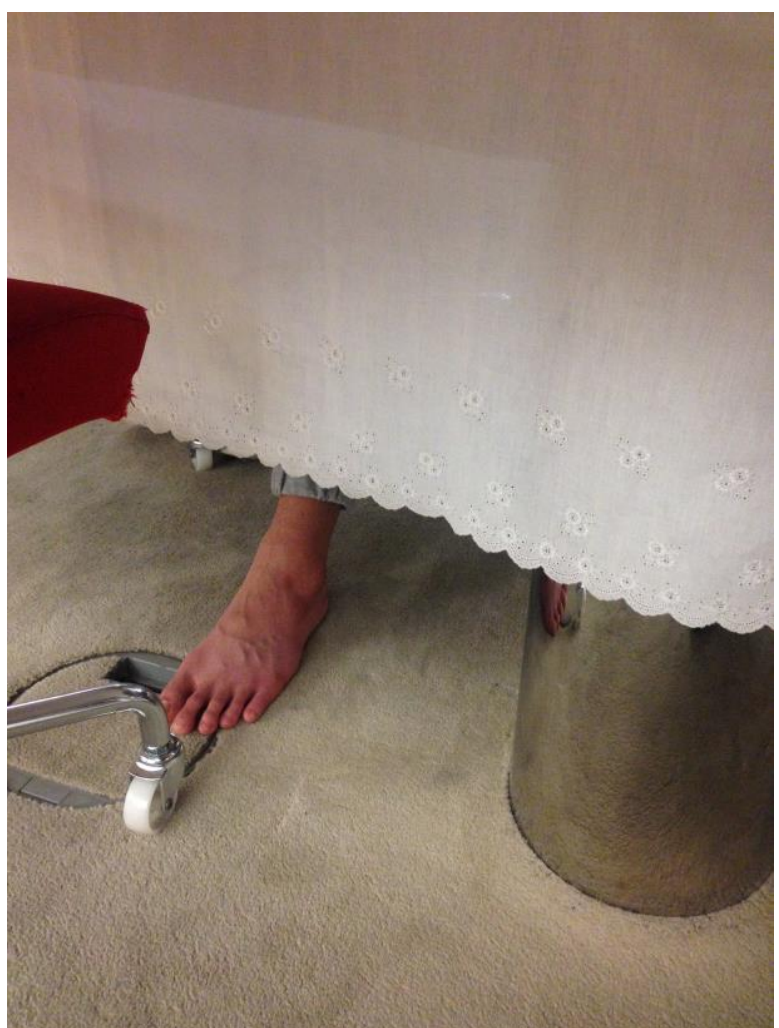

Figura 44: Detalhe do acréscimo da cortina na parte inferior da mesa de estudos. Mezanino no pavimento da Biblioteca da Midiateca Sendai

Fonte: Silvana Nicolli 


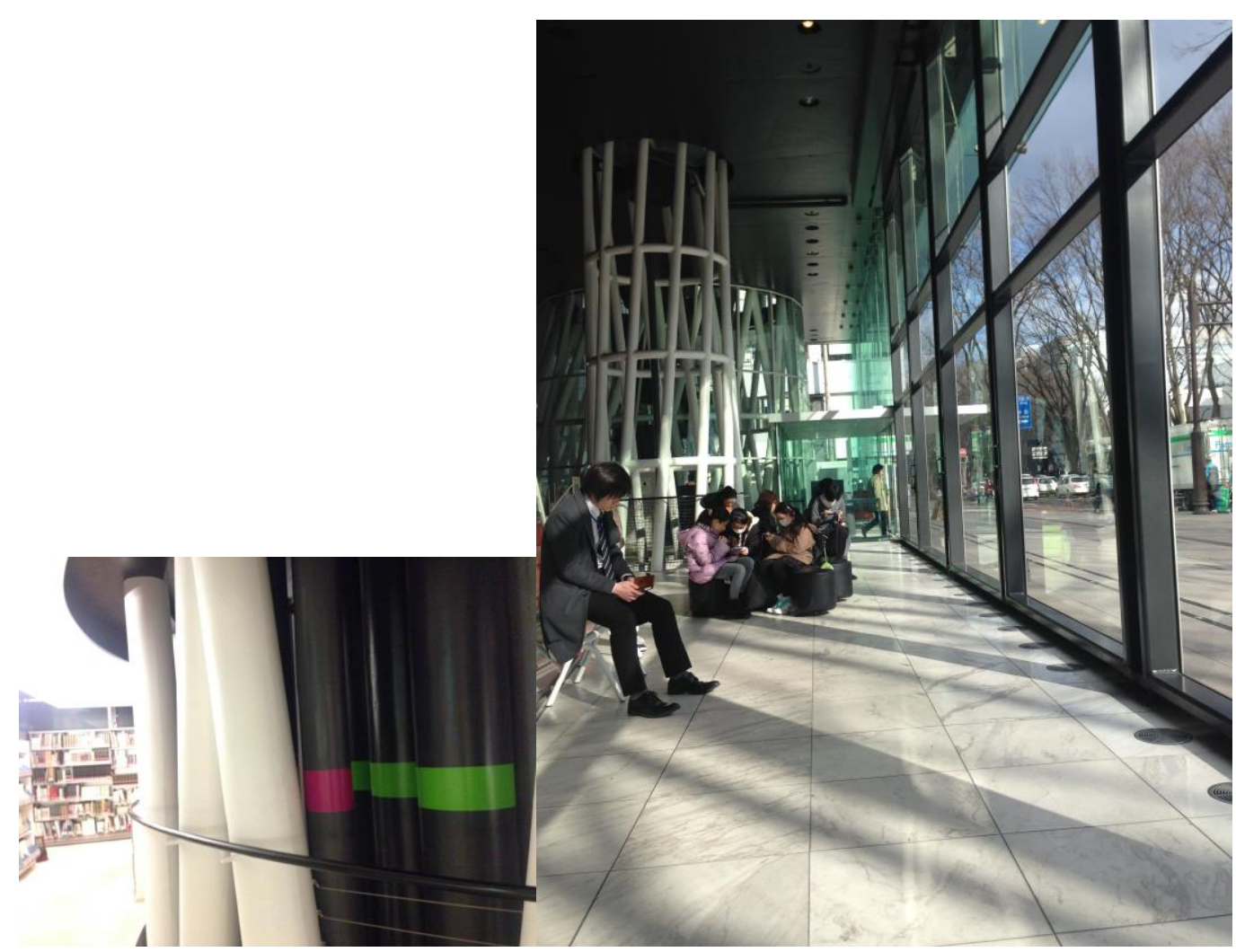

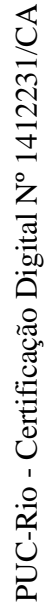

Figuras 45 e 46: Midiateca Sendai.

Detalhe estrutura vazada com dutos no interior à esquerda. Pavimento Térreo à direita.

Fonte: Silvana Nicolli

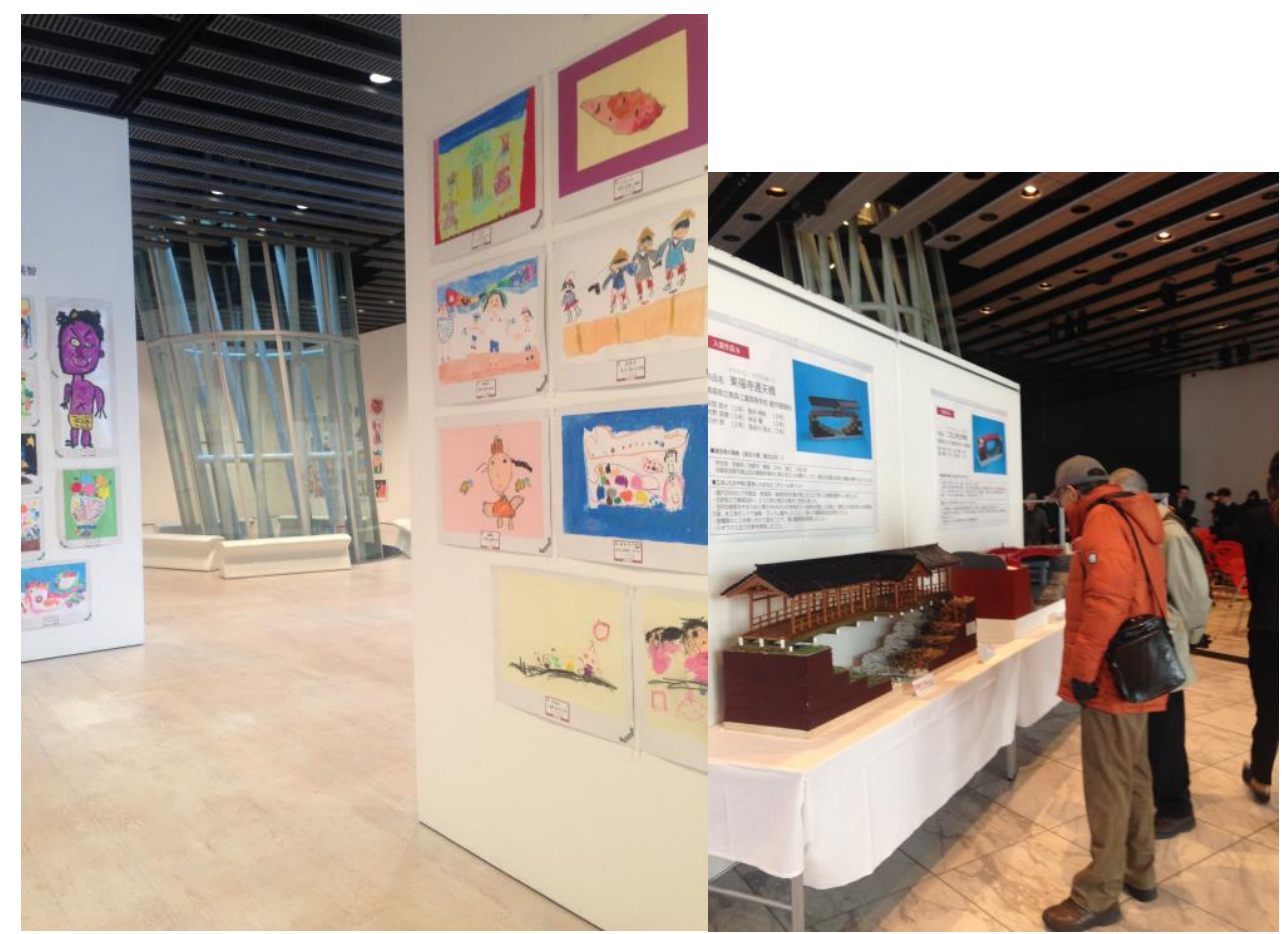

Figuras 47 e 48: Exposições escolares na Midiateca Sendai em 2017.

Fonte: Silvana Nicolli 


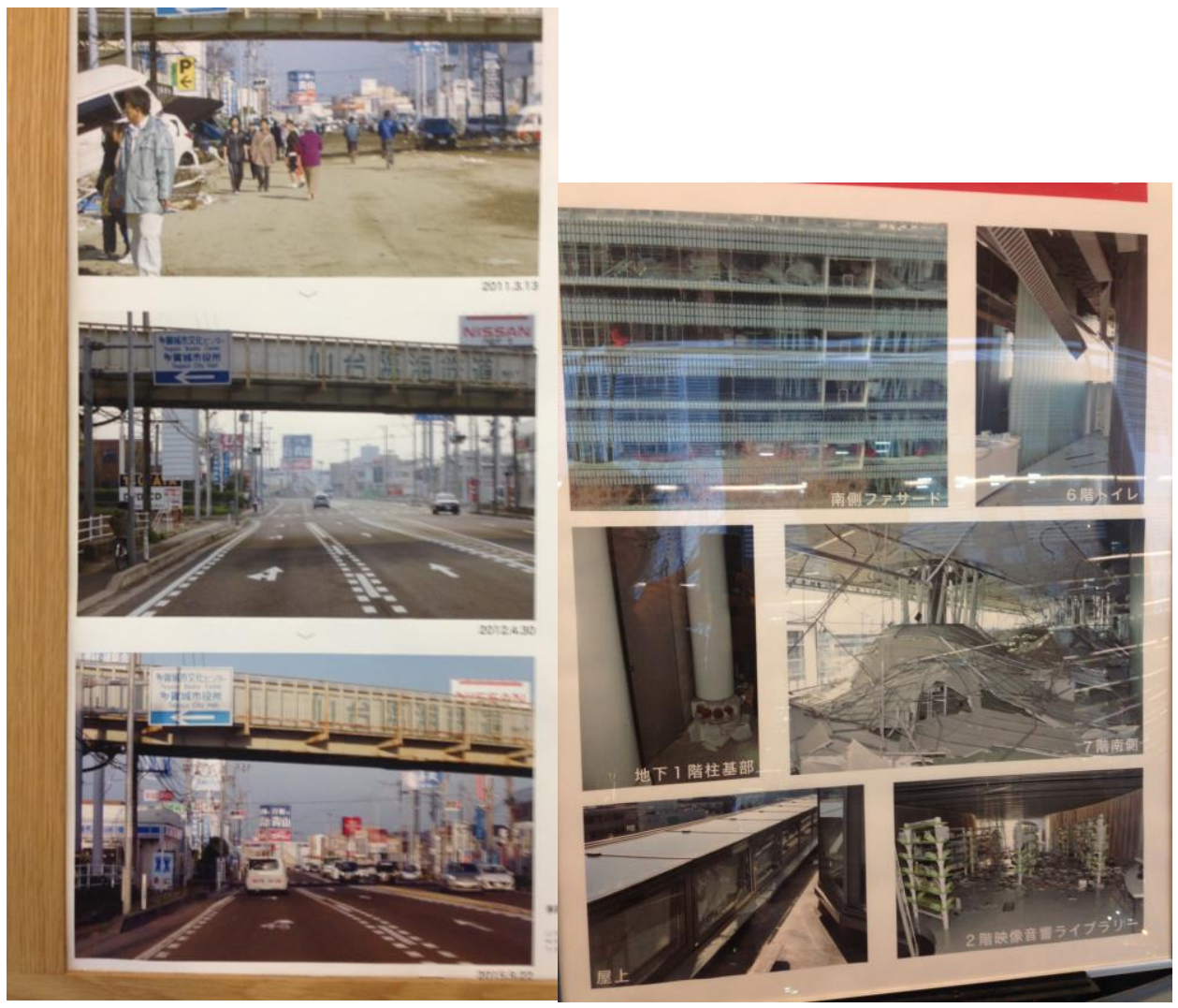

Ư
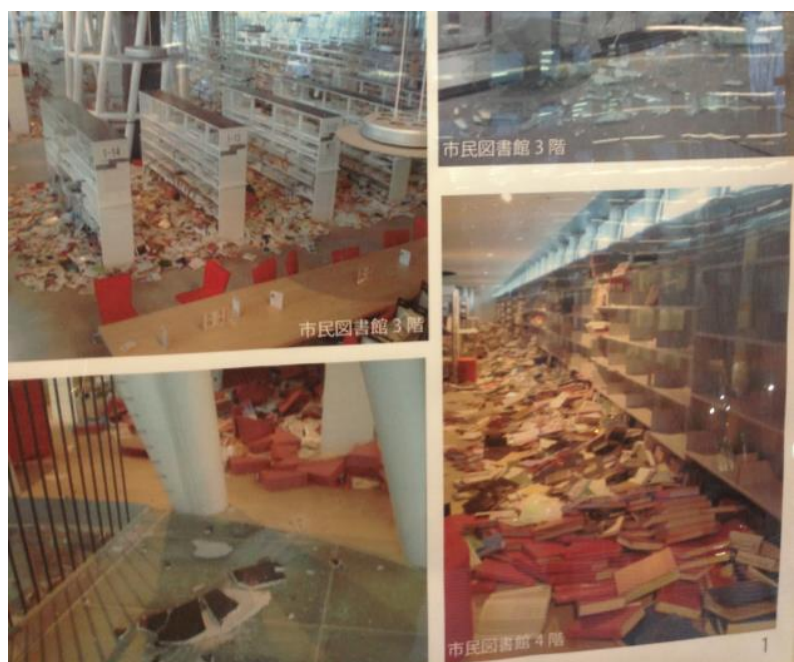

Figuras 49 e 50: Exposição na Midiateca com as fotos de danos causados pelo Terremoto de 2011 na Midiateca e na Cidade.

Acima à esquerda; informe sobre a área restaurada da cidade.

Fonte: Silvana Nicolli 


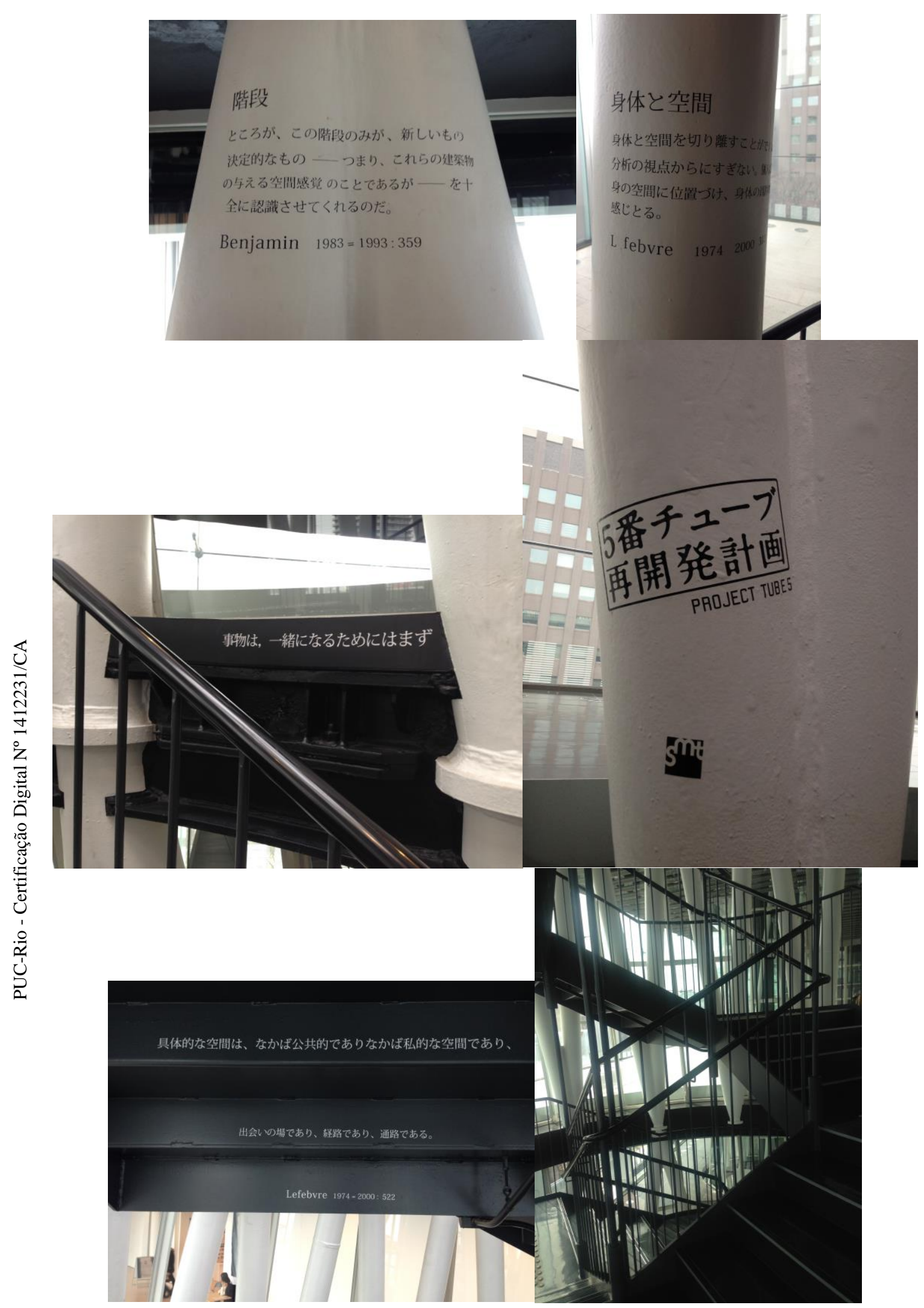

Figura 51: Projeto Tubos, instalação na escadaria interior aos tubos da Midiateca, desenvolvida pela equipe de curadoria.

Fonte: Silvana Nicolli 


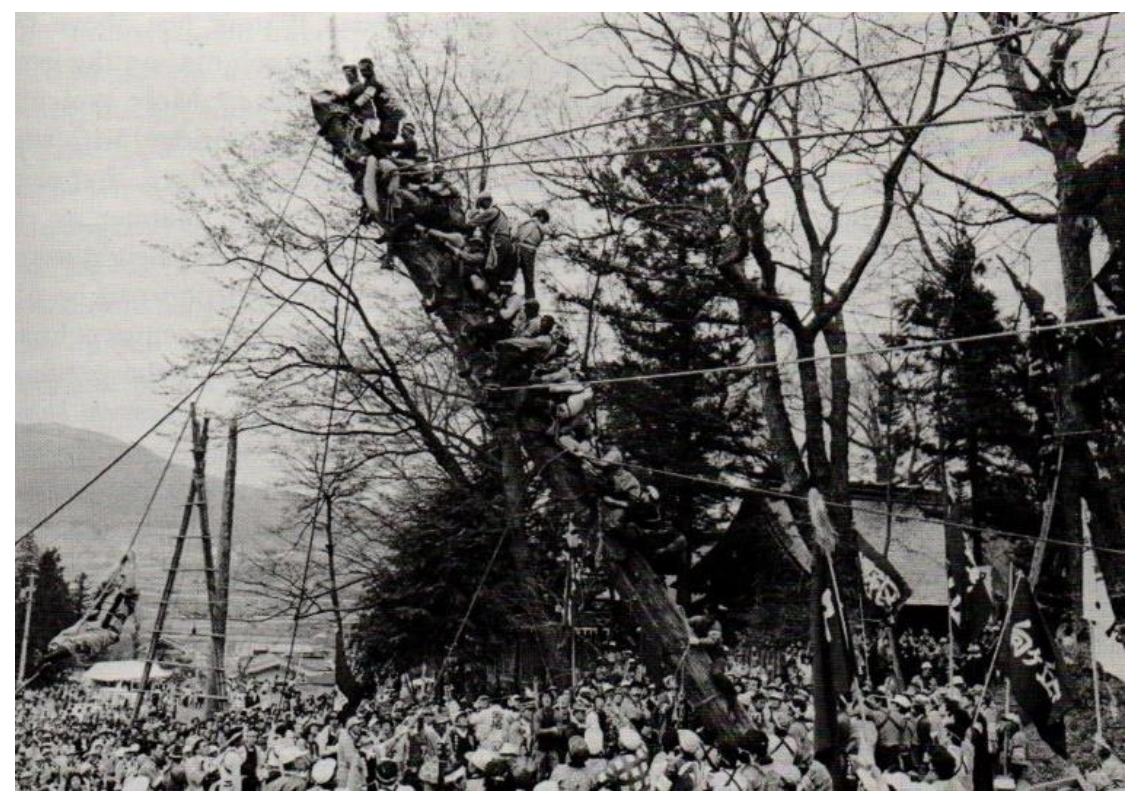

Figura 52: Ritual de elevação da Onbashira em Nagano.

Fonte: INOUE, Mitsuo. Space in Japanese Architecture. NY and Tóquio: Weatherhill, 1985.

\section{3.}

\section{A Midiateca Sendai}

\section{A história da Midiateca}

O projeto para a Midiateca Sendai representou um marco de virada conceitual para o arquiteto Toyo Ito. Por um lado, significou o coroamento de sua metodologia de pesquisa do espaço, por outro, representou uma abertura do processo arquitetônico para a participação da comunidade. Sendai é descrita por ele como uma arquitetura em processo, que teria se iniciado antes mesmo da abertura do concurso para o edifício em 1995 e da inauguração em 2001. Seu processo teria tido início com a formação de comitês de técnicos consultores, de funcionários das instituições que seriam agrupadas no edifício (uma biblioteca pública, uma galeria de arte e um centro de estudos audiovisuais) e cidadãos. Esses comitês continuam atuando na decisão sobre o espaço da midiateca até hoje, sendo o arquiteto Toyo Ito ainda consultado.

A cidade de Sendai havia ultrapassado um milhão de habitantes nos anos 1990, buscava também, aproveitando a onda de globalização, recolocar-se no mapa mundial. Em março de 2011, no entanto, acontece o maior terremoto da história da cidade (nove graus de magnitude), que levou ao acidente na usina nuclear de Fukushima na região ao sul. O terremoto Tohoku foi seguido de 
tsunami, sendo superior ao previsto em projeto. Ainda assim não derrubou o edifício, apesar de danificar o acabamento de alguns andares. O evento deu margens para reforçar sua vocação de espaço público e cívico, onde se desenvolvem continuamente debates entre representantes institucionais e cidadãos sobre situação de danos provocados no edifício e na cidade (Fig.49 e 50). A visita de Ito à midiateca para discutir os reparos do edifício levou-o de modo mais direto à questão da participação social e do envolvimento comunitário na elaboração de diretrizes do projeto. Uma segunda escala da atuação social de Ito em Sendai corresponde ao projeto "Home for all", desenvolvido com os arquitetos Riken Yamamoto, Hiroshi Naito, Kengo Kuma e Kazuyo Sejima, envolvendo a provisão e a chamada aberta de ideias a nível mundial para o alojamento adequado das vítimas do terremoto Tohoku.

A competição para a Midiateca refletiria um evento incomum na história das competições públicas no Japão; tanto por se procurar estabelecer uma nova tipologia de edifício, como pela busca de "transparência sem concessões" (ITO: 2003, p. 7) de todo o processo que envolveu decisões políticas, discussões técnicas, sociológicas e econômicas com a participação dos cidadãos inclusive no processo de desenvolvimento arquitetônico.

O programa da midiateca, cujo nome teria sido dado pelo membro do jurado e arquiteto, Arata Isozaki, definiria-se por oferecer um "serviço público que iria responder aos requerimentos atuais e futuros da era da informação" (ITO: 2003, p. 175). A Midiateca Sendai foi concebida como um amálgama de quatro diferentes programas de serviços, que inclui uma galeria de arte, biblioteca pública, serviços audiovisuais, local para o desenvolvimento de oficinas e laboratórios multimídia.

O termo serviço deveria, no entanto, ser compreendido num sentido amplo como meio de serviço para receber e transmitir informação, o qual é suposto ser utilizado por uma diversidade de cidadãos numa diversidade de modos. $\mathrm{O}$ edifício não deveria ser projetado para atender um programa fixo, mas estar aberto para o desenvolvimento de atividades de acordo com o interesse da comunidade e membros da instituição. Ela deveria ainda promover a inclusão social de deficientes físicos, idosos, diferentes culturas, estrangeiros etc., seja através do 
atendimento com leitores para cegos ou do atendimento bilíngue, bem como da concepção do espaço adequado à circulação dos mesmos.

Ela não seria concebida nem como mera prestadora de serviço, nem como instituição de conhecimento estabelecida tradicionalmente, a qual visaria educar o público. Seu espaço multifuncional requalificaria a relação entre as instituições e entre as instituições e o público. Ao hibridizar suas determinações programáticas (ela é tanto museu como biblioteca) e também ao funcionar como consórcio de bibliotecas da região. Assim, ela deveria ser concebida como "nó" na estrutura de acesso e produção de conhecimento. Assim explica o diretor da Midiateca, Emiko Okuyama.

O filósofo Mr. Taki, que foi um membro do comitê de projeto, explicou como a Midiateca "não é um terminal, mas um nó", e que "ela não oferece os assim chamados serviços, mas é uma plataforma para a investigação intelectual" Contudo, é muito difícil dar forma a essas ideias, e, ao mesmo tempo, a Midiateca tem que manter as características de um edifício público em vez de uma laboratório experimental. (ITO: 2003, p. 139)

Um programa tal como a Midiateca não teria muitos precedentes mesmo no Ocidente. Ito cita o projeto de Norman Foster para o Carré d'Art (1993) em Nimes, que também acrescenta galerias de arte às bibliotecas de livros e audiovisuais e aos meios informacionais. Ito também cita o projeto vencedor do concurso para o ZKM (Zentrum für Kunst und Medientechnologie - Eletronic Bauhaus) (Fig. 24 e 25), desenvolvido pelo escritório OMA entre 1989 e 1992, mas não realizado. Ele se localizaria na cidade de Karlsruhe na Alemanha. O ZKM seria dedicado à pesquisa das tecnologias fundidas digital e artística e oferecia um espaço de laboratório para os artistas multimidiáticos. Podemos acrescentar o projeto do OMA para o concurso da Biblioteca Nacional da França (TGB-1989) (Fig. 21, 22, 23), também não realizado, cujo programa incluiria o amálgama de cinco instituições (várias bibliotecas de livros e audiovisual, cinemateca).

Sendai seria definida tanto como centro cívico, conforme o projeto em Nimes, mas também, ampliaria o conceito de midiateca, sendo definida pela abertura programática para eventos futuros. Além da indeterminação do projeto, tal abertura incluiria a participação cívica desde o início do empreendimento até a 
participação no design e nas atividades ali desempenhadas. O projeto deveria estabelecer um arquétipo da nova era, que serviria tanto para promover a imagem da cidade, como para revitalizar a região escolhida, que correspondia a uma bonita alameda, deteriorada na altura do terreno escolhido.

\begin{abstract}
"Uma facilidade cuja infraestrutura de tecnologia da informação do presente compõe uma soma de massa intelectual, tal como se devesse também ser usada para criar novas ideias emblemáticas...uma facilidade cívica destinada a promover artes e cultura e permanente estudo, não pelos padrões de serviços do presente, mas pelo apoio das atividades participativas, auto-expressivas." (ITO: 2003, p. 9)

Também os jurados tiveram um papel diferenciado nesta competição. Ito aponta o fato deles efetivamente terem desempenhado o papel de representantes e clientes, prestando serviço à administração pública como clientes e assistindo aos cidadãos como usuários. O jurado teria tornado a relação entre as partes mais clara e justa, segundo Ito, sendo inclusive transmitido ao vivo para a cidade.
\end{abstract}

\title{
Memorial descritivo
}

\section{O protótipo moderno}

O objetivo da proposta de Ito para o concurso (1994) foi a definição de um edifício protótipo (Fig. 26, 27 e 28) que fosse capaz de atender às variadas condições programáticas que pudessem aparecer. A solução foi a definição de um partido altamente abstrato, definido por três elementos arquitetônicos básicos: lâminas (pisos), tubos (colunas) e pele (fachada/paredes exteriores). Tal imagem prototípica derivaria do sistema Dom-inó, desenvolvido por Le Corbusier, composto por colunas e lajes planas sem vigas e em concreto armado: "um sistema que poderia se chamado um "Novo Dom-inó". Quer dizer sete planos de piso (50m x 50m em lâminas de colmeia) são suportadas por 13 estruturas tubulares sem nenhuma parede estrutural ou consoles" (ITO, 1999, 2011: 137). Em vez do concreto, Ito adotaria na Midiateca a estrutura em aço e o vidro, utilizados anteriormente por Mies Van Der Rohe em malhas estruturais tridimensionais que determinavam o espaço como homogêneo, fluido e transparente. Na midiateca, no entanto, a disposição quase aleatória dos tubos, que determinaria um grid distorcido, e as alturas variáveis de cada andar 
corromperiam a homogeneidade do espaço e determinariam lugares específicos e distribuição de forças não uniformes (ITO, 2003: p. 11-13).

\section{As lâminas e os tubos}

As lajes são compostas por lâminas duplas estruturadas com nervuras, que possibilitam vencer grandes vãos e lhes dão a aparência de "favos de mel" (ITO, 2003: p.13). As colunas são determinadas por vãos circulares de 2 a 9 metros estruturados por feixes variados de tubos de aço. Os vãos circulares mudam de direção de andar para andar, determinando a angulação variada dos tubos que atravessam os pisos. Esses feixes ocos de tubos de aço alojam os elevadores, escadarias, conexões energéticas, dutos e cabos (Fig. 45). Alguns dos vãos são fechados ao redor com vidros e servem para suprir de ar puro, fazer exaustão e levar luz natural para os andares inferiores. "Dentro desse ambiente estratificado feito pelo homem, os tubos funcionam como conduítes para os elementos naturais luz e de ar" (ITO: 2003, p. 13)

A proposta teria sido explorar essas qualidades específicas encontradas na natureza, evocando a experiência espacial de caminhar numa floresta. " $A$ presença de árvores cria espaços diferentes entre os quais as pessoas podem escolher onde fazer seja lá o que for, do mesmo modo como o homem desde tempos antigos criou lugares para viver dentro do fluxo da natureza." (ITO: 2003, p. 15). Tal experiência permitiria aliviar a asfixia sentida pelo corpo, quando limitado aos espaços fechados, que caracterizam a arquitetura das cidades modernas, onde não se experimentaria a fluidez própria do espaço natural aberto. Sendai deveria, portanto, oferecer "espacialidades diferentes", que suporiam a fluidez dos espaços abertos e não compartimentados, segundo funções específicas. Os espaços da midiateca não foram compartimentados com paredes fixas, que definiriam uma funcionalidade específica. Segundo Ito, a funcionalidade específica de cada ambiente pressuporia uma relação de causa e efeito unidimensional que não corresponderia à complexidade das ações humanas, representando um cerceamento da liberdade. As atividades não deveriam ser fixadas através da determinação de hierarquias espaciais, tais como espaços servidos e servidores distinguidos. "Isso é porque penso que é essencial remover as barreiras entre as duas ordens a fim de permitir um modelo de serviço 
interativo" (ITO: 1999, 2011, p. 138). A solução para atender tanto o programa aberto requisitado pelo edital do concurso quanto o desejo de recuperar a relação com lugar, segundo a fluidez dos espaços naturais foi feita através da disposição variada dos tubos, da iluminação e do mobiliário (Fig. 43 e 44). Este último desenhado por quatro escritórios de design diferentes ${ }^{179}$. Os móveis também foram concebidos segundo o princípio da flexibilidade de uso, sendo passíveis de serem compostos uns com os outros. O resultado foi a ampla flexibilização da planta-baixa que permitiria ao usuário a descoberta de novos lugares e usos. "Não deveria um novo edifício público convidar verdadeiramente à descoberta e a um pouco de criatividade? Nossos esforços, ao fazer cada tubo devidamente diferente, aspiravam criar uma arquitetura que iria permitir "tal descoberta de lugares" (ITO: 2003, p. 15).

Mesmo depois de inaugurado o edifício, o escritório de Ito continuou a desenhar variações para a disposição das plantas-baixas, seguindo o princípio da não-compartimentação, e a acompanhar o desenvolvimento de seu programa aberto. Após o terremoto de 2011, por exemplo, não apenas a disposição do sétimo pavimento foi modificada com a retirada do mobiliário original danificado, como o forro do teto original, com luminárias de lâmpadas fluorescentes dispostas aleatoriamente, foi trocado por outro com lâmpadas embutidas.

\section{A pele}

A fachada principal (Fig. 29), faceando as árvores Zelkova da Avenida Jozenji-dori, é coberta por duplos panos de vidro, onde a camada externa tem efeito de tela flutuante, embora fixa por braçadeiras transversais, iniciando-se a partir do segundo andar. Ela é coberta por tracejados horizontais que formam faixas horizontais e verticais na extensão da fachada e outros efeitos visuais a partir do interior. A dupla camada de vidro permite que os reflexos de luz mudem ao longo do dia em termos do tipo de sombreamento no interior e de cor na fachada. O telhado e a fachada Oeste são cobertos por telas de venezianas

\footnotetext{
${ }^{179} \mathrm{O}$ designer Karim Rashid desenhou móveis do térreo e o multi-banco dos quinto e sexto andares. O designer Ross Lovegrove desenhou o acento para o cinema180 graus do sétimo andar. $\mathrm{O}$ escritório de arquitetura KTA o banco circular vermelho multi-uso do terceiro andar. O escritório da arquiteta Kazuyo Sejima desenhou os banquinhos em forma de trevo e as mesas de navegação do segundo andar.
} 
metálicas, também com efeito de telas leves flutuando sobre o volume do edifício. O revestimento das fachadas "de fundo" e Leste refletem as demandas do interior, variando o material a cada andar, sendo metálicas ou de vidro transparentes ou semi-transparentes. Para Ito, a ênfase no tratamento das superfícies teria definido o caráter diferenciado do edifício. Em vez de resolver o espaço nos limites da planta-baixa, o processo teria se desenvolvido através de seções transversais do volume de 36 metros de altura por 50 metros quadrados de terreno (ITO: 2003, p. 17).

\section{O projeto de Iluminação}

O projeto de iluminação, desenvolvido por Kaoru Mende (Lighting Planners Associates), intensifica a sensação de interpenetração dos andares despertada pelos vãos dos tubos vazados e, ao mesmo tempo, reforça a ideia dos tubos como elemento estrutural contínuo da fachada transparente, quando vista do lado externo à noite. Luzes frias branco-azuladas foram colocadas no subsolo e, dentro dos tubos, luzes de mercúrio azul. Nos andares superiores foram colocadas luzes quentes que se encontram com as luzes frias vindas do subsolo. Esse sistema funciona à noite. As luzes coloridas ainda refletem nos planos dos andares criando faixas intermediárias de cor. Além dessa iluminação da estrutura, cada andar tem um projeto de iluminação diferenciado em função das atividades desempenhadas, tal como a leitura ou luz ambiente, controladas em função da luz natural (Fig. 30). Elas também serviram como forma de reforçar o caráter do lugar no interior e de mudar a imagem do edifício ao longo do dia e noite. Durante o dia, dois dos 13 tubos transmitem a luz natural vinda da cobertura (ITO: 2003, p. 95-97).

Após o terremoto de 2011 e acidente da usina nuclear de Fukushima, parte do sistema de iluminação noturna foi desativado como parte da decisão de poupar energia.

\section{Estrutura}

A solução estrutural foi desenvolvida a partir de um trabalho conjunto e interativo do arquiteto Toyo Ito com os engenheiros Mutsuro Sasaki e Masahiro Ikeda (Fig. 40, 41, 42 e 51). O conceito estrutural inicial era que tubos inteiros de forma retorcida atravessariam os pisos configurando feixes, como troncos de 
árvores. No final, a solução mais adequada, em função do transporte (a altura do edifício é de 35 metros, que é o limite quando há risco de terremoto), fabricação e da montagem no lugar, foi fabricá-los cortados no nível de cada andar. Por outro lado, a montagem foi complexa, pois a fixação nas lâminas de piso não poderiam deformar os tubos, através da soldagem e dos parafusos, e nem desalinhar a continuidade visual dos tubos. A solução encontrada foi não apertar rigidamente os parafusos e soldá-los no final. O escritório de engenharia enviou os desenhos com a marcação apenas dos eixos dos tubos. Eles foram lidos pelos computadores da fábrica, que geraram o dimensionamento do diâmetro, dos sulcos de soldagem de cada seção e da junta de cada um, sendo então cortados.

Alguns dos feixes são fechados por vidro no edifício como forma de isolar do fogo, já que o custo do aço à prova de fogo é muito alto. Nas lâminas do piso também houve revezamento entre áreas expostas e outras cobertas com uma camada de $7 \mathrm{~cm}$ de concreto (ITO: 2003, p. 47-57).

As soldas aparentes das lâminas aparentes também tiveram a aplicação de uma técnica especial para evitar a rebarba, e a linha aparente é interpretada pelo engenheiro Sasaki como "expressão da arquitetura moderna”. A espessura do tubo mais grosso é de $40 \mathrm{~mm}$ e $240 \mathrm{~mm}$ de diâmetro, o que deu extrema solidez à estrutura face aos terremotos possíveis. Tal espessura representaria um salto evolutivo na técnica de fabricação, que mesmo assim não teria estourado o orçamento (SASAKI; IKEDA; ITO: 2003, p. 57). O feitio desmaterializado do edifício pronto teria desapontado seus engenheiros, dado que os tubos desapareciam frente aos outros elementos e não se podia mais enxergar seu vigor estrutural tão claramente: "os tubos repentinamente soavam como ruído no espaço" (ITO: 2003, p. 57).

\section{O princípio da ambiguidade espacial}

A proposta inicial de Toyo Ito era desenvolver o edifício para a Midiateca a partir do conceito da pureza espacial, retomado da arquitetura moderna pelo viés da complexidade pós-moderna. Ele não queria, no entanto, que tal complexidade se traduzisse no comprometimento da beleza estética abstrata, despertada pela transparência, leveza (aérea) e fluidez espacial do partido moderno. Estas 
qualidades serviam de metáfora para representar a segunda dimensão do realidade determinada pelas mídias eletrônicas. Para Ito, as redes de comunicação configurariam uma realidade líquida, onde os fluxos naturais, inclusive do nosso corpo, se comunicariam com fluxos de elétrons, compondo um grau da ordem cósmica ${ }^{180}$. Ele observa, no entanto, que os limites do corpo individual estariam modificados pela nova mídia. As novas mídias despertariam a sensação de fazer o corpo fluir para dentro da tela e de outros mundos (ITO, 1997, 2011: 119). Para atender a esses novos corpos, a Midiateca seria concebida como uma natureza artificial, leve e invisível relativa aos feixes de elétrons, que não antagonizaria com a natureza orgânica. “(...) Eu mesmo havia imaginado um lugar para que o otaku ${ }^{181}$ de computadores encontrasse seus corpos eletrônicos, um espaço etéreo livre de qualidades materiais. " (ITO, 2002, 2011: 160)

Tampouco através da busca de pureza espacial na Midiateca Sendai, Ito estaria interessado na dimensão da transparência e leveza aéreas do espaço moderno. Tais qualidades estariam associadas ao pragmatismo e racionalismo da era da máquina. Elas seriam responsáveis pela homogeneidade da arquitetura corporativa que domina os grandes centros urbanos. Ito estava buscando no espaço moderno apenas as qualidades da transparência líquida e transluzente que ele reconheceu como existente no Pavilhão de Barcelona (1928-1929) de Mies van der Rohe. Este sim seria capaz de despertar a sensação corporal "de flutuação no fundo do mar". Para ele, conforme vimos, a memória da sensação funcionaria como um morfema, fazendo parte da estratégia abstrata de projeto desde a White Ring (ITO, 1976, 2011: 36). Ito buscou tal modo de abstração-sensível, que ele reconhecia na arquitetura do Pavilhão de Mies, em Sendai.

No desenho que eu fiz bem no primeiro estágio do projeto, rabisquei as palavras "colunas como algas marinhas" próximo aos tubos. As colunas foram concebidas como estruturas que oscilavam e dançavam cimo algas-marinhas na água. Assim

\footnotetext{
180 "No Oriente, "natureza" sempre significou o principio básico do cosmo. No século IV a.C., por exemplo, o filósofo Lao-tzu ensinou que a natureza segue adiante seu próprio caminho de acordo com regras cósmicas independentemente de qualquer ato humano. De acordo com essa filosofia, o corpo humano não é independente do mundo mas parte integral do continuum que o liga ao mundo. (...)

Na era moderna, entretanto, essa visão cósmica foi esquecida, e as pessoas começaram a dar importância ao individual, corpo físico. As pessoas estão agora obcecadas com um modo de pensar que coloca o individuo no centro do mundo, e que disseca o mundo em pedaços”. (ITO, 1997, 2011: p.120-121).

${ }^{181}$ Otaku é o termo em japonês para os obcecados em tecnologias, mangás, animes etc.
} 
o volume, medindo $50 \mathrm{~m}$ de um lado e cerca 30 na altura, é a consolidação do tanque de água (ITO: 1997, 2011, p. 118).

Se o espaço líquido da Midiateca metaforizaria o mundo profano do Otaku, a estrutura seria a metáfora do sagrado. As duas dimensões comprimidas na superfície transparente da fachada determinam um espaço ambíguo, oscilando entre o sagrado e o profano; entre o superficial e o profundo (ITO, 1978, 2012:114). Os feixes de tubos da midiateca distorcem a malha estrutural homogênea que compõe seu partido miesaniano inicial, determinando campos de espaço diferenciado ao redor que equivaleriam a lugares na natureza, devido seu apelo corporalmente sensível: "para permitir que as pessoas estabeleçam um lugar onde elas sejam guiadas pelo instinto animal em vez de signos" (ITO, 2016: 8). As estruturas da Midiateca remontariam ao mito do pilar sagrado na cultura japonesa, que teria tanto o potencial de ativação das qualidades espaciais heterogêneas do espírito do lugar, quanto estabeleceria a ponte com o divino e, assim, com a ordem cósmica.

\section{Onbashira- abstração sensível}

Nos ensaios iniciais sobre a Midiateca, não consta a associação com a arquitetura sagrada que existe no ensaio, "On Creating Architecture”, de 2016. Neste ensaio, Ito aponta a importância de recuperar a força e os poderes das antigas tradições na realidade contemporânea. Ele associa os tubos da midiateca ao ritual sagrado japonês da Onbashira (Fig. 52), que ele teria presenciado ao longo de sua infância. "O ritual implica que novas Onbashira (pilares sagrados) sejam re-eretas nos quatro cantos da construção do santuário uma vez a cada sete anos" (ITO, 2016: 8). O ritual teria origem no período Jomon (? - III a.C.), pré-histórico japonês, e derivava da crença de que, entre os pilares, surgiria um campo especial espiritual. Além disso, o próprio pilar em sua verticalidade evocaria uma ligação sagrada entre a terra e o céu. Na construção dos templos e santuários, também um pilar da construção é considerado sagrado ${ }^{182}$,

\footnotetext{
182 "Em adição aos pilares independentes, os antigos japoneses também atribuíam um significado especial aos pilares incorporados nos edifícios. Dois importantes exemlos são a coluna cetral sagrada (shin no mihashira) dos santuários principais de Ise (Prefeitura de Mie) e o santuário de Izumo (Prefeitura de Shimane). A coluna do central sagrado deve ter sido uma vez um membro estrutural importante carregando a viga de cume" (INOUE, 1985: p.8)
} 
demonstrando o valor simbólico do elemento vertical na cultura japonesa ${ }^{183}$. No ensaio de 2016, Ito evoca o pilar sagrado da arquitetura japonesa não por uma reação nostálgica, mas pela evocação sensível da presença de tal elemento. "Espaços que preenchem as sete camadas que compõem a Midiateca Sendai são integrados por meio de tubos espessos e poderosos que percorrem todos os sete pisos. (...) Pilares levantam do chão e alcançam o céu; é por tais aspectos simbólicos que as pessoas desenvolvem um senso de referência.” (ITO, 2016: 8).

Segundo o historiador Mitsuo Inoue, os antigos povos japoneses tenderiam a adorar objetos materiais e seriam dependentes do elemento tátil para o exercício da espiritualidade. Eles teriam evoluído posteriormente por influência do budismo vindo da China à abstração, esta associada ao elemento puramente visual e desmaterializado das representações bidimensionais. Os pilares eram considerados a origem de tudo por serem sagrados, e por isso serviam de unidade básica também da contagem. "O forte interesse do japonês antigo por pilares deve ser atribuído a sua comumente encontrada vontade de construir. Além disso, a deificação e a adoração do pilar e seu uso para contar deuses e humanos sugerem uma tendência geral dos antigos japoneses para conceituar, não abstratamente, mas concretamente. "(INOUE, 1985: p.12). Também na Midiateca, a estrutura evoca o sagrado de modo sensível, através da memória da natureza (árvores) recuperada na corporeidade construtiva. Tal processo de realização da memória sensível através de morfemas, conforme utilizada por Ito, remete aos processos de pintura e de produção das gravuras japonesas, que também envolveriam a memorização e abstração. Também elas não remeteriam ao realismo da representação, mas a um processo de abstração que é entendido como "elevação" dos elementos da natureza vistos a conceitos e sua pintura. A busca de pureza espacial por Ito remete à tal processo de abstração. O sagrado, portanto, seria uma dimensão abstrata e ontológica, que diferiria da relatividade e caos do mundo profano (Ito, 1978, 2012: p. 101). Para Ito, o espaço sagrado estaria relacionado à escuridão, à centralidade do espaço e também à casa. A associação do sagrado à casa teria sido promovida pelos arquitetos em função da laicização e perda de aura do mundo moderno. Os artistas denegariam tal perda

\footnotetext{
${ }^{183}$ Segundo a mitologia do Nihon shoki, a divindade Amaterasu teria subido para o céu através de um pilar sagrado (Ame no Mihashira-Pillar of Heaven), construído no início dos tempos, quando “céu e terra não estavam ainda tão longe” (INOUE, 1985: p.8).
} 
de autenticidade, e os arquitetos teriam promovido a casa ao elemento sagrado. "Esse tipo de anseio pelo sagrado dos arquitetos é baseado no mito da casa como modelo do mundo, e arquitetos são, claro, as mãos que constroem aquela casa, aquele modelo" (ITO, 1978, 2012: 102). Uma dimensão do sagrado, portanto, estaria relacionada à ordem cósmica; a outra, ao habitar. Por isso, a importância de estabelecer uma relação com a suposta centralidade do lugar. Haveria uma tendência centrífuga; outra centrípeta no sagrado. Assim, podemos compreender que Ito está buscando a integração numa ordem cósmica através da abertura da casa à cidade; da arquitetura aos fluxos eletrônicos, à comunidade e à natureza. A tecnologia dos computadores permitiria que os fluxos da natureza atravessassem os da arquitetura sem serem freados através da geometria estática euclidiana. $\mathrm{O}$ poder material da estrutura arquitetônica incorporaria o equilíbrio em movimento próprio dos corpos e das "algas no fundo do mar" a partir do espaço homogêneo da malha estrutural abstrata; e não contrapondo formas geométricas ou orgânicas à natureza.

Assim, (...) em Sendai, contrariamente à ordem histórica da arquitetura tomando forma na natureza, eu tentei o processo reverso: induzir natureza a partir das formas construídas, como também injetar materialidade no espaço "menos é mais", precisamente a fim de devolver alguma realidade vívida ao vazio da economia e da informação. Podemos denominar de "novo real" esta materialidade que vai além do modernismo. (ITO: 2006, 2011, p. 165)

\section{A transparência fenomênica na Midiateca}

$\mathrm{O}$ arquiteto Toyo Ito associa a Midiateca ao conceito de arquitetura borrada, (Blurring architecture ${ }^{184}$ ) que teria o sentido de ser "livre de barreiras" (ITO, 2003: p. 25) tanto em referência ao acesso para deficientes como ao fato de ter os programas funcionais abertos a modificações, relativamente indefinidos. Tal indefinição permitiria a não-compartimentação dos espaços internos e daria liberdade aos seus usuários e funcionários para definirem a disposição (Fig. 46, 47, 48). Além disso, os espaços internos não-especializados por um programa definido se interpenetrariam facilmente, tornando-se ambíguos. Para Ito, tal efeito

\footnotetext{
${ }^{184}$ Do Final do outono de 1999 ao princípio de 2000, o escritório de Ito montou a exposição Blurring Architecture, que foi mantida simultaneamente em Aachen, na Alemanha, e Tóquio e então no Singel, Antuérpia, e no Museu Lousiana de Arte Moderna, perto de Copenhague. A instalação com simulações de computação gráfica da Midiateca Sendai foi criada para a exposição, elas consistiam de muitas plantas e cortes desenvolvidos no processo de projeto uma se sobrepondo a outra em sequências de minutos. (ITO, 2003: p. 27)
} 
se estenderia ao exterior do edifício. A arquitetura definida por um programa funcional rígido desenharia uma paisagem urbana composta por caixas fechadas sem relação uma com as outras. A indefinição do programa, no entanto, permitiria que a relação com a fachada também fosse borrada, possibilitando a contextualização com as arquiteturas do entorno, sem precisar expressar na forma a verdade do programa. Na Midiateca, portanto, Ito pôde também explorar sua estratégia do dispositivo de superfície, a partir da qual a pele do edifício é tratada como ornamento discrepante em relação ao espaço interior. Através da ambiguidade suscitada pelas contradições da superfície de fachada, o edifício se comunicaria com os observadores e se abriria para a cidade (ITO, 2012: p.117). Sua fachada de vidro transparente poderia parecer contrariar tal busca de ambiguidade, mas, conforme verificaremos, ela não remete à transparência literal, embora explore completamente a qualidade desse material e revele o espaço interior fluido. A exploração da fachada transparente por Ito, traz à tona a questão da transparência fenomênica, apresentada por Colin Rowe. Esta seria definida pela ambiguidade de leitura implicada na utilização de grids contraditórios (relações de traçado incompleto que geram reversibilidade da percepção) e da estratificação do espaço profundo e superficial (criaria ambiguidade visual). Para Rowe, a materialidade do vidro redundaria numa transparência literal. Para Ito, por outro lado, a interpenetração poderia não ser apenas visual ou intelectual, mas do programa, do ar e da luz.

Até os anos 1990, Ito jamais utilizara o vidro nas fachadas (ITO, 2009: 69). Verificamos em seu ensaio, "Reflection of the sacred in the profane world" (1978), que somente através da discrepância entre a superfície da fachada o interior se poderia provocar a ambiguidade espacial necessária para suscitar a sombra do sagrado no mundo contemporâneo. Assim, a literalidade da transparência do vidro também não lhe interessa, mas sim a interpenetração entre interior e exterior e entre as camadas de espaço interior (entre os andares e os “compartimentos"). Por isso até então, teria preferido o uso de telas shoji da arquitetura tradicional japonesa, que produzem sombras, e chapas de alumínio perfurado que não definem uma barreira entre um espaço e outro, pois vazam ar e luz. Assim, a utilização do vidro somente lhe teria interessado quando pode fazer uso dos efeitos efêmeros de superfície através das novas tecnologias, tal como o 
sanduíche de vidro com filme de cristal líquido, controlado eletronicamente. Tal tecnologia permite mudar a fachada da transparência à opacidade, assim como variar os efeitos de cor e reflexos produtores de imagens. $\mathrm{O}$ primeiro projeto com fachada de vidro foi desenvolvido por Ito para o concurso da Maison de la culture du Japon em 1990. Dentro desse edifício flutuariam "naves midiáticas" que surgiriam na fachada, conforme ela permitissem transparecer (ITO, 2009: 69). A contradição da fachada eletrônica com o interior se manteria, portanto, de modo intermitente.

A Midiateca Sendai, apesar do volume quadrangular, não é tratada como a caixa de vidro modernista transparente sem hierarquia de fachadas. A fachada principal inclusive segue o alinhamento do terreno de modo a contextualizar com as demais edificações. O pavimento térreo recuado em relação à tela de vidro externa, conforme sendo aproximado, remete ao pavimento de uso comum dos edifícios corbusianos. Seu fechamento em vidro permite a sensação de integração com o espaço da rua em função da continuidade do nível do piso entre esses espaços e da transparência da parede. O pano de vidro da camada externa flutuante tem como tratamento gráfico tracejados enfileirados que remetem a códigos de barra e reforçam sua superficialidade vítrea. Sua fachada principal em dupla camada de vidro permite que o jogo de luz natural, filtrado pelas faixas leitosas ou direto, e reflexos variem ao longo do dia, conforme a incidência solar, e à noite em função do jogo de luzes artificiais. O edifício se colore de azul quando reflete o céu, misturando-se com ele, e parece diminuir de altura (Fig. 33, 34). Também se colore de verde ou cinza em dias chuvosos em que reflete os troncos de árvore enegrecidos pela umidade (Fig. 31, 32 e 35, 36). Às vezes, é naturalmente transparente, e a fachada parece riscada pela estrutura vertical esbranquiçada. Também fica transparente à noite, quando a estrutura vertical, colorida pelas luzes, parece atravessar os andares e as faixa leitosas na fachada. A fachada de Sendai oscila, portanto, entre a transparência transluzente com efeitos ambíguos e a literal. Mesmo a transparência literal do material, no entanto, é subvertida pelo jogo que estabelece com a transparência da estrutura.

A impressão de continuidade da estrutura através dos andares e sustentando a cobertura é completada intelectualmente, gerando uma imagem de 
colunas colossais que vazam através do edifício. Ao mesmo tempo, a estrutura é definida por colunas transparentes que deixam vazar o espaço do edifício na fachada e também o seu "sistema nervoso" de escadarias, shafts de elevadores, dutos elétricos etc., que está enclausurado no seu interior oco. No sentido horizontal, a transparência, a profundidade e a impressão de flutuação parecem enfatizadas. No sentido vertical, certa materialidade da estrutura irrompendo o volume e sustentando a cobertura é evocada. O jogo de profundidade e superficialidade não remete tanto para uma profundidade diagonal controlada, conforme na transparência fenomênica descrita por Rowe, mas para o grid formado na superfície da fachada entre os andares e os tubos ondulantes, estes um pouco recuados, e o espaço aberto entre a última lâmina horizontal e o teto metálico. A transparência do tubo revela a escadaria fazendo oscilar visualmente; ora a estrutura branca, ora a escadaria preta dentro dela, que também atravessa os andares. Os tubos dão, quando vistos do exterior ou através de seu vão no interior do edifício, uma sugestão visual de continuidade entre os andares, efetivamente servindo para o tráfego e a conexão vertical mútua. Eles contribuem para pontuar a interpenetrabilidade entre os andares, bem como entre o interior revelado e o exterior que também pode ser incorporado visualmente sem barreiras.

As fachadas leste e de fundos da Midiateca Sendai receberam tratamento variado em cada andar e remeteriam a projetos anteriores de Ito. O edifício de escritório ITM em Matsuyama (1993) também tem a fachada principal em vidro, marcada horizontalmente na altura dos andares pela variação de faixas de vidro leitoso transluzentes, transparentes e metálicas. A fachada deixa entrever as instalações metálicas expostas no espaço. O edifício também possui as fachadas secundárias com tratamento mais opaco que a fachada principal, conforme Sendai. A sobreposição dos materiais reflexivos, tais como o metal e o vidro transluzente, associados ao vidro transparente criaria, segundo Ito, uma grande variação na qualidade de luz no interior, que se torna difusa e dá aquela qualidade líquida que Ito tanto admira no Pavilhão de Barcelona de Mies: "A luz moderada difusa por essas superfícies perturba as percepções de direção: o interior do edifício é inundado com leveza e a sensação de flutuação”. (ITO, 2009: 69). 
As fachadas de fundo e Leste (Fig. 38 e 39) têm faixas em dégradé de opacidade, variando de andar para andar, indo do metal ao vidro semi-opaco e transluzente num crescendo até a faixa da cobertura sem fechamento. Elas tendem a se tornar mais banais e a desaparecer no meio de outras fachadas do contexto, tanto por não contarem com o jogo opulento das colunas colossais projetadas na fachada, como porque tendem a se fragmentarem em acordo com a variedade de tratamento dado ao material (vidro e metal). $\mathrm{O}$ encontro dessas duas fachadas iguais permite configurar visualmente o volume de vidro do edifício. Tal efeito de volume, entretanto, é contradito no encontro com as outras fachadas de telas sobrepostas, que parecem ser finas superfícies soltas de vidro e metal orbitando o volume quadrangular, gerando a ambiguidade da geometria sólida.

A fachada Oeste em veneziana metálica (Fig 37) deixa entrever as sombras também acinzentadas dos andares, das escadarias e dutos, funciona como uma cortina metálica que torna a fachada abstrata e homogeneizada como os caixotes modernistas coroados por terraços-jardim. No caso de Sendai, é coroado com a estrutura vazada dos tubos, teto flutuante e chaminés do edifício. Sua austeridade prateada contrasta com o dinamismo das outras fachadas.

\section{A descoberta do espaço público real}

A Midiateca é um ponto de virada na arquitetura de Ito. Para ele, seria a consolidação de anos de investigação sobre a pureza do espaço. Esta realizada mediante a abertura para a sociedade como participante. Pela primeira vez em sua vida profissional, ele não considera a interferência externa no processo de desenvolvimento de projetação e realização como fonte de distorção de suas ideias. Para o arquiteto Riken Yamamato, a Midiateca representaria uma mudança de perspectiva por parte de Ito, que até então teria se mantido fiel ao hermetismo da Escola Shinohara e afastado de seu antigo chefe Kiyonori Kitutake. Este último comprometido com o envolvimento social. A herança de Shinohara implicava em tomar o processo intelectual como individual. Ito seguiria a ideia de que a obra devia ser o resultado de um processo intelectual isolado, que não deveria sofrer a interferência de fatores externos; sejam eles clientes; a sociedade; fatores econômicos ou demandas do cotidiano. Para ele, a interferência externa determinaria a corrupção da pureza de concepção. A midiateca, no entanto, 
desenvolveu-se como um trabalho participativo tanto por parte da sociedade, como dos técnicos que também interferiram no projeto, injetando novas dimensões de materialidade (Fig. 47 e 48).

O primeiro projeto apresentado aos jurados e ao comitê de representantes teria parecido extremamente abstrato, suscitando o questionamento sobre sua viabilidade e capacidade de atender o público. Segundo Yamamoto, Ito teria tido que fazer um longo exercício de ouvir os outros e reavaliar seu processo de projetação. Conforme verificamos, depois da experiência da White Ring, seu processo passou a ser baseado na busca de pureza espacial e abertura para a cidade. Para tanto, ele dispunha do dispositivo da superficialidade e ambiguidade espacial. Para Yamamoto, este dispositivo não configuraria uma abertura para o Outro, pois continuaria dependendo de um processo intelectivo individual. Yamato conclui que, na Midiateca, ele teve que adotar finalmente uma perspectiva relativista e verificar se suas próprias ideias, quando realizadas, eram realmente puras.

Por outro, a empatia com ideias alheias, através das reuniões com participação ampla da comunidade, promoveu mudanças internas em Ito. O processo empático permitiu a interferência exterior no processo de projeto, sem que isso significasse a corrupção da ideia.

Adotar uma perspectiva relativista é se permitir mudar no processo de realização arquitetônica. Ito percebeu, pela primeira vez, que descobrir esse eu mutante era parte do processo de projeto. Este era inteiramente diferente de seu modo de pensar anterior, que era ver o espaço puro sendo distorcido pelos fatores externos.

Não há razão para criar arquitetura se alguém perde a vontade de alcançar o espaço puro, um espaço que é puro precisamente porque é pessoal, mesmo se é loucura.(...) Ito veio a perceber que a mudança não distorce a pureza, mas sim permite-lhe alcançar uma arquitetura mais rica. (YAMAMOTO; ITO, 2009: P. 33)

Os conceitos conforme realizados, por sua vez, seriam diferentes do conceito puro. Segundo Yamato, o espaço puro seria algo criado internamente, por isso seria "extremamente pessoal". O caráter abstrato do espaço puro é perdido devido às interferências externas, tais como as dificuldades de execução dos tubos que determinaram que fossem cortados e soldados, deixando "cicatrizes" como efeito. "Pureza, quer dizer, o feitiço do fechamento lançado 
pela pureza, é, na realidade, uma contradição inerente à arquitetura moderna em si. A teoria da arquitetura moderna tornou imperativo que o espaço fosse puro." (YAMAMOTO; ITO, 2009: P. 33). O espaço abstrato ressurgiria do espaço do contexto real. Através do processo participativo, haveria um processo de apropriação interativo que tornaria a ideia de Ito também um símbolo da comunidade. “(...) a singularidade e pureza de Ito vêm a ser aceitas pelas pessoas como símbolo daquele lugar, daquele tempo, daquela história e daquela comunidade" (YAMAMOTO; ITO, 2009: P. 33). O processo do projeto da Midiateca teria sido também um processo pessoal da auto-aceitação de Ito a partir de um “eu” não-idealizado, que seria o "eu”, conforme visto pelos outros.

O que Ito descobriu no processo de realização não foi um modo de dar precedência aos fatores externos que distorcem a pureza do espaço, ou um formalismo que abandona qualquer esforço para abrir o espaço para o mundo exterior, ou um cinismo que lhe permite fingir que ele sozinho está do lado de fora, mas um modo de transformar sua própria pureza num edifício real. Através daquele processo, Ito experimentou o momento quando o espaço abstrato se torna real. (YAMAMOTO; ITO, 2009: P. 33)

\section{O espaço puro e o espaço paranoico}

Gostaria de retornar ao projeto do OMA para o concurso da Biblioteca Nacional da França (TGB-1989), citado, no início do texto, como tipologia antecedente à Midiateca Sendai. A similaridade decorreria do programa para a mídia digital; da transparência ambígua de superfície e dos elementos internos; da volumetria quadrangular e da espacialidade líquida. O espaço da biblioteca francesa é descrito pelo arquiteto Rem Koolhaas como um "líquido placentário", cujos embriões corresponderiam à abertura do programa para acontecimentos eventuais (rever capítulo 5.2). A biblioteca seria constituída por um volume quadrangular "escavado"185 e dotada de tendência desmaterializante; seja por sua transparência ou pela estratégia utilizada da "escavação de vazios". Seu espaço seria atravessado por shafts, eixos de circulação vertical, que transpareceriam na fachada. Os espaços interiores revelados na fachada gerariam aquela impressão de

\footnotetext{
${ }^{185}$ A estratégia do projeto se desenvolveria a dos elementos não-construídos, conforme já experimentado no ZKM, possibilitando a abertura do projeto segundo o desenvolvimento do programa. "Já que são vazios - eles não têm que ser "construídos" - bibliotecas individuais podem ser configuradas estritamente de acordo com sua própria lógica, de modo independente uma da outra, do envelope externo, das dificuldades comuns da arquitetura, até da gravidade." (KOOLHAS; SIEGLER; MAU:1995, 620)
} 
interpenetrabilidade e ambiguidade espaciais que definem o conceito da transparência fenomênica; e nos permite comparar a Biblioteca Nacional da França à Midiateca Sendai.

O edifício da Midiateca, no entanto, é associado por Riken Yamamoto ao processo pessoal de Toyo Ito de abertura para ouvir o Outro; e, do ponto de vista social, seria interpretado como a forma simbólica que representaria tanto a pureza do espaço abstrato criado por Ito quanto aquela comunidade. A Midiateca envolveria um processo de recuperação, enquanto Vidler aponta, no projeto do OMA, um sintoma da patologia do homem da era digital, cuja realidade seria marcada pelo borrado das fronteiras entre homem e tecnologia, orgânico e inorgânico, privado e público. Tal arquitetura não se definiria pela necessidade do habitar, dado a dimensão duplicada do homem pela tecnologia cibernética na figura do ciborgue. Ela espelharia esse estágio de auto-estranhamento do sujeito, tornado ciborgue, através da tendência ao abjeto que se poderia encontrar na biblioteca do OMA. Os vazios escavados da biblioteca seriam como órgãos internos transparentes que o sujeito veria refletidos, como sendo ele visto internamente.

Vimos como no capítulo 5.2, Anthony Vidler associou o espaço da biblioteca do OMA ao espaço paranoico e ao sentimento de Unheimlich, ligado à escuridão, à morte e à ansiedade despertada pelo que denominei como transparência abjeta. A ansiedade do espaço paranoico seria despertada pela ambiguidade da fachada de vidro, que migraria primeiramente da transparência à reflexividade transluzente, que ele associa ao "simulacro bidimensional do espaço interior" (VIDLER, 1992: p. 221) e ao efeito do duplo na fase do espelho da teoria lacaniana. A fachada mudaria depois, migrando para uma recusa da reflexão, "sua absorvência tanto à representação interior quanto reflexão externa” (VIDLER, 1992: p. 223), que ele associa ao fim do estágio do espelho, "caracterizada pela alienação paranoica, a qual remonta do desvio do Eu especular ao Eu social” (VIDLER, 1992: p. 223).

Termino me perguntando o porquê do contraste das interpretações para as duas obras bastante comparáveis em termos de programa aberto, ainda que a participação da comunidade seja exclusividade da cidade menor que é Sendai, e 
também das estratégias de projeto, baseadas na transparência fenomênica e na espacialidade líquida. Assim, recoloco a questão da persistência da referência clássica antropomórfica na análise de Vidler. Para ele, a transparência literal do vidro corresponderia à relação de clareza entre sujeito e objeto; a reflexão, ao narcisismo; e a ambiguidade transluzente, à falta de referência ao corpo orgânico do sujeito contemporâneo. A arquitetura desenvolvida a partir do impulso para a abstração não traria felicidade ao homem, pois provocaria nele o sentimento do desenraizamento e serviria às instituições de Poder para lhe amedrontar e manipular. (ver capítulo 5.3).

$\mathrm{Na}$ Midiateca, apesar de também pressupor ser frequentada por sujeitos com corpos ambíguos, eletrônicos e carnais, a imagem a que remonta não é a do homem, mas da Onbashira. Vimos que a Onbashira é o pilar sagrado, levantado em rituais por vários homens em conjunto e com o testemunho da comunidade. Isso desde tempos imemoriais a cada sete anos. Certamente seria uma visão otimista da Era Digital, aquela que nos levaria a interpretar os feixes estruturais ocos da Midiateca, que levantam seu teto, também como uma metáfora das redes paradoxalmente sólidas e desmaterializadas que configuram as comunidades virtuais.

Para concluir, podemos acrescentar que a ambiguidade da transparência e do espaço provocam um estranhamento sutil, que não mais provoca choque, mas que instiga à participação devido à indefinição de seus espaços. A pureza de sua concepção, que causou estranheza quando apresentada à população, estaria agora apropriada. O edifício, às vezes, se mostra à contemplação; outras, parece banal. Do seu interior, muitas pessoas contemplam a rua arborizada, tal como, no interior dos espaços em estilos Shinden e Shoin ${ }^{186}$, se contemplava os jardins. Essa imagem ilustraria o potencial da arquitetura da transparência para abrigar (Fig. 46).

\footnotetext{
${ }^{186}$ Residências nesse estilo tinham jardins (com lagos ao sul - Estilo Shinden), que se integravam com o espaço da casa conforme se abriam as portas de correr e podiam ser contemplados (INOUE, 1985).
} 


\section{7. \\ Conclusão}

A arquitetura contemporânea aponta desde os anos 1990 o retorno da linguagem moderna das Vanguardas dos anos 1920, representada através dos valores da abstração, da leveza e da transparência. Desta vez, tal linguagem não estaria associada à estética mecânica, mas à estética fluida da Era digital. Tal fluidez estaria tanto associada às novas tecnologias digitais quanto à realidade estruturada segundo a dinâmica do capitalismo pós-industrial. Estas configurariam uma estrutura urbana desmaterializada, instável e independente da construção física. Tais mudanças teriam tornado obsoletos os paradigmas da solidez, funcionalidade e beleza, herdados da tradição clássica. A tendência ao desaparecimento das qualidades substanciais da arquitetura e a consequente mudança dos referenciais fenomenológicos é associada a diferentes patologias contemporâneas. Para o arquiteto Anthony Vidler e o crítico de arte Hal Foster, a perda dos referenciais substanciais representaria um desvirtuamento da experiência corporal com o espaço, determinando o sentimento de desenraizamento do homem moderno. Para o arquiteto Toyo Ito, a alteração dos referenciais substanciais da arquitetura seria acompanhada de uma mudança no próprio corpo humano estendido nos meios eletrônicos. Tal mudança, compreendida segundo a cosmologia oriental, não representaria alienação, mas a continuidade entre os fluxos líquidos do corpo e dos elétrons e a integração entre natureza e tecnologia.

A arquitetura japonesa continua sendo uma referência para a arquitetura da transparência, tendo o arquiteto Toyo Ito se tornado um dos mestres na nova geração. A transparência também teria passado por um período de latência no Japão, que não a impediu de ser influente por outros quesitos, tais como massa, expressividade e opacidade. Tal qualidade epifenomênica da arquitetura japonesa contemporânea daria continuidade ao que Reyner Banham denominou japonização do mundo da arquitetura. A japonização veio acompanhada da ocidentalização da arquitetura japonesa, o que não teria neutralizado suas diferenças e o estranhamento ela ainda provocaria. Para Banham, haveria dois elementos que levariam a apropriação da linguagem moderna universal pelos japoneses à expressão de uma diferença irredutível: os arquitetos japoneses seriam 
mais livres para utilizar as novas tecnologias e a linguagem abstrata, porque não carregariam o referencial construtivo relacionado à solidez da alvenaria e estariam utilizando a linguagem geométrica destituída da associação com a metafísica ocidental. A arquitetura moderna ocidental carregaria um lastro da cultura clássica mediterrânea, enquanto a arquitetura japonesa faria uso dos signos vazios. Tamanha liberdade teria propiciado o fato do Japão ter lançado a primeira vanguarda moderna não-ocidental em 1960 e também de ter se tornado um dos berços da arquitetura pós-moderna posteriormente.

A japonização do mundo da arquitetura, no entanto, viria acompanhada de um processo de mitificação da japonidade. A mitificação teria sido desencadeada pela relação complexa estabelecida com o Ocidente desde o final do século XIX, quando o país teve sua abertura para o comércio exterior forçada. O fluxo do comércio teria sido acompanhado do consumo de objetos de arte, sendo eles escolhidos em função de seu exotismo. A recepção das obras artísticas e arquitetônicas japonesas coincidiu com a busca de paradigmas alternativos ao academicismo por parte dos artistas europeus. As pinturas e gravuras japonesas encantaram pela transparência, pela ênfase na sensação visual e nas relações de cores e formas, que as distanciava do da retórica e do compositivismo acadêmico. Eles pintariam os fenômenos sem imobilizá-los, pintariam a vida das formas. A onda da Japonnerie determinaria a produção orientada em função do olhar exterior. Segundo o arquiteto, Arata Isozaki, tal momento teria sido propício para evocar a discussão sobre a japonidade, que se desdobraria em função do contexto histórico. Num primeiro momento, ela teria sido alimentada pela campanha nacionalista. O momento atual corresponderia ao movimento de desmistificação dos debates sobre a identidade japonesa e à abertura para o Outro.

Para a arquitetura, a busca por transparência nas obras japonesas também tratava da necessidade de encontrar uma linguagem adequada às novas tecnologias construtivas e mecânicas que permeavam a realidade no início do século XX. Frank Lloyd Wright teria identificado o vazio como o princípio da arquitetura japonesa que lhe interessava para "abrir a caixa", que representava a arquitetura tradicional ocidental. Num primeiro momento, a arquitetura desenvolvida no Japão por influência do critério de exotismo foi Eclética, como 
também foram as incorporações de elementos japoneses na arquitetura Ocidental. Segundo Isozaki, os próprios arquitetos japoneses insatisfeitos com a arquitetura eclética do primeiro momento, teriam promovido a releitura de seus monumentos a partir do olhar moderno. Eles teriam levado o arquiteto, Bruno Taut, expressionista refugiado do Nazismo para visitar o Santuário Ise do século VII, obra em madeira reconstruída a cada vinte anos e alvo de peregrinações. $\mathrm{O}$ santuário foi comparado por ele ao Parthenon com base na pureza de sua forma, inaugurando uma ponte, baseada na linguagem moderna, entre as duas culturas. Assim, a japonidade foi identificada com a transparência, simplicidade, pureza das formas e funcionalidade. Taut era um refugiado do Nazismo e, com o referendo do templo Ise, estaria reforçando indiretamente a legitimidade do sistema imperial (Tennô) e garantindo sua estadia. O sistema Tennô estaria relacionado tanto à dimensão política do Estado Imperial, quanto ao mito de fundação do mesmo e à metafísica do vazio. $\mathrm{O}$ sistema tennô não se encerraria em um objeto, mas no mecanismo de construir uma ficção em torno do signo zero, assim produzindo um não-lugar a-histórico. Tal marco zero seria o vazio e a escuridão. A presença divina do imperador, portanto, seria marcada por esse paradoxal vazio.

Quando o Japão perdeu a guerra e foi ocupado pelos Estados Unidos, os próprios japoneses teriam passado a rejeitar aquela primeira identidade da transparência e pureza elegantes. O período de ocupação foi o momento em que o centro da arquitetura moderna se moveu para os Estados Unidos e recebeu a alcunha de Arquitetura Internacional. O sentimento anti-ocupação teria movido os arquitetos japoneses para a procura de novos paradigmas, que não fossem baseados na estética da transparência, pureza e beleza. Essas qualidades ressaltadas teriam sido, em parte, efeito do resquício nacionalista, que era associado ao sistema imperial e às arquiteturas do Palácio Katsura e do Santuário Ise. Tais qualidades associadas à transparência estariam sendo propagadas por fotos que enfatizavam aspectos de composição abstrata mondrianesca e cortavam aqueles que não se encaixavam, tal como nas fotos de Ishimoto para o livro de Kenzo Tange sobre o Palácio Katsura em 1960, que seria prefaciado pelo arquiteto da Bauhaus, Walter Gropius. O Memorial de Hiroshima (1950) de Kenzo Tange, espaço plano e flutuante e apoiado em estrutura transparente, seria 
a realização de tal ideal de japonidade, associado ao sistema Tennô e ao modernismo da pureza e leveza formais da Primeira Vanguarda.

O critério alternativo ao juízo estético do belo seria o conceito de Kunstwollen (vontade de forma ou arte), desenvolvido por Aloïs Riegl e Wilhelm Worringer e interpretado por Ryûichi Hamaguchi através da comparação dos métodos ocidentais e orientais. Segundo Hamaguchi, a arquitetura ocidental seria baseada em princípios compositivos, categorizados como objetivos e construtivos. A japonesa seria caracterizada pelos aspectos de performatividade, seguindo como princípio o método intersticial $(M a)$, que foca nos intervalos vazios e não nos elementos construídos. A morte e a destruição associadas à escuridão fariam parte desse processo que define o espaço japonês a partir do aspecto performativo e não segundo uma metafísica do construído. Isozaki enfatiza a importância da estética do sabi no método japonês. Tal estética retrataria as paisagens da morte, cenários de destruição tais como os do pós-guerra, como espaço transitório $(M a)$. A matéria destruída seria o último estágio da dimensão de coisa dos seres; o último estágio antes do desaparecimento. Tal cenário corresponderia ao espaço da escuridão, de onde surgiria um vazio produtivo $(M a)$; que é intervalo e abertura para o acontecimento da vida. Na concepção japonesa de espaço, que toma como princípio a ideia de intervalo e impermanência $(M a)$, espaço e tempo não se configurariam como entidades distintas. $\mathrm{O}$ efeito da concepção arquitetônica baseada no princípio de impermanência e na dimensão performativa da construção, é a ênfase no seu tornar-se, e nas qualidades espaciais mais que na materialidade do construído.

Tal mudança de enfoque do gosto para uma dimensão performativa teria impacto sobre a estética da transparência e da pureza formal abstrata. Pela influência do artista Taro Okamoto, ligado ao movimento surrealista, seria introduzida, na interpretação da japonidade duas tendências da Vontade de Arte. As duas teriam sido retiradas da pré-história japonesa: Jômon e Yayoi. A cerâmica produzida em cada período as ilustraria; a primeira seria primitiva, dinâmica, popular e dionisíaca; a outra, de beleza elegante apolínea. A Jômon estaria associada à expressão popular; e a Yayoi, à arquitetura da transparência 
elegante do Memorial de Hiroshima, que passou a ser associado ao imperialismo, à ocupação americana e à moda da japônica nos Estados Unidos.

A mudança de paradigma para o critério da performatividade e dos valores associados à cerâmica Jômon não significou um fechamento para influências externas; tais como a participação nos debates internacionais sobre a revisão crítica do espaço universal moderno e a incorporação da estética brutalista. Esta tanto apontava uma inspiração regionalista e primitivista ligada à figura de Le Corbusier, quanto uma estética da decadência associada à paisagem de destruição do pós-guerra e ao caos urbano, associada aos arquitetos ingleses Alison e Peter Smithson. Tanto o primitivismo do Brutalismo corbusiano quanto a estética da decadência e da destruição urbanas seriam associáveis ao Jômonismo e foram incorporados. A arquitetura japonesa responderá a tais influências através do expressionismo megaestrutural tecnotópico do movimento Metabolista, que expressava com a pesada estética brutalista tanto às questões do debate interno sobre a performatividade quanto às questões sobre o espaço urbano deteriorado.

Os dispositivos associados à valorização do Jômon se baseariam no princípio da performatividade espacial e visariam um tipo de transparência opaca e não literal, própria da abertura para o tempo, que a espacialidade por camadas da arquitetura japonesa propiciaria. A ênfase na performatividade detonou uma série de releituras dos espaços tradicionais, interpretados anteriormente pela qualidade da transparência literal e da leveza. A transparência opaca revelaria um tipo de profundidade espacial, insinuada e não revelada, que corresponderia à diagonalidade da disposição Ganko no Palácio Katsura. Também o Santuário Ise seria dotado de tal transparência opaca. A releitura se direcionou ao espaço do entorno, marcado por sucessivas camadas de portões e cercamentos, orientados pelo gosto do ocultamento $(O k u)$ e da escuridão. Pode-se dizer que a arquitetura japonesa pode ser identificada pela transparência fenomênica, devido suas qualidades de ambiguidade espacial relacionadas à percepção do espaço em camadas e à sobreposição de eixos na disposição Ganko.

À noção da transparência fenomênica, podemos associar o conceito de "espaço-movimento", cuja apreensão é topológica, aproximada e depende da movimentação corporal que infere a sensação de profundidade. Tal sensação de 
profundidade não corresponde à percepção visual de uma totalidade contraposta de figura e fundo. Assim, a diagonalidade, a planaridade e a profundidade, conforme apresentadas na disposição Ganko, são experimentadas segundo a interação com o movimento corporal. Não há visão de profundidade, mas a sensação de profundidade porque o espaço se mostra de modo estratificado, interrompido visualmente na diagonal pelo escalonamento dos espaços; e nos eixos ortogonais, limitados à abertura sucessiva dos painéis móveis.

Vimos como Colin Rowe, Robert Slutzky e também Henri Lefebvre apontam os anos por volta de 1910 como de ruptura da concepção de espaço euclidiano. Tal época coincidiria também com um período revolucionário nas artes modernas. Lefebvre estende o impacto de tal ruptura à prática social, ao poder político, ao senso comum, ao conhecimento e à moral. Para ele, as instituições estabelecidas teriam criado a ilusão de um espaço fragmentado sobre o qual as pessoas estariam condicionadas a agir segundo entidades separadas: domínios do mental, corporal e social. O espaço euclidiano corresponderia para Lefebvre ao espaço abstrato e à impossibilidade da experiência em seu sentido pleno, como geradora de diferenças espaço-temporais e da vida corporal. A concepção do espaço euclidiano e perspectivista, desenvolvida a partir da tradição greco-romana e incorporada como base da filosofia e artes ocidentais, teria sido progressivamente suplantada por outra a partir da virada do XIX, baseada numa geometria topológica. Ainda que na prática, o espaço abstrato ainda fosse instrumentalizado como forma de controle e violência contra os corpos.

A ruptura da concepção do espaço de forma tão ampla teria se fundamentado na ciência a partir da Teoria da Relatividade e das descobertas de Hermann Minkowski, que teria unido o tempo à concepção tridimensional do espaço segundo um continuum, mas também através do próprio senso comum. Segundo Paul Virilio, a percepção humana teria se modificado através da disseminação de imagens aéreas promovidas pelo cinema, inicialmente como forma documental de guerra e depois apropriadas pelas produções de entretenimento. A aviação teria determinado um novo modo de ver através de suas manobras, tais como "loopings", "folha-seca", grande-oito", que implicariam na perda das referências polares homogêneas do espaço métrico. 
Essas manobras em grande velocidade implicariam na apreensão do espaço topológica, segundo ordens de grandeza inexatas.

Também a vida nas grandes cidades, tal como demonstrara o sociólogo Georg Simmel em seu ensaio de 1903, teria modificado o aparato sensório humano através da intensificação da vida nervosa, devido às velozes e ininterruptas mudanças de impressões provocadas pelo ambiente urbano. O ambiente metropolitano, na integração dos meios técnicos ao dinamismo da própria vida social e de trabalho, tais como bondes; automóveis e elevadores, teria contribuído para a modificar o conceito de espaço, que promoveria a revolução artística associada ao topológico e à abstração. Não somente o argumento científico, mas também o econômico, sociológico e psicológico são incorporados nos debates artísticos da época. O debate sobre o Expressionismo refletiu o impacto da mudança de concepção do espaço que correspondeu àquele momento.

De um lado, Geörgy Lukács acusava os artistas expressionistas de estarem manifestando, através da deformação e da fragmentação da linguagem, uma mera Vontade de perda-de-perspectiva, que resultava numa tendência estetizante e vazia relacionada à condição resignada do boêmio-burguês dos cafés. Do outro lado, Ernst Bloch, Brecht e Adorno que apontavam o paradoxal conservadorismo implícito na crítica de Lukács. Em sua defesa da revolução efetuada através da luta de classes, ele rejeitaria a expressão subjetivista existencial de tais obras, traduzida na forma fragmentária. Para Lukács, somente uma perspectiva totalizante da realidade permitiria a tomada de posição necessária à revolução. Somente a revolução acabaria com a causa do sofrimento do homem moderno, que é a exploração capitalista. As obras de arte deveriam refletir a realidade humana numa perspectiva totalizante de modo a afirmar a emancipação do sujeito. Para Bloch, Lukács estaria preso a um tipo de formalismo classicista, subentendido em sua defesa da "totalidade da forma". Ele estaria evocando o classicismo por nostalgia de uma realidade "fechado-objetivista" e da regularidade do belo acabado. Podemos acrescentar que Lukács estaria rejeitando a fragmentação do próprio sujeito imerso na realidade cambiante e caótica, metralhado por informações vindas de todos os lados, diante da qual interior e exterior misturam-se. $O$ sujeito se reconhece também como objeto de tal 
realidade. Diante de tantas oscilações, ele perde seu anteparo de representação tanto para a noção do que é como indivíduo, quanto para o que é do ponto de vista social e da cultura. Simmel associava a experiência da vida na cidade ao choque. Tal realidade teria se tornado obscura a ponto de remeter o sujeito moderno à condição do primitivo tateante, conforme descrito por Riegl e Worringer. O sujeito moderno, portanto, retornaria à concepção do espaço topológica, aproximada e fragmentária. Para Bloch, no entanto, ela não significaria um mero retrocesso, pois significaria uma abertura para uma dimensão invisível da realidade do homem, que revelaria seu mundo onírico e inconsciente, e também a abertura para o Outro: crianças, doentes mentais, não-ocidentais, primitivos, popular. Tal dimensão invisível se revelaria através do esvaziamento de conteúdo da obra, que chocava e permitiria o desdobramento de significados de pavor e revolta através da extravasão do Eu.

Para Adorno, a obra expressionista seria crítica da realidade. Apesar de sua falta de perspectiva, ela não seria expressão de alienação conforme acusava Lukács. Se a visada totalizante, relativa à apreensão em perspectiva e relativa ao espaço euclidiano, determinava um tipo de obra a ser contemplada; a obra fragmentada envolveria uma apreensão monadológica e reflexiva, tal como a reflexão implicada pelo "fragmento crítico" dos primeiros românticos. Segundo Adorno, as obras expressionistas incorporariam o tempo vivido através da fragmentação. Este estaria objetificado na defesa do realismo lukácsiano em função do sentido determinado pela perspectiva revolucionária. O tempo vivido manifestado, através das obras expressionistas, revelaria a realidade encoberta do tempo instrumentalizado pela ciência e pelo trabalho.

Na crítica ao subjetivismo patológico e esvaziado expressionista, Geörgy Lukács apontava o agnosticismo dos argumentos sociológico e psicológicos, associados à filosofia kantiana e pós-kantiana do “como se", como responsáveis pela disseminação de um sentimento de resignação diante da realidade, descrita como deformada, "expressionista em si" e caótica. Tal visão de mundo estaria levando os artistas à uma atitude regressiva, melancólica e solipsista, cuja referência seria a aparência imediata da realidade e não a realidade em si, que seria socioeconômica. Para Lukács, a transparência da realidade seria possível 
através do movimento dialético entre sujeito e realidade com a emancipação do primeiro. Lukács defendia um tipo de realismo que confrontasse as relações de produção consideradas como a totalidade que define o mundo capitalista. Para ele, a deformação associada às obras expressionistas refletiria o fato de que o confronto dialético com realidade teria se efetivado pela metade, o que resultava numa representação fragmentária. O Expressionismo se conformaria com um confronto superficial com a realidade, dado que somente os efeitos neurotizantes da realidade capitalista, imperialista e bélica estariam expostos e não, a essência da violência da exploração capitalista. Os efeitos seriam a patologia neurótica ou melancólica exprimidas através de uma linguagem deformante e fragmentária que exaltava tais estados de ânimos, mimetizando o estado subjetivo do artista. A revolta com a realidade se realizaria como um manifesto vazio, dado que não considerava a expressão do essencial, que seria socioeconômico. O idealismosubjetivo dos expressionistas propagaria o afastamento do foco sobre as coisas reais através do discurso abstrato que situaria as determinantes do real na cabeça dos homens. Ele promoveria o desvio do campo de batalha da luta de classes para o campo privado da moral, onde a batalha é restrita aos efeitos deformantes promovidos no homem. Tal desvio resultaria na mudança do foco das coisas para a relação entre as coisas, para as relações intersubjetivas e para a expressão da crise existencial do homem moderno. O sentimento de desenraizamento do homem moderno, expresso nessas obras, seria o resultado dessa relação superficial com a realidade, que abstrairia as causas reais. Também o pacifismo relacionado ao Expressionismo seria um efeito dessa relação evasiva com a realidade. Na medida em que a revolução social a favor dos operários somente poderia ser feita através do combate físico e da violência da guerra, a tendência democrático-pacifista do movimento representaria um atraso e um enfraquecimento da luta que estaria beneficiando a burguesia ligada ao imperialismo. Para Lukács, as estratégias abstratas vanguardistas se pautavam no fragmento e na montagem seriam dotadas de um transcendentalismo de tendências utópicas, dado o pacifismo em tempos de guerras. Tais estratégias se baseavam numa apreensão espontânea, imediatista, evocando a simultaneidade dos acontecimentos de modo tal que apenas uma impressão caótica da realidade seria fixada. Tais estratégias estariam, portanto, restritas à expressão da sensação patológica do homem moderno e à expressão abstrata da realidade. Sua abstração 
seria comparável à fetichização da mercadoria no sistema capitalista. O Expressionismo teria disponibilizado métodos desviantes de esvaziamento do conteúdo da realidade através da abstração do contexto histórico social, que permitiram a disseminação de uma ideologia da intermediação. Esta corresponderia ao pacifismo, ao deslocamento do foco da luta revolucionária para o combate espiritual e ao esvaziamento de conteúdo das formas. O esvaziamento de conteúdo das formas expressionistas teria permitido que elas fossem utilizadas arbitrariamente tanto para a propaganda nazista quanto para a expressão do pacifismo e da revolta contra a realidade. O medo da violência da guerra afastaria o operário da luta de classes e o medo da bagunça, o burguês também da luta. A ênfase nas relações intersubjetivas patológicas desviariam do problema históricosocial. Esses movimentos teriam facilitado a tomada de poder por parte do fascismo na Alemanha.

Lukács aponta Worringer como um dos precursores e fundadores do movimento expressionista através da contribuição teórica do conceito de abstração. A defesa do Expressionismo assim como o seu ataque utilizaram o argumento da relação com o espaço, levantado por Worringer. Segundo a teoria worrigeriana, o impulso para a abstração corresponderia à experiência de medo que o homem primitivo e o gótico sentiriam pelo espaço. O outro impulso definido por Worringer seria o de empatia, que pressuporia na estrutura psíquica do homem a existência de um anteparo de representação do mundo. Este anteparo seria desenvolvido a partir da cultura, do conhecimento, da introjeção de uma visão de mundo, cósmica etc. O primitivo seria desprovido dela e o gótico, parcialmente provido. Através desse anteparo, o homem manteria uma relação de continuidade sem hostilidade com o mundo. $\mathrm{O}$ antropomorfismo, relacionado aos períodos clássicos, corresponderia à expressão desse sentimento de poder humano em relação à realidade, traduzido na Vontade de Forma empática. Ele remeteria à eternização do próprio homem. Já o medo do primitivo implicava num apaziguamento dos fenômenos naturais através de representações que os negavam, tais como as formas abstratas geométricas e inorgânicas. A fantasmagoria informe da arte gótica corresponderia à necessidade de exaltação elevada até o ponto do êxtase a ser experimentada por parte do povo nórdico. Tal fantasmagoria não representaria elementos da natureza, mas fragmentos de 
realidade agrupados de modo a tornarem-se expressivos sem implicarem numa apreensão exatamente sensual, porque resultava numa ornamentação desprovida da clareza formal orgânica. A ornamentação gótica corresponderia a uma geometria tornada vívida e expressiva da histeria sublime do nórdico. O gótico, assim como o primitivo, também não teria uma concepção cósmica ou de natureza. Seu impulso para a abstração, traduzido em impulso para a exaltação, resultava da angústia experimentada pelo medo do espaço e também do processo de individuação que experimentaria através da Mística. Assim, através da exaltação, embriaguez e êxtase, ele buscava se salvar do sentimento de abandono individual. Pela negação do Eu, ele se descobria, mas devia renegar-se para "reconhecer Deus".

Assim, a teoria Worringeriana é introduzida no debate sobre o expressionismo tanto pela dimensão da relação com o espaço, herdada da sociologia simmeliana, quanto pela dimensão da patologia da histeria sublime relacionada ao gótico. Aqueles anos de guerra, revoluções e vida metropolitana implicariam na mesma sensibilidade para a coisa em si no homem moderno que os homens do passado teriam experimentado, despertando seus impulsos para a abstração. Segundo Lukács, a contribuição teórica de Worringer se refletiria, portanto, em três aspectos problemáticos do método de criação do movimento: a realidade seria descrita como caos incompreensível e degradante; o único modo de se relacionar com ela seria através de uma imersão patológica, irracional, impulsiva, apaixonada; a coisa capturada deveria ser isolada de suas relações que reconduzem ao caos através da abstração, tipificação. A abstração implicada no método resultaria numa expressão da revolta vazia do pequeno-burguês desmoralizado, perdido e esmagado pelas engrenagens capitalistas. O método expressionista levaria à contradição insuperável entre forma e conteúdo. A forma "refinada" em sua essência através da abstração ficaria aberta à arbitrariedade, à falta de conteúdo objetivo. O esvaziamento de conteúdo e afastamento da realidade permitiriam que tais formas fossem preenchidas com conteúdo de propaganda que servia para a ordenação e alinhamento ideológicos, necessários para o funcionamento do sistema totalitarista do fascismo. 
Para Adorno, Bloch e Benjamin, no entanto, tal esvaziamento de conteúdo teria o sentido oposto ao da alienação e evasão, ele possibilitaria a crítica da realidade. A contradição entre a forma e o conteúdo provocada pelo esvaziamento da primeira, permitiria o contínuo exercício reflexivo e crítico. Para Benjamin, a inadequação entre forma e conteúdo não seria propriedade exclusiva do Expressionismo, mas estaria relacionada aos períodos de decadência da arte e patologia do homem, tais como o Gótico, Barroco e a modernidade metropolitana. No caso da arquitetura do Barroco, a pompa encobriria o esvaziamento de conteúdo, direcionando o interesse aos fragmentos e etapas do processo de construção no lugar da forma totalizada. Assim, a forma do barroco não seria plástico-expressiva, mas objeto de contemplação meditativa e especulação filosófica. A patologia barroca corresponderia à melancolia e ao satanismo que assombravam aqueles que não participavam ativamente do exercício da ética luterana do trabalho, que envolveria a valorização da banalidade cotidiana e a fé. Esses excluídos se entregariam ao exercício de contemplação, movidos pela ilusão de liberdade e autonomia na busca do proibido. As alegorias seriam objeto de contemplação por sua qualidade de emblema esvaziado. A alegoria maior do Barroco seria o cadáver, um corpo esvaziado de vida; reificado; correspondendo à condição existencial melancólica do período e também à abstração da lógica monetária capitalista. O estado de apatia melancólica ressurgiria como efeito de falha do aparato sensório do homem moderno, provocado pela experiência de choque devido à superestimulação da vida urbana. A poesia metropolitana retomará o instrumental alegórico, tal como verificado na poesia de Baudelaire. A alegoria corresponderia à necessidade meditativa de ultrapassar os limites da coisa percebida e estaria relacionada ao desprezo pelo mundo das aparências, comum ao príncipe barroco e ao sujeito metropolitano. A alegoria enquanto abstração se prestaria ao exercício meditativo do sujeito melancólico e despersonalizado, cuja satisfação reside em tentar desvendar hieróglifos. Em contraposição a ela, estaria a forma simbólica ligada à beleza clássica e empática. A forma simbólica e a alegoria estariam relacionadas aos impulsos worringerianos de empatia e abstração respectivamente. A alegoria worringeriana seria paradoxalmente esvaziada de verdade e meio para o desvelamento da história por meio da apropriação. Assim transformando os tais conteúdos históricos em conteúdos de verdade filosóficos. 
A alegoria operaria como o fragmento crítico romântico. Este teria permitido a ruptura com o conceito de forma (mimética), tomado como determinação hegemônica da arte até então, e a abertura para o reconhecimento do impulso de abstração como vontade de arte. Para Walter Benjamin, a mudança do estatuto da reflexão através dos primeiros românticos, Schlegel e Novalis, implicou tanto na mudança do conceito de forma como do próprio conceito de obra de arte. Para os românticos, o homem moderno seria qualificado como sujeito reflexivo. Enquanto imerso na cultura e distanciado das formas da natureza, estaria condenado a experimentá-la de modo apenas indireto através da reflexão. Ao lado deste sentimento de desenraizamento e perda de percepção da forma orgânica do mundo promovida pela reflexão, o sujeito moderno romântico descobriria a liberdade infinita do espírito em contato com as ideias da razão. A reflexão, que até Kant, estaria condicionada a um estatuto lógico-racional e ligada ao juízo do belo, encontra nos primeiros românticos uma abertura infinita e ambígua no absoluto, tendo por meio o Eu e a arte. O procedimento reflexivo, dissociado do estatuto lógico, distanciaria a noção de que a arte derivaria da noção de imitação do real, permitindo que a noção de inconsciente viesse a ser futuramente incluída na reflexão.

Para os primeiros românticos, a obra de arte é tomada como um centro de reflexão, livre do racionalismo das regras de beleza, que mediariam a produção imitativa. A reflexão seria um processo infinito, portanto, a obra de arte não poderia ser entendida como meio de expressão de um conteúdo determinado. A reflexão dissolveria a forma no absoluto. O procedimento reflexivo se confundiria com o crítico e este com a abstração e a fragmentação. O fragmento seria crítico, porque seu recorte (abstração) seria também fruto de reflexão. A crítica daria acabamento à obra ao elevá-la por meio de reflexões à Ideia de arte e distingue-se do ajuizamento, pois este pressupõe a obra completa para o desfrute. Os primeiros românticos teriam valorizado a forma em detrimento do conteúdo na teoria da arte, enquanto Goethe seguiria o caminho inverso. Goethe teria canonizado as obras da Antiguidade grega, tomando-as modelo do Ideal e conteúdo da natureza verdadeira e arquetípica. Os primeiros românticos teriam dado mais valor à crítica que à obra. A obra de arte era definida pelo fragmento, que seria uma forma crítica de conteúdo infinito e um momento transitório da crítica imanente. 
Geoffrey Waite retoma o texto de Lukács para apontar a alienação promovida pelos meios digitais ao disseminarem imagens abstraídas da realidade do mundo. Os meios digitais também apresentariam a realidade segundo o conceito de espaço topológico, definido, conforme vimos, a partir da visão tátil, aproximada e fragmentada, que ele associa à teoria da abstração worringeriana, reintroduzida pelo pós-estruturalismo. Waite retomou aqueles três pontos problemáticos, que Lukács denunciou como contribuição de Worringer para disseminar a ideologia da intermediação, possibilitando a desarticulação da luta de classes e permitido o estabelecimento do fascismo no Poder. Waite atualiza esses três pontos segundo o contexto da Era digital. Assim, o primeiro ponto que corresponderia à realidade do pré-guerra, problematicamente descrita como caótica, corresponderia à realidade atual distópica. Afinal, as tecnologias não resolveram o problema da pobreza e ainda contribuíram negativamente para a questão ecológica. O agnosticismo contemporâneo decorreria de um processo de estetização da realidade, promovido pelos meios de comunicação, que torna a realidade e a virtualidade indistintas. $O$ segundo, à imersão na realidade patológica e irracional que recaía num solipsismo. Esse segundo ponto seria atualizado na patologia da tecnofilia sublime e na figura do homem como ciborgue; ser híbrido, dotado de visão topológica eletrônica, alimentado pelos produtos da cultura de massa e destituído do sentimento de empatia pela falta de contato corporal e convivência no espaço público. O terceiro, derivaria diretamente da teoria do impulso para a abstração, que Lukács associa ao esvaziamento de conteúdo e fragmentação da realidade. Tal esvaziamento permitiria que formas isoladas do contexto e tipificadas pelo processo de abstração fossem neutralizadas, servindo à apropriações ideológicas díspares. A abstração corresponderia, portanto, à perda de visão da totalidade do real. O impulso para a abstração levaria à perda de perspectiva. Tal impulso pressuporia um enfoque aproximado, que relaciona os objetos topologicamente e sem inferir um continente, que fosse delimitado por um olhar transcendente. Assim, segundo Waite, as artes abstratas pressuporiam o olhar enucleado do sujeito, assim como os filmes de ficção científica, onde aos equipamentos é que são atribuídos olhos intra-oculados. O cinema tempo, conforme descrito por Deleuze, também expressaria tal tendência. Suas imagens corresponderiam à conexão onírica com a realidade, representada segundo uma indistinção entre o olhar do sujeito e do 
objeto; real e imaginário. Além disso, as imagens seriam definidas como sensação óptica pura, tal qual o Impressionismo, abstraídos os elementos sensório-motores que corresponderiam à unidade orgânica corporal. Por fim, os personagens do filme é que pareceriam assistir ao espectador. Tal fenômeno de inoculação e intraoculação dos equipamentos se estenderia ao modo como a guerra se desenvolveria hoje na interação com as mídias eletrônicas, que tornam o inimigo um alvo abstrato do espaço cibernético, com efeitos ainda mais cruéis.

Assim, o espraiamento do olhar do sujeito pelos objetos que compõem o real determinaria uma realidade abstraída do referencial orgânico-corporal. O referencial fornecido pelos meios tecnológicos reforçariam essa visada topológica e fragmentada, conforme pontuou Paul Virilio. Tal fragmentação da realidade ainda seria reforçada pelo processo de comodificação, que reduz os objetos ao valor de mercadoria e os torna equivalentes intercambiáveis, abstraídos de qualidades próprias. A ausência de hierarquia entre sujeito e objeto e de diferenças qualitativas entre os objetos propiciaria a concretização do espaço real como se fosse virtual, tornando indiscerníveis as fronteiras entre vida cotidiana, arquitetura, cinema e guerras. Uma realidade estaria retroalimentando a outra. A estética informando a política; a economia, à estética.

Para Waite, a disseminação da nova tecnologia digital alteraria a sociabilidade dos homens ao substituir a presença física corporal das relações pela comunicação digital. Tal abstração remeteria à alienação do homem e não à tomada de consciência de sua própria estrutura na relação com a realidade do mundo. As mídias ainda promoveriam a desmobilização da dimensão política ao alterar a relação do homem com o espaço público, que antes seria marcada pelas experiências da presença corporal e do olhar não intermediadas pelas imagens fragmentadas das telas. A perda de visão da totalidade do real implicaria numa perda de perspectiva e da tomada de posição política. Tal como Lukács, Waite acredita que o fim da exploração capitalista somente se daria através da luta de classes, segundo um posicionamento que, para o sociólogo Henri Lefebvre, seria anacrônica. Para Lefebvre, o espaço abstrato estaria relacionado às grandes narrativas históricas e, portanto, dissociado da dimensão do espaço vivido corporalmente e espiritualmente, associável ao topológico. Para ele, nas 
sociedades do capitalismo tardio pós-industrial, o operariado lutaria pela diminuição do tempo de trabalho e não pela tomada dos meios de produção. Waite, além desse anacronismo, comete um equívoco ao associar o espaço topológico ao abstrato lefebvreano.

Conforme verificamos neste trabalho, o espaço topológico, segundo Lefebvre, contradiria o abstrato e remeteria a uma mudança positiva, proporcionada pela possibilidade de apropriação do mesmo, sem a camada de significados pré-determinados que é associada à pressuposição de totalidade da concepção euclidiana. Já o espaço euclidiano, geométrico, abstrato e homogêneo estaria relacionado às políticas institucionais e seria estabelecido historicamente às custas de violência e guerra. $\mathrm{O}$ espaço, no entanto, não se tornaria homogêneo em si através do desenho abstrato. $\mathrm{O}$ desenho provocaria apenas um esvaziamento ilusório na heterogeneidade e na multiplicidade da matéria multiforme espacial. Tal esvaziamento decorreria do dualismo corpo e espírito, conservado no pensamento ocidental, e refletido no modo reducionista da concepção espacial, ora privilegiando o aspecto mental, ora o físico. A ênfase do mental ou do físico levaria à abstração; seja através da ilusão de transparência ou de substancialidade da realidade do espaço. Estas ilusões se traduziriam na ideia de que a dimensão subjetiva dos desejos e pensamentos não teria tanta realidade quanto as coisas que ocupam o espaço visualmente. $\mathrm{O}$ espaço abstrato estaria relacionado à emancipação da razão, que Lefebvre associa ao cristianismo do período medieval e à sua reprodução posterior através da concepção do espaço euclidiano e fálico. A partir do Medievo, a tendência a valorizar a dimensão visual se juntará à abstração geométrica do espaço homogêneo euclidiano, determinando a espetacularização da arquitetura fálica, segundo Lefebvre, marcada pela verticalização da arquitetura e associada à imposição do Poder. A reprodução do espaço abstrato na cidade moderna se traduziria na fragmentação determinada pela lógica mecânico-funcionalista do zoneamento urbano, que pressuporia também o esvaziamento do próprio sujeito, como peça da engrenagem do sistema de produção. Para Lefebvre, tal fragmentação poderia ser superada através da apropriação dos usuários. A apropriação do espaço corresponderia à liberação das predeterminações que reduzem a experiência à realização de atividades postuladas como necessárias. 
O espaço, para Lefebvre, seria um meio ambíguo capaz de alienar ou despertar o sujeito em sua integridade mental e erótica. O desejo despertado seria o efeito da reversão do espaço abstrato em espaço diferencial, reavivando a heterogeneidade própria do processo de sedimentação do espaço, que as determinações funcionais abstraem. As necessidades são a abstração do desejo humano, são desejos objetivados e desambiguizados. O desejo impulsiona mudanças, é ambíguo e envolve a experiência multidimensional do corpo vivido, que não exclui os efeitos da castração e dos condicionamentos sociais sobre o corpo. Por isso, a nova concepção de espaço, almejada por artistas e arquitetos a partir do conceito de espaço topológico, usaria como dispositivo a ambiguidade espacial associada à transparência fenomênica. É preciso ressaltar, no entanto, que o impulso para a abstração worringeriano não corresponde ao exercício puramente mental da abstração, apontado por Lefebvre. A contradição reside, portanto, na contraposição logos-erótica proposta por Lefebvre, pois esta determinaria o logos como extensão do estado mental, que excluiu a princípio a dimensão erótica e é associada ao espaço abstrato. A tendência dos arquitetos a projetarem os espaços segundo as necessidades funcionais e não segundo uma abertura para o desejo refletiria a preponderância do logos em detrimento do erótico. Há ainda um problema de nomenclatura quanto ao termo abstração usado por Worringer e Lefebvre, que determina o equívoco de Waite.

Para Worringer, o impulso para a abstração seria uma resposta corpóreopsíquica que derivaria da sensibilidade extremada para as coisas em si no homem primitivo e gótico. Tal sensibilidade seria mais tátil que visual. Este impulso corporal corresponderia ao sentimento agorafóbico e demostraria a falta de controle da consciência sobre a vontade. Tanto o impulso para abstração como para a empatia pressuporiam o corpo e não uma escolha espírito-intelectual. O que predisporia a expressão artística diferente seria o modo de estruturação psíquica, associada à cada um: a empatia corresponderia à Vontade de autoafirmação da consciência dos povos mediterrâneos; enquanto a abstração, ou estaria associada ao fato do primitivo ser desprovido de visão cósmica que lhe desse referência como indivíduo ou, à negação do Eu no Gótico. A arquitetura gótica estaria a meio caminho de uma visão cósmica e apresentaria, portanto, um equilíbrio entre sensibilidade e razão, decorrente da expressão do cristianismo sob influência da 
mística e da escolástica que lhe foi característica. O corpóreo e o espiritual surgiriam representados em imagens da transfiguração dos corpos reencarnados do Juízo Final. O tema do corpo seria lembrado através do cadáver. E através desse cadáver reencarnado, podemos afirmar que o erotismo não teria sido esquecido na Idade Média.

Conforme verificamos com Bataille, a arte; o erotismo; as religiões e a guerra seriam resultantes do processo de organização e retardamento dos violentos instintos humanos. Tal retardo estaria implicado no processo de racionalização demandado pela experiência do trabalho. O trabalho envolveria a contenção do dispêndio de excessos próprios à natureza em função da racionalização dos resultados almejados. Tal contenção teria resultado também na estruturação social e no processo que desencadeará a afirmação do indivíduo, como distinto da natureza e do grupo. A morte o devolveria à continuidade. Assim, o erotismo refletiria a nostalgia da continuidade com a natureza perdida através do misto de pavor, angústia e prazer. Ele se desdobraria em três formas de superação da descontinuidade; nos erotismos respectivos ao corpo, coração e sagrado, que comporiam a estrutura ambígua do desejo. As obras de arte espelhariam essas três dimensões, sendo seu impulso primeiramente marcado pela violência e deformação das formas expressas. $\mathrm{O}$ naturalismo das artes miméticas seria a expressão do distanciamento da violência instintiva, relacionada à tendência de racionalização propiciada pelo desenvolvimento da estruturação social e da consciência individual. Para Bataille, as estilizações e deformações nas expressões artísticas pré-históricas corresponderiam ao impulso artístico primário, marcado pelo sadismo destrutivo. Portanto, podemos inferir que o erotismo do impulso para a abstração estaria mais distante de uma suposta tendência racionalizante que o impulso para a empatia, associado ao naturalismo.

Verificamos assim que a ambiguidade da distinção entre o abstrato e o concreto persiste no dualismo entre o corpo e o espírito; e entre o virtual e o real. Schiller apontava o olho como o órgão privilegiado no sentido da elevação da realidade material e concreta ao mundo das formas. A apreensão visual favoreceria ao desenvolvimento estético desinteressado adequado aos espíritos evoluídos em contraposição à apropriação tátil. A alienação do homem moderno 
seria decorrente da cisão entre razão e sensibilidade; e sua integridade dependeria da sensibilização do olhar para a forma aparente e depois para a reflexão das formas. A reflexão levaria à razão e à ideia do bem comum. Para ele, o homem habitaria mediante os exercícios de liberdade do espírito via imaginação e do prazer liberto das dimensões subjetivo-individuais. Se o homem sensível e espiritual, como teria afirmado Kant, se define pela Vontade, Schiller complementa: ela não deve ser sublime, mas sensível. A vontade sensível supõe a diluição do sujeito no objeto e sua elevação racional em prol do bem comum. A razão seria vitoriosa. Schopenhauer rompe com a descrição do homem como um Ser da razão e também com a querela histórica entre a realidade das ideias ou dos fenômenos. A coisa em si do mundo é a Vontade. Tanto o pensamento racional quanto as paixões seriam representações da Vontade. Schopenhauer estabelece uma hierarquia entre as representações da vontade, que se organizam em função da ideia de humanidade. Elas iriam do grau mais alto que são as paixões, passando pela clareza das ideias até chegar nas qualidades materiais e corporais. A música seria uma abstração sensível, por comunicar a Vontade sem a mediação da representação. A arquitetura manteria seu status inferior em relação às outras artes devido à sua dimensão utilitária (partilhada com as ciências) e material. No entanto, para Schopenhauer é a matéria que dá força de expressão à arquitetura e não as relações de composição ou o ornamento. A matéria expressaria a ideia do drama humano no tempo e no espaço como a luta entre a gravidade e a rigidez estrutural. O material inorgânico seria dotado de vontade de arte. Vemos aqui um caminho aberto para romper o determinismo com que a história da arte e arquitetura eram descritas, submetidas a outros campos do saber ou às limitações técnicas. A estética de Schopenhauer favoreceu o desenvolvimento da psicologia dos estilos de Aloïs Riegl e Wilhelm Worringer segundo a noção da Vontade de Arte/Forma. Tal desenvolvimento permitirá questionar a supremacia do paradigma antropomórfico, associado à metafísica do sujeito como o ser que dá forma ao mundo e é simultaneamente o modelo do mundo. Os impulsos formais serão explicados pela psicologia como função da relação de estranhamento ou empatia do homem com o espaço da vida e não como um exercício reflexivo, dominado pela razão. Nem todos os impulsos levariam o homem à reconciliação com o mundo ou com a humanidade. Conforme apontará Bataille, o impulso para a destruição teria permanecido encoberto. 
Apesar da persistência dos ideais iluministas no mundo contemporâneo, a realidade não se tornou transparente mediante o conhecimento racional e nem o homem mais consciente de si. Segundo Gianni Vattimo, a multiplicação de imagens através dos meios de comunicação e das ciências serviram para enturvar ainda mais nossa visão de mundo. A disseminação midiática teria apenas tornado o homem mais consciente da inevitável fabulação do mundo produzida pelo pensamento metafísico; objetividade da ciência e ideal de progresso. A pósmodernidade rompeu de vez com a perspectiva unitária da realidade e teve que assumir a visão fragmentada e oscilante anunciada no início do século XX. Esta rechaçada pelos hegelianos, que supunham possível a emancipação do real e do sujeito contraposto. A transparência, a verdade e a liberdade teriam se tornado oscilantes e fracas, assim como a noção de realidade. A relação do homem com o mundo oscilaria entre o sentimento do habitar e do desenraizamento. Este sentimento angustiante, no entanto, abriria espaço para o Outro e para a diferença. Também para Vattimo, a arte se mostra como o espaço especial para tal abertura. Não pela conciliação com a forma, conforme propunha Schiller mas pela experiência do choque ou Stoss, conforme propunham Benjamin e Heidegger. As obras realizariam a verdade, porque seriam acontecimentos do ser que revelariam a crise do habitar e levariam o homem a pensar sua condição segundo o estranhamento. $\mathrm{O}$ choque proporcionaria a experiência ambígua da conciliação e do desenraizamento, sendo o segundo termo responsável pelo alargamento de significados que levaria ao Outro, ao não consumável que determinaria a obra de arte.

Conforme verificamos, o sentimento de fragmentação não seria propriedade da pós-modernidade. Ele teria sido despertado no início do século XX com a mudança do olhar, associada à disseminação do conceito de espaço topológico. Tal conceito corresponderia à perda de visão da totalidade do real e da clareza e estaria relacionado à percepção da realidade partir do movimento; como nos voos de avião e nos veículos em velocidade. Os artistas futuristas e cubistas teriam procurado representar a ambiguidade de tais imagens apreendidas. A incorporação da concepção de espaço topológica teria determinado, segundo Colin Rowe e Robert Slutzky, a inovação na pintura cubista que foi caracterizada por eles como transparência fenomênica. Tal transparência se manifestaria através 
da inclusão do movimento nas representações, que resultava na multiplicação dos pontos de vista e na simultaneidade das imagens. A arte cubista, especificamente, desenvolveria um tipo de espaço marcado pela ambiguidade de sua transparência. Ele foi descrito comumente pelo aspecto da interpenetração dos seus planos pictóricos e também foi associado às novas descobertas da ciência, quanto à unidade espaço-temporal. Para Colin Rowe e Robert Slutzky, no entanto, nem todas as pinturas da época alcançariam tais qualidades da transparência ambígua, cuja técnica teria sido herdada de Cézanne, sendo esta determinada pelo ponto de vista frontal; supressão de elementos sugestivos de profundidade; retração dos planos primeiro, médio e de fundo; interesse visual periférico determinado pela sobreposição de dois grids e transparência de certas pinceladas. Ele contrapõe essa transparência ambígua, denominada como fenomênica à literal. A transparência literal se caracterizaria por remeter ao espaço profundo naturalístico, apesar da linguagem abstrato-geométrica das pinturas, e, portanto, por remeter ao sentido realista da transparência e à visão de totalidade.

Para Rowe e Slutzky, a pintura teria influenciado de modo direto no desenvolvimento da técnica que expressou a concepção do espaço topológico na arquitetura, determinado pela inclusão do tempo como sua quarta dimensão. $\mathrm{O}$ tempo, portanto, determinaria a ambiguidade de tal espaço que depende do movimento corporal para ser apreendido na dimensão da profundidade. A visão imediata forneceria apenas uma camada superficial, marcada pela ênfase na frontalidade e em contradição com o espaço interior. Ela exigiria do observador o exercício intelectual de deduzir e completar mentalmente a imagem apreendida. Tal contradição na percepção do espaço caracterizaria a transparência fenomênica arquitetônica. A arquitetura utilizaria os mesmos recursos herdados da pintura cubista e cézanneana adaptados ao espaço da realidade: frontalidade, superficialidade e transparência. A transparência literal seria determinada pela materialidade translúcida dos próprios materiais empregados, tais como o vidro, que teria uma importância muito maior que na transparência fenomênica e implicaria na percepção simultânea e imediata dos espaços. A literal estaria, portanto, associada à visão contínua e instantânea da profundidade espacial. 
Anthony Vidler critica tanto a transparência literal da arquitetura moderna quanto as arquiteturas da transparência fenomênica iluminista e pós-moderna. A transparência literal da arquitetura moderna seria problemática por sua associação à lógica do exercício de Poder através do controle visual. Este seria facilitado pelas formas claras, racionais e funcionais, conforme apontado por Foucault. A transparência literal, em princípio, teria sido uma herança da arquitetura panóptica, herdada do Iluminismo. Para Vidler, no entanto, tal associação do Poder à forma visível e funcional, feita por Foucault, teria deixado desapercebido o aspecto obscuro e sombrio das estéticas do sublime. Tal estética exploraria os efeitos de sombra e de desmaterialização, despertando o sentimento do desenraizamento. $\mathrm{O}$ jogo de luz e sombras determinaria a ambiguidade espacial que define sua transparência como fenomênica. Segundo Vidler, tal ambiguidade espacial constituiria um instrumental de manipulação do sujeito pelo medo. $\mathrm{O}$ sujeito reconheceria nas sombras seu corpo morto. As sombras produzidas nas arquiteturas da transparência fenomênica espelhariam a morte do sujeito, a angústia e o sentimento de desenraizamento do homem moderno. Para Vidler, a experiência do desenraizamento paralisaria o homem no sentimento da angústia desestruturante, associada ao que foi descrito por Freud como estranhamente familiar (Unheimlich). Enquanto duplo do sujeito, tais sombras também espelhariam seu lado abjeto, seu estado de ansiedade e pânico. Elas representariam a perda da perspectiva do sujeito associada à parte do processo de desenvolvimento psíquico do sujeito ou ao estado regressivo traumático em que ele perderia seu anteparo de representação, sendo confrontado pelo real. Tal experiência provocaria um efeito parecido àquele das imagens aéreas e à concepção do espaço topológico, correspondendo também à apreensão fragmentada da realidade e à indistinção entre interior e exterior. A diferença é que o paradigma das imagens é sempre a representação do corpo humano. A arquitetura contemporânea também faria uso da estética do sublime e da transparência fenomênica, conforme Vidler descreveu o projeto do OMA para o edifício da $T G B$, que associamos à transparência abjeta devido à associação com a estética abjeta.

Assim como para Waite e Hal Foster, a realidade contemporânea seria descrita por Vidler sob a égide da alienação do corpo orgânico, dado que as 
tecnologias constituiriam um prolongamento do mesmo. A visão fragmentada da realidade e a indistinção entre os espaços interior e exterior, que estavam associadas à visão topológica do espaço, espelhariam hoje o estado paranoico do sujeito contemporâneo. Este viveria a sensação de perda da unidade orgânica do corpo e a fetichização desse corpo-cadáver perdido. As bio-tecnologias e a cibernética teriam contribuído para confundir os limites entre os corpos orgânicos e inorgânicos que determinariam a perversão contemporânea. $O$ ápice do desenraizamento seria, portanto, representado pelos robôs e ciborgues, manifestado primeiramente na literatura de ficção científica e no cinema e, depois, através da disseminação da realidade virtual na era digital. A experiência do desenraizamento seria levada assim da relação com o ambiente para o presumido limite do corpo sadio ou não, natural ou protético.

A Midiateca Sendai representou a consolidação de anos de investigação do arquiteto Toyo Ito sobre a pureza do espaço. Esta foi realizada mediante a abertura para a participação da sociedade. Pela primeira vez em sua vida profissional, ele não teria considerado a interferência externa no processo de desenvolvimento, projetação e realização como fonte de distorção de suas ideias. A Midiateca representaria uma mudança de perspectiva por parte de Ito, que até então teria se mantido fiel à pesquisa do espaço puro, associada ao hermetismo da Escola Shinohara, e afastado de seu antigo chefe Kiyonori Kitutake. Este último comprometido com o envolvimento social. Seu programa seria multifuncional, aberto a mudanças e consideraria a participação da comunidade e dos demais membros institucionais desde o processo de projeto. A abertura do programa representaria também uma perspectiva do relacionamento com o saber na Era Digital, sendo configurado como Inteligência Coletiva, conforme proposta do filósofo Pierre Levy. A Midiateca constituiria um nó de recepção, produção e partilha do conhecimento, supondo a atividade dos usuários e democratização da tecnologia digital. A fragmentação do conhecimento seria explorada em seu potencial de recombinação e de não cristalização numa totalidade semântica.

A Midiateca levaria ao extremo a noção de transparência ao estendê-la das fachadas às estruturas vazadas. $\mathrm{O}$ conceito da pureza espacial seria retomado da arquitetura moderna pelo viés da complexidade pós-moderna. Tal complexidade 
se traduziria no dispositivo da transparência fenomênica, caracterizado neste projeto pela exploração da interpenetração espacial; ênfase nas qualidades superficiais e ambíguas das telas e dos vidros da fachada, na indeterminação dos espaços internos e na transparência e efeito de distorção da malha homogênea pelos feixes de tubos. Tal ambiguidade não comprometeria a beleza de estética abstrata, despertada pela transparência, leveza e fluidez espacial do partido moderno. Estas qualidades serviriam ainda de metáfora para representar a realidade determinada pelas mídias eletrônicas e a segunda dimensão dos corpos também eletrônicos dos usuários.

Em contrapartida ao espaço abstrato e profano, estaria a associação dos feixes de tubos à Onbashira, o pilar sagrado, levantado em rituais por vários homens em conjunto e com o testemunho da comunidade. Podemos interpretar os feixes de tubos da Midiateca, que levantam seu teto, também como uma metáfora das redes paradoxalmente sólidas e desmaterializadas que configuram as comunidades virtuais. E também podemos dizer que essa estrutura evocaria o sagrado de modo sensível, através da memória da natureza (árvores) recuperada na corporeidade construtiva. Tal processo de realização da memória através de morfemas sensíveis, que não remeteria ao realismo da representação, mas a um processo de abstração, entendido como "elevação" dos elementos da natureza vistos a conceitos. O sagrado a ser alcançado seria uma dimensão abstrata e ontológica, que diferiria da relatividade e caos do mundo profano. Uma dimensão do sagrado estaria relacionada à ordem cósmica; a outra, ao habitar. Assim, podemos compreender que Ito está buscando a integração numa ordem cósmica através da elevação dos feixes de tubos da Midiateca ao céu; da arquitetura aos fluxos eletrônicos, da comunidade à natureza. Ele inverteria o processo de abstração ao tornar a arquitetura abstrata um elemento sensível.

Podemos concluir que a obra de Ito responderia tanto à questão da autonomia artística em sua busca de pureza da forma quanto à da perda de função social, associadas ao esteticismo das vanguardas modernas. E também, que ele recupera o referencial fenomenológico do espaço, representado pela apreensão corporal, por meio do processo de sensibilização da arquitetura abstrata e homogênea através de distorções de cunho naturalístico. A transparência 
fenomênica associada à essa obra pode ser descrita como baseada no princípio da performatividade espacial, que caracterizaria as obras tradicionais japonesas como abertas para o tempo. E por fim, que Ito procura dar sentido ao habitar através do dispositivo da transparência fenomênica, que na Midiateca Sendai se estenderia às metáforas relativas à oposição entre sagrado e profano. 


\section{8. \\ Referências bibliográficas}

ABBAGNANO, N. Dicionário de Filosofia. SP: Martins Fontes, 2007.

AGAMBEN, Giorgio. O homem sem conteúdo. BH: Autêntica, 2012.

ALLEN, Stan; SOMOL, R., E.. Points + lines: diagrams and projects for the city. NY: Princeton Architectural Press, 2012. First Edition Reformatted.

ARGAN, Giulio C. Arte Moderna. São Paulo: Cia das Letras. 1992.

ARGAN, Giulio C. Imagem e persuasão: ensaios sobre o barroco. SP: Cia das Letras. 2004.

ARGAN, Giulio C. Projeto e Destino. São Paulo: Editora Ática, 2004

BAKER, Geoffrey H. Le Corbusier: uma análise da forma. São Paulo: Livraria Martins Fontes, 1998.

BANHAM, Reyner. Teoria e projeto na primeira era da máquina. São Paulo: Perspectiva, 2003.

BANHAM, Reyner; KOBAYASHI, Katsuhiro; SUZUKI, Hiroyuki. Contemporary Architecture of Japan 1958-1984. London: The Architectural Press, 1985.

BARTHES, Roland. EI Imperio de los signos. Barcelona: Editorial Seix Barral, 2007.

BATAILLE, Georges. Tradução de SCHEIBE, Fernando. O Erotismo. Belo Horizonte: Autêntica Editora, 2013.

BAUDRILLARD, Jean et al. Art and Philosophy. New Criticism Series nº 2 . Milão: Giancarlo Politi Editore, 1991.

BAUDRILLARD, Jean. The Conspiracy of Art: Manifestos, Interviews, Essays. London, MA: The MIT Press, 2005.

BAUDRILLARD, Jean. Why hasn't everything already disappeared? London, NY, Calcutta: Seagull, 2011.

BAUDRILLARD, Jean; LOTRINGER, Sylvère. Forget Foucault. London, MA: The MIT Press, 2007.

BEASLEY, W. G. The Meiji Restoration. California: Stanford University Press, 1972. 
BENEVOLO, Leonardo. História da arquitetura moderna. SP: Editora Perspectiva, 1989.

BENJAMIN, Walter; Tradução de João Barrento. Origem do Drama trágico alemão. 2.ed. Belo Horizonte: Autêntica Editora, 2013.

BENJAMIN, Walter; Tradução de SELIGMANN, Marcio. O Conceito de Crítica de Arte no Romantismo Alemão. São Paulo: Iluminuras, 1993.

BENTON, C.; BENTON, T.; SHARP, D., Form and Function. A source book for the History of Architecture and Design 1890-1939. Londres: Granada Publishing, 1980.

BOIS, Yve-Alain. A pintura como modelo. SP: Martins Fontes, 2009.

BRANZI, Andrea. Weak and Diffuse Modernity: The World of Projects at the beginning of the 21st Century. NY: Rizzoly, 2006.

BURDETT, R (org.). Living in the Endless City. London: Phaidon, 2009

BÜRGER, Peter. Teoria da Vangurada. SP: Cosac Naify, 2012.

BUSBEA, Larry. Topologies: the urban utopia in France, 1960-1970. Spain: MIT Press, 2007.

CACCIARI, Massimo. A Cidade. Barcelona: Gustavo Gilli, 2010.

CACCIARI, Massimo. Architecture and Nihilism: On the Philosophy of Modern Architecture. New Haven, London: Yale University Press, 1993.

CACCIARI, Massimo. Posthumous People: Vienna at the Turning Point. California: Stanford University Press, 1996.

CARVER, Norman. Form and Space of Japanese Architecture. Toquio, 1955.

CHOAY, F. O urbanismo: utopias e realidades, uma antologia. São Paulo: Perspectiva, 2013.

CONRADS, Ulrich. Programs and Manifestoes on 20th-century architecture. Massachusets: MIT, 1971.

DAVIS, Kingsley. SIOBERG, Gideon, BLUMENFELD, Hans e outros. Cidades: A Urbanização da Humanidade. RJ: Zahar Editores, 1972.

DELEUZE, G., GUATTARI, F. Cinema 2 - A Imagem-tempo. SP: Editora 34, 2018.

DELEUZE, G., GUATTARI, F. Mil Platôs, vol, 4. SP: Editora 34, 1997.

DELEUZE, G., GUATTARI, F. Mil Platôs, vol, 5. SP: Editora 34, 1997. 
DONAHUE, NEIL H. (ed.). Invisible cathedrals: the expressionist art history of Wilhelm Worringer. Pensilvânia: Pennsylvania State University Press, 1995.

EISENMAN, Peter \& KOOLHAAS, Rem with KIPNIS, Jeffrey \& SOMOL, Robert. Architecture Words, Supercritical. London: AA Publications, 2010.

EL CROQUIS. The very best works at the turn of the century. Madrid: El croquis editorial, 2011.

FOCILLON, Henri. Hokusai. Paris: Libraire Félix Alcan, 1914.

FOCILLON, Henri. L’art bouddhique. Paris: Henri Laurens, 1921.

FOCILLON, Henri. The Life of Forms in Art. London, MA: The MIT Press, 1992.

FOSTER, Hal (ed); BAUDRILLARD, Jean et al. The anti-aesthetic: essas on postmodern culture. NY: The New York Press, 1998.

FOSTER, Hal. O complexo arte-arquitetura. SP: Cosac \& Naify, 2015.

FOSTER, Hal; KOOLHAAS, Rem. Junkspace with Running Room. Londres: Notting Hill Editions Ltd, 2013.

FRAMPTON, Kenneth. História crítica da arquitetura moderna. São Paulo: Martins Fontes, 1997.

FRAMPTON, Kenneth. Le Corbusier. NY: Thomas \& Hudson, 2001.

FRAMPTON, Kenneth; CAVA, John. Studies in Tectonic Culture: The poetics of construction in Nineteenth and Twentieth Century Architecture London, MA: The MIT Press, 1995.

FULLER, R. Buckminster. The Buckminster Fuller Reader. London: Ebenezer Baylis and Son, 1970.

FULLER, R. Buckminster. Utopia or Oblivion: prospects for humanity. London: Allen Lane The Penguin Press, 1970.

GIEDEON, S. Espaço, tempo e arquitetura: o desenvolvimento de uma nova tradição. São Paulo: Martins Fontes, 2004.

GOMBRICH, E. H. The History of Art. London: Phaidon Press Limited, 1995.

GOODMAN, Grant K. Japan: The Dutch Experience. London: The Athlone Press, 1986. GOODMAN, Grant K. Japan: The Dutch Experience. London: The Athlone Press, 1986.

GROPIUS, Walter. Bauhaus: Novarquitetura. São Paulo: Perspectiva, 1972. 
HAYS, Michael K. (ed). Architecture Theory since 1968. NY: MIT Press, 2000.P. 396.

HEGEL, Georg Wilhelm Friedrich. Curso de Estética: o belo na arte. Tradução de Orlando Vitorino e Álvaro Ribeiro, 2ª ed.SP:WMF Martins Fontes, 2009.

HERSHALL, Kenneth G. História do Japão. Lisboa: Edições 70, 2004.

HERZOG, Jacques; DE MEURON, Pierre. Treacherous Transparencies. NY: Actar, 2016

INOUE, Mitsuo. Space in Japanese Architecture. NY and Tóquio: Weatherhill, 1985.

ISER, Wolfgang. Tradução de KRETSCHNER, Johannes. O Fictício e o

Imaginário: Perspectivas de uma Antropologia Literária. RJ: Ed UERJ, 1996.

ISHIDA, Takeshi. Japanese Political Culture. New Jersey: Library of Congress, 1989.

ISOZAKI, Arata. Japan-ness in Architecture. London, MA: The MIT Press, 2011.

ISOZAKI, Arata; OSHIMA, Ken T.. Arata Isozaki. London: Phaidon Press, 2009.

ITO, Toyo et al. A Japanese Constellation. NY: The Museum of Modern Art, 2016.

ITO, Toyo; BUNTROCK, Dana; IRAGASHI, Taro; YAMAMOTO, Riken. Toyo Ito. London: Phaidon Press, 2009.

ITO, Toyo; FUTAGAWA, Yoshio. Sendai Mediatheque. Tóquio: GA Detail. A.D.A. Edita, 2001.

ITO, Toyo; SAKAMOTO (ed), Tomoko; FERRÉ (ed), A. Toyo Ito 2002-2016. Tóquio: GA, 2016.

ITO, Toyo; SASAKI, Mutsuru. Sendai Mediatheque, Myagi, Japan, 1995-2000. Barcelona: Actar, 2003.

ITO, Toyo; STEELE, Brett (ed) . Architecture Words 8: Tarzans in The Media Forest. London: AA Publications, 2011.

ITO, Toyo; TURBULL, Jessie (ed). Forces of Nature. NY: Princeton Architectural Press, 2012.

JAMESON, Fredric. Tradução de GAZOLLA, Ana Lúcia A.. Espaço e Imagem: teorias do pós-moderno e outros ensaios de Fredric Jameson. RJ: Editora UFRJ, 1994. 
KAHLFELDT, Paul et al. Ludwig Mies van der Rohe. Berlim: be.brawissenschaft verlag $\mathrm{GmbH}, 2007$

KANT, Immanuel. Crítica da Faculdade do Juízo. Tradução de Valério Rohden e António Marques. 2a ed. RJ: Forense Universitária, 2008.

KANT, Immanuel. Crítica da Razão Pura. Tradução de Manuela Pinto dos Santos e Alexandre Fradique Morujão. $6^{\text {a }}$ ed. Lisboa:Fundação Calouste Gulbenkian.

KATO, Shuichi. Tempo e espaço na cultura japonesa. Tradução de neide Nagai e Fernando Chamas. São Paulo: Editora Estação Liberdade, 2007.

KOOLHAAS, Rem. Nova York delirante: um manifesto retroativo para Manhattan. São Paulo: Cosac \& Naif, 2008.

KOOLHAAS, Rem; OBRIST, BOERI, Stefano; SANFORD, Kwinter; ULRICH, Hans. Mutations. Bordeaux: ACTAR, 2000.

KOOLHAAS, Rem; OBRIST,Hans Ulrich. Project Japan, Metabolism Talks. Köln: Taschen, 2011.

KOOLHAAS, Rem; SIEGLER; MAU, Bruce. S, M, L, XL: Office for Metropolitan Architecture. New York: Monacelli Press, 1995.

KRACAUER, Siegfried. O ornamento da massa. SP: Cosac \& Naify, 2009.

KRAUSS, Rosalind E. The originality of the avant-garde and other modernist myths. London, MA: The MIT Press, 1986.

LATOUR, B. Jamais fomos modernos. SP: editora 34, 2009.

LE CORBUSIER et JEANNERET, Pierre. Oeuvre Complète de 1929-1934. Zurich : Artemis, $9^{\circ}$ ed, 1974.

LE CORBUSIER. Os três estabelecimentos humanos. São Paulo: Perspectiva, 1979.

LE CORBUSIER. Planejamento urbano. São Paulo: Perspectiva, 2004.

LE CORBUSIER. Por uma arquitetura. São Paulo: Perspectiva, 2014.

LEFEBVRE, Henri. The production of space. Oxford: Blackwell Publishing, 1991.

LEVY, Pierre. A inteligência coletiva. Por uma antroplologia do ciberespaço. 2. ed. SP: Edições Loyola, 1999.

LEVY, Pierre. Cibercultura. 3. ed. São Paulo: Editora 34, 2010. 
LIMA, LUIZ Costa. Mímesis e arredores. Curitiba: CRV, 2017.

LIMA, LUIZ Costa. O controle do imaginário: razão e imaginação nos tempos modernos. 2. Ed. RJ: Forense Universitário, 1989.

LIN, Zhongjie. Kenzo Tange and the Metabolist Moviment: Urban Utopias of Modern Japan. New York: Routledge, 2010.

LÖSCHKE, Sandra K. Materiality and Architecture. London, NY: Routledge, 2016.

LUKÁCS, Georg. Die Eigenart Des Ästhetischen. Werke, 1. Halbband. Luchterhand, 1965, 1971.

LUKÁCS, Georg. Georg Lukács Werke. Probleme des Realismus: Essays über Realismus. Berlim: Hermann Luchterland Verlag GmbH, 1971.

LUKÁCS, Georg. Grösse und Verfall” des Expressionismus”, 1934

LYOTARD, Jean-François. Lições sobre a analítica do sublime. SP: Papirus, 1993.

MACHADO, Carlos Eduardo J. Um capítulo da história da modernidade estética: debate sobre o expressionismo. 2.ed. São Paulo: Editora Unesp, 2016.

MAKI, Fumihiko. Nurturing dreams: collected essays on architecture and the city. London: MIT Press, 2008.

MONDRIAN, Piet, FERREIRA MARTINS, Carlos A. (org). Neoplasticismo na pintura e na arquitetura. SP: Cosac Naify, 2008.

MONTANER, Josep Maria. Arquitetura e crítica. Barcelona: Gustavo Gili, 2007.

MONTANER, Josep Maria. Depois do movimento moderno: arquitetura da segunda metade do século XX. Barcelona: Gustavo Gili, 2001.

NAKAGAWA, HISAYASU. Introducción a la cultura japonesa. Espanha: Editorial Melusina, 2006.

NESBITT, Kate (organização). Uma Nova Agenda para a arquitetura: antologia teórica 1965 - 1995. São Paulo: Cosac Naify, $2^{\circ}$ ed., 2008.

NEUMEYER, Fritz. Mies van der Rohe: Das Kunstlose Wort. Gedanken zur Baukunst. Berlim: Dom, 2016.

NISHI, Kazuo, HOZUMI, Kazuo. What is Japanese Architecture: A survey of tradicional Japanese architecture. NY: Kodansha, 1983.

PAZ, OCTAVIO. Conjunções e Disjunções. SP: Perspectiva, 2018. 
PEVSNER, N. Estudios sobre Arte, Arquitetura y Diseño: del maneirismo al romantismo, era Victoriana y siglo XX. Barcelona: Gustavo Gili, 1983.

PLÜM, Kerstin. Mies van der Rohe im Diskurs: Inovationen-HaltungenWerke. Aktuelle Positionen. Bielefeld: transcript Verlag, 2013.

POERSCHKE, UTE. Funktionen und Formen: Architekturtheorie der Moderne, Bielefeld: transcript Verlag, 2014.

Probleme der Mimesis I. Die Entstehung der Ästhetischen Widerspiegelung. "Allgemeine Probleme der Mimesis"

RAUTERBERG, Hanno. Talking Architecture. Interviews with architects. Munique: Prestel Verlag, 2012.

RIEGL, Aloïs. Historical Grammar of the Visual Arts. Tradução de Jacqueline E. Jung de Historische Grammatik der bildenden Künste, 1966. NY: Zone Books, 2004.

RITTER, J. (ed.) Historisches Wörterbuch der philosophie. Basel/Stuttgart: Schwabe \& Co, 1971

SALVINI, Roberto. Pure Visibilité et Formalism: dans la critique d'art au début du XX' ${ }^{\mathrm{e}}$ siècle. Paris: Klincksieck, 1988.

SCHILLER, Friedrich. Ausgewählte Werke. Stuttgart: W. Kohlhammer, 1949.

SCHILLER, Friedrich. Tradução de Márcio Suzuki. Poesia Ingênua e

Sentimental. SP: Iluminuras, 1991.

SCHILLER, Friedrich. Tradução de Roberto Schwarz e Márcio Suzuki. A Educação Estética do homem. SP: Iluminuras, 1990.

SCHILLER, Friedrich. Tradução de Süssekind e Vladimir Vieira. Friedrich Schiller: do sublime ao trágico. BH: Autêntica, 2011.

SCHLEGEL, Friedrich. Tradução de Márcio Suzuki. O dialeto dos Fragmentos. São Paulo: Iluminuras, 1997.

SCHOPENHAUER, Arthur. Tradução de Wolfgang Leo Maar. III Parte. O Mundo como Vontade e Representação. Os Pensadores. SP: Abril S.A. Cultural e Industrial, 1974.

SEJIMA, Kazuyo; ISOZAKI, Arata. Kazuo Sejima: Living Space. Ja: The Japan Architect. Tóquio: Schinkenchiku-sha Co Ltd., n.99, outono, 2015.

SEJIMA, Kazuyo; NISHIZAWA, Ryue; HASEGAWA, Yuko. SANAA. Veneza: Mondadori Electa, 2005. 
SIMMEL, Georg. Tradução César Benjamin. Schopenhauer \& Nietzche. RJ: Contraponto, 2011.

SMITHSON, Alison; SMITHSON, Peter. The Charged Void: Urbanism. NY: The Monacelli Press, 2005.

SMITHSON, Alison; SMITHSON, Peter; RISSELADA, Max (ed). A Critical Anthology. Barcelona: Poligrafa, 2011.

SMITHSON, Peter. Conversaciones con estudiantes. Barcelona: Editorial Gustavo Gilli. 2004.

STEELE, James. Contemporary Japanese architecture: tracing the next generation. NY: Routledge, 2017.

SYKES, A. Krista. Constructing a new agenda: architectural theory 19932009. NY: Princeton Architectural Press, 2010.

TAFURI, M. Architecture and Utopia. Design and Capitalist Development. Cambridge: MIT, 1976.

TANIGUCHI, Yoshio. Yoshio Taniguchi: Nine Museums. NY: The Museum of Modern Art, 2004.

TAYLOR, Jennifer with CONNER, James. The Architecture of Fumihiko Maki : Space, City, Order and Making. Basel: Birkhäuser, 2003.

TOYNBEE. A. Mankind and Mother Earth. EUA: Oxford, 1976.

VATTIMO, Gianni. A sociedade transparente. Lisboa: Relógio d'Água, 1992.

VENTURI, Robert. BROWN, S. Denise. IZENOUR, Steven. Aprendendo com Las Vegas. São Paulo: Cosac \& Naify, 2003.

VIDLER, Anthony. Histories of the Immediate Present: inventing architectural modernism. MA: The MIT Press, 2008.

VIDLER, Anthony. The Architectural Uncanny: essays in the modern unhomely. EUA: The MIT Press, 1992.

VIDLER, Anthony. The Scenes of the Street and Other Essays. NY: The Monacelli Press, 2011.

VIDLER, Anthony. Warped space: art, architecture, and anxiety in modern culture. MA, London: The MIT Press, 2001.

VIRILIO, PAUL, PIRES, Paulo R. (trad.). Guerra e cinema. SP: Ed. Página Aberta LTDA, 1993. 
VIRILIO, Paul. Tradução Julie Rose. Art as far as the eye can see. Oxford, NY: Berg, 2007.

VIRILIO, Paul. Tradução Paulo Roberto Pires. O espaço crítico. SP: Editora 34, 1993.

VIRILIO, Paul. Tradução Vera Ribeiro. Estética da desaparição. RJ:

Contraponto, 2015.

WESTNEY. D. Eleanor. Imitation and Innovation: The transfer of Western Organizational Patterns to Meiji Japan. Massachusetts: Harvard University Press, 1987.

WÖLFFLIN, Heinrich. Principles of Art History: The Problem of the Development of Style in Later Art. USA: Dover Publications, INC, 1950.

WORRINGER, Wilhelm. Abstraction and Empathy: A Contribution to the Psychology of Style. 3 a Edição. NY: International Universities Press, INC, 1953.

WORRINGER, Wilhelm. Formprobleme der Gotik. 2a ed. Munique: R. Piper \& Co, 1912.

\section{PERIÓDICOS}

http://www.zeno.org/Philosophie/M/Schopenhauer,+Arthur/Die+Welt+als+Wille +und+Vorstellung/Erster+Band/Drittes+Buch. Acesso em 15/11/2017.

ITO, Toyo; FUTAGAWA, Yoshio. Sendai Mediatheque. Tóquio: GA Detail. A.D.A. Edita, 2001.

KLEIN, Y. L'évolution de l'art vers l'immateriel. Conference à la Sorbonne. 1959? www.yvesklein.com/downloud

OKUYAMA, Schin-ichi. Kazuo Shinohara: Complete Works in Original Publications. Ja: The Japan Architect. Tóquio: Schinkenchiku-sha Co Ltd., n.93, Spring, 2014.

ROWE, C.; SLUTZKY, R., Transparency: Literal and Phenomenal. Perspecta, Vol. 8. (1963), pp. 45-54.

SCHOPENHAUER, Arthur. Die Welt als Wille und Vorstellung. ( $3^{\mathrm{a}}$ ed.) Zurique: Zürcher, 1977.

SEJIMA, Kazuyo; ISOZAKI, Arata. Kazuo Sejima: Living Space. Ja: The Japan Architect. Tóquio: Schinkenchiku-sha Co Ltd., n.99, outono, 2015. 